

\author{
Helsingin yliopisto \\ Kasvatustieteellisen tiedekunnan julkaisuja 2020 \\ Julkaisu on vertaisarvioitu
}

\title{
Mikko Ojala
}

Perusteita ja haasteita varhaiskasvatuksen, esiopetuksen ja koulun alun kehittämiselle erityisesti lapsen oppimisen ja kehittymisen näkökulmasta 
ISBN 978-951-51-5777-5 (nid.)

ISBN 978-951-51-5778-2 (PDF)

DOI $10.31885 / 9789515157782$

Unigrafia

Helsinki 2020

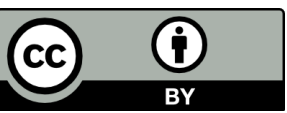

Perusteita ja haasteita varhaiskasvatuksen, esiopetuksen ja koulun alun kehittämiselle erityisesti lapsen oppimisen ja kehittymisen näkökulmasta, tekijänä Mikko O. Ojala, on lisensoitu Creative Commons Nimeä 4.0 Kansainvälinen -lisenssillä. 


\section{Sisällysluettelo}

Esipuhe .ix

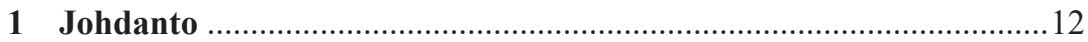

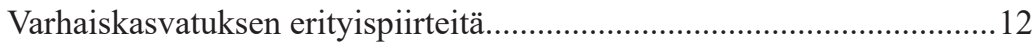

Suomalaista varhaiskasvatusta määrittävät lait ja asiakirjat ...................16

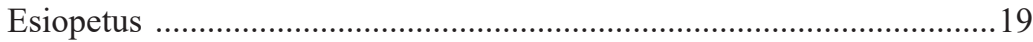

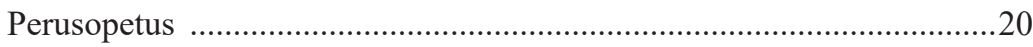

Julkaisun näkökulma varhaiskasvatukseen ........................................21

2 Näkökulmia lapsen kehitykseen ja oppimiseen .................................23

Oppimisen ja kehittymisen dynaamisuus ............................................23

Miten oppimista ja kehittymistä on pyritty selittämään? ........................24

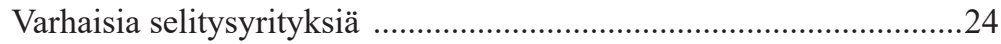

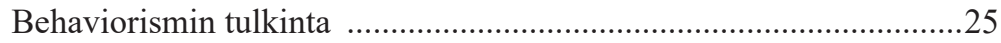

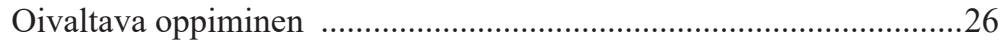

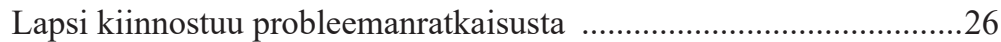

Lapsi konstruoi omaa oppimistaan ja kehittymistään .......................27

Sosiaalinen ympäristö kanavoi oppimista ja kehittymistä ..................28

Miten kognitiotiede lähestyy oppimista ja kehittymistä? ....................29

Oppimisen ja kehittymisen neuropsykologinen perusta ......................30

Lapsen ääni ja tulkinnat oppimisesta ja kehittymisestä ........................32

3 Taitojen kehittyminen ja oppiminen eri osa-alueilla .........................37

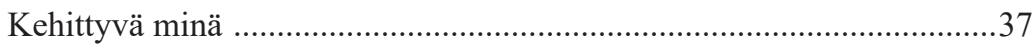

Mahlerin kuvaukset ja tulkinnat minän varhaisesta kehittymisestä ........38

Winnicottin näkemyksiä lapsen minän kehittymisestä ..........................41

Läheisen aikuisen merkitys minäkuvan muodostumiselle ......................42

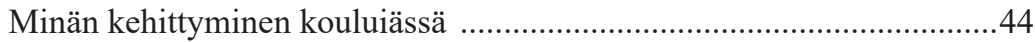

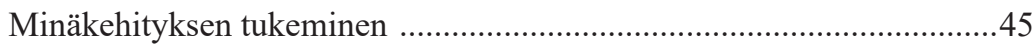

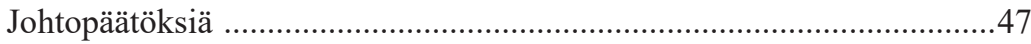

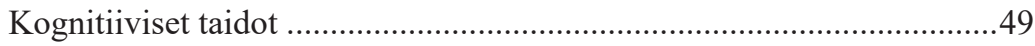

Piaget'n tulkinta lapsen kognitiivisten rakenteiden kehittymisestä ....50

Kehittyminen ensimmäisen kahden ikävuoden aikana ..................52

Kehittyminen ikävuosina 2-6 ..................................................53

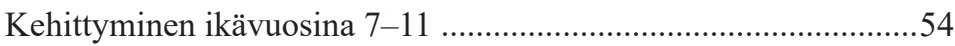

Miten Vygotsky tulkitsee lapsen kognitiivisen kasvun? ......................55 


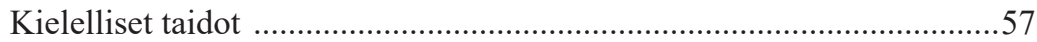

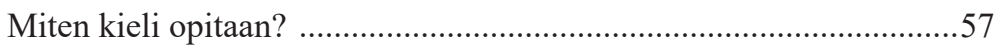

Kielen osa-alueet ja niiden kehittyminen …………..........................58

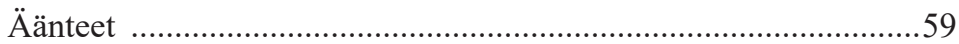

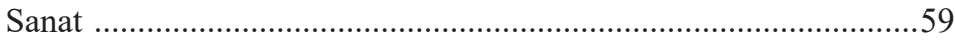

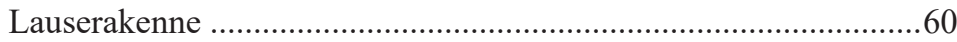

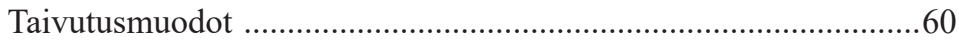

Kielellinen tietoisuus ja sen harjaannuttaminen ................................61

Äänneasun tietoisuuden harjaannuttaminen ...................................62

Sanarakenteen tietoisuuden harjaannuttaminen .............................63

Tietoisuus lauserakenteesta ja sen harjaannuttaminen ...................64

Kirjaintietoisuuden kehittyminen ja tukeminen ............................65

Kielen tukeminen siirryttäessä esiopetuksesta kouluun ......................66

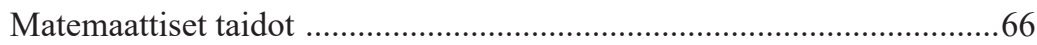

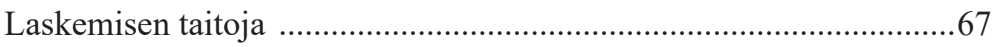

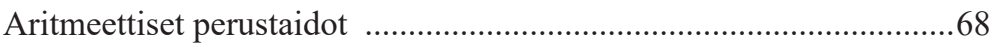

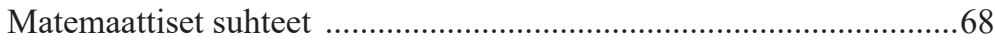

Lukumääräisyyden ymmärtäminen ……….....................................70

Matemaattisen taitojen kehittyminen ja tukeminen .............................70

Esimerkkejä matemaattisten taitojen opettamisesta varhaisvuosina ....73

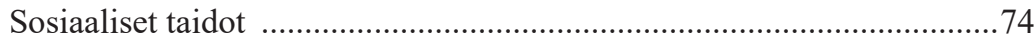

Sosiaalisen kognition kehittyminen …….......................................

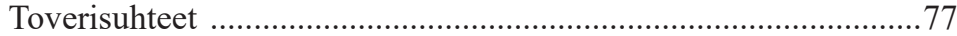

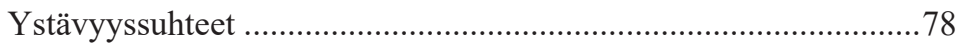

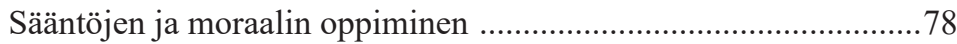

Sosiaalisten taitojen tukeminen ja kehittäminen ……........................81

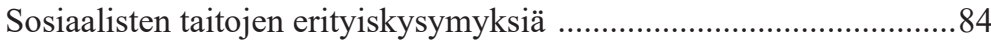

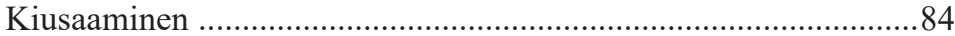

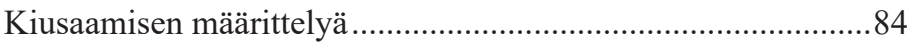

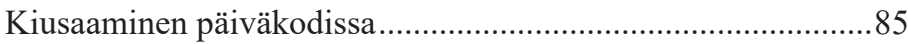

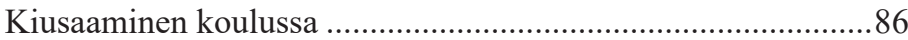

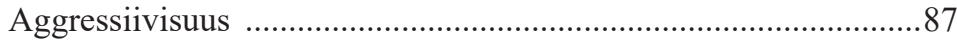

Torjutuksi tuleminen ja syrjään vetäytyminen .............................89

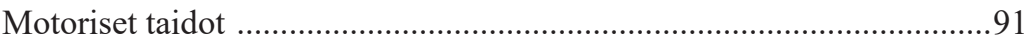

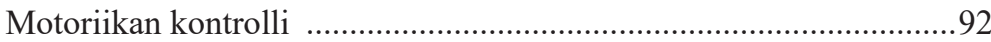

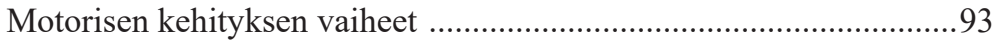

Motorisen kehittymisen eteneminen ................................................94

Reflektiivisen kehittymisen vaihe ..............................................94

Tahdonalaisten motoristen toimintojen kehittyminen .....................96 
Motoristen perustaitojen vahvistuminen .96

Kehitysodotuksia karkea- ja hienomotoristen taitojen kehittymisestä 97

Motoristen taitojen oppiminen ja kehittäminen ..................................98

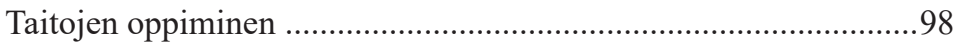

Taitojen kehittäminen .99

4 Lapsen oppimista ja opettamista jäsentävät opetussuunnitelmat varhaiskasvatuksessa (ikävuodet 1-5), esiopetuksessa (ikävuosi 6) ja perusopetuksen vuosiluokilla 1-2 102 Opetussuunnitelmien uudet perusteet (2014-2016) ..............................102

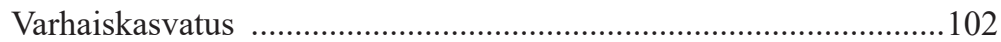

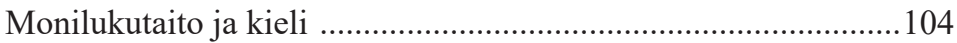

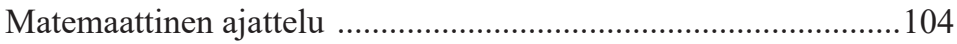

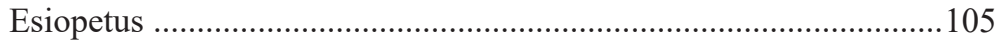

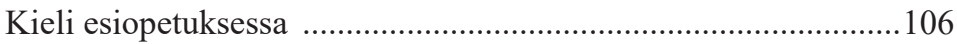

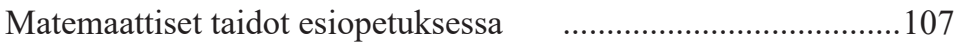

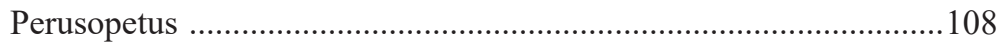

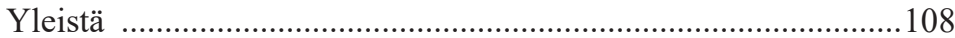

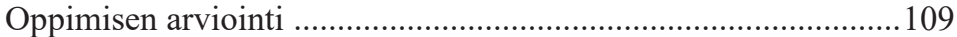

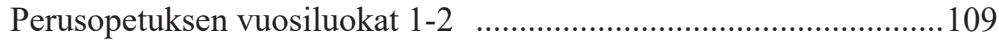

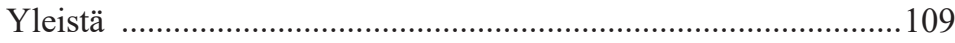

Oppiaineet vuosiluokilla 1-2 _....................................................... 111

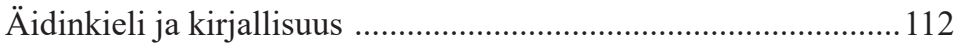

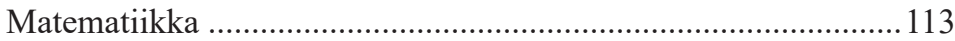

Opetussuunnitelmien tavoitteiden ja sisältöjen vertailua ...................115

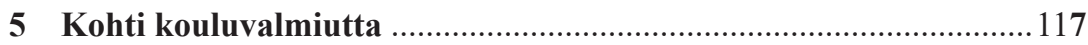

Lapsen kouluvalmiuden erilaisia tulkintoja ........................................ 117

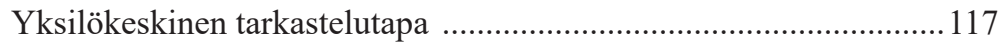

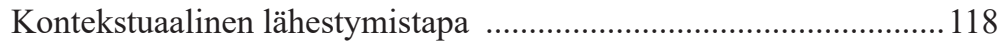

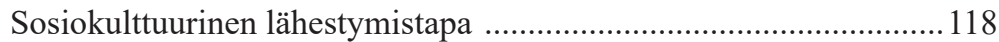

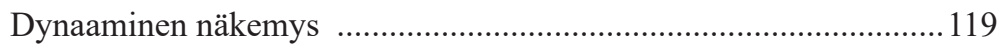

Kouluvalmiuden kehittymisen seuranta ja arviointi .............................119

Kognitiiviset taidot kouluun siirryttäessä .......................................120

Koulutulokkaiden sosio-emotionaalinen kyvykkyys .......................122

Koulutulokkaan motoriset taidot ja fyysinen kehitys ........................123

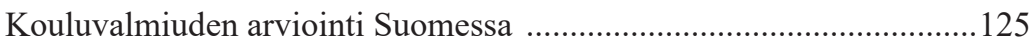

Kouluvalmiuden pedagogista tarkastelua .........................................128

Pohdintaa kouluun siirtymisestä ja kouluvalmiudesta ..........................132 


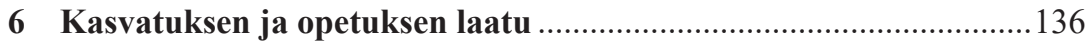

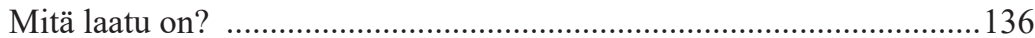

OECD:n arvioita Suomen varhaiskasvatusjärjestelmästä.....................137

Pitkän aikavälin analyysit lapsen oppimisesta ja kehittymisestä

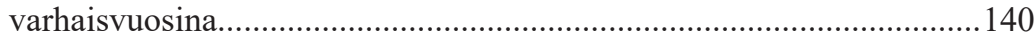

Varhaiskasvatuksen laatu ja lasten kehittyminen Ruotsissa ...............140

Varhaiskasvatuksen pitkäaikaisvaikutukset High/Scope

-tutkimuksessa

USA:n kansallisen tutkimuslaitoksen arviot varhaiskasvatuksen

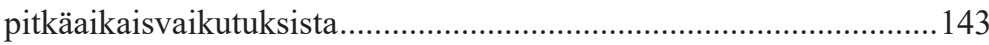

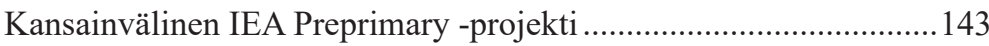

Varhaiskasvatuksen pitkäaikaisvaikutukset Englannissa .................147

Havainnot esiopetuksen laadusta ..................................................147

Siirtymä esiopetuksesta perusopetukseen .................................148

Kansallisia arviointeja varhaiskasvatuksen toteutuksesta ja laadusta....149

Kansallisia arviointeja esiopetuksen toteutuksesta ja laadusta ..............151

Arviointeja suomalaisesta perusopetuksesta........................................153

Perusopetuksen oppimistulosten arviointi .......................................153

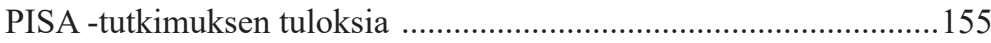

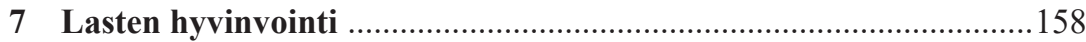

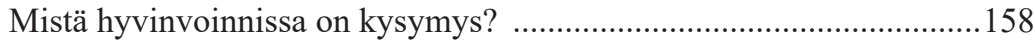

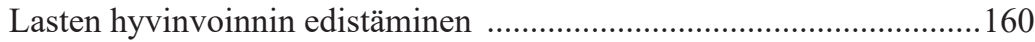

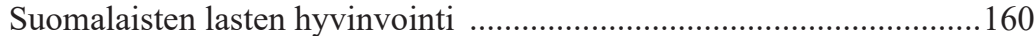

Päivähoidon ja neuvolan yhteistyö lapsen hyvinvoinnin tukemisessa ..163

Avaus lapsen hyvinvoinnin ja voimavarojen arviointiin.........................164

Lasten hyvinvoinnin seurannan haasteellisuus ......................................165

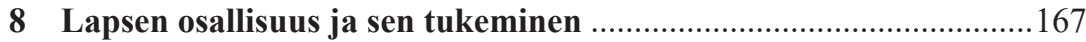

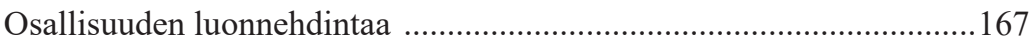

Osallisuuden kehittyminen ja kehittäminen ........................................170

Lapsen osallisuus ja sen esteitä päiväkodin käytänteissä .....................172

Lapsen osallisuuden kehittäminen päiväkodeissa ja esiopetuksessa ....173

Kansainvälisiä periaatteita lasten osallisuudesta ..................................175

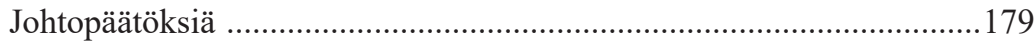

9 Leikin monet mahdollisuudet .....................................................180

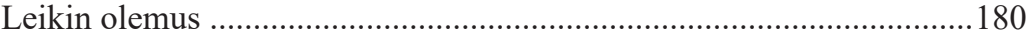

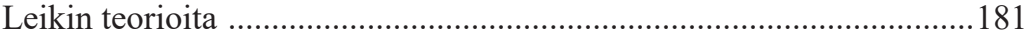

Leikin vaikutukset lapsen kehittymiseen ...........................................184 


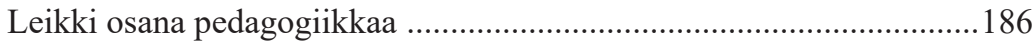

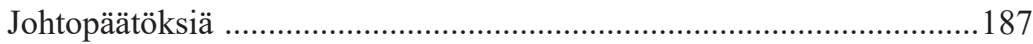

10 Monikulttuurinen kasvatus ja opetus .............................................190

Monikulttuurisuuskasvatuksen tunnusmerkkejä .................................190

Miksi on tärkeää kehittää monikulttuurista kasvatusta? .......................190

Monikulttuurisuuskasvatuksen kehittäminen .....................................192

Esimerkkejä inklusiivisen monikulttuurisuuskasvatuksen

kehittämisestä esiopetuksessa ja koulussa ...........................................194

Eurooppalainen INCLUD-ED -projekti .........................................194

Havaintoja monikulttuurisen pedagogiikan kehittämisestä

esiopetuksessa ja koulun alussa (INCLUD-ED -projekti) .................196

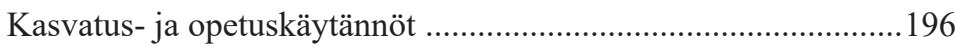

Vanhempien ja lähiyhteisön osallistuminen lasten

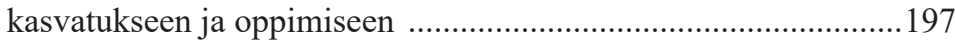

Keinoja tukea perheiden ja muun lähiyhteisön osallisuutta .........199

Inklusiivisen kasvatuksen ja opetuksen yhteydet

lapsen oppimiseen ja kehittymiseen ...........................................201

Perhekasvatus ja lähiyhteisön mukaantulo .................................202

Yhteenvetoa monikulttuurisuuskasvatuksen toteutumisessa

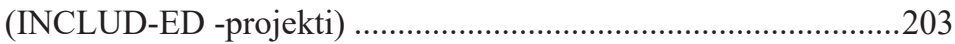

Esimerkkejä monikulttuurisuuden kehittämisestä suomalaisessa

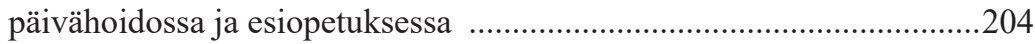

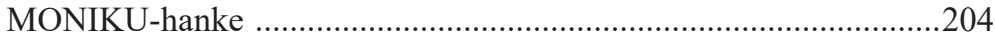

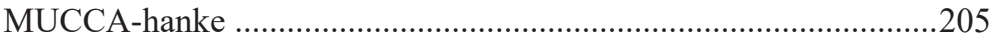

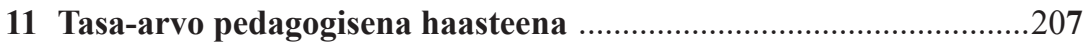

Tasa-arvon perusteita suomalaisessa koulutuspolitiikassa ....................207

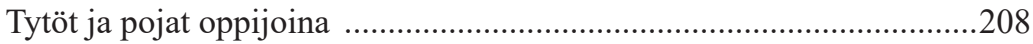

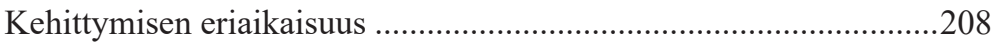

Tyttöjen ja poikien saavutukset oppimisessa ...................................209

Havaintoja tyttöjen ja poikien oppimisesta esiopetuksessa

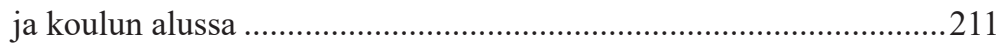

Alueellinen tasa-arvo esiopetuksessa ja koulussa ................................212

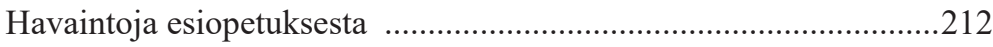

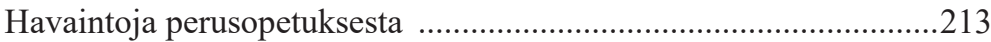

Kohti sukupuolisensitiivistä varhaisvuosien kasvatusta ja opetusta......214 


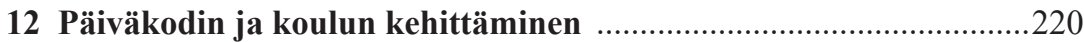

Päiväkoti toiminta- ja kehittämisympäristönä .....................................220

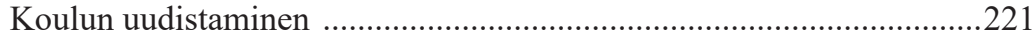

Refleksiivinen lähestymistapa kasvatustoiminnan kehittämisessä .......223

Refleksiivisen toiminnan tunnusmerkkejä ......................................223

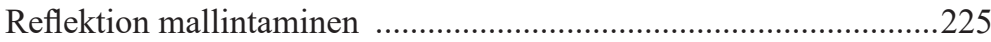

Havaintoja varhaiskasvatuksen ja esiopetuksen kehittämisestä

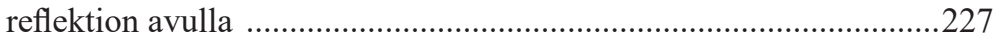

Reflektiivinen kehittäminen pedagogisen dokumentoinnin avulla ....231

Varhaiskasvattajan ja esiopettajan kompetenssit ..............................234

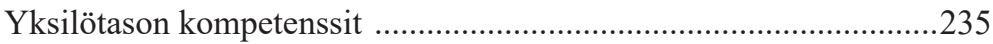

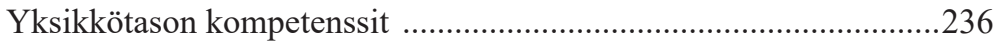

Toimintayksiköiden väliset kompetenssit .......................................237

Ohjantaa ja hallinnointia koskevat kompetenssit ...........................237

Osaamisalueet suomalaisessa varhaiskasvatustyössä ……………........238

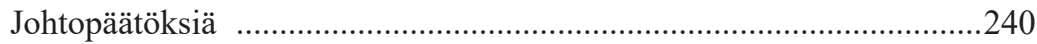

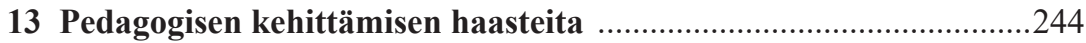

Toimenpiteitä lasten oikeuksien edistämiseen ....................................244

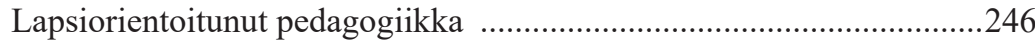

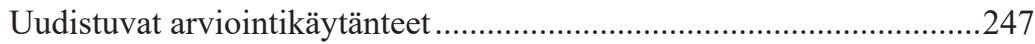

Varhaiskasvatuksen nykytilan arviointi .........................................247

Varhaiskasvatuksen laatuindikaattorit ...........................................250

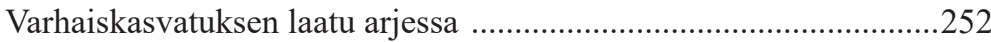

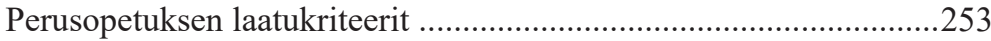

Oppimisen ja osaamisen arviointi perusopetuksessa........................255

Esimerkkejä lasten/oppilaiden oppimisen ja

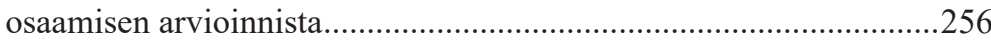

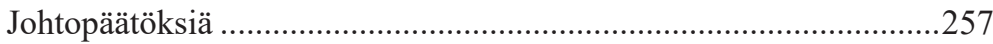

Näkökulmia varhaisvuosien opettamisen ja

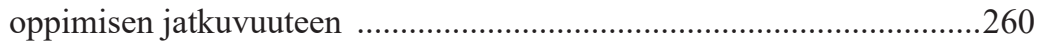

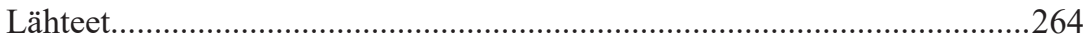

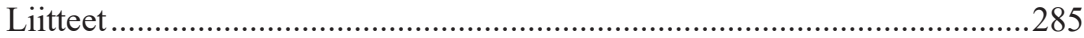




\section{Esipuhe}

Varhaiskasvatusta on yleensä hahmotettu kasvatuksen osana, jolla on omat spesifit tehtävät, tavoitteet ja toteutustavat. Lähestymistavan todennäköisenä etuna on tunnistaa varhaiskasvatuksen erityisyys ja sen omaperäisyys. Mutta tällaiseen lähestymistapaan liittyy myös rajoituksia, joiden seurauksena on vaikeuksia muodostaa kokonaisvaltaisempaa käsitystä erityisesti kasvatuksen, opetuksen ja oppimisen jatkuvuudesta varhaiskasvatuksesta esiopetukseen ja tätä kautta kouluun.

Tässä julkaisussa halutaan viestiä ammattikasvattajille, vanhemmille, opiskelijoille, tutkijoille ja kehittäjille mahdollisimman monipuolinen ja kokonaisvaltainen kuva varhaiskasvatuksesta ja sen jatkuvuudesta esiopetukseen ja kouluun. Julkaisussa tarkastellaan varhaiskasvatuksen, esiopetuksen ja koulun tavoitteita ja toiminta. Oppivaa ja kehittyvää lasta tarkastellaan kahdessa ulottuvuudessa. Toinen näistä muotoutuu oppimisja kehitysteorioiden välityksellä. Toisessa lähestymistavassa tarkastellaan lapsen kehittymisen ja oppimisen taitoja (minän kehitys, kognitiiviset taidot, kieli, matemaattiset taidot, sosiaaliset taidot sekä motoriset taidot). Kouluun siirtyminen on lapsen oppimisen ja kehittymisen jatkuvuudessa tärkeä ja merkityksellinen tapahtuma, jota tarkastellaan teoksessa kouluvalmiuden näkökulmasta.

Kasvatusta ja opetusta uudistetaan kiinnittämällä huomiota erityisesti laadun ylläpitoon varhaiskasvatuksessa, esiopetuksessa ja koulussa. Opetuksen ja oppimisen laatua tarkastellaan monipuolisesti hyödyntämällä sekä kansainvälistä että kotimaista tutkimusta. Muita ajankohtaisia teemoja ovat kasvatuskumppanuus, lasten hyvinvointi ja osallisuus, leikin mahdollisuudet sekä monikulttuurinen kasvatus ja opetus. Keskeisenä kasvatuksen ja opetuksen tavoitteena erityisesti Suomessa on tasa-arvon ylläpitäminen ja sen kehittäminen. Julkaisussa tarkastellaan tasa-arvon toteutumista varhaiskasvatuksessa, esiopetuksessa ja koulussa kiinnittämällä erityistä huomiota sukupuolisensitiivisen kasvatuksen ja opetuksen pedagogisiin haasteisiin. Edellisten teemojen lisäksi tarkastellaan päiväkotia ja koulua toiminta- ja kehittämisympäristönä. Tässä kiinnitetään huomiota varhaiskasvatuksen ja esiopetuksen reflektiiviseen kehittämiseen sekä varhaiskasvattajien ammatillisiin kompetensseihin ja osaamisalueisiin. Julkaisun päättää luku, jossa tiivistetään näkemyksiä ja ehdotuksia 
varhaiskasvatuksen, esiopetuksen ja koulun alun kehittämiseksi erityisesti pedagogisen jatkuvuuden näkökulmasta.

Tästä aihepiiristä on aiemmin ilmestynyt julkaisu (Ojala 2015: Varhaiskasvatus, esiopetus ja koulun alku lapsen oppimisen ja kehittymisen näkökulmasta), jota on olennaisilta osin uudistettu perustuen aihepiirin uusimpiin tutkimuksiin ja julkaisuihin. Uudistetut sisällöt ovat kohdistuneet etenkin johdantoon, kasvatus- ja opetussuunnitelmien perusteisiin, kasvatuksen ja opetuksen laatuun, sukupuolisensitiiviseen kasvatukseen ja opetukseen sekä opetuksen ja oppimisen arviointiin ja kehittämiseen.

Julkaisun laadintaa varten olen saanut apurahaa Suomen tietokirjailijat ry:Itä ja Helsingin yliopiston kirjastolta, joista lausun lämpimän kiitoksen. Julkaisun ideoinnissa ja laadinnassa on hyödynnetty alan kansainvälistä ja kotimaista tutkimusta sekä tekijän pitkäjännitteistä kansainvälistä ja kotimaista tutkimus- ja kehittämistoimintaa. Näistä haluan mainita erityisesti pääkaupunkiseudun varhaiskasvatuksen kehittämisyksikön (VKK Metro) projektit, Helsingin kaupungin esiopetuksen toimivuutta ja vaikuttavuutta koskevat projektit, eurooppalaisen monikulttuurisuuspedagogiikkaan kohdistuneen kuusivuotisen INCLUD-ED -projektin, yhdeksänvuotisen kansainvälisen varhaiskasvatuksen laatua analysoivan IEA Preprimary Study-projektin sekä vuonna 2012 päättyneen OECD:n varhaiskasvatuksen laatua analysoivan projektin. Myös opetustoimintani Helsingin yliopistossa ja avoimessa yliopistossa ovat monin tavoin inspiroineet ja ohjanneet kiinnittämään huomiota varhaiskasvatuksen, esiopetuksen ja alkuopetuksen ydinkysymyksiin.

Julkaisun laadinnassa olen saanut arvokasta palautetta monilta asiantuntijoilta. Näistä haluan mainita erityisesti professori Jari Lavosen, dosentti Tuulikki Vennisen, lisensiaatti Anna-Leena Lastikan, tohtori Jonna Kankaan, tohtori Reko Niemelän sekä tohtori Jyrki Reunamon Helsingin yliopistosta. Olen kiitollinen, että julkaisuni on hyväksytty Helsingin yliopiston kasvatustieteellisen tiedekunnan julkaisusarjaan. Kiitän Kasvatustieteellisen tiedekunnan tutkimustoimikuntaa ja sen puheenjohtajaa professori Miriam Kallandia käsikirjoituksesta saamasta palautteesta. Palaute on johtanut merkittäviin uusiin avauksiin ja painotuksiin. Julkaisun työstämisestä painatusasuun kiitän Unigrafiaa. Verrattomina inspiraation lähteinä julkaisun tekemisessä ovat olleet aluksi omat lapseni Aleksi ja Saija-Leena sekä nyttemmin lastenlapseni Luka, Niki, Pihlaja ja Aulikki, 
joiden kehitystä ja oppimista minulla on ollut mahdollisuus seurata varhaiskasvatuksessa, esiopetuksessa ja koulun alkutaipaleella.

Helsingissä 6.12.2019

Mikko Ojala 


\section{Johdanto}

\section{Varhaiskasvatuksen erityispiirteitä}

Varhaiskasvatusta pidetään perustavaa laatua olevana lapsen kehittymisen ja oppimisen kannalta ja se muodostaa perustan kaikelle myöhemmälle kehittymiselle. Tämä ikävaihe on myös omaleimainen, jolloin lapsen kehitystarpeet ovat erilaiset kuin myöhemmin kouluiässä. Osoituksena tästä on kehittyminen, joka varhaiskasvatusiässä on nopeaa ja muuntuvaa. Taustana on etenkin aivojen nopea kehittyminen lähes täyteen kapasiteettiin. Kehitys ja oppiminen ovat silmiinpistävää kaikilla kehittymisen alueilla kuten käveleminen, puhuminen, itsetunto, näkemys maailmasta, moraalikäsitykset jne. Kaiken kaikkiaan lapsi elää kriittistä ja samalla myös varsin haavoittuvaa vaihetta juuri varhaiskasvatusiässä kehittymisensä kaikilla alueilla.

Vaikka kodissa tapahtuva kasvatusta ei lasketa kuuluvaksi institutionaaliseen varhaiskasvatukseen, lasten vanhemmilla ja tätä kautta kodilla on keskeinen asema varhaiskasvatuksen toteutuksessa ja lapsen kehittämisessä. Lapsen varhaiskehittymisen tukemisen kannalta on tärkeää hoiva ja huolenpito, jota erityisesti pieni lapsi tarvitsee. Tämän vuoksi varhaiskasvatuksessa kiinnitetään myös huomiota lapsen perushoitoon, tunnesuhteeseen ja kiintymykseen häntä hoitaviin ja kasvattaviin aikuisiin (esim. Bowlby, 1973).

Koska varhaiskasvatusta voidaan ilmiönä lähestyä monesta näkökulmasta käsin, tämän termin määrittelykin on haasteellista. Näkökulmat voivat olla historialliskulttuurisia, kasvatuksellisia, opetuksellisia tai hoidollisia. Varhaiskasvatus näyttäytyy hieman eri tavoin sen mukaan, tarkastellaanko sitä reviirinvartijoiden (opetussuunnitelman laatijat, opettajat, vanhemmat, yhteiskunnan intressitahot) vai edunsaajien (vanhemmat, opettajat ja lapset/oppilaat, työnantajat ja yhteiskunta) näkökulmasta (esim. Woodhead, 1996; Katz, 1993).

Oman spesifin lähestymistapansa varhaiskasvatus saa sen mukaan kohdistetaanko siihen mielenkiintoa tutkimuksesta vain kasvatuksen käytännöstä käsin (Ojala, 1993; Härkönen, 2003). Tämän ohella erityistä huomiota voidaan kohdistaa koulutukselliseen näkökulmaan, jossa varhaiskasvatusta lähestytään myös oppiaineen näkökulmasta (Hujala ym., 1998). Tieteeseen, käytäntöön ja oppiaineiseen kohdistuvan tarkastelun oheen on ehdotettu myös kasvatusajattelun mukaan ottamista (Härkönen, 2002). 
Menemättä tarkemmin esitettyihin varhaiskasvatuksen määrittelyehdotuksiin ja niiden oikeutuksiin on syytä todeta, että varhaiskasvatukseen on kohdistettu lisääntyvässä määrin tieteellistä mielenkiintoa. Tutkimuksellisesti varhaiskasvatusta lähestytään kansainvälisesti ja myös meillä Suomessa monitieteisesti. Suomalaisessa kontekstissa keskiössä ovat kasvatustiede, psykologia ja sosiologia. Sen lisäksi että tutkijat oman tieteenalansa tarkastelukulmista ja teorioista käsin tutkivat aktiivisesti varhaiskasvatusta ja sen toteutusta, suomalaisilla tutkijoilla on ollut pyrkimystä määritellä varhaiskasvatusta niin, että siitä aste asteelta voisi kehittyä oman tieteenala (esim. Karila ym., 2001). Joka tapauksessa varhaiskasvatuksesta on muotoutunut useimmissa maissa omaleimainen monitieteinen tutkimusalansa, jonka painopistealueet kehittyvät ja muuntuvat tieteellisten aktiviteettien valtavirtojen vanavedessä.

Kodin ulkopuolista varhaiskasvatusta ohjaavat kansalliset kasvatusja opetusjärjestelmät ovat kulttuurisidonnaisia ja kiinnittyvät kansallisiin järjestelmiin. Erilaisuutta näihin tuo jo se, että kouluuntuloikä vaihtelee. Eräissä maissa (esim. Englanti ja Australia) koulu alkaa 5-vuoden iässä. Useimmissa maissa tämän tapahtuu vuotta myöhemmin paitsi Suomessa, jossa koulu alkaa kansainvälisesti varsin myöhään 7-vuoden iässä. Erilaiset ratkaisut koulunkäynnin aloittamisessa merkitsevät myös eri tavoin ajoitettua esiopetusta, jonka tarkoituksena on valmentaa pedagogisesti lapsia siirtymään kouluun. Kouluuntuloikä määrittää myös sen, miten pitkään lapsia hoidetaan, kasvatetaan ja opetetaan varhaiskasvatuksessa. Suomessa kansainvälisesti myöhään tapahtuva koulun aloittaminen voi tukea kestoltaan pidempää lapsuutta kuin maissa, joissa koulu alkaa aikaisemmin.

Lasten osallistuminen ikäluokkana kansallisiin suunnitelmiin perustuviin varhaiskasvatuspalveluihin antaa yleiskuvan varhaisen kasvatuksen ja opetuksen intensiteetistä eri maissa. Oheiseen taulukoon (Taulukko 1) on koottu OECD:n keräämien tietojen perustella lasten osallistumisaste koulun ulkopuoliseen varhaiskasvatuksen päivähoidon ja esiopetuksen osalta. 
Taulukko 1. Eri-ikäisten lasten osallistuminen kodin ulkopuoliseen varhaiskasvatukseen OECD maissa (Taguma et al., 2002)

\begin{tabular}{|l|c|c|c|c|}
\hline Maiden vertailu & alle 3-vuotiaat & 3-vuotiaat & 5-vuotiaat & 6-vuotiaat \\
\hline Suomi & $29 \%$ & $46 \%$ & $63 \%$ & $\begin{array}{c}\text { lähes koko } \\
\text { ikäluokka (98\%) }\end{array}$ \\
\hline OECD keskiarvo & $30 \%$ & $63 \%$ & $90 \%$ & $94 \%$ \\
\hline Ruotsi & $47 \%$ & $90 \%$ & $93 \%$ & $\begin{array}{c}\text { koko ikäluokka } \\
\text { koulussa }\end{array}$ \\
\hline Norja & $51 \%$ & $93 \%$ & $97 \%$ & $\begin{array}{c}\text { koko ikäluokka } \\
\text { koulussa }\end{array}$ \\
\hline Tanska & $66 \%$ & $95 \%$ & $86 \%$ & $94 \%$ \\
\hline
\end{tabular}

Vuoden 2012 jälkeen lasten osallistumisaseet varhaiskasvatukseen ovat Suomessa OECD:n tilastoissa hienokseltaan lisääntyneet (Education at a glance 2015, Education at a glance 2018). Vuonna 2016 alle 3 -vuotiaiden suomalaisten lasten osallistumisaste oli $30 \%$, 3- vuotiaiden $73 \%$, 4-vuotiaiden 79\%, 5 -vuotiaiden $84 \%$ ja 6-vuotiaiden $98 \%$. Esiopetusta lukuun ottamatta osallistumisasteet ovat kuitenkin Suomessa jonkin verran alhaisemmat kuin Pohjoismaissa eivätkä yllä OECD-maiden yhteiseen keskiarvoon.

Keskeinen kysymys on, miksi Suomen osallistumisprosentit ovat alemmat moniin OECD -maihin nähden? Eräänä selityksenä voi olla Suomen kansallisen varhaiskasvatuspolitiikan pitkäaikainen kehitystrendi, johon liittyy kotikasvatuksen arvostaminen siinä määrin, että sen katsotaan tavallaan korvaavan kodin ulkopuolisen varhaiskasvatuksen kotihoitoa tukemalla. Ratkaisulla on kuitenkin omat haittansa erityisesti laadun ylläpitämisen ja kehittämisen näkökulmasta käsin. OECD -maiden varhaiskasvatuksen laadun arvioinnissa on korostettu yhtenäisen ja varhain aloitetun varhaiskasvatuksen aloittamisen tärkeyttä. Kokemus on osoittanut, että laatua on vaikea valvoa ja kehittää, mikäli varhaiskasvatussysteemi on sirpaleinen (OECD, 2012). Järjestelmän kirjavuus voi vaikeuttaa esimerkiksi intensiivistä yhteistyötä vanhempiin, kasvatuksen ja opetuksen tavoitteiden yhtenäisyyttä, tavoitteiden toteuttamista, riittävän rahoituksen aikaansaamista, yhtenäisen ja pitkäjännitteisen varhaiskasvatuspolitiikan muodostumista sekä riittävän korkea tasoisen kasvatushenkilöstön ylläpitämistä. Varhaiskasvatuksen kannalta on keskeistä ottaa huomioon koko ikäluokan kasvatukselliset ja opetukselliset tarpeet. Tästä hyötyvät eniten lapset, joiden kehittymistä ja oppimista tuetaan mahdollisimman varhain ja intensiivisesti. Näin voidaan 
lähestyä preventoivasti oppimis- ja kehitysvaikeuksia sekä yhteiskunnalliskulttuurista syrjäytymistä (Starting Strong III, 2012).

Tutkimustoiminnassa varhaiskasvatusta tarkastellaan usein (esim. Spodek \& Saracho, 2005; UNESCO, 2010; NAEYC, 2009) kohdentamalla huomio lasten lähikehitykseen tai pitkän aikavälin kehitykseen. Lähikehyksessä on keskeistä siirtyminen varhaiskasvatuksen ja esiopetuksen kautta koulun alkuun. Pitkän aikavälin kohteena on aikuisuus.

Suomalaisessa kontekstissa varhaiskasvatusta on määritelty lapsen elämänpiirissä tapahtuvana vuorovaikutukseen perustuvana kasvatustoimintana. Käsitteet elämänpiiri ja vuorovaikutus ovat esiintyneet Ojalan (1993) ja Varhaiskasvatussuunnitelman perusteiden (2004) määritelmissä. Kolmas keskeinen käsite suomalaisessa määrittelyssä on viittaus lapsen kehittymiseen (Ojala, 1993). Myös varhaiskasvatussuunnitelman perusteissa (2004) mainitaan lapsen kehitys, mutta mukaan otetaan myös kasvu ja oppiminen. Neljäs määrittelyn kulmakivi on ajatus varhaiskasvatuksen tavoitteellisuudesta (Ojala 1993, Varhaiskasvatussuunnitelman perusteet, 2004). Varhaiskasvatuksen eräänä erityispiirteenä on pitkään pidetty leikkiä ja toiminnallisuutta erotukseksi koulun omaksumaan työtapaan, jossa opettamisen ja tavoitteellisen oppimisen asema korostuu.

Viime aikoina varhaiskasvatusta on ryhdytty tarkastelemaan lisääntyvässä määrin osana osa lapsen elinikäistä kehittymistä. Suurta kansainvälistä huomiota on saanut Cunhan ja Heckmannin (2005) perustelut varhaiskasvatuksen perustavaa laatua olevasta merkityksestä lapsen pitkän aikavälin kehittymiselle. Olettamuksena on, että varhaiskasvatusvuosien aikana lapselle kehittyy perustaitoja, joiden varaan lapsen myöhempi kehittyminen ja elämä voisi perustua. Näitä ovat yhteistyötaidot vertaisryhmään ja aikuisiin, autonomia, taito luoda merkityksiä, luovuus, probleemanratkaisu ja peräänantamattomuus. Pitkän aikavälin lapsen kehittymisen ja oppimisen seurannat, joissa lapsia seurataan varhaiskasvatuksen päättymisen jälkeen jopa aikuisikään asti, täydentävät monelta osin tietoa varhaiskasvatuksen merkityksestä ja vaikutuksista ihmisen kehittymiseen (esim. Schweinhart et al., 2010).

Varhaiskasvatuksen erityispiirteitä etsittäessä on ollut yleistä lähestymistapa, jossa varhaisvuosien merkitys hahmotetaan lapsen kehittymisen ja kasvuun etenemisenä lapsuudesta aikuisikään (esim. Cunha et al., 2005). Tämän vastapainona on yhtä tärkeää hahmottaa varhaiskasvatusta suhteessa niihin olosuhteisiin, joissa lapset elävät ja toimivat. Näin hahmotettuna 
lapsuus itsestään on merkittävää eikä jatkuvaa valmistautumista johonkin, joka lasta odottaa. Näkökulmaa korostetaan lapsuuden sosiologiassa, jossa lapsia lähestytään lapsuuden, osallisuuden ja toimijuuden näkökulmasta (Alanen \& Karila, 2009; Alanen \& Mayall, 2001).

Varhaiskasvatuksen tavoitteena on lapsuuden näkökulmasta ajaa lasten asiaa tavalla, jossa lasta ja lapsuutta tarkastellaan sosiaalisena ilmiönä eräänlaisena vastapainona esimerkiksi kehityspsykologiselle ja kasvatustieteelliselle lähestymistavalle (Alanen \& Karila 2009; Alanen \& Mayall, 2001). Tällöin lapsia ei tarkastella toisistaan erottelevien ominaisuuksien mukaan vaan kiinnittämällä huomiota niihin piirteisiin, jotka ovat heille yhteisiä ja erottavat heidät muista väestöryhmistä. Tavoitteena on hahmottaa ne yhteiskunnalliset prosessit, joiden kautta lapsuudelle muotoutuu sille luonteenomaiset muodot, elämäntavat ja toimintamahdollisuudet. Lapset ymmärretään yhteiskunnallisina toimijoina eikä vain muiden toimijoiden ja yhteiskunnallisten muutosprosessien kohteina. Huomio kohdistetaan lapsuuden kokemiseen, tekemiseen ja rakentumiseen. Esimerkiksi päiväkodissa huomiota voidaan kiinnittää siihen, miten lapset kokevat päiväkodin vuorovaikutussuhteissa heille rakennetun lapsuuden, oman asemansa, toimintamahdollisuutensa ja niiden rajoitukset. Näkemys lapsesta ja lapsuudesta rakentuu sosiaalisesti prosessina, jossa yhteiskunta ja siinä toimivat instituutiot rajaavat ajallisesti ja paikallisesti lapsen ja lapsuuden sosiaalisen aseman.

Lasta ja lapsuutta korostavat myös YK:n lapsen oikeuksien yleissopimus, joka hyväksyttiin vuonna 1989. Suomi liittyi sopimukseen 1991. Sopimuksessa viestitään, että jokaista lasta riippumatta kehittymisen nopeudesta tai hitaudesta tulee pitää ainutkertaisena ja että aikuisten ja yhteiskunnan pitää suojella ja tukea lasta. Lähtökohtana on, että lapsi ruumiillisen ja henkisen kypsymättömyytensä tähden tarvitsee ennen syntymäänsä ja sen jälkeen erityistä turvaa ja huolenpitoa.

\section{Suomalaista varhaiskasvatusta määrittävät lait ja asiakirjat}

Valtakunnallista varhaiskasvatusta ryhdyttiin Suomessa kuvaamaan ja määrittelemään aluksi päivähoidon yhteydessä 1970 -luvun alussa. Tällöin säädettiin laki lasten päivähoidosta (36/1973). Lain mukaan lasten päivähoidossa tulee edistää lapsen kehitystä ja oppimismahdollisuuksia. 
Päivähoitolakiin ei vielä sisältynyt kasvatustavoitteita vaan niihin palattiin vasta 1980-luvun alussa. Taustana oli päivähoidon kasvatustavoitekomitean mietintö (1980), jonka mukaan päivähoidon yhteiskunnalliset tehtävät ovat sekä sosiaalisia että pedagogisia. Yhteiskunnallisissa tavoitteissa korostetaan kotien kasvatustehtävän tukemista ja lapsen kokonaispersoonallisuuden tasapainoista kehitystä. Kasvatustavoitekomitea täsmensi myös päivähoidon kasvatustoimintaa jakamalle ne seitsemään osa-alueeseen asettaen kullekin osa-alueelle omat tavoitteensa. Osa-alueet olivat uskonnollinen, eettinen, älyllinen, esteettinen, emotionaalinen, sosiaalinen ja fyysinen. Mietinnön ehdotukset johtivatkin siihen, että vuonna 1973 säädettyyn lasten päivähoitolakiin lisättiin vuonna 1983 erillinen tavoitepykälä valtakunnallisille kasvatustavoitteille noudatellen mietinnön ehdotuksia.

Uutta täsmennystä varhaisvatukseen ilmaantui vuonna 2004, jolloin julkaistiin varhaiskasvatussuunnitelman perusteet (Varhaiskasvatussuunnitelma 2004). Perusteiden tarkoituksena oli ohjata päivähoidossa toteutettua alle 6 -vuotiaiden lasten kasvatusta, opetusta ja hoitoa. Merkille pantavaa on, että opetus sisällytetään ensimmäistä kertaa virallisella tasolla päivähoidon kasvatustehtäviin. Vuoden 2004 Varhaiskasvatussuunnitelman perusteissa korostetiin varhaiskasvatuksen arvopohjaa ja yleisiä kasvatuspäämääriä. Varhaiskasvatuksen yleiset päämäärät kohdennettiin (a) lapsen henkilökohtaisen hyvinvoinnin edistämiseen, (b) toisten huomioon ottavien käyttäytymismuotojen ja toimintatapojen edistämiseen sekä (c) lapsen itsenäisyyden asteittaiseen lisäämiseen. Toiminnan ja toteutuksen tasolla huomiota kiinnitettiin (a) lapsen hyvinvointiin, (b) hoidon, kasvatuksen ja opetuksen kokonaisuuteen, (c) moniammatilliseen yhteistyöhön, (d) kasvatusympäristön fyysiseen, psyykkiseen ja sosiaaliseen kokonaisuuteen, ( e ) oppimisen iloon, (f) kielen merkitykseen, (g) lapselle ominaiseen tapaan toimia (leikki, liikkuminen, taiteellinen kokeminen ja ilmaisu, tutkiminen) sekä (h) sisällöllisiin orientaatioihin (matemaattinen, luonnontieteellinen, historiallis-yhteiskunnallinen, esteettinen, eettinen ja uskonnollis-katsomuksellinen).

Vuoden 2015 lopussa säädetyssä asteittain voimaantulleessa varhaiskasvatuslaissa (540/2018) varhaiskasvatuksella tarkoitetaan lapsen suunnitelmallista ja tavoitteellista kasvatuksen, opetuksen ja hoidon kokonaisuutta, jossa painottuu erityisesti pedagogiikka. Laki vahvisti varhaiskasvatuksen toimintamuodoiksi päiväkotitoiminnan, perhepäivähoidon ja avoimen 
varhaiskasvatustoiminnan. Lain ehdottamat varhaiskasvatuksen tavoitteet muodostavat perustan vuonna 2016 laadituille varhaiskasvatussuunnitelman perusteille, jota tarkastellaan tämän julkaisun luvussa 4 .

Varhaiskasvatuslain myötä myös suomalaisen varhaiskasvatuksen ohjausjärjestelmä on täsmentynyt ja uudistunut (Mikkola ym. 2017). Ohjausjärjestelmä on moniportainen sisältäen sekä varhaiskasvatuksen järjestämisen että laadunarvioinnin velvoitteet. Normiohjauksen keskiössä ovat varhaiskasvatuslaki ja päivähoitoasetus, laki varhaiskasvatuksen asia-kasmaksuista, varhaiskasvatuksen järjestämistä koskeva sosiaalihuollon alainen lainsäädäntö sekä varhaiskasvatussuunnitelman perusteet (2016). Varhaiskasvatuksen kansallisen ohjauksen tärkein väline on lainsäädännön ohella varhaiskasvatussuunnitelman perusteilla. Ohjausjärjestelmään ku-luvaa laadun arviointia tarkastellaan tässä julkaisussa syventävästi omana kokonaisuutenaan.

Ohjausjärjestelmään liittyy henkilöstömitoitus, jonka ei ole ollut päivähoitoa järjestettäessä sitova. Tilanne on muuttunut varhaiskasvatuslain säätämisen myötä. Toinen keskeinen asia ohjausjärjestelmässä kohdistuu opettajakelpoisuusuuteen, josta myös säädetään varhaiskasvatuslaissa (540/2018). Lain mukaan kasvatuksesta ja opetuksessa vastaavat päiväkodin osalta varhaiskasvatuksen opettaja, varhaiskasvatuksen sosionomi, varhaiskasvatuksen lastenhoitaja sekä varhaiskasvatuksen erityisopettaja. Varhaiskasvatuksen opettajalla tulee olla vähintään kasvatustieteiden kandidaatin kelpoisuus ja varhaiskasvatuksen sosionomilla vähintään sosiaali-ja terveysalan ammattikorkeakoulututkinto, johon sisältyy varhaiskasvatukseen ja sosiaalipedagogiikkaan suuntautuneet vähintään 60 opistopisteen laajuiset opinnot. Lastenhoitajalla on oltava kasvatus- ja ohjausalan perustutkinto, sosiaali- ja terveysalan perustutkinto tai muu vastaava tutkinto. Varhaiskasvatuksen erityisopettajalla tulee olla kasvatustieteen maisterin tutkinto pääaineena erityispedagogiikka tai kelpoisuus varhaiskasvatuksen opettajan tehtäviin, joista säädetään asetuksella. Päiväkodin toiminnasta vastaa johtaja, jolla on tehtävään soveltuva kelpoisuus, vähintään maisterin tutkinto ja riittävä johtamistaito.

Myös päiväkotien lapsiryhmien enimmäiskoko ja henkilöstömitoitus säädetään varhaiskasvatuslaissa (450/2018) ja siihen liittyvässä valtioneuvoston asetuksessa. Säädösten mukaan yhdessä päiväkodin ryhmässä saa olla korkeintaan kolmea kasvattajaa vastaavaa määrää lapsia. Kasvattajia voi tarvittaessa olla enemmän. Tämä tarkoittaa käytännössä sitä, että 
- alle 3-vuotiaiden ryhmässä voi olla korkeintaan 12 lasta (1 kasvattaja / 4 lasta)

- yli 3-vuotiaiden ryhmässä korkeintaan 24 lasta (1 kasvattaja / 8 lasta, ellei kunta ole erikseen päättänyt pitäytyä aikaisemman lainsäädännön mukaisessa mitoituksessa 1 kasvattaja /7 lasta, jolloin ryhmässä on korkeintaan 21 lasta)

- Yli 3-vuotiaiden osapäivähoidossa 1 kasvattaja / 13 lasta.

Varhaiskasvatuksen suunnittelun ja arvioinnin käynnistäminen määrätään laissa opetushallituksen tehtäväksi, jonka velvollisuutena on laatia varhaiskasvatussuunnitelman perusteet yhteistyössä eri tahojen kanssa. Lakiin on kirjattu myös paikallisen ja lapsen varhaiskasvatussuunnitelman laatiminen. Varhaiskasvatuksen arvioinnista todetaan, että sen tarkoituksena on turvata lain tarkoituksen toteutumista, tukea varhaiskasvatuksen kehittämistä sekä edistää lapsen kehityksen, oppimisen ja hyvinvoinnin edellytyksiä. Varhaiskasvatuksen järjestäjälle ja tuottajalle asetetaan velvoite annetun varhaiskasvatuksen arviointiin sekä velvoite osallistua ulkopuoliseen toiminnan arviointiin.

\section{Esiopetus}

Esiopetuksesta säädetään Suomessa perusopetuslain yhteydessä. Vuonna 2014 säädettiin laki perusopetuslain muuttamisesta esiopetuksen osalta (1040/2014). Lakia ryhdyttiin soveltamaan vuonna 2015. Tällä lainsäädännöllä esiopetus on muuttunut velvoittavaksi. Uuden lain mukaan lapsen on osallistuva oppivelvollisuuden alkamista edeltävänä vuonna vuoden kestävään esiopetukseen tai muuhun esiopetuksen tavoitteet saavuttamaan toimintaan. Laki sallii myös sen, että vanhemmat voivat myös itse järjestää lapsen esiopetuksen edellyttäen, että lapsi saavuttaa esiopetuksen opetussuunnitelman perusteissa asetetut tavoitteet. Tämä periaate on myös sisällytetty oppivelvollisuuden suorittamiseen. Esiopetusta säätelevän lain tavoitteena on opetus- ja kulttuuriministeriön mukaan parantaa lasten oppimisedellytyksiä ja lisätä koulutuksellista tasa-arvoa saamalla koko ikäluokka esiopetuksen piiriin.

Esiopetusta voidaan järjestää päiväkodissa, koulussa tai muussa soveltuvassa paikassa. Pidennetyn oppivelvollisuuden piirissä olevien lasten on osallistuttava esiopetukseen oppivelvollisuuden alkamisvuonna. Näillä 
lapsilla on myös oikeus saada esiopetusta sinä vuonna, kun he täyttävät viisi vuotta. Velvoittavuudesta huolimatta esiopetus ei kuitenkaan ole osa oppivelvollisuutta. Esiopetuksen laajuus on vähintään 700 tuntia (Esiopetuksen järjestäminen, Opetushallitus 2019). Päivittäinen tuntimäärä on keskimäärin 4 tuntia päivässä, mutta yhteen päivään saa kuulua enintään viisi tuntia. Maksuttomuus koskee myös kuljetusta, jos matka on yli viisi kilometriä tai jos se todetaan lapselle liian vaikeaksi, rasittavaksi tai vaaralliseksi.

Esiopetuksen henkilöstömitoitus suhteessa lapsiryhmään perustuu opetus- ja kulttuuriministeriön suositukseen. Suosituksen mukaan yhden opettajan esiopetusryhmässä saa olla enintään 13 lasta. Jos ryhmässä on toinen opettaja, lapsia saa olla enintään 20. Päiväkodeissa järjestettävään esiopetukseen sovelletaan varhaiskasvatuslain säädöksiä ryhmäkoosta ja henkilöstömitoituksesta.

Esiopetuksen kehittämiseksi opetushallitus on ryhtynyt selvittämään siirtymistä kaksivuotiseen esiopetukseen (Holappa ym., 2019). Selvityksessä käsitellään lainsäädännön ja opetussuunnitelman muutostarpeita ja esitetään tulevaisuuden eri vaihtoehtoja. Johtopäätöksenä esitetään, että esiopetusta tulisi kehittää joka tapauksessa riippumatta siitä, muuttuko tämä 2-vuotiseksi. Selvityksessä viestitään myös, että 2-vuotinen esiopetus voisi lisätä kasvatuksen ja oppimisen tasa-arvoa maassamme.

\section{Perusopetus}

Perusopetuslaissa säädetään pääsääntöisesti perusopetuksesta ja oppivelvollisuudesta. Tämän lisäksi siinä säädetään myös esiopetuksesta, lisäopetuksesta, maahanmuuttajille järjestettävästä valmistavasta opetuksesta sekä aamu -ja iltapäivätoiminnasta. Perusopetusta annetaan yleensä 7-16 vuotiaille peruskoulussa, joka käsittää vuosiluokat 1-9. Kuuden ensimmäisen vuoden aikana opetusta antaa yleensä luokanopettaja ja kolmen seuraavan aika aineenopettajat. Lukuvuodessa on 190 työpäivää.

Perusopetuslain (21.8.1998/628) mukaan tavoitteena on tukea oppilaiden kasvua ihmisyyteen ja eettisesti vastuunkykyiseen yhteiskunnan jäsenyyteen sekä tarjota oppilaille elämässä tarpeellisia tietoja ja taitoja. Lain mukaan perusopetuksen tulee myös edistää sivistystä ja tasa-arvoisuuta yhteiskunnassa sekä oppilaiden edellytyksiä osallistua koulutukseen ja itsensä 
kehittämiseen elämänsä aikana. Perusopetus on kaikille maksutonta. Laki korostaa myös riittävän yhdenvertaisuuden turvaamista koko maassa.

Perusopetuslaissa määritellään myös oppilasryhmien koko. Erityistä tukea saavien oppilasryhmien koko voi olla enintään 10 ja pidennetyn oppivelvollisuuden 8-6 riippuen erityisen tuen tarpeesta. Jos erityisen tuen saaneita oppilaita integroidaan normaaleihin opetusryhmiin näiden koko on enintään 20. Edellä mainittujen oppilasryhmien koko voidaan kuitenkin ylittää opetuksen järjestäjien perustelujen pohjalta.

Uusimpien OECD-tilastojen (Education at a glance, 2019) mukaan suomalaisessa perusopetuksessa opiskellaan keskimääräistä pienemmissä opetusryhmissä (Opetushallitus 2019, päivitetty 08.10. 2019). Alaluokkien (vuosiluokat 1-6) ryhmäkoko on Suomessa keskimäärin 19,6 oppilasta, kun OECD-maiden keskiarvo on 21,1 oppilasta. Myös yläluokkien (vuosiluokat 7-9) ryhmäkoko jää Suomessa alle OECD-maiden keskiarvon. Tiedot ovat vuodelta 2017.

Arvioinnin osalta perusopetuslaissa kohdistetaan huomio sekä koulutuksen että oppilaan arviointiin. Opetuksen järjestäjällä on velvollisuus arvioida antamaansa koulutusta. Kansallisen koulutuksen arvioinnista vastaa Kansallisen koulutuksen arvioitikeskus tästä säädetyn lain mukaisesti (1295/2013).

\section{Julkaisun näkökulma varhaiskasvatukseen}

Varhaiskasvatuksen erityispiirteiden tarkastelun avulla olemme voineet päästä ainakin alustavaan ymmärrykseen niistä tunnusmerkeistä, joiden varaan varhaisvuosien kasvatus ja opetus rakentaa omaa identiteettiään. Erityispiirteiden tunnistaminen on tarpeen alan kehittymiselle tutkimuksena, oppiaineena ja käytäntönä. Vaikka näillä kolmella tehtävällä on omat erityisluonteensa ja perusteensa, jotka kaikissa suhteissa eivät ole yhteismitallisia, alan kehittymiselle on tärkeää pyrkiä tunnistamaan varhaiskasvatukseen liittyvät erityispiirteet.

On tärkeää tiedostaa, että varhaiskasvatuksen yksiselitteinen kuvaaminen on vaativaa, aukollista ja kulttuurisidonnaista. Tieteellinen lähestymistapa on usein väljempää kuin esimerkiksi kansalliset lähestymistavat. Nojautuen edellä käsiteltyihin näkemyksiin varhaiskasvatuksessa on kysymys lapsen ja kasvatusympäristön vuorovaikutukseen perustuvasta tavoitteellisesta kasvatus- ja opetustoimista, jossa lapsuutta tuetaan osallisuuden ja 
toimijuuden näkökulmasta. Kodin ulkopuolinen varhaiskasvatus perustuu pedagogisiin ohjelmiin, joiden tarkoituksena on tukea ja edistää kokonaisvaltaisesti lapsen hyvinvointia, kehittymistä ja oppimista. Varhaiskasvatus luo perustan lapsen kouluun siirtymiselle ja hänen myöhemmälle koko eliniän kattavalle kehittymiselleen ja oppimiselleen. Koti ja lapsen huoltajat vaikuttavat merkittävästi lapsen kehittymiseen ja oppimiseen erityisesti varhaislapsuudessa mutta myös myöhemmin. Varhaiskasvatuksen peda-gogiselle toiminnalle on tunnusomaista tavoitteellisuus, toiminnallisuus ja leikin merkitys. Huomion kiittäminen lapsen perushoitoon ja tunnesitee-seen häntä hoitaviin aikuisiin on erityisen tärkeää erityisesti lapsen kehit-tymisen varhaisvaiheessa.

Tässä julkaisussa varhaiskasvatusta hahmotetaan lapsen kehittymisen, oppimisen ja opettamisen jatkumona kattaen lapsen ensimmäiset 8 ikävuotta. Jatkumoa tarkastellaan oppimis- ja kehityspsykologisten teorioiden, kasvatus- ja opetussuunnitelmien, kouluvalmiuden, laadun, lapsen hyvinvoinnin ja osallisuuden, leikin, monikulttuurisuuden, tasa-arvon sekä pedagogisen kehittämisen näkökulmista. Koulutusjärjestelmän tasolla kirjan lähestymistapa pyrkii identifioimaan kasvatuksen ja opetuksen erityispiirteitä varhaiskasvatuksessa, esiopetuksessa ja perusopetuksen alkuvaiheessa (vuosiluokat 1-2). 


\section{Näkökulmia lapsen kehitykseen ja oppimiseen}

\section{Oppimisen ja kehittymisen dynaamisuus}

Kehittyminen ja oppiminen muodostavat toinen toisiinsa kietoutuneen kokonaisuuden ja niiden välinen suhde kiinnostaa tutkijoita ja lasten kanssa toimivia. Kumpaankin ilmiöön liitetään hieman eri tavoin painottuneita ominaisuuksia. Kun kuvaamme oppimista saatamme puhua rutiininomaisesta oppimisesta, luovasta oppimisesta, ongelmanratkaisukeskeisestä oppimisesta, tiettyjen taitojen oppimisesta, yksilöllisestä oppimisesta, kollektiivisesta oppimisesta jne. Kehittymiseen liitetään puolestaan sellaisia ominaisuuksia kuten kypsyminen (esim. koulukypsyys), lapsen ikä, kehitysvaiheet, kehityskriisit, kehityksen dynamiikka jne. Kehittymiseen liitetään usein jotain universaalista, joka yhdistää lapsia yli kulttuureiden olettaen, että kehittyminen etenee tietyssä iässä tiettyjen vaiheiden kautta riippumatta suurestikaan siitä missä lapsi elää ja varttuu. Oppimiseen liitetään sen sijaan usein mielikuvia sen sidonnaisuudesta ympäristöön ja opettamiseen. Usein oletamme, että voimme säädellä ja ohjata lapsen oppimista tarkemmin ja määrätietoisemmin kuin kehittymistä.

Kasvatus- ja opetussuunnitelmien tavoiteasettelu perustuu paljolti näkemyksiin oppimisesta eikä niinkään kehittymisestä. Esimerkiksi maamme varhaiskasvatus- ja opetussuunnitelmiin liitetty ajatus lapsen yksilöllisestä oppimissuunnitelmasta ei niinkään liity kehittymiseen vaan oppimiseen. Voi myös havaita, että mielenkiinto kehittymiseen on voimakasta erityisesti lapsen ollessa pieni. Esiopetus ja erityisesti koulu tuo mukanaan yhä määrätietoisemmin oppimisen näkökulman.

Kehittymistä ja oppimista koskeviin käsityksiin ovat vaikuttaneet niitä kuvaavat ja selittävät teoriat. Asian tekee haastavaksi se, että oppimiselle on pyritty kehittämään ikään kuin omia teorioita ja samoin on laita kehittymisen. Lisäksi kumpaakin varten on useita teorioita. Tässä julkaisussa lähdetään siitä, että erityisesti varhaisina elinvuosina lapsen kehittyminen ja oppiminen liittyvät läheisesti yhteen, joten niiden teoreettisia ulottuvuuksia on mielekästä tarkastella dynaamisesti suhteessa toinen toisiinsa. Jossain teorioissa korostuu näkyvämmin kehittyminen ja joissain puolestaan oppiminen. Yleisellä tasolla kummankin ilmiön taustalla ovat lapsen 
sisäiset kehittymisen ja oppimisen syvärakenteet, jotka ovat aktiivisessa ja dynaamisessa vuorovaikutuksessa ympäristöön.

Varhaiskasvatuksen, esiopetuksen ja koulun alun kohteena on oppiva ja kehittyvä lapsi, josta varhaiskasvattajat, opettajat, vanhemmat sekä kasvatuksen ja opetuksen järjestäjät tarvitsevat monipuolista tietoa. Tämä tieto kohdistuu etenkin seuraavaan kolmeen peruskysymykseen: mitä tiedämme lapsen kehittymisestä ja oppimisesta, mitä tiedämme kunkin lapsen yksilöllisestä kehittymisestä, ja mitä tiedämme siitä sosiaalisesta ja kulttuurisesta ympäristöstä ja olosuhteista, jossa lapsi kasvaa ja kehittyy (Developmentally appropriate practice in early childhood programs serving children from birth through age 8, 2009).

Lapsen oppimisen ja kehittymisen perusmekanismeja kuvataan tässä julkaisussa kahdessa toisiinsa liittyvässä ulottuvuudessa. Näistä toisessa tarkastellaan oppimista ja kehittymistä kuvaavia ja selittäviä lähestymistapoja (esim. Phillips \& Soltis, 2004; Hedegaard et al., 2012). Tämän jälkeen oppimista ja kehittymistä tarkastellaan syventävästi kehitykseen ja oppimiseen liittyvien taitojen ulottuvuudessa (luku 3).

\section{Miten oppimista ja kehittymistä on pyritty selittämään?}

\section{Varhaisia selitysyrityksiä}

Varhaisimpia oppimisen ja sitä kautta myös kehittymisen selityksiä ovat esittäneet Platonin ja Locke (Phillips \& Soltis, 2004). Oppimisen yhteydessä Platon pohti sitä, miten joku ihminen voi oppia uutta. Platon päätyi siihen, että oppimisen ja uuden tiedon tulee perustua johonkin, jonka ihminen jo pohjimmiltaan tietää. Nykysinkin esitetty ajatus sitä, että oppiminen ankkuroituu aiemmin opittuun, perustuu monelta osin Platonin ajatuksiin. Platonille oppiminen oli siis jotain sisäistä, jonka lapsi saa jo syntymästä. Hän mielsi oppimisen sellaiseksi, jonka avulla niin lapsi kuin aikuinen voi kehittyä ja oppia näkemään selkeämmin asioita. Platonin tulkinnassa oppiminen liittyi ajatteluun, jota ihminen voi tai hänen tulisi harjoittaa huolimatta siitä, että ihminen saa jo syntymässä tietyn valmiuden oppimiseen ja tietämiseen. Vailla selitystä jää kuitenkin se, mistä jo olemassa oleva tieto itse asiassa voisi olla peräisin? 
Platonia selkeämmin oppimisen ja tätä kautta myös kehittymisen perusluonteen hahmottamiseen ovat vaikuttaneet Locken esittämät ajatukset. Käsitys on vastakkainen verrattuna Platonin tulkintaan: oppiminen perustuu ympäristön aikaansaamiin kokemuksiin. Lähtökohtana on, että vastasyntynyt lapsi ei tiedä mitään. Mutta heti syntymän jälkeen lapsi hankkii aistiensa avulla yhä uusia ja uusia kokemuksia. Näin lapsi oppii havaitsemaan, mieltämään yhä laajempia ja monimutkaisimpia asioita ja kokonaisuuksia. Kehon tapaan lapsen mieli omaa potentiaalin, joka ympäristön ärsykkeiden, kokemusten ja muistin avulla kasvaa ja kehittyy. Locken ideaa on myöhemmin hyödynnetty esimerkiksi rikastuttamisohjelmissa (esim. Head start, Sesame street, Montessori materiaalit), joissa on pyritty tarjoamaan aistimuksiin perustuvia oppimiskokemuksia lapsille, jota varttuvat virikeköyhässä ympäristössä.

\section{Behaviorismin tulkinta}

Behavioristisen käsityksen mukaan oppiminen ja tätä kautta myös kehittyminen mahdollistuvat ympäristön aikaansaamista vaikutteista ja siitä, miten lapsi reagoi niihin (esim. Phillips \& Soltis, 2004; Skinner, 1953). Onnistuneet reaktiot vahvistavat oppimista ja epäonnistuneet sammuttavat (vaikutuksen laki). Tunnustus ja palkinnot vahvistavat oppimista ja suuntavat sitä toivottuun suuntaan. Näin lapsi oppii toimimaan oppimistilanteissa päämäärähakuisesti. Behaviorismilla on ollut laaja vaikutus lasten kasvatukseen ja opettamiseen: oppiminen perustuu harjoitteluun, oppimistehtävät suunnitellaan asteittain vaikeutuviksi, lapsen oppimispolkua on tarpeen ohjata opettamisen, kannustamisen ja palautteen avulla jne. Behaviorismi on vahvistanut käsitystä siitä, että oppiminen on monessa suhteessa yksilöllistä. Behaviorismin myötä on vahvistanut käsitys siitä, että oppimista voidaan tehokkaasti ohjata myös ohjelmoitujen opetuspakettien avulla (esim. multimedioiden käyttö).

Behaviorismin olettamuksena on, että oppimisen taustalla ovat ehdollistumiseen perustuvat mekanismit, jotka aktivoituvat ulkoisista ärsykkeistä. Periaatteessa mikä tahansa ärsyke voi yhdistyä tai ehdollistua tiettyyn reaktioon tai suoritukseen, kun tämä yhteys saa vahvistusta. Eräät teoreetikot, kuten esimerkiksi Vygotsky (1978), mieltävät behaviorismin kuvaamat oppimismekanismit niin, että niiden avulla voidaan kuvata ja selittää alemman tason oppimista. Tällainen oppiminen perustuu lähinnä assosiaatioihin 
ja on suhteellisen mekaanista. Behavioristinen käsitys oppimisesta on lähes täysin vastakkainen Platonin ideoiden kanssa. Oppiminen tulkitaan ja sitä ohjataan lapsen ulkoisen käyttäytymisen avulla. Tämä on tukenut mielikuvaa siitä, että niin oppiminen kuin opettaminenkin ovat perusperiaatteiltaan helppoja. Tässä lienee eräs syy sen saamaan suosioon. Behaviorismin avulla on kuitenkin vaikea selittää oppimiseen liittyvää syvällisempää ymmärrystä, jota tarvitaan esimerkiksi lukemisessa. Lukemisen yhteydessä lapsi kohtaa jatkuvasti lauserakennelmia, joihin hän saa ymmärryksen, vaikka hän kohtaa ne ensimmäistä kertaa.

\section{Oivaltava oppiminen}

Behaviorismin sivuuttamaa korkeamman tason oppimista ovat analysoineet muiden ohella uraa uurtavalla tavalla hahmopsykologit (esim. Phillips $\&$ Soltis, 2004). Huomio on suunnattu oppijan sisäisiin oppimismekanismeihin, joihin liittyy ajattelua, kokeilua, ennakointia, testaamista jne. Tällaisen prosessin kuluessa syntyy autenttisia oivalluksia, jotka viestivät että, 'nämä liittyvät yhteen', 'näinhän tämä menee', 'keksin ratkaisun' jne. Tapa tarkastella oppimista irtautuu oppimisympäristöstä ja käyttäytymisestä. Hahmopsykologien havainnot ja selitykset oppimisesta ovat luoneet pohjaa probleemanratkaisuun perustavalle oivaltavalle oppimiselle, jossa korostetaan oppijan aktiivista ajattelua ja pohdintaa. Hahmopsykologien viesti lapsen oppimiselle on: jokainen lapsi on aktiivinen oppija sekä ajatuksiltaan että toiminnoiltaan. Mutta myös hahmopsykologien tulkintaan liittyy aukkoja. Lähestymistapa ei selitä juurikaan sitä, millaisia perusrakenteita lapsi tarvitsee probleemanratkaisutyyppiseen oivaltavaan oppimiseen, miten oppimisympäristö voi tukea keksivää oppimista, millaisia aikaisempia oppimiskokemuksia tai taitoja tarvitaan jne. Hahmopsykologien havainnot eivät nekään vastaa kysymykseen, mitä oikeastaan lapsessa tapahtuu oppimisen aikana.

\section{Lapsi kiinnostuu probleemanratkaisusta}

Hahmopsykologien tapaan Dewey (1933) kiinnitti huomiota probleemanratkaisutyyppiseen oppimiseen antaen sille kuitenkin yksityiskohtaisempia tulkintoja (esim. Phillips \& Soltis, 2004). Keskeisen merkityksen Dewey kohdisti lapsen tekemiseen ja oppimiskokemusten mielekkyyteen. Jos 
nämä elementit puuttuvat oppimisessa, lapsi kokee oppimisen keinotekoiseksi eikä lapsi aktivoi oppimisen syväprosesseja. Näihin kuuluu aktiivisuus, probleemanratkaisu ja oman oppimisen reflektointi. Dewey korosti sitä, että oppiminen perustuu lapsen dynaamiseen eikä edeltä käsin määriteltyyn tavoiteasetteluun, joka ohjautuu, jäsentyy ja muuntuu aktiivisen tekemisen, toiminnan ja oppimiskokemusten myötä (esim. Ojala, 2009; Ojala \& Venninen, 2011).

Deweyn tulkinnat ovat rikastuttaneet merkittävästi probleemanratkaisuun perustuvaa oppimista. Huomiota on saanut oppimisen luovuus ja joustavuus ja se, että aktiivinen probleemanratkaisu kiinnittyy lapsen omakohtaisiin kysymyksiin. Probleemanratkaisussa ei useinkaan voi edetä suoraviivaisesti vaan siinä palataan takaisin, keksitään uusia osaratkaisuja, testataan niitä, hankitaan uutta tietoa jne. Toisin kuin hahmopsykologit, Dewey kiinnitti huomiota oppimisympäristöön korostaen sen yhteiskunnallista ja sosiaalista merkitystä oppijalle. Probleemakeskeisen oppimismekanismin kautta tavoitteena on kasvattaa lapsista aktiivisia oppijoita ja yhteiskunnallisia toimijoita. Probleeman kautta etenevästä lapsen oppimisesta ja kehittymisestä ovat nyttemmin olleet kiinnostuneita varhaiskasvatuksessa erityisesti Reggio Emilian pedagogit (esim. Ojala, 1993; Ojala, 2009).

\section{Lapsi konstruoi omaa oppimistaan ja kehittymistään}

Lisääntyvää huomiota lapsen oppimisen ja kehittymisen sisäisiin rakenteisiin ja prosesseihin on saatu konstruktivismiin kiinnittyvän teoriasuuntauksen avulla. Varhaisoppimista silmällä pitäen tätä suuntausta voi lähestyä Piaget'n kehittämän teorian avulla (esim. Piaget, 1969). Hänen teoriaansa voi tarkastella sekä oppimisteoriana että kehityspsykologisena teoriana.

Kun teoriaa pyrkii luonnehtimaan lyhyesti, keskeisenä voi pitää sisäisiä rakenteita, jotka jäsentyvät ja kehittyviä oppimisen yhteydessä. Oletuksena on, että nämä rakennelmat jäsentävät tapaa, jolla lapsi kohtaa ulkoisen maailman. Oppimisen ja kehittymisen ytiminä ovat asteittain kypsyvät sisäiset rakennelmat, joilla lapsi muodostaa ja hienosäätää aktiivisesti ulkoista maailmaansa tavoitellen tasapainoa tai mukautumista ulkoisen ja sisäisen maailmansa välillä. Piaget'n teoria tarjoaa kuvauksia ja selityksiä erityisesti käsitteiden muodostumisesta sekä loogisen päättelyn ja ajattelun mekanismeista. 
Piaget'n käsitykset ja tulkinnat lapsen kehittymisen ja oppimisen ydinaineksista eivät saa varauksetonta hyväksyntää (esim. Phillips \& Soltis, 2004). Oletus kehittymisen ja oppimisen universaalisuudesta askarruttaa ja jättää ympäristöön ja kulttuuriin liittyvät tekijät taka-alalle. On myös kysytty, mitä oikeastaan itse asiassa merkitsee tasapainomekanismi, jonka avulla lapsen oletetaan liitettävän olemassa oleviin rakennelmiin niitä osin vahvistavia ja osin muuttavia elementtejä. Piaget kyllä kuvaa tätä prosessia, mutta ei juuri anna selitystä miksi se on olemassa. Ehkä vielä olennaisempi kysymys on, mistä tällainen mekanismi on peräisin, miten se on tullut lapsen sisäisiin rakenteisiin? Piaget nimittäin olettaa, että niitä ei aluksi ole lapsella. Myös Piaget'n käyttämä avoin ja tulkinnallinen lapsen haastattelumenetelmä (kliininen haastattelu) on epäilyttänyt. Voiko sen perusteella tehdä universaaleja yleistyksiä?

Piaget'n teoriaa käsitellään yksityiskohtaisemmin tässä kirjassa asiayhteydessä, jossa tarkastellaan lapsen kognitiivisten taitojen oppimista ja kehittymistä.

\section{Sosiaalinen ympäristö kanavoi oppimista ja kehittymistä}

Sosiaalisen ympäristön merkitystä lapsen oppimiselle korosti jo Dewey (1933). Huomattavaa lisätulkintaa ja perusteluita sosiaalisen ympäristön ja vuorovaikutuksen merkityksestä on tuonut Vygotsky (esim. Vygotsky, 1978). Tutustuttuaan Piaget'n teoriaan Vygotsky teki merkittäviä päätelmiä (Phillips \& Soltis, 2004). Hän päätteli, että Piaget'n hahmottavat kognitiiviset prosessit ja siirtymät eivät voi syntyä itsestään ja itseohjautuvasti. Vygotsky päätteli, että oppiminen tarvitsee sosiaalisia puitteita ja toimintaympäristöjä, joissa lapsi saa ohjausta ja opetusta. Erityistä huomiota hän kohdisti lapsen oppimisen potentiaaliin. Viitaten Piaget'n pelkistämiin oppimisen ja kehittymisen vaiheisiin Vygotsky päätteli, että kaksi samalla kognitiivisella tasolla olevaa lasta voivat olla oppimispotentiaaliltaan erilaisia. Oppimispotentiaali aktivoituu lapsen vuorovaikutuksesta toisiin, joilta lapsi oppii paljon havainnoinnin ja jäljittelyn avulla. Erityisen merkittävänä Vygotsky pitää kieltä ja muita kulttuurin luomia välineitä, joiden avulla lapsi oppii käsitteitä, symboleita, loogista päättelyä, lukuja jne. Nämä kaikki ovat tärkeitä rakennusaineita lapsen ajattelulle ja päättelylle. Nämä mahdollistavat lapselle käsitteellisesti korkeamman tason oppimisen, probleeman ratkaisun ja uusien taitojen oppimisen. Kuten Piaget'n teoriaa 
niin Vygotskyn teoriaa tarkastellaan tässä esityksessä seikkaperäisemmin lapsen kognitiivisten taitojen oppimisen ja kehittymisen yhteydessä.

\section{Miten kognitiotiede lähestyy oppimista ja kehittymistä?}

Piaget'n ja Vygotskyn uraauurtavien havaintojen pohjalta tutkijoilla on ollut lisääntyvää mielenkiintoa saada lisäselvyyttä kognitiivisten toimintojen rakenteista ja niiden käytöstä oppimisessa. Mielenkiinnon kohteina on ollut löytää oppimiselle jäsentäviä periaatteita (esim. advance oragizers, Ausubelin idea), jotka voidaan tarjoa lapsen oppimisen ja kehittymisen käsitteelliseksi tueksi. Eräät tutkijat (esim. Bruner) päätyivät toteamukseen, jonka mukaan oppijalla tulisi olla käytössään yleinen ymmärrys oppimisen kohteena olevasta ilmiöstä, jotta hän voisi soveltaa oppimaansa uuteen tilanteeseen. Kognitiivisia rakenteita on pohdittu myös suhteessa eri oppiaineisiin. Olettamuksena on ollut, että kullakin tiedonalla tai oppiaineksella voisi olla oma rakenne, jonka ohjaamana oppiminen ja opettaminen voisivat edetä (esim. Hirst). Esimerkiksi voisi ottaa vaikkapa matematiikan, jossa lukujonokäsitteen ymmärtämistä pidetään keskeisenä monien muiden matemaattisten taitojen oppimiselle. Toisena esimerkkinä on vuoden 2004 Varhaiskasvatuksen perusteet, jossa varhaisoppimiseen liittyviä tiedonaloja ja oppiaineksia on pyritty jäsentämään orientaatioiksi hyödyntämällä Hirstin ajatuksia. Tiedon jäsentämistä on viime aikoina pyritty toteuttamaan myös käsikarttojen avulla.

Moderni kognitiotiede on merkinnyt paljon oppimisen ja kehittymisen dynamiikan selvittämiselle (esim. Phillips \& Soltis, 2004). Taustalla ovat olleet havainnot oppimisprosessin erityispiirteistä. Keskeistä on ollut tutkimustieto, jossa kohteena on ollut informaation prosessointi. Prosessoinnissa on rakenteita, jotka paikallistuvat tiettyihin aivonalueisiin. Kysymyksessä on kokonaisvaltainen ja dynaaminen prosessointi, joka aktivoi tarkkaavaisuutta, havaintojen tekemistä, muistia, probleemanratkaisua, ajattelua ja päättelyä, tiedon arviointia jne. Oppimisprosessi on myös joustavaa ja sitä työstetään oppimistehtävien ja tilanteiden mukaisesti. Päätelmänä on ollut, että oppimisessa työstetään erilaisia oppimisen strategioita ja että lapsen tietoisuus (metakognitio) näistä voi muuttaa oppimisen mielekkäämmäksi ja syvemmäksi. Tietoisuuselementistä onkin tullut väline lähestyä lapsen oppimista. Varhaisoppimisessa huomiota ovat saaneet esimerkiksi lapsihaastattelut, joissa lapset reflektoivat oman oppimisensa sisältöä ja 
tapojaan oppia (esim. Pramling, 1990). Toisena esimerkkinä voi mainita kielellisen tietoisuuden, jonka dynamiikkaa ja merkitystä tarkastelemme tässä teoksessa tarkemmin kielellisten taitojen yhteydessä. Palaamme myös informaation prosessointiin silloin, kun tarkastelun kohteena ovat lapsen kognitiiviset taidot. Kognitiotieteeseen liittyen tarkastelemme seikkaperäisemmin tässä luvussa myös neuropsykologien tekemiä havaintoja oppimisen dynamiikasta.

Kognitiotieteen tarjoamaa näkökulmaa oppimiseen on epäilty tai kritisoitu. On kysytty mikä on sellaisten affektiivisten elementtien osuus kuin motivaatio tai tunteet oppimisessa. Myös minäkuvan ja millainen käsitys lapsella on itsestään oppijana jäävät taka-alalle. Taka-alalle jää myös oppimisen sosiaalinen ulottuvuus, jonka oletetaan monella tavoin kanavoivan ja ohjaavan lapsen oppimista.

\section{Oppimisen ja kehittymisen neuropsykologinen perusta}

Kehityspsykologisen tutkimuksen uutta aluetta edustaa 1960-luvulla käynnistynyt neuropsykologinen tutkimus, joka on neurotieteen osa-alue (esim. Mariën \& Abutalebi, 2008). Tarkoituksena on ymmärtää, kuinka aivojen rakenne ja sen toiminnot ovat yhteydessä kognitiivisiin ja psykologisiin prosesseihin (esim. ajattelu, päättely, käsitteenmuodostus, oppiminen, emootiot ja käyttäytyminen). Kohteena ovat sekä normaalit että viivästyneet kognitiiviset ja psykologiset toiminnot sellaisina kuin ne ilmenevät elinkaaren eri vaiheissa.

Neuropsykologien tutkimus on osoittanut, että lapsen kolmen ensimmäisen elinvuoden aikana aivoissa ja niiden toiminnoissa tapahtuu hämmästyttävää kasvua. Vastasyntyneen aivot painavat noin 25 prosenttia aikuisen aivoista, mutta aivoihin on jo muodostunut noin 100 biljoona aivosolua valmiina aktivoitumaan. Kolmanteen ikävuoteen mennessä aivoihin on muodostunut biljoonia soluja ja sata triljoonaa aivosolujen (neuronit) välistä synapsista yhteyttä. Kehittymisen nopeutta voi kuvata havainnolla, jonka mukaan voimakkaassa kehittymisen vaiheessa muodostuu 250000 neuronia joka minuutti. Aivojen potentiaali varhaiseen oppimiseen ja kehittymisen on siis uskomaton ja käytännössä rajaton.

Lapsen varhaisen kehittymisen ja oppimisen perusta on neuronien välisissä yhteyksissä, jotka aktivoituakseen tarvitsevat kokemuspohjaista vuorovaikusta ulkoiseen maailmaan. Varhaiset kokemukset välittyvät 
aistien välityksellä (näkeminen, kuuleminen, haistaminen, koskettelu) ja ne pitävät yllä, aktivoivat ja kanavoivat neuronien välisiä yhteyksiä. Neuronien väliset yhteydet aktivoituvat varhaisten kokemusten avulla mahdollistaen älyllisen, sosiaalisen, emotionaalisen ja motorisen kehittymisen. Koska lapsen aivoihin on kehittynyt kolmanteen ikävuoteen mennessä lukematon määrä aivosolujen välisiä yhteyksiä, kaikki nämä eivät voi aktivoitua. Osa yhteyksistä vahvistuu ja jää pysyväksi, kun taasen osa häviää kehityksen kuluessa. Vain sellaiset synapsiset yhteydet, joita lapsi toistaa kokemuksissaan ja toiminnoissaan varhaisten elinvuosiensa aikana, voivat muodostaa perustan myöhemmälle aivotoiminnalle. Aivojen kehittymisen ja kasvun logiikka on seuraavan tapainen: käytä ja aktivoi minua, muutoin menetät minut. Jos esimerkiksi lapsi kasvaa ympäristössä, jossa hän saa huomattavan vähän kokemuksia puhumisesta tai lapselle ei juuri lueta, tästä kehittymisen alueesta saattaa tulla heikko tai alikehittynyt. Samoin voi tapahtua myös leikkikokemuksissa. On arveltu, että harvoin tai vähän varhaisia leikkikokemuksia tai sosiaalista vuorovaikutusta saaneilla lapsilla saattaa olla myöhemmin vaikeuksia sosiaalisessa käyttäytymisessä.

Lisääntyvä tietoisuus aivojen kehittymistä ja kasvua selittävistä neuroja kognitiotieteellisistä mekanismeista voi rikastuttaa myös kasvattajien ja opettajien ajattelua. Kujala kumppaneineen (2012) ovat tiivistäneet neuropsykologiaan pohjautuvia havaintoja opettajille ja kasvattajille (Kujala ym., 2012, sivut 64-67) seuraavan tapaisesti:

Oppiminen aiheuttaa pysyviä muutoksia hermoston toiminnassa. Elinikäisessä oppimisessa aivot muotoutuvat jatkuvasti aistien kautta välittyvän informaation myötä. Kasvuympäristöstä saatavat kokemukset säätelevät aivojen toimintaa ja oppimista. Oppimisessa yksilö muodostaa havaintojensa ja kokemustensa perusteella kuvan maailmasta. Toistuvista kokemuksista toisten ihmisten kanssa jää muistijälkiä, jotka voivat vahvistavaa lapsen turvallisuuden tunnetta, käsitystä itsestä, luottamusta toiseen ja myönteisten ihmissuhteiden kehittymistä. Peilisolujärjestelmän toimintaan kuuluvien periaatteiden mukaan kasvattajan hyväksyvä ja kannustava tapa katsoa lasta saattaa virittää lapsessa oppimiseen kannustavan myönteisen tuntemuksen. Aikaisempien oppimistapahtumien vaikutukset kumuloituvat: mitä enemmän lapsella on myönteisiä kokemuksia oppimisesta, sen myönteisemmin hän suhtautuu tulevaan oppimiseen. Kieli on keskeinen osa kouluvalmiutta. Se on ajattelun ja itsesäätelyn väline yhdessä leikkimisen ja toiminnan kanssa. Varhainen kielellinen osaaminen heijastuu 
myöhemmin lukutaidon oppimisessa. Esimerkiksi lukutaitoisilla esikoululaisilla on jo kaksivuotiaina muita ikätovereitaan ja laajempi sanavarasto. Kolmivuotiaina he osaavat taivuttaa sanoja muita taitavammin. Kouluiän lukutaitoon vaikuttaa ennen kaikkea kielellinen tietoisuus, joka ilmenee taitavuutena erottaa sanojen äänteet, sanat ja lauserakenne. Päivähoidossa ja esi- ja alkuopetuksessa voidaan tukea lapsia, joilla on muita heikommat kielelliset ja sosiaaliset taidot tai vähäisimmät tiedot valtakulttuurista. Sekä kotona että päivähoidossa kouluvalmiuksia voi tukea kohdistamalla leikkija lukutuokioiden aikana huomiota asioihin, joihin lapsen tarkkaavaisuus on suuntautunut, vahvistamalla sanojen merkitysten ja sanataivutusten oppimista sekä tukemalla lapsen kasvavaa kielellistä tietoisuutta. Liikunnan merkitys kognitiiviselle kehitykselle ja oppimiselle on kiistaton.

Yhteenvedonomaisesti voidaan todeta, että neuropsykologisen tutkimuksen havainnot voivat auttaa ja vahvistaa kasvattajia tukemaan ja ymmärtämään lapsen kehittymistä, kasvua ja oppimista. Keskeisiä viestejä ovat esimerkiksi seuraavat: ole lämmin, rakastavainen ja vastavuoroinen; puhu, lue ja laula lapsille; luo lapsen oppimiskokemuksille struktuuri, joka pitää yllä rutiineja ja jatkuvuutta sekä rohkaise lasta tutkimaan ja leikkimään. Voi päätellä, että esimerkiksi struktuurin rakentaminen ja toistuvien oppimiskokemusten ylläpitäminen on tärkeää. Eräs Piaget'n teorian perusoletus on ollut, että kehitysasteiden rakenteelliset muutokset tapahtuvat hitaasti. Ennen kuin lapsi on valmis siirtymään uuteen kehitysvaiheeseen ja jäsentämään kognitiivista struktuuriaan uudella tavalla (akkommodaatio) lapsella pitäisi olla aikaa ja mahdollisuuksia kerrata ja vahvistaa olemassa olevia ajattelun ja päättelyn mekanismeja (assimilaatioprosessi).

\section{Lapsen ääni ja tulkinnat oppimisesta ja kehittymisestä}

Kasvatusta, oppimista ja kehittymistä on ryhdytty viime aikoina analysoimaan lisääntyvässä määrin lapsiperspektiivistä (esim. Hedegaard et al., 2012). Näkökulman teoreettisena tausta on ollut etenkin Vygotskyn ajatukset ja niiden edelleen tulkinnat kulttuuripsykologisesta lähestymistavasta käsin (esim. Rogoff, 2003; Valsiner, 2007). Toisena keskeisenä elementtinä on toiminut lapsuuden sosiologia (esim. Jenks, 1982; James et al., 1998). Lähestymistapa haastaa traditionaalisen kehityspsykologian, jossa lapset nähdään tulevina. Lapsinäkökulmassa lapsia pyritään tarkastelemaan sellaisina, kun he ovat. 
Lapsuuden sosiologia nostaa esiin kaksi tärkeää teemaa (Alanen \& Karila, 2009; Alanen \& Mayall, 2001). Näistä toinen on tuonut esille lapset sosiaalisena arjen toimijana, joissa he tutustuvat yhteiskuntaan, osallistuvat heille tarjottuihin kulttuuriaktiviteetteihin ja rakentavat sosiaalista maailmaansa. Viestinä on, että lapset ovat yhteiskunnan aktiivisia toimijoita pienestä pitäen eikä heitä siksi voida sulkea ulkopuolelle yhteiskunnan jäsenyydestä omaksi marginaaliryhmäkseen. Lasten omaa toimintaa, vastarintaa, yhteistyötä, ja yhteisöllistä toimintaa pidetään keskeisenä. Toinen keskeinen seikka liittyy sukupolvien väliseen kohtaamiseen, jota halutaan tarkastella sosiaalisen tasa-arvon lähtökohdista käsin. Tällöin kiinnitetään huomiota esimerkiksi siihen, millaisilla taloudellisilla, sosiaalipoliittisilla ja kasvatuksellisilla toimenpiteillä aikuisväestö haluaa pitää yllä lapsuuden toimintaedellytyksiä ja lapsen hyvinvointia. Tasa-arvon esteenä on usein sukupolvien välinen kuilu, jossa lapset ja lapsuus uhkaavat jäädä marginaaliseen asemaan. Yhden lapsuuden maailman sijasta lapsuuden sosiologia tarkastelee lapsuutta erilaisina maailmoina, joiden kesken voi esiintyä jännitteitä. Näitä ovat aikuisen maailma, lapsen itselleen rakentama maailma ja maailma, joka luodaan toisten lasten kanssa (esim. Waksler, 1991).

Kulttuuripsykologian ja lapsuuden sosiologian viitoittamana avautuu näköala, jossa lapsen oppimisen ja kehittymisen nykyhetkeä halutaan tarkastella suhteessa aikaisempaan ja uusiin kehittymisen ja oppimisen näkymiin. Lapsen oppiminen ja kehittyminen nähdään kiinnittyneenä sosiaaliseen toimintaan ja kanssakäymiseen, joka on läsnä ja johon lapsi osallistuu arkitodellisuuden eri foorumeilla. Näkemyksenä on, että lapsi löytää sosiaalisessa vuorovaikutuksessa runsaasti uusia mahdollisuuksia, jota hän voi tulkita ja joista hän voi löytää uusia merkityssisältöjä, joiden avulla hän voi orientoitua uudella tavalla ja uusissa ulottuvuuksista oppimiseen ja kehittymiseen.

Samoin kuin traditionaalisessa kehityspsykologissa lapsinäkökulmaa ja lapsen toimintaa korostavassa lähestymistavassa pidetään keskeisenä hankkia tietoa oppimisen ja kehittymisen kulkusta. Tiedonhankinnan kohteena ovat lapset, osallistuvat toiset lapset ja aikuiset. Keskeinen tiedonhankintakeino haastattelu, joka viritetään kehitys- ja oppimistarinaksi, jossa on läsnä mennyttä, nykyisyyttä ja tulevaisuuden näköaloja (Gulbransen, 2012). Haastatteluja tukemaan voidaan suorittaa kenttähavainnointia ja muita laadullisen tiedonhankinnan keinoja. Keskeisiä lapsen kasvuun liittyvinä kysymyksiä ovat mitä lapsi tekee, kuinka hän ymmärtää tapahtumat, 
joissa hän on mukana ja mitä tämä ymmärrys merkitsee lapsen tulevalle kasvulle. Tämän lisäksi kartoitetaan paikallista ja kulttuuriympäristöä lapsen oppimiselle ja kehittymiselle. Kolmas keskeinen tiedonkeruun kohde on lapsen sosiaalinen kumppanuus, jossa neuvotellaan, toimitaan yhdessä, etsitään uusia mahdollisuuksia, viritetään uusia tulkintoja jne.

Lähestymistavassa korostetaan oppimisen ja kehittymisen tilannesidonnaisuutta ja sosiaalisia areenoja, joissa lapsi kasvaa ja kehittyy. Lapsinäkökulmassa kohdistetaan huomio lasten arkikokemuksiin ja siihen, miten lapset kuvaavat ja tulkitsevat kokemuksiaan. Tiedonhankinnassa lapset toimivat informantteina ja lasten kokemuksia dokumentoidaan pyrkimyksenä ymmärtää lasten kertomuksia ja tulkintoja siitä sosiaalisesta kanssakäymisestä ja todellisuudesta, jossa he kulloinkin ovat ja varttuvat. Lähestymistapa mahdollistaa lasten elinolosuhteiden analyysin.

Erityistä huomiota kiinnitetään lasten osallisuuteen erilaisissa sosiaalisissa ympäristöissä. Kohteena voivat olla tavat, joilla lapsi ottaa osaa sosiaalisiin aktiviteetteihin, miten he orientoituvat toisiin toimijoihin ja kuinka toiset orientoivat lapseen. Keskeistä on myös analysoida, miten lapset keskustelevat ja neuvottelevat aikuisten kanssa omista näkemyksistään, toivomuksistaan ja mielenkiinnon kohteistaan. Osallisuudesta hankitaan tietoa, jossa informantteina ovat toiset lapset ja aikuiset, joiden kanssa lapsi toimii ja kasvaa. Näkemyksenä on, että lapsen oppimista ja tietoa ei voi irrottaa tunteista, subjektiivista kokemuksista ja sosiaalisista puitteista. Eräänlaisena johtoajatuksen on, että oppimisyhteisö on oppijoiden yhteisö.

Analysoitaessa lapsen kehittymistä ja oppimista oppimisyhteisössä erityistä huomiota kiinnitetään lasten omiin käsityksiin omasta kasvusta ja kehittymisestä. Kerättyjen dokumenttien avulla on mahdollista analysoida tapoja, joilla lapsi oppii ja joiden avulla voidaan identifioida lasten kehittymisen ehtoja. Tavoitteena on jalkauttaa lasten oppiminen ja kehittyminen päivittäisiin aktiviteetteihin osana kulttuurisia ja historiallisia tapahtumia. Tässä kontekstissa on keskeistä analysoida sitä, miten lapsen aktiivinen merkitysten antaminen ja tulkinta kehittyvät ja millä tavoin lapset orientuvat tulevaisuuteen.

Havaintojen mukaan lasten kuvaus omasta kasvusta ja oppimisesta on dynaamista, koostuu tulkinnoista ja uudelleentulkinnoista ja sijoittuu erilaisiin sosiaalisiin areenoihin (Gulbrandsen, 2012). Kehitys ei tästä näkökulmasta etene suoraviivaisesti ajankohdasta toiseen. Lapsen kehittymisen 
ja oppimisen kuvaukset ovat kertomuksenomaisia ja niissä ovat läsnä lapsi itse ja toiset läsnäolijat. Kertomusten eteneminen on spiraalinomaista ja dynaamista tavalla, jossa lasten tulkinnat joskus kehittyvät juonellisiksi ja yhteen liittyviksi. Joskus taasen tulkinnat viestivät, että kehittymistä ei tapahdu, asioita ei koeta tärkeänä ja ne ovat merkityksettömiä lapsille, jolloin ne sammuvat ja lapsi pyrkii sulkemaan ne pois tietoisuudestaan.

Lapsen kulttuuriympäristöön ja siinä olevaan toimintaan kiinnittyvän lähestymistavan etuna on mahdollisuus kuvata ja seurata lapsen oppimista ja kehittymistä lapsen näkemänä ja tulkitsemana sellaisissa sosiaalisen elämän, vuorovaikutuksen ja toiminnan ympäristöissä, joihin lapsen arkitodellisuus rakentuu. Lähestymistapa mahdollistaa näköalan oppimiseen ja kehittymiseen, jolla on kulttuurillista ja sen kehittymiseen liittyvää syvyyttä, joka ankkuroituu nykyisyyteen ja joka tarjoaa näköaloja lasten toimintaympäristön ja osallisuuden kehittämiselle. Näin hahmotettuna lapsen oppiminen ja kasvu on dynaamista eikä suoraviivaista eikä sitä voi kovinkaan hyvin seurata ja arvioida etukäteen rakennettujen mekanismien avulla. Arvioinnin ja seurannan keskeiseksi välineeksi soveltuu dokumentointi, josta esimerkkinä tämän julkaisun yhteydessä on pedagoginen dokumentointi.

Lapsen oppiminen ja kehittyminen kiinnittyvät sosiaaliseen toimintaan, jossa lapsi on läsnä ja johon lapsi osallistuu arkitoimintojen erilaisissa konteksteissa. Lapsen tulkinnat kehittymisestä ja oppimisesta perustuvat dynamiikkaan, jossa pyritään tulkitsemaan sosiaalisia kokemuksia muuttuvissa konteksteissa. Lapsen asema toimijana ei ole vakaa, vaan siihen liittyy usein jännitteitä, taistelua vallasta, neuvottelua, uusien toimintotapojen testaamista jne. Keskeisiä elementtejä kehittymisen ja oppimisen hahmottamisessa ovat lapsen ymmärrys itsestään ja muista, jaetut aktiviteetit sekä merkitykset, joita lapsi muodostaa arkipäivän toiminnoissa erilaisissa sosiaalisissa konteksteissa. Näiden tutkimisessa ollaan ehkä vasta alussa. Jatkossa on tarpeen selventää näiden tekijöiden dynamiikkaa, kehittää dynaamisia tutkimusmenetelmiä ja seurata lapsen oppimisen ja kehittymisen kulkua pitkäjännitteisesti. On tärkeää saada syventää tietoa esimerkiksi lapsen ja lapsiryhmän voimavaroista kohdata toisensa ja olla vuorovaikutuksessa tai siitä, miten lapsia, joiden voimavarat eivät riitä, autetaan ja tuetaan kykenevämmäksi. Vuoropuhelua muihin lähestymistapoihin (esim. kognitiot, kieli ja ajattelu, sosiaalinen oppiminen, sosiaalinen kognitio jne.) on tarpeen pitää yllä ja tiivistää. Kulttuuripsykologian ja 
lapsuuden sosiologian taustalle muotoutunut lapsen näkökulmaa korostava lähestymistapa haastaa traditionaalisemmat lapsen oppimisen ja kehittymisen lähestymistavat niiden dynamiikan syvällisempään tutkimiseen. 


\section{Taitojen kehittyminen ja oppiminen eri osa-alueilla}

Tässä luvussa tarkastellaan lapsen varhaista kehittymistä ja oppimista kiinnittämällä huomiota taitoihin. Tämä tarkastelu kohdistetaan minän kasvuun sekä kognitiivisiin, kielellisiin, matemaattisiin, sosiaalisiin ja motorisiin taitoihin. Tarkastelun kohteena on taitojen kehittyminen, oppiminen ja tukeminen.

\section{Kehittyvä minä}

Minällä on perustavaa laatua oleva merkitys ihmisen kasvulle ja kehitykselle. Ilman minätunnetta ihminen ei tunne olevansa olemassa maailmassa. Minän avulla havainnoidaan sisäisiä ja ulkoisia ärsykkeitä, ohjataan ja kootaan aistimuksia sekä pannan toimeen aktiviteetteja. Minän perusolemus on psyykkinen ja sen yhteydessä puhutaan usein minätunteesta. Se koostuu synnynnäisistä toiminnoista, sisäisistä elämyksistä ja niiden muistikuvista sekä tavoista, joilla sisäistämme kokemukset ulkomaailmasta. Minää pidetään osin tietoisena ja osin tietoisuuden ulkopuolella olevana. Tietoisessa minässä muodostuu tietoisuuden perustan. Minätunne muodostuu useista minäkuvista, jotka aktivoituvat sisäisten muistikuvien ja ulkoisten kokemusten ohjaamina (esim. Aho, 1996). Näitä ovat esimerkiksi reaaliminä (käsitys omasta minästä), ihanneminä (millainen haluasi olla) ja normatiivinen minä (millaisena muut pitävät). Minän avulla myös hahmotetaan maailmankuvaa.

Oletetaan, että minäkuvat ovat olemassa piilevinä tai torjuttuina, mutta ne ovat ikään kuin valmiina aktivoitumaan. Minätunteen tärkeänä tehtävänä on suojella minää mutta myös muuttaa sitä tarpeen vaatiessa. Minän välityksellä muodostuu myös tietoisuus omasta arvosta, jota nimitetään usein itsetunnoksi (esim. Keltikangas-Järvinen, 1994). Kysymys on oman itsensä ja mahdollisuuksiensa hyväksymisestä. Vahvaa itsetunnon kehittymistä ja sen tukemista pidetään kasvatuksessa keskeisenä. Heikko itsetunto vaikeuttaa oman minän vahvistumista ja kehitysvaikeuksien voittamista.

Minäkuvien kautta muodostuu lapsen identiteetti. Edellytyksenä identiteetin muodostumiselle pidetään sitä, että minäkuvien välillä ei vallitse ristiriitaa ja niihin liittyy todellisuuden tajua. Esimerkiksi Mahler 
kumppaneineen (1975) korostavat, että vuorovaikutus lapsenomaisiin minätunteisiin tukee turvallisen identiteetin muodostumista. Edellä mainitut tutkijat pitävät keskeisenä erityisesti lapsen varhaisia objektisuhteita, jotka muodostuvat lapsuudenaikaisista merkityksellistä ihmissuhteista. Oletuksena on, että lapsen kanssakäymisessä on tavallaan aina läsnä aikaisemmat mielikuvat omasta itsestä ja lapsuudenaikaiset ihmissuhteet. Ilmiötä nimitetään transferenssiksi. Tällä tarkoitetaan taipumusta suhtautua toisiin samantapaisin odotuksin kuin suhtaudutaan lapsuudenaikaisiin tärkeisiin ihmisiin.

\section{Mahlerin kuvaukset ja tulkinnat minän varhaisesta kehittymisestä}

Minän kehittymisessä viitataan usein Mahlerin ja kumppaneiden tulkintaan (Mahler et al., 1975; Kronqvist \& Pulkkinen, 2007). Oletuksena on, että vastasyntyneelle ei ole kehittynyt minätunnetta. Hän nukkuu suurimman ajan. Ulkoiset tapahtumat etenevät omaa rataansa ja lapsi elää omassa eristyneisyyden tilassaan. Lapsi kuitenkin tajuaa kiintymyssuhteen äitiin tai häntä läheisesti hoitavaan henkilöön mutta niin, että hän ei erota omaa itseään erilliseksi.

Alustava käsitys omasta olemassaolosta kehittyy lapselle Mahlerin teorian oletusten mukaan kolmen ensimmäisen elinkuukauden aikana. Tätä vaihetta nimitetään minän kehittymisessä normaaliautismin vaiheeksi. Lapsen sisäinen maailma on tällöin suljettu, eikä hän pysty erottamaan toisistaan sisäistä ja ulkoista. Tällöin lapsi jäsentää sisäiset kokemukset mielihyvän tai mielipahan perusteella. Ensimmäisten elinkuukausien aikana lapsen oman olemuksen hahmottaminen peittyy alussa elämysten tulvaan ja kaaokseen, mutta kasvattajan tarjoaman ravitsemisen ja muun perushoidon säännöllisyys tuo siihen jäsennystä. Näin säännöllisellä ravinnon antamisella ja perushoidolla voi olettaa olevan oma tärkeä merkityksensä myös lapsen minätunteen jäsentymiselle. Mahlerin teoriassa korostetaan, että tässä vaiheessa lasta hoitavan henkilön tärkeänä tehtävänä on toimia myös liiallisten ärsykkeiden kilpenä ja suojella lasta näiden tulvalta.

Keskeistä normaaliautismin vaiheessa on kuitenkin perusturvallisuuden kokeminen, joka myönteisessä tapauksessa kehittyy syvemmäksi kiintymykseksi hoitajan ja lapsen välille. Lapsi reagoi kiintymykseen hymyllä ja kehon liikkeillä. Myönteisessä tapauksessa lapsi oppii luottamaan 
hoitoympäristöönsä ja hän hoitavaan aikuiseen. Jotta perusturvallisuus voisi vahvistua, lasta ei suositella jätettäväksi pitkäksi aikaa yksin. Peruskiintymyksen häiriintymisellä oletetaan olevan haitallisia vaikutuksia lapsen minätunteen kehittymiselle, joka voi ilmetä kyvyttömyytenä tehdä eroa oman minän ja toisten välillä. Muita mahdollisia seurausvaikutuksia voivat olla kyvyttömyys sisäistää sääntöjä, empatian puute, pakonomainen tarve tunnekuohuille tai vaikeus solmia pysyvien ihmissuhteita.

Kolmannen kuukauden jälkeen ensimmäiseen ikävuoteen asti lapsen kokemukset omasta itsestään kiinnittyvät häntä hoitavaan henkilöön, joka edustaa huolenpitoa ja voimaa. Tällöin lapsen minäkehitys on valppaassa lepotilassa. Mahlerin teoriassa tätä vaihetta nimitetään normaalisymbioottiseksi vaiheeksi minän kehittymisessä. Lapsen herkkyys häntä hoitavaan henkilöön lisääntyy, jonka lapsi mieltää apuminänään. Mielikuvat lasta hoitavasta henkilöstä auttavat lasta hahmottamaan sisäisen ja ulkoisen välisiä eroja. Molemminpuoliset vihjeet, jotka syntyvät lapsen ja häntä hoitavan henkilön välille perushoidossa, jossa herkistytään lapsen tarpeisiin, luovat pohjaa lapsen minäkäsityksen muodostumiselle.

Normaalisymbioottisen vaiheen kehityssaavutuksena pidetään lapsen sosiaalista hymyä, joka osoittaa lapsen kiintymystä häntä hoitavaan henkilöön. Tässäkään vaiheessa lapsi ei tunne itseään erilliseksi vaan oman itsensä osaksi, voimaksi tai kyvyksi, joka on hänen käytössään. Lapsi ammentaa tätä ulkoa käsin sisäistettyä voimaa kaikkivoipaisesti tuntien mielihyvää kyvystään hallita tätä voimaa. Kysymyksessä on kuvitelma, mutta kasvattajia neuvotaan säilyttämään tämä. Näin siksi, että kaikki voimaisuuden elämykset lisäävät lapsen turvallisuuden tunnetta ja luottamusta omiin kykyihin. Vaikka lapsi tässä vaiheessa on avuton, hänen kehittyvälle minätunteelleen ei ole eduksi, jos hän tuntee ja kokee jatkuvaa avuttomuuden tunnetta.

Mahlerin teoriassa puolen vuoden ikää pidetään käännekohtana minäkäsityksen kehittymiselle. Tällöin lapsi alkaa vähitellen löytää itsensä. Kysymyksessä on lapsen psykologinen syntyminen. Tätä osoittaa esimerkiksi se, että lapsi alkaa erottaa äidin tai häntä läheisesti hoitavan henkilön muista henkilöistä. Lapsi reagoi alussa pelolla muiden kuin äidin tai oman hoitajan poissaoloon. Pelko yksinjäämisestä ja vieraita henkilöitä kohtaan kuuluu lapsen luontaiseen minäkehitykseen. Hälyttävämpää voi olla, jos tällaiset reaktion puuttuvat. Ainoastaan poikkeustapauksessa toistuvat ja 
pitkäaikaiset erokokemukset voivat johtaa pysyvään lamaantumiseen, joka voi ilmaantua fyysisenä ja psyykkisenä näivettymisenä.

Ensimmäisen ikävuoden lopulla lapsi tutkii aktiivisesti oman ruumiinsa rajoja ja erillisyyttä (Mahler et al.,1975). Hän katselee ja koettelee aktiivisesti käsillään häntä hoitavan aikuisen kasvoja ja ruumista. Lapsi alkaa esimerkiksi leikitellä ryömimällä pois ja kohden aikuista tai hakeutuu toistamiseen lähelle aikuista. Näin hänelle syntyy oivallus, että hän on fyysisesti erillinen häntä hoitavasta aikuisesta. Lapsi alkaa varmistaa aikuisen läsnäolon lisääntyvillä visuaalisilla vihjeillä ja lisää näin havaintojaan myös erillisyydestään. Lapsen eriytymiskehitys saa alkunsa. Kehitystä tukee kehokaavion syntyminen ja asteittainen psyykkinen eriytyminen. Lapsi kuitenkin kokee yleensä vielä tässä vaiheessa pelkoa erilleen joutumisesta, yksinjäämisestä ja avuttomuudesta.

Seuraavaksi lapsen minän kehittymisessä on vuorossa harjoitteluvaihe, joka tapahtuu ensimmäisen ikävuoden tienoilla. Minän eriytymistä tukevat lisääntyvät motoriset taidot, jotka kulminoituvat kävelemiseen ja liikkumiseen. Emotionaalisella tasolla lapsi tarkkailee valppaasti häntä hoitavan henkilön läsnäoloa. Mahler kumppaneineen (1975) kutsuvat tätä emotionaaliseksi 'tankkaukseksi', jolla pidetään yllä ja vahvistetaan perusturvallisuutta. Kehityksen aikana riippuvuus lasta hoitavasta henkilöstä vähenee ja uteliaisuus ympäristöön kasvaa. Kiintymyssuhde maailmaan saa alkunsa ja lapsi kokee monelta osin olevansa kaikkivoipainen.

Noin puolentoista ikävuoden tienoilla lapsen kehittymisessä tapahtuu merkittäviä uusia asioita (Mahler et al., 1975). Kävelemisen ohella lapsi oppii puhumaan ja sisäinen ajattelu kehittyy. Tämä heijastuu erityisesti kielen oppimisessa ja symbolileikkien kehittymisessä. Lapsi kehittyy omatoimisuudessa lisäten vuorovaikutustaan ympäröivään maailmaan. Tämä kaikki vahvistaa kaikkivoipaisuuden tunnetta. Minätunteen kehittymisessä voidaan havaita merkkejä itsearvostuksen muodostumisesta, joka heijastuu mielihyvänä lisääntyvistä omista kyvyistä ja riippumattomuudesta.

Ikävuosina 2-3 lapsi näyttää palaavan takaisin turvaan häntä hoitavan henkilön pariin. Mahlerin teoriassa tätä kautta luonnehditaan suhteiden hiomisen ja välien parantamisen ajanjaksoksi minän kehittymisessä. Lapsi ikään kuin pyytää anteeksi aikuiselta siitä, että on osittanut voimakasta halua irtautua hänestä. Lapsi voi kokea tällöin myös pelkoa eriytymisestään aikuisen luomasta turvallisuudesta. Erityisesti uudet aikaisemmasta poikkeavat tapahtumat vuorovaikutussuhteissa voivat laukaista eroahdistuksen. 
Siksi on ymmärrettävää, että lapsi ikään kuin palaa uudelleen häntä hoitavan henkilön turvaan. Näin lapsi testaa eriytymisensä rajoja luoden pohjaa lisääntyvälle itsenäisyydelle. Lapsella on samanaikaisesti voimakas tarve itsenäistyä mutta myös aikuisen tukeen.

Ristiriita itsenäistymisen ja aikuisen tuen välillä saattaa johtaa pettymyksen tunteeseen ja lisääntyvään aggressiivisuuteen (Mahler at al., 1975). Käyttäytymiseen voi liittyä esineiden paiskimista ja ei-ilmaisuja. Ei-ilmaisuja voidaan pitää lapsen pyrkimyksenä kehittä autonomisuuttaan. Minätunteen kehittymisessä lapsi harjoittelee erilaisilla toiminnoilla hyvien ja pahojen ominaisuuksien erottelua omassa minässään ja toisissa ihmisissä. Lisääntyvien psyykkisten voimavarojensa ansiosta lapset kykenevät yleensä voittamaan eroahdistuksen, jonka kohtaaminen ja läpikäyminen liittyy luontaisena osana lapsen minätunteen kehittymiseen.

Minän varhaiskehittymisen viimeisenä vaiheena Mahler kumppaneineen (1975) pitävät yksilöllisyyden kehittymistä, jonka tapahtuu kolmannen ikävuoden kuluessa. Tällöin lapsen varhaiset objektisuhteet jäsentyvät pysyviksi ja lapsen minäidentiteetti on syntynyt. Lapsi ymmärtää, että häntä läheisesti hoitava henkilö on olemassa, vaikka hän ei olekaan läsnä. Tässä kehitysvaiheessa lapsi jäsentää ja kokoaa aikaisempien vaiheiden aikana tapahtuneita yrityksiä minänsä eriytymiseksi ja itsenäistymiseksi. Ajattelun ja kielen lisääntyvät taidot luovat perustaa sille, että lapsi oppii symbolisella tasolla sisäistämään häntä hoitavan henkilön eikä tämän tarvitse fyysisesti olla läsnä. Tämä mahdollistaa yksilöllisen identiteetin syntymisen tavalla, jossa on läsnä sekä käsitys itsestä että muista. Muita lapsi kykenee nyt erittelemään jäsentyneemmin esimerkiksi hyvä - huono -ulottuvuudella. Vastavuoroiset vuorovaikutussuhteet ovat nyt mahdollisia.

\section{Winnicottin näkemyksiä lapsen minän kehittymisestä}

Toinen merkittävä tulkinta lapsen minän kehittymisen varhaisvaiheesta perustuu Winnicottin (1971 ja 1982) ajatuksiin. Minän kehittymisen avaintekijänä hän pitää asteittaista siirtymisestä riippuvuudesta kohti riippumattomuutta olosuhteissa, joissa lapsi saa hyvää hoitoa, suotuisan kehitysympäristön ja tarvittavan tuen, jolla autetaan minän kehitystä. Positiivisen minätunteen omaava lapsi on luova, spontaani ja hänelle on kehittynyt 
todellisuudentajua. Negatiivinen minätunne rakentuu myöntyvyydelle, ohjeille ja määräyksille. Tällöin minän kehitystä ohjaa voimakas sisäinen kontrolli.

Mahlerin tapaan Winnicott kohdistaa huomion minätunteen objekteihin. Oletuksena on, ett lapsen erityisenä mielenkiinnon kohteena ovat siirto-objektit. Lapsi voi niitä käsitellä ja ne edustavat ensimmäisiä konkreettisia asioita, jotka lapsi mieltää oman minänsä ulkopuolisina. Näitä edustavat esimerkiksi nukke, leikkiauto, pehmeä hyväilyvaate, valokuvat hoitajista jne. Käsittelemällä näitä haluamallaan tavalla lapsi voi lieventää ahdistustaan prosessissa, jossa hän vähitellen irtaantuu turvallisista primäärisuhteistaan ja itsenäistyy. Lapsen siirto-objektit voivat laajeta toimintoihin, joita edustavat esimerkiksi hyppiminen ja fantasiat.

Winnicott kehitti teoriansa tekemällä havaintoja erityisesti äidin ja lapsen vuorovaikutuksesta. Tulostensa perusteella hän erotti kolme lapsen minäkuvan kehittymiseen vaikuttavaa tekijää. Minän kehittymisen varhaisimmassa vaiheessa keskeiseksi muodostuu äidin fyysinen ja psyykkinen omistautuminen lapseen (holding). Viestinä on, että lapsen tulee voida kokea fyysistä turvallisuutta ja tunnetta jatkuvasta hoitamista. Tämän ohella minän kehittymiselle on keskeistä äidin ja lapsen yhdessäolo. Kolmas minän muodostumiseen vaikuttava tekijä kohdistuu erityisesti molempien vanhempien ja lapsen väliseen yhdessäoloon.

Kolmannen ikävuoden jälkeen minä kehittymiseen vaikuttavat yhä enenevässä määrin oman ajattelun jäsentyminen sekä lisääntyvät ja laajenevat kokemukset vuorovaikutuksesta ympäristöön ja kulttuuriin (Winnicott, 1971). Kodin ulkopuoliset kasvatusympäristöt tuovat kehityksen myötä uusia elementtejä lapsen minäkuvan kehittymiselle. Määrätietoisuus lisääntyy, jota voi tukea esimerkiksi lapsen harrastustoiminta. Realismi lapsen kehittymisessä vahvistuu.

\section{Läheisen aikuisen merkitys minäkuvan muodostumiselle}

Psykoanalyyttispainotteisessa minän kehittymisessä huomio on ehkä liiankin yksipuolisesti kohdistettu äidin ja lapsen väliseen vuorovaikutukseen. Kuitenkin molemmilla vanhemmilla ja/tai muilla lapsen kanssa välittömässä vuorovaikutuksessa olevilla henkilöillä voi olettaa olevan merkitystä lapsen minäkehitykselle. 
Isän merkitys lapselle osana vanhemmuutta on yhteydessä yhteiskunnalliseen muutoksen ja näihin liittyviin käsityksiin, joita esimerkiksi Kekäle ja Eerola ovat analysoineet (2014, 19-21). Heidän mukaansa esimodernilla ja modernilla aikakaudella miehisyys perustui selkeään ja naiseudesta erilaiseen malliin, jossa korostetiin esimerkiksi patriarkaalisuutta kotona, valtaa sekä keskittymistä työhön ja julkiseen elämään. Postimodernissa yhteiskunnassa miehisyyden ja naiseuden eroa on alettu kyseenalaistaa korostamalla jaettua vanhemmuutta, jossa sekä isä että äiti voivat osallistua tasa-arvoisina lasten hoitoon ja kasvatukseen kotona. Tällöin miehisyys on muuttumassa kohti kunnioittavaa, osallistuvaa, läheistä ja hoivaa mallia. Myös perhemallin moninaisuus alkaa korostua.

Useissa tapauksissa isä on nykyisin läsnä ja toimii aktiivisesti lapsen vuorovaikutuskumppanina jo syntymästä lähtien. Ensimmäisten elinkuukausien aikana isät voivat olla aktiivisesti mukana lapsen varhaisessa hoitotapahtumassa. Avustamalla ja täydentämällä äitiä isä voi tukea lapsen minäkehitystä jo Mahlerin kuvaamilla normaaliautismin ja normaalisymbioosin kehityskausilla. Isän aktiivinen läsnäolo ja toiminta voivat auttaa äitiä ymmärtämään monipuolisemmin lapsen käyttäytymistä. Isä voi myös tuoda lisäarvoa varhaisen vuorovaikutustapahtuman säätelyyn ja tavoitteellisuuteen. Joka tapauksessa isän läsnäolo tuo lapsen minän kehittymiselle uuden virikkeen ja sen synnyttämät sisäiset kokemukset. Normaalisymbioosin kehittymisajankohtana isä voi toimia lapselle toisena rakastamisen kohteena.

Silloin kun lapsen minä alkaa eriytyä, isä voi tarjota lisääntyvää vuorovaikusta lapselle täydentäen näin äidin vuorovaikutusta. Kun lapsi ryhtyy aktiivisemmin harjoittelemaan omaa eriytymistään, isä voi toimia toisena merkityksellisenä vuorovaikutuskumppanina lapselle ja vaimentaa lapsen pettymyksiä eriytymiskokeiluista. Silloin kun lapsi alkaa tajua sukupuolieroja, isä tarjoaa äidistä poikkeavan maskuliinisen identiteettikohteen. Isän läsnäolo ja vuorovaikutus voivat auttaa lasta jäsentämään ja lieventämään eriytymisen mukanaan tuomia ahdistuksen, pettymyksen ja kiukkuisuuden tuntemuksia.

Asettamalla rajoja lapsen hallitsemattomille itsenäistymisen pyrkimyksille aikuiset voivat auttaa lasta kärsivällisyyteen ja epävakaiden tunteiden eheyttämiseen. Voi olla, että esimerkiksi isä, äiti tai joku muu läheinen aikuinen tarjoaa aktiivisen vuorovaikutuksensa kautta lapsen kokemusmaailmaan toimintaa, määrätietoisuutta ja jännittävyyttä täydentäen 
näin jonkun muun läheisen aikuisen huolenpitoa, perusturvaa ja emotionaalista lämpöä. Silloin kun esimerkiksi läheinen aikuinen tai aikuiset ovat aktiivisessa vuorovaikutuksessa lapseen, lapsi saa monipuolisia kokemuksia ja elämyksiä, joiden voi olettaa auttavan lasta kehittämään taitojaan monipuoliseen tunneilmaisuun ja kanssakäymiseen toisten kanssa (esim. Burlingham, 1973).

\section{Minän kehittyminen kouluiässä}

Tietoisuus omasta minästä voimistuu kouluiässä. Kouluikäinen kykenee erittelemään minäänsä eri ulottuvuuksia ja tunnistamaan omia vahvuuksiaan esimerkiksi koulun eri oppiaineissa (esim. Engler, 2009). Kyky hallita uusia asioita on omiaan vahvistamaan oppilaan minää. Kouluiän alkuvaiheessa oppilas suhtautuu yleensä melko optimistisesti omiin mahdollisuuksiinsa ja pyrkii arvioimaan omia suorituksiaan paremmiksi kuin ne ovat todellisuudessa (esim. olen luokan parhaita matematiikassa, urheilussa, musiikissa jne.) Ihanneminä ja todellinen minä eivät vielä kohtaa toisiaan. Otaksutaan, että kouluiän alussa lapsi on haavoittuvainen suhteessa omiin heikkouksiinsa ja kokee helposti alemmuuden tunnetta (Kronqvist \& Pulkkinen, 2007). Vasta noin 10-vuoden iässä oppilaan omat arviot kyvyistään ja suorituksistaan muuttuvat kriittisimmiksi ja pyrkivät vastaamaan todellisuutta.

Kouluiässä tapahtuvaa minän kehittymistä on pyritty selittämään viittaamalla esimerkiksi samaistumiseen (peilisuhde), viettipohjaisten voimien asteittaiseen tasaantumiseen (latenssivaihe), kouluiän kehityskriiseihin tai kouluikäisen laajenevaan sosiaaliseen maailmaan (Kronqvist \& Pulkkinen, 2007). Kouluiässä lapsen peilisuhde maailmaan laajenee, jolloin lapsi löytää laajenevassa määrin kodin ulkopuolisia samaistumiskohteita. Esimerkiksi kuuluisat jalkapallo- tai jääkiekkosankarit voivat olla suosittuja ihailukohteita. Myös kavereista ja tovereista voi muodostua keskeisiä samaistumiskohteita. Samaistumiskohteiden avulla kouluikäinen muodostaa ihanteita siitä, millaiseksi hän haluaisi tulla ja kehittyä. Samalla kun tämä antaa aineksia ihanneminän kehittymiselle, jännite ihanneminän ja todellisen minän välillä kasvaa. On kuitenkin tärkeää korostaa, että ihanteet ja vertaaminen muihin sekä näihin liittyvä jännite todellisuuden kanssa ovat tärkeitä kouluikäisen minäkäsityksen kehittymiselle (Kronqvist \& Pulkkinen, 2007). 
Psykoanalyyttisessä näkemyksessä (esim. Freud, 1936; Bunker \& Freud, 1936) luonnehditaan kouluikäisen minän kasvua viittaamalla psykoseksuaalisen kehittymisen neljänteen vaiheeseen, jota nimitetään latenssivaiheeksi. Tämä alkaa noin 6 vuoden iässä ja jatkuu puberteetti-ikään. Latenssivaiheessa lapsi on ainakin osin irtautunut mielihyvähakuisesta oman minänsä rakentamismekanismista. Tämän korvaa mekanismi, joka perustuu yhä enenevässä määrin omaan ajatteluun ja päättelyyn. Aineksena ovat toiminta ja aktiviteetit, jotka tapahtuvat sosiaalisessa vuorovaikutuksessa kodissa, koulussa, toveripiirissä tai harrastuksissa.

Psykoanalyysiin pohjautuvan Eriksonin (1963) psykososiaalisen teorian mukaan lapsen minän ja persoonallisuuden kasvu kuvataan kehityskriisien avulla. Ennen kouluikää lapsen minään muotoutuu luottamuksen tai epäluottamisen tunne (varhaisin kehityskriisi), tunne itsenäisyydestä tai epäilystä/häpeästä (toinen kehityskriisi) ja aloitteellisuus tai syyllisyys (kolmas kehityskriisi). Kouluiän (ikävuodet 6-12) kehityskriisissä lapselle kehittyy sisäinen tunne pätevyydestä tai alemmuudesta. Tällöin lapsi vertaa itseään muihin. Erityisesti koulussa lapsi havaitsee eroja itsenä ja muiden välillä, jotka luovat jännitteitä ja kriisejä oman minän muotoutumiselle. On tärkeää, että vanhemmat ja opettajat auttavat lasta kohtaamaan jännitteitä ja työstämään niitä niin, että tunne alemmuudesta ei muodostu pysyväksi ja lapsi voi tuntea olevansa pätevä ja kyvykäs. Tehtävä on tärkeä. Voi perustellusti olettaa, että alemmuudentuntoisella lapsella on taipumus käydä jatkuvaa kriisiä oman itsensä ja muiden välillä. Vastaavasti voi olettaa, että pätevyyden tunteen omaava lapsi kriisiytyy vain aika ajoin ja yleensä selviytyy niistä.

\section{Minäkehityksen tukeminen}

Minäkuvan kehittymistä analysoivat teoriat välittävät kasvattajille ajatuksia periaatteista ja keinoista, joilla lapsen minäkuvan myönteistä kehittymistä voidaan tukea. Aikuisen rooli on erityisen tärkeä erityisesti lapsen minäkuvan kehittymisen varhaisvaiheessa, jolloin lapsi pyrkii asteittaiseen irtautumiseen häntä hoitavista aikuisista. Tällöin lapsi odottaa aikuiselta emotionaalista herkkyyttä ja pysyvää läsnäoloa. Lapsi tarvitsee suojaa ja tukea minäkehitykselleen, jossa lapsi kamppailee riippumattomuuden ja riippuvuuden välillä. Kärsivällinen aikuinen salli itsenäistymisen pyrkimykset, mutta asettaa niille myös rajoja. Tämä edistää lapsen 
perusturvallisuutta, joka luo perustan positiivisen minäkuvan jatkuvalle kehittymiselle.

Jos varhainen minäkuvan kehitys etenee onnistuneesti, lapselle on muodostunut tietoisuus omasta itsestä. Tämän jälkeen lapsi kykenee jäsentämään minäänsä lisääntyvien ajattelu- ja päättelytaitojen avulla. Tietoisuus ihanneminän, todellisen minän ja normatiivisen minän olemassaolosta kasvaa ja lapsella on lisääntyviä edellytyksiä suhteuttaa näitä toisiinsa. Positiivisen minäkuvan kehittymiselle on tärkeää, että lapsi kykenee liittämään yhteen ja integroimaan erityyppiset minäkäsitykset. Kodin ohella päiväkoti, esikoulu ja koulu tulevat tärkeiksi minäkuvan kehittymiselle. Kodin ulkopuoliset kasvatusfoorumit antavat uusia aineksia erityisesti normatiivisen minän ja todellisen minän kasvulle. Perusopetuksen yksi keskeinen tehtävä on ehyen ja realistisen minäkäsityksen kehittäminen. Tässä tehtävässä opettajilla on keskeinen rooli. Toveripiirin lisäksi opettaja voi antaa lapsille käyttäytymismalleja ja vaatimuksia vuorovaikutuksessa, joka luo turvallisuutta ja vahvistaa molemminpuolista luottamusta.

Itsetunto liittyy läheisesti oppimiseen. Positiivisen itsetunnon omaava koululainen on yleensä tehtäväorientoitunut, toimii itsenäisesti, sietää epäonnistumisia, haluaa uusia haasteita ja on valmis auttamaan toisia. Sen sijaan heikon itsetunnon omaava orientoituu usein suoritustilanteissa omaan minäänsä ja syyttää epäonnistuessaan suorituksistaan omaa itseään. Hänellä on taipumus välttää uusia haasteita, kestää pettymyksiä ja hän turvautuu usein aikuisten apuun. Aidon emotionaalisen tuen puuttuminen ja yksipuolinen moite vaikeuttavat positiivisen minäkuvan kehittymistä. Myönteistä kehittymistä edistetään, jos kasvattajat huomioivat ensin lapsessa olevat myönteiset ominaisuudet ja liittävät tämän yhteyteen viestejä ominaisuuksista, joissa voi toivoa tapahtuvan muutosta.

On olemassa havaintoja, joiden mukaan koululaisten minäkuva saattaa muuttua negatiivisemmaksi (esim. Aho, 1996). Samoin voi käydä murrosiässä. Myöskään suomalaisten kouluikäisten lasten itsetunto ei ole osoittanut kansainvälisissä vertailuissa niin hyväksi kuin voisi olettaa esimerkiksi PISA -oppimistulosten perusteella. Kysymyksessä saattaa hyvin olla myös se, että lapsen minäkäsitys tulee lisääntyvän kognitiivisen kyvyn ja sosiaalisen vuorovaikutuksen vuoksi realistisemmaksi. 


\section{Johtopäätöksiä}

Minän tukeminen on keskeistä suomalaisessa varhaiskasvatuksessa. Esiopetuksessa minän kehittäminen on asetettu yhdeksi keskeiseksi tavoitteeksi. Minää pyritään tukemaan myös perusopetuksessa. Tavoitteen toteutuminen niin, että lapselle kehittyy myönteinen minäkäsitys, on ensiarvoisen tärkeä koko lapsen kehittymiselle ja oppimiselle.

Minä tarvitsee kehittymisessä sisäisiä tukirakenteita. Näitä ovat eritelleet erityisesti psykoanalyyttisen suuntautumisen edustajat nimittämällä niitä minän puolustusmekanismeiksi. Lapsi suojelee kehittävää minäänsä tarpeen vaatiessa regressiolla ja torjunnalla. Regressiossa lapsen käyttäytyminen palaa muotoon, joka aikaisemmassa kehittymisessä on jo sivuutettu. Torjunta on keino suojautua ahdistukselta, joka syntyy nöyryyttävistä epäonnistumisen kokemuksista tai sopimattomiksi koetuista pyrkimyksistä. Kehittyvän lapsen suojautumiskeinona voi olla myös kieltäminen. Siinä lapsi ummistaa silmänsä epämiellyttäviltä tai pelottavilta asioilta. Myös projektio eli omien sisäisten tunteiden heijastaminen ulkomaailmaan voi aktivoitua. Se toimii suojautumiskeinona kielletyksi koettuja impulsseja vastaan.

Edellä mainittujen suojautumismekanismien lisäksi lapselle kehittyy muitakin minää suojelevia mekanismeja, jotka kuitenkin edellyttävät kehittyneempiä ajattelutoimintoja. Näitä ovat rationalisointi (järkeistäminen), reaktionmuodostus (tunteen muuttaminen vastakohdakseen), sisäistäminen (ulkoinen syy sovitetaan itseen) ja eristäminen (tunnesisältö irrotetaan asiayhteydestä).

Mahlerin näkemyksiin lapsen minätunteen varhaisen kehittymisen perusmekanismeista voi myös suhtautua kriittisesti. Esimerkiksi monet kiintymyssuhdeteoreetikot (esim. Bowlby, 1969; Bowlby, 1973; Stern, 1985; Lyons-Ruth, 1991) ovat epäilleet Mahlerin käsityksiä lapsen normaaliautismin ja normaalisymbioosin esiintymisestä. Kiintymyssuhdeteoreetikoiden oletuksena on, että lapsiin on ohjelmoitunut jo syntymästä asti voimakas pyrkimys liittyä häntä hoitavaan äitiin tai aikuiseen. Herkintä kiintymyskauttaan lapsen oletetaan elävän 6 kuukauden ja puolentoista vuoden välillä. Oletetaan, että voimakas tarve liittyä aikuiseen estää lapsen eriytymispyrkimykset, koska lapsi ei kaipaa eroa vaan haluaa päinvastoin liittyä ja kiintyä häntä hoitavaan henkilöön. Lähestymistavassa minäkuvan kehittyminen hahmotetaan subjektiivisen tuntemuksen lisääntymisenä 
omasta minästä ja toisista. Minän oletetaan kehittyvän lisääntyvistä kokemuksista, jotka jäsentyvä ja muotoutuvat kognitiivisen ja affektiivisen kehittymisen myötä. Näin ollen varhaisen minäkehityksen jaottelua eri vaiheisiin ja niiden perusmekanismien analyysia ei koeta kiintymyssuhdeteoriassa tärkeäksi.

Vasta-argumenttina kiintymyssuhdetulkinnalle voi esittää, että erityisesti Mahlerin ja myös Winnicottin analyysit kykenevät tarjoamaan lapsen minäkuvan kehittymiselle syvemmän ja monipuolisemman tulkinnan. Vaikka kiintymyssuhdeteoriassa pohditaankin lapsen sisäisiä toimintamalleja, päähuomio kohdistuu vain yhteen tekijään. Tämä on lapsen luontainen tarve kiintyä häntä läheisesti hoitavaan aikuiseen. Jos tätä tarvetta vahingoitetaan, lapsen psyykkisen eheytymisen oletetaan vahingoittuvan. Myös Mahler tunnistaa vaikeudet lapsen erotessa häntä hoitavasta aikuisesta. Mutta hänen tulkintansa on lähes päivänvastainen. Eroreaktiot, ahdistuksentunteet ja aggressionpurkaukset nähdään osoituksena lapsen lisääntyvästä pyrkimyksestä eriytyä häntä hoitavasta aikuisesta. Ne mahdollistavat asteittaisen itsenäistymisen ja kuuluvat olennaisena osana lapsen varhaiseen minäkuvan kehittymiseen. Ilman niitä minäkuva ei kehity.

Mahlerin ja Winnicottin tulkintoihin sisältyy ajatus objektisuhteiden merkityksestä lapsen minäkehitykselle. Objektit toimivat alussa samaistumiskohteina ja liittymiskohteina lapsen minän asteittaisessa eriytymisessä häntä läheisesti hoitavasta henkilöstä. Myöhemmässä vaiheessa mukaan tulevat Winnicottin esittämät minän siirto-objektit. Konkreettisia ja asiaa hyvin kuvaavia esimerkkejä siirto-objekteista ovat esimerkiksi lasten autoleikit ja nukkeleikit. Objektikäsitettä ei tunnisteta kiintymyssuhdeteoriassa. On myös syytä tiedostaa, että kiintymyssuhdeteoria ei itse asiassa ole minän kehitysteoria, vaikka sekä kiintymyssuhdeteoriassa että Mahlerin teoriassa pohditaan lapsen peruskiintymistä häntä hoitaviin aikuisiin.

Kiintymyssuhdeteorialla ja Mahlerin teorialla on myös jotain yhteistä viestiä kasvattajille. Pieni lapsi saa varhaisesta vuorovaikutustapahtumasta sisäisiä elämyksiä. Nämä jäävät lapsen mieleen ja lapsi muodostaa niiden perusteella odotuksia, jotka ohjaavat hänen käyttäytymistään oman identiteetin muodostamisessa. Yhteistä edellä mainituille kahdelle teoriasuuntaukselle on myös oletus lapsen jatkuvasta emotionaalisesta tarpeesta saada tukea ja turvaa häntä hoitavalta aikuiselta erityisesti minäkehityksen alkutaipaleella. 
On myös tärkeää tiedostaa, että edellä esitellyt minän kehitysteoriat ja kiintymyssuhdeteoria ovat kulttuurisidonnaisia. Niiden taustalla on näkemys yksilökehittymisen ensisijaisuudesta, joka on vallitsevaa länsimaisissa yhteiskunnissa. Monissa ei-länsimaisissa yhteiskunnissa minän yksilöitymisen sen sijaan korostetaan liittymistä muihin. Tällöin minäkäsitys muotoutuu yksilöiden välisen ja yhteisöllisen tietoisuuden ohjaamana (esim. Matsumoto, 1999).

\section{Kognitiiviset taidot}

Lapsen kehittymisen ja oppimisen keskiössä ovat kognitiiviset taidot. Ne koostuvat muistitoiminnoista, päättelystä, probleeman ratkaisusta ja ajattelusta, joiden kehittymisessä tapahtuu varhaisvuosina merkittävää muutosta. Näihin perustoimintoihin voidaan liittää myös kieli, jonka merkitystä korostaa erityisesti Vygotksy (1978).

Kognitiiviset toiminnot perustuvat informaation prosessointiin, jossa on useita osavaiheita (esim. Ojala, 1993). Prosessoinnin alkuvaiheessa niin lapsi kuin aikuinenkin hankkivat uutta tietoa maailmasta prosessoimalla informaatiota sensorisiin rekistereihin, jotka liittyvät eri aistinalueisiin. Tarkkaavaisuus ja huomion kiittäminen kohteena olevaan ilmiöön edistää sensorista prosessointia. Havaittu informaatio siirtyy tämän jälkeen sisäiseen prosessointiin. Alussa informaatio tallennetaan lyhytaikaiseen taltioon, jossa sitä prosessoidaan työmuistin avulla. Työmuistin kesto ja kapasiteetti on rajallinen. Millerin (2011) kehittämän säännön mukaan ihminen kykenee kerrallaan taltioimaan lyhytaikaiseen muistivarastoon noin viisi asiaa. Kolmannessa vaiheessa informaatiota pyritään tallentamaan pitkäaikaiseen muistiin. Siirron taltiointia lyhytaikaisesta muistista pitkäaikaiseen auttaa ja tehostaa opittavan asian mielekkyys ja merkitys lapselle. Samoin tekee asian toistaminen. Toistaminen on tärkeä muistitoiminto, sillä sen kautta opitaan taitoa palauttaa mieleen oppimisen kohteena olevia asioita. Opittavaa asiaa toistamalla saadaan myös lisäaikaa informaation siirtämiselle pitkäaikaiseen muistiin. Kun henkilö etsii myöhemmin pitkäaikaiseen taltioon varastoitua tietoa, tässä tarvitaan mieleen palauttamisen monia keinoja.

Kognitiivisten prosessien tarkemmassa analyysissa on käynyt ilmi, että ne sisältävät monia tärkeitä osatoimintoja, jotka voivat aktivoitua tiedon hankinnassa ja sisäisessä prosessoinnissa. Näitä ovat havaintojen 
tekeminen, mieleen palauttaminen, mielikuvien luominen, muistaminen, ajattelu, arviointi, probleeman ratkaisu, käsitteellistäminen ja oppimisstrategiat. Kognitiivisia prosesseja työstetään kielen, ajattelun, mielikuvien ja symbolien avulla. Kognitiivisissa prosesseissa otetaan vastaan ärsykkeitä, analysoidaan niitä, hyödynnetään aikaisempia kokemuksia ja arvioidaan kognitiivista prosessointia ja uuden tiedon merkitystä.

Informaation prosessoinnin perusmekanismit luovat perustan lapsen kognitiiviselle kehittymiselle. Kehittymisen myötä lapsen kognitiiviset prosessit jäsentyvät ja harjaantuvat. Taustalla ei ole oletusta laadullisesti erilaisista kehitysasteista, vaan edistymisen oletetaan tapahtuvan iän ja aivojen kasvun myötä.

\section{Piaget'n tulkinta lapsen kognitiivisten rakenteiden kehittymisestä}

Lapsen kognitiivisten rakenteiden asteittaista kehittymistä iän myötä on korostanut erityisesti Piaget $(1969,1971,1971)$. Eräs hänen keskeisistä havainnoistaan oli, että lasten ajattelu ja päättelykyky eivät ehkä olekaan aikuisiin verrattuna mitättömämpää. Kysymys on lähinnä siitä, että lapset ajattelevat ja päättelevät eri tavoin kuin aikuiset. Aikuisten tapaan myös lapset pyrkivät aktiivisesti tulkitsemaan ja ymmärtämään maailmaa ja sen ilmiöitä eivätkä otata vastaan passiivisesti informaatiota.

Lapsen kognitiivisen kyvykkyyden keskeisenä perustana Piaget pitää skeemaa, joka on kielen sisäinen malli tosimaailmasta. Sen avulla ajatteluun ja päättelyyn muodostuu rakenteita, joiden avulla lapsi jäsentää ja tulkitsee tietoa, havaintoja ja tapahtumia. Kokemusten avulla lapsi muokkaa informaatiota, lisää siihen uutta ja muuttaa olemassa olevaa skeemaa. Esimerkiksi eläimestä muotoutuu skeema, joka rakentuu turkin ja neljän jalan perusteella. Esimerkkinä voi olla koira. Alussa kaikki muutkin eläimet, joilla on turkki ja neljä jalkaa, ovat lapselle koiria. Myöhemmin tämä skeema tarkentuu koskemaan vain koiraa ja lapselle syntyy uusia skeemoja muille eläimille.

Prosessi, jolla lapsi liittää uutta informaatiota olemassa olevaan skeemaan, koostuu assimilaatiosta ja akkommodaatiosta. Assimilaatiossa uutta informaatiota liitetään skeemaan niin, että skeeman perusrakenne ei muutu. Kun lapsi esimerkiksi näkee koiran, hän pystyy jo muodostuneen skeeman avulla nimeään näkemänsä koiraksi. Akkommodaatiossa puolestaan uutta 
informaatiota ei liitetä aikaisempaan skeemaan vaan lapsi muuttaa olemassa olevan skeemaa uudeksi. Näin voidaan jokin eläin nimetä esimerkiksi uudeksi eläimeksi tai yhteenlaskun skeemaa muuttaa vähennyslaskun skeemaksi. Pohtiessaan assimilaatiota ja akkommodaatiota Piaget päätyi olettamukseen, jonka mukaan nämä kaksi prosessia pyrkivät tasapainoon. Tällä on tärkeä merkitys kognitiivisen kyvykkyyden kehittymiselle niin, että olemassa olevaan tietoon assimilaation avulla muodostuneet skeemat ja tätä akkommodaation kautta muuttavat skeemat tukevat toinen toisiaan. Tähän perustuen Piaget nimesi kognitiivisen kehittymisen asteet mutta niin, että siirtymää ei tapahdu jatkuvasti vaan lapsi vahvistaa niitä suhteellisen pitkään assimilaation välityksellä ennen siirtymistä uuteen kasvun vaiheeseen.

Lapsen kognitiiviset taidot kehittyvät Piaget'n teorian mukaan kognitiivisiksi operaatioiksi, joista keskeisimpiä ovat luokittelu, sarjoittaminen, säilyvyyden käsittäminen suhteessa määrään, painoon, pituuteen, tilavuuteen ja kokonaisuuteen sekä päättely ja mittaaminen (Piaget, 1969, 1971; Ojala, 1993; Hautamäki, 1995).

Luokittelutoiminta voi perustua yhteen (esim. väri), kahteen (esim. väri ja koko) tai vaativammassa kerrannaisessa luokittelussa useampaankin (esim. väri, koko, muoto) luokittelun perusteeseen. Sarjoittamisessa lapsi pyrkii suhteuttamaan toisiinsa luokkia ja niiden sisältämiä alkioita. Yksinkertaisessa sarjoittamisessa kohteena on yksi luokka. Vaativammassa kerrannaisessa sarjoittamisessa lapsi vertaa kahta tai useampaa sarjaa.

Kun lapsi alkaa tajuta säilyvyyttä, hänelle on kehittymässä ajattelun perustekijä, jonka avulla hän voi tehdä monipuolisia johtopäätöksiä määrästä. Kohteena voi olla paino, pituus, tilavuus tai pinta-ala. Säilyvyyden tajuaminen edellyttää, että lapsi tajuaa esimerkiksi nesteen määrän pysyvän samana, vaikka sitä kaadetaan erimuotoisiin astioihin tai savimassa pysyy samana, vaikka sitä muotoillaan eri tavoin. Säilyvyyden kehittyneempää ajattelua lapsi tarvitsee ymmärtääkseen lukumäärän säilyvyyttä. Huomio kiinnittyy tällöin konkreettisiin objekteihin, joita lapsi alkaa luokitella tai sarjoittaa kiinnittämällä huomiota samanlaisuuksiin ja erilaisuuksiin. Ajatteluoperaatio perustuu yksi-yksi -vastaavuuden ymmärtämiseen. Tällöin lapsi kykenee vertaaman lukumäärän säilyvyyttä tarkkaillessaan esimerkiksi esinesarjaa, jota muunnellaan tiheämmäksi tai harvemmaksi, jolloin pituus muuttuu. 
Käsitys säilyvyydestä, yksi-yksi -vastaavuuden kehittyminen ja erityisesti luokittelu- ja sarjoittamisoperaatiot luovat perustaa sille, että lapsi alkaa tajuta numeerisuutta. Numeerisuus ilmenee kahdella ulottuvuudella: käsitys lukumäärästä (kardinaalisuus) ja lukujen järjestyksestä (ordinaalisuus). Lukumäärän ymmärrys merkitsee sitä, että lapsi huomaa, että joukon alkioiden lukumäärä ei ole sidoksissa niiden järjestykseen. Lukumäärän ja lukujen järjestyksen tajuaminen mahdollistavat yhdessä numero-operaatiot, joita tarvitaan yhteen- ja vähennyslaskuissa sekä jakamisessa ja kertomisessa.

\section{Kehittyminen ensimmäisen kahden ikävuoden aikana}

Piaget nimitti lapsen kognitiivisen kehittymisen varhaisinta vaihetta sensomotoriseksi. Tällöin lapsen tiedonhankintaa, ajattelua ja päättelyä ohjaavat aistihavainnot ja motoriset toiminnot. Katsominen, imeminen, tarttuminen ja kuunteleminen ovat keskeisiä toimintoja, joiden avulla lapsi oppii uutta ympäristöstään. Varhaisimman kehitysvaiheen ajattelun ja päättelyn taidoista eräs keskeisimpiä on kohteen pysyvyyden ymmärtäminen. Tämä edellyttää, että lapsi ymmärtää jonkin asian tai kohteen olemassaolon ilman, että hän ei näe tai kuule sitä.

Ensimmäisen elinkuukauden aikana lapsen ymmärrys tapahtumista perustuu lähes yksinomaan synnynnäisiin reflekseihin, joista tavanomaisia ovat imeminen ja katseleminen. Tämän jälkeen noin ensimmäisen 1-4 kuukauden ikäisenä lapsi oppii liittämään yhteen yksinkertaisia toimintoja niin, että niistä rakentuu usein mielihyvää tuottavien aistimusten myötävaikutuksella alkeellisia skeemoja. Esimerkiksi sormien tahaton refleksinomainen imeminen kehittyy toistamalla tahdonalaiseksi alkeelliseksi kehäreaktioksi. Kehittymisen seuraavassa vaiheessa (4-8 kk) lapsi oppii enenevässä määrin toistamaan tahdonalaisesti toimintojaan esimerkiksi poimimalla esineen ja laittamalla sen suuhun. 8-12 kuukauden ikäinen lapsi kykenee tarkoituksenmukaisiin toimintoihin. Tällöin hän kykenee yhdistämään eri skeemoja päästäkseen halumaansa päämäärään. Lapsi oppii myös jäljittelemään toisten käyttäytymistä ja tunnistamaan kohteisiin liittyviä spesifejä ominaisuuksia. Toisen ikävuoden lopulla lapsi oppii ymmärtämään symboleja, joilla kuvataan tapahtumia tai kohteita. Tätä vaihetta pidetään käännekohtana siirryttäessä esioperationaalisesta toimintaan tiiviisti yhdistyvästä ajattelusta sisäiseen ajatteluun. 


\section{Kehittyminen ikävuosina 2-6}

Uutta kehityskautta Piaget nimittää esioperationaalisen ajattelun ja päättelyn vaiheeksi, joka sijoittuu karkeasti ikävuosiin 2-6. Tällöin kielestä muodostuu yhä keskeisempi väline, jolla lapsi jäsentää ympäristönsä tapahtumia ja toimintojaan. Kieli mahdollistaa lapselle symbolimaailman avautumisen, jota lapsi käyttää esimerkiksi ajattelussaan, puheessaan ja roolileikeissään. Lapsen ajattelu ja päättely on kuitenkin vielä esiloogista ja omaan itseensä suuntautuvaa, egosentristä. Lapsen kyky ymmärtää asioita toisen perspektiivistä käsin on tällöin vielä sangen rajoittunut.

Esioperationaalisen kauden alussa lapsen ajattelu ja päättely on esiloogista noin 4. ikävuoteen asti. Lapsi hahmottaa maailmaa konkreettisen havaintojen ja toimintojen avulla. Myöhemmässä vaiheessa ajattelu käsitteellistyy, mutta perustuu paljolti lapsen intuitioihin ja on näin ollen arvauksenomaista. Lapsella on vaikeuksia erottaa mikä on mielikuvitusta ja mikä todellisuutta. Vaihe on otollinen lapsen mielikuvituksen kehittymiselle ja roolileikeille. Mielikuvitus on silmiinpistävää myös saduissa, tapahtumien seuraamisessa, kokemuksissa ja peloissa.

Esiloogisen ajattelun ja päättelyn kehittymisen alussa lapsen käsitys säilyvyydestä on vielä varsin rajallinen. Jos kaadamme esimerkiksi vettä tilavuudeltaan ja muodoltaan erilaisiin astioihin lapsen päättely on vielä sidoksissa konkreettisiin havaintoihin eikä lapsi kykene päättelemään, että astioissa on sama märä vettä. Myöhemmin noin viiden vuoden iässä lapselle näyttää Piaget'n havaintojen mukaan kehittyvän käsitys määrän, pituuden, painon, tilavuuden ja kokonaisuuden säilyvyydestä sekä mittaamisesta.

Lapsen ajattelulle on esioperationaalisella kaudella tunnusomaista kykenemättömyys käänteisiin ajattelutoimintoihin, jolloin ajattelu etenee yleensä vain yhteen suuntaan. Lapsi ymmärtää esimerkiksi, että hänellä on veli, mutta hän ei välttämättä ymmärrä kuka on hänen veljensä veli. Tai lapsi voi hyvinkin ymmärtää, että juna menee tältä asemalta esimerkiksi Tikkurilaan mutta ei ymmärrä, että tämä juna yleensä kulkee myös Tikkurilasta samalle asemalle takaisin.

Esioperationaalisen ajattelun eräs tunnusmerkki on myös animismi. Tunnusomaista animistiselle ajattelulle on liittää elottomiin esineisiin tai kohteisiin elollisia ominaispiirteitä (esim. aurinko hymyilee, tuoli satuttaa ja satutan sitä takaisin jne.). Animaatioelokuvien suuri vetovoima pieniin lapsiin perustuu esioperationaalisen ajattelun tunnusmerkkeihin. 
Esioperationaalisella kaudella lapsella on myös vaikeaa erottaa tapahtumissa sitä, mikä on ihmisten aikaansaamaa. Lapsi ajattelee esimerkiksi, että aurinko, pilvet, tuuli tai vuoret ovat ihmisten aikaansaamia. Puiden humistessa noin 4-vuotias lapsi saattaa todeta, että isän on kaadettava humiseva puu, koska se tekee tuleen.

Esioperationaalisen kauden ajattelu on myös itsekeskeistä. Kysymys ei ole itsekkyydestä vaan siitä, että lapsi ajattelee ja kokee asioita omasta itsestään käsin. Esimerkiksi 2-4 vuotiaan lapsen on vaikea todeta, että huone näyttää erilaiselta jonkun toisen katsomana silloin kun toinen henkilö katselee huonetta eri paikasta. Lapsi on tällöin tietämättään oman ajattelunsa tuottaman näkökulman vanki. Niinpä lapsi ajattelee ja toimii pitkälti siten kuin hän oma perspektiivinsä olisi ainoa mahdollinen. Esioperationaalisen kauden loppupuolella lapsi alkaa kuitenkin vähitellen Piaget'n mukaan tajuta, miltä joku tapahtuma näyttää, jos sitä katselee ja siitä tekee johtopäätöksiä erilaisista näkökulmista. Vähittäinen irtautuminen itsekeskeisestä ajattelusta mahdollistaa sen, että lapsi alkaa tajumaan sen, että joku muu voi ajatella eri tavoin kuin hän itse.

Piaget'n olettama lapsen itsekeskeinen ajattelu on herättänyt tutkijoissa myös epäilyjä (esim. Donaldson, 1982; Ojala, 1993). Vasta-argumenttina on esitetty, että alle kouluikäiset lapset eivät ehkä olekaan ajattelussaan niin itsekeskeisiä kuin Piaget on olettanut kokeidensa perusteella. Lapsi kykenee irtautumaan itsekeskeisestä ajattelustaan, mikäli hän ymmärtää, että muiden perspektiivi voi olla myös hänen itsensä. Jos lapsi pyrkii ymmärtämään mitä muut tarkoittavat, hänen on kyettävä tajuamaan, että muiden perspektiivi on tarkoituksenmukainen myös hänen itsensä kannalta.

\section{Kehittyminen ikävuosina 7-11}

Kouluuntuloiän alussa noin 7-vuotiaina lasten ajattelussa ja päättelyssä tapahtuu Piaget'n tulkinnan mukaan rakenteellisia muutoksia, jotka ilmenevät konkreettisena ajatteluna ja päättelyä (konkreettisten operaatioiden kausi). Ajattelu muuttuu kohti aikuismaisuutta. Tämä mahdollistaa sen, että lapset kykenevät erottamaan selkeämmin oman ajattelunsa toisten ajattelusta. Aikaisemmin kehittyneet luokittelutaidot täsmentyvät ja lapset kykenevät luokittelemaan esineitä tai ilmiöitä moniulotteisemmin esimerkiksi määrän, tilavuuden ja painon suhteen. Ajantaju, välimatkojen ymmärtäminen ja aikakäsitys suhteessa kelloon, menneisyyteen, nykyisyyteen ja tulevaisuuteen täsmentyvät. Määrän ja säilyvyyden lisääntyvä ymmärrys auttaa 
esimerkiksi lukujonotaitojen kehittymisessä ja peruslaskutoimituksissa. Itsekeskeinen ajattelu vähenee ja kyvykkyys ymmärtää toisten perspektiiviä lisääntyy. Moraalisessa ajattelussaan lapsi kykenee tarkastelemaan asioita eri perspektiiveistä eikä yksinomaan omasta.

Nimeämällä noin 7-vuoden iässä kehittyvää ajattelun ja päättelyn vaihetta konkreettisten operaatioiden kaudeksi Piaget on halunnut korostaa, että lapsi tarvitsee ajattelunsa ja päättelynsä tueksi konkreettisia havaintoja, esimerkkejä ja välineitä. Nämä auttavat jäsentämään omaa ajattelua ja päättelyä, joka ei vielä ole kaikelta osin loogista, koska abstraktinen ajattelu on vasta kehittymissä. Esimerkiksi probleeman ratkaisussa lapset tarvitsevat tehtäviä, joihin he voivat liittää konkreettisia tapahtumia tai kohteita. Johtopäätösten teko perustuu induktiiviseen ajatteluun, jossa yleistykset perustuvat konkreettisiin havaintoihin. Deduktiivisen ajattelun taidot, joissa edetään yleisistä periaatteista, säännöstä tai mallista yksityiseen, ovat lapsille usein vaikeita tai ylivoimaisia, koska lapsilla on vaikeuksia tunnistaa oman ajattelunsa logiikka ilman konkreettisia havaintoja. Esimerkkinä voi mainita päättelytaidon, jossa lapsi kykenee ymmärtämään esimerkiksi, että A on suurempi kuin B ja B suurempi kuin C, mutta ei että A on suurempi kuin C. Esimerkki vahvistaa oletusta siitä, että lapsi kykenee muodostamaan mielessään yksikertaisia ajattelun sääntöjä. Luokittelussaan lapsi kykenee muodostamaan ylä- ja alakäsitteitä sekä sarjoittamisen. Jotta vanhemmat, opettajat ja lapsi itse ymmärtäisivät paremmin lapsen konkreettista ajattelua ja päättelyä, suositeltavana keinona on pyytää lasta kertomaan itselleen ja muille oman ajattelun ja päättelyn perusteita.

Konkreettisten operaatioiden hallinta luo perustan Piaget'n mukaan formaalisen ajattelun taidoille, jotka alkavat kehittyä murrosiän tienoilla (ikävuodet 11-12). Tällöin lapsi kykenee abstraktiin ajatteluun ja aikuismaiseen loogisen ajattelun. Lapsi kykenee nyt asettamaan oletuksia testaten niitä. Päättely tapahtuu sisäisten ajatusmallien ja symbolien avulla. Olettamuksenomaiset, ideologiset ja tulevaisuuteen liittyvät kysymykset herättävät nyt huomiota ja lapsi alkaa pohtia niitä.

\section{Miten Vygotsky tulkitsee lapsen kognitiivisen kasvun?}

Piaget'n ohella lapsen kognitiivisia taitoja voidaan tarkastella myös sosiokulttuurisesta lähestymistavasta käsin. Sosiaalista konstruktiota korostava lähestymistapa perustuu pitkälti Vygotskyn (1978) teoreettiseen 
lähestymistapaan kehityksestä ja oppimista. Tässä lähestymistavassa kognitiiviset taidot eivät ole niinkään lapsen sisäisen kehittymisprosessin tuloksia, vaan ne välittyvät ympäristöstä ja kulttuurista käsin. Olettamuksena on, että lapsen kognitiiviset taidot kehittyvät ihmisen ja kulttuuriympäristön välisen vuorovaikutuksen kautta niistä merkityksistä käsin, joita ihmiset muodostavat toimiessaan yhteiskunnassa ja erityisesti sen kulttuuriinstituutioissa (päiväkodit, esikoulut, koulu ja perhe).

Myös Vygotsky hyväksyy kypsymisen olemassaolon lapsen kehityksessä, mutta hän rajaa kypsymisen pelkästään organismin biologiseksi mekanismiksi. Biologista kypsymistä keskeisempänä Vygotsky pitää kulttuuria. Lapsen kehittymisellä on kaksi erilaista tasoa, joista toinen mahdollistuu biologisten prosessien tuottaman kysymisen ja toinen kulttuurin avulla. Vastaavalla tavalla on erotettavissa myös matalan ja korkean tason mentaaliset toiminnat. Korkeamman tason kognitiiviset toiminnot ovat psykologisia ja niitä ovat etenkin muisti, ajattelu ja puhe (Yudina, 2007).

Kehittyäkseen psykologisten toimintojen pitää aktivoitua. Tähän tarvitaan erityisiä välineitä, työkaluja tai merkkejä, jotka ovat sekä sisäisiä että ulkoisia. Nämä merkit ovat läsnä kulttuurissa, jonka keskeisin merkkisysteemi on kieli. Sanat toimivat merkkeinä erilaisille asioille ja toiminnoille mutta myös ajatuksille ja tunteille. Sanojen lisäksi kulttuurissa on myös muita merkkisysteemeitä kuten esimerkiksi taide, luonnontiede, arkkitehtuuri jne. Merkkien jokapäiväinen käyttö mahdollistuu sisäistymisprosessin kautta, jossa ne siirtyvät tai muuntuvat ulkoisesta merkkimaailmasta sisäiseksi. Kulttuuri merkkisysteeminä toimii välityslinkkinä henkilön sisäisen ja ulkoisen maailman välillä, jossa se on läsnä psykologisena välineenä ihmisen toiminnoissa. Ihmisen toiminta välittyy siis kulttuurin kautta, sen toiminnoista ja ihmisistä käsin.

Korkeamman tason henkiset toiminnot ovat ainutkertaisia ihmiselle. Kielen ja muiden kulttuurivälineiden käyttö ovat ensiarvoisen tärkeitä niiden kehittymiselle. Käsitteenmuodostus edellyttää korkeamman tason oppimista. Vygotsky tekee eron arkikäsitteiden ja tieteellisten käsitteiden välillä. Arkikäsitteiden oppiminen mahdollistuu matalan tason mentaalisilla operaatioilla. Sen sijaan tieteellisten käsitteiden oppiminen edellyttää korkeamman tason kielellisiä ja mentaalisia operaatioita. Vygotsky pitää tärkeänä, että lapselle opetettaisiin tieteellisiä käsitteitä mahdollisimman varhain. 
Kulttuurin kehitys heijastuu Vygotskyn mukaan lapsen kehittymiseen kahdella tasolla: ensiksi sosiaalisella interpersoonallisella ja tämän jälkeen yksilöllisellä psykologisella tasolla. Lähikehityksen alue on hypoteettinen, dynaaminen alue lapsen kehittymiselle ja oppimiselle. Alue voidaan määrittää etäisyytenä sen välillä, miten lapsi pystyy itsenäisesti oppimaan asioista suhteessa siihen, mihin oppiminen yltää aikuisen tai kyvykkäämmän henkilön avustamana. Koska kulttuurit jäsentävät ja kanavoivat eri tavoin kulttuuriaktiviteettinsa varhaiskasvatuksessa, esikoulussa ja koulussa, korkeamman tason oppimisessa esiintyy vaihtelua kulttuurien välillä. Vygotskyn lähestymistapa rohkaisee kehittämään lapsen oppimispotentiaalia saattamalla hänet nykykehityksen alueelta lähikehityksen alueelle. Kielen ja käsitteellisen ajattelun kehittämisellä on tässä prosessia keskeinen osuus.

Lapsen kehittymisen ja oppimisen arvioinnissa Vygotskyn lähestymistapa korostaa dynaamista arviointia. Mielenkiinto on lähikehityksen alueella. Tavoitteena on auttaa ja ohjata lasta vaativiin oppimissuorituksiin, jossa lapsi tarvitsee kyvykkäämpien oppijoiden malleja ja tukea. Opettamalla ja selostamalla lapselle vaativia ja toimivia oppimisen malleja kyvykkäämmät oppijat ohjaavat lasta näihin suorituksiin. Oppimisen edistymisen kriteeri dynaamisessa arvioinnoissa on muutos, jonka tapahtuu lähikehityksessä suhteessa nykykehitykseen.

\section{Kielelliset taidot}

\section{Miten kieli opitaan?}

Tutkijoita on kiinnostanut jo kauan vastauksen saaminen siihen, mikä mahdollistaa kielen oppimisen. Tarjolla on vaihtoehtoisia teorioita, joista osa korostaa kielen perustekijöiden olevan valmiina lapsessa. Tätä kantaa edustaa etenkin Chomsky $(1964,1966)$, jonka mukaan jokaisella lapsella on synnynnäinen kyky tuottaa lauseita niin pian kun hän on omaksunut riittävän sanavaraston. Tätä kykyä Chomsky nimittää synnynnäiseksi kieliopiksi. Sanavaraston hankinta mahdollistuu Chomskyn mukaan paljolti sen mukaan mitä sanoja ja viestejä lapsi kuulee kasvuympäristössään. Todisteena sille, että lapsella on tämän tapainen sisäinen tieto ja herkkyys kieleen, Chomsky pitää sitä, että lapsen kielen varhaisoppiminen tapahtuu nopeasti ja usein luonnollisesti ilman erityistä ponnistelua. Kielen oppimisen perusrakenne on siis olemassa ja lapsen pitää oppia vain suhteellisen vähän 
ja tiettyjä spesifejä uusia kielen ulottuvuuksia. Synnynnäinen kielioppi on yleistä ja mahdollistaa formaalisen kielen oppimisen. Perustana on formaalinen kielioppi, jossa voidaan erottaa vaikeustason mukaan porrastuvia osa-alueita, joita tarvitaan kielen ilmaisemiseen. Kuuntelemalla vallitsevaa kieltä lapsi oppii Chomskyn mukaan erityisesti kielen morfologiaa eli sanojen taivutusmuotoja, mutta tämä ei ole vielä riittävää kielen syntaksin eli lauserakenteen oppimiselle.

Osa tutkijoista kiinnittää erityistä huomiota siihen, millaisia kielellisiä virikkeitä ja malleja kasvuympäristö tarjoaa. Tässä lähestymistavassa mallioppimisella ja oikeiden kielellisten ilmaisujen vahvistamisella on keskeinen merkitys. Tausta on behavioristinen lähestymistapa, joka pyrkii kielen rikastuttamiseen opetuksellisin keinoin. Yhdistelmällä Chomskyn ja behavioristisen teorian aineksia voidaan päätyä uudenlaiseen lähestymistapaan. Tätä voi nimittää interaktiiviseksi, jossa on kaksi komponenttia. Näistä toinen koostuu informaation prosessoinnin mekanismeista, joilla havainnoidaan, rekisteröidään ja prosessoidaan ulkoisia ärsykkeitä, joita ovat esimerkiksi kuvat, sanat, tapahtumat jne. Toinen ulottuvuus kohdistaa huomion siihen sosiaalisen vuorovaikutukseen, joilla ihmiset kommunikoivat, ilmaisevat ajatuksiaan ja ottavat niitä vastaan. Tämän perusteella on oletettu, että sosiaalista vuorovaikutusta voisi pitää eräällä tavoin vygotskylaisena kielenoppimisen perustekijänä olettaen, että ihmisillä olisi tavallaan synnynnäinen kyky tai halu pyrkiä ymmärtää muita ja tulla ymmärretyksi.

\section{Kielen osa-alueet ja niiden kehittyminen}

Kieli on keskeisessä asemassa lapsen kehityksessä ja oppimisessa. Koska se on sekä oppimisen kohde että sen väline, kieleen liittyvän pedagogiikan ymmärtäminen on erittäin tärkeää (Korkeamäki, 2011). Kielellisten taitojen avulla lapsi jäsentää havaitsemaansa, suuntautuu ympäristöön, saa tietoa ympärillään olevasta maailmasta ja tapahtumista sekä hankkii itse tietoa maailmasta (Lyytinen, 1995). Kieli säätelee myös käyttäytymistä, sosiaalista vuorovaikutusta ja toimii ajatusta ja tunteiden tulkkina.

Kielellä on kaksi perustavaa laatua olevaa tasoa, jotka määrittävät kielen oppimista ja kehittymistä ja myöhemmin luku- ja kirjoitustaidon oppimista. Nämä ovat muoto ja merkitys (esim. Myöhänen, 2011; Lyytinen, 1995). Kielen muodon oppiminen edellyttää kolmen keskeisen osa-alueen kehittymistä, jotka kohdistuvat sanojen äännerakenteeseen eli fonologiaan, 
taivutusmuotoihin eli morfologiaan ja lauseiden muodostamiseen eli syntaksiaan. Kielen eri toiminnot yhdistyvät lapsen taitoihin omaksua ja hallita äidinkieli. Keskeisiä tekijöitä äidinkielen oppimisessa pidetään äänteiden, sanojen ja lauseiden muodostamisen periaatteita, joiden kautta kieli saa sille ominaisen rakenteen. Kielen rakenneosat koostuvat foneemeista, morfeemeista, sanoista ja lauseista. Tutkijat ovat havainneet, että lapsi oppii kielen perusrakenteet keskimäärin noin viiden vuoden iässä (Lyytinen, 1995). Nurmilaakson (2011) mukaan neljä-viisivuotiaat lapset hyväksyvät yleensä lauseet, jotka ovat heidän mielestään mahdollisia. Jos lauseen sisältö ei ole lapsen mielestä hänen kokemuksiensa mukainen, lapsi arvioi sen virheelliseksi. Vasta kuusi-seitsemänvuotiaat arvioivat lauseita kieliopillisin perustein.

\section{Äänteet}

Lasten kielenoppimista seurattaessa on havaittu, että äänteiden erottelu opitaan yleensä ensimmäisen ikävuoden aikana (Lyytinen, 1995). Oppiminen tapahtuu pitkälti sen perusteella, millaisia äänteitä lapsi kuulee ympäristössään. Yleensä lapsi oppi vokaalit helpommin kuin konsonantit. Kuulemalla ja jäljittelemällä puheen äänteitä lapsi kykenee ymmärtämään ensimmäisen ikävuoden lopulla suhteellisen paljon ympäristönsä puheesta ja alkaa käyttää kieltä omaan viestintäänsä.

\section{Sanat}

Sanojen ymmärtäminen etenee kehityksessä nopeammin kuin puheen tuottaminen. On havaittu, että lapset alkavat ymmärtää ensimmäisiä sanoja keskimäärin hieman alle vuoden ikäisenä. Yhden vuoden ikäiset lapset kykenevät esimerkiksi tunnistamaan nimensä heitä kutsuttaessa, lopettamaan toiminnan, kun heille sanotaan ei, tulemaan luokse, kun heitä kutsutaan, taputtamaan käsiä pyydettäessä tai etsimään isää/äitiä pyydettäessä (Lyytinen, 1995).

Sanojen oppiminen etenee alussa hitaasti. Esimerkiksi kymmenen ensimmäisen sanan oppiminen voi kestää useita kuukausia. Suomalaisessa seurannassa on havaittu, että lapset voivat oppia ymmärtämään ensimmäiset sanansa noin yhden kuukauden iässä (Lyytinen, 1995; Nieminen, 1991). Vuoden iässä lapsi voi ymmärtää noin 20 sanaa ja puolitoistavuotiaana noin 200 sanaa. Ensimmäisen ja toisen vuoden taitteessa lapset ryhtyvät 
tuottamaan omaa sanastoaan. Toisen ikävuoden loppupuolella lapsi näyttää kykenevän ymmärtämään kielen sosiaalista merkitystä.

Ennen kouluikää lapsen sanavarasto laajenee kiihtyvällä vauhdilla. On havaittu, että 3-5 -vuotiaat voivat oppia päivittäin noin kymmenen sanaa (Lyytinen, 1995). Viisivuotias näyttää hallitsevan jo 2000 sanaa kyeten käyttämään näitä eri tilanteissa. Adjektiivien ymmärtäminen on kuitenkin vielä epätäydellistä ja lapsille tuottaa vaikeuksia ymmärtää, että ne koskevat sekä ihmisiä että fyysisiä ominaisuuksia (esim. kylmä).

\section{Lauserakenne}

Lauserakenteen oppiminen edellyttää riittävää sanavarastoa ja tietämystä periaatteista, joilla yhdistetään sanoja. Kysymyksessä on taito erotella ja yhdistellä sanoja (syntaksi). Lapsen yksisanaiset ilmaisut muuttuvat asteittain lauserakenteiksi noin kahden vuoden iässä (Lyytinen, 1995). Tällöin lauseet ovat lyhyitä sähkösanomatyyppisiä ja niiden kieliopillinen koostumus on usein varsin puutteellista. On kuitenkin tärkeää huomata, että lapset ymmärtävät kielestä ja sen rakenteesta enemmän kuin pystyvät ilmaisemaan. Lauserakenteen kehittymisessä on havaittu tietynsuuntaista etenemistä (Lyytinen, 1995; Anisfield, 1984). Siirryttäessä yksisanaisista ilmaisuista kaksisanaisiin kysymyksessä on usein nimeäminen (esim. hauva tuolla). Nimeämisen jälkeen lauseisiin liitetään muitakin ominaisuuksia kuten koko, väri jne. Kahden ikävuoden vaiheilla lapsi liittää lauserakenteeseen myös omistusta ilmaisevia merkityksiä (esim. äiti sukka) ja toimintaa (esim. isi ajaa).

Kolmivuotiaan lauseisiin ilmaantuu usein apuverbejä, aikamuotoja ja persoonaan liittyviä taivutusmuotoja (Lyytinen, 1995). Lasten tuottamat kysymykset ilmaantuvat (esim. kuka tämä on), lisääntyvät ja lapsi kykenee vastaamaan niihin lisääntyvässä määrin (esim. mitä sinä teet). Suomen kielen peruslausetyypit ilmaantuvat kieleen viisi-kuusi vuotiaana.

\section{Taivutusmuodot}

Suomen kielessä on noin 6000 perussanaa (Myöhänen, 2010). Uusia sanoja saadaan lainaamalla niitä muista kielistä ja etenkin yhdistelemällä tai johtamalla perussanoja. Johdoksia kielessämme on noin $44 \%$. Kun sanaa tarkastellaan muodon eli morfologian kannalta, se voi koostua yhdestä (esim. auto) tai useammasta foneemista (kuorma/auto, tull/e/ssa/mme, talo/t, kerros/talo, tuli/i/mme ). 
Verrattuna moniin muihin kieliin Suomen kieliessä on runsaasti taivutusmuotoja, joiden avulla sanoja taivutetaan, johdetaan ja yhdistellään (Lyytinen, 1995). Kielellemme on ominaista esim. sijamuotojen runsas käyttö, verbien taivuttaminen eri persoonissa ja sanavartalon runsaat taivutukset (esim. polku/auto, polku/pyörä). Tavutusmuotojen omaksuminen on näyttää olevan nopeinta 2-4 -vuoden ikäisillä (Lyytinen, 1988, 1995, 2003). Kaksivuotiaat suomalaislapset voivat oppia tavuttamaan esimerkiksi yksikkömuotoisia sanoja monikkoon (esim. tossu - tossut). Kaksivuotiaan vallitseva aikamuoto puheessa on preesens. Muut aikamuodot ilmaantuvat hieman myöhemmin yleensä 2-3 -vuotiaina. Kolmivuotiaat voivat ilmaista tapahtuminen aikamuotoja (esim. äiti tuli, pian, huomenna), asioiden paikkaa ja sijaintia (esim. etu-, taka-, ylä- ja alapuoli), esineiden ominaispiirteitä (esim. iso/pieni, talo on näin iso) ja komparatiiveja (tämä pallo on isompi). Superlatiivit ilmaantuvat lapsen puheeseen hieman myöhemmin 3-4 vuoden vaihteessa.

5-6 -vuotiaina lapset kykenevät ilmaisemaan tapahtumien ajallista järjestystä (Lyytinen, 1995, 115). Näissä ilmaisuissa voi olla sanoja, jotka kuvaavat ennen/jälkeen, samanaikainen sekä perfektiä ja pluskvamperfektiä (esimerkiksi pesen hampaat ennen kuin menen nukkumaan, ruoan jälkeen saan jäätelöä, sitten kun olen syönyt, menen ulos). Tässä ikävaiheessa lapsen puheeseen voivat liittyä myös aikakäsitteet (esim. viikonpäivät, kuukaudet ja vuodenajat). Viisivuotiaana lapset voivat hallita kielemme taivutusjärjestelmän ja sanojen yhdistämisen perussäännöt sekä ilmaista eri sanaluokan sanoja lähes samassa määrin kuin aikuisetkin arkipuheessaan (Lyytinen, 1995, 2003; Myöhänen, 2010).

\section{Kielellinen tietoisuus ja sen harjaannuttaminen}

Kielellisiä taitoja ja niiden kehittymistä on ryhdytty tarkastelemaan enenevässä määriin kielellisen tietoisuuden näkökulmasta (esim. Nurmilaakso, 2011). Kielellisellä tietoisuudella tarkoitetaan ajattelua, ymmärrystä tai kykyä, joka kohdistuu kielen muotoon ja sen koostumukseen eikä niinkään kielen merkitykseen. Kysymyksessä on tietämys kielestä, joka mahdollistaa eri kielten tunnusomaisten piirteiden tunnistamisen. Tietoisuus on laajempaa kuin kielen symbolinen tietämys. Siihen liittyy tietoisuutta siitä, että sanat ovat eri asia kuin niiden merkitys. Merkitys on ajattelun ja mielen tuote, se ei ole sanassa. Kielelliseen tietoisuuteen liittyy ymmärrys 
kielen rakenteista ja siitä, että näitä rakenteita voi muuttaa ja ilmaista asioita näin eri tavoin.

Kielellisen tietoisuuden kehittymisen myötä lapsen kyvyt kasvavat kielen yksikköjen tarkasteluun ja muuteluun esimerkiksi jakamalla kieltä sanoihin, tavuihin ja äänteisiin tai poistaa, lisätä, ja vaihtaa näitä yksikköjä (Myöhänen, 2010). Kielen rakenteen ymmärtämisellä on havaittu olevan keskeinen merkitys erityisesti luku- ja kirjoitustaidon oppimiselle ja opettamiselle. Kielellisen tietoisuuden tarkastelussa on kohdistettu huomiota erityisesti kolmeen tietoisuuden komponenttiin, jotka ovat äänneasu eli fonologia, sanarakenne eli morfologia ja lauserakenne eli syntaksi (esim. Nurmilaakso, 2011; Myöhänen, 2010).

\section{Äänneasun tietoisuuden harjaannuttaminen}

Tutkimuksiin viitaten Myöhänen (2010, 33-49) toteaa, että fonologisen tietoisuuden eli äänneasun harjoittelu voidaan aloittaa 4-5 -vuotiaana, vaikka se voisi olla mahdollista aikaisemminkin. Harjoitukset edellyttävät, että lapsi havaitsee puheen osat, kykenee pitämään ne muistissa, kykenee tunnistamaan/yhdistelemään/jakamaan osiin ja muuntelemaan poistamisella, lisäämisellä ja siirtämisellä hänelle tarjottuja kielellisiä yksiköitä. Yksikköinä voivat olla lauseet/lausekkeet, sanat, loppusoinnut, tavut ja äänteet (alku-, loppu-, keskiäänne). Harjoitusten vaikeus yleensä lisääntyy siirryttäessä lauseista ja sanoista äänteisiin ja siirryttäessä tunnistamisesta muunteluun. Yksinkertaisimmissa harjoituksissa lapsen tulisi esim. tunnistaa, millä äänteellä sana alkaa. Astetta monimutkaisempi on esimerkiksi harjoitus, jossa lapsen tulee päätellä alkaako kaksi sanaa samalla äänteellä.

Analysoidessaan kattavan määrän esiopetuskirjojen harjoituksia kielellisen tietoisuuden näkökulmasta Myöhänen (2011) on havainnut niiden sisältävän kuulemiseen ja kirjain-äännevastaavuuteen perustuvia harjoituksia sekä harjoituksia, joissa sana jaetaan osiin (segmentointi), äänteitä yhdistetään tavuiksi (fonologisen prosessoinnin liittäminen lukemiseen) ja tunnistetaan sanahahmoja. Tyypillisin harjoitustyyppi on kirjain - äänne vastaavuuden tunnistaminen niin, että tunnistettava äänne/kirjain esiintyy alussa. Kirjain-äänne vastaavuuden harjoittelussa käytetään myös tehtäviä, joissa edellytetään niiden yhdistämistä sanaan tai sanoiksi niin, että äänne/kirjain on useassa paikassa. Kirjain-äänne vastaavuutta edellyttävien harjoitusten lisäksi esiopetuskirjoissa käytetään myös sanan jakamista osiin perustuen tavuihin niin, että äänne/kirjain on useassa paikassa. 
Kolmanneksi tyypillisin harjoitustehtävä perustuu samanlaisuuden tunnistamiseen kuuntelemisen avulla. Näissä harjoituksissa tunnistaminen perustuu yleensä loppusointuun, jos tehtävänä on kuulemisen perusteella tunnistaa alkuäänne/kirjain.

\section{Sanarakenteen tietoisuuden harjaannuttaminen}

Sanarakenteen eli morfologisen tietoisuuden harjoitukset lisäävät lapsen tietoisuutta sanoista (Högström \& Saloranta, 2001). Morfologiset harjoitukset ovat hyödyllisiä, koska ne voivat edistävää myös äänneasun (fonologista) ja kirjoitusasun (ortografista) tietoisuutta sekä sanan merkityksen ymmärtämistä (Myöhänen, 2011).

Harjoitusten kohteena ovat usein yhdyssanat, joiden suhteen voidaan tehdä kahdenlaisia harjoituksia (Högström \& Saloranta, 2001; Myöhänen, 2011). Yhdyssanoja voidaan yhdistää (esim. koripallo) tai niistä voidaan poistaa toinen osa (esim. tuli-?). Yhdyssanaharjoituksia pidetään helpoimpina lasille. Yhdyssanojen lisäksi harjoitukset voivat kohdistua myös sanojen taivutuspäätteisin, jotka ovat astetta vaikeampia kuin yhdyssanaharjoitukset. Sanojen taivutuspäätteiden korostaminen voi auttaa esim. maahanmuuttajalapsia ymmärtämään suomen kielen taivutusmuotoja (Ketonen et al., 2003). Näiden lisäksi morfologisen tietoisuuden harjoituksessa voidaan kohdistaa huomio sanojen johtamiseen (Myöhänen, 2011).

Esiopetuskirjojen harjoituksessa on mukana myös morfologista tietoisuutta edistäviä harjoituksia (Myöhänen, 2011, 131). Yhdyssanoihin liittyviä harjoituksia voi olla kahdentyyppisiä. Yhdyssanojen tekemistä voidaan harjoittaa esimerkiksi harjoituksella, jossa kysytään, mikä on sellainen toveri, jonka kanssa voi leikkiä (leikkitoveri). Toisen tyypin muodostavat yhdyssanaharjoitukset. Niissä tehtävänä on jakaa yhdyssana (esim. sanotaan yhdyssana, lapset kuuntelevat ja sanovat mistä sanoista se muodostuu) tai käsitellä yhdyssanaa (tehtävänä on vaihtaa yhdyssanan osien paikkaa).

Yhdyssanaharjoitusten lisäksi esiopetuskirjat sisältävät myös sanan johtamisharjoituksia ja taivutuspääteharjoituksia (Myöhänen 2011, 131). Esimerkkeinä sanan johtamisharjoittelusta ovat harjoitukset, joissa tehtävänä on keksiä verbi tai verbejä substantiiville (esim. tuuli-tuulee). Toisentyyppisessä harjoituksessa annetaan monipuolisempi johtoajatus, jossa lapsi johtaa sanan (esim. joka ei liiku on....?..liikkumaton). Sanan johtamisharjoituksissa voi olla myös tehtäviä, joissa tarkastellaan johdettua sanaa (esim. mitä kaikkea voisi olla lautasellinen). Tavutuspääteharjoituksia 
edustaa esimerkiksi tehtävä, jossa kerrotaan, että sanaan voidaan lisätä monikon t ja tällä saadaan yhdestä sanasta monta (esim. omena - omenat). Esiopetuskirjojen morfologisen tietoisuuden harjoitukset painottuvat yleensä sanan johtamisharjoituksiin.

\section{Tietoisuus lauserakenteesta ja sen harjaannuttaminen}

Lauserakenteen eli syntaksisen tietoisuus kohdistuu lauseen rakentamisen kieliopillisiin sääntöihin. Kun lapselle kehittyy syntaktinen tietoisuus, hän alkaa käyttää kieliopillisia sääntöjä tietoisesti (Myöhänen, 2011, 57). Tämä tietoisuus mahdollistaa sen, että lapsi voi arvioida ja analysoida kieltä. Lapsia voidaan auttaa syntaktisen tietoisuuden kehittymisessä esimerkiksi tarjoamalla hänelle erilaisia lauseita, joista häntä pyydetään korjaamaan väärät ja perustelemaan tämän jälkeen korjaukset. Tietoisuus lauserakenteen erittelyyn kehittyy suhteellisen myöhään yleensä hieman ennen kouluun siirtymistä tai koulun alussa.

Lauseranteen ymmärtämistä voidaan harjoitella monin tavoin (Myöhänen, 2011, 58). Keinoina voivat olla kehotukset tai käskyt (esim. laita Pihlajan kenkä Aulikin kengän viereen), lauseiden sanojen laskeminen, satujen kuunteleminen, lapselle annetaan muutamia sanoja, joista he tekevät lauseita jne. Esiopetuksessa lapsen syntaktista tietoisuutta voidaan harjaannuttaa esimerkiksi täydentämällä lauseita, joista puuttuu sanoja, kuvalukemisella tekemällä kuvakorteista lauseita, rikastuttamalla lauseita uusilla sanoilla, keksimällä käsite (esim. työkalu) kuvakorttien (esim. vasara, pora, saha) esittämille sanoille (Högström \& Saloranta, 2001).

Suomalaisiin esikoulukirjoihin on sisällytetty harjoituksia, joiden tehtävänä on tukea syntaktisen tietoisuuden kehittymistä (Myöhänen, 2011, sivut 161,232-233). Näissä harjoituksissa on kohteena voivat olla lauseen jakaminen (esim. lapsi laskee lauseen sanat), lauseen tekeminen (esim. lauseen tekeminen kuvakorteista, lauseen tekeminen annetuista sanoista), lausetyypit (lapset keksivät kuvasta kysymyksiä), lauseiden vertailu esimerkiksi yhtäläisyyksien ja pituuden perusteella, sanaluokat (esim. erivärisiä korttipinoja, joissa on nimisanoja, verbejä, adjektiiveja jne. ja lasta pyydetään nostamaan kustakin pinosta aina yksi kortti kerrallaan) ja lauseen käsittely (esim. sanan poistaminen tai vaihtaminen lauseesta). Esikoulukirjoissa lauseen tekemiseen sekä lauseen käsittelyyn liittyvät harjoitukset ovat olleet yleisimpiä ja niissä on yleensä käytetty lauseen sanojen laskemista, lauseen jatkamista ja sanan poistamista lauseesta. 


\section{Kirjaintietoisuuden kehittyminen ja tukeminen}

Erityisesti lukemaan ja kirjoittamaan oppimista silmällä pitäen on perusteltua tarkastella myös kirjaintietoisuutta ja sen kehittymistä tavallaan omana spesifinä kielellisen tietoisuuden alueena pitäen kuitenkin mielessä sen, että kirjainten oppiminen on yhteydessä erityisesti fonologiseen tietoisuuteen (Myöhänen, 2011, 61-64, Puolakanaho, 2007). Tärkeä havainto on, että lasten tietoisuus kirjaimista ja niiden nimistä ennen lukemaan oppimista ennustaa myöhempää lukutaidon (esim. Holopainen ym., 2000), kirjoittamisen (esim. Leppänen ym., 2006) sekä luetun ymmärtämisen ja lukemisen sujuvuuden (esim. Puolakanaho ym., 2008) kehittymistä.

Näyttäisi siltä, että useimmat lapset oppivat ennen kouluikää kirjainten nimiä. Lerkkanen ja Poikkeus (2006) havaitsivat, että esikouluikäiset suomalaislapset osasivat nimetä esikouluvuoden syksyllä 16 ja keväällä 22 kirjainta kahdestakymmenestä yhdeksästä. Kirjaintietoisuuden harhaannuttamisessa toiston osuus voi olla merkittävä ja opettelu voi olla tietokoneavusteista (esim. Ekapeli -Eskarissa, joka tuotettu Niilo Mäki instituutissa). Nurmilaakso (2011) pitää hyvänä aakkosmuistipelien käyttöä, jotka sisältävät sekä isoja että pieniä kirjaimia ja jonkun kyseisellä kirjaimella alkavan kuvan. Tämä ohella aakkosmuistipeli harjoittaa myös tarkkaavaisuutta, muistia, kehittää vuorovaikutusta, kykyä odottaa vuoroaan ja pettymisten sietokykyä.

Kirjaimia voidaan opetella joko kirjain kerrallaan tai lukemisen yhteydessä. Jos kirjaimia opetellaan erillisinä, suositellaan että se voisi tapahtua helpommasta vaikeampaan eli ensin vokaalit ja sitten konsonantit niin, että ensin tulevat konsonanttialkuiset ja sitten vokaalialkuiset (Myöhänen, 2011). Kohteena ovat sekä kirjaimet että äänteet.

Monissa suomalaisissa esikoulukirjoissa (Myöhänen, 2011,155-156) kirjaimet opetellaan usein seuraavassa järjestyksessä: AIUSNEOLRMTÄPKJVHYÖD. Osassa esiopetuskirjoissa opetellaan vain suuraakkosia, osassa kohteina ovat sekä suur- että pienaakkoset. Harjoitustehtävissä on yleensä sekä kirjainten mekaanista kopiointia että kopiointia merkityksellisiä sanoja käyttäen. 


\section{Kielen tukeminen siirryttäessä esiopetuksesta kouluun}

Koulun alulla on keskeinen merkitys erityisesti lukutaidon oppimisessa. Nurmen ja kumppaneiden (Nurmi et al., 2013) tutkimuksessa selvitettiin ensimmäisen luokan opettajien käytänteitä lukemisen opettamisessa. Lasten lukemisvalmiuksia arvioitiin esiopetusvuoden päättövaiheessa. Ensimmäisen luokan alussa selvitettiin millaista tukea opettajat antavat lapsille lukemisessa. Tulokset osoittivat, että opettajat tukivat oppilaita yksilöllisesti sitä enemmän mitä huonommaksi lukemisen- ja kirjoittamisen taidot oli arvioitu esiopetusvuoden päättövaiheessa. Toinen merkittävä opetuskäytäntöihin liittyvä havainto oli se, että vähemmät kokeneet opettajat tai ne, joilla oli vähemmän avustajia, suuntasivat suuremmassa määrin opetustaan lasten lukemisen- ja kirjoittamisen taitoihin verrattuna muihin opettajiin.

Koulun alkuvaiheessa voidaan auttaa merkittävästi lapsia, joilla on havaittu lukemisen vaikeuksia. Tämä kävi ilmi Kiurun ja kumppaneiden (Kiuru et al., 2013) tutkimuksessa, jossa seurattiin perusopetuksen neljännelle vuosiluokalle asti lapsia, joilla oli todettu lukemisen vaikeuksia ennen koulunkäynnin alkua. Tutkimuksessa kävi ilmi, että lapsen lähiympäristöön liittyvillä ehkäisevillä tekijöillä oli selkeä yhteys lasten lukemisen sujuvuuteen 4. luokalla. Keskeisimmät näistä olivat vertaisryhmän hyväksyntä ja opettajan positiivinen tuki. Lukemisvaikeuksien olemassaolo heijastui negatiivisella tavalla lapsen hyväksymiseen vertaisryhmässä, muutti negatiivisemmaksi opettajien positiivisia uskomuksia ja vähensi vanhempien ja opettajien välistä vuorovaikutusta.

\section{Matemaattiset taidot}

Ennen kouluikää matemaattiset taidot kehittyvät läheisessä yhteydessä lapsen ajattelun ja päättelyn kehittymiseen. Näitä mekanismeja ja niille tunnusomaisia lapsen ajattelun ja päättelyn operaatioita olemme tarkastelleet yleisellä tasolla jo Piaget'n kehitysteorian yhteydessä. Piagetlaisittain hahmotettuna lapsen ajattelun operaatiot liittyvät luokitteluun, sarjoittamiseen, säilyvyyteen, päättelyyn (yksisuuntainen, käänteinen/transitiivinen) ja mittaamiseen. Voimme ajatella, että nämä lapsen ajattelun kehittyvät perustaidot muodostavat perustan lapsen matemaattisille taidoille, jotka kehityksen ja opetuksen myötä eriytyvät asteittain omaksi taitoalueeksi esikouluiässä ja kouluun siirtymisen yhteydessä. 
Tutkimukset osoittavat, että lapsille kehittyy runsaasti matemaattisia taitoja jo ennen kouluikää (Aunio, 2008; Aunola ym., 2004). Näiden taitojen on havaittu olevan yhteydessä matematiikan myöhempään oppimiseen (Aunola ym., 2004). Mikäli lapsella on todettu olevan 5-6 -vuotiaana heikot matemaattiset taidot, hänellä on todennäköisesti vaikeuksia oppia koulumatematiikkaa. Myös erot hyvin matematiikkaa osaavien ja heikosti matematiikkaa osaavien lasten välillä näyttävät kasvavan siirryttäessä luokka-asteelta toiselle.

Esikouluikäisen ja koulunsa aloittavan lapsen matemaattisia taitoja on kuvannut esimerkiksi Aunio (2008). Myös LukiMat -tietoverkossa kuvataan lapsen matemaattisia perustaitoja. Näissä matemaattiset taidot jaetaan neljään pääalueeseen. Näitä ovat laskemisen taidot, aritmeettiset taidot, matemaattisten suhteiden ymmärtämisen taidot ja lukumääräisyyden taju. Aunion (2008) mukaan ennen koulua kehityksen painoalueina ovat laskemisen taidot, matemaattisloogiset taidot liittyen matemaattisten suhteiden ymmärtämiseen, lukumääräisyyden ymmärtäminen sekä aritmeettisten perustaitojen harjoittelun aloittaminen.

\section{Laskemisen taitoja}

Laskemisen taidossa on kysymys lukujonojen luettelemisesta, lukumäärän laskemisesta, numerosymbolien hallinnasta ja lukujonotaitojen siirtämisestä laskemisen taitoihin (Aunio, 2008; LukiMat-tietoverkko). Lukujonotaitoja voidaan harjoitella esim. luettelemalla lukuja eteen tai taaksepäin, hyppäyksittäin (esim. joka toinen), jatkamalle lukujonojen luettelemista muusta kuin luvusta yksi. Harjaantuminen lukujonojen luettelemisessa hyödyntää lapsia yhteen- ja vähennyslaskujen hallinnassa.

Alasalmen (2008) tutkimusaineistossa selvitettiin, miten lasten lukujonotaidot kehittyvät esiopetusvuoden syksystä ensimmäisen luokan syksyyn. Tulosten mukaan lukujonotaidot kehittyvät esiopetusvuoden aikana siten, että esiopetuksen lopulla noin kolmannes lapsista hallitsi tehtävät täysin. Noin kymmenesosalla lapsista oli vielä heikot lukujonotaidot. Sukupuolivertailut osoittivat, että pojat olivat merkitsevästi parempia kuin tytöt esiopetusvuoden lukujonotaidoissa. Tätä eroa ei kuitenkaan ilmennyt ensimmäisellä luokalla.

Lukumäärän laskemisen hallinta edellyttää omia osaprosessejaan (Aunio, 2008). Lapsen tulisi kyetä luettelemaan lukujono oikeassa 
järjestyksessä, luomaan yksi-yhteen -suhde sanotun sanan ja esineen välille, tajuamamaan että viimeksi sanottu luku ilmaisee esineiden kokonaismäärän, oivaltamaan että keskenään erilaisia esineitä voi laskea ja vielä tajumaan, että esineet voi laskea missä järjestyksessä tahansa mutta niin, että jokainen esine lasketaan vain kerran.

Numerosymbolien harjoittelussa lapsen tulisi oppia yhdistämään lukusana ja sitä vastaava symboli (Aunio, 2008). Käytännössä harjoituksen voi esimerkiksi toteuttaa siten, että lapselle sanotaan tai näytetään kuvakortilla lukusana ja lapsi harjoittelee vastaavan numerosymbolin kirjoittamista. Numerosymbolien lukumäärän ilmaisemista lapsi voi harjoitella esimerkiksi näyttämällä numerosymboli, joka on yhtä suuri kuin esineiden lukumäärä. Harjoituksen voi toteuttaa myös niin, että kun lapselle näytetään numero, hänen tulisi poimia esineitä numeron osoittama määrä.

\section{Aritmeettiset perustaidot}

Laskutoimituksissa tarvitaan aritmeettisia perustaitoja (Aunio, 2008; LukiMat-tietoverkko). Näiden harjoittelu aloitetaan yleensä yhteen- ja vähennyslaskuilla. Suositeltava tapa on aloittaa nämä harjoitukset esineitä käyttäen (esim. jos kahteen esineeseen lisätään yksi, paljonko niitä sen jälkeen on kasassa). Seuraavassa vaiheessa voidaan käyttää lukujonoja esimerkiksi niin, että lapsi koskettaa esineitä yhteenlaskun edetessä ja päättelee lopuksi, paljonko niitä on yhteensä. Tämän tapaisten harjoitusten jälkeen voidaan harjoitella yhteen ja vähennyslaskuja myös ilman esineitä. Tavoitteena on, että lapsen aritmeettiset taidot kehittyvät muistinvaraisiksi, jolloin lapsi palauttaa aikaisemmin opitut laskuoperaatiot mieleensä ja soveltaa niitä uusiin laskutoimituksiin ilma, että hän laskee joka kerta alkiot uudestaan.

\section{Matemaattiset suhteet}

Matemaattiseen ajatteluun voidaan katsoa sisältyvän myös matemaattisten suhteiden ymmärtäminen. Tähän sisältyvät matemaattisloogiset periaatteet ja aritmeettiset periaatteet, joita käytetään yhteen- ja vähennyslaskuissa, kymmenjärjestelmän ja paikan ymmärtämisessä sekä matemaattisten symbolien hallinnassa (Aunio, 2008; LukiMat -tietoverkko).

Loogis-matemaattiset periaatteet liittyvät Piaget'n kuvaamiin ajattelun ja päättelyn periaatteisiin, joista sarjoittamisella, vertailulla, luokittelulla ja 
yksi-yksi -suhteella katsotaan olevan keskeisin yhteys matemaattisiin taitoihin. Matemaattisen ajattelun kannalta sarjoittaminen on lukujonotaito, jota lapsi harjoittelee aluksi yleensä esineillä järjestäessään niitä pituusjärjestykseen (Aunio, 2008). Siirryttäessä lukuihin lapselle voidaan antaa esimerkiksi lukusarjoja, joista puuttuu luku ja lapsen tehtävänä on päätellä mikä puuttuva luku on.

Matemaattisessa ajattelussa tarvitaan myös vertailutaitoa, johon lapsi harjaantuu vertaillessaan aluksi esineitä esimerkiksi koon suhteen (Aunio, 2008). Matemaattisena taitona vertailu kohdistuu lukumääriin, joita vertaillessaan lapsi harjaantuu myös ongelmanratkaisuun.

Luokittelusta lapsi on yleensä saanut jo varhaiskehityksessään konkreettisia kokemuksia ryhmittämällä esineitä omiin luokkiinsa esimerkiksi koon tai värin perusteella (Aunio, 2008). Matemaattisena taitona luokittelu kohdentuu esimerkiksi osajoukkojen lukumäärän laskemiseen ja niiden vertailuun (esim. laskee tyttöjen ja poikien määrän luokassaan). Myös luokittelutaito liittyy ongelmanratkaisutaitoon.

Yksi yhteen -suhteen ymmärtäminen on perusehto sille, että lapsi kykenee lukumäärän laskemiseen (Aunio, 2008). Lisäksi lapsen on opittava, että esine tai luku voidaan laskea vain kerran, jota lukumäärän laskeminen johtaisi oikeaan tulokseen. Piaget'n teoriassa on kuvattu yksityiskohtaisemmin sitä, miten yksi yhteen -suhteen ymmärtäminen kehittyy lapsen ajattelun ja päättelyn varhaisessa kehittymisessä.

Aritmeettiset perustaidot luovat pohjaa niiden periaatteiden syvällisemmälle ymmärtämiselle, jotka liittyvät laskutoimituksiin (Aunio, 2008). Kun kohteena ovat yhteen- ja vähennyslaskut, niissä suoriutuminen edellyttää yleisempien periaatteiden ymmärtämistä ja niiden käyttöä laskutoimituksissa. Ensinnäkin lapsen tulee ymmärtää, että kokonaisuudet voivat muodostua pienemmistä osista (esim. luvun 4 summa voidaan laskea 2+2, $3+1,1+1+1+1)$. Toinen keskeinen periaate laskutoimituksille on, että luvut voidaan esimerkiksi laskea yhteen missä järjestyksessä tahansa (esim. $2+2=3+1$ ). Edelliseen liittyy vielä oma spesifi periaate, joka koskee laskutoimitusten hajottamista osiin ja laskemista yhteen eri järjestyksessä tulosten pysyessä samana kuten esimerkiksi $(1+2)+3=1+(2+3)$. Neljäs laskutoimituksia määrittävä periaate on käänteisyyden periaate, jonka mukaan esimerkiksi yhteen- ja vähennyslaskut ovat käänteisiä (esim. 4+3-3=4).

Matemaattisen suhteiden perustaitoihin liittyy myös kymmenjärjestelmän ja paikka-arvon ymmärtäminen. Kun luvuissa siirrytään lukualueelta 
1-9 suurempiin lukuihin, lapsi tutustuu kymmenjärjestelmään (Aunio, 2008). Esimerkiksi Montessori-pedagogiikassa käytetyt materiaalit on jo alun perin rakennettu niin, että lapset tutustuvat kymmenjärjestelmään ja tätä kautta satoihin ja tuhansiin. Kymmenjärjestelmä tutustuttaa lapsen myös paikka-arvon ymmärtämiseen niin, että ykkösillä, kymmenillä, sadoilla jne. luvuissa oma paikkansa. Matemaattisten suhteiden alueeseen voidaan vielä sisällyttää matemaattiset symbolit, joita käytetään esimerkiksi kuvaamaan suurempi $(>)$ tai pienempi $(<)$, yhtä suuri $(=)$ jne. Kun lapsi oppii käyttämään tämän tapaisia symboleita, hänen ymmärryksensä laajenee käsittämään matematiikan symbolimaailma laajemmin kuin lukumäärien symbolit sinänsä mahdollistavat (Aunio, 2008).

\section{Lukumääräisyyden ymmärtäminen}

Matemaattisten taitojen neljäs laajempi osa alue liittyy lukumääräisyyden kokonaisvaltaiseen tajuamiseen. Tällä tarkoitetaan kykyä hahmottaa lukumääriä ilman laskemista (Aunio, 2008). Valmiudet tähän näyttävät kehittyvän jo varhaislapsuudessa, jolloin lapsi kykenee erottamaan toisistaan esimerkiksi ison ja pienen määrän esineitä. Lukumääräisyyden ymmärtämistä voidaan hyödyntää myöhemmin esimerkiksi arvioimalla ja suhteuttamalla toisiinsa lukumääriä. Kysymyksessä on siis taitoalue, joka liittyy läheisesti matemaattiseen ajatteluun eikä niinkään laskutoimituksiin sinänsä.

\section{Matemaattisen taitojen kehittyminen ja tukeminen}

Lapsen matemaattinen kehitys etenee yleensä lukujonotaidoista lukumäärän laskemiseen ja siitä edelleen yhteen- ja vähennyslaskutaitoihin. Seuraavassa esimerkkejä lukumäärän harjoittelusta (Aunio, 2008). Lukumäärää voi harjoitella esimerkiksi sanomalla lapsille jokin lukusana. Lapsen tehtävänä on kirjoittaa tai tunnistaa korteista sitä vastaava numerosymboli. Lapsille voi myös näyttää esimerkiksi korteilla jonkin numerosymbolin pyytämällä lasta tämän jälkeen sanomaan sitä vastaava lukusana. Lukumäärän numerosymboleita voidaan harjoitella pyytämällä lasta näyttämään se numerosymboli, joka on yhtä suuri kuin näytettyjen esineiden lukumäärä. Toinen tapa on näyttää lapselle numero ja hänen pyydetään ottamaan yhtä monta esinettä. 
Lukujonojen luettelemisen kehittyminen lukumäärän laskemiseksi kehittyy asteittain (Aunio, 2008). Noin kahden vuoden iässä lapset ymmärtävät (primääri ymmärrys), että eri lukusanoilla voidaan viitata eri lukumääriin. Erottelu on karkeaa. Noin kolmen vuoden iässä lapsi kykenee lorumaiseen laskemiseen. Tällöin lapsi osaa sanoa lukusanoja, mutta lukujonoa ei sanota oikeassa järjestyksessä eikä sitä aloiteta useinkaan ykkösestä. Noin neljän vuoden iässä lapsi osoittaa kykenevänsä eriaikaisen laskemisen. Tällöin lapsi osaa sanoa lukusanat oikeassa järjestyksessä ja osoittaa laskettavia esineitä, mutta sanat ja osoittaminen eivät useinkaan ole samanaikaisia. Noin 41/2-vuotiaana lapsi kykenee järjestämällä laskemiseen sanomalla lukusanat oikein ja osoittaa tai siirtää esinettä sormella merkitäkseen sen esineen, jota luku koskee. Noin viiden vuoden iässä lapsi alkaa kiinnittämään huomiota tulokseen laskemisessa. Tällöin lapset luettelevat lukusanat oikeassa järjestyksessä alkaen ykkösestä. He ymmärtävät myös, että jokainen laskettava esine tulee lasketuksi vain kerran ja että viimeisenä mainittu lukusana ilmaisee, kuinka monta yksikköä laskutoimituksessa on yhteensä. Lapsi tietää myös, että lukujonossa olevat sanat on järjestetty suuruusjärjestykseen, jolloin suurempi luku viittaa suurempaan lukumäärään. Noin 51/2 ikäisenä lapsi kykenee lyhentyneeseen laskemiseen. Tällöin lapset tunnistavat esimerkiksi nopan silmäluvut ilman, että laskevat jokaista pistettä ja kykenevät jatkamaan laskemista eteenpäin.

Matemaattisten taitojen oppiminen on yhteydessä monen muun tekijän ohella opettajan ohjaustyyliin. Tämä kävi ilmi Rajalan (2008) tutkimuksessa, jossa selvitettiin matematiikan valmiuksien ohjaamisessa käytettäviä esiopetuksen opetuskäytänteitä. Tulokset osoittivat, että esiopettajat käyttivät opetustuokioilla monia erilaisia tapoja ohjata lasten matematiikan valmiuksia. Näihin sisältyi esimerkiksi leikkiä, lauluja, pelejä, liikuntaa ja tehtäviä. Opettajat myös kyselivät lapsilta sekä numeroihin että muotoihin liittyviä käsitteitä. Matemaattista ajattelua virittävät ohjauskeskustelut olivat kuitenkin vähäisiä. Itse asiassa havaittiin, että yhdessäkään kohteena olleessa esiopetustuokiossa esiopettaja ei kysynyt lapsilta, miten he olivat päätyneet ratkaisuunsa. Esiopettajien kysymykset lapsille olivat pääosin faktakysymyksiä. Sen sijaan prosessikysymyksiä, joiden avulla opettaja jatkaisi tai johdattelisi pohdintaa eteenpäin, ei juuri esiintynyt.

Tutkiessaan lasten matematiikan taitoja peruskoulun ensimmäisellä luokalla Mäkinen ja Pitkäaho (2008) havaitsivat, että riskilasten matematiikan taidot olivat verrokkilasten taitoja heikommat jo peruskoulun 
ensimmäisellä luokalla. Riskilasten vanhempien lastensa oppimista koskevat uskomukset olivat verrokkilasten vanhempien uskomuksia alemmat niin isien kuin äitienkin osalta. Vanhempien lastensa matematiikan oppimista koskevat uskomukset olivat yhteydessä lasten matematiikan taitoihin sekä riskilapsilla että verrokeilla. Vanhempien lastensa yleistä oppimista koskevat uskomukset ja lasten matematiikan taidot sen sijaan olivat yhteydessä vain verrokkiryhmässä. Edelleen havaittiin, että vanhemmilla ei ollut erilaisia uskomuksia koskien tyttöjen ja poikien matematiikan oppimista. Sen sijaan vanhempien tyttöjen oppimista yleisesti koskevat uskomukset olivat poikien oppimista koskevia uskomuksia korkeammat sekä riski- että verrokkiryhmässä. Tulokset viittaavat siihen, että oppimisvaikeusriskin omaavien lasten vanhempien uskomuksissa esiintyy epävarmuutta, joka puolestaan voi heijastua oppimisvaikeuksien kehittymiseen.

Rönkän ja kumppaneiden (2011) tutkimuksessa selvitettiin siirtymää esiopetuksesta perusopetuksen toiselle luokalla. Tarkastelun kohteena olivat lasten luku- ja laskutaidon ja matematiikan oppijaminäkuvien kehitys sekä lasten sosiaalisen statuksen yhteys. Tulosten mukaan lasten luku- ja laskutaidot (samoin kuin äidinkielen taidot) kehittyivät jokseenkin tasaisesti esikoulusta toiselle luokalle. Laskutaidon ja matematiikan oppijaminäkuvissa voitiin havaita sekä taitokeskeistä että minäkeskeistä sisältöä. Matematiikan minäkuvat kuitenkin heikkenivät koulupolun alussa. Suositut lapset pärjäsivät muita lapsia paremmin. Tutkimuksen tulokset osoittavat, että lasten hyvät koulutaidot edistävät positiivisten oppiainekohtaisten minäkuvien kehitystä. Kuitenkin matematiikassa myös myönteisen oppijaminäkuvan tukemisella voidaan edistää matematiikan taitojen kehitystä.

Maassamme on tuotettu suhteellisen runsaasti lasten matemaattisten taitojen varhaiskehittymistä tukevaa materiaalia päiväkotien, esiopetuksen ja alkuopetuksen käyttöön. Näistä esimerkkeinä voi mainita (a) Nallematikka, joka on varhaisten matemaattisten oppimisvalmiuksien kehittämisohjelma (Mattinen ym., 2010), (b) Pikkumetsän esiopetusmateriaalin, jossa on matematiikanharjoitusten lisäksi myös kielellisen tietoisuuden harjoituksia (Wäre ym., 2009), (c) Ekapeli-Matikka, joka tarkoitettu esi- ja alkuopetusikäisten matematiikan perustaitojen oppimisen tukemiseen (LukiMat) sekä (d) matematiikkalehden Solmu, joka sisältää koulutusmateriaalia alkuopetuksen käyttöön (Peda.net). Kehittävää tutkimusta on tehty esimerkiksi laskemisen taidoista ikävuosina 6-8 (esim. Hannula ym., 2007) sekä lukukäsitteen hallinnasta ja sen kehittymisestä kolmivuotiailla (Mattinen, 
2006) ja esiopetusikäisillä (esim. Vuorio, 2005) lapsilla. Vuonna 2018 julkaistu Matikkaa lapsen kanssa -kirja on laadittu erityisesti vanhemmille, isovanhemmille ja muille aiheesta kiinnostuneille (Näveri, 2018).

\section{Esimerkkejä matemaattisten taitojen opettamisesta varhaisvuosina}

Mielenkiinto matematiikan alkeistaitojen opettamiseen ei rajoitu vain Suomeen, vaan sitä analysoidaan yleismaailmaisesti. Esimerkiksi USA:ssa Ginsburg ja Ertle (2008) ovat koonneet kattavan tutkimuskoosteen varhaisvuosien matematiikan oppimisesta ja opettamisesta. Koosteen tekijät pelkistävät varhaisvuosien opettamisen perusstrategiat kahteen suuntaukseen. Näistä toinen korostaa matematiikan kiinteää liittämistä lapsen päivittäisiin toimintoihin ja aktiviteetteihin. Toisessa strategiassa puolestaan korostetaan opetussuunnitelman ja suunnitellun opetuksen tärkeyttä. Tämän esteenä kuitenkin on usein havaittu opettajien oman tietämyksen ja ymmärryksen puute matematiikan perusteista ja peruskäsitteistä. Ginsburgin ja Ertlen (2008) raportoima vertailu USA:n ja Kiinan välillä osoitti, että kiinalaisten opettajien tietämys oli syvällisempää ja kokonaisvaltaisempaa amerikkalaisiin nähden. Viime aikaiset PISA -tutkimukset osoittavat, että ero Kiinaan esimerkiksi matematiikassa on mieluummin kasvamassa kuin vähenemässä. Matemaattisen tiedon ja opetussuunnitelman kehittämisessä olisi tutkimuskatsauksen mukaan tärkeää analysoida huolella esimerkiksi matematiikan sisältöjä, lasten omia ajatuksia, käytettyjä oheismateriaaleja, opettajan opetuksellisia ratkaisuja sekä opettajankoulutuksen ja täydennyskoulutuksen riittävyyttä matematiikan ymmärtämiseen ja opettamiseen.

Toisena kansainvälisenä esimerkkinä voidaan ottaa matematiikkaa koskeva Englannin kansallinen opetussuunnitelman, joka kattaa ikävuodet 0-5 (Early years foundation stage statutory framework, 2017) sekä ikävuodet 5-7 (National curriculum in England, Framework for key stage 1, 2014). Ikävuosien 0-5 opettamiselle ja oppimiselle on asetettu seitsemän standardia: (a) laskemisen ja numeroiden ymmärtäminen, (b) tietoa numeroista ja niiden käyttö, (c) laskutoimitukset, (d) muodon ymmärtäminen, ( e ) mittaaminen, (f) tiedon käsittely sekä (g) matematiikan käyttö ja soveltaminen. Ikävuosien 0-5 opettamisessa kohdennetaan erityistä huomiota (a) matematiikan kieleen, (b) sarjojen tunnistamiseen ja tuottamiseen, (c) kohteiden ja tapahtuminen vertailuun, luokitteluun, yhteensovittamiseen 
ja laskemiseen, (d) numeroiden ymmärtämiseen (numerosymbolit ja laskeminen) sekä ( e ) matematiikan käyttöön probleeman ratkaisussa. Ikävuosien 5-7 opetussuunnitelmassa matematiikan oppimisessa ja opettamisessa harjoitellaan (a) numeerisia ja mentaalisia laskemisen strategioita, (b) paikka-arvon ymmärtämistä (esim. yksinumeroiset, kaksinumeroiset, kolminumeroiset jne. luvut), (c) peruslaskutoimituksia erilaisissa konteksteissa ja probleemanratkaisua, (d) geometristen muotojen ja symmetrian tunnistamista sekä ( e ) mittaamista ja estimointia. Esimerkiksi 6-vuoden iässä peruslaskutoimituksissa käytettään 2-4 numeroisia lukuja, murtolukuja, prosenttilaskuja ja yhtälöjen muodostamista. Mittaamisessa kohteina ovat mitta-, pinta-ala- ja tilavuusyksiköt. Geometriassa käsitellään 2- ja 3 -ulotteisuutta.

\section{Sosiaaliset taidot}

Lapsen sosiaalisten taitojen kehittyminen mahdollistaa liittymisen ja vuorovaikutuksen niin aikuisiin kuin lapsiinkin. Ne määrittävät omalta osaltaan sen, millaiseksi lapsen suhteet kavereihin ja ystäviin sekä omaan itseen, annettuihin tehtäviin, sääntöihin, oma-aloitteisuuteen tai osallisuuteen leikissä muodostuvat (esim. Kronqvist \& Pulkkinen, 2007; Salmivalli, 2005). Kaverisuhteisiin liittyviä sosiaalisia taitoja ovat esimerkiksi avun tarjoaminen muille, toisten tunnetilojen huomioon ottaminen, yhteiseen keskusteluun osallistuminen, toisten pyytäminen mukaan leikkeihin ja kaverin puolustaminen. Keskeisiä sosiaalisia taitoja suhteessa omaan itseen voivat olla kritiikin hyväksyminen muilta, taito tehdä kompromisseja ja taito hillitä itsensä vihaisena. Lapsen sosiaalisia taitoja suhteessa hänelle annettuihin tehtäviin voivat olla esimerkiksi taito kuunnella ja seurata ohjeita, kyky itsenäiseen työskentelyyn, kyky työskennellä häiriintymättä sekä taito pysyä sovitussa aikataulussa.

Lapsen sosiaalisia taitoja, niiden kehittymistä ja kehittymisen tukemista voidaan tarkastella ainakin kahdesta lähtökohdasta (esim. Poikkeus, 1995). Yhtäältä huomia voidaan kohdistaa sosiaalisiin taitoihin sellaisina kuin ne ilmenevät ja kehittyvät eri-ikäisillä lapsilla sosiaalisissa vuorovaikutustilanteissa. Tällöin sosiaalisia taitoja voivat olla esimerkiksi kyky yhteistoimintaan, taito vastavuoroiseen kommunikaatioon, kyky eläytyä toisen asemaan, tunteiden ilmaisu, taito sovitella ristiriitoja jne. 
Toinen näkökulma kohdistaa huomionsa siihen, millaista ajattelua, päättelyä ja tulkintaa liittyy lapsen sosiaalisen käyttäytymiseen. Tämä ulottuvuus ilmenee esimerkiksi kykynä tehdä oikeansuuntaisia havaintoja toisten ja omasta käyttäytymisestä, ajatuksista tai tunteista. Tätä lähestymistapaa nimitetään usein sosio-kognitiiviseksi, jossa sosiaalista käyttäytymistä tarkastellaan lapsen ajattelun ja siinä tapahtuvan kehityksen puitteissa. Kehityspsykologisesti kysymyksessä on lapsen sosiaalisen kognition kehitys (esim. Korkiakangas, 1995).

Sosiaaliset ja sosio-kognitiiviset taidot liittyvät laajempaan kokonaisuuteen, jota usein nimitetään sosiaaliseksi kyvykkyydeksi eli kompetenssiksi (esim. Poikkeus, 2011; Laine, 2005). Tarkastelukulmana on tällöin lapsen kyky hyödyntää omia ja ympäristön resursseja sosiaalisten tavoitteiden saavuttamiseksi. Esimerkiksi se, miten lapsi pääsee vuorovaikutukseen ja leikkiin tai solmii ystävyyssuhteita, ohjautuu ja muovautuu lapsen sosiaalisen kompetenssin kautta. Sosiaalista kompetenssia voi myös määritellä niin, että siinä on kysymys lapsen kyvystä toimia sosiaalisesti suotuisalla tavalla. Sosiaaliseen kompetenssiin oletetaan sisältyvän useita taitoja. Näitä ovat itsesäätely- ja tunnetaidot, sosio-kognitiiviset taidot, sosiaaliset taidot sekä kiintyminen ja osallisuus (Poikkeus, 2011).

\section{Sosiaalisen kognition kehittyminen}

Sosiaalinen kognitio muodostuu lapsen sosio-kognitiivista taidoista mahdollistaen tietoisuuden omasta ja toisten ajattelusta ja mielen liikkeistä (Zelazo, 2012). Tietoisuuteen sisältyy emootioita, motiiveja, tunteita ja mieltymyksiä. Sosiaalinen kognitio kehittyy iän myötä mielen taidoiksi (a theory of mind), jota tarvitaan sosiaalisten tilanteiden ja toisten ajattelun ymmärtämisessä, kuvaamisessa ja ennustamisessa. On arveltu, että lapsen sosiaalisen kognition taidot voisivat ohjata lasta esimerkiksi haluun leikkiä samoilla leikkivälineillä toisten kanssa. Varhaislapsuudessa sosiaalinen kognitio ohjaa keskeisellä tavalla lapsen havaintoja. Myöhemmin sosiaalinen kognitio vaikuttaa lapsen vuorovaikutussuhteiden laatuun ja koulumenestykseen. Lasten sosiaalisen kognition myönteisellä kehittymisellä on havaittu olevan myönteistä vaikutusta esimerkiksi kommunikaatiotaitoihin, sosiaaliseen kyvykkyyteen, toverisuosioon, koulun myönteiseen kokemiseen ja oppimissaavutuksiin. 
Sosiaalisen kognition merkityksen sosiaalisessa vuorovaikutuksessa oletetaan perustuvan siihen, että ihmiset pyrkivät jo pienestä pitäen muodostamaan käsitystä vakaasta, säädeltävästä ja ennustettavissa olevasta sosiaalisesta maailmasta, jonka he olettavat olevan itsellään ja toisilla. Nämä käsitykset pelkistyvät käyttäytymistä jäsentäviin ja selittäviin persoonallisuuden piirteisiin, joilla etsitään selitystä käyttäytymisen syille ja haetaan ymmärrystä käyttäytymiseen.

Sosiaalisen kognition näkökulmasta kognitiivinen kehittyminen on yhteydessä sosiaaliseen kanssakäymiseen ja kokemuksiin (Korkiakangas, 1995, 188-201). Vastaavasti oletetaan, että sosiaalinen interaktio vaikuttaa kognitiiviseen kehittymiseen. Kognitiivinen kehittyminen vaikuttaa erityisesti siihen, miten lapset ovat vuorovaikutuksessa, kuinka lapset käsitteellistävät ja hahmottavat vuorovaikutussuhteita ja tilanteita, kuinka tarkkaan lapset kykenevät tulkitsemaan toisten lasten sosiaalista käyttäytymistä sekä kuinka hyvin lapset kykenevät kartuttamaan informaatiota aikaisemmista sosiaalista tilanteista ja siirtämään tätä nykytilanteeseen tai tulevaisuuteen. Moraalin kehittyminen on yksi sosiaalisen kognition kautta jäsentyvä ominaisuus, jonka keskiössä ovat säännöt ja käyttäytymisen normit.

Lapsen sosiaalinen kognitio kehittyy iän myötä (esim. Zelano, 2011; Yamaguchi, 2009). Varhaislapsuudessa sen vaikutukset kohdistuvat tavoitehakuiseen käyttäytymiseen (esim. kohteen tavoittelu) ja vähän myöhemmin tietoisuuteen toisten mielentiloista (esim. mistä joku toinen pitää tai mistä ei). Ennen kouluikää sosiaalinen kognitio vaikuttaa kielellisiin taitoihin ja kehittymiseen (esim. ymmärtää toisen näkökulmia ja tunteita). Kouluiässä sosiaalinen kognitio säätelee vuorovaikutusta kognitiivisten taitojen, käyttäytymisen ja toiminnan tilannetekijöiden välillä. Tähän liittyy mallioppimista, tuloksen ennakointia, itsearviointia saavuttamisen mahdollisuuksista, tavoitteen asettamista ja itsesäätelyä.

Tutkittaessa lapsen sosiaalisen kognition kehittymisestä siihen näyttää liittyvän seuraavan tapaisia tunnusmerkkejä (Korkiakangas, 1995):

- Ennen kouluikää lapselle ovat tunnusomaista tässä ja nyt päätelmät, joita ohjaavat aikuisten käsitykset eikä käyttäytymisen taustalla olevien sisäisten tilojen tai persoonallisuuden piirteiden ymmärtäminen.

- Tulkinta pelkistyy sosiaalisiin tilanteisiin, joita pitää yllä aikuisten jäsennys. Tämä luo lapselle ennustettavuutta ja jäsennystä sosiaalisiin tilanteisiin ja niiden tulkintaan. 
- Lapsen kuvailut toisista pelkistyvät usein emootioihin, joissa tulkitaan käyttäytymistä tietyllä hetkellä ja tietyissä tilanteissa. On kysymys tunnetiloista, jotka ikään kuin ymmärretään ulkoa käsin synnytetyiksi.

- Sosiaalisten kognitioiden kehittyminen mahdollistaa sen, että lapsen kuvitteluun toisista ihmisistä liittyy pysyviä piirteitä tai persoonallisuuden piirteitä (esim. ahkera, ystävällinen tai tyhmä). Näiden tulkinta perustuu ajatteluun ja oivallukseen kohteena olevan henkilön sisäistä tekijöistä.

- Lapsille ovat tunnusomaisia hyvä-paha -erottelut.

- Ennen ikävuosia 6-8 lapset eivät toimi helposti aikuisten heihin kohdistamien tulkintojen mukaisesti.

- Sen sijaan kouluiässä lapset ottavat yhä enemmän huomion aikuisten tulkinnat heidän käyttäytymisestään. Kouluiässä vanhempien, opettajien ja tovereiden tulkinnoilla ja kuvauksilla voi olla merkittävää vaikutusta sosiaalisen kognition jäsentymiseen ja kehittymiseen.

\section{Toverisuhteet}

Lapsen näkökulmasta sosiaalisia taitoja tarvitaan toveri- ja ystävyyssuhteissa (Poikkeus, 1995, 130-135). Toverisuhteiden avulla lapselle muodostuu tunne ryhmään kuulumisesta, joka on varsin merkityksellinen lapsen minäkäsityksen muodostumiselle, jonka yksi keskeinen osa, sosiaalinen minä, rakentuu sosiaalisen vuorovaikutuksen avulla. Voi olettaa, että periaatteessa jokainen lapsi haluaa olla suosittu toveripiirissä. Lapset liittävät suosittuihin tovereihin sellaisia ominaisuuksia kuten avuliaisuus, ystävällisyys ja yhteistyökykyisyys. Toverisuhteissa arvostetaan myös johtajuutta. Johtava asema voi perustua määräilevyyteen, jossa voi olla mukana myös aika ajoin aggressiivisia piirteitä. Leikkitoiminnoissa johtava asema on usein sillä, joka kykenee hallitsemaan leikkivälineitä ja osaa käyttää niitä taitavasti. Varttuneimmilla lapsilla johtava asema toveripiirissä voi perustua taitoon ohjata ja pitää yllä toimintaa.

Vastaavasti ei-suosittujen ja monesti torjuttujen lasten ominaisuuksiin voidaan liittää aggressiivisuus, kärsimättömyys sekä piittaamattomuus toisten tunteista ja säännöistä. Epäsuosittuna oleminen saattaa johtaa siihen, että lapsi on epävarma ja varovainen tekemään aloitteita toveripiirissä. Näiden kahden ääriryhmän lisäksi toverisuhteissa voi erottaa lapset, jotka monesti jäävät vailla huomiota. Nämä lapset saattavat olla ujoja, helposti 
syrjään vetäytyviä, yksinäisiä tai surullisia. Neljännen osaryhmän voivat muodostaa lapset, joihin toiset suhtautuvat ristiriitaisesti. Näillä lapsilla saattaa olla vahvuuksina esimerkiksi jokin taito tai lahjakkuus tai huumorintaju, mutta näiden vastapainona he voivat olla esimerkiksi helposti ärsyyntyviä, aggressiivisuuteen taipuvaisia, keskittymättömiä tai hyperaktiivisia. Lasten toverisuhteet näyttävät muodostuvan suhteellisen pysyviksi varsin pian jo toisen tai kolmannen yhteistapaamisen kuluessa.

\section{Ystävyyssuhteet}

Erotuksena toverisuhteisiin lasten ystävyyssuhteet ovat usein kahdenvälisiä vuorovaikutussuhteita. Niille on ominaista sitoutuneisuus, kiintymys, fyysinen tuki, myönteisen minäkäsityksen tukeminen ja emotionaalinen vuorovaikutus (Poikkeus, 1995; Salmivalli, 2005; Kronqvist \& Pulkkinen, 2007). Ystävyyssuhteisiin voi liittyä tiivistä yhdessäoloa, läheisyyttä, katsekontaktia, hymyilyä ja keskustelua. Ystävyys auttaa tukemaan myönteistä käsitystä itsestä ja omasta merkityksestä toiselle. Jos ystävien välille syntyy erimielisyyksiä, ne pyritään yleensä ratkaisemaan pian. Ystävyyssuhteet edustavatkin usein lapsen sosiaalisessa kanssakäymisessä pysyvyyttä ja niitä voi olla sekä suosituilla että torjutuilla. Ystävyyssuhteet edistävät usein myös lapsen toverisuhteita. Varhaisiässä ystävyyssuhteet syntyvät usein niiden välillä, jotka leikkivät ja toimivat usein yhteydessä (Poikkeus, 1995). Myöhemmin ystävyyteen liittyy asioiden jakamista, kahdenkeskeistä luottamusta ja auttamista sekä pyrkimystä pitää konfliktien ja aggressioiden määrä alhaisena.

\section{Sääntöjen ja moraalin oppiminen}

Lapsen vuorovaikutusta kavereihin sekä suhtautumista omaan itseen ja annettuun tehtäviin ohjaavat säännöt. Lapsi kohtaa arjessa runsaasti tilanteita, joissa odotetaan, että hän kehittyy ja oppii toimimaan vallitsevien sääntöjen ja periaatteiden mukaisesti. Säännöillä asetetaan normeja lapsen käyttäytymiselle ja niillä luodaan jäsennystä ja järjestystä lapsen arkipäivään perushoitotilanteissa, ulkoilussa, liikenteessä, leikissä, peleissä, keskustelussa jne.

Tutkittaessa kehityspsykologisesti sääntöjen oppimista ja niiden ymmärtämistä on havaittu, että sääntöjen oppimisella ja ymmärtämisellä on läheinen yhteys lapsen ajattelun ja päättelyn kehittymiseen. On myös oletettu, että sääntöjen oppiminen liittyy laajempaan kokonaisuuteen, jonka 
keskiössä ovat lapset moraalinen päättely ja käsitykset oikeudenmukaisuudesta. Näin hahmotettuna säännöt ovat avain lapsen moraalin maailmaan ja sammalla myös keino moraalin kehittämiseen. Teoreettista taustaa lapsen sääntöjen ja moraalin kehittymiselle tarjoavat etenkin Piaget $(1932,1975)$ ja Kohlberg (1984).

Piaget on tarkastelut sekä sääntöjen ymmärtämistä että moraalista päättelyä. Tutkiessaan sitä, miten eri-ikäiset lapset muodostavat sääntöjä leikkitoiminnoissa ja kuinka tietoisia he ovat niistä Piaget (1975) havaitsi, että kehittymisen varhaisvaiheessa ikävuosina 1-2 (sensomotorinen vaihe) lapsella on ainoastaan tietoisuus yleisestä vallitsevasta järjestyksestä ja säännönmukaisuudesta, joka vallitsee hänen ympärillään olevassa maailmassa ja sen tapahtumissa. Säännöt peittyvät yksilöllisiin suorituksiin, jotka ovat usein motorisia. Koska säännöt kohdistuvat pääasiassa motorisiin suoritukseen, Piaget'n mukaan voidaan puhua motorisista säännöistä. Tällöin lapsi ei kykene Piaget'n mukaan tajuamaan spesifejä sääntöjä eikä ymmärtämään niiden yhteisöllistä luonnetta.

Esioperationaalisen kehityskauden (ikävuosina 2-6) alussa noin 3-5 -vuoden iässä lapsi alkaa Piaget'n mukaan tajumaan sääntöjen olemassaoloa. Tunnusomaista tällöin on se, että lapsi mieltää säännöt minäkeskeisesti ja käyttäytyy aluksi leikeissä tai peleissä välittämättä siitä, miten muut toimivat. Lapsi haluaa muodostaa säännöt itse. Esimerkiksi peleissä lapset uskovat pelaavansa oikein, kunhan pelin säännöt vastaavat lapsen omia tarkoitusperiä. Pelaaminen muiden kanssa merkitsee lapselle paljolti samaa kuin pelaisi yksin. Näin tämän ikäiset lapset muiden näkökulmasta käsin usein rikkovat sääntöjä. Säännönmukaisuuksia etsiessään lapsi omaksuu kuitenkin malleja aikuisilta ja vanhemmilta lapsilta. Lapsen tietoisuus säännöistä perustuu esioperationaalisen kauden alussa Piaget'n mukaan sääntöjen yksipuoliseen kunnioittamiseen. Lapsi pyrkii kunnioittamaan sääntöjä, koska hän ajattelee, että ne ovat aikuisen tai jonkun yliluonnollisen tahon asettamia.

Esioperationaalisen kehityskauden jälkipuoliskolla ja koulun alussa lasten tietoisuus säännöistä Piaget'n mukaan syvenee. Tällöin hän alkaa tajuta, että säännöt eivät ole pyhiä ja muuttumattomia, vaikka ulkopuoliset ovatkin ne asettaneet. Sääntöjä aletaan pitää sopimuksina ja lapsille syntyy ajatuksia ja ideoita siitä, miten niitä voitaisiin muuttaa. Muutokselle lapsi asettaa usein vaatimuksen, että kaikkien tulee olla niistä yhtä mieltä. Lisääntyvä sosiaalinen vuorovaikutus ja kognitiivinen kyvykkyys 
mahdollistavat vähitellen sen, että lapsi voi oppia ja ymmärtää sääntöjä ja periaatteita, joita tarvitaan sosiaalisessa vuorovaikutuksessa. Kouluun siirtymisen vaiheessa lapsi mieltää säännöt voittopuolisesti yhteistyöhön liittyväksi ja hänelle kehittyy perustaa ymmärtää myöhemmin sääntöjen edellyttämää sitoutumista, joka periaatteessa koskee kaikkia sääntöjä. Kouluiän alussa sääntöjen muodostus kohdistuu yleensä suppeaan määrään sääntöjä ja niiden ymmärtäminen vaihtelee sääntöjen ja niihin liittyvien tilanteiden mukaisesti.

Lapsen moraalisen päättelyn kehittymisessä Piaget (1932) erotti kaksi vaihetta. Näistä ensimmäistä (ikävuodet 4-7) hän nimitti moraaliseksi realismiksi. Tällöin lapsi esimerkiksi tajuaa, että hän saattaa hajottaa tahallisesti jotain esineitä, mutta lapsi, joka hajottaa niitä enemmän on syyllisempi kuin lapsi, joka rikkoo tahattomasti vain yhden esineen. Lapset siis ennen kouluikää ovat taipuvaisia yleensä kiinnittämään huomiota ensisijaisesti tekojen seurauksiin eikä niiden vaikuttimiin ja syihin. Moraalisen päättelyn toisessa vaiheessa seitsemännen ikävuoden jälkeen muotoutuu vähitellen autonominen päättely, jossa tekoja analysoidaan ja pohditaan niiden syiden ja vaikuttimien perusteella. Tällöin lapset alkavat tajuta, että säännöt ovat tavallaan keinotekoisia ja niitä muodostetaan sosiaalisessa yhteisössä valitsevien ja yhteisesti sovittavien oikeudenmukaisuus- ja tasa-arvokäsitysten perusteella. Syntyy myös oivallus siitä, että sääntöjä voidaan yhteisten sopimusten perustella muuttaa.

Piaget'n tapaan myös Kohlberg (1984) pohti sääntöjä voittopuolisesti ymmärtämisen ja päättelyn näkökulmasta eikä niinkään sääntöjen sisällön kannalta. Tarkastelukulmana olivat lasten moraaliset päätelmät ja niissä esiintyvät perustelut eri ikäkausina. Kohlberg erottaa lapsen moraalin kehittymisessä kolme tasoa, jotka ovat esisovinnainen, sovinnainen ja jälkisovinnainen. Esisovinnainen moraali perustuu aluksi rangaistukseen ja tottelevaisuuteen. Myöhemmin se ymmärretään välineelliseksi ja suhteelliseksi. Sovinnainen moraali perustuu aluksi hyvien suhteiden korostamiseen ja myöhemmin auktoriteetin kunnioittamiseen. Kolmannella tasolla (jälkisovinnan) moraali kehittyy kohti autonomiaa ja periaatteita koskevaksi. Kolmannen jakson alkuvaiheelle on tunnusomaista huomion kiinnittäminen sosiaalisiin sopimuksiin. Myöhemmin moraali kehittyy omantunnon ja periaatteiden pohjalle.

Kohlbergin (1984) mukaan alle kouluikäinen lapsi tekee moraaliset päätelmät aluksi välttyäkseen rangaistuksilta, mielipahalta ja moitteilta, 
jotka usein seuraavat väärin toimimisesta. Tällainen moraali on Kohlbergin mukaan esisovinnaista (esimoraalista). Esimerkkinä Kohlberg mainitsee päätelmän, jossa lapsi pitää tuhmempana lasta, joka rikkoo 10 kuppia auttaessaan äitiä kuin lasta, joka rikkoo 2 kuppia oltuaan tottelematon äidille. Esisovinnaiset moraalipäättelyt lapsi tekee esisijaisesti oman itsensä kannalta, koska hänen taitonsa harkita asioita toisten näkökulmasta ovat puutteelliset. Esisovinnaisen moraalisen päättelyn lapsi näyttää siis tekevän ajattelemalla lähinnä teon seurausta. Tämän rinnalle näyttää kehittyvän esisovinnaisen moraalikehityksen jälkipuolella myös toinen moraalista ajattelua ohjaava periaate. Tälle on tunnusomaista se, että lapsi pohtii tekoaan tai käyttäytymistään eräänlaisen vaihtosuhteen avulla: jos teet tämän minulle teen tämän sinulle. Siirtymä tällaiseen päättelyn on sikäli merkityksellinen, että siinä on havaittavissa myös toisen perspektiiviä ja yhteistä sopimista säännöistä (esim. lapset alkavat koulunkäynnin kynnyksellä tehdä toisensa kanssa "kättä päälle" sopimuksia). Kouluikäisen lapsen moraalin kehittyminen on aluksi voittopuolisesti sovinnaista moraalia, jonka tavoitteena on ylläpitää hyviä suhteita sosiaalisessa kanssakäymisessä ja kunnioittaa auktoriteetteja kuten esimerkiksi opettajia, joiden lapsi tajuaa edustavan omalta osaltaan yhteiskunnassa lakia ja järjestystä.

\section{Sosiaalisten taitojen tukeminen ja kehittäminen}

Lapsen sosiaalisten taitojen kehittymiseen ja tukemiseen on kiinnitetty lisääntyvää huomiota. Salmivallin (2005) mukaan sosiaalisia taitoja voidaan edistää monin keinoin. Näistä yksi on suora opettaminen. Opettamisessa suositellaan asteittaista etenemistä. Alussa lapsen kanssa keskustellaan kehittämisen kohteena olevasta taidosta ja sen merkityksestä. Tämän jälkeen voidaan ottaa konkreettisia esimerkkejä oikeanlaisesta ja vääränlaisesta käyttäytymisestä. Kolmannessa vaiheessa voidaan harjoitella kehittämisen kohteena olevaa sosiaalista käyttäytymistä lavastetuissa tilanteissa esimerkiksi roolileikkinen tai draaman keinoin. Viimeisessä vaiheessa kehittämisen kohteena olevaa taitoja vahvistetaan toiminnassa antamalla siitä positiivista ja kannustavaa palautetta.

Suoran opettamisen ohella sosiaalista käyttäytymistä voidaan tukea kiinnittämällä huomiota lapsen käyttäytymisen taustalla oleviin ajattelurakenteisiin. Lähtökohtana on tällöin sosiaalisten kognitioiden tunnistaminen ja niiden muuttaminen. Tässä lähestymistavassa lapsia voidaan esimerkiksi 
ohjata pohtimaan tunteitaan, asennoitumista toisiin, tulkitsemaan tilannevihjeitä ja toisten lasten näkökulmaa, kehittämään vaihtoehtoisia toimintatapoja sekä ennakoimaan toiminnan seurauksia (Salmivalli, 2005).

Kolmas lähestymistapa sosiaalisten taitojen tukemisessa ja kehittämisessä Salmivallin mukaan on yhteisöllinen. Lähtökohtana on ajatus, että koko lapsiryhmä tai koululuokka on sosiaalisten taitojen kehittämisessä mukana. Näin kehittämistä erityisesti tarvitseva lapsi tai lapset eivät tunne olevansa yksin kehittämisongelmiensa kanssa, vaan he voivat saada tukea ja oppia kehittyneitä käyttäytymismalleja toisilta lapsilta. Sosiaalisen käyttäytymisen dynamiikassa sekä lapsen omilla ja lapsiryhmän muiden lasten odotuksilla on keskeinen merkitys. Hyväksymällä kaikki lapset ryhmän jäseniksi ja muuttamalla negatiivisia odotuksia positiiviseksi voi olla myönteiset vaikutukset erityisesti lapsiin, joiden sosiaalinen käyttäytyminen on johtanut poissulkemiseen ryhmästä ja sen ylläpitämästä sosiaalisesta vuorovaikutuksesta.

Vaikka edellä olevassa erittelyssä esitetyt vaihtoehdot näyttävät erillisinä tehokkaina ja toimivina, ratkaisuna voi olla myös niiden joustava soveltaminen lapsen sosiaalisen kehittymisen ja oppimisen tukemiseen. Salmivalli $(2005,188)$ toteaa, että usean vaihtoehdon soveltamisesta on saatu myönteisiä kokemuksia. Tällaisilla menettelytavoilla on voitu muuttaa lapsen sosiaalista käyttäytymistä myönteisemmäksi. Keinoina voidaan käyttää esimeriksi ryhmäistuntoja, joissa keskustellaan, katsotaan videoita, harjoitellaan käyttäytymisen hallintaa ja asetetaan uusia rakentavampia tavoitteita.

Lasten sosiaalinen kyvykkyys perustuu moniin osataitoihin. Näihin voidaan sisällyttää kielellisiä taitoja, ongelmanratkaisutaitoja, sosiaalisia taitoja, tunteiden ilmaisuun ja säätelyyn taitoja sekä sosiaalisen kognition taitoja (Neitola, 2011). Lapsen kokonaiskehittymiselle on tärkeää, että vanhemmat osallistuvat aktiivisesti näiden taitojen tukemiseen. Tutkittaessa vanhempien havaintoja ja käsityksiä alle kouluikäisten ja koulunsa aloittaneiden lasten sosiaalisesta kompetenssista on havaittu, että vanhempien epäsuorilla ja suorilla vaikutustavoilla oli merkittävää vaikutusta lapsen sosiaalisen kompetenssiin muotoutumiseen ja sen laatuun (Neitola, 2011). Vanhempien epäsuoraan vaikutukseen liittyy perheen sosioekonomiset tekijät, vanhemmuuteen ja lastenkasvatukseen liittyvät käytännöt sekä lapsen ja vanhemman välinen vuorovaikutus. Suoraan vaikutukseen liittyy vanhempien erilaiset roolit ja tehtävät sosiaalisen kompetenssin edistämiseksi. 
Neitolan (2011) saamissa tuloksissa ilmeni, että vertaissuhdeongelmaisten ja ei-ongelmaisten lasten sosiaaliset verkostot olivat osin erilaiset. Ei-ongelmaisten lasten vanhemmat olivat sensitiivisempiä, vastavuoroisempia ja lapsen näkökulmaa ja tarpeita lähtökohtanaan pitäviä sekä tunnetaitoihin ja tunnetilan käsittelyyn keskittyvämpiä kuin ongelmaisten lasten vanhemmat. Vertaissuhdeongelmaisten lasten vanhemmat kuvasivat kasvatuksen kuormittavuutta, ajan puutetta sekä muuntuvaa isyyttä ja äitiyttä ei-ongelmaisten lasten vanhempia enemmän. Työn ja perheen yhteensovittamisen vaikeus tuli myös esille. Vertaissuhdeongelmaisten lasten vanhemmat eivät olleet riittävän hyvin perillä lapsen taidoista ja kyvykkyydestä tuottaakseen oikea-aikaista ohjausta ja tukeakseen lasta riittävästi sopivilla tavoilla. Ei-ongelmallisten lasten vanhemmilla oli käytettävissään epävirallisia tukiverkostoja lastensa kasvatuksessa. Tällainen arjen tuki kuitenkin puuttui usein vertaissuhdeongelmaisten lasten vanhemmilta. Erityisesti näiden vanhempien tukemisessa ovat tärkeitä perheille ja lapsille suunnatut palvelut, monitahoinen yhteistyö perheiden, lasten ja heidän kanssaan työskentelevien ammattilaisten kesken sekä yhteiskunnan perheitä koskevat säädökset ja tukitoimet.

Keinänen kumppaneineen (Keinänen et al., 2011) tutkivat vanhemmuustyylejä osana lasten sosiaalista kompetenssia esiopetuksessa ja koulun vuosiluokilla $1-2$. Sosiaalisen kompetenssin ohella kiinnitettiin huomiota lapsen sukupuoleen ja kognitiivisiin taitoihin. Esiopettajat arvioivat lasten sosiaalista kompetenssia kiinnittämällä huomiota yhteistyötaitoihin, empaattisuuteen, impulsiivisuuteen ja häiritsevään käyttäytymiseen. Luokanopettajat arvioivat lasten sosiaaliset taitoja 1. ja 2. luokalla. Vanhemmuustyylien arviointi perustui vanhempien itsearviointiin lapsen ollessa 1. luokalla. Vanhemmuustyylit jaettiin tutkimuksessa kolmeen tyyppiin, joita olivat lämmin, kontrolloiva ja ristiriitainen (välillä lämmin ja välillä kontrolloiva). Tulokset osoittivat, että vanhempien lämmin vanhemmuustyyli edisti lasten sosiaalisen kompetenssin taitoja. Äidin vahva kontrolli asettamalla lapselle rajoja tai syyllistämällä lasta lisäsi esiopetuksessa lasten impulsiivisuutta ja häiritsevää käyttäytymistä ja vähensi sosiaalisia taitoja. Ristiriitainen vanhemmuustyyli oli yhteydessä lasten heikkoon sosiaaliseen kompetenssiin mutta rajoittui vain tyttöihin ja lapsiin, joiden kognitiiviset taidot olivat paremmat. Lasten kontrollointi asettamalla rajoja yhdistyneenä autoritääriseen vanhemmuustyyliin tuki sosiaalisia taitoja erityisesti lapsilla, joilla kognitiiviset taidot olivat keskimääräistä heikommat. 
Kasvattajien ja opettajien käyttöön on saatavilla materiaaleja lapsen ja oppilaan sosiaalisen kasvun ja oppimisen tukemiseksi. Lasten kykyä säädellä tunteita ja käyttäytymistä päivähoitoiässä ja keinoja lapsen itsesäätelytaitojen tukemiseen avataan Aron ja Laakson (2011) toimittamassa julkaisussa "Taaperosta taitavaksi toimijaksi". Teoksessa tarkastellaan, miten itsesäätelyn puutteet heijastuvat lapsen hyvinvointiin, sosiaalisiin taitoihin sekä ryhmässä toimimiseen. Tämän ohella siinä kuvataan keinoja tukea lasta, vanhempia ja päivähoidon henkilökuntaa lapsen itsesäätelyssä. Teos soveltuu myös koulun ala-asteelle.

MASK-monitahoarvioinnin avulla perusopetuksen opettajat voivat seurata oppilaan sosiaalisen kyvykkyyden kehitystä ja tehdä havaintoja uuden oppilaan sopeutumisesta luokkaan (Kaukiainen ym., 2005). Seurannan kohteena ovat yhteistyötaidot, empatia, impulsiivisuus ja häiritsevyys. Kaksi ensimmäistä hahmotetaan sosiaalisina taitoina. Impulsiivisuus ja häiritsevyys liittyvät emootioiden ja käyttäytymisen säätelyjärjestelmään. Myös vanhemmat voivat tehdä havaintoja ja arviointeja MASK -materiaalin pohjalta. Seurannan kohteena voi olla myös tarkkaavaisuushäiriö, jonka arviointia voi tehdä koulutulokkaasta lähtien perusopetuksessa (Aro \& Närhi, 2003). Koulutulokasta ja häntä vanhempaa oppilasta voi arvioida monipuolisesti käyttäytymisen ja tunteiden hallinnassa (Lappalainen ym. 2008; Lappalainen ym., 2009; Lappalainen \& Sointu, 2013). Lähestymistapa kohdistuu käyttäytymisen ja tunteiden vahvuuksiin. Arvioinnin voi suorittaa lapsi, opettaja ja vanhemmat. Vahvuuksiin kohdistuva arviointi on tervetullut lähestymistapa, jonka voi olettaa vaikuttavan lapsen sosioemotionaalisen kasvuun myönteisellä tavalla.

\section{Sosiaalisten taitojen erityiskysymyksiä}

\section{Kiusaaminen}

\section{Kiusaamisen määrittelyä}

Kiusaamiselle, kuten monille käyttäytymisen ulottuvuuksille, ei ole yksiselitteistä määritelmää. Salmivalli (2010) määrittelee sen aggression muotona, jossa yksilö tai ryhmä yksilöitä systemaattisesti ja usein pidempiaikaisesti loukkaa, ahdistelee, halventaa tai sulkee henkilön pois, joka on heikompi tai voimattomampi. Alan tutkimuksessa kiusaamista luonnehditaan kohdistamalla huomio sen ilmenemismuotoihin (esim. Levine \& 
Tamburrino, 2013). Tästä lähtökohdasta käsin kiusaaminen voi olla fyysisistä, sanallista tai sosiaalista manipulaatiota. Fyysinen kiusaaminen on usein suoraa ja siinä on pyrkimyksenä tuottaa uhrille fyysistä väkivaltaa esimerkiksi lyömällä, potkimalla, tönimällä, sylkemällä jne. Kiusaaminen on usein tarkoitushakuista ja toistuvaa. Sanallisessa kiusaamisessa käytetään sanoja, lauseparsia ja nimittelyä. Taustalla on usein kiusaajan pyrkimys näyttää tai lisätä valtaa ja kontrollia kiusattua kohtaan. Aikuisen on usein vaikea nähdä sanallista kiusaamista, koska se tapahtuu paikoissa, joissa aikuiset eivät ole läsnä. Sosiaalisessa kiusaamisessa pyritään usein sulkemaan yksilö tai osaryhmä erilleen muista, levitetään huhuja, luodaan sosiaalisesti epämiellyttäviä tilanteita ja särjetään luottamus. Ruotsissa on havaittu (Thornberg, 2010), että kiusaaminen kohdistuu usein lapsiin, jotka erottuvat valtavirrasta (esim. poikkeava käyttäytyminen, pukeutuminen, ulkomuoto, kehityksen jälkeenjääneisyys jne.).

\section{Kiusaaminen päiväkodissa}

Suomalaisessa kasvatuskeskustelussa on noussut lisääntyvässä määrin pohdinnan kohteeksi kiusaaminen, jonka kehittymisdynamiikka ja ilmiasu kehittyvät yleensä jo ennen kouluun tuloa. Repo (2015) raportoi omaan tutkimukseensa vedoten päiväkodeissa tapahtuvan kiusaamisen yleisyyttä. Tulosten mukaan noin 7 \% 3-6 -vuotiaista lapsista kiusasi muita, noin 3\% tuli muiden kiusaamaksi ja noin $2 \%$ sekä kiusasi että tuli muiden kiusaamiksi. Arvion mukaan keskimäärin jokaisessa 3-6 -vuotiaiden päiväkotiryhmässä on keskimäärin 1,3 kiusaajaa. Heistä $14 \%$ kiusasi muita, $7 \%$ oli kiusattu ja $8 \%$ oli sekä kiusaaja että kiusattu.

Päiväkodeissa tehdyn peruskartoituksen mukaan 3-6 vuotiaat lapset kertoivat kiusaamisesta lähinnä sen, mitä tuntemuksia heillä on ollut kiusatuksi tulemisesta (Kirves \& StoorGrenner, 2010; Repo, 2015). Osa lapsista ei osannut kertoa, miten ja missä heitä oikeasti oli kiusattu. Osa lapsista sitä vastoin pystyi erittelemään, millaisesta kiusaamisesta oli ollut kysymys. Lapset hahmottivat kiusaamisen usein fyysiseksi väkivallaksi, mutta myös haukkuminen ja poissulkeminen liitettiin kiusaamiseen. Näin kiusaaminen voitiin mieltää ei ainoastaan fyysisenä vaan myös sanallisena ja psyykkisenä toimintana, joka koskettaa sekä kiusaajaa että kiusattuja aiheuttaen heille yleensä mielipahaa. Fyysinen kiusaaminen pienten lasten keskuudessa oli usein lyömistä, potkimista, nipistelyä, repimistä tai estämistä. Sanallinen kiusaaminen oli yleensä haukkumista, nimittelyä ja selän takana 
puhumista. Sosiaalinen kiusaaminen miellettiin usein ryhmästä poissulkemiseksi ja uhkailuksi. Eniten kiusaamista näytti esiintyvän vapaiden leikkien aikana joko sisällä tai ulkona. Sitä esiintyi kuitenkin myös muiden päiväkodin toimintojen yhteydessä kuten lepotilanteissa tai aamupiireissä, joissa myös aikuinen oli läsnä.

Kiusaamiseen myös puututtiin edellä mainitun peruskartoituksen tulosten mukaan. Lasten mukaan keinoina käytettiin rankaisua ja jäähypenkille lähettämistä sekä myös anteeksi pyytämistä. Henkilökunta pyrki yleensä keskustelemaan lasten kanssa tapahtumista. Muina keinoina käytettiin anteeksi pyytämistä, nuhtelua ja jäähypenkkiä. Lapset pyrkivät ratkaisemaan kiusaamistilanteen tai tilanteet kertomalla tästä henkilökunnalle, kertomalla asiasta kodissa, lähtemällä pois tilanteesta, sulkemalla asian pois mielestään tai esimerkiksi lyömällä kiusaajaa takaisin.

Kiusaamisen ennaltaehkäisyyn ei toistaiseksi ole varhaiskasvatuksessa Kiva-koulu -tyyppistä valtakunnallista foorumia. Ennaltaehkäisyssä Repo (2015) korostaa seuraavia yleisiä periaatteita: sensitiivinen aikuisen merkitys, oikeudenmukaisuuden periaate, lapsen identiteetin vahvistaminen, lasten tasa-arvoinen kohtaaminen ja laadukas pedagogiikkaa. Repo viittaa myös eräissä päiväkodeissa laadittuihin kiusaamisen ennealtaehkäisyn ja puutumisen suunnitelmiin. Näihin on liitetty esimerkkejä kiusaamisen muodoista, lasten, kasvattajien ja vanhempien tehtäviä, ohjeita kiusaamistilanteeseen puuttumisesta ja niiden käsittelystä sekä arviointisuunnitelmista.

\section{Kiusaaminen koulussa}

Selvitysten mukaan kiusattuja lapsia on Suomen kouluissa 5-15 prosenttia (Salmivalli, 2003). Luokka-asteilla 1-6 on arvioitu olevan ainakin yksi systemaattisesti kiusattu oppilas. Vuoden 2009 tilannekartoituksessa (KiVa koulu hanke) ilmeni, että kiusatuksi itsensä koneita lapsia oli eniten ensimmäisellä ja toisella luokalla, mutta määrä vähenee tämän jälkeen vuosiluokkien 1-6 kuluessa. Kun huomio kohdistetaan muita kiusaavien lasten määrään, havaitaan hieman erilainen kehityskulku (Salmivalli, 2010): muita kiusaavien lasten määrä alenee aluksi ensimmäisten kouluvuosien aika, mutta pysähtyy viidennellä luokalla ja kasvaa tämän jälkeen suhteellisen tasaisesti vuosiluokilla 6-9.

Kouluissa on aktivoiduttu koulukiusaamisen vähentämiseksi. Valtakunnallista tiedonvälitystä ja ohjausta varten on kehitetty Kiva Koulu -ohjelma. Se on Turun yliopistossa kehitetty kiusaamisen vastainen 
toimenpideohjelma, jota on kehitetty vuodesta 2016 lähtien. Sen kehittämistä tehdään yhdessä koulujen kanssa. Se tarjoaa filmimateriaalia, opettajan opastusta sekä pelejä (esim. Pulmikas -peli, KIVAppi-mobiiliappi). Ohjelmaan liittyvissä tutkimuksissa (esim. Kärnä et al., 2013) sen on todettu olevan tehokas keino kiusaamisen ehkäisyssä.

Salmivalli (2010) on hahmottanut koulukiusaamiseen puuttumisen kokonaismallin, joka kattaa yksilötason, luokkatason ja koulun tason. Luokkatason keinoissa korostetaan koko luokan vastuuta. Keinoina voivat olla yhteiset keskustelut, kiusaamisen vastaiset säännöt, pienryhmätoiminta, eläytymis- ja rooliharjoitukset sekä erilaiset aihetta käsittelevät materiaalit. Yksilötason keinoina voivat olla välitön puuttuminen, tuki kiusatulle, yhteiset keskustelut kiusaamiseen osallistuneiden kanssa, ratkaisujen pohtiminen, vanhempien mukanaolo ja seurantakeskustelut.

\section{Aggressiivisuus}

Moniin sosiaalisen kanssakäymisen tilanteisiin kuten esimerkiksi kiusaamiseen saattaa liittyä aggressiivisia käyttäytymispiirteitä. Aggressiivisuuden dynamiikalla on sille ominaisia tunnusmerkkejä, joita on tunnistettu. Selitykset ja näkemykset aggressiivisuuden olemuksesta voidaan jakaa kahteen erilaiseen selityskehikkoon (esim. Salmivalli, 2005). Näistä toinen perustuu ajatukseen siitä, että aggressio on vihamielinen reaktio koettuun turhautumiseen. Selityksellä on psykoanalyyttinen tausta. Toinen lähestymistapa lähtee siitä, että aggressiivinen käyttäytyminen opitaan ja täten myös opitaan pois säätelemällä lapsen käyttäytymistä mallioppimisen avulla.

Aggressiot tyypitellään usein reaktiiviseen ja proaktiiviseen (esim. Carroll et al., 2018; Salmivalli, 2000). Reaktiiviselle aggressiolle on tyypillistä impulsiivisuus ja harkitsemattomuus. Sen voi aiheuttaa väärin tulkittu tilanne, ärsyttäminen tai aiemmat kokemukset. Tunnetila on kiihtynyt ja henkilöön on vaikea saada tunnetilan aikana kontaktia. Proaktiivinen aggressio on puolestaan ennakkoon suunniteltua ja harkittua. Tunnetila on viileä, joskus kylmäverinen. Proaktiivisen aggression taustalla voi olla käsitys väkivallan oikeutuksesta tai kostosta.

Reaktiivista ja proaktiivista aggressiivista käyttäytymistä voidaan luonnehtia myös ulottuvuudella epäsuora - suora (esim. Salmivalli, 2005). Suoraan aggressiivisuuteen liittyy kohteen fyysistä tai sanallista vahingoittamista. Fyysinen vahingoittaminen voi toteuta esimerkiksi lyömällä, 
potkimalla tai tönimisellä. Sanalliseen vahingoittamiseen liittyy esimerkiksi nimittely, pilkkaaminen tai uhkailu. Epäsuora aggressiivinen käyttäminen perustuu tavalla tai toisella manipulaatioon. Lasten toveripiirissä tämä voi toteutua niin, että vihamielisiä tunteita kokeva lapsi kehottaa ryhmää olemaan leikkimättä tietyn tai tiettyjen lasten kanssa, mustamaalaa lapsen vaatetusta, ulkonäköä, puhetapaa jne. Tällaisen manipulaation kautta vihamielisiä tunteita kokeva lapsi välttyy itse suorasta aggressiivisesta toiminnasta. Tarkoituksena on kuitenkin ryhmädynamiikkaa usein taitavasti käyttäen vahingoitta kohdelasta tai kohdelapsia.

Frustraatiotaustainen reaktiivinen aggressiivisuus voidaan kokea toveriryhmissä negatiivisena ja suosiota vähentävän (Salmivalli, 63). Sille on ominaista yliherkkyys aggressiivisiin yllykkeisiin ja vihjeisiin lapsen kasvuympäristössä. Sen sijaan sosiaalisen oppimisen kautta hankittu aggressiivinen käyttäytyminen voi yhdistyä toveriryhmässä johtajuuteen ja näin periaatteessa lisätä toverisuosiota. Sosiaalisen oppimisen mekanismi voi myös liittää aggressiivisia lapsia tai oppilaita yhteen, jolloin heistä muodostuu oma osaryhmänsä. Tämä vahvistaa edelleen aggressiivisuuden juurtumista näiden lasten ajatteluun ja toimintaan.

Pidetään mahdollisena, että reaktiivisen ja mallioppimisen kautta kehittyneelle aggressiiviselle käyttäytymiselle on löydettävissä erilaisia taustatekijöitä (Salmivalli 2005, 64; Dodge 1991). Reaktiivisen aggression taustana voivat olla vaikeudet varhaisissa vuorovaikutussuhteissa, turvattomuuden kokemukset tai väkivallan kohteeksi joutuminen. Mallioppisen kautta kehittyneeseen aggressiiviseen käyttäytymiseen on voinut vaikuttaa aggressiiviset mallit ja toverit kasvuympäristössä, väkivaltaa sisältävien filmien ja videoiden katselu tai rajojen puute tai kokemukset siitä, että aggressiivisella käyttäytymisellä voi saada aikomiaan asioita perille.

Samoin kuin monissa muissakin ei-toivotuissa sosiaalisen käyttäytymisen muodoissa kasvattaja kehotetaan tunnistamaan ja puuttumaan määrätietoisesti lasten aggressiiviseen käyttäytymiseen. Esimerkiksi Salmivalli (2003, 2005) rohkaisee kasvattajia kiinnittämään huomiota ympäristössä olevien vihamielisten ja aggressiivisten yllykkeiden vähentämiseen ja huomion suuntaamiseen käyttäytymiseen ja aikomuksiin, joita ei sävytä vihamielisyys. Lapsille on myös eduksi positiivisten tunteiden ja niihin liittyvien käyttäytymismuotojen harjoittelu. Lasten aggressiivisuutta ja sen kohtaamisesta on käsitellyt myös Cacciatore teoksissaan Aggression portaat (2008) ja Kiukkukirja (2008). 
Aggressiivisuutta ylläpitävät ja säätelevät mekanismit ovat tarkentuneet tutkimustoiminnan lisääntyessä. Tutkimuksen kohteena on ollut esimerkiksi emotionaalinen ymmärtäminen, jonka voi olettaa auttavan alle kouluikäisten lasten aggression säätelyssä ja tämän kautta auttaa lapsia sosiaalisessa säätelyssä (Laurent et al., 2018). Laurentin ja kumppaneiden tutkimuksessa arvioitiin lasten emotionaalista ymmärrystä ja sosiaalista käyttäytymistä. Tutkimukseen osallistui kaksi samanlaistettua lapsiryhmää. Lapset olivat iältään keskimäärin 4,6 vuotiaita. Toisen ryhmän lapset oli arvioitu käyttäytymiseltään aggressiiviseksi ja toisen ei-aggressiiviseksi. Tulokset osoittivat, että aggressiivisen käyttäytymisen omaavilla lapsilla oli vertailuryhmään nähden alempi emotionaalien ymmärrys, hyväksyntä vertaisryhmässä ja sosiaalisesti hyväksytty käyttäytyminen. Tutkijat esittivät johtopäätöksenään, että lasten kyvykkyys tunnistaa ja nimetä emootioita voi toimia ehkäisevänä tekijänä aggressiivisen käyttäytymisen ehkäisyssä.

Toisessa tutkimusesimerkissä analysoitiin reaktiivisen ja proaktiivisen aggression toimintamekanismeja (Carroll et al., 2018). Kohteena olivat kouluikäiset 7-12 vuotiaat lapset. Suoritetussa analyysissa havaittiin, että pääsääntöisesti reaktiivisen aggression omaaville lapsille oli ominaista korkea impulssivisuus, kun sitä vastoin proaktiivisen aggression omaavilla lapsilla korostui korkea antisosiaalisuus. Lapsissa havaittiin myös niitä, joilla oli kumpiakin tunnuspiirteitä. Tutkijat korostavat johtopäätöksenään, että sekä reaktiivisen ja proaktiivisen aggressiivisen käyttäytymisen omaavat lapset tarvitsevat tukitoimenpiteitä. Tutkijat viittaavat esimerkiksi koulussa toteutettuun antisosiaalisen käyttäytymisen interventioon, jossa kohdistettiin huomio lasten sosiaalisen ja emotionaalisen säätelyyn parantamiseen sekä empatian lisäämiseen. Näillä toimenpiteillä näytti olevan vähentävä vaikutus esimerkiksi verbaaliseen proaktiiviseen aggressioon, fyysiseen proaktiiviseen aggressioon ja verbaaliseen reaktiiviseen aggressioon.

\section{Torjutuksi tuleminen ja syrjään vetäytyminen}

Lasten välisessä vuorovaikutuksessa voi havaita lapsia, jotka jäävät, vetäytyvät tai jätetään syrjään. Seurauksena usein on torjutuksi tuleminen etenkin vertaisryhmän toiminnoissa. Torjutuksi voivat tulla monenlaiset lapset. Erityinen alttius tulla torjutuksi on kuitenkin vetäytyvillä ja aggressiivisilla lapsilla (Salmivalli 2000, 43- 45). Tällainen sosiaalinen käyttäytyminen heijastuu negatiivisella tavalla lapsen sosiaaliseen vuorovaikutukseen ja lisää usein vetäytymistä tai häiritsevää käyttäytymistä. Kun torjutuksi 
tulemisen taustalla on aggressiivinen käyttäytyminen, lapsella on pyrkimys hakeutua toveriryhmässään kaltaisiinsa tovereihin. Tämä vahvistaa omalta osaltaan sekä aggressiivista ongelmakäyttäytymistä että syrjäytymistä rakentavasta sosiaalisesta vuorovaikutuksesta. Myöhemmin kouluiässä näillä lapsilla on usein muita suurempi taipumus keskeyttää koulunkäynti.

Torjutuksi tulemisen dynamiikka on erilainen silloin, kun se perustuu kiusatuksi tulemiseen. Negatiiviset vaikutukset eivät tällöin heijastu välttämättä ulkoiseen käyttäytymiseen vaan lapsi kääntää ne omaan itseensä. Tällä puolestaan saattaa olla haitallisia vaikutuksia lapsen tunne-elämän myönteiseen kehittymiseen esimerkiksi itsetunnon suhteen. Tuntemuksiin saata liittyä lisääntyviä pelkotiloja ja masentuneisuutta. Myös tässä tapauksessa heijastusvaikutuksena saattaa olla esimerkiksi suurempi alttius keskeyttää koulunkäynti.

Torjutuksi tulemisen tekijöitä voi olla monia ja usein ne liittyvät toinen toisiinsa ja vahvistavat lapsen eristäytymistä muista lapsista. Tutkijoiden taholta on ryhdytty puhumaan negatiivisesta vuorovaikutuksen kehästä (Laine \& Neitola, 2002). Ilmiöön on oletettu vaikuttavan ainakin seuraavat tekijät:

- Kehittymättömät sosiaaliset taidot

- Heikko itsearvostus

- Kielteiset käsitykset ja odotukset itsestä

- Epäsuotuisat aikeet muita kohtaan

- Muiden kielteiset havainnot ja reaktiot: torjunta ja epäsuosio

- Vähän myönteistä vuorovaikutusta

Negatiivisen vuorovaikutuksen voi periaatteessa laukaista mikä tahansa edellä olevista tekijöistä kuten esimerkiksi heikot vuorovaikutustaidot (Kirves \& StorGrenner, 2010). Kun kohteena ovat pienet lapset, lapsen omat voimavarat eivät yksi riittää katkaisemaan tämän tapaista negatiivisen vuorovaikutuksen kehää. Lasten auttamisessa voidaan periaatteessa käyttää sama tapaisia keinoja kuin sosiaalisen kehittymisen tukemisen yhteydessä käytetään.

Havainnollisen esimerkin yksinäisestä ja toisista enemmän tai vähemmän erityksessä olevasta lapsesta päiväkodin alle 3-vuotiaiden lapsiryhmässä on dokumentoinut Kalliala (2008, 232-239). Tutkiessaan lasten sitoutuneisuutta päiväkodin toimintoihin hän kuvaa lasta, joka nimetään 
"ulkokehän lapseksi". Kallialan kuvaama lapsi ei ole täysin passiivinen mutta ei myöskään aktiivinen toisten lasten tai aikuisten seurassa. Hänen yleinen kiinnittymisensä päiväkodin toimintoihin on varsin matala, oli kysymyksessä sitten oma toiminta tai toiminta muiden kanssa. Lapsi ei myöskään katsele tarkkaavaisesti ympäristön tapahtumia. Lapsi ikään kuin viestii, eikö kukaan huomaa minua. Lapsi ei juurikaan tuota häiriötä muille lapsille tai opettajalle, joten vaarana on, että hän jää päivästä päivään yksin ilman tovereita ja opettajan aktiivista läsnäoloa. Saattaa hyvin olla, että negatiivisen vuorovaikutuksen kehä alkaa esimerkiksi päiväkodissa jo varhain, kuten Kallialan havainnot osoittavat.

Vertaisryhmästä torjutuksi tulemisella on Suomessa havaittu olevan vaikutuksia, jotka heijastuvat kielellisiin taitoihin esiopetuksessa ja koulun alussa. Tähän liittyvässä tutkimuksessa (Vartiainen et al., 2012) arvioitiin lukutaidon valmiuksia esiopetuksessa, luokilla 1-3 luetun ymmärtämistä ja toisella luokalla tuottavaa kirjoittamista. Vertaisryhmätorjuntaa analysoitiin kiinnittämällä huomiota kolmeen erityyppiseen torjuntaan (toistuva torjunta, lyhytkestoinen torjunta ja torjunnan puuttuminen). Tulokset osoittivat, että vertaisryhmästään torjutuilla ensiluokkalaisilla lukemisen valmiudet olivat heikompia kuin ei-torjutuilla lapsilla. Toistuvan torjunnan kohteeksi joutuneiden lasten luetun ymmärtäminen ja tuottava kirjoittaminen olivat heikompia kuin lyhytkestoisesti torjutuilla tai ei-torjutuilla lapsilla. Hieman yllättävä, mutta sinänsä positiivinen havainto oli puolestaan se, että toistuvasti torjutuilla luetun ymmärtäminen oli muita nopeampaa erityisesti siirryttäessä toiselta luokalta kolmannelle.

\section{Motoriset taidot}

Terminä motorinen viittaa liikkeisiin ja liikkumiseen (Nurkkala, 2007). Motorisilla taidoilla tarkoitetaan taitoja, joissa esiintyvät sekä liikkuminen että toiminnan tulos. Motorinen taito on käsitteenä laaja (Kurikka ym., 2004). Se ulottuu yksittäisen motorisen toiminnan aktivoitumisesta (esim. tarttuminen) monimutkaisiin toimintoihin (esim. pyörällä ajo).

Motorisia taitoja tutkittaessa huomiota on suunnattu erityisesti kahteen komponenttiin, joita ovat motorinen kontrolli ja motorinen kehittyminen (esim. O’Brien \& Hayes, 1995; Nurkkala, 2007). Motorisen kontrollin saa aikaan motorinen systeemi, jolla on neurofysiologinen perusta. Tällä ohjataan ja tuetaan liikkeiden kontrollia. Silloin kun kohteena on motorinen 
kehittyminen, halutaan kohdistaa huomio liikkeiden kehittymiseen ja niissä tapahtuviin muutoksiin ihmisen elämänkaaren aikana. Puhutaan myös motorisesta oppimisesta, jossa huomio on kohdistettu liikkeiden verbaaliseen ohjantaan ja oppimisen. Termillä motorinen käyttäytyminen viitataan fyysiseen kasvatukseen ja sen myötä kehittyneisiin liikuntatottumuksiin. Motoriseen käyttäytymiseen vaikuttavat puolestaan motorinen kontrolli, motorinen oppiminen ja motorinen kehittyminen.

Motorista kehitystä voidaan eritellä monella tavoin. Eräs tapa on suunnatta huomio liiketyyppeihin (Bigge \& Shermis, 1992). Osa liikkeistä pitää yllä tasapainoa (stabiliteettia ylläpitävät liikkeet). Näitä käytetään lähinnä karkeamotorisissa toiminnoissa (esim. heiluminen, kääntyminen, työntäminen jne.). Toisenlaista liiketyyppiä tarvitaan silloin, kun liikutaan paikasta toiseen (logomotoriset liikkeet). Näitä ovat kävely, juoksi, hyppääminen jne. Kolmas liiketyppi voidaan havaita, kun lapsi tarttuu johonkin (manipulatiivinen liike). Manipulatiiviset liikkeet voidaan erotella karkea- ja hienomotorisiin. Karkeamotoriset toiminnot kohdistuvat suurten lihasryhmien hallintaan ja liikkumiseen. Näitä ovat esimerkiksi kävely ja juoksu, joissa käytetään suuria lihaksia tai suuria lihasryhmiä. Hienomotoristen taitojen avulla lapsi säätelee pieniä lihaksia tai lihasryhmiä. Hienomotorinen liike on tarkkaa ja kontrolloitua. Näitä käytetään esimerkiksi piirtämisessä, kirjoittamisessa ja soittamisessa. On kuitenkin huomattava, että liikkeissä yhdistyy usein sekä karkea- että hienomotoriikka.

\section{Motoriikan kontrolli}

Liikkeiden säätelyllä ja kontrollilla on neurologinen perusta, joka sijaitsee keskushermostossa (esim. Wise \& Shadmehr, 2002; Kurtz, 2007). Motorista kontrollia ohjaa liikemotorinen systeemi, joka prosessoi informaatiota liikkeiden koordinointiin ja taitoa vaativiin liikesuorituksiin. Esimerkiksi esineen tavoittelu vaatii lihasten, raajojen ja hermoratojen koordinaatiota. Liikemotorinen systeemi prosessoi informaatiota, joka koostuu havainnoista, motoristen toimintojen suunnitelmista, motorisen toiminnan toteutuksesta, palautteesta ja biomekaniikasta (liikkeisiin liittyvät sisäiset ja ulkoiset voimat). Motoriikan kontrollimekanismi pitää yllä kokonaisvaltaista, dynaamista ja jatkuvaa vuorovaikutusta aivojen, ruumiin ja ympäristön väillä. Liikkeiden suorittaminen ei ole mahdollista ilman motorista koordinaatiota, joka on prosessina monimutkaista vuorovaikutusta aivojen 
tuottamien neuraalisten prosessien ja työstettyjen liikkeiden välillä. Motorinen kontrolli voi perustua reflekseihin tai se voi olla tahdonalaista.

\section{Motorisen kehityksen vaiheet}

Motorinen kehittyminen on kokonaisvaltaista ja dynaamista, jossa keskushermosto, vartalon hallinta ja ympäristö toimivat yhdessä (Kronqvist \& Pulkkinen, 2006). Motorinen kehittyminen nähtiin pitkään hermoston kypsymisen tulokseksi. Hermoston kypsyessä keskushermoston säätely lisääntyy ja alemman tason refleksit jäävät taka-alalle. Tällöin ylemmän tason säätelyä tarvitsevat vaativammat toiminnot pääsevät esille (Nurkkala, 2007).

Uudempi lähestymistapa hahmottaa kehittymisen joustavammin. Näin oletetaan etenkin dynaamisten systeemien teoriassa (Thelen 1995; Thelen 2000; Viholainen, 2006; Siren-Tiusanen, 1995; Kronqvist \& Pulkkinen, 2007). Teorian mukaan motorinen kehitys ja sitä ilmentävä käyttäytyminen eivät ole ohjelmoitu aivoihin etukäteen. Lähtökohtana on, että motorinen käyttäytyminen ja siinä tapahtuvat muutokset syntyvät toiminnan aikana yksilön käytössä olevien rakenteiden, energiavarastojen ja tehtävän luonteen perusteella toimintaan osallistuvien järjestelmien välisenä dynaamisesti jäsentyvänä vuorovaikutuksena. Dynaaminen lähestymistapa korostaa myös toiminnan ja havaintojen välistä yhteyttä. Pidetään todennäköisenä, että toiminnan aikana tapahtuu jatkuvaa havaintotiedon keruuta ja uudelleen käsittelyä, jota suhteutetaan toiminnan muutoksiin ja verrataan päämääräksi asetettuun toimintaan.

Dynaamisten systeemien teoriassa mielletään motorinen kehitys jatkuvasti uudelleenorganisoituvana ja edeltävää rakennetta kertaavana prosessina eikä yksinkertaisena lineaarisena lisääntymisenä (Siren-Tiusanen, 1995, Kronqvist \& Pulkkinen 2007). Uuteen sisältyy ainesta aikaisemmasta ja samalla pohjan luomista myöhemmälle. Teorian mukaan uusia motorisen kehittymisen toimintoja syntyy tilanteissa, joissa vanhat toimintamallit eivät ole riittäviä. Kehitystä tapahtuu, kun siihen osallistuvien järjestelmien osissa ja niiden välisessä vuorovaikutuksessa tapahtuu kehitystä, jonka seurauksena järjestelmät alkavat toimia dynaamisemmin. 


\section{Motorisen kehittymisen eteneminen}

Kuten kognitiiviselle kehittymiselle niin myös lapsen motoriselle kehittymiselle on pyritty hahmottaman iän mukaan porrastuvia kehitysvaiheita (Ayres 2008; Kronqvist \& Pulkkinen, 2006; Nurkkala, 2007; Pehkonen, 1999). Kehitysvaiheita voidaan eritellä hyvinkin yksityiskohtaisesti, jolloin niiden määräksi esitetään esimerkiksi kuutta tai sitäkin huomattavasti enempää (esim. Adolph \& Berger, 2006). Dynaamisten systeemien ollessa kyseessä vaiheita on ryhdytty tarkastelemaan kokonaisvaltaisemmin, jolloin varhaislapsuuteen ja koulun alkuun sijoittuu kolme lapsen iän mukaan porrastuvia motorisen kehittymisen vaihetta (esim. Seefeldt \& Haubenstricker, 1982; O’Brien \& Hayes, 1995; Kronqvist \& Pulkkinen, 2007). Näitä ovat reflektiivisten motoristen toimintojen vaihe (ennen syntymää ensimmäinen ikävuosi), tahdonalaisten motoristen toimintojen vaihe (ikävuodet 1-2) ja motoristen perustaitojen vaihe (ikävuodet 2-7).

\section{Reflektiivisen kehittymisen vaihe}

Reflektiiviset liikkeet ovat keskushermoton säätelemiä ei-tahdonalaisia motorisia toimintoja, jotka muodostavat perustan liikkeiden myöhemmälle kehittymiselle (esim. Seefeldt \& Haubenstricker, 1982; O'Brien \& Hayes, 1995; Kronqvist \& Pulkkinen, 2007). Refleksien välityksellä vastasyntynyt lapsi kartuttaa tietoa välittömästä ympäristöstään. Vastasyntynyt reagoi kosketukseen, valoon ja ääniin, jotka yhdistyvät reflekseihin ja saavat aikaan muutosta lapsen liikkeissä. Näin lapsi oppii ensimmäisten elinkuukausiensa aikana uutta kehostaan ja välittömästä ulkoisesta ympäristöstään.

Reflekseissä erotetaan usein primitiiviset ja aseintoihin liittyvät refleksit. Primitiivisillä reflekseillä lapsi hankkii informaatiota, hankkii ravintoa ja suojelee itseään. Asentoihin liittyvillä lapsi ikään kuin testaa motoriikkansa vakautta, liikemotoriikka ja käden taitojaan. Näihin toimintoihin yhdistyy myöhemmin lisääntyvässä määrin tahdonalaisuutta, joka ilmenee esimerkiksi kävelemään oppimisessa ja ryömimistaitojen kehittymisessä. Näidenkin taitojen perusta on refleksit (askelrefleksi ja ryömimisrefleksi).

Ensimmäisen neljän elinkuukauden aikana lapsi hankkii reflektoiden välityksellä uutta informaatiota. Neljännen kuukauden jälkeen painopiste siirtyy asteittain informaation prosessointiin. Tällöin ei-tahdonalaisten refleksien merkitys vähenee tai sammuu. Muutoksen mahdollistaa korkeampien aivokeskusten kehittyminen, jolloin alempien aivokeskusten ylläpitämien sensomotoristen aktiviteettien merkitys vähenee ja motoriikkaa 
aletaan työstää havaintomotoristen mekanismien avulla. Esimerkiksi näköhavainnot ohjaavat lasta kurkottamaan ja tarttumaan esineisiin.

Kattavan kuvan lasten karkeamotoristen taitojen varhaisesta kehittymisestä voi saada YK:n alaisen maailman terveysjärjestön WHO:n (2006) koonnista, jossa kehittymisen virstanpylväät on suhteutettu lasten ikään kuukausina (Taulukko 2). Tässä arvioinnissa kehittymisen seuranta on pelkistetty kuuteen kehityssaavutukseen, jotka ovat istuu ilman tukea, seisoo tukemalla, konttaa käsillä ja polvilla, kävelee tuen kanssa, seisoo yksin ja kävelee yksin. Tulos pelkistetään taulukossa 2 ilmoittamalla keskimääräinen ikä kuukausina, jolloin lasten oletetaan saavuttavan kyseessä olevat taidot. Suluissa on vielä esitetty se, missä iässä varttunein 5\% ja hitain 5\% saavuttaa arvioinnin kohteena olleet karkeamotoriset taidot.

Taulukko 2. Pienten lasten karkeamotoristen taitojen kehittyminen suhteessa ikään kuukausia (WHO, 2006)

\begin{tabular}{|l|l|}
\hline Istuu ilman tukea & $\begin{array}{l}\text { Ikä keskimäärin } 6 \mathrm{kk} \\
\text { (nopein } 5 \% 4,3 \mathrm{kk} \text {; hitain } 5 \% 7,9 \mathrm{kk} \text { ) }\end{array}$ \\
\hline Seisoo tukemalla & $\begin{array}{l}\text { Ikä keskimäärin 7,6 kk } \\
\text { (nopein } 5 \% 4,3 \mathrm{kk} \text {; hitain } 5 \% 9,9 \mathrm{kk} \text { ) }\end{array}$ \\
\hline $\begin{array}{l}\text { Konttaa käsillä ja } \\
\text { polvilla }\end{array}$ & $\begin{array}{l}\text { Ikä keskimäärin 8,5 kk } \\
\text { (nopein } 5 \% 6,1 \mathrm{kk} \text {; hitain } 5 \% 11,3 \mathrm{kk} \text { ) }\end{array}$ \\
\hline $\begin{array}{l}\text { Kävelee tuen } \\
\text { kanssa }\end{array}$ & $\begin{array}{l}\text { Ikä keskimäärin 9,2 kk } \\
\text { (nopein } 5 \% 6,9 \mathrm{kk} \text {; hitain } 5 \% 11,8 \mathrm{kk} \text { ) }\end{array}$ \\
\hline Seisoo yksin & $\begin{array}{l}\text { Ikä keskimäärin } 11,0 \mathrm{kk} \\
\text { (nopein } 5 \% 8,1 \mathrm{kk} \text {; hitain } 5 \% 14,4 \mathrm{kk} \text { ) }\end{array}$ \\
\hline Kävelee yksin & $\begin{array}{l}\text { Ikä keskimäärin 12,1 kk } \\
\text { (nopein } 5 \% 9,4 \mathrm{kk} \text {; hitain } 5 \% 15,3 \mathrm{kk} \text { ) }\end{array}$ \\
\hline
\end{tabular}

Taulukko 2 osoittaa, että maailman terveysjärjestön laatiman arvioinnin pohjalta lapset oppivat keskimäärin istumaan puolen vuoden iässä ja kävelevät vuoden ikäisenä. Merkille pantavaa kasvatusta ja opetusta ajatellen on tiedostaa, että kehityksessään nopeimpien ja hitaimpien välillä on huomattavia eroja. Esimerkiksi konttaamisen ja kävelemään oppimisen ero voi olla lähes puolivuotta. 


\section{Tahdonalaisten motoristen toimintojen kehittyminen}

Ensimmäisen elinvuoden aikana reflektioihin perustuvat liikkeet yleensä jäävät taka-alalle. Tämän jälkeen ikävuosina 1-2 lapselle kehittyy valmiuksia ja uusia taitoja säädellä tahdonalaisesti liikkeitään (esim. Seefeldt \& Haubenstricker, 1982; O’Brien \& Hayes, 1995; Kronqvist \& Pulkkinen, 2007). Myös liikkeiden ja liikesuoritusten tarkkuus lisääntyvät. Liikkeitä säätelevissä systeemeissä tapahtuu muutoksia, jotka ilmenevät sensorisen ja motoristen systeemin eriytymisenä. Toinen huomattava muutos saa aikaan sen, että lapsi kykenee integroimaan havaintoihin ja motoriseen toimintaan liittyvää informaatiota. Korkeamman tason kognitiivisissa ja motorisissa prosesseissa tapahtuu nopeaa muutosta, jonka avulla lapsi kykenee enenevässä määrin työstämään tahdonalaisia motorisia toimintoja.

Kehitykselliset muutokset ikävuosia 1-2 on nopeita ja varsin merkityksellisiä lapsen motorisella alueella. Lapsi oppii esimerkiksi tasapainon hallinnan, käsittelemään monipuolisesti esineitä ja liikkumaan lähiympäristössään monipuolisesti ja taitavasti. Esimerkkinä voi mainita tornin rakentamisen kahta palikkaa käyttäen (opitaan yleensä hieman yli vuoden ikäisenä) ja kävelemisen portaissa tuen avulla (opitaan yleensä puoleentoista vuoteen mennessä). Ikävuosina 1-2 lapsi oppii myös ruokailuvälineiden käytön, piirtämisen taitoja tai hyppimään paikallaan. Kävelemisen lisäksi lapset oppivat ikävuosina 1-2 merkittäviä liikunnallisia taitoja, joita ovat etenkin juokseminen, hyppääminen, kiinni ottaminen, ja esineiden pujottaminen kohteeseen käden tai molempien käsien avulla.

\section{Motoristen perustaitojen vahvistuminen}

Ikävuosina 2-7 lapsen motoriset perustaidot vahvistuvat ja aktivoituvat (esim. Seefeldt \& Haubenstricker, 1982; O’Brien \& Hayes, 1995; Kronqvist \& Pulkkinen, 2007). Lapset harjoittelevat monipuolisesti aikaisemmin omaksumiaan motorisia taitoja ja oppivat uusia tutkimalla ja testaamalla kehonsa liikunnallisia mahdollisuuksia. Lapsen kyvyt kontrolloida erillisiä, peräkkäisiä ja jatkuvia liikesuorituksia lisääntyvät. Lapset kykenevät ottamaan huomioon muutokset vaatimuksissa, joita kohdistetaan motorisiin suorituksiin.

Ikävuosina 3-4 perusliikkeiden hallinnassa ilmene lisääntyvää kontrollikykyä ja parempaa rytmistä koordinaatiota. Ikävuosina 5-6 lasten liikesuoritukset ovat pääpirteissään tehokkaita ja koordinoituja. Niitä hienosäädetään kokemuksilla ja palautteella, joka saadaan liikkeiden 
toteutuksesta. Käsittelytaidot, joissa vaaditaan visuaalismotorisia taitoja (esim. kiinniottaminen, osuminen, lentopalloilun taidot, käveleminen köysiradalla) kehittyvät. Harjoittelun osuus motoristen perustaitojen vahvistumisessa tulee tärkeäksi sekä lapselle että häntä ohjaavalle kasvattajalle erityisesti lähestyttäessä kouluikää.

Kouluuntulo 7-vuoden iässä sijoittuu vaiheeseen, jossa lapsi on siirtymässä uuteen motorisen kehittymisen vaiheeseen, jossa vahvistetaan olemassa olevia liikuntataitoja ja kehitetään uusia liikuntamuotoja (esim. uinti, rullalautailu, luistelu, tanssi, baletti jne.). Reaktio, liikkeen nopeus ja koordinaatiokyky kasvavat liikesuorituksissa. Lapsissa voidaan havaita monia liikuntaa liittyvä muutoksia. Ruumiin lihaksistossa tapahtuu muutoksia kohti aikuistyyppiä. Pituus ja pano lisääntyvät. Liiketottumukset alkavat muotoutua. Vertaisryhmän merkitys kasvaa. Asenteiden ja emootioiden merkitys kasvaa.

\section{Kehitysodotuksia karkea- ja hienomotoristen taitojen kehittymisestä}

Motorisen kehittymisen seurantaa varten on olemassa runsaasti ohjeistoa (esim. von Wend \& Voutilainen, 2008; Järviluoto \& Väänänen, 2008). Karkeamotoriikan etenemistä 3-7 -vuoden iässä on kuvattu liitetaulukossa 3. Kuvauksen mukaan 3-vuotiaan odotetaan seisovan yhdellä jalalla hetken, hyppivän tasajalkaa ja ajavan kolmirataspyörää. Kehityksen oletetaan etenevän niin, että kouluuntuloiän tienoilla lapsi juoksee ulkona taitavasti, ottaa pallon kiinni ja heittää sekä seisoo ja hyppää yhdellä jalalla jokseenkin taitavasti. Hienomotoriikan kehittymisodotuksia ikävuosina 3-7 on kuvattu liitetaulukossa 4. Voimme havaita, että 3-vuotiaana lapsen odotetaan hallitsevan käsien bilateraalista toimintaa ja sormien näppäryyttä, kätisyys on vakiintunut, lapsi kiertää pullon korkin auki ja kiinni, lapsi repii paperin käsien vastakkaisliikkeillä sekä hallitsee kynänotteen käyttäen sormenpääotetta tai aikuismaista kolmisormiotetta. Kouluun tullessaan lapsen odotetaan esimerkiksi hallitsevan oikean kynäotteen, kykenevän jäljentämään kolmion sekä sitovan kengännauhat. 


\section{Motoristen taitojen oppiminen ja kehittäminen}

\section{Taitojen oppiminen}

Taitojen oppiminen ja kehittyminen kulkevat yleensä käsi kädessä. Erityisesti opetusta ja kasvatusta ajatellen on keskeistä valottaa motoristen taitojen oppimismekanismeja. Näiden taitojen oppimismekanismista on esitetty ainakin kaksi samansuuntaista mutta toisistaan hieman poikkeavaa tulkintaa (esim. Nurkkala, 2007).

Näistä toisen mukaan (esim. Hakala, 1999; Ahonen ym., 2001) motoristen taitojen oppiminen etenee kolmen peräkkäisen vaiheen kautta. Alussa motorisen taidon oppimisessa korostuvat tiedolliset ulottuvuudet. Oppija hankkii tietoa uudesta opittavasta eri aistein havainnoimalla, katsomalla, kuuntelemalla ja tunnustelemalla. Näin oppija etsii sopivaa suoritustapaa ja kielellistä tai fyysistä ohjausta. Toisessa vaiheessa aistinhavaintojen kautta saatua tietoa verrataan ja liitetään muistissa olevaan tietoon. Kolmannessa vaiheessa ulkoisen ja kognitiivisen ohjauksen tarve vähenee ja toiminta muuttuu automaattiseksi. Motoristen taitojen oppimisprosessin yhteydessä muodostuu uusia sisäisiä toimintamalleja, joita kokeillaan käytännössä motorisen toiminnan avulla. Ahosen ym. (2001) mukaan kielellä ja liikkeellä on läheinen yhteys. On havaittu, että oppilailla, joilla on kielellisiä oppimisvaikeuksia, saattaa esiintyä enemmän motorista kömpelyyttä. Motoristen taitojen harjoittelulla on merkitystä. Harjoittelun avulla motorinen taito voi rakentua laajempaan hermoverkostoon, jolloin sen toteuttaminen on varmempaa.

Hieman toisenlaisen tulkinnan (Pehkonen, 1999) mukaan motoristen taitojen oppimisen ensimmäisessä vaiheessa oppija muodostaa kuvan tavoiteltavasta taidosta kokonaisuutena käyttäen hyväksi erilaisia vihjeitä, näkö- ja kuuloaistiin perustuvia ohjeita tai malleja sekä muuntaa tiedon tarkoituksenmukaiseksi liikkeeksi. Taidon oppimisen toisessa vaiheessa tapahtuvat koordinaatioprosessit, jossa siirrytään karkeakoordinaatiosta hienosyisempään koordinaatioon. Prosessin tuloksena taidon suoritus on mahdollisimman virheetön. Taidon oppimisen kolmannessa vaiheessa liikekokonaisuuksien osat automatisoituvat eikä niitä ole tarpeen juurikaan kontrolloida tietoisesti. 


\section{Taitojen kehittäminen}

Motoriset taidot ja niissä harjaantuminen ovat tärkeitä lapsen kokonaiskehityksen kannalta, koska motoriikan kehitys on yhteydessä kognitiivisen ja sosiaalisen alueen kehittymiseen. Tämän lisäksi motorisia taitoja tarvitaan päivittäin useissa toiminnoissa, joihin lapsi osallistuu kodin ja kodin ulkopuolisten kasvatusinstituutioiden arjessa.

Motoristen taitojen kehittäminen voi tarpeen mukaan kohdistua esimerkiksi seuraaviin alueisiin (Karvonen, 2000):

1. Puhe-elinten motoriikka: Kehittäminen kohdistuu tällöin suun seudun lihaksiin.

2. Kehon tuntemus: Kehitetään tietoisuutta omasta kehosta ja sen suhteesta ympäristöön.

3. Avaruudelliset suhteet: Harjoitetaan orientoitumista suuntaan, aikaan ja paikkaan.

4. Tasapaino ja koordinaatio: Kehitetään kehon kontrollia ja koordinaatiokykyä.

5. Karkeamotoriikka: Kehitetään laajojen liikkeiden hallintaa ja suorituskykyä.

6. Silmän-käden koordinaatio: Harjoitetaan hienomotorisia taitoja kuten tarttumista sekä silmän ja käden/jalan koordinaatiota.

7. Kehon rytmi: Kehitetään rytmitajua.

8. Kestävyys ja lihasvoima: Harjoitetaan ja kehitetään peruskuntoa.

Lasten motoristen taitojen harjaannuttamiseen on maassamme kiinnitetty lisääntyvää huomiota (esim. Numminen, 1995; Karvonen, 2000; Ahonen ym., 2005; Mattila, 2009; Järviluoto \& Väänänen, 2008; Ronkanen, 2009; Tuomi, 2010). Mattilan (2009) tuottamassa kehittämishankkeen raportissa Motoriikka paremmaksi (MOPPA) korostetaan sitä, että opettaminen ja harjoittaminen tulisi kohdistaa aistimuksia tuottavaan lasten fyysiseen toimintaan eikä yksittäisiin taitoihin. Lähtökohtana tulisi olla auttaa lasta edistymään motoriikan, toiminnan, tunne-elämän ja oppimisen haasteissa. Liikunnalliset harjoitukset kuten esimerkiksi tasapainoharjoitukset, telineharjoitukset ja liikuntavälineiden käyttö voivat harjaannuttaa esimerkiksi 
keskittymistä, katsomista, kuuntelemista, vertailua, luokittelua, etäisyyksien ja koon arviointia, ongelman ratkaisutaitoja, itsehillintää ja toisten huomioimista. Näin liikunnalliset harjoitukset voivat edistää myös kognitiivisia taitoja. Ne voivat myös edesauttaa lapsen itsetunnon myönteistä kehittymistä kuhan harjoitukset eivät ole lapselle liian vaikeita tai helppoja.

Vuonna 2018 Sääkslahti on tuottanut kirjan liikunnasta varhaiskasvatuksessa. Kirjan tarkoituksena on auttaa varhaiskasvattajia ja vanhempia valitsemaan lapsen kehitystasolle soveltuvia liikunnallisia aktiviteetteja, jotka tukevat fyysistä, motorista, kognitiivista, psyykkistä ja sosioemotionaalista kehitystä eri ikävaiheissa.

Erityisen tärkeänä motoristen taitojen harjaannuttamista pidetään lapsilla, joilla on oppimisvaikutuksia. Harjoitukset kohdistetaan etenkin havaintomotorisiin (senso-motoriisiin) taitoihin (esim. Karvonen 2000; Koljonen, 2005). Näitä ovat oman kehon hahmotus (kehokaavio), käsitys kehon eri puolista (lateraalisuus), itsenä hahmottaminen suhteessa tilaan (spatiaalinen hahmotus), itsensä ja liikkeen hahmottaminen suhteessa aikaan ja paikkaan sekä toimintojen motorinen ohjailu tahdonalaisesti (esim. kehon keskilinjan ylittäminen).

Havaintomotoristen taitojen harjaannuttamisella voidaan tukea lapsen tasapainotaitojen, liikkumistaitojen ja käsittelytaitojen kehittymistä, jotka kaikki ovat liikunnallisia perustaitoja (esim. Ayres, 2008; Ahonen ym. 2005). Kun harjaannuttamisessa kiinnitetään huomio sekä havaintomotoristen taitojen että hieno- ja karkeamotoriikan kehittämiseen, voidaan lasta usein auttaa lukemis- ja kirjoittamisvaikeuksissa, keskittymisvaikeuksissa, motorisessa kömpelyydessä, tasapainon ylläpitämisen vaikeuksissa ja kuuloon liittyvissä vaikeuksissa (esim. yliherkkä kuulo).

Useat motoriset taidot ja niiden kehittyminen on yhteydessä lapsen liikuntatottumuksiin. Kehittämällä ja tarpeen vaatiessa lisäämällä fyysistä aktiviteettia päiväkodissa, esikoulussa, koulussa ja vapaa-aikana voidaan tukea ja kehittää lapsen motorisia taitoja (esim. Tuomi, 2010). Liikunnan tulisi olla reipasta ja riittävän kuormittavaa. Levon ja rasituksen välttämiseksi päivittäinen aktiivinen liikunta-aktiviteetti olisi tarpeen jakaa pienempiin jaksoihin, joiden kesto olisi vähintään 10 minuuttia.

Ammattikasvajille ja vanhemmille on olemassa oppaita ja niihin liitettyjä harjoitteita, joiden tarkoituksena on kiinnittää huomiota ja auttaa kasvattajia tukemaan lapsen havaintomotorisia ja motorisia perustaitoja. Esimerkiksi Tuomen (2010) laatimassa oppaassa (Moto-taituriksi) on 60 
käytännön harjoitetta, jotka kohdistuvat havaintomotorisiin sekä tasapainon hallinnan, liikkumisen ja käsittelyn taitoihin. Oppaassa on myös ohjeita pihatelineillä tapahtuviin fyysisiin aktiviteetteihin.

Varhaisvuosien fyysiselle aktiivisuudelle Suomessa on laadittu vuonna 2016 suositukset (Opetus- ja kulttuuriministeriön julkaisuja 2016:21). Kattavasta joukosta suosituksia tarkastellaan tässä julkaisussa lähemmin ensimmäistä suositusta (Vauhti virkistää). Suosituksen mukaan lasten tulisi liikkua joka päivä vähintään kolme tuntia. Tämä voi koostua vauhdikkaasta tunnin mittaisesta fyysisestä aktiviteetista (esim. hippaleikit, trampoliinihyppely, kiipeily, uinti, hiihto) sekä yhteensä kahden tunnin mittaisesta reippaasta ulkoilusta (esim. retkeily, pyöräily, luistelu) ja kevyestä liikunnasta (esim. kävely, pallonheitto, keinuminen, tasapainoilu).

Opetus- ja kulttuuriministeriön toimesta on myös julkaistu tieteellisiä perusteita liittyen varhaisvuosien fyysiselle aktiivisuudelle (Opetus- ja kulttuuriministeriön julkaisuja 22: 2016). Tässä julkaisussa on tutkimuspohjaista tietoa esimerkiksi 3-10 -vuotiaiden suomalaislasten motorisista perustaidoista. Havaintona oli, että lapset hallitsivat liikkumistaitoja (esim. juokseminen, eri tavoin hyppääminen, laukkaaminen) paremmin kuin käsittelytaitoja. Esimerkiksi 5- vuotiailla tytöillä havaittiin poikiin nähden enemmän vaikeuksia pallon pomputtelussa, potkaisemisessa ja mailalla lyömisessä. Kuitenkin vain vähän yli puolet 8-vuotiaista pojista osasi mittauksen kohteena olleita käsittelytaitoja. 


\section{Lapsen oppimista ja opettamista jäsentävät opetussuunnitelmat varhaiskasvatuksessa (ikävuodet 1-5), esiopetuksessa (ikävuosi 6) ja perusopetuksen vuosiluokilla 1-2}

\section{Opetussuunnitelmien uudet perusteet (2014-2016)}

\section{Varhaiskasvatus}

Varhaiskasvatussuunnitelman perusteita täsmennettiin ja uudistettiin varhaiskasvatuslain säätämisen jälkeen (Varhaiskasvatussuunnitelman perusteet 2016; Opetushallitus, 2016). Suunnitelman johtoajatuksena on varhaiskasvatus, joka on suunnitelmallista ja tavoitteellista kasvatuksen, opetuksen ja hoidon kokonaisuutta, jossa painottuu erityisesti pedagogiikka. Viittaus pedagogiikkaan on uusi, jota ei ole selkeästi mainittu aikaisemmissa varhaiskasvatussuunnitelmissa. Perusteiden mukaan varhaiskasvatus on järjestäjälle lakiin perustuvaa ja velvoittavaa. Perusteissa määritelty varhaiskasvatuskokonaisuus koostuu valtakunnallisista varhaiskasvatuksen perusteista, paikallisista varhaiskasvatussuunnitelmista sekä lasten varhaiskasvatussuunnitelmista. Varhaiskasvatuksen arvoperusteina korostuvat (a) lapsuuden itsearvo, (b) ihmisenä kasvaminen, (c) lapsen oikeudet, yhdenvertaisuus, tasa-arvo ja moninaisuus, (d) perheiden monimuotoisuus sekä (e) terveellinen ja kestävä elämäntapa. Oppimiskäsitys korostaa lapsen vuorovaikutusta muihin ihmiseen ja lähiympäristöön.

Pedagogisen toiminnan kehys jäsennetään perusteissa laaja-alaisen osaamisen, oppimisen alueiden sekä lasten mielenkiinnon ja tarpeiden kohtaamisena, jonka taustana ovat arvoperusta ja oppimiskäsitys. Arvoperusta ja oppimiskäsitys kiinnittyvät toimintakulttuuriin, oppimisympäristöön, työtapoihin, yhteistyöhön, pedagogiseen dokumentointiin sekä arviointiin ja kehittämiseen.

Laaja-alainen osaaminen kohdentuu (a) ajatteluun ja oppimiseen, (b) kulttuuriseen osaamiseen, vuorovaikutukseen ja ilmaisuun, (c) itsestä huolehtimiseen ja arjen taitoihin, (d) monilukutaitoon ja tieto- ja viestintäteknologiseen osaamiseen sekä (e) osallistumiseen ja vaikuttamiseen. Aikaisemmissa perusteissa ei kohdistettu huomiota laaja-alaiseen osaamiseen eikä osaaminen sisältynyt näiden suunnitelmien perusteisiin. 
Varhaiskasvatussuunnitelman perusteissa (2016) varhaiskasvatuksen pedagogisen toiminnan yleistavoitteena on oppiva ja hyvinvoiva lapsi. Oppiva lapsi keskeisenä tavoitteena edustaa uutta ajattelutapaa aikaisempiin suunnitelmiin verrattuna. Sen sijaa lapsen hyvinvointiin on viitattu jo aikaisemmissa perusteissa. Oppimisen alueet kohdistuvat (a) kielten rikkaaseen maailmaan, (b) ilmaisun moniin muotoihin, (c) minään ja meidän yhteisöömme, (d) tutkimiseen ja toimimiseen omassa ympäristössä sekä (e) kasvamiseen, liikkumiseen ja kehittymiseen. Aikaisemmissa perusteissa alueita nimitettiin sisällöllisiksi orientaatioiksi.

Perusteissa hahmotellaan myös pedagogisen toiminnan arviointia ja kehittämistä, jonka tarkoituksena on varhaiskasvatuksen kehittäminen sekä lapsen kehityksen ja oppimisen parantaminen. Tämä tapahtuu paikallisen varhaiskasvatussuunnitelman ja lasten varhaiskasvatussuunnitelman seurannalla ja arvioinnilla. Arviointia pyritään toteuttamaan monella tasolla. Kansallisen tason arvioinnilla pyritään tukemaan varhaiskasvatuksen järjestäjän arviointia ja laadunhallintaa. Toisen tason muodostaa varhaiskasvatuksen järjestäjä, jonka tehtävänä on seurata ja arvioida varhaiskasvatussuunnitelmia ja niiden toteutusta säännöllisesti. Myös henkilöstöä pyritään arvioimaan perustuen lähinnä itsearviointiin kiinnittämällä huomiota esimerkiksi vuorovaikutukseen lasten kanssa, ryhmän ilmapiiriin, pedagogisiin työtapoihin, toiminnan sisältöön ja oppimisympäristöön. Yksilötason arvioinnissa kiinnitetään huomiota lasten varhaiskasvatussuunnitelman toteutukseen yhdessä lapsen, huoltajan ja henkilöstön kanssa. Näin hankittua tietoa pyritään hyödyntämään myös lapsen oppimisen ja hyvinvoinnin tukemisessa.

Vaikka perusteissa toiminnan arviointia ja kehittymistä lähestytään jossain määrin monipuolisemmin kuin aiemmissa varhaiskasvatuksen perusteissa, huomiota kiinnittää se, että systemaattiseen lapsen oppimisen ja kehittymisen seurantaan ei juurikaan kiinnitetä huomiota. Saadaanko perusteissa kuvatulla pedagogisella arvioinnilla lapsen oppimisen ja kehittymisen polusta luotettavaa kokonaiskuvaa, joka voisi välittyä esimerkiksi esiopetukseen ja koulun alkuun? Edelleen voi kysyä, onko perusteissa mainittu huomion kiinnittäminen varhaiskasvatussuunnitelman toteutukseen riittävän spesifi arviointiperuste lapsen yksilötason arvioinnille?

Syventävän käsityksen perusteista voi saada ottamalla tarkastelun kohteeksi joitain oppiaineita. Seuraavassa huomio kohdistuu kahteen oppiaineeseen, joista toinen liittyy kieleen ja toinen matemaattiseen ajatteluun/ 
matematiikkaan. Näiden jatkumoa tarkastellaan tämän luvun lopussa varhaiskasvatuksesta esiopetukseen ja esiopetuksesta perusopetuksen vuosiluokkiin 1-2.

\section{Monilukutaito ja kieli}

Varhaiskasvatuksen opetussuunnitelman perusteissa kieleen liittyvää ainesta tarkastellaan lähinnä monilukutaidon ja kielen rikkaan maailman kautta. Perusteiden mukaan monilukutaidossa pyritään tutustuttamaan lapsia erilaisten viestien tulkintaan ja tuottamiseen. Asioiden ja esineiden nimeäminen sekä erilaisten käsitteiden opettelu ovat monilukutaitoon liittyviä aktiviteetteja. Perusteissa korostetaan myös, että lapsia tulisi innostaa tutkimaan, käyttämään ja tuottamaan viestejä erilaisissa ympäristöissä mukaan luettuna digitaaliset viestit.

Kieltä käsitellään varhaiskasvatussuunnitelman perusteissa monipuolisesti. Varhaiskasvatuksen tehtävänä nähdään kielellisten taitojen ja valmiuksien sekä kielellisen identiteetin kehittymisen vahvistaminen. Perusteissa eritellään lapsen kielen kehittymisen keskeiset osa-alueet. Näitä ovat (a) vuorovaikutustaidot (esim. kuulluksi tuleminen ja lapsen aloitteisiin vastaaminen), (b) kielen ymmärtämisen taidot (esim. kielellinen mallintaminen sekä toiminnan sanallistaminen), (c) puheen tuottamisen taidot (esim. lasta rohkaistaan puhumaan eri tilanteissa aikuisten ja toisten lasten kassa), (d) kielen käyttötaidot (esim. harjoitellaan kertomista, selittämistä ja puheen vuorottelua), (e) kielellinen muisti ja sanavarasto (esim. lorut, laululeikit, keskustelu, lukeminen, tarinoiden kertominen jne.) sekä (f) kielellinen tietoisuus (herätetään kiinnostusta suullista ja kirjoittua kieltä sekä vähitellen lukemista ja kirjoittamista kohtaan, kiinnitetään huomiota sanojen merkitykseen sekä kielen muotoihin ja rakenteisiin).

\section{Matemaattinen ajattelu}

Matemaattista ajattelua ei käsitellä varhaiskasvatussuunnitelman perusteissa omana kokonaisuutena vaan yhdistyneenä ympäristön tutkimiseen ja toimiseen ympäristössä. Perusteiden mukaan varhaiskasvatuksen tulee tukea lasten matemaattisen ajattelun kehittymistä ja myönteistä suhtautumista matematiikkaan. Tavoitteena on tutustuttaa lapset matematiikkaan ja sen osa-alueisiin havainnollisessa ja leikinomaisessa toiminnassa. Päivittäiset tilanteet ja ympäristössä ilmenevä matematiikka ovat keskeisiä. Näissä tehtäviä havaintoja pohditaan ja kuvaillaan. Tilaisuuksia luodaan 
luokitteluun, vertailuun ja järjestykseen asettamiseen sekä säännönmukaisuuksien löytämiseen.

Matemaattisen ajattelun kehittymisen tukeminen kohdistuu varhaiskasvatuksen opetussuunnitelman perusteissa myös lukukäsitykseen havainnoimalla lukumääriä ympäristössä ja liittämällä ne taitojen karttuessa lukusanaan ja numeromerkkiin. Nimeämistä ja lukutaitoja pyritään tukemaan. Myös mittaamista sekä sijainti- ja suhdekäsitteitä harjoitellaan. Matemaattisen ajattelun kohteena on myös tilan ja tason hahmottaminen. Kohteina voivat olla kappaleiden ja muotojen tutkiminen. Rakentelu, askartelu ja muovailu voivat vahvistaa lasten geometrista ajattelua. Aikakäsitettä pyritään kehittämään esimerkiksi havainnoimalla vuorokauden- ja vuodenaikoja.

\section{Esiopetus}

Vuonna 2000 laadittuja esiopetuksen opetussuunnitelman perusteita uudistettiin edellisen kerran vuonna 2010. Perusopetuksen opetussuunnitelmauudistuksen yhteydessä uudistettiin myös esiopetuksen opetussuunnitelma perusteet (2014), joihin on vuonna 2016 liitetty määräyksiä ja ohjeita (Opetushallitus, 2016).

Perusteissa korostetaan, että huoltajan on huolehdittava siitä, että lapsi osallistuu esiopetukseen tai muuhun esiopetuksen tavoitteet saavuttavaan toimintaan oppivelvollisuutta edeltävänä vuonna. Tavoitteena on esiopetuksen kautta muodostaa lapselle johdonmukaisesti etenevä laadukas kokonaisuus varhaiskasvatuksesta perusopetukseen. Toiminnan tulee olla tavoitteellista mutta niin, että lasten osaamiselle ei aseteta tavoitteita. Huomiota kiinnittää toteamus, jonka mukaan osaamiselle ei aseteta tavoitteita. Voi kysyä, mitä etuja saataisiin, jos osaaminen olisi tavoitteellista? Tai millaista on tavoitteellinen toiminta ilman tavoitteellista osaamista? Joka tapauksessa tavoitteista irtautuminen lasten osaamisessa on kansainvälisesti poikkeuksellinen.

Esiopetuksen arvoperusta ja oppimiskäsitys ovat suurelta osin yhteneväiset varhaiskasvatuksen perusteisiin nähden. Arvoperusteissa keskeisinä pidetään esiopetuksessa lapsuuden itseisarvoa, oikeutta oppia leikkien, oppimisen iloa sekä tasa-arvon tukemista. Tasa-arvon toteutumista pyritään täydentämään laaja-alaisella yhdenvertaisuuden periaatteella järjestämällä esiopetus lapsille puoluepoliittisesti, uskonnollisesti ja katsomuksellisesti 
sitoutumattomana ja vapaana kaupallisesta vaikuttamisesta. Oppimiskäsitys perustuu varhaiskasvatuksen tapaan lapsen vuorovaikutukseen toisten lasten, opettajien, eri yhteisöjen ja lähiympäristön kanssa. Keskeisenä pidetään lapsen omaa toimintaa ja luottamusta omiin mahdollisuuksiin.

Uuden varhaiskasvatussuunnitelman perusteiden tapaan esiopetus perustuu laaja-alaiseen osaamiseen kohdistuen (a) ajatteluun ja oppimiseen, (b) kulttuuriseen osaamiseen, vuorovaikutukseen ja ilmaisuun, (c) itsestä huolehtimisen ja arjen taitoihin, (d) monilukutaitoon ja tieto- ja viestintäteknologiseen osaamiseen sekä (e) osallistumiseen ja vaikuttamiseen. Näihin liittyen korostetaan, että esiopetuksen painopisteinä ovat kestävän elämäntavan sosiaaliset ja kulttuuriset näkökulmat sekä lasten valmiudet suuntautua elinikäisen oppimisen polulle.

Esiopetuksella on yhteisiä tavoitteita ja oppimiskokonaisuuksia. Nämä kohdistuvat (a) ilmaisun moniin muotoihin, (b) kielten rikkaaseen maailmaan, (c) minään ja meidän yhteisöömme, (d) tutkimiseen ja toimimiseen omassa ympäristössä sekä (e) kasvamiseen ja kehittymiseen. Kokonaisuudet ovat käytännössä yhtenevät varhaiskasvatukseen nähden. Ainostaan liikkumista ei mainita kasvun ja kehittymisen yhteydessä toisin kuin varhaiskasvatuksessa.

Esiopetuksen opetussuunnitelman perusteiden mukaan arvioinnilla on kaksi keskeistä tehtävää. Ensinnäkin sen avulla voidaan suunnitella ja kehittää opetusta. Toiseksi arvioinnin avulla voidaan tukea lasten hyvinvointia, kasvua ja oppimista. Arviointia toteutetaan havainnoinnin, dokumentoinnin, arvopäätelmien ja palautteen keinoin niin, että lapsi ja huoltajat osallistuvat siihen. Esiopetuksessa halutaan myös kehittää lapsen edellytyksiä itsearviointiin. Myös arviointitiedon siirtämistä pidetään tärkeänä lapsen siirtyessä ensimmäiselle luokalle esimerkiksi hyödyntämällä lasten etenemistä kuvaavia dokumentteja ja lapselle laadittuja oppimissuunnitelmia. Opetushenkilöstöä kannustetaan tavoitteelliseen itsearviointiin, jonka nähdään olevan laadun ylläpitämisen ja kehittämisen ehto. Voi kuitenkin panna merkille, että esiopetussuunnitelman perusteissa ei käsitellä laatua, sen osatekijöitä eikä laadun arviointia.

\section{Kieli esiopetuksessa}

Esiopetuksen opetussuunnitelman uusissa perusteissa kieltä tarkastellaan kielellisten taitojen kehittymisestä käsin. Oletuksena on, että kielelliset taidot kehittyvät kokonaisvaltaisesta kielen hahmottamisesta kohti 
yksityiskohtaisempaa kielen rakenteiden ja muodon havaitsemista. Esiopetuksessa halutaan vahvistaa lapsen kiinnostusta puhuttua kieltä sekä lukemista ja kirjoittamista kohtaan. Kielellinen mallintaminen, viestien tulkinta ja tuottaminen suullisesti ja viestinnän välineillä ovat tärkeitä ja tukevat lapsen monilukutaidon kehittymistä sekä tieto- ja viestintäteknologista osaamista. Kielellistä tietoisuutta pyritään tukemaan eri kielten havaitsemisella, kielellä leikkimällä, loruillen sekä puhutun ja kirjoitetun kielen tutkistelulla.

Esiopetuksessa tuetaan kehittyvää luku- ja kirjoitustaitoa. Erilaisten tekstien lukeminen ja niistä keskustelu voivat auttaa lasta ymmärtämään lukemisen merkityksen. Esimerkein ja erilaisten harjoitusten avulla lapsille pyritään antamaan kokemuksia siitä, miten puhe muuntuu kirjoitetuksi kieleksi ja päinvastoin. Lapsia autetaan havaitsemaan, miten puhe jakautuu sanoihin, tavuihin ja äänteisiin. Leikillinen kirjoittaminen ja omien tekstien tuottaminen tieto- ja viestintäteknologiaa käyttäen sekä lapsen tuottamat kirjaimet, sanat ja tekstit tukevat lasten lukutaidon kehittymistä. Hienomotorisia taitoja harjoitellaan samoin kuin lasten kykyä hahmottaa tilaa ja suuntia. Huomiota kiinnitetään myös kynäotteen ja näppäimistöjen käytön harjoitteluun sekä lastenkirjallisuuden käyttöön.

\section{Matemaattiset taidot esiopetuksessa}

Matematiikan oppiainesta hahmotetaan esiopetuksen opetussuunnitelman perusteissa kiinteässä yhteydessä matemaattisiin taitoihin. Tavoitteena on vahvistaa lasten matemaattista ajattelua ja matematiikan oppimista. Huomiota kiinnitetään lukuihin, muutokseen, ajan käsitteisiin sekä tason ja avaruuden hahmottamiseen ja mittaamistaitoihin. Matemaattisia havaintoja pohditaan ja kuvaillaan erilaisissa tilanteissa opettajan mallintamisen ja kielellistämisen avustuksella. Luokittelua, vertailua, järjestykseen asettamista ja säännönmukaisuuksien havaitsemista tuetaan.

Esiopetuksessa pyritään perusteiden mukaan tukemaan lukukäsitteen kehittymistä kiinnittämällä huomiota lukumääriin ympäristössä ja liittämällä havainnot lukusanaan ja numeromerkkeihin. Lukumääriä vertaillaan ja pohditaan lukumäärän muutosta. Erityisenä huomion kohteena ovat lukujonotaidot ja nimeäminen. Tason ja tilan hahmottamista harjoitellaan tutkimalla ja kokeilemalla 2- ja 3-ulotteisuutta sekä opetellaan sijaintiin liittyviä käsitteitä (esim. edessä, ylhäällä, joka toinen). Mahdollisuudet rakenteluun, askarteluun ja muovailuun tukevat geometristä ajattelua. 
Mittaamista harjoitellaan eri tavoin keholla ja välineillä. Aikakäsitettä vahvistetaan (esim. joskus, eilen, aamulla). Vuorokaudenaikoja havainnoimalla lapset johdatetaan pohtimaan aikajärjestystä.

\section{Perusopetus}

\section{Yleistä}

Uudet perusopetuksen opetussuunnitelman perusteet julkistettiin vuonna 2014 (Perusopetuksen opetussuunnitelman perusteet, 2014). Lähtökohtana on, että perusopetus luo perustan yleissivistykselle. Sen avulla halutaan varmistaa koulutuksen tasa-arvo ja laatu sekä luoda hyvät edellytykset oppilaiden kasvulle, kehitykselle ja oppimiselle. Perusopetusta pidetään kivijalkana, joka tarjoaa mahdollisuuden laajan yleissivistyksen muodostumiseen ja oppivelvollisuuden suorittamiseen.

Uudet opetussuunnitelman perusteet kiinnittyvät arvoperustaan. Näissä korotetaan (a) oppilaan ainutlaatuisuutta ja oikeutta hyvään opetukseen, (b) ihmisyyttä, sivistystä, tasa-arvoa ja demokratiaa, (c) kulttuurista moninaisuutta rikkautena sekä (d) kestävän elämäntavan välttämättömyyttä. Oppilaan ainutlaatuisuuden yhteydessä viitataan lapsuuden itseisarvoon, jota korostettiin myös varhaiskasvatuksen ja esiopetuksen perusteissa.

Oppimiskäsityksessä korostetaan, että oppilas on aktiivinen oppija, oppiminen tapahtuu vuorovaikutuksessa ja oppimaan oppimisen taidot ovat perustana tavoitteelliselle ja elinikäisille oppimiselle. Näissä on yhteneväisiä elementtejä varhaiskasvatuksen ja esiopetuksen perusteiden kanssa. Erona on lähinnä oppimisen korostaminen (oppilas on aktiivinen oppija) perusopetuksessa.

Perusopetukselle on säädetty valtakunnalliset opetuksen ja kasvatuksen tavoitteet, jotka ohjaavat opetussuunnitelmien laadintaa ja koulun työskentelyä. Näiden mukaan perusopetuksen tavoitteena on (a) kasvu ihmisyyteen ja yhteiskunnan jäsenyyteen, (b) tarpeelliset tiedot ja taidot sekä (c) sivistyksen, tasa-arvoisuuden ja elinikäisen oppimisen edistäminen. Osaamisessa pyritään laaja-alaisuuteen.

Opetussuunnitelmallisena ratkaisuna ovat seitsemän laaja-alaista osaamiskokonaisuutta, jotka ovat (a) ajattelu ja oppiminen, (b) kulttuurinen osaaminen, vuorovaikutus ja ilmaisu, (c) itsestä huolehtiminen ja arjen taidot, (d) monilukutaito, (e) tieto- ja viestintäteknologinen osaaminen, (f) työelämän taidot ja yrittäjyys sekä (g) osallistuminen, vaikuttaminen ja 
kestävän tulevaisuuden rakentaminen. Voi panna merkille, että perusopetuksen opetussuunnitelman perusteissa esitetyt osaamiskokonaisuudet ovat suurelta osin yhteneväiset varhaiskasvatuksen, esiopetuksen ja perusopetuksen uusissa suunnitelmissa. Osaamiskokonaisuuksien avulla pyritään tukemaan lasten ja oppilaiden laaja-alaista oppimista, joka ei ole itsestäänselvyys etenkään oppiainejakoisessa perusopetuksessa. On syytä kuitenkin seurata ja arvioida, millä tavoin tällaiset ikävuodesta toiseen toistuvat ja etukäteen nimetyt eheyttävät osaamiskokonaisuudet toimivat käytännössä erityisesti lasten ja oppilaiden tasolla.

\section{Oppimisen arviointi}

Arvioinnilla on perusopetuksessa periaatteita, joita eritellään opetussuunnitelman perusteissa. Näitä ovat (a) arvioinnin perustuminen tavoitteisiin ja kriteereihin, (b) ikäkauden ja edellytysten huomioon ottaminen sekä (c) itsearvioinnin edellytysten kehittäminen. Arviointi kohdistetaan oppimiseen, työskentelyyn ja käyttäytymiseen.

Opintojen aikainen arviointi on pääosin jatkuvaa palauteen antamista oppimisprosessista opettajan tekeminen havaintojen ja vuorovaikutuksen perusteella (formatiivinen arviointi). Keinona käytetään myös vertaisarviointia ja itsearviointia. Arviointipalautteen tarkoituksena on auttaa oppilaita hahmottamaan, mitä heidän olisi kulloinkin tarkoitus oppia, mitä he ovat oppineet ja miten he voisivat edistää omaa oppimistaan ja suoriutumistaan. Lukuvuoden päättyessä tehdään oppimaan oppimisesta kokoaavaa arviointi (summatiivinen arviointi). Oppilaalle annetaan lukuvuositodistus, joka voi olla sanallinen tai numeerinen tai näiden yhdistelmä. Lukuvuositodistukseen liitetään myös kuvausta oppilaan käyttäytymisestä.

Voi todeta, että suhteessa varhaiskasvatukseen ja esiopetukseen perusopetuksen arviointi kiinnittyy selkeämmin opetuksen tavoitteisiin ja kriteereihin. Maininta siitä, että arviointi perustuu kriteereihin, ei ole mukana varhaiskasvatuksen ja esiopetuksen opetussuunnitelmien perusteissa.

\section{Perusopetuksen vuosiluokat 1-2}

\section{Yleistä}

Kouluun siirtyminen esiopetuksesta on merkittävä tapahtuma lapsen kasvun, kehittymisen ja oppimisen kannalta. Tämä edellyttää molemminpuolista yhteistyötä ja tiedon vaihtoa esiopetuksen ja perusopetuksen välillä. 
Kouluun siirtyminen aktivoi yleensä myös lapsen huoltajia tiiviimpään yhteistyöhön.

Vuosiluokkien 1-2 erityistehtävä on tukea perusopetuksen opetussuunnitelman perusteiden mukaan oppilasta kasvamaan koululaiseksi. Erityisenä tehtävänä on luoda perusta oppilaiden myönteiselle käsitykselle itsestä oppijana ja koululaisena ja kehittää valmiuksia myöhempää oppimista ja koulunkäyntiä varten. Vuosiluokkien 1-2 työtavoissa halutaan korostaa esimerkiksi havainnollisuutta, toiminnallisuutta, leikkiä, pelillisyyttä, mielikuvitusta sekä tarinallisuutta.

Ennen kouluun siirtymistä uusissa opetussuunnitelmien perusteissa on korostettu oppimisen alueita (varhaiskasvatus) ja oppimiskokonaisuuksia (esiopetus). Nämä muuttuvat perusopetuksessa oppiaineiksi. Vuosiluokkien 1-2 opetus voi kuitenkin olla perusteiden mukaan edelleenkin eheytettyä. Oppilaiden omatoimisuutta, yhdessä toimimisen taitoja ja asioiden välisten yhteyksien ymmärtämistä varten vuosiluokkien 1-2 opetussuunnitelman perusteisiin on liitetty monialaisia oppimiskokonaisuuksia. Näissä kokonaisuuksissa kaikki oppiaineet voivat olla vuorollaan mukana. Kokonaisuuksien sisällöt määräytyvät toimintakulttuurin, oppilaiden kiinnostuksen, kulloinkin valitun oppiaineen sekä opettajien välisen yhteistyön kautta. Niiden tulee heijastaa myös koulun arvoja ja oppimiskäsitystä.

Laaja-alainen osaaminen vuosiluokilla 1-2 kohdistuu seitsemään alueeseen, joita toteutetaan koko perusopetuksen ajan. Niiden sisältö kuitenkin painottuu vuosiluokkien mukaisesti. Seuraavassa havainnollistetaan vuosiluokkien 1-2 laaja-alaista osaamista kolmen osa-alueen mukaan, joiksi on valittu (a) ajattelu ja oppimaan oppiminen, (b) monilukutaito ja (c) tieto- ja viestintäteknologinen osaaminen.

Ajattelun ja oppimaan oppimisen osaamista tuetaan kannustamalla oppilaita kysymään ja kuuntelemaan, tekemään tarkkoja havaintoja, etsimään tietoa, tuottamaan yhdessä ideoita sekä esittämään työskentelyn tuloksia. Ongelmanratkaisu- ja tutkimustehtävät liittyvät ajattelun ja oppimaan oppimisen aktiviteetteihin. Oppilaita kannustetaan kyseenalaistamaan havaintojaan ja päätelmiään sekä huomaamaan, että tieto voi olla ristiriitaista ja ehkä epäselvää. Perusteiden mukaan monipuolinen liikkuminen ja motoriset harjoitukset tukevat ajattelua ja oppimista. Saduilla, tarinoilla, peleillä, laululla ja leikeillä sekä taiteen eri muodoilla voidaan perusteiden mukaan tukea laaja-alaista ajattelua ja oppimaan oppimista. 
Monilukutaitoa pyritään tukemaan vuosiluokilla 1-2 ohjaamalla oppilaita monenlaisten ja ikäkauteen sopivien tekstien tulkintaan, tuottamiseen ja arviointiin. Moniaistisuus, kokonaisvaltaisuus ja ilmiökeskeisyys tukevat monilukutaidon kehittymistä. Kuvalukutaito, tekstien lukutaito, numeerisen informaation käsittely ja tiedon hankinta erilaista lähteistä vahvistavat monilukutaitoa. Perusteissa korostetaan myös sitä, että oppilaille luodaan tilaisuuksia kysyä ja ihmetellä, kertoa tarinoita, esittää näkemyksiään ja jakaa kokemuksiaan erilaisilla välineillä ja ilmaisun keinoin.

Tieto- ja viestintäteknologista osaamista perusopetuksen vuosiluokilla 1-2 harjoitellaan kiinnittämällä huomiota oppilaiden käytännön taitoihin ja omaan tuottamiseen. Kohteena ovat laitteiden, ohjelmiston ja palvelimien käyttö ja niiden toimintaperiaatteet. Lisäksi harjoitellaan näppäintaitoja ja tekstin tuottamista. Digitaalista mediaa ja pelillisyyttä hyödynnetään. Vastuullinen ja turvallinen toiminta on toinen pääalue. Tähän alueeseen liittyen huomiota kiinnitetään myös terveellisiin työasentoihin ja sopiviin työjaksoihin. Osaamisen kolmas pääalue on tiedonhallinta sekä tutkiva ja luova työskentely. Neljäs alue on vuorovaikutus ja verkottuminen, jossa kohdistetaan huomiota yhteisöllisten palvelimien käyttöön oppimisessa.

Vuosiluokkien 1-2 arviointiin on liitetty perusteissa erillinen arviointi, joka suoritetaan toisen vuosiluokan päätteeksi. Tätä silmällä pitäen arvioinnin pääpaino siirtyy toisen vuosiluokan lopulla oppilaan oppimisen edistymisen arvioinniksi. Tavoitteena on tuoda esille oppijan vahvuuksia, vahvistaa hänen itsetuntoaan ja oppimismotivaatiotaan. Arviointiprosessissa opettajan, oppilaiden ja huoltajan välistä vuorovaikutusta pidetään tärkeänä.

Toisen lukuvuoden päättöarvioinnissa huomioidaan laaja-alaisen osaamisen tavoitteet. Erityistä huomiota kiinnitetään oppilaiden edistymiseen kielellisissä valmiuksissa (erityisesti kysymisen ja kuuntelemisen taidot sekä vuorovaikutustaidot ja taidot ilmaista itseään eri keinoin), edistymiseen työskentelytaidoissa (erityisesti taito työskennellä itsenäisesti ja ryhmässä) sekä edistymiseen taidoissa huolehtia omista ja yhteisesti sovituista tehtävistä.

\section{Oppiaineet vuosiluokilla 1-2}

Perusopetuksen kahdella ensimmäisellä luokalla oppiaineina ovat äidinkieli ja kirjallisuus, toinen kotimainen kieli (joko suomi tai ruotsi), vieraat kielet, matematiikka, ympäristöoppi, uskonto, elämänkatsomustieto, musiikki, 
kuvataide, käsityö, liikunta ja oppilaan ohjaus. Tässä julkaisussa tarkastellaan lähemmin kahta oppiainetta, joiksi on valittu äidinkieli ja kirjallisuus sekä matematiikka. Nämä kaksi oppiainetta ovat myös olleet mukana perusopetukseen kohdistuneessa kansainvälisessä vertailussa.

\section{Äidinkieli ja kirjallisuus}

Opetussuunnitelman perusteissa painotetaan, että äidinkielen ja kirjallisuuden opetuksen erityisenä tehtävänä vuosiluokilla 1-2 on edistää yksilölliseltä pohjalta oppilaiden itsensä ilmaisemisen ja vuorovaikutuksen taitoja, kielellistä tietoisuutta sekä kehittää perustaitoja kuuntelemisessa, puhumisessa, lukemisessa ja kirjoittamisessa. Oppilaiden kiinnostusta pyritään vahvistamaan kielelliseen ilmaisuun, draamaan, kaunokirjallisuuteen sekä erilaisten tekstien tulkintaa ja ilmaisuun. Opetuksen ja oppimisen kohteina ovat sekä äidinkielen perustaidot että laaja-alainen osaaminen. Perusteissa korostetaan, että painopisteinä opetuksessa ovat luku- ja kirjoitustaitojen perustan luominen sekä oppimaan oppimisen ja vuorovaikutuksen taidot.

Vuosiluokkien 1-2 äidinkieleen ja kirjallisuuteen liittyy arviointia ja palautteen antoa. Perusteiden mukaan arvioinnissa ja palautteessa kiinnitetään huomiota seuraaviin asioihin: (a) oppilaan edistymiseen itsensä ilmaisemisessa ja vuorovaikutustaidoissa sekä sana- ja käsitevaraston kartuttamisessa, (b) oppilaan edistymiseen lukutaidossa sekä tekstien ymmärtämisessä ja lukemisessa, (c) oppilaan edistymiseen tekstien tuottamisessa (erityisesti käsin kirjoittamisen ja näppäintaitojen kehittyminen) sekä (d) oppilaan edistymiseen kielen ja kulttuurin ymmärtämisessä (erityisesti havaintojen tekeminen sanojen merkityksestä ja kielenkäyttötilanteista arjessa).

Perusteiden mukaan suomen kielen ja kirjallisuuden opetukselle vuosiluokilla 1-2 asetetut tavoitteet kohdistuvat (a) vuorovaikutustilanteissa toimimiseen, (b) tekstien tulkitsemiseen, (c) tekstien tuottamiseen sekä (d) kielen, kirjallisuuden ja kulttuurin ymmärtämiseen. Esimerkiksi vuorovaikutustilanteissa toimimisessa kiinnitetään huomiota oppilaan taitoihin toimia erilaisissa vuorovaikutustilanteissa, osallistumiseen ryhmäviestitilanteissa, ilmaisurohkeuteen myös draaman välityksellä, oman viestijäkuvan rakentamiseen sekä taitoihin ymmärtää ihmisten erilaisia viestimisen tapoja. Tekstien tuottamisen tavoitteissa kiinnitetään huomiota esimerkiksi oppilaan kerrontaan (tarinat ja mielipiteet) ja kuvauksiin kokemuksista (puhumalla, kirjoittamalla ja kuvilla), lyhyiden tekstien tuottamiseen, 
harjaantumiseen käsikirjoittamisen ja näppäinkäsittelyn taidoissa, tekstien suunnitteluun ja rakentamiseen sekä oikeinkirjoituksen perusasioihin.

Kielen, kirjallisuuden ja kulttuurin ymmärtämisessä tavoitteet kohdistuvat oppilaan kielitietoisuuden ja kielen peruskäsitteiden kehittämiseen sekä havaintojen tekemiseen puhutusta ja kirjoitetusta kielestä (esim. huomiot oman kielenkäytön vaikutuksista toisten käyttäytymiseen). Edellisten lisäksi kielen, kirjallisuuden ja kulttuurin ymmärtämisessä tavoitteena on innostaa oppilasta kuuntelemaan ja lukemaan lapsille suunnattua kirjallisuutta, valitsemaan itseään kiinnostavaa lukemista sekä kehittämään lukuharrastusta ja kirjaston käyttöä. Ymmärtämiseen liittyen oppilasta ohjataan myös arvostamaan omaa kieltään ja kulttuuriaan osana kulttuurista moninaisuutta sekä tutustumaan joihinkin lastenkulttuurin muotoihin kannustaen myös oman kulttuurin yhteiseen tuottamiseen. Vieraan kielen oppiminen voi perusteiden mukaan alkaa jo ennen 3. luokkaa. Vuonna 2018 valtioneuvosto on täsmentänyt että, oppiminen voi alkaa jo 1. luokasta lähtien.

\section{Matematiikka}

Perusopetuksen matematiikan yleistehtävänä on opetussuunnitelman perusteiden mukaan kehittää oppilaiden loogista, täsmällistä ja luovaa matemaattista ajattelua. Käsitteiden ja rakenteiden ymmärtäminen ja oppilaiden kyky käsitellä tietoa ja ongelmia ovat keskeisiä. Opetus etenee systemaattisesti ja opiskelu on tavoitteellista ja pitkäjännitteistä. Tavoitteena on myös ohjata oppilaita ymmärtämään matematiikan hyödyllisyys omassa elämässä ja yhteiskunnassa sekä kehittää oppilaiden kykyä käyttää ja soveltaa matematiikkaa.

Vuosiluokkien 1-2 matematiikan opetuksessa pyritään tarjoamaan oppilaille monipuolisia kokemuksia ja perusteita matemaattisten käsitteiden ja rakenteiden muodostukselle. Oppilaiden kykyä ilmaista matemaattista ajattelua konkreettisin välinein suullisesti, kirjallisesti, piirtäen ja kuvia tulkiten pyritään tukemaan ja kehittämään. Tavoitteena on luoda vahva pohja lukukäsitteen ja kymmenjärjestelmän ymmärtämiselle ja laskutaidolle.

Vuosiluokkien 1-2 matematiikan tavoitteet kohdistuvat (a) merkitykseen, arvoihin ja asenteisin, (b) työskentelytaitoihin sekä (c) käsitteellisiin ja tiedonalakohtaisiin tavoitteisiin. Viimeksi mainituissa (kohta c) tavoitteissa kohdistetaan huomio matemaattisten käsitteiden ja merkintätapojen ymmärtämiseen, lukukäsitteen kehittymiseen ja kymmenjärjestelmän ymmärtämiseen, peruslaskutoimitusten periaatteisiin ja niiden sujuvuuteen, 
päässälaskustrategioiden kehittämiseen peruslaskutoimituksissa, geometristen muotojen ymmärtämiseen, mittaamisen periaatteiden ymmärtämiseen, taulukoihin ja diagrammeihin sekä vaiheittaisten toimintaohjeiden laatimiseen ja ohjeen mukaan toimimiseen.

Matematiikan opetussuunnitelmien perusteissa vuosiluokkien 1-2 tavoitteet eritellään myös keskeisten sisältöalueiden osalta. Näitä ovat (a) ajattelun taidot, (b) luvut ja laskutoimitukset, (c) geometria ja mittaaminen sekä (d) tietojenkäsittely ja tilastot. Esimerkiksi tavoitealueella luvut ja laskutoimitukset kohteena ovat luonnolliset luvut, joissa oppilailta edellytetään lukumäärän, lukusanan ja numeromerkinnän välisen yhteyden hallitsemista. Lukujonotaitoja, vertailua ja lukujen järjestykseen asettamista harjoitellaan samoin kuin lukujen parillisuutta, monikertoisuutta ja puolittamista (lukualue 1-10). Yhteen- ja vähennyslaskutaitoja kehitetään ensin lukualueella 0-20 ja sitten lukualueella 0-100. Kertolaskussa opetellaan kertotaulut 1-5 ja 10. Tässä yhteydessä luodaan ymmärrystä myös jako- ja kertolaskun yhteydelle. Kertolaskuissa perehdytään myös vaihdannaisuuteen ja liitännäisyyteen. Murtolukuihin perehdytään jakamalla kokonainen yhtä suuriin osiin.

Geometriaan ja mittaamiseen kohdistuvan alueen sisällöissä kohteina ovat kappaleet ja tasokuviot. Oppiminen tapahtuu tunnistamalla, rakentamalla ja piirtämällä. Myös kappaleiden ja tasokuvioiden luokittelua harjoitellaan tunnistamalla ja nimeämällä niiden ominaisuuksia. Mittaamista harjoitellaan sekä käsitellään suureita pituus, massa, tilavuus ja aika niihin liittyvine mittayksikköineen (metri, senttimetri, kilogramma, gramma, litra ja desilitra). Edellisten lisäksi harjoittelun kohteina ovat myös kellonaika ja ajan yksiköt. Tietojenkäsittelyn ja tilastojen sisältöalueella kehitetään oppilaiden taitoja kerätä ja tallentaa tietoa sekä laatia ja tulkita yksinkertaisia taulukoita ja pylväsdiagrammoja.

Oppilaan oppimisen arviointiin matematiikassa vuosiluokilla 1-2 on opetussuunnitelman perusteissa liitetty tarkentavia kriteereitä toisin kuin muissa oppiaineissa. Näiden mukaan oppilaalta edellytetään edistymistä (a) lukukäsitteen ymmärtämisessä ja lukujonotaidoissa, (b) kymmenjärjestelmän ymmärtämisessä, (c) laskutaidon sujuvuudessa, (d) kappaleiden ja kuvioiden luokittelun taidoissa sekä (e) matematiikan käyttämisessä ongelmanratkaisussa. 


\section{Opetussuunnitelmien tavoitteiden ja sisältöjen vertailua}

Vuosina 2014 - 2016 toteutettu laaja-alainen opetussuunnitelmien ja varhaiskasvatuksen perusteiden uudistaminen on liittänyt varhaiskasvatuksen, esiopetuksen ja vuosiluokkien 1-2 opetuksen ja oppimisen aikaisempaa kiinteämpään yhteyteen. Perusteiden rakenteissa on havaittavissa yhteisiä rakenteita ja periaatteita, joiden tarkoituksena on tukea lapsen oppimisen ja osaamisen kehittymisen jatkuvuutta. Kussakin näissä kolmesta perusteissa korostetaan samantapaisia arvoja, laaja-alaista osaamista ja oppimisen alueita. Myös arvioinnin pääperiaatteet ovat suurelta osin yhtenevät.

Seuraavassa tehdään yhteenvetoa ja johtopäätöksiä opetuksen ja oppimisen jatkumosta kielessä ja matematiikassa edellä tehdyn erittelyn pohjalta.

Suoritettu erittely osoittaa, että kieltä lähestytään varhaiskasvatuksessa monilukutaidon, kielellisten taitojen ja valmiuksien sekä kielellisen identiteetin näkökulmista. Esiopetuksessa vahvistetaan kielellisiä taitoja ja kielellistä tietoisuutta kiinnittämällä huomiota myös kielen rakenteisiin ja muotoihin. Keskeisenä opetuksen ja oppimisen kohteena esiopetuksessa on kehittyvä luku- ja kirjoitustaito. Perusteissa ei kuitenkaan kehoteta opettamaan lapsille lukemista ja kirjoittamista. Tämä tapahtuu vasta perusopetuksen vuosiluokilla 1-2, jossa huomio kohdistetaan lukemisen ja kirjoittamisen perustaitoihin osana äidinkieltä ja kirjallisuutta. Perustaitojen ohella huomio kiinnitetään myös oppilaiden itseilmaisuun, vuorovaikutustaitoihin ja kielelliseen tietoisuuteen. Uutena haasteena on myös vieraaseen kieleen orientoituminen ja oppimisen aloittaminen.

Matemaattinen oppiaines kohdentuu varhaiskasvatuksessa matemaattiseen ajatteluun, jossa lapsia johdatetaan matemaattisen ajattelun perustaitoihin. Näitä ovat vertailu, järjestykseen asettaminen, säännönmukaisuuksien havaitseminen, lukumäärä, mittaaminen, sijainti- ja suhdekäsitteet, tilan ja tason hahmottaminen sekä aikakäsite. Esiopetuksessa painopiste matematiikassa siirtyy matemaattisiin taitoihin. Kohteina ovat jo varhaiskasvatuksessa esiintyneet matemaattisen ajattelun perustekijät, joita harjoitellaan ja tarkastellaan syvemmin (esim. lukusana liitetään numeromerkkiin, lukujonotaidot, 2- ja 3-ulotteisuus, sijainti- ja suhdekäsitteet, mittaaminen välineillä, vuorokaudenajat jne.). Siirtymä esiopetuksesta perusopetuksen vuosiluokille 1-2 on huomattava. Painopiste on nyt matemaattisen ajattelun ja taitojen sijasta matematiikassa, joka edellyttää loogista, täsmällistä ja luovaa ajattelua. Opetus on nyt systemaattista, tavoitteellista 
ja pitkäjännitteistä. Sisällöt kohdistuvat lukuihin ja laskutoimituksiin, geometriaan ja mittaamiseen, tietojenkäsittelyyn ja tilastoihin. Lukujonotaitoihin kiinnitetään lisääntyvää huomiota (esim. parillisuus, moninkertaistaminen ja puolittaminen). Yhteen- ja vähennyslaskuja harjoitellaan yltäen lukualueeseen 100, kertolaskuissa kohteina ovat kertotaulut 1-5 ja 10, huomio kiinnitetään murtolukuihin ja mittasuureissa kohteina ovat myös näihin liittyvät mittayksiköt. Tietojenkäsittelyssä ja tilastoissa sisällöllisinä kohteina ovat yksikertaiset taulukot ja pylväsdiagrammit.

Johtopäätöksenä voi todeta, että kielen ja matematiikan oppiaineksessa voi löytää perusteissa jatkumoa varhaiskasvatuksen, esiopetuksen ja perusopetuksen vuosiluokkien 1-2 välillä. Siirtymä ei kuitenkaan ole kovinkaan huomattava siirryttäessä varhaiskasvatuksesta esiopetukseen. Sen sijaan siirtymässä esiopetuksesta koulun alkuun on havaittavissa huomattavaa muutosta opetuksen ja oppimisen tavoitteissa ja sisällöissä sekä kielessä ja matematiikassa. Siirtymä koulun vuosiluokille 1-2 kielessä ja matematiikassa on vaativa sekä opettamista ja oppimista ajatellen. Tätä siirtymää voi pehmentää aikaistamalla osaa opetusta ja oppimista esiopetukseen, jonka ero varhaiskasvatuksen tavoitteisiin ja sisältöihin jää nykyisissä perusteissa vaatimattomaksi. Osan esiopetuksen perusteissa mainittuja tavoitteita ja sisältöjä voi puolestaan siirtää varhaiskasvatussuunnitelman perusteisiin. 


\section{Kohti kouluvalmiutta}

\section{Lapsen kouluvalmiuden erilaisia tulkintoja}

Lapsen siirtyminen erilaisten varhaiskasvatuspolkujen ja esiopetuksen kautta kouluun on merkittävä siirtymä, johon lapsia myös tavalla tai toisella valmennetaan. Kouluvalmius puhututtaa ja koskettaa lasta itseään, hänen vanhempiaan ja kasvatuksesta ja opetuksesta vastaavia opettajia ja viranomaisia. Kouluvalmiudesta keskusteltaessa on vahvistunut näkemys, jossa korostetaan koulun valmiutta kohdata erilaisia lapsia (Linnilä, 2006). Lapsen näkökulmasta kouluvalmius voidaan määritellä kehityksen vaiheeksi, jossa lapsi on saavuttanut kouluun siirtymisen kannalta tarkoituksenmukaisen tason keskeisissä kehittymisen ja oppimisen alueissa. Kohteena ovat olleet etenkin sosiaalinen kompetenssi, motorinen koordinaatio ja fyysinen terveys sekä kognitiiviset ja kielelliset taidot (esim. Janus \& Offord, 2000). Linnilä (2006) pelkistää lapsen kouluvalmiuden lapsen fyysiseen, sosioemotionaaliseen ja kognitiiviseen kompetenssiin. Fyysiseen alueeseen liittyvät terveys, motoriikka, aistitoiminnot ja kehonkuva. Sosioemotionaalinen kompetenssi kattaa minäkuvan/itsetunnon/identiteetin, temperamentin sekä sosiaaliset ja tunnetaidot. Kognitiivisen kompetenssin tärkeitä osatekijöitä ovat hahmotus/havaitseminen, muisti, kieli, ajattelu, metakognitio ja motivaatio. Näiden lisäksi Linnilä mainitsee itsesäätelyn, tarkkaavaisuuden ja toiminnan ohjauksen, joilla on ajateltu olevan yhteyttä esimerkiksi oppimis- ja keskittymisvaikeuksiin.

Linnilän (2006) mukaan käsitys kouluvalmiudesta on yhteydessä erilaisiin tulkintoihin, jotka voidaan karkeasti jakaa yksilökeskeisiin ja kontekstuaalisiin. Näiden yhdistelmänä kouluvalmiutta voidaan tarkastella myös dynaamisena perustuen yksilön ja kontekstin väliseen vuorovaikutukseen.

\section{Yksilökeskinen tarkastelutapa}

Kouluvalmiuteen kytkeytyvissä teoreettisissa ja tutkimuksellisissa lähestymistavoissa on erilaisia painotuksia (esim. Meisels, 1999; Linnilä, 2006). Yksilökeskeisessä kouluvalmiuden tarkastelussa on kiinnitetty huomiota erityisesti kypsymiseen eli maturaatioon. Alkuun tutkijoiden esittämät tulkinnat lapsen kouluvalmiudesta perustuivat näkemykseen siitä, että lapsen sisäinen kypsyminen määrittää koulunvalmiuden (esim. Gesell, 1930; 
Gesell \& Ilg, 1949; Ilg \& Ames, 1964; Ilg et al., 1978; Ojala, 1993; Linnilä, 2006). Tietoa hankittiin havainnoimalla tarkkaan eri-ikäisten lasten oma-aloitteista ja sosiaalista käyttäytymisestä. Havainnot johtivat päättelemään, että lapsen uudet käyttäytymismuodot ilmaantuvat ilman suoranaisia ulkoisia vaikutteita. Tämän perusteella tehtiin johtopäätös, jonka mukaan lapsen kouluvalmius syntyy lapsen sisäisen kehittymisprosessin tuloksena ilman, että ympäristö voi siihen vaikuttaa merkittävästi. Havaintoja sisäisestä lapsen iän mukaan etenevästä kehitysprosessista pidettiin siinä määrin luotettavina, että niiden perustella laadittiin ikäkausikohtaisia normeja lapsen kokonaiskehittymisestä. Jos lapsi alitti nämä normit, häntä pidettiin kypsymättömänä siirtymään kouluun ja suositeltiin, että hän odottaisi kypsymistään esimerkiksi vielä vuoden. Kypsymisteorian pohjalta ei eritelty tarkkaan kehittymistä esimerkiksi kognitiivisella, sosiaalisella ja fyysisellä alueella. Huomion kohteena oli lapsen kokonaiskehittymisen spiraalimainen eteneminen erilaisissa käyttäytymisen tilanteissa, joissa olivat mukana mm. perushoitotilanteet.

\section{Kontekstuaalinen lähestymistapa}

Kontekstuaalisessa tarkastelutavassa on erotettavissa karkeasti behavioristinen ja sosio-kulttuurinen lähestyminen (Linnilä, 2006). Behavioristisessa kouluvalmiuden tarkastelussa kohdistetaan huomiota erityisesti ympäristön merkitykseen. Johtopäätöksenä on näkemys, jonka mukaan kouluvalmius muotoutuu sen mukaisesti, millaisia virikkeitä kehitysympäristö tarjoaa ja miten lapsen käyttäytymistä säädellään. Behaviorismiin perustuen kouluvalmis voidaan määritellä lapsen käyttäytymiseen perustuvien suoritusten avulla. Suoriutumisen taustalla otaksutaan olevan sellaisia kouluvalmiuteen liittyviä taitoja kuten värien ja muotojen tietäminen, oman nimen kirjoittaminen, tuntemus aakkosista, tietämys numeroista 1-10 jne.

\section{Sosiokulttuurinen lähestymistapa}

Sosiokulttuurisessa lähestymistavassa kouluvalmiutta tarkastellaan sosiaalisen konstruktion kautta. Taustana on Vygotskyn (1978) teoreettinen lähestymistapa kehitykseen ja oppimiseen. Tässä lähestymistavassa valmiuden ei katsota olevaan niinkään lapsessa vaan ympäristöstä käsin opituista taidoissa. Valmius liittyy kulttuuriin ja sen kehittymiseen. Valmiuden 
ydinainekset kehittyvät ihmisen ja kulttuuriympäristön välisen vuorovaikutuksen kautta niistä merkityksistä käsin, joita ihmiset konstruoivat toimiessaan yhteiskunnassa ja erityisesti sen kulttuuri-instituutioissa (päiväkodit, esikoulut, koulu ja perhe). Valmiuksien kehittymisen keskeisiä välineitä ovat kieli ja ajattelu. Sosiokulttuurinen lähestymistapa uskoo vankasti lapsen kykyjen kehittämiseen. Kehittämisen avain on saattaa lapsi kehittymisen nykytasoa vaativampaan lähikehityksen alueelle lasta kyvykkäämpien oppijoiden ohjaamana ja tukemana. Näin tulee ymmärrettäväksi myös se, miksi kouluvalmiutta ei lähestytä yksilösuorituksena, kuten on tehty kypsymiskorosteisessa ja behavioristisessa lähestymistavassa (Linnilä, 2006).

\section{Dynaaminen näkemys}

Dynaamisessa lähestymistavassa kouluvalmius hahmotetaan lapsen ja ympäristön välisenä vuorovaikutuksena, joka on luonteeltaan muuttuva, dynaaminen eikä staattinen (Linnilä, 2006). Muutoksen dynamiikassa kiinnitetään huomiota sekä kehittyvään, kypsyvään että kehittyneeseen, kypsyneeseen valmiuteen. Kumpaakin näistä ohjaavat sekä lapsen yksilölliset että yhteisölliset tekijät kasvatuksen ja opetuksen välityksellä. Kasvatuksen ja opetuksen erityisenä tehtävänä on dynaamisen tulkinnan mukaan kiinnittää huomiota kehittyvään kouluvalmiuteen.

\section{Kouluvalmiuden kehittymisen seuranta ja arviointi}

Kouluvalmiutta myös arvioidaan. Tässä tehtävässä ovat mukana etenkin tutkijat, psykologit, erityisopettajat ja pedagogit päiväkodeissa, esikouluissa ja perusopetuksessa. Arviointiin ei meillä Suomessa ole yhdenmukaisia välineitä ja menettelytapoja, joka voi vaikeuttaa pitkäjännitteisen ja luotettavan kokonaiskuvan syntymistä lapsen kouluvalmiuden kehittymisestä. Arvioinnin viitekehyksenä käytetään yleensä kehityspsykologista erittelyä lapsen kehittymisen osa-alueista. Näiden määrittämisessä on teoreettista ja kulttuurista vaihtelua. Esimerkiksi Amerikassa ja Kanadassa ja Australiassa kouluvalmiuden kohteina on pidetty esimerkiksi lapsen sosiaalista kyvykkyyttä, motorista koordinaatiota ja fyysistä terveyttä, emotionaalista tasapainoa, kielellisiä ja kognitiivisia taitoja sekä tiedon tasoa (esim. Janus \& Offord, 2000; Dockett et al., 2000; Dockett \& Perry, 2002). 


\section{Kognitiiviset taidot kouluun siirryttäessä}

Piaget'n teorian viitekehyksessä lapsen kouluun siirtyminen tapahtuu esioperationaalisen kehitysjakson lopussa, kun lapsi siirtyy noin 6-7 -vuoden iässä konkreettisten operaatioiden vaiheeseen. Tällöin lapsen kyvyt sisäiseen abstraktiin ajattelun kasvavat. Esimerkiksi matemaattisen ajattelun alueella lapsi kykenee muodostamaan numeroiden avulla sisäisen rakenteen eli skeeman yhteen laskemisen, vähentämisen, kertomisen ja jakamisen operaatioille eikä hän välttämättä tarvitse tuekseen konkreettisia esineitä tai kuvia niistä. Syvempi käsitteellinen ajattelu, jota tarvitaan esimerkiksi kehittyneessä probleemanratkaisussa, mahdollistuu kuitenkin vasta kehittyneemmässä formaalisten operaatioiden vaiheessa.

Hautamäki (1995) on porrastanut koulutulokkaiden omaamia konkreettisten operaatioiden taitoja seuraavasti (Lapsen porrastuvia ajattelun ja kehittymisen tasoja kuvataan symboleilla 1-2 ja kirjaimilla A ja B seuraavasti: 1 kuvaa sensomotorista ja esioperationaalista tasoa, 2 kuvaa konkreettisten operaatioiden tasoa, A kuvaa alempaa ja B kehittyneempää tasoa):

- 1:1 vastaavuuden ymmärtäminen (Taso IB): Kahden sarjan vertailu ja yksikön säilyvyys, luvun operaatioista hallitaan kardinaalisuus. Tällöin lapsi tajuaa, että joukon alkioiden lukumäärä ei riipu siitä, missä järjestyksessä ne luetaan.

- Ymmärtää määrän säilyvyyden ja luokittelun yhden ominaisuuden avulla (Taso 2 A). Kysymyksessä on suhteellisen vaativa suoritus, koska reaalimaailmassa esineillä on monia ominaisuuksia.

- Painon säilyvyys eriytyy aineen määrästä (Taso2A/2B). Sarjoittamisessa lapsi siirtyy yhdestä luokitteluperusta kahteen (luokittelut seuraavat toisiaan eivätkä vielä ole samanaikaisia). Numeerisuus (alkioiden lukumäärä, kardinaaliluvut) kehittyy ja lapsi alkaa ymmärtää järjestyksen (ordinaalisuus). Kardinaalisuuden ja ordinaalisuuden ymmärtäminen mahdollistavat yhteen ja vähennyslaskun sekä jakamisen osiin.

- Säilyvyyden, luokittelun, järjestyksen ja numeerisuuden skeemat vahvistuvat (Taso 2B). Kysymyksessä on kypsä konkreettisten operaatioiden vaihe, jolloin lapsi käsittelee hyvin kahden ominaisuuden suhdetta. Yksi ominaisuus voi olla esimerkiksi selkärankaiset ja toinen asuminen. Selkärankaiset voidaan luokitella ominaisuuksien puolesta esimerkiksi nisäkkäisiin ja kaloihin. Vastaavasti 
asuminen voidaan luokitella asumiseksi maalla ja asumiseksi vedessä. Vaativassa ajatteluoperaatiossa lapsi osaa päätellä, että on olemassa myös ei kuulu luokka (esim. ei-nisäkäs ja ei-kala ja ei-maalla ja ei-vedessä).

Hautamäen (1995) tulosten mukaan lapsen konkreettisten operaatioiden kehittymisessä on erotettavissa aikainen konkreettinen, keskivaiheen konkreettinen ja vakiintunut konkreettinen. Näissä saavutuksissa lapsilla voi olla kuitenkin suuriakin eroja, kuten seuraavasta tiivistyksestä voi havaita:

- Koulutulokkaat näyttävät ikäluokkana saavuttavan aikaisen ja keskivaiheen tason.

- Lähes kaikki koulutulokkaat saavuttavat jonkin konkreettisen operaation tason

- Yli 90 \% varhaisen konkreettisen tason omaavista koulutulokkaista näyttäisi hallitsevan yksi-yksi -vastaavuuden (ei vielä vaativaa sarjoittamista).

- Hieman yli puolet lapsista näyttäisi hallitsevan perusluokittelua ja määrän säilyvyyttä.

- Vaativampaa luokittelua ja sarjoittamista sekä säilyvyyttä suhteessa painoon, pituuteen ja pinta-alaan näyttäisi hallitsevan varhaisen konkreettisen tason vaiheessa olevista lapsista noin kolmannes.

- Sen sijaan tilavuuden ymmärtämiseen kykenee vain alle $10 \%$ lapsista varhaisessa konkreettisessa kehitysvaiheessa.

-Vähintään 75 \% 7-vuotaiden ikäluokasta hallitsee määrän säilyvyyden ja luokittelun yhden ominaisuuden avulla (taso A2 konkreettisissa operaatioissa)

- Sen sijaan hitain $5 \%$ saavuttaa konkreettisten operaatioiden tason vasta 5. luokalla, 2-3 \% ei saavuta tätäkään tasoa.

- Noin puolet lapsista saavuttaa yleistetyn konkreettisten operaatioiden taso (2B taso konkreettisissa operaatioissa), jolloin ajattelussa kyetään operoimaan kahden ominaisuuden avulla suhteuttaen niitä toisiinsa.

Hautamäen (1995) arvion mukaan normaali toimiminen normaalissa kasvuympäristössä mahdollistaa useimmiten konkreettisten operaatioiden 
kehittymisen. Kehittyneempi ajattelu mahdollistuu yleensä vasta formaalisten operaatioiden kaudella ja vaatii määrätietoista opetusta ja harjoittelua. Lapsi kykenee tällöin ajattelemaan vaihtoehtoja, jotka eivät välttämättä ole läsnä aistihavainnoissa. Hän kykenee myös ajattelemaan etukäteen eri tavoin ja eri yhteyksissä, muodostamaan hypoteeseja sekä ajattelemaan ja tulkitsemaan omaa ajatteluaan.

\section{Koulutulokkaiden sosio-emotionaalinen kyvykkyys}

Lapsen varhaisvuosina saavuttamaa sosio-emotionaalista kyvykkyyttä voi pitää hyvänä ennusteena aikuisiän sosio-emotionaaliseen hyvinvointiin (esim. Hartup, 1992). Käyttökelpoisena voi pitää erittelyä, jossa lapsen sosio-emotionaalista kypsyyttä tarkastellaan kolmen osatekijän avulla: yksilölliset ominaisuudet, sosiaaliset taidot ja vertaisryhmätaidot (McClellan \& Katz, 2001).

Myönteiseen yksilölliseen sosiaaliseen kyvykkyyteen liittyy sellaisia ominaisuuksia kuten positiivinen mieliala, irtaantuminen aikuisesta, halukkuus osallistua oppimisaktiviteetteihin, taito hallita vihanpurkauksia, empatiakyky, kyky ylläpitää ystävyyssuhteita yhteen tai kahteen kaveriin, huumorikyky ja kyky välttää voimakasta yksinäisyyden tunnetta. Myönteiset sosiaaliset taidot ilmenevät esimerkiksi lapsen haluna lähestyä positiivisesti toisia lapsia, kykynä eritellä toimintaansa ja sen tarkoitusperää, kykynä arvioida itseään sosiaalisena toimijana, kykynä välttää kiusaamista, rakentavana ryhmätoimintana, pettymyksen ja kiukun ilmaisussa toisia haavoittamatta, taidossa keskustella, vuoron antamisena toisille, mielenkiinnon osoittamisena toisia kohtaan, neuvotteluna ja kompromissien tekemisenä, etnisten kavereiden ja aikuisten hyväksymisenä jne. Lapsen myönteiset vertaisryhmätaidot ilmenevät esimerkiksi siinä, että toiset hyväksyvät lapsen, lapsi saa vertaisryhmässä kutsuja muilta leikkiin ja toimintaan tai että lapsi nimetään ystäväksi toisten lasten taholta.

Sosio-emotionaalinen kehittymisen alue on tärkeässä asemassa siirtymissä kodista päivähoitoon ja myöhemmin kouluun. Selvitysten mukaan (Katz \& McLellan, 2001; Childs \& McKay, 2001) yli 40 \% opettajista pitää kouluvalmiuden eräänä tärkeänä ominaisuutena lapsen kypsyyttä irtautua vanhemmista ja erityisesti äidistä. Varsinkin psykoanalyyttisesti orientoituneet kiintymyssuhdetta analysoineet tutkijat ovat pyrkineet selittämään eroreaktion psykodynamiikka (esim. Bowlby, 1973). 
Sosio-emotionaalisen kehittymiseen liittyy myös eräitä kouluvalmiuden kannalta keskeisinä pidettäviä taitoja, joita erityisesti koulutulokkaan opettajat korostavat. Näitä ovat esimerkiksi keskittymiseen liittyvät taidot kuten istuminen ja kuunteleminen, kyky tehdä aikuisen ohjeiden mukaan, taito seurata opetusta ja istua hiljaa ja keskittyä. Näiden osuutta kouluvalmiudessa korostaa myös Linnilä (2006). Riittämätöntä keskittymiskykyä on alettu yhä enenevässä määrin pitää oppimisen esteenä erityisesti kouluoppimista ajatellen. Vaarana kuitenkin on, että keskittymättömät lapset saavat helposti negatiivisen leiman opettajilta. Tämä leima voi vaikuttaa negatiivisesti aikuisen ennakko-odotuksiin ja lapsen itsetunnon kehittymiseen tavalla, jolla on taipumusta vahvistua.

\section{Koulutulokkaan motoriset taidot ja fyysinen kehitys}

Motorisen koordinaation kehittyneisyys ja fyysinen terveys luovat perustaa lapsen kokonaiskehittymiselle ja kouluvalmiudelle. Erään selvityksen mukaan (Lewitt \& Baker, 1995) valtaosa opettajista piti lapsen fyysistä terveyttä sekä hyvää nukkumista ja syömistä olennaisina kouluvalmiuteen liittyvinä tekijöinä. Laajasti niin Kanadassa ja Yhdysvalloissa kuin muuallakin hyväksytty näkemys on, että lapsen fyysinen hyvinvointi ja motorinen kehittyminen ovat avaintekijöitä hyvän kouluvalmiuden kehittymiselle.

Vaikka motoriseen kehittymiseen kuten muuhunkin kehittymiseen liittyy yksilöllisiä eroja, kouluuntulon kynnyksellä oletetaan, että suurimmalle osalla lapsista on kehittynyt seuraavan tapaisia karkeamotorisia perustaitoja (esim. Brainline, 2003; von Wend \& Voutilainen, 2006):

- Hallitsee varvaskävelyn

- Hallitsee tasapainon kävellessään puomia pitkin

- Pukeutuu ja riisuu itsenäisesti

- Seisoo yhdellä jalalla pitkähkön ajan

- Hyppää yhdellä jalalla paikallaan useita kertoja

- Hyppää kummallakin jalalla

- Hallitsee kantapäällä ja varpailla kävelyn

- Kävelee puomia pitkin

- Pystyy hyppäämään pituutta noin 2 metrin päähän

- Pystyy liikkumaan musiikin tahdissa

- Pystyy juoksemaan, hyppäämään ja taputtamaan käsiään 
- Pystyy ryömimään tunneleissa

- Ottaa kiinni palloja, potkaisee palloja ja pomputtaa palloja

- Osaa kiivetä

- Osaa uida ilman avustusta

- Osaa luistella

- Osaa kaatua hallitusti

- Osaa hypätä hyppynarulla

- Osaa pyöriä alas rinnettä

Järviluoto ja Väänänen (2008) erittelevät esikouluikäisten lasten karkeamotoriset perustaidot seuraavasti:

- Kahden käden pallon heitto - kiinniotto (esim. kiinniotto tapahtuu käsillä, silmät ja kädet seuraavat kiinniottoa, heitto kohdistuu johonkin kohteeseen, ei säikähdä palloa)

- Pallon heitto yhdellä kädellä (esim. heittokäden vastakkainen jalka edessä, painonsiirto takajalalta etujalalle, heitto kohdentuu kohteeseen, kyynärpää johtaa heittoliikettä)

- Pallon potkaiseminen kohteeseen (esim. potkaisu jollain jalkaterän osalla, potku kohdistuu jojonkin kohteeseen, raajoissa on vastaliikkeitä)

- Kuperkeikka eteenpäin (esim. selkä pyöreänä ja leuka rinnassa, pyöriminen eteen takaraivolta selälle, asento pysyy sidottuna)

- Kehon keskiviivan ylittäminen (esim. poimiminen, käsi ylittää keskilinjan, molemmat kädet käytössä)

- Yhdellä jalalla seisominen (esim. vapaa jalka ei kosketa, katse eteenpäin, asento säilyy 20 sekuntia)

- Viivakävely (esim. kantapäät koskettavat varpaita, jalkaterät pysyvät teipin päällä, kehonosat rentoutuvat)

- Juokseminen (esim. jalkaterät osoittavat eteenpäin, kädet liikkuvat koukussa vartalon vierellä eteen ja taakse, vastakkainen käsi ja jalka liikkuvat ristikkäin)

- Tasaponnistushyppy ylöspäin (esim. ponnistus yhtäaikaisesti molemmilla jaloilla, alastulossa jousto nilkoista ja polvista, kädet luontevasti liikkeessä mukana)

- Yhdellä jalalla hyppy (esim. ponnistus koko jalkapohjalla, alastulossa jousto nilkoista ja polvista, kädet luontevasti liikkeessä mukana) 
- Haara-perushyppy (esim. hyppääminen rytmikästä ja koordinoitua, raajojen liikkeet yhtäaikaisia, ponnistus on yhtäaikaista molemmilla jaloilla)

Vastaavasti suurimmalle osalle kouluun siirtyvistä on kehittynyt seuraavanlaisia hienomotorisia perustaitoja (esim. Brainline, 2003; von Wend \& Voutilainen, 2006; Järviluoto \& Väänänen, 2008):

- Solmii kengännauhat

- Kiinnittää nappeja

- Koskettaa vasemmalla kädellä oikeaa korvaansa

- Leikkaa saksilla yksinkertaisia kuvioita

- Käyttää ruokailuvälineitä

- Pitää kynää kädessään aikuismaisella kynäotteella

- Kontrolloi käden ja sormien liikkeitä

- Maalaa pensselillä

- Piirtää mallin mukaisen viivan

- Käyttää näppäimiä

- Maalaa kohteita

- Värittää tehtäviä ja kuvioita rikkomatta niiden ääriviivoja

- Sitoo yhteen

- Tekee malleja savella

Kouluuntuloiän tienoilla lapsi kykenee yleensä työskentelemään molemmilla käsillä. Käden dominanssi suhteessa oikeaan tai vasempaan on identifioitavissa ja kasvattajat voivat tätä tukea. Kynän käytössä useimpien lapsien oletetaan hallitsevan kolmisormiote. Lapsi kykenee kopioimaan toisiaan leikkaavia linjoja ja yksinkertaisia geometrisia kuvioita. Piirtämisessä ja maalaamisessa lapsi käyttää tarkkoja sormiliikkeitä. Saksien käytössä lapsi osoittaa kypsää aikuismaista tapaa.

\section{Kouluvalmiuden arviointi Suomessa}

Esiopetusiässä lapseen kohdistuu lisääntyvässä määrin huomiota kouluvalmiuden näkökulmasta. Tässä tarkoituksessa lapsen oppimista ja kehittymistä seurataan erilaisin havainnointilomakkein (esim. Huolila ym., 1999) ja lapselle tehdään opettajien, vanhempien, koulupsykologien ja joskus 
myös lääkäreiden välisenä yhteistyönä erillisiä kouluvalmiuden arviointeja. Erityisopettajien tehtävänä on selvittää yhteistyössä eri asiantuntijoiden kanssa lapsen oletettuja kehitys- ja oppimisvaikeuksia.

Kouluvalmiuden arvioinnilla on pitkä kehityshistoria. Taustana ovat olleet älykkyystutkimukset, joihin kehitettiin ensimmäisiä arviointivälineitä 1800-1900 lukujen taitteessa (esim. Stobart, 2008; Kontturi, 2011). Suomessa koululaisia tutki ensimmäisenä Mikael Soininen 1910 arvioimalla heidän psyykkistä ja fyysistä normaaliuttaan (Jauhiainen, 1993). Älykkyyden arvioinnin jälkeen ryhdyttiin kehittämään koulukypsyystestejä 1900-luvun alussa (Oinonen, 1969). Ensimmäiset koulukypsyystutkimukset tehtiin Suomessa 1940-luvulla. Kaikkiin lapsiin ulottuvia koulukypsyyden arviointeja ryhdyttiin tekemään Suomessa 1960-luvulla (esim. Kiviluoto, 1963).

Koulukypsyyden arviointi tapahtui Suomessa aluksi Stanford-Binet -testistön avulla, joka sovellettiin Suomen oloihin (Lehtovaara, 1950). Vaikka arvioinnin tärkeänä kohteena oli älykkyyden taso, huomiota koulupsykologien tutkimuksissa kiinnitettiin lapsen keskittymiskykyyn ja työskentelytaitoihin, itseluottamukseen ja asemaan toveripiirissä. 1970-luvulla arviointia tehtiin alun perin ruotsalaisella Malmqvistin koulukypsyystestillä. Lapsen kehitystä ajatellen koulukypsyys jaettiin usein älylliseen, fyysiseen, emotionaaliseen ja sosiaaliseen alueeseen (Poijärvi \& Teikari, 1968).

Erityisesti Oinosen (1969) vaikutuksesta koulukypsyysajattelua ryhdyttiin kritisoimaan ja termistöön otettiin koulukypsyyden ohella ajatus kouluvalmiudesta, johon kypsymisen ohella vaikuttaa myös ympäristö. 1980-luvulla myös lastenneuvolat ottivat osaa lapsen kouluvalmiuden arviointiin käyttöön otetun 5-vuotistarkastusten yhteydessä, joka käytäntönä on jatkunut nykypäiviiin. 5-vuotistarkastusten oheen on vuodesta 2009 lähtien otettu vielä käyttöön lapsen yleiset terveydenhoitajan ja lääkärin suorittamat terveystarkastukset, jotka suoritetaan ennen kouluikää neljän kuukauden, puolentoista vuoden ja neljän vuoden iässä.

Vaikka nykyiset näkemykset kouluvalmiuden/koulukypsyyden määrittelystä eivät ole yhteneväisiä, kouluvalmiuden määrittämisessä kohdistetaan huomio lapsen kognitiiviseen, fyysiseen ja sosio-emotionaalisen kehittymiseen, johon vaikuttavat sekä kysyminen että ympäristö (esim. Linnilä, 2006). Suhteellisen runsaasti käytössä olevassa Turun kouluvalmiuden arvioinnissa kohdistaan huomiota seuraaviin asioihin (esim. Huolila ym.,1999): 
- Omatoimisuus päivittäisissä toiminnoissa (pukeminen ja riisuminen, syöminen, siisteys, päivärytmi)

- Sosiaaliset taidot ja tunneilmaisu (suhtautumien aikuisiin, leikkitaidot ja suhtautumien toisiin lapsiin)

- Motoriikka, visuo-motoriikka ja hahmotus (esim. heittää ja ottaa kiinni palloa, kynäote, perusmuodot, palapelien kokoaminen)

- Kielelliset valmiudet (esim. kuuntelee satuja ja muistaa niitä, riimittelee, rytmittää sanoja tavujen mukaiset, kuuntelee ja tunnistaa sanojen alkuäänteitä)

- Matemaattiset valmiudet (liikutaan lukualueella 1-10)

- Työskentelytaidot ja käyttäytyminen oppimistilanteissa (esim. keskittyy toimintaan vapaassa ja ohjatussa ryhmätoiminnassa, noudattaa sääntöjä leikissä ja peleissä, kykenee itsenäiseen työskentelyyn)

Kouluun tulon lähestyessä voidaan suorittaa lapselle kouluvalmiuden arviointi. Arviointiin päädytään lapsen vanhempien suostumuksella yhteistyössä joko päiväkodin tai koulun kanssa. Keskeisessä asemassa on psykologien suorittama arviointi. Nykyisen maamme psykologit käyttävät kouluvalmiuden arvioinnissa kansainvälistä perustestistöä (Wechsler-testistön versio alle 6-vuotialle ja yli 6-vuotialle). Myös Suomessa kehitettyä lasten neuropsykologista NEPSY-testistöä käytetään. Näiden lisäksi saatetaan käyttää lukemisen vaikeuksia kartoittavia testejä (esim. nopean sarjallisen nimeämiset testi, lukukäsitetesti, ihmisen piirtämisen testi ja visuaalismotorisen integraation testiä: VIM-piirrostesti). Myös persoonallisuuden piirteitä ja tunne- elämää kartoittavia testejä voidaan käyttää (Ahtola \& Kotturi, 2011). Lausunnossaan psykologit pyrkivät muodostaan kokonaiskuvan lapsen päättelytaidoista, karkea- ja hienomotorisista taidoista, muistitoiminnoista, tarkkaavaisuudesta, ja toiminnan ohjaukseen liittyvistä taidoista sekä lapsen motivaatiosta ja asennoitumisesta koulutyöskentelyyn (Nevalainen, 2007; Kontturi, 2011).

Kouluvalmius käsitteenä ja sen arvioiminen eivät ole yksiselitteisiä. On esitetty, että kouluvalmiuden sijaan tulisi puhua mieluummin oppimisvalmiuksista tai koulun valmiudesta ottaa vastaan koulutulokkaita (esim. Linnilä, 2006). Kouluvalmiustutkimus on yleensä aikaa vievä prosessi, johon osallistuvat vanhemmat, lapsi ja asiantuntijat. Näin ei ole mikään ihme, että kouluvalmistutkimus prosessina ja sen tulokset herättävät erilaisia tulkintoja ja monenlaisia tunteita. Vanhempien kannalta esiopetus 
on tärkeä, koska vanhemmat yleensä tässä ikävaiheessa motivoituvat ja kiinnostuvat lastensa kouluvalmiudesta (Linnilä 2006).

Esiopetuksella on nykyisin valmius työstää menestyksellä yleisiä, tehostettuja ja erityisiä tukimuotoja jo ennen kouluun siirtymistä. Näin ainakin osa kouluvalmiuden ongelmista voidaan tunnistaa ja ennalta ehkäistä ajoissa. Tässä mielessä kouluvalmiustutkimusten ajoittaminen esiopetusvaiheen kevääseen voi olla liian myöhäinen ajankohta. Monessa tapauksessa ennalta ehkäisyyn pitää ryhtyä jo ennen esikouluvaihetta päivähoidon ja terveydenhuollon yhteistyönä. Myös peruskoululakia on äskettäin uudistettu erityisesti opiskelun tuen osalta (Laki peruskoululain muuttamisesta, 2011). Lakiin liittyen Psykologiliitto on lausunnossaan ilmoittanut olevansa valmis omalta osaltaan tehostamaan psykologista toimintaa varhaiskasvatuksessa.

Kouluvalmiustutkimuksen puutteina on havaittu vanhempien liian vähälle jäänyt tukeminen, tiedonkulun ongelmat ja puutteet lasten seurannassa (Kontturi, 2011). Kouluvalmiustutkimuksen tärkeimpänä antina voi pitää tietoa lapsen kehittymisen ja oppimisen vahvoista ja tuettavista alueista sekä suosituksista, joilla lapsen oppimista voidaan tukea koulussa (Kontturi, 2011). Kaikkein keskeisimpänä viime kädessä on se, miten onnistuneesti kouluvalmiustutkimuksen tuloksia ja suosituksia voidaan siirtää opetuskäytäntöön.

\section{Kouluvalmiuden pedagogista tarkastelua}

Kouluun siirtymistä ajatelleen esiopetuksella on ensisijainen pedagoginen vastuu tukea ja valmentaa lasta siirtymään kouluun. Keskinen kysymys tällöin on, millaisen valmiuden maamme esiopetus antaa kouluun siirtymiselle?

Arvioitaessa esiopetuksen toimivuutta ja vaikuttavuutta Helsingin kaupungissa opettajat painottivat arvoissaan tärkeimmiksi minäkuvaan ja tunne-elämään, altruismiin ja erilaisuuden hyväksymiseen, sosiaalistumiseen sekä eettiseen kasvatukseen liittyvä tavoitteita (Hytönen ja Krokfors, 2002). Näihin nähden huomattavasti vähemmän painotettiin erilaisten katsomusten arvostamista, oman uskonnon keskeisiä sisältöjä ja musiikkia.

Esiopetuksen keskeisenä tarkoituksen on valmentaa lapsia ja vanhempia kouluun siirtymisessä. Tämä siirtymä tuo Suomessa mukanaan muutoksia opetussuunnitelmassa, opetushenkilöstössä ja oppimisympäristössä. 
Helsingin esiopetusta tutkittaessa opettajat arvioivat sitä, miten opetussuunnitelman tavoitteet olivat toteutuneet keskimäärin ryhmätasolla esiopetuksessa ja koulun 1. luokalla (Hytönen, 2004). Tuloksena oli, että esiopetuksen opettajat arvioivat lasten saavuttaneen parhaiten fyysisen ja motorisen alueen, ympäristö- ja luontotiedon sekä esiopetuksen yleiset tavoitteet. Näihin nähden huomattavasti alempaa olivat tavoitteiden saavutukset erityisesti etiikassa ja katsomuksessa sekä taidekasvatuksessa. Kun lapset olivat siirtyneet kouluun alkuopettajat arvioivat, että lapset olivat saavuttaneet koulussa parhaiten matematiikkaan ja äidinkieleen liittyvät tavoitteet ja näin nähden heikommin erityisesti musiikkiin ja etiikkaan liittyvät tavoitteet. Tulosten perusteella esitettiin johtopäätös, jonka mukaan esiopetuksen siirtovaikutus kouluoppimiseen voisi olla voimakkainta matematiikkaan, kieleen ja oppimisen taitoihin liittyvissä tavoitteissa.

Syventävässä analyysissa Helsinki-aineistolla Lumiaro (2007) selvitti alkuopettajien arvioita esiopetuksen toimivuudesta. Tulosten mukaan lapset osoittivat koulun aloittamisvaiheessa vahvinta osaamista kiinnostuksessa lukemiseen ja kirjoittamiseen sekä terveyskasvatuksen (terveet elämäntavat) ja liikunnan (liikunnalliset perustaidot ja ilo liikunnassa) alueilla. Vastaavasti heikoimmat osaamisalueet olivat tieto- ja viestintätekniikassa sekä musiikkikasvatuksessa (musiikillisten perinteiden tunteminen). Toinen merkittävä tulos oli se, että koulun yhteydessä toteutettu esiopetus tuotti opettajien käsityksen mukaan parempaa osaamista kuin päivähoidon yhteydessä toiminut. Erot olivat tieto- ja viestintäteknisissä taidoissa sekä taito- ja taideaineissa. Sen sijaan päivähoidon yhteydessä toteutettu esiopetus oli vahvistanut opettajien havaintojen mukaan enemmän lasten sosiaalisia taitoja kuin koulun tarjoama esiopetus. Kolmas huomion arvoinen tulos oli se, että opettajat näkivät koulun aloittamisen onnistumisen kannalta keskeisimpinä lapsen myönteisen suhtautumiseen kouluun ja koulunkäyntiin sekä valmiuden toimia luokkatilanteissa.

Esiopetuksen toteutus ei kuitenkaan ole yhdenmukaista. Esiopetuksen joustavat järjestelyt maassamme antavat mahdollisuuden toteuttaa esiopetusta pedagogisesti erilaisista toimintamuodoista ja toimintakulttuureista käsin. Tutkiessaan esiopetuksen toimintakulttuuria Helsingin kaupungissa Brotherus (2004) analysoi esiopetusta päiväkodin 6-vuotiaiden esiopetusryhmässä, päiväkodin 3-6 -vuotiaiden ryhmässä, koulun esiluokassa ja koulun esi- ja alkuopetusluokassa. 
Brotheruksen tutkimuksessa kävi ilmi, että päiväkodin 6-vuotiaiden ryhmän esiopetuksessa korostui äidinkielen taitojen oppiminen. Lapset olettivat oppivansa päiväkodissa mutta erityisesti alkuopetuksessa myös matematiikkaa. Toiminnassa oli tarkasti määriteltyjä oppituokiota ja vapaata leikkipainotteista aktiviteettia sekä perushoitotilanteiden ja arjen toimintojen jaksottelua. Oppimisympäristö oli järjestetty toimintanurkkauksiin. Lapset pitivät erityisesti leikistä ja ulkoilusta. Päiväkodin 3-6 -vuotiaiden ryhmässä toteutetulle esiopetukselle oli tunnusomaista lapsikeskeisyys ja lasten yksilöllinen tukeminen, teemaoppiminen, oppituokiot ja vapaa leikkitoiminta sekä perushoitotilanteiden ja arjen toimintojen jaksottelu. Lasten mieltymykset olivat leikissä, erilaisissa tehtävissä ja ulkoilussa. Oppimisen painopiste oli äidinkielessä. Toimintaympäristössä oli runsaasti lasten keskinäistä kommunikaatiota ja vuorovaikutusta.

Koulun esiluokassa toteutetulle esiopetukselle oli tunnusomaista teematyöskentely ja yhteistoiminnallinen oppiminen. Keskinäistä vuorovaikutusta ja kommunikaatiota esiintyi niin vapaan kuin ohjatun toiminnan yhteydessä. Lapset pitivät erityisesti leikistä, ulkoilusta ja liikunnasta. Koulun esi- ja alkuopetuksen luokassa toteutetulle esiopetukselle oli tunnusomaista oppiainespainotteinen opetus ja ohjattu toiminta oppituntien aikana. Keskiössä oli äidinkieli, jossa tavoitteena oli luku- ja kirjoitustaidon oppiminen. Erotuksena muihin esiopetuksen toteutustapoihin oli välituntitoiminta. Lasten mieltymykset kohdistuivat ulkoiluun, liikuntaan ja äidinkieleen.

Edellä olevat havainnot osoittava, että esiopetuksen toteutuksen eri muodoilla on yhteisiä mutta myös erottavia piirteitä. Ratkaiseva erottava tekijä on sillä, toteutuuko esiopetus päiväkodin ja koulun toimintaympäristössä. Brotheruksen havainnot osoittavat, että päiväkodin toimintakulttuurissa esiopetus toteutuu kodinomaisessa arjen toimintojen sävyttämässä toimintaympäristössä, jossa korostetaan lapsen omatoimisuutta ja lasten keskinäistä yhdessäoloa. Koulun toimintaympäristö luo sitä vastoin esiopetukselle tilaisuuksia opiskella koululaisen roolia ja oppimaan oppimisen taitoja oppiaineskeskeisessä opetuskulttuurissa. Ero kouluoppimiseen on vähäinen.

Esiopetuksen ja perusopetuksen väliset erot ilmenevät myös opettajien pedagogisessa ajattelussa. Hartingin (2003) havaintojen mukaan esiopettajien pedagogisessa ajattelussa korostuivat vuorovaikutuksen ja lapsilähtöisyyden merkitys, kun vastaavasti alkuopettajille oli ominaista 
opettajakeskeisyys. Esiopettajat pohtivat myös monipuolisemmin ja syvällisemmin lapsen kehitystä alkuopettajiin nähden. Motivaation merkitystä esiopettajat pohtivat suhteessa leikkiin ja oppimiseen, kun vastaavasti alkuopettajien ajattelussa motivaation merkitys kohdistui oppimiseen. Eroa oli myös metakognitiivisille taidoille ja lasten itseohjautuvuudelle annetuissa merkityksissä. Näiden pohtiminen oli tyypillistä esiopettajien keskuudessa. Alkuopettajat hyväksyivät periaatteessa lapsen itseohjautuvuuden, mutta heidän ajattelussaan lapset olivat koulun alussa vielä kehittymättömiä tässä taidossa. Erot suhtautumisessa lapsen itseohjautuvuuteen voi ymmärtää erilaisen pedagogisen kulttuurin kautta. Esiopetuksessa korostetaan sitä, että lapset voivat asettaa itse oppimiselleen tavoitteita. Alkuopetuksessa itseohjautuvuuden pohdinnan taustalla on opettajien asettamat oppimistavoitteet.

Tutkiessaan vanhempien näkemyksiä lapsen siirtymisestä esiopetuksesta perusopetukseen Karikoski (2008) havaitsi, että vanhemmat tiedostivat lapsen kasvuympäristön muuttuvan kouluun siirtymisessä lapsikeskeisestä leikkipainotteista oppimisympäristöstä opettajajohtoiseksi tavoitteelliseksi oppimis- ja opetusympäristöksi. Ennen koulua vallinnut sosiaalinen kasvatusympäristö muuttui koulussa vanhempien mielestä kohti yksin työskentelyn ympäristöä, jota sävytti kansalaiskasvatuksen toimintakulttuuri.

Karikosken (2008) tutkimuksessa verrattiin myös erilaisia esikouluympäristöjä. Kohteina olivat esiopetus kunnallisessa päiväkodissa ja esi- ja alkuopetuksen yhteistoimintayksikössä sekä Montessoripainotteinen päiväkoti ja esi- ja alkuopetuksen yhdysluokka. Tuloksissa kiinnitettiin huomiota siihen, miten lapset kasvoivat ja löysivät kouluun aloittajan rollin. Päätulos oli, että vanhemmat arvioivat roolinmuutokset vähäisemmiksi lapsilla, joita olivat saaneet esiopetuksen esi- ja alkuopetuksen yhdysluokilla. Tulos viittaa siihen, että näin toteutettu esiopetus on mahdollistanut koululaisen rollin kasvamisen jo esiopetusvuotena. Suurinta roolinmuutosta vanhemmat havaitsivat päiväkodin toimintaympäristössä esiopetuksen saaneilla lapsilla mukaan lukien Montessoripäiväkoti. Erilaisista kouluun siirtymisen vaiheista huolimatta havaittiin kuitenkin, että lapset sopeutuivat vanhempien mukaan kouluympäristöön ja sen toimintakulttuuriin ensimmäisen kouluvuoden päättyessä. Selityksenä nähtiin olevan koulun vahva sopeuttava ja yhdenmukaistava toimintakulttuuri.

Sillä, millaista pedagogiikka lapsi kohtaa esiopetuksessa ja koulun alussa, on ratkaiseva merkitys koulun valmiudella kohdata erilaisia lapsia. Rausku-Puttonen ja Lerkkanen (2010) ovat hahmotelleet keskeisiä tekijöitä, 
jota ovat yhteydessä lapsen oppimiseen ja motivaatioon esiopetuksessa ja koulussa. Tutkijat korostivat kolmea keskeistä tekijää, jotka ovat rakenne ja prosessi sekä lapsen akateeminen oppiminen ja sosiaalinen kehitys. Rakennetekijöihin voidaan sisällyttää opetussuunnitelmat, standardit, materiaali ja opettajankoulutus. Keskeinen haaste prosessissa pelkistyy kysymykseen siitä, miten lapsen tunnetuki, ohjauksellinen tuki ja toiminta järjestetään esiopetuksessa ja koulun alussa. Seuraavassa muutama esimerkki tutkimustuloksista (Alkuportaat-tutkimus) koskien eri tekijöiden vaikutuksia lasten oppimiseen ja motivaatioon (Rausku-Puttonen \& Lerkkanen, 2010):

Rakennetekijöissä pienempi luokka ja kouluavustajien suurempi määrä auttoivat lukutaidon kehittymisessä 1. luokan aikana. Tämän lisäksi opettajien vähäisempi stressikokemus ja suurempi kouluavustajien määrä auttoivat matematiikan taitojen kehittymisessä 1-luokan aikana. Kun tarkasteltiin prosessitekijöitä, opettajan antama tunnetuki, oppimisen tukeminen ja ryhmän organisointi edistivät vuorovaikutuksen laatua. Lapsi-/oppilaslähtöinen ohjaus edistivät akateemisten taitojen kehittymistä, sopeutumista ja sitoutumista kouluun, sosiaalisia taitoja ja motivaatiota. Näiden lisäksi havaittiin, että opettajajohtoiset ohjauskäytännöt edistivät perustaitojen ja -valmiuksien (esim. kirjaintuntemus, lukutaito, matemaattiset taidot) oppimista erityisesti oppimisvaikeuksia omaavilla lapsilla. Keskeisenä siirtymävaiheen pedagogiikan kannalta pidettiin huomion kiinnittämistä esiopetuksesta alkaen lapsiin, joilla oli heikot oppimisen ja kehittymisen valmiudet, sukuriski ja heikko motivaatio. Lapsen valmiuksien ja taitojen vahvistamisen ohella korostettiin myös motivaatiotekijöiden merkitystä.

\section{Pohdintaa kouluun siirtymisestä ja kouluvalmiudesta}

Kouluun siirtymistä voidaan pitää merkittävä varhaislapsuuden tapahtumana, jota on pitkään tarkastelu aikuisten antamien merkitysten kautta. Tämän tarkastelun keskiössä on ollut lapsen kypsyminen (Linnilä, 2006, 255-256). Yhtäältä kouluun siirtymisen yhteydessä toivotaan kehityksellistä muutosta, jossa lapsuus muuttuu aikuismaisemmaksi ajatteluksi ja toiminnaksi, jolle on ominaista esimerkiksi päämäärätietoisuus ja vastuuntunto omasta oppimisesta ja käyttäytymisestä. Tällöin on vaarana, että unohdetaan lapsen luontaisen kypsymisen dynamiikka, joka ei etene kaikilla lapsilla nopeasti, samanlaisena tai noudata etukäteen säädettyä 
koulunalkamisikää. Toisaalta koulukypsymisen idea voi ohjata ajattelutapaan, jossa lapsen oletetaan kypsyvän pois monista aikaisemman kehityskauden oppimisvaikeuksistaan. Karttuva tieto oppimisvaikeuksista ja niiden minimoimisesta osoittaa kuitenkin, että lapsen oppimisvaikeuksiin tulee puuttua mahdollisimman varhain ja että toiminnan tulee olla hyvin suunnittelua ja pitkäjännitteistä.

Myös yksilöllisyyden korostaminen on problemaattista (Linnilä 2006, 256-257). Yhtäältä yksilöllisyyttä ylikorostetaan. Jo pitkään on vallinnut käsitys, jonka mukaan kouluvalmius on lapsen yksilöllinen ominaisuus. Yksilöllisyyttä on vahvistanut edelleen modernina pitämämme konstruktiivinen oppimiskäsitys, jonka mukaan jokainen lapsi hahmottaa, prosessoi ja etenee oppimisessa yksilöllisesti. Oletetaan, että lapset ovat aktiivisia oman tietoisuutensa rakentajia, pieniä tiedemiehiä tai naisia, jotka kyseenalaistavat asioita ja ovat uteliaita hankkimaan tietoa kiinnostuksensa mukaisista kohteista. Korostunut yksilökeskeisyys on omiaan herättämään myös kritiikkiä ja seuraavan tapaisia vastakysymyksiä:

- Luotetaanko oppimisessa liikaa lapsen omaan aktiivisuutteen ja jatkuvaan uteliaisuuteen saada uutta tietoa?

- Kaikki lapset eivät osoita innokkuutta oma-aloitteiseen oppimiseen eivätkä kykene ottamaan vastuuta omasta oppimisestaan.

- Muodostuuko opettajan rooli passiiviseksi?

- Kanavoituuko lapsen oppiminen yksipuolisiin kohteisiin ja kysymyksiin?

- Oppivatko lapset monipuolisia oppimisen taitoja: pitkäjännitteisyys, perustiedot, taitojen harjoittelu jne.?

- Millainen on lasten oppimisen sosiaalinen ulottuvuus?

Pedagogista kritiikkiä yksilökeskeisyyteen ovat esittäneet etenkin postmodernin koulukunnan edustajat (esim. Beck, 1992; Dahlberg et al., 1999). Heidän esiintuomansa kriittinen lähestymistapa tarkastelee opetusta ja oppimista demokratian ja tasa-arvon näkökulmasta, jota voidaan nimittää emansipatoriseksi. Lähestymistapa suhtautuu kriittisesti idealistisiin ja kehityspsykologisiin oppirakennelmiin, koska ne ovat historiattomia ja eivät ota huomioon yhteiskunnan valtarakenteita ylläpitäviä ns. piilo-opetussuunnitelmallisia tekijöitä. Erityisen kritiikin kohteeksi on otettu jälkiteollisen yhteiskunnan koulutusideologia, jossa tiedon tuottaminen ylittää 
sen hyödyntämisen ja jossa kaikkien pitäisi olla jo pienestä pitäen aktiivisia itseohjautuvia oppijoita. Kriittisen tarkastelutavan mukaan tällainen oppimisideologia johtaa noidankehään: Jos usko oppimisen autonomiaan, siihen että ei tarvitse ketään tai selviytyy itse kaikesta oppimisesta ei toimikaan, seurauksena on voimavarojen loppuminen, luottamuksen väheneminen oppimiseen ja luovuttaminen. Ja kun oppija luovuttaa, hän syrjäytyy ja usein vielä pysyvästi.

Toisaalta pedagoginen käytäntö voi toteutua ilman, että yksilöllisyyden haastetta ei oteta huomioon riittävästi (Linnilä, 2006). Näin voi käydä silloin, kun pedagogista toiminta toteutetaan samanlaisin periaattein ja haastein kaikille lapsille yhteisenä oppimistarjontana. Pedagogisen ajattelun taustalla on tunnistettavissa tällöin eräänlainen ihannekuva, mielikuva tai normi koulukypsistä lapsista, joille pyritään kehittämään esiopetusvuotena yhteisiä kouluvalmiuksia varmistamaan koulunkäynnin ongelmaton aloittaminen.

Kouluvalmiskysymyksessä on jäänyt taka-alalle lapsen äänen kuuleminen. Jos pysähdymme miettimään, ketkä määrittelevät ja millä tavoin lapsen kouluvalmiuden, emme juurin erehdy, jos toteamme, että määrittäjätahona ovat lähes yksinomaan aikuiset (opettajat, vanhemmat, koulupsykologit jne.). Kuitenkin Linnilän (2006, 257-258) tutkimusaineistosta pelkistyi tärkeä johtopäätös, joka mukaan lasten antama merkitys koulunaloitukselle on erilainen kuin aikuisten. Lapsella on taipumus hahmottaa koulunkäynnin alku nykyisyyden eikä tulevaisuuden maailmana. Keskeistä merkitystä lapsen ajattelussa ei ole valmiuksilla eikä oppimisessa pärjäämisessä. Tämä kuulu aikuisten koulunkäynnille antamaan merkitykseen. Näyttää siltä, että lapsi hahmottaa yleensä kouluun siirtymisen luonnollisena tapahtumana, kun esiopetusvaihe päättyy. Kouluun siirtymisen merkitys näyttää lapselle olevan mieluimmin yhteisöllinen kuin yksilöllinen. Ystävien ja kavereiden merkitys on keskeinen. Lapsi toivoo koulun mahdollistavan etenkin toiminnallisuutta, liikuntaa ja leikkiä.

Linnilän havainnot lasten tulkinnasta saavat tukea ruotsalaisen Pramlingin suorittamista lapsihaastatteluista (esim. Pramling et al., 1995). Keskeinen koulua ja esikoulua erottava tekijä Ruotsissa tehtyjen havaintojen mukaan oli leikki, joka koulussa rajoittuu lähes yksinomaan ulkoleikkeihin. Lapsilla oli ruotsalaisessa tutkimuksessa tärkeä viesti, joka on tarpeen ottaa huomioon esiopetuspedagogiikassa myös meillä. Lapset nimittäin kokivat, että heillä ei ollut esiopetuksessa tarpeeksi vaativia tehtäviä ja vaadittu 
oppiminen oli yksinkertaista esimerkiksi työmäärän ja vaatimustason suhteen. Lapset näkivät kouluun siirtymisen voittopuolisesti myönteisenä ja jännittävänä tapahtumana. Kannustimena oli, että koulussa oppii uusia asioista. Epäilyt ja pelot olivat lähinnä sosiaalisia, koska lapset eivät voineet tietää ja tuntea tulevia opettajiaan ja oppilaitaan koulussa. Emotionaalista pelkoa herätti ajatus ja tunne epäonnistumisesta. 


\section{Kasvatuksen ja opetuksen laatu}

Laadullisesti hyvän kasvatuksen ja opetuksen järjestämistä on tullut keskeinen kehitystehtävä varhaiskasvatuksessa, esiopetuksessa ja koulussa. Laatua arvioidaan ja kehitetään eri tasoilla. Toimintaan osallistuvat koulutuksen ja kasvatuksen järjestäjät, opetuksen ja kasvatuksen toteuttajat sekä tutkijat. Erityisen tärkeänä laadun ylläpitäminen ja kehittäminen koetaan ennen kouluikää ja koulun alussa, koska lapset hyötyvät tässä iässä eniten laadullisesta hyvästä kasvatuksesta ja opetuksesta (esim. Sylva et al., 2010). Laatua on tarkoituksenmukaista analysoida eri ulottuvuuksista käsin hyödyntämällä alan tutkimusta ja kehittämisnäkemyksiä.

\section{Mitä laatu on?}

Laatu on ominaisuus, jolla arvioidaan erinomaisuuden astetta. Tähän tarvitaan kriteeriä, jolla määritetään tai todetaan laadun aste. Laadun arviointi voi olla subjektiivista tai objektiivista. Objektiivinen laadun määrittely pyrkii havaintoihin, jotka ovat mahdollisimman virheettömiä ja vertailukelpoisia. Tähän pääsemiksi laatua arvioidaan empiirisin mittavälinein. Subjektiivinen arviointi perustuu johonkin, jota pidetään hyvänä ja käyttökelpoisena. Arvio perustuu ymmärtämiseen. Laatu arvioidaan korkeaksi, jos havainnot ylittävät odotukset. Vastaavasti laatu arvioidaan matalaksi, jos havainnot alittavat odotukset. Tyydyttävässä laadussa havainnot ja odotukset suhteutuvat toinen toisiinsa jokseenkin hyvin.

Laadun valvontaa on tehty erityisesti teollisissa tuotteissa. Tätä silmällä pitäen on kehitetty standardeja, joiden avulla voidaan tunnistaa puutteelliset tuotteet, vähentää vaihtelua ja saada aikaan kriteerit täyttäviä samankaltaisia tuotteita, jotka tyydyttävät asiakkaita, tuotteiden käyttäjiä ja niiden kehittäjiä sekä heidän tarpeitaan. Teollisuudessa laadun tarkkailu ja arviointi ovat levinneet yhteiskunnan eri sektoreille ja tätä kautta myös kasvatukseen ja opetukseen. Esimerkiksi opetus- ja kulttuuriministeriön koulutuksen ja tutkimuksen kehittämissuunnitelmassa vuosille 2011-2016 korostetiin laadukkaiden sivistyspalvelujen merkitystä, perusopetuksen kehittämisessä tasalaatuista saatavuutta sekä koulutuksen arvioinnissa ja saatavuudessa määrällistä ja laadullista ennakointia. Kasvatuksen kehit-tämisessä määrän ohella laadulla on yhtä keskeisempi merkitys. Laatua tutkitaan ja arvioidaan, jotta kasvatuspalvelut olisivat mahdollisimman 
laadukkaita ja näin tyydyttävät asiakkaiden, palvelujen tuottajien ja valtiovallan toiveita.

Kasvatuksessa ja opetuksessa on korostettu, että laadun määrittely perustuu viime kädessä siihen, millaiseksi laatu halutaan käsittää (esim. Moss 1994; Penn, 1994; Dahlberg et al., 1999). Käsitykset voidaan pelkistää kahteen erilaiseen lähestymistapaan, jotka voivat myös taitavasti käytettynä täydentää toisiaan. Näistä toinen on analyyttinen. Tällöin laatu pyritään määrittämään mahdollisimman objektiivisesti yleisiin kriteereihin tai indikaattoreihin. Arviointivälineinä pyritään käyttämään yhteismitallisuuteen perustuvia kriteeripohjaisia mittavälineitä, joilla on usein kansainvälinen perusta (esim. Harmsin ja Cliffordin kehittämä Early childhood environmental rating scale (ECERS), 1980; High/Scope Program Quality Assessment - Preschool version, 1998; LIS-YC, 1994). Toista lähestymistapaa voidaan nimittää dynaamiseksi. Tällöin laatua lähestytään subjektiivisesti ja mahdollisimman kokonaisvaltaisesti suhteessa moniin eri tekijöihin, vallitsevaan kasvatuskulttuuriin ja sen puitteisiin liittyvänä, arvosidonnaisena ja erilaisia intressejä sisältävänä (esim. lapset, vanhemmat, opettajat, hallintovirkamiehet/tarkastajat, esimiehet jne.).

Tässä julkaisussa tarkastellaan kasvatuksen, opetuksen ja oppimisen laatua kansainvälisten ja kotimaisten tutkimuksen ja raporttien avulla. Kohteina ovat varhaiskasvatus, esiopetus ja koulu.

\section{OECD:n arvioita Suomen varhaiskasvatusjärjestelmästä}

Suomen varhaiskasvatusjärjestelmää on OECD-järjestön taholta analysoitu yksityiskohtaisemmin vertaamilla sitä muihin maihin, joista vertailuun on valittu Ranska ja Irlanti (Bennett, 2006). Tavoitteena on ollut pelkistää kansallisen varhaiskasvatusjärjestelmän keskeisiä laatuun liittyviä ulottuvuuksia. OECD:n vertailun perusteella suomalaisen varhaiskasvatusjärjestelmän vahvuuksina korostuvat seuraavat (Bennet, 2006):

- Aikuisten lukumäärän suhde lapsiryhmän kokoon on suotuisa.

- Opettajat hyvin koulutettuja, koulutus (lastentarhanopettajat) on pätevää ja pieniä lapsia painottavaa.

- Pedagoginen lähestymistapa lapsiin on kokonaisvaltaista. 
- Opetussuunnitelma on kokonaisvaltainen ja tunnustaa lapsen aktiivisen roolin sekä oppijana että sosiaalisena toimijana.

- Päiväkodit, esikoulut ja koulut ovat itsenäisiä.

- Lapset hyväksytään arvokkaina yksilöinä, joilla on erilaisia tarpeita ja lahjakkuuksia.

- Vanhemmat huomioidaan kumppaneina.

- Oppiminen tapahtuu erilaisissa ympäristöissä.

- Tukipalvelut ovat hyvin käytössä.

- Verkostumista ja alueellista koordinaatiota korostetaan.

- Laatua varmistetaan osallistuvalla arvioinnilla ja tutkimuksella.

- Koulutus on taloudellista verrattuna moniin muihin maihin.

- Koulutuksen tasa-arvo on keskeinen koulutuspoliittinen arvo, jolla halutaan pitää yllä ja lisätä yhteen kuuluvuutta. Tämä heijastuu lapsiköyhyysasteeseen, joka on Suomessa alhainen (2,8 \%) verrattuna useimpiin muihin maihin (Ranska=7.5 \%, Irlanti $=15$ $\%$ ).

- Saavutukset koulussa ovat olleet korkeita esimerkiksi PISA -tutkimuksissa.

- Äitiysloma 5 kk, vanhempainloma 6 kk, hoitovapaa 36 kk; palkallinen. Muissa maissa yleensä palkallinen on vain äitiysloma.

OECD:n vertailun perustella on tuotu esiin Suomen varhaiskasvatukseen liittyvän järjestelmän mahdollisia rajoituksia, joiden suhteen toivotaan kehittämistoimenpiteitä (Bennett, 2006):

- Miten arvioidaan maata kattavalla ja systemaattisella tavalla lapsen keskeiset suoritteet kehittymisessä ja oppimisessa?

- Päiväkotien toteuttamalla varhaiskasvatuksella on suhteessa moniin muihin EU- maihin alhainen kattavuus 3-5 -vuotiaiden keskuudessa.

- Miten voidaan sovittaa paremmin yhteen yhtäältä työelämän ja kasvatuksen ja toisaalta opetuksen ja hoidon tarpeet? Suomessa naisia, joilla on pieniä lapsia osa-aikatyössä on vain $15 \%$ kun esimerkiksi Ranskassa vastaava luku on noin $24 \%$ ja Irlannissa noin $35 \%$.

OECD:n vertailevan aineiston perustella suomalaiselle varhaiskasvatukselle ja esiopetukselle on tunnusomaista käsitykset, joita esiintyy pohjoismaissa. Näitä ovat 
- Demokraattiset arvot, inkluusio, laajat perusteet, opetuksen paikallinen kehittäminen.

- Laajat kehitystavoitteet, lapsi toimii yhdessä opettajan ja toisten oppijoiden kanssa, vertaisryhmän vuorovaikutus.

- Tavoitteet ovat yleisiä, leikkiä, musiikkia, taiteita, oppimisprojekteja sekä vuorovaikutusta vertaisryhmään ja luontoon korostetaan.

- Lapsen yksilölliset tavoitteet määritellään lapsesta eikä kehitysnormeista käsin.

- Oppiminen liittyy kulttuurisesti arvostettuihin aiheisiin ja teemoihin, joihin lapsella on kiinnostus.

- Korostetaan kehittyvää yksilöllistä kieltä ja suullista ilmaisua. Lukemiseen ja kirjoittamiseen liittyy paljon leikkiä.

Suomen ja pohjoismaisen varhaiskasvatuksen hahmottaminen poikkeaa useissa maissa omaksutusta esikoulumaisesta lähestymistavasta (Bennett, 2006). Esimerkiksi Ranskan ja Irlannin varhaiskasvatuspedagogiikalle on tunnusomaista seuraavan tapaiset periaatteet:

- Opetussuunnitelmaa pyritään kehittämään keskitetysti autonomiaa ja kilpailua korostaen. Myös oppimisessa kilpaillaan paremmuudesta.

- Painotetaan oppimisstandardeja, luokkamaista ympäristöä, opetusta, opettajien roolia ja lasten valmentamista kouluun.

- Tavoitteet sekä odotetut tulokset ja kompetenssit määritetään mahdollisimman tarkkaan etukäteen.

- Arviointia ja testausta korostetaan, vaikka lapsi ei yleensä osaa lukea.

- Opetus tapahtuu oppiaineittain.

- Painotetaan kansallista kielen suullista ja ääntämyksellistä osaamista sekä luku- ja kirjoitustaidon kehittymistä.

Vuonna 2012 OECD-verkosto teki laajan varhaiskasvatuksen laatua koskevan arvion, jossa myös Suomi oli mukana (Taguma et al., 2012). Laadun rakenteissa pidettiin Suomessa myönteisenä henkilöstömitoitusta suhteessa lasten määrään ikävuosina 1-6. Varhaiskasvatukseen osallistumisastetta sen sijaan pidettiin alhaisena. Kasvatuksesta ja opetuksesta vastaavan henkilöstön koulutustasoa Suomessa pidetiin yleisesti ottaen laadullisesti korkeana. Samaan tasoon yltävät myös esimerkiksi Ruotsi ja Uusi-Seelanti. Raportissa kuitenkin tuodaan esiin, että henkilöstössä on monenlaisen 
koulutuksen saaneita ja varhaiskasvatuksen ja perusopetuksen opettajien koulutuksen tasossa on eroja. Esimerkiksi Ruotsissa ja Uudessa-Seelannissa on ryhdytty uudistamaan henkilöstön koulutusta ja sen laatuvaatimuksia. Uudessa-Seelannissa kiinnitetään lisääntyvää huomiota uusiin laatuvaatimuksiin henkilöstön koulutuksessa. Ruotsissa kehitetään uudentyypistä ja yhtenäisempää koulutusta laadun parantamiseksi. Kasvatushenkilöstön täydennyskoulutuksen järjestäminen saa arvioinnissa kiitosta. Laadun kehittämisessä OECD-verkosto kehottaa jäsenmaitaan kiinnittämään huomiota henkilöstön pätevyyden parantamiseen, pätevän työvoiman saatavuuteen ja johtajuuden kehittämiseen.

\section{Pitkän aikavälin analyysit lapsen oppimisesta ja kehittymisestä varhaisvuosina}

\section{Varhaiskasvatuksen laatu ja lasten kehittyminen Ruotsissa}

Ruotsissa on suoritettu merkittävä pitkän aikavälin tutkimus varhaiskasvatuksen vaikutuksista myöhempään kehittymiseen. Tutkimus perustui vuonna 1968 aloitettuun seurantatutkimukseen, jossa oli mukana 119 lasta, joilla oli erilainen päivähoitokokemus (Andersson, 1986; Andersson, 1992; Andersson \& Strander, 2004). Osa lapsista oli ollut yksivuotiaasta lähtien pitkään päiväkodeissa aina koulunkäyntiin asti. Toisen ryhmän muodostivat päiväkodeissa vähemmän aikaa olleet lapset. Kolmannen ryhmän muodostivat lapset, jotka olivat olleet ensiksi perhepäivähoidossa mutta siirtyneet tämän jälkeen päiväkoteihin. Neljänteen ryhmään kuuluneet lapset olivat olleet pääsääntöisesti perhepäivähoidossa, mutta tämän lisäksi myös 12 vuotta osa-aikaisessa päiväkodissa. Viidennen ryhmän lapset olivat olleet pääsääntöisesti kotihoidossa, mutta myös osa-aikaisessa päiväkodissa.

Kun tutkijat arvioivat lasten tiedollisia ja sosiaalisia valmiuksia 8-vuoden iässä he pystyvät osoittamaan, että päiväkodeissa 1-2 -vuotiaasta alkaen olleet lapset omasivat parhaimmat mitatut valmiudet sekä kognitiivisessa että sosiaalisessa kehittymisessä. Suurimmat erot olivat kotona hoidettujen ja pitkään päiväkodeissa olleiden lasten välillä. Kun lapsia oli seurattu 25 vuotta, tulokset osoittivat, että päiväkodeissa varhain (1-2 -vuotiaat) ja pitkään (koulunkäyntiin asti) hoidetut lapset olivat menestyneet myöhemmässä elämässään parhaiten, kun kriteereinä olivat hankittu koulutus, tyytyväisyys työhön ja myönteinen suhtautuminen elämään. 
Seurantatutkimuksensa tulosten perusteella tutkijat pohtivat päivähoidon laatua. Laadun indikaattoreiksi nostettiin esiin päivähoitohenkilöstön korkea koulutustaso, joka on yliopistotasoinen suurella osalla henkilöstöä. Korkeatasoisen pedagogisen koulutuksen kautta päiväkoteihin muodostuu suunnitelmallinen pedagoginen kasvatus- ja opetuskulttuuri, joka voi alkaa jo 1-vuoden iässä. Koulutuksen lisäksi tutkijat päättelivät, että varhaiskasvatuksen laatutekijät henkilöstön pätevyysvaatimuksissa, ryhmäkoossa ja henkilökunnan määrästä suhteessa lasten määrään selittävät varhaiskasvatuksen myönteiset pitkän tähtäimen saavutukset.

\section{Varhaiskasvatuksen pitkäaikaisvaikutukset High/Scope -tutkimuksessa}

Pitkäjännitteinen laatua arvioiva pitkittäistutkimus on tehty USA:ssa (Weikart, 1996; Schweinhart \& Weikart, 1981; Schweinhart et al., 1985; Schweinhart \& Weikart, 1988; Schweinhart et al.,1993; Barnett, 1996; Schweinhart et al., 2005; Schweinhart et al., 2010). Tutkimuksessa seurattiin kahta umpimähkään valittua lapsiryhmää $(\mathrm{n}=123)$, joista toinen ikävuosina 3-5 sai korkeatasoista varhaiskasvatusta. Toisen ryhmän lapset (kontrolliryhmä) olivat kotihoidossa. Lapset olivat asuinalueella Michiganissa, joka oli riskialtis lapsen kehittymiselle. Lapsia on seurattu systemaattisesti vuodesta 1962 alkaen 40-vuoden ikään (Schweinhart et al., 2005). Verrattuna kontrolliryhmään lasten kognitiiviset saavutukset olivat paremmat esiopetuksen päättövaiheessa, lapset menestyivät paremmin koulun oppiaineissa (10-vuotiaat), nuorten oppimistulokset ja sosiaalinen käyttäytyminen koulun ulkopuolella oli parempi (15-vuotiaat) sekä koulusaavutukset, työelämään kiinnittyminen ja vastuuntuntoinen antisosiaalinen käyttäytyminen parempaa (19-vuoden ikä).

Koulutusjärjestelmän aikaisen seurannan päättymisen jälkeen seurantaa jatkettiin ensin ikävuoteen 27 . Verrattuna kontrolliryhmään esiopetukseen osallistuneiden lasten rikosrekisteri on huomattavasti pienempi, sosio-ekonominen status korkeampi, menestyminen koulutuksessa parempi ja kiinnittyminen perhe-elämään ehyempää. Kun seurantaa jatkettiin vielä 40-vuoden ikään, aikuisten elämän laatu arvioitiin myönteisemmäksi (Schweinhart et al., 2005). Tätä osoittivat esimerkiksi korkeammat ansiotulot, pysyvämmät työpaikat, alhaisempi alttius rikollisuuteen sekä korkeampi koulutushalukkuus ja sen avulla hankittu koulutustaso. Seurannassa 
havaittiin, että esiopetusta saaneiden lasten kehittyminen ja oppiminen sekä myöhempi aikuiselämän laatu näyttäytyivät systemaattisesti paremmalta verrattuna kodissa hoidettuihin lapsiin. Seurannan indikaattorit kohdennettiin kasvatukseen, rikolliseen käyttäytymiseen, taloudelliseen hyvinvointiin, perhe- elämään ja terveyteen. Esiopetusta 3-5 -vuotiaina saaneiden lasten kognitiiviset suoritukset tehostuivat vuosina 5-7, koulusaavutukset paranivat ikävuoteen 14 asti ja lukuaineiden oppiminen tehostui lukiossa (päättövaihe 19-vuotiaana). Seurannan päättövaiheessa havaittiin, että esiopetusta saaneiden tulotaso oli korkeampi ja rikollisuus alhaisempi kuin kotona hoidettujen.

Pitkä seuranta on antanut tietoa siitä, millaiset esiopetukseen ja sen toteuttamiseen liittyvät tekijät voisivat selittää lasten myönteistä kehittymistä pitkälle aikuisikään. Tutkijoiden mukaan systemaattiset erot esiopetusta saaneiden ja kotona hoidettujen lasten välillä selittyvät monelta osin varhaiskasvatuksen laatutekijöillä. Näitä olivat:

- Kehittyminen ja oppiminen hahmotetaan kokonaisvaltaisena, kaikki oppimisen alueet tulee nähdä yhtä tärkeinä.

- Korostetaan lapsen aloitteellisuutta, sosiaalisten suhteiden vastuuntuntoa sekä ajattelun ja päättelyn taitoja.

- Kehitetään lasten kielellisiä taitoja.

- Ohjataan lasten taitoja kuunnella, seurata ohjeita, kokonaismotorisia taitoja ja fyysisen energian kanavointia (esim. musiikkiliikunnan avulla).

- Opettajien tehostettu täydennyskoulutus ja työnohjaus ovat laadun ylläpitämisessä keskeistä.

- Lapsen kehittymisen ja oppimisen systemaattinen, yksityiskohtainen ja jatkuva arviointi luo perustan lapsen kehittymisen ja oppimisen ymmärtämiseen ja tukemiseen.

- Tehostetut kotikäynnit ja vanhempien neuvonta ja tuki auttavat monella tavoin lapsen oppimisen ja kehittymisen laadun ylläpidossa ja parantamisessa. 


\section{USA:n kansallisen tutkimuslaitoksen arviot varhaiskasvatuksen pitkäaikaisvaikutuksista}

Varhaiskasvatuksen pitkäaikaisvaikutuksia on USA:ssa tutkinut jo 1970-luvun alusta lähtien kansallinen tutkimuslaitos (NICHD), joka seuraa ja arvioi varhaiskasvatuksen ja hoidon laatua (esim. NICHD Early Child Care Research Network, 2002; NICHD Early Child Care Research Network, 2005; Belsky et al., 2007; Vandell, 2010). Vuonna 2010 raportoidussa seurantatutkimuksessa analysoitiin kodin ulkopuolisessa hoidossa ja kasvatuksesta olleiden 0-4,5 -vuotiaiden lasten ( $\mathrm{n}=1364)$ pitkäaikaiskehittymistä 15-vuoden ikään (Vandell, 2010). Tulokset osoittivat, että lasten varhaisen kasvatuksen ja hoidon korkea laatu ennusti 15-vuoden iässä korkeampaa tasoa kognitiivisissa kouluoppimiseen liittyvissä saavutuksissa ja vähäisempää probleemakäyttäytymistä, jona pidettiin esimerkiksi toisten lyömistä, kurittomuutta, levottomuutta, asioiden vastustamista jne. Sen sijaan kodin ulkopuolisessa kasvatuksessa ja hoidossa olon pituus (vähintään 10 tuntia viikossa, keskiarvo 16 tuntia viikossa) yhdistyi ulospäin suuntautuvan probleemakäyttäytymisen määrän lisääntymiseen. Hieman aikaisemmin tehty seuranta 12-vuoden iässä osoitti samalla aineistolla vastaavanlaisia tuloksia (Belsky et al., 2007). On myös näyttöä siitä, että laadullisesti korkeatasoisen varhaiskasvatuksen ja hoidon vaikutukset näkyvät seurannoissa eräissä tapauksissa jo varhaiskasvatuksen päättövaiheessa (esim. Weikart et al., 1970; Schweinhart et al.,1993; Schweinhart et al., 1980; Schweinhart et al., 2005).

\section{Kansainvälinen IEA Preprimary -projekti}

Varhaiskasvatuksen vaikutuksia ikävuosina 4-7 on analysoitu kansainvälisen IEA Preprimary Study -projektin yhteydessä seurantatutkimuksella 10 maassa Suomi mukaan lukien (Montie et al., 2007). Seurannassa kiinnitettiin huomiota kehittymisen ja oppimisen tuotoksiin kognitiivisella ja kielellisellä alueella. 4-vuotiaiden lasten varhaiskasvatuksen prosesseista hankittiin havainnoinnin avulla prosessitietoa opettajan pedagogisista aktiviteeteista ja haastattelun avulla opettajan odotuksista lapsen kehittymiselle ja oppimiselle. Analyysissa oli mukana myös opettajankoulutuksen laatu ja määrä ja oppimismateriaalin määrä ja monipuolisuus. Kognitiivisen alueen tuotosta mitattiin 4-vuoden iässä kognitiivisella (spatiaaliset 
suhteet ja määrä) ja kielen kehittymisen (vastaanottava ja ilmaisu) alueilla. 7-vuoden iässä kognitiivisen alueen mittaukset kohdistuivat spatiaalisiin suhteisiin, määrään, aikaan, muistiin ja ongelman ratkaisuun. Kielen mittauksessa kohteena olivat kielen ymmärtäminen, käsitteiden nimeäminen ja lauseen ymmärtäminen.

Tuloksissa eriteltiin kaikkia 10 maita koskevat samansuuntaiset tulokset ja tulokset, jotka olivat yhteydessä maakohtaisiin painotuksiin pedagogisessa kulttuurissa. Kaikki maita koskevat päätulokset olivat:

- 4-vuotiaiden lasten valintaan perustuvien pedagogisten aktiviteettien määrän lisääntyessä kielellisen kehittymisen taso oli 7-vuoden iässä korkeampi.

- Opettajankoulutuksen tason nousu 4-vuotiaiden lasten opettajilla edisti kielellisen kehittymisen tasoa 7-vuoden iässä.

- Mitä vähemmän 4-vuotiaat lapset olivat kokoryhmätoiminnassa, sitä parempia olivat heidän kognitiiviset suorituksensa 7-vuoden iässä.

- Kun oppimismateriaalin määrä ja vaihtelevuus lisääntyi 4-vuotiaiden lasten pedagogiikassa, lasten kognitiiviset suoritukset olivat paremmat.

Kun tuloksia analysoitiin ottaen huomioon maiden pedagoginen kulttuuri, päätulokset olivat seuraavat:

Kielellinen kehittyminen:

- Lisääntyvä aikuisten ja lasten välinen vuorovaikutus 4-vuotiden pedagogiikassa oli yhteydessä parempaan kielen kehittymiseen 7-vuoden iässä maissa, joissa pedagoginen kulttuuri ei painottanut aikuisjohtoista opettamista ja oppimista. Vastaavasti maissa, joissa painotettiin aikuisjohtoista opettamista ja aktiviteetteja 4-vuoitiaiden lasten pedagogiikassa, lasten kielellisen kehittymisen taso oli alhaisempi.

- 4-vuotiaiden lasten välisen vuorovaikutuksen määrän lisääntyessä lasten kielellisen kehittymisen taso parantui maissa, joissa 4-vuotiaiden lapsen pedagogiikassa käytettiin vähemmän kokoryhmäaktiviteetteja. Sen sijaan maissa, joissa käytettiin enemmän kokoryhmäaktiviteetteja, lasten kielen kehittymisen ja oppimisen taso oli matalampi. 
- Lisääntyvä 4-vuotiaiden lasten välinen vuorovaikutus johti 7-vuoden iässä parempaan kielen kehittymisen ja oppimisen tasoon maissa, joissa 4- vuotiaiden lasten opettajilla oli korkeita odotuksia lapsen kielen oppimisen tärkeydestä. Jos 4-vuotiaiden lasten pedagogisessa kulttuurissa ei korostettu kielen oppimisen tärkeyttä, lasten kielen kehittymisen ja oppimisen taso jäi matalammaksi.

- Yhteys 4-vuotiaiden ja 7-vuotiaiden lasten kielen kehittymisen ja oppimisen tasoon oli voimakkaampaa maissa, joissa 4-vuotiaiden lasten opettajat osallistuivat ajallisesti enemmän lasten toimintoihin. Maissa, joissa opettajien osallistumisen määrä oli alhaisempi, 7-vuotiaiden lasten kielellisen kehittymisen ja oppimisen taso oli alhaisempi.

Kognitiivinen kehittyminen:

- Lisääntyvä aikuisten ja 4-vuotiaiden lasten välinen vuorovaikutus paransi kognitiivisia suorituksia maissa, joissa 4-vuotiaiden lasten opettajat käyttivät runsaasti lasten valintaan perustuvia aktiviteetteja. 7-vuotiaiden lasten kognitiiviset suoritukset olivat huonommat maissa, joissa 4-vuotiaiden lasten opettajat käyttivät vähemmän lasten valintaan perustuvia aktiviteetteja.

- 4-vuotiaiden ja 7-vuotiaiden lasten kognitiivisen kehittymisen yhteys oli alhaisempi maissa, joissa 4-vuotiaiden lasten opettajat opettivat useita aktiviteetteja lapsille. Vastaava yhteys oli voimakkaampi maissa, joissa opettaja ei opettanut runsaasti 4-vuotiaille lapsille aktiviteetteja.

- 4-vuotiaiden ja 7-vuotiaiden lasten kognitiivisen kehittymisen yhteys oli korkeampi maissa, joissa 4-vuotiaiden lasten opettajat suosivat esiakateemisia lukemisen, kirjoittamisen ja matematiikan aktiviteetteja. Maissa, joissa 4-vuotiaiden lasten opettajat eivät preferoineet esiakateemisia aktiviteetteja, kognitiivisen kehittymisen ja oppimisen taso oli alhaisempi.

IEA Preprimary Study-projektin tuloksista voidaan identifioida myös suomalaisen varhaiskasvatuksen laadullisia ulottuvuuksia. Tutkittaessa opettajien ja vanhempien odotuksia lasten kehittymisestä ja oppimisesta havaittiin, että suomalaiset 4-vuotiaiden lasten opettajat ja myös vanhemmat pitivät keskeisimpinä odotuksina lasten kehittymisessä ja oppimisessa sosiaalisia 
taitoja vertaisryhmässä ja omatoimisuuden taitoja (Ojala, 2000; Ojala, 2004; Ojala, 2005). Näihin nähden selvästi vähemmän korostettiin kielellisiä ja motorisia taitoja. Sen sijaan varhaisia lukemisen, kirjoittamisen ja matematiikan taitoja ei pidetty tärkeinä lapsen oppimisessa ja kehittymissä ennen esiopetusikää. Erityisesti tässä suhteessa odotukset poikkesivat muista maista, jotka olivat Euroopasta, Aasiasta, Pohjois-Amerikasta (Yhdysvallat) ja Afrikasta (Nigeria). Mielenkiintoinen yksityiskohta Suomen aineistossa oli se, että 4-vuotiaden lasten vanhemmat korostivat opettajia enemmän lasten kehittymistä lukemisen, kirjoittamisen ja matematiikan taidoissa.

IEA Preprimary Study -projektin yhteydessä havainnoitiin myös lasten ja opettajien aktiviteetteja ja kasvatusprosesseja (Ojala, 2004; Ojala, 2005). Lasten toimintaa havainnoitaessa päiväkodeissa suomalaiselle varhaiskasvatuspedagogiikalle oli tunnusomaista erityisesti karkea- ja hienomotoriikkaa aktivoivat toiminnot, joita oli noin $30 \%$ aamupäivän aktiviteeteista (Ojala, 2004). Seuraavaksi yleisimmäksi muodostuivat sosiaaliseen vuorovaikutukseen painottuvat aktiviteetit (19\%), joihin sisältyi perushoitotilanteita, kontaktit muihin ja ryhmän hallintaa ylläpitävät aktiviteetit. Ilmaisuun liittyviä aktiviteetteja oli noin $15 \%$ aamupäivän aktiviteeteista. Sen sijaan lukemiseen, kirjoittamiseen ja matematiikkaan (5\%) sekä emootioihin kohdistuneita aktiviteetteja (2\%) tapahtui varsin vähän aamupäivän aktiviteeteissa. Kun vertailukohteeksi otetaan Irlanti, 4-vuotiaiden lasten aktiviteetit painottuivat siellä esiakateemisten taitojen oppimisen tukemiseen, kirjoittamiseen ja matematiikaan (36\%). Sosiaaliseen vuorovaikutukseen painottuvia lasten aktiviteetteja oli Irlannissa suurin piirtein sama määrä kuin Suomessa (17 \%). Sen sijaan karkea- ja hienomotoristen aktiviteettien määrä oli vähäinen (10 \%) Suomeen verrattuna.

Kun suomalaisissa päiväkodeissa tapahtuvia 4-vuotiaden lasten aktiviteetteja havainnoitiin kohdistamalla huomio opettajan toimintoihin, keskeisinä olivat kolme erilaista aktiviteettia (Ojala, 2004). Näistä ensimmäinen kohdentui toiminnan suunnittelun, materiaalien, tilojen ja kasvatusympäristön järjestämiseen sekä perushoitoon (23\%). Toiseksi yleisin opettajan toiminto oli opettaminen (20\%) ja kolmanneksi yleisin ohjaus (19\%). Kun tuloksia verrataan Irlantiin, 4-vuotiaden lasten opettajien yleisin toiminta siellä oli opettaminen (37\%), toiseksi yleisin oli osallistuminen lapsille suunniteltuihin yhteisiin aktiviteetteihin (25\%) ja kolmanneksi yleisin toimintakokonaisuus, johon kuului toiminnan suunnittelua, materiaalien, tilojen ja kasvatusympäristön järjestämistä sekä perushoitoa (16 \%). 
Aktiviteettien havainnoinnin yhteydessä kiinnitettiin huomiota vielä erikseen edellä mainitussa vertailevassa kansainvälisessä varhaiskasvatustutkimuksessa lasten toiminnan sosiaaliseen vuorovaikutukseen havainnoimalla sitä, kenen kanssa lapsi toimi (Ojala, 2004). Tulosten mukaan suomalaiset lapset toimivat aamupäivän toiminnoissa päiväkodeissa useimmiten pienessä ryhmässä (25\%), yksin (20\%), toisen lapsen kanssa (15\%) ja suuressa ryhmässä ilman aikuista (8\%). Vähiten toimintaa tapahtui toiminnoissa, joissa aikuisella oli johtava asema (noin $6 \%$ ). Irlannissa lasten toiminnan sosiaalinen konteksti oli Suomeen verrattuna kovin erilainen. Aamupäivän aktiviteettien aikana 4-vuotias lapsi oli Irlannissa lähes koko ajan joko suuressa (50 \%) tai pienessä (32 \%) ryhmässä aikuisen kanssa.

\section{Varhaiskasvatuksen pitkäaikaisvaikutukset Englannissa}

Englannissa on vuodesta 1997 alkaen toteutettu pitkäaikaista EPPE-seurantutkimusta, jossa arvioitiin erityyppisen varhaiskasvatuksen toimivuutta ja vaikutuksia lasten kehittymiseen ikävuosina 3-11 (Sylva et al., 2004; Sylva et al., 2010). Seuranta käsitti siirtymän esiopetuksesta perusopetukseen. Tämän jälkeen seurantaa jatkettiin keskiasteella. Yhteensä 3000 lapsen otokseen tulleet lapset edustivat erilaisia varhaiskasvatuksen toteutusmuotoja: leikkikerhot, yksityiset päivähoitoryhmät, koulun yhteydessä toimivat lapsiryhmät, paikalliset päivähoitoryhmät, hoitoa ja kasvatusta integroivat yksiköt ja kodeissa hoidetut lapset. Tutkimuksessa kerättiin yksityiskohtaista tietoa hoitopaikasta, lapsen kehittymisestä, lasten kotitausta ja kodin tarjoamasta oppimisympäristöstä. Lasten seurannassa huomion kohteena olivat äidinkielen, matematiikan ja sosiaalisen alueen (itsesäätely, sosiaalinen kypsyys, levottomuus ja häiriökäyttäytyminen) kehittyminen. Kehittymisen ja oppimisen etenemistä tarkasteltiin lasten perhetaustan, kasvatus- ja opetushenkilöstön, pedagogisen havainnoinnin, koulun oppimisilmaston sekä lasten ja opettajien näkemysten kautta.

\section{Havainnot esiopetuksen laadusta}

Kun EPPE-seurannan tuloksia analysoitiin ikävuotena 7, tulosten perusteella oli mahdollista pelkistää esiopetuksen laadusta seuraavia keskeisiä tekijöitä, jotka selittivät lapsen hyvää tiedollisen ja sosiaalisen alueen kehittymistä: 
- Kognitiivinen ja sosiaalinen kehittyminen nähdään toisiaan tukevina.

- Opettajat tarvitsevat hyvän tietämykset opetussuunnitelmasta ja sekä tietoa että ymmärrystä lapsen kehittymisestä.

- Lapset tarvitsevat palautetta toiminnoistaan ja tämä lisää heidän ymmärrystään.

- Laadukkaissa yksiköissä käytetään sekä aikuisjohtoisia että lapsilähtöisiä toimintatapoja. Potentiaalisesti ne ovat opetuksellisia, mutta niitä toteutetaan usein aktiviteettipainotteisina, joissa myös leikki on läsnä.

- Lasten kognitiivinen kehitys on yhteydessä sekä määrällisesti että laadullisesti aikuisten suunnittelemaan ja ohjaamaan ryhmätyöskentelyyn, joka tukee lapsen oppimista.

- Lasten sosiaalista kehittymistä tuetaan parhaiten, mikäli opettajat ovat ongelmatilanteissa taka-alalle vetäytyviä mutta samanaikaisesti ovat rationaalisia ja käsittelevät puhumalla esiintyneitä ongelmia.

- Keskustelu vanhempien kanssa kasvatuksen tavoitteista heijastuu myönteisellä tavalla lapsen kehittymiseen.

\section{Siirtymä esiopetuksesta perusopetukseen}

EPPE Seurannan perusteella identifioitiin seuraavia laatuun liittyviä tekijöitä:

- Esiopetuksen laadulla oli merkitystä sosiaalisen alueen kehittymiseen: Laadukkaassa esiopetuksessa olleilla olivat paremmat taidot omatoimisuudessa 9-vuoden iässä.

- Kodeissa varttuneilla lapsilla oli alhaisempi sosiaalinen kypsyys/empatia kuin esiopetuksessa olleilla. Ero oli suurin laadukkaassa esiopetuksessa olleisiin.

- Mitä laadukkaampi esiopetus sitä korkeammat olivat oppisaavutukset (matematiikka).

- Mitä paremmaksi koulu oli arvioitu oppimisilmastoltaan (academically effective), sitä korkeammat olivat oppimissaavutukset (matematiikka).

- Lapset, jotka olivat olleet ladullisesti hyvässä esiopetuksessa, hyötyivät oppimisilmastoltaan alhaisesta ja jopa keskitasoisesta koulusta sosiaalisessa oppimisessa ja kehittymisessä (itsesäätely). 
- Vastaavasti oppimismiljööltään laadullisesti hyvä koulu edisti niiden lasten oppimista, jota eivät olleet esiopetuksessa tai olivat olleet laadullisesti heikossa esikoulussa (itsesäätely).

- Lasten tiedollisen oppimisen hyvä edistyminen 11-vuoden iässä selittyi laadukkaalla esiopetuksella, joka tuki myönteisellä tavalla lasten oppimiskapasiteettia ja oppimismotivaatiota.

- Myös kodin taustatekijöillä oli merkitystä: laadukas/hyvä oppimisympäristö kodissa ja äidin korkeahko koulutustaso olivat yhtä voimakkaita selittäjiä sekä äidinkielessä että matematiikassa.

- Opetuksen laadulla oli merkittävä ennustearvo sekä äidinkielen että matematiikan oppimiseen.

- Oppimisympäristön ja opetuksen erilaisilla häiriötekijöillä oli yhteys huonoon oppimiseen sekä lisääntyvään levottomuuteen.

- Mitä tehokkaampi ja hallitumpi koulun hallinnointi, sitä parempia olivat lasten oppimistulokset sekä tiedollisella että sosiaalisella alueella.

- Kun opettajilla oli oppimista väheksyvä (anti-academic) asenne, lapsissa havaittiin lisääntyvää levottomuutta ja vähäisempää sosiaalisuutta, jotka heijastuivat myös huonompana lukemisen ja matematiikan oppimisena.

\section{Kansallisia arviointeja varhaiskasvatuksen toteutuksesta ja laadusta}

Varhaiskasvatuksen laatuun kiinnitettiin huomiota myös sosiaali- ja terveysministeriön ohjauksessa (Ruokolainen \& Alila, 2004). Sen suorittamassa arvioinnissa huomio kohdistettiin varhaiskasvatuksen laadunhallintaan ja ohjaukseen sekä raportoitiin kokemuksia 11 pilottikunnan kanssa toteutetuista varhaiskasvatuksen laadunhallinnan projekteista. Johtopäätöksenä todettiin, että laadunhallinta ja arviointi ovat selkiytymättömiä ja varhaiskasvatuksessa tarvitaan laadun ja arvioinnin teoreettista ja tutkimuksellista vahvistamista. Kuntien väillä havaittiin suuria eroja päivähoidon laadunarvioinnissa. Suuret kunnat näyttivät olevan laadun arvioinnissa pidemmällä kuin pienet. Henkilöstön todettiin tarvitsevan merkittävästi lisää koulutusta laadun kehittämisessä. 
Kun vanhemmat ovat arvioineet suomalaisen varhaiskasvatuksen laatua, sitä voi pitää laadullisesti varsin hyvänä. Laajassa kansainvälisessä vertailussa, jossa oli mukana yhteensä 11 maata Euroopasta, Aasiasta, Afrikasta ja USA:sta suomalaisten 4 -vuotiaiden lasten vanhemmat olivat yhdessä USA:n kanssa kaikkien tyytyväisempiä lastensa saamaan kodin ulkopuoliseen hoitoon ja kasvatukseen (Ojala \& Opper, 1994). Tässä aineistossa $81 \%$ suomalaisista vanhemmista oli erittäin tyytyväisiä.

Päivähoidon laadun arviointikyselyssä vanhemmat opettajien tapaan arvioivat lapsen varhaiskasvatuksen ja hoidon hyväksi (Hujala ym., 2006; Hujala ym., 2012). Lähes kaikki vanhemmat kuvasivat päivähoitoa tyytyväisyyttä viestivillä maininnoilla. Jäljelle jäänyt pieni vähemmistö vanhemmista ei ilmaissut olleensa selkeästi tyytyväisiä, mutta eivät myöskään tyytymättömiä. Kukaan vanhemmista ei ilmaissut olevansa täysin tyytymätön. Vanhempien kielteinen palaute kohdistui enemmän päivähoidon puitetekijöihin kuin itse toiminnan sisältöön. Opetus, oppimismahdollisuudet sekä henkilöstön suhtautuminen lapsiin oli vanhempien arvioissa erityinen tyytyväisyyden aihe. Vaikka lasten mahdollisuus oppia uutta päiväkodissa oli vanhemmille tyytyväisyyden aihe, lasten sosio-emotionaalinen kasvatus on ollut heidän arvioinneissaan erityisen tärkeää.

Kun vanhempien ja opettajien tyytyväisyyttä päivähoitoon on verrattu, tuloksena on ollut se, että vanhemmat ovat yleensä olleet tyytyväisempiä kuin opettajat (esim. Hujala et al., 2012). Poikkeuksen ovat olleet rakennetekijät, yhteistyö, opettajien ammattitaito, johtajuus ja työyhteisö sekä opetussuunnitelman sisällöt ja pedagogiikka. Näissä vanhempien arviot laadusta ovat olleet yleensä matalammat kuin opettajien. Näissäkin laadun osatekijöissä vanhempien arviot olivat kuitenkin hyvää laatua osoittavia. Sen sijaan lähiyhteisön osallistumista laatutekijänä ei korosteta suomalaisessa varhaiskasvatuksessa eikä esiopetuksessa läheskään siinä määrin kuin monissa muissa maissa. Näissä maissa on kehitetty monia toimintatapoja, joissa paikalliset vapaaehtoisjärjestöt ja toimijat vanhemmat mukaan lukien pyrkivät avustamaan päiväkotia, esikoulua tai koulua kasvatuksen ja opetuksen suunnittelussa ja toteutuksessa (Ojala, 2010) 


\section{Kansallisia arviointeja esiopetuksen toteutuksesta ja laadusta}

Suomalaisen esiopetuksen oppimistuloksista on arvioitu Helsingin kaupungissa. Arvioitaessa koko kaupunkia koskevan edustavan otoksen avulla 6-vuotiaiden lasten oppimissaavutuksia esiopetuksen päättövaiheessa eri tavoitealueilla perustuen opettaja-arvioihin ilmeni eroja eri tavoitealueissa (Ojala \& Talts, 2007). Yleistulos oli, että lapset saavuttivat hyvin lähes kaikki arvioinnin kohteena olleet esiopetuksen tavoitealueet (liitekuva 1). Poikkeuksen muodosti ympäristöön ja luontoon liittyvät tavoitteet, joissa saavutukset olivat kaikkein alhaisimmat. Myöskään etiikan ja katsomustiedon tavoitteita ei saavutettu niin hyvin kuin muita tavoitealueita ympäristöja luontotietoa lukuun ottamatta. Parhaiten oli saavutettu terveyteen ja fyysismotoriseen kehittymiseen liittyvät tavoitteet. Myös matematiikan tavoitteet oli saavutettu hyvin verrattuna useimpiin muihin arvioinnin kohteena olleisiin tavoitteisiin. Siirryttäessä esiopetuksesta perusopetuksen toiselle luokalle lasten/oppilaiden oppiainekohtainen oppimisen profiili ei näytä suurestikaan muuttuvan kuten liitekuva 2 osoittaa (Ojala 2007).

Opetus- ja kulttuuriministeriön alaisuudessa toimiva Koulutuksen Arviointineuvosto arvioi vuonna 2010 esi- ja perusopetuksen toimivuutta opetussuunnitelmajärjestelmänä (Esi- ja perusopetuksen opetussuunnitelmajärjestelmän toimivuus, 2010). Esiopetukseen kohdistettuun arviointiin osallistuivat esiopetuksen järjestäjät, päiväkodin johtajat, esiopetuksesta vastaavat opettajat päiväkodeissa ja kouluissa sekä huoltajat. Arviossa valtakunnallisia esiopetussuunnitelman perusteita pidettiin yleisesti ottaen selkeinä ja ne antoivat riittävästi mahdollisuuksia toteuttaa oppisisältöjä. Tavoitteiden ja sisältöjen väljyyden arveltiin kuitenkin lisäävän kuntakohtaisia eroja esiopetuksen toteutuksessa. Kehittämistoimenpiteinä perusteisiin toivottiin kasvatusja sivistysnäkemyksen selkeää kirjaamista, käsitteiden selkeyttämistä sekä sisältöjen ja tavoitteiden täsmentämistä. Myös lisääntyvää herkkyyttä tiedon ja yhteiskunnan muuttuvuuteen toivottiin. Arviointiin ja kehittämiseen toivottiin lisää resursseja.

Paikallisen esiopetussuunnitelman arvioinnin säännöllisyyden toteutumisesta vastaajaryhmät vuoden 2010 arvioinnissa olivat hieman eri mieltä. Päiväkodin johtajilla oli huomattavasti positiivisempi käsitys arvioinnin säännöllisyydestä kuin esiopetusta toteuttavilla opettajilla. Sekä opetuksen järjestäjät että esiopetuksesta vastaavat opettajat toivoivat, että paikallista 
opetussuunnitelmaa tuli arvioida säännöllisemmin. Päiväkodin johtajat sen sijaan katsoivat, että paikallista suunnitelmaa arvioidaan ja kehitetään suhteellisen säännöllisesti. Vuoden 2010 arvioinnissa tuodaan esiin huoli esija perusopetuksen jatkumon puuttumisesta. Lapsen aikaisempi oppimispolku tulisi tehdä näkyväksi. Esiopetuksen ja perusopetuksen perusteisiin ehdotettiin, että yhteistyön tavoitteet esi- ja alkuopetuksessa sekä huoltajien kanssa tulisi kirjata selkeästi. Huoltajien arvioiden mukaan esiopetusvuoden aikana käsitellyt asiat ja opetusmenetelmät olivat lapsen ikäkaudelle sopivia. Myös esiopetuksen mahdollisuuksiin tukea lasten kasvua ja oppimista oltiin tyytyväisiä. Kehittämisehdotuksissa korostettiin riittävän tiedon saamista esiopetukseen liittyvistä käytänteistä ja eri tukimuodoista. Huoltajien tulisi voida myös vaikuttaa esiopetussuunnitelman sisältöihin jo laatimisvaiheessa.

Vuonna 2010 arvioitiin erillisessä raportissa oppimaan oppimista Vantaan ensiluokkalaisilla. Tuloksena oli, että koulujen väliset erot olivat varsin pieniä (Vainikainen et al., 2010). Kun myöskin luokkien väliset erot olivat melko vähäiset ja niiden arveltiin osaksi johtuvan sattumanvaraisista tekijöistä, esiopetus näytti tämänkin aineiston perusteella toimivan Suomessa tasa-arvoa edistävänä koulutusjärjestelmän osana, johon liittyvän ohjantajärjestelmän voi otaksua olevan tehokkaan ja laadukkaan.

Vuonna 2012 Koulutuksen arviointineuvosto suoritti opetus- ja kulttuurineuvoston toimeksiannosta esiopetuksen laadun arvioinnin (Hujala ym., 2012). Arvioinnin kohteena olivat esiopetuksen saatavuus, tavoitteiden, tasa-arvon ja yhdenvertaisuuden toteutuminen, lasten kasvu-, kehitys- ja oppimisedellytysten edistäminen sekä esiopetuksen oppimis- ja kasvuympäristön laatu. Arvioinnissa laatutekijät ryhmiteltiin toimintaedellytyksiin/puitetekijöihin, välillisiin prosesseihin (esim. yhteistyö ja henkilöstön osaaminen), prosessitekijöihin (vuorovaikutus ja lasten osallisuus) ja vaikuttavuuteen (esim. lasten kokemukset ja kasvu, kehitys ja oppiminen sekä huoltajien tyytyväisyys). Arviointiaineisto kerättiin viranhaltijoilta, johtajilta/rehtoreilta, esiopettajilta ja huoltajilta.

Vuoden 2012 arvioinnin perusteella suomalaisen esiopetuksen kokonaislaatu todettiin osin tyydyttäväksi osin hyväksi. Johtajien/rehtoreiden ja esiopettajien arvioiden mukaan laatu oli keskimäärin tyydyttävä. Viranhaltijoiden ja huoltajien arvioissa laatu oli keskimäärin hyvä. Laatu arvioitiin miltei poikkeuksetta samantasoiseksi eri laatutekijöissä, mikä voi myös viestiä siitä, että vastaajilla on saattanut olla vaikeuksia erotella eri 
laatutekijöitä toinen toisistaan tutkimuksessa esitetyllä tavalla. Vertailua sosiaalitoimen ja koulutoimen välillä vaikeuttaa se, että arviointitutkimuksessa esiopetuksen laadun orientaatio ja sen osatekijöiden erittely on tapahtunut voittopuolisesti varhaiskasvatuksen tutkimusintresseistä käsin, jolloin kytkeymä perusopetukseen jää helposti taka-alalle.

Vuoden 2012 arvioinnissa esiopetuksen saatavuus oli hyvä (osallistumisaste 96 \%) ja opettajien kelpoisuus korkea (99 \%). Henkilöstön poissaolot koettiin ongelmiksi. Lasten arvioitiin viihtyvän ja olleen motivoituneita esiopetukseen. Myös huoltajat olivat arvioinnin mukaan tyytyväisiä. Tyypillisessä esiopetusryhmässä oli 10-20 lasta, mutta lähes 40 \% ryhmistä oli yli 20 lasta. Esiopetuksen toteutuksessa arvioitiin olevan puutteita koskien pedagogiikkaa, opetusjärjestelyitä, työtapoja ja huoltajien osallistumista. Varhainen tuki oli toteutunut melko hyvin, mutta siihen toivottiin lisää resursseja. Oppilashuollossa todettiin olevan organisatorisia puutteita ja ne puuttuivat kokonaan noin $15 \%$ esiopetusyksiköistä. Oppimisympäristön laadussa arvioitiin olleen monia puutteita (esim. ahtaus, jakotilat, liikuntatilat). Pedagogiseen johtajuuteen, henkilöstön osaamisen kehittämiseen ja tiedonkulkuun ei oltu kovinkaan tyytyväisiä. Huoltajien arvioitiin tuntevan esiopetusta keskimäärin vähän.

\section{Arviointeja suomalaisesta perusopetuksesta}

\section{Perusopetuksen oppimistulosten arviointi}

Opetushallitus seuraa perusopetuksen tuloksellisuutta maata kattavilla arvoinnoilla, joita on suoritettu eri oppiaineissa (esim. Huisman, 2006; Rajakorpi, 2000; Halkka, 2003; Jakku-Sihvonen et al., 1996; Tuokko, 2003; Korkeakoski, 1998; Rusama, 2002). Keskeisinä arvioinnin kohteina ovat olleet etenkin äidinkieli ja matematiikka mutta myös luonnontiede. Arvioinnit ovat viestineet, että oppimistuloksissa ei esiinny koko maan huomioon ottaen huomattavia alueellisia ja koulukohtaisia eroja (esim. Kuusela, 2006). Oppilaiden sukupuoleen liittyviä eroja on havaittu etenkin äidinkielessä (Huisman, 2006), taideaineissa sekä uskonnossa ja etiikassa tyttöjen eduksi (Korkeakoski, 1998; Rusama, 2002.

Uutta havaintoa perusopetuksemme tuloksellisuuteen on saatu opetushallituksen suorittamasta kansallisesta arvioinnista keväällä 2012, joka kohdistui matematiikan oppimistuloksiin perusopetuksen päättövaiheessa 
(Rautopuro, 2013). Arvioinnin mukaan eroja ei esiintynyt suomen- ja ruotsinkielisten koulujen välillä eikä myöskään tyttöjen ja poikien välillä lukuun ottamatta sitä, että hyvin menestyneiden poikien osuus oli suurempi kuin tyttöjen. Pojat myös luottivat osaamiseensa tyttöjä paremmin. Huolestuttavana pidettiin päässälasku- ja prosenttilaskutaitojen riittämättömyyttä, jotka eivät suurella osalla oppilaita riittäneet välttämättä edes arkielämän tarpeisiin. Lukujen ja laskutoimitusten heikentynyt hallinta tulkittiin perusopetuksen matematiikan osaamisen perustan murenemisena.

Toinen huolta aiheuttava arviointitulos liittyi koulujen välisten erojen kasvuun verrattuna aikaisempiin arviointeihin. Koulujen välinen vaihtelu oli suurinta niillä matematiikan osa-alueilla, jossa oppilaiden menestys arvioinnissa oli heikointa. Vanhempien koulutustaustan yhteys oppimistuloksiin on huomattava, koska keskimääräinen ratkaisuprosentti oli noin $14 \%$ korkeampi niillä oppilailla, joiden molemmat vanhemmat ovat ylioppilaita verrattuna oppilaihin, joiden vanhemmista kumpikaan ei ollut ylioppilas. Vanhempien koulutustausta selitti koulujen välisestä vaihtelusta $30 \%$. Myös opettajan kelpoisuudella oli merkitystä koulujen välisiin eroihin. Kun koulussa oli opettajana muodollisesti kelpoinen aineenopettaja, arviointimenestys oli keskimäärin parempaa ja koulujen väliset vaihtelut pienempiä verrattuna kouluihin, joissa opettaja ei ollut muodollisesti kelpoinen. Myös arvosanakäytännöissä havaittiin koulujen välistä vaihtelua, jolloin oppilaiden koulutodistuksen arvosanat saattoivat poiketa kouluissa kahden arvosanan verran, vaikka oppilaat saivat opetushallituksen arviointikokeessa samantasoisen tuloksen. Myös annettujen kouluarvosanojen suhteen tulos oli ristiriitainen. Tyttöjen arvosanat olivat poikia korkeammat, mutta poikien osuus oli tyttöjä suurempi hyvin ja erinomaisesti menestyneiden joukossa.

Vuonna 2018 perusopetusta on vuosiluokkien 7-9 osalta arvioitu kansainvälisesti OECD:n opetuksen ja oppimisen tutkimuksessa (Taajamo \& Puhakka 2019). Tutkimukseen osallistui 48 maata tai aluetta. Raportissa kohdennetaan päähuomiota koulujen oppimisympäristöön, opettajan työoloihin ja tapoihin sekä opettajien ammatilliseen osaamiseen. Suomen osalta tutkimukseen osallistui lähes 150 rehtoria ja yli 2800 opettajaa. Suomesta pelkistyy tutkimuksessa kuva, jossa opettajat ovat korkeasti koulutettuja, tyytyväisiä ammattiinsa, innovatiivisia ja omiin kykyihinsä luottavia. Oppilaiden ja opettajien keskinäisiä suhteita pidetään hyvinä ja luottamusta hyvänä. Oppilaita arvostetaan ja heidän hyvinvointinsa oli opettajille 
tärkeää. Tämän vuoksi ryhmäkokoa on haluttu pienentää. Opettajien arviointikäytännöt olivat tulosten mukaan monipuolistuneet käyttämällä esimerkiksi välitöntä palautetta tuntityöskentelystä ja kannustamalla oppilaita arvioimaan enemmän omaa työskentelyään. Suurin osa kouluista tarjoaa tulosten mukaan uusille opettajille perehdytystä, mutta enemmistö torjuu tämän. Erillistä mentorointiohjelmaa tarjosi kuitenkin vain vajaa viidennes. Esimerkiksi Ruotsi tarjoaa tällaista lähes joka toisessa koulussa. Tulosten mukaan myös opettajien osallistuminen pitkäkestoiseen ammatillista kehittymistä tukevaan koulutukseen on vähenemässä. Suomesta kerätty aineisto viesti myös, että työrauha on koettu ongelmalliseksi ja rehtorin hallinnolliset tehtävät ovat lisääntyneet.

\section{PISA -tutkimuksen tuloksia}

Suomalaisen perusopetuksen tuloksellisuutta on toistuvasti arvioitu myös kansainvälisesti PISA-tutkimusten avulla (esim. Pisa 2009, Pisa 2003). Ennen vuoden 2012 arviointia 15-vuotiaat suomalaislapset ovat sijoittuneet äidinkielessä, matematiikassa ja luonnontieteissä vertailtavien maiden kärkijoukkoon. Vuoden 2012 PISA-tulokset ovat kuitenkin osoittaneet, että matematiikan kansallinen keskiarvo on laskenut vuoden 2003 arvioinnista merkittävästi. Myös lukutaito ja luonnontieteiden osaaminen on selvästi heikentynyt (Opetus- ja kulttuuriministeriö, Pisa 2012). Matematiikan osaamisen kansallinen keskiarvo (519) on Suomessa laskenut vuoden 2003 arvioinnista 25 pistettä, joka vastaa noin puolen kouluvuoden edistymistä. Vuoden 2003 kärkimaista Suomen keskiarvon lasku on kaikkein suurin ja kehityksen suunta erittäin huolestuttava. Suoritustasoltaan heikkojen matematiikan osaajien määrä on kasvanut Suomessa 7 prosentista 12 prosenttiin ja erinomaisten matematiikan taitajien määrä vähentynyt 23 prosentista 15 prosenttiin.

Vuoden 2012 PISA menestyjien joukossa oli seitsemän Aasian maata tai aluetta. Aiemmin menestyneet maat ja alueet, kuten Shanghai, Singapore, Hongkong, Taiwan ja Korea, ovat entisestään parantaneet tulostaan. Euroopan maista Suomea paremmin menestyivät Lichtenstein, Sveitsi, Alankomaat ja Viro. Tästä huolimatta suomalaisnuorten osaaminen on edelleen OECD-maiden joukossa parhaimmistoa, koska Suomi sijoittui matematiikassa kuudenneksi, lukutaidossa kolmanneksi ja luonnontieteissä toiseksi. 
Euroopan maista Suomi oli lukutaidossa ja luonnontieteiden osaamisessa edelleen paras.

Positiivista vuoden 2012 PISA-tuloksissa Suomen osalta oli se, että lukutaito ja luonnontieteiden osaaminen oli korkealla tasolla, vaikka näissäkin oppiaineissa oli havaittavissa laskua. Suomen lukutaidon keskiarvo oli kaikkien osallistujamaiden ja -alueiden joukossa kuudenneksi ja OECDmaiden joukossa kolmanneksi paras. Suomea paremmin menestyi viisi Aasian maata tai aluetta: Shanghai, Hongkong, Singapore, Japani ja Korea. Edellisiin lukutaidon mittauksiin (2000 ja 2009) verrattuna keskiarvo on laskenut selvästi, vuoteen 2000 verrattuna jopa 22 pistettä. Luonnontieteiden osaamisessa suomalaisnuoret olivat kaikkien osallistujamaiden ja -alueiden joukossa viidensiä. OECD-maiden joukossa Suomen pistemäärä oli parhaimmistoa yhdessä Japanin, Viron ja Korean kanssa. Luonnontieteiden osaamisen keskiarvo on laskenut 18 pistettä vuoden 2006 tutkimuksesta.

Toinen myönteinen seikka matematiikan osaamisessa vuoden 2012 PISA-arvioinnissa oli Suomessa se, että erot koulujen ja alueiden välillä olivat pienet. Matematiikan osaamisen sukupuoliero oli erittäin pieni. Ensimmäistä kertaa tytöt menestyivät paremmin kuin pojat. Myös koulujen väliset erot matematiikan osaamisessa olivat edelleen varsin pieniä ja osaaminen maan eri alueilla on tasaista kaikilla kolmella arviointialueella. Kuitenkin ensimmäistä kertaa Suomessa erottui myös joukko kouluja, joiden tulos jäi OECD:n keskiarvon alapuolelle. Jo vuoden 2003 PISA-arvioinnissa vaihtelu matematiikan osaamisessa koulujen välillä kasvoi noin kaksi prosenttiyksikköä. Samalla oppilaiden kotien sosioekonomisten erojen vaikutus kasvoi hieman. Suomessa hyvään matematiikan osaamiseen liittyvät sekä nuorten motivoituminen että heidän asenteensa matematiikan opiskelua ja oppimista kohtaan. Kiinnostus matematiikkaan, usko omiin oppimismahdollisuuksiin sekä luottamus matematiikan tehtävistä suoriutumiseen selittävät Suomessa nuorten matematiikan suoritusten vaihtelusta enemmän kuin OECD:ssä keskimäärin. Huolestuttavaa oppimistulosten heikentymisen osalta ovat olleet jo aiemmat arviot, joissa on kiinnitetty huomiota yleisen koulumyönteisyyden laskuun niin oppilaiden kuin koko yhteiskunnan osalta.

PISA-tulosten lasku herättää luonnollisesti huolta ja antaa perusteita kehittää suomalaista perusopetusta kiinnittämällä huomiota esimerkiksi koulumyönteisyyden ja viihtyvyyden lisäämiseen, oppimis- ja opiskelumotivaation kehittämiseen sekä perusopetuksen tasa-arvosta huolehtimiseen. 
Erityisesti matematiikan taitojen parantamiseksi on ehdotettu opetushenkilöstön täydennyskoulutusmahdollisuuksien, oppimateriaalien ja oppimisympäristöjen kehittämistä, arviointikäytänteiden ja perusteiden tarkentamista sekä ohjaavien kokeiden käyttöön ottoa koskien myös äidinkieltä (Peruskoululaisten matematiikan taidoissa huolestuttavia puutteita, Opetushallitus 2013).

Vuoden 2015 PISA -tulokset osoittivat, että suomalaisnuorten luonnontieteiden osaaminen on laskenut vuoden 2006 tasosta, jolloin luonnontiede oli edellisen kerran pääalueena (Opetus- ja kulttuuriministeriö 6.12.2016). Suomessa luonnontieteiden keskiarvo on pudonnut 32 pistettä vuoteen 2006 verrattuna, jolloin luonnontiede oli edellisen kerran pääalueena. Tulosten heikkeneminen vastaa miltei yhden kouluvuoden edistystä. PISA-arvion mukaan vuosittain runsaat 6000 nuorta jää Suomessa vaille riittäviä perustaitoja luonnontieteissä, mikä lisää riskiä selvitä jatko-opintojen ja nykyaikaisen työelämän vaatimuksista. Luonnontieteiden keskiarvopistemäärässä suomalaiset 15-vuotiaat olivat kuitenkin OECD-maiden joukossa kolmanneksi parhaita. Lukutaidossa suomalaisnuoret ovat edelleen parhaiden joukossa ja matematiikan osaaminen on säilynyt ennallaan. Yhteistoiminnallisen ongelmanratkaisun taitoja arvioitiin ensimmäistä kertaa. Suomalaisnuoret sijoittuivat myös tässä arvioinnissa parhaiden joukkoon.

Vuoden 2015 PISA-tutkimus viestii kahta seikkaa (Opetus- ja kulttuuriministeriö 6.12.2016). Yhtäältä Suomi on edelleen koulutuksen kärkimaa. Jo kymmenen vuotta jatkunut oppimistulosten lasku on taittunut lukutaidossa ja matematiikassa se on hidastunut. Koulujen väliset erot ovat meillä edelleen pienet. Toisaalta tulokset viestivät huolta koulutuksen tasa-arvosta, erityisesti pojista. Myös sosioekonomisen taustan vaikutus oppimistuloksiin on kasvussa. On tarpeen pohtia, mitkä kouluun tai yhteiskuntaan liittyvät muutokset ovat johtaneet koulutuksellisen tasa-arvon heikkenemiseen ja miksi etenkin poikia ei kiinnosta koulussa tarjottu oppimisen malli. 


\section{Lasten hyvinvointi}

\section{Mistä hyvinvoinnissa on kysymys?}

Hyvinvoinnista on muodostunut laaja ja monimerkityksellinen ihmisen kokemuksiin liittyvä käsite, joka voi tarkoittaa taloudellista hyvinvointia mutta myös ihmissuhteisiin tai elämän ja ympäristön laatuun liittyvää (Hoffren et al., 2010). Hyvinvoinnin kautta voidaan täsmentää, mitä ihminen tarvitsee voidakseen hyvin. Hyvinvoinnin ajatellaan lisäävän onnellisuutta. Onnellisuudella puolestaan tarkoitetaan ihmisten kokemaa pysyvää tai pidempikestoista hyvän olon ja tyytyväisyyden tunnetta, joka perustuu kokemuksiin, luonteenpiirteisiin ja persoonallisuuteen (Hoffren et al., 2010). Onnellisuutta pidetään usein osoituksena subjektiivisesta hyvinvoinnista, joka koostuu taloudellisesta hyvinvoinnista, mutta myös muista elämän laatuun, ihmissuhteisin ja ympäristön laatuun liittyvistä tekijöistä, jota riippuvat kunkin henkilön omista mieltymyksistä.

Kansainvälisessäkin mielessä Erik Allard (1993) on tehnyt uraauurtavaa työtä hyvinvointikäsitteen kehittämisessä. Hänen jaottelussaan hyvinvoinnissa on kysymys kolmesta keskeisestä alueesta. Näitä ovat elintaso (having), joka voidaan määritellä tai mitata omilla indekseillään. Toinen keskeinen alue kohdistuu sosiaalisiin suhteisiin (loving), jotka muodostuvat perhe-, ystävyys- ja yhteisyyssuhteista. Kolmas alue liittyy itsenä toteuttamiseen (being), johon liittyy myös arvonanto, ainutkertaisuus ja mielekäs tekeminen, mutta myös poliittiset toiminnan edellytykset. Allardin (1993) mukaan hyvinvoinnin tarkastelussa on yhdistettävä objektiivista ja subjektiivista tietoa.

Hyvinvointiin liittyvää tietoa on pyritty tiivistämään indekseiksi ja indikaattoreiksi, joiden avulla voidaan seurata ja verrata myös kansainvälisesti hyvinvoinnin kehittymistä eri alueilla (Hoffren et al., 2010). Indeksi kuvaa ilmiötä yhdellä luvulla, joka on skaalattu esimerkiksi nollasta (0) yhteen (1) tai sataan (100). Hyvinvoinnin indeksi voi olla myös usean eri indikaattorin avulla laskettu suhdeluku, jonka avulla voidaan kuvata ilmiötä tai kehityksen muutosta esimerkiksi jostain perusvuodesta lähtien. Indikaattori puolestaan ilmaisee ilmiön tilaa tai kehitystä tavalla, jota ei kyetä suoraan mittaamaan. Indikaattoreiden avulla ilmaistaan yleensä kehityksessä tapahtuneita muutoksia. 
Tieteenalat eroavat tavassa tarkastella hyvinvointia (Hoffren et al., 2010). Taloustieteelliset hyvinvoinnin indikaattorit pyrkivät objektiivisuuteen, kun niissä tarkastellaan käytettävissä olevia materiaalisia ja henkisiä resursseja. Sosiologinen lähestymistapa on subjektiivinen. Tavoitteena on tarkastella hyvinvointia yhteisöjen ja yhteiskunnan kautta kiinnittäen huomiota esimerkiksi yhteiskunnalliseen hyvinvoinnin jakautumiseen, altruismiin, yhteisöllisyyteen tai väestöryhmien välisiin eroihin. Tarkoituksena on myös analysoida esimerkiksi mistä hyvinvointi rakentuu tai miksi ihmisten, ihmisryhmien ja yhteiskuntien välillä esiintyy eroja hyvinvoinnissa. Psykologinen lähestymistapa hahmottaa hyvinvointia ihmisten kokeman subjektiivisen hyvinvoinnin kautta. Esimerkkeinä psykologisesta hyvinvoinnista ovat erilaiset ihmisen tarvehierarkiat, joista tunnetuin on Maslowin (1954) kehittämä tarvehierarkia. Sen mukaan ihminen pyrkii tyydyttämän ensin fysiologiset perustarpeensa ja siirtyy tämän jälkeen korkeampiin tarpeisiin, jotka pelkistyvät esimerkiksi turvallisuuteen, yhteenkuuluvuuteen ja itsensä totuttamiseen, joka on korkein tarve tämän teorian mukaan.

Hyvinvointi-indikaattoreita on runsaasti. Sitran toimesta (Hoffren et al., 2010) tehty katsaus kattoi 16 kansainvälistä indikaattoria. Näistä yhden ryhmän muodostavat bruttokansantuloa korjaavat mittarit, joissa erilaisia tekijöitä lisäämällä tai vähentämällä muokataan bruttokansantuloa sellaiseksi, että siinä huomioidaan hyvinvointia lisäävät tai vähentävät tekijät. Toisen ryhmän muodostavat ei-rahamääräiset useista eri ulottuvuuksista muodostetut kooste-indikaattori (komposiitti-indikaatorit), joilla kuvataan hyvinvointia asetettuun tavoitetasoon nähden (usein vaihteluvälillä 0-1 tai 0-100). Sosiaalista ja subjektiivista hyvinvointia mittavat indeksit tai indikaattorit ovat yleensä koosteindikaattoreiden tapaisia. Esimerkkinä voidaan mainita kansallisen hyvinvoinnin (National Accounts of Well-being; NAW) indikaattori, jolla seurataan subjektiivista hyvinvointia useissa Euroopan maissa. Tässä indikaattorissa hyvinvointi määritellään moniulotteiseksi prosessiksi, joka syntyy yksilön olosuhteiden, toiminnan ja henkisten resurssien vuorovaikutuksena. Näin hahmotettuna hyvinvointi on moniulotteinen tila, jossa yksilö kykenee kehittymään, toimimaan tuotteliaasti ja luovasti sekä rakentamaan pysyviä positiivisia suhteita kanssaihmisiin. 


\section{Lasten hyvinvoinnin edistäminen}

Lasten hyvinvointi ja sen tukeminen on liitetty osaksi suomalaista varhaiskasvatusta (Varhaiskasvatussuunnitelman perusteet, 2005 ja 2016). Jo tätä aikaisemmin lasten hyvinvointiin kiinnitettiin huomiota Lapsen oikeuksien julistuksessa, joka hyväksyttiin 1959. Vuonna 1989 lapsen oikeudet kirjattiin valtioita ja siis Suomeakin sitovaksi YK:n lapsen oikeuksien sopimukseksi.

Myös Suomessa on ryhdytty kehittämään kansallisia indikaattoreita lasten hyvinvoinnin seurantaan ja kehittämiseen (Lasten hyvinvoinnin kansalliset indikaattorit, 2011). Lähtökohtana on ollut seurata hyvinvointia yhtäältä lasten elinolosuhteiden ja toisaalta lasten omien kokemusten näkemisen ja kuulemisen avulla. Lasten oikeutta osallisuuteen, vuorovaikutukseen ja kuulluksi tulemiseen pidetään keskeisinä. Indikaattoreita kehitettäessä pyritään kiinnittämään huomioita asioihin ja sisältöihin, jotka olisivat lapsen mielestä tärkeitä.

Lasten hyvinvoinnin kansallisiin indikaattoreihin (2011) ehdotetaan sisällytettäväksi kuusi hyvinvoinnin ulottuvuutta. Näitä ovat materiaalinen taso, terveys- ja hyvinvointi, koulu ja oppiminen, turvallinen kasvuympäristö, osallistuminen ja sosiaalinen toiminta sekä yhteiskunnan tarjoama tuki ja suojelu. Esimerkiksi osallistumisen ja sosiaalisen toiminnan alueella pidetään tärkeänä lapsen oikeutta osallistua, tulla kuuluksi, ilmaisun vapautta, tiedon saamista sekä oikeutta lepoon, leikkiin, vapaa-aikaan ja taide- ja kulttuurikokemuksiin. Ehdotuksessa korostetaan, että nämä oikeudet kuuluvat myös maahanmuuttajataustaisille ja erityistä tukea tarvitseville lapsille.

\section{Suomalaisten lasten hyvinvointi}

Suomi on ollut mukana kansainvälisissä lasten hyvinvointia koskevissa vertailuissa (The state of the world's children, 2007). Tässä 21 maan vertailussa suomalaisten lasten hyvinvointi oli materiaalisessa hyvinvoinnissa, terveydessä ja turvallisuudessa, koulutuksellisessa hyvinvoinnissa sekä käyttäytyminen ja riskiulottuvuudella tutkittujen maiden parhaita. Subjektiivisen hyvinvoinnin alueella suomalaiset lapset sijoittuivat vertailussa keskialueelle. Kohteena oli koettu terveydentila, henkilökohtainen hyvinvointi ja hyvinvointi koulussa. Sen sijaan perhe- ja ystävyyssuhteissa 
suomalaisten lasten hyvinvointi sijoittui vertailussa huonoimpien maiden luokkaan. OECD:n 30 maan vertailevassa tutkimuksessa (Doing better for children, 2009) Suomi sijoittui 10 parhaan maan joukkoon koulutuksellisen hyvinvoinnin ulottuvuudessa, jossa se oli neljänneksi paras. Kohteena eivät olleet alle kouluikäiset lapset. Kouluelämän laadussa suomalaisten lasten hyvinvointi sen sijaan sijoittui keskivaiheelle (sijaluku 18). Koulukiusaaminen oli moniin muihin maihin vähäisempää (8 \% suomalaislapsista ilmoitti tuleensa koulukiusatuksi, kun OECD-maiden yhteinen keskiarvo oli $11 \%$ ). Eniten parannettavaa lastemme hyvinvoinnissa OECD:n vertailun perusteella oli riskikäyttäytymisessä, jossa Suomen sijaluku 30 maan vertailussa oli 26 .

Varhaiskasvatusikäisten lasten hyvinvoinnista Suomessa on toistaiseksi suhteellisen vähän tutkimukseen perustuvaa tietoa. Tutkittaessa 2000-luvun alussa pienen lasten sosiaalisia suhteita päiväkodeissa (Laine \& Neitola, 2002) havaittiin torjuttuja, kiusattuja, kiusaajia, syrjäänvetäytyviä ja yksinäisiä lapsia, joiden arvioitiin olevan syrjäytymisriskissä. Näyttäisi siltä, että ainakin osa lasten hyvinvointia uhkaavia tekijöistä päiväkodissa liittyy toverisuhteisiin niin, että niillä on taipumusta kasautua.

Eräässä toisessa 2000-luvun alussa suoritetussa tutkimuksessa kohteena olivat päiväkodin integroidut ryhmät (Tauriainen, 2000). Havaintona oli, että henkilökunnalla, lapsilla ja aikuisilla huomio painottuu päiväkotitoiminnassa eri asioihin. Aikuisille on tärkeää lapsen tulevaisuus, oppiminen ja kehittyminen. Lapset sen sijaan kiinnittävät pääasiallisen huomion nykyisyyteen. Tärkeitä heille on esimerkiksi kehon aistimukset, ystävyyssuhteet, vapaa ryhmätoiminta, aikuisilta suljetut leikkitilat, peuhaaminen, liikunta ja omaehtoinen toiminta. Jos nämä seikat pitävät paikkansa yleisemminkin, niillä on keskeinen merkitys myös lasten hyvinvoinnin ylläpitämisessä ja kehittämisessä.

Teoreettisesti perusteltua uusinta suomalaista varhaiskasvatusikäisten lasten hyvinvointitutkimusta edustaa Puroilan kumppaneineen (2012) tekemä laadullinen analyysisi lasten tuottamista kertomuksista koskien omaa hyvinvointia päiväkodissa. Käyttäen apuna Allardin (1976) hyvinvoinnin mallia tutkijat kuvasivat lasten ajatuksia suhteessa sille mitä voi saada ja omistaa (having), sosiaalisiin suhteisiin ja emootioihin (loving) sekä haluun olla hyväksytty sellaisena suhteessa kasvuun ja kehittymiseen, oppimiseen ja sen kyvykkyyteen sekä toimintaan (being). 
Saamiseen ja omistamiseen liittyen lapset liittivät hyvinvointiin tämän tutkimuksen perusteella hyvät fyysiset ja materiaaliset lapsia varten suunnitellut tilat ja materiaalit, jotka osin ovat yhteisiä mutta lapsi kaipaa myös päästä niihin käsiksi yksilönä (Puroila, 2012). Lapset nostivat esille esimerkiksi ruuan (mutta eivät välttämättä pitäneet syömisestä), työskentelytilan puutöille (johon pääsyä usein rajoitetaan), materiaalit, joihin voi itse keksiä käyttötarkoituksen (esim. oksaa käytetään miekkana, jonka käyttöä aikuiset usein rajoittavat), keinuminen (johon pitää miltei aina odottaa vuoroa) tai halun saada uusia leikkivälineitä (joita usein joutuu odottamaan). Sosiaalisiin suhteisiin ja niiden herättämiin tunteisiin lapset mainitsivat aikuinen-lapsi -suhteisiin ja toverisuhteisiin liittyviä ajatuksia. Aikuisen ja lapsen kohtaamisessa lapset toivovat saavansa päiväkodin aikuisiin samantapaisen turvallisen suhteen, johon he ovat jo tottuneet kotona. Lisäksi he toivovat yksilöllistä huomiota, leikkiä muiden kanssa, saavansa tunnustusta toiminnastaan, vapaata leikkiä, rauhaa aika ajoin istua hiljaa muiden kanssa, saavansa moitteita, kun on syytä siihen tai itkeä ilman mitään erityistä syytä. Lasten väliset vuorovaikutussuhteet ja niihin liittyvät kokemukset ilmenivät lasten kertomuksissa. Tovereita ja ystäviä odotetaan innolla, heidän kanssaan voidaan neuvotella, pelottavaksi koetaan hylätyksi tuleminen, pienimuotoista kiusoittelua tapahtuu jne. Lasten kokemuksissa suhteessa omaan kasvun ja kehittymiseen (beeing) lapset pohtivat kasvamista ja halua tulla varttuneemmaksi, henkilökohtaisia mieltymyksiä johonkin toimintaan (esim. musiikki, maalaaminen, päivärutiinit jne.), koululaiseksi kasvamista jne.

Lapsihaastattelujen perusteella muodostunut kuva lapsen hyvinvointiin päiväkodissa vaikuttavista keskeisistä kokemuksista voidaan pelkistää hyvinvointia ylläpitäviin ja sitä rajoittaviin tekijöihin (Puroila et al., 2012). Myönteisimmät kokemukset liittyvät toimintaympäristöön ja sen tarjoamiin materiaaleihin, lapset huomioiviin aikuisiin, hyviin ystäviin ja mielekkäiksi koettuihin aktiviteetteihin. Vähemmän myönteisimmissä kokemuksissa korostuivat päiväkodin rakenteelliset rajoitukset, lasten ja aikuisten välinen etäisyys, lapsiryhmästä poissulkeminen ja lasten kunnioittaminen. 


\section{Päivähoidon ja neuvolan yhteistyö lapsen hyvinvoinnin tukemisessa}

Sosiaali- ja terveysministeriön alaisuudessa käynnistetty Hyve-hanke on pyrkinyt kehittämään yhteistyötä yli hallintorajojen (Tarkka ym., 2013). Sen Hyve 4 -osahankkeella pyritään kehittämään päivähoidon ja terveyskeskusten yhteistyönä uutta hyvinvoinnin toimintamallia 4-vuotiaille lapsille ja heidän perheilleen. Kehittämisen taustana on uusi lastenneuvolaasetus, joka velvoittaa kunnat järjestämään laajennetut terveystarkastukset, jossa fyysisen hyvinvoinnin lisäksi tarkastellaan myös psykososiaalista hyvinvointia. Hanketta pyritään toteuttamaan niin, että tiedonsiirto ja yhteistyö päivähoidon varhaiskasvatussuunnitelman ja terveyskeskusten 4-vuotistarkastusten välillä kehittyy. Yhteistyön tavoitteena on lisätä myös lasten ja perheiden varhaista tukea. Pääkaupunkiseudulla Hyve 4 -hanketta on työstetty VKK- metron kehittämisprojektina, johon osallistuivat Helsingin yliopisto yhteistyössä Helsingin, Espoon, Vantaan ja Kauniaisen Katse-lapseen hankkeen tutkimuspäiväkotien ja neuvoloiden työntekijät.

Kehittämishankkeen yhteydessä on kehitetty strukturoitu varhaiskasvatuskeskustelurunko 4-vuotialle ja tiedonsiirtolomake päivähoidon ja neuvolan välille. Varhaiskasvatuskeskustelurunko sisältää vanhempien ja päivähoidon laadullista arviota 4-vuotiaan lapsen kehittymisestä sekä havaintoja kehittymiseen mahdollisesti liittyvistä huolenaiheista. Lapsen kehittymisessä kohdistetaan huomiota (a) tunne-elämän kehitykseen, sosiaalisiin taitoihin, vuorovaikutukseen ja leikkiin, (b) tarkkaavaisuuteen, motivoitumiseen, ajatteluun, muistiin ja oppimiseen, (c) kielelliseen kehitykseen ottaen huomioon myös maahanmuuttajataustaisen lapsen erityispiirteet ja vanhempien arviot sekä (d) motorisiin taitoihin ja omatoimisuuteen. Tiedonsiirtolomakkeessa päivähoidon ja neuvolan välille tiivistetään vanhempien ja päivähoidon näkemys 4-vuotiaan lapsen kehittymisestä eri alueilla perustuen varhaiskasvatuskeskusteluihin ja lapsesta tehtyihin havaintoihin.

Neuvolan tekemään laajennettuun 4-vuotiaiden tarkastukseen tiivistetään arviota lapsen vuorovaikutuksesta, leikistä, tarkkaavaisuudesta, puheen tuottamisesta ja ymmärtämisestä, kuullun hahmottamisesta, karkeamotoriikasta, silmän ja käden yhteistyöstä, omatoimisuudesta sekä näöstä, kuulosta ja poikkeavista liikkeistä. Näiden lisäksi mukaan voidaan liittää laajempaa lapsen kokonaistilanteen arviointia sisältäen havaintoja 
arviointitilanteesta sekä tiedonkeruusta vanhemmilta, hoitopaikasta, esikoulusta, lapsen aiemmasta kehityskulusta ja riskitekijöistä.

Erityisesti lapsen psykososiaalisen hyvinvointitiedon arviointi suhteessa lapsen kehittymisen on vaativaa. Pohdintaa aiheuttaa, mitkä ovat ne kehittymisen alueet, joiden oletetaan olevan keskeisiä lapsen hyvinvoinnille. Toinen keskeinen kysymys liittyy hyvinvointitiedon dokumentointiin. Yhteismitallisuuden lisäämiseksi tavoitteena on ollut kehittää lomakkeita, jotka ovat osin strukturoituja ja osin avoimia. Liitetaulukossa 5 on esimerkki keskustelurungosta, joka liittyy 4-vuotiaan lapsen hyvinvoinnin kuvaukseen kielellisen kehittymisen alueella.

Lapsen hyvinvointia kartoittavista lomakkeista on tehty arviointia pääkaupunkiseudulla (Laaksonen, 2011). Kun kohteena olivat kehityksen osa-alueet, ne oli nimetty ja ryhmitelty lomakkeissa (26 lomaketta) hieman eri tavoin. Vaihtelua esiintyi myös kuntien sisällä lomakkeesta toiseen. Arvion mukaan tietoa on kerätty vähän tai ei juuri ollenkaan esimerkiksi lapsen itsetunnosta (minäkäsitys), työskentelytaidoista (tarkkaavaisuus ja keskittyminen, oppimisvalmiudet, oman toiminnan ohjaus), ilmaisusta, matemaattisista valmiuksista, hienomotoriikasta ja visuaalisesta hahmottamisesta, katsomuskasvatuksesta sekä lasten vahvuuksista ja tavasta toimia.

Maassamme on alettu kiinnittää lapsen ja lapsiperheiden hyvinvoinnin tukemiseen enenevässä määrin huomiota järjestelmätasolla (Rimpelä, 2007). Ehdotuksena on ollut hyvinvointineuvolatoiminnan kehittäminen, jonka toimintaan voitaisiin liittää lapsiperheiden määräaikainen hyvinvointiarvio. Kohteena tulisivat olemaan lapsiperheet raskauden alusta 10. ikävuoteen asti. Tässä innovaatiossa lasten hyvinvointia voitaisiin tukea edistämällä myös isän ja äidin terveyttä ja hyvinvointia mahdollisimman varhaisen puuttumisen periaatteella.

\section{Avaus lapsen hyvinvoinnin ja voimavarojen arviointiin}

Pääkaupunkiseudun varhaiskasvatuksen kehittämisyksikkö VKK-Metron vuosina 2011-2013 toiminut Katse Lapseen -hanke on loppuraportissaan tuottanut kattavaa tietoa siitä, miten lasten ja perheiden hyvinvointia edistetään päiväkodeissa (Salmi \& Lipponen, 2013). Tuotetussa Hyvemallissa on kehitetty tapoja arvioida nelivuotiaan lapsen kehitystä ja hyvinvointia vanhempien, päivähoidon ja neuvolan yhteistyönä 4-vuotiaan 
lapsen hyvinvoinnin näkökulmasta. Päiväkodin ja neuvolan välille kehitettiin Hyve-tiedonsiirtolomake, jossa on hyödynnetty myös lapsen omia näkemyksiä omasta hyvinvoinnistaan, mielenkiinnonkohteistaan, haasteista ja mahdollisuuksista. Näin pyritään vahvistamaan myös lapsen tunnetta osallisuudesta.

Tuotettu Hyve-tiedonsiirtolomake sisältää kuvauksia lapsen sosiaalisista, inhimillisistä materiaalisista ja kulttuurisista voimavaroista sekä kuvauksia lapsesta päivähoidossa, lapsen ajatuksia ja lapsen kehittymisestä. Sosiaaliset voimavarat kiinnittyivät lapsen vuorovaikutustaitoihin ja empatiaan. Inhimillisissä voimavaroissa kiinnitettiin huomiota oppimiseen ja oppimisvalmiuksiin, kielellisiin ja motorisiin taitoihin, omatoimisuuteen, leikkitaitoihin, positiivisiin luonteenkuvauksiin sekä lapsen mielenkiinnon kohteisiin ja tunneilmaisuun. Materiaalisissa voimavaroissa pyrittiin kuvaaman lapsen hyvinvointia edistäviä tavaroita, tiloja tai fyysisiä järjestelyitä. Lapsen kulttuurisissa voimavaroissa kuvaukset kohdistuivat positiivisiin mainintoihin lapsen taidoista sopeutua toimintakulttuuriin ja siihen liittyviin sääntöihin ja ohjeisiin. Kuvaukset, joissa kohteena oli lapsi päivähoidossa, perustuivat numeerisiin arviointeihin (skaala 1=täysin eri mieltä - 5=täysin samaa mieltä) kuudella eri osa-alueella suhteessa lapsen päivähoitoryhmään (toimintaympäristö, päivärytmi, kaverit/ystävät, kiusaaminen, ryhmän aikuisten luottamus lapsen osaamiseen) ja vaikuttamisen mahdollisuuksiin itseä koskevissa asioissa. Yhteenvetona voi todeta, että kehitetty Hyve 4 -tiedonsiirtolomake haastaa monipuoliseen lapsen hyvinvoinnin dokumentointiin tavalla, jossa arvostetaan ja hyväksytään myös lapsen omia ajatuksia ja tulkintoja hänen omasta hyvinvoinnistaan.

\section{Lasten hyvinvoinnin seurannan haasteellisuus}

Lapsen hyvinvointia ajatellen kehityksen seurannassa pääkaupunkiseudulla käytetyt lomakkeet voivat antaa suppean kuvan. Esimerkiksi arvioinnin kohteina olleissa lomakkeissa (Laaksonen, 2011) oli vain harvoin tietoa kavereista, tärkeistä aikuisista, peloista ja osallisuudesta. Yksinoloa tai kiusaamista ei huomioitu lainkaan. Muiden maiden (esim. Englanti) hyvinvoinnin indekseissä on liitetty terveyden lisäksi havaintoja esimerkiksi lapsen perheestä, kodista, vertaisryhmästä, päiväkodista/koulusta, ajankäytöstä, valinnanmahdollisuuksista, osallisuudesta ja tulevaisuuden odotuksista (A guide to measuring children's well-being, 2009). 
Osa lapsen hyvinvoinnin indikaattoreista pyritään tekemään objektiivisiksi. Näyttää siltä, että lastenneuvoloiden määrävuotistarkistuksissa hankittu tieto täyttää pääosin tämän vaatimuksen. Sen sijaan päiväkodeissa hankittu psykososiaalinen hyvinvointitieto on pääosin subjektiivista. Tällaista tietoa tulisi tuottaa myös lapsilta itseltään kiinnittämällä huomiota esimerkiksi lapsen onnellisuuteen, tyytyväisyyteen ja arkipäivän kokemuksiin.

Lapsiperspektiivin korostaminen on ollut keskeinen motiivi lähestyä lapsen hyvinvointia. Esimerkiksi edellä esitettyä Puroilan ja kumppaneiden (2012) tapaa lähestyä hyvinvointia lasten kokemana ja kertomana voi pitää rohkaisevana suomalaisena esimerkkinä. Näitä ulottuvuuksia voisi olla tarpeen liittää mukaan täydentämään kokonaiskuvaa lapsen hyvinvoinnista.

Koska hyvinvointi koostuu monista toisiinsa liittyvistä tekijöistä, yksinomaan subjektiiviset hyvinvoinnin indikaattorit eivät ole riittäviä. Tämän vuoksi tarvitaan myös kriteeripohjaisia hyvinvoinnin indeksejä, joita voidaan suhteuttaa esimerkiksi lapsen kehittymiseen. Kehittymisessä voidaan kuvata esimerkiksi (a) fyysinen terveys ja motorinen kehitys (lääketieteelliset indeksit ja motorinen kehitys, (b) sosiaalinen kehitys, kognitio ja kompetenssi, (c) emotionaalinen terveys (ahdistuneisuus, ylivilkkaus, aggressiivisuus) sekä (e) kognitiivinen oppiminen, kieli ja kommunikaatio (A guide to measuring children's well-being, 2009). Kun näitä Englannissa tuotettuja indikaattoreita verrataan pääkaupunkiseudulla kokeilun alla olleisiin kuvauksiin, ne vastaavat kohtalaisen hyvin toinen toisiaan ehkä leikkiä ja omatoimisuutta lukuun ottamatta, joka korostuu suomalaisessa lapsen hyvinvoinnin tarkastelussa.

Uusinta lasten hyvinvoinnin lähestymistapaa edustaa ratkaisu, jossa asiantuntijat ja lapset/nuoret yhdessä osallistuvat hyvinvoinnin keskeisten ulottuvuuksien ja sisältöjen tunnistamiseen. Esimerkkinä tästä voisivat olla seuraavat lapsen hyvinvoinnin (lapset alkaen ikävuodesta 4) ulottuvuudet: (a) mahdollisuus vaikuttaa, toimijuus (agency), (b) turvallisuus, (c) oma minä toiminnassa, (d) aktiviteetit (niiden vapaus, pitäminen, ilo niistä), (e) vastoinkäymisen kohtaaminen, (f) materiaaliset ja taloudelliset resurssit, (g) fyysinen ympäristö, (h) fyysinen terveys, terveelliset ruokatottumukset ja aktiivisuus sekä (i) sosiaalinen vastuuntunto, moraali ja kuvaus missä kokee olevansa hyvä (Dex \& Hollingworth, 2012). 


\section{Lapsen osallisuus ja sen tukeminen}

\section{Osallisuuden luonnehdintaa}

Lapsen osallisuus on sisällytetty YK:n lasten oikeuksien julistukseen. Osallisuudessa on kysymys lapsen osallistumisesta häntä koskevaan päätöksentekoon, toimintaan ja prosesseihin ja toiminnan arviointiin. Osallisuuteen liittyy oikeus mielipiteiden ilmaisuun. Päätöksentekoon osallistumisessa lähtökohtana voidaan pitää sitä, että niillä, joihin päätöksenteko liittyy eniten, tulisi olla oikeus ilmaista myös eniten mielipiteensä. Osallisuutta voidaan edistää kasvatusinstituutioiden käytänteillä ja tukemalla kasvua aktiiviseksi kansalaiseksi. Eräs varhaiskasvatuksen keskeisistä uusimmista tutkimusaiheista on kohdistunut lapsen kuulemiseen ja osallisuuden tukemiseen.

Lasten osallisuus on ilmiönä moniulotteinen. Osallisuuden tutkimuksessa huomiota on kiinnitetty kolmeen keskeiseen toisiinsa liittyvään ulottuvuuteen (Lipponen, 2012; Kumpulainen ym., 2010), joita ovat pystyvyys, osallisuus ja toimijuus (agency). Pystyvyys on lapsen tietoisuutta omista kyvyistään suunnitella ja toteuttaa asioita. Pystyvyys muodostuu prosessissa, jossa lapsi oppi tietämään ja tuntemaan kuka hän on. Tämä mahdollistuu oppimisprosessissa, jossa lapsi oppii toimimaan sitoumusten ja tilanteen vaatimusten mukaan, tekemään aloitteita, vastustamaan, ottamaan ja antamaan apua. Osallisuus on lapsen käsitystä itsestä toimijana, jolla on oikeuksia ja velvollisuuksia. Osallisuus tapahtuu vuorovaikutuksessa, jossa lapsen ajatuksia, tietoja, taitoja ja tunteita muut arvostavat. Toimijuudessa on kysymys osallistumisesta toimintaan, jossa lapset ovat osallisena ja kanssatoimijoina. Toimijuuden mahdollistaa ja sitä pitävät yllä lapsen aloitteet. Näihin aloitteisiin pitäisi suhtautua kannustavasti, neuvottelevasti ja tukevasti.

Lapsuuden sosiologian näkökulmasta lasten osallisuus mahdollistaa myös sen, että lapset voivat ottaa osaa, muotouttaa ja rakentaa lapsuutta (James et al., 1998; Mayall, 2002; Prout \& James, 1997). Käsitys lapsista irrationaalisena ja kykenemättömänä suhteessa aikuiseen on väistymässä. Tämän tilalle on muotoutumassa näkemys lapsista vahvoina, voimakkaina ja kykenevinä toimijoina suhteessa myös aikuisiin ja vertaisryhmään (Dahlberg \& Moss, 2005). Lisääntyvät tutkimushavainnot osoittavat, että varhaiskasvatusikäiset lapset luovat aktiivisesti ja yhteistyössä sääntöjä 
vertaisryhmän toiminnalle, kehittävät strategioita itsensä arviointiin, pitävät yllä sääntöjä ja neuvottelevat sosiaalisesta asemasta (esim. Alcock, 2007; Markström \& Hallden, 2009). Havainnot suomalaisessa päiväkodissa osoittavat, että 2-vuotiaat lapset kykenevät luomaan yhdessä opettajan kanssa toimintakulttuuria prosessissa, johon sisältyy aikuisten pyrkimyksiä kanavoida lasten toimintaa sekä lasten pyrkimyksiä kokeilla ja vastustaa sääntöjä ja vallitsevia toimintarutiineja (Rutanen, 2007). 3-4 -vuotiaista tehdyt havainnot osoittavat, että lapsilla on tietoa, pyrkimyksiä ja toiminnallisia taitoja arvioida omaa autonomiaa ja edistää lapsiryhmän toimintaa kodin ulkopuolisessa kasvatusinstituutiossa (Ebrahin, 2011). Osallisuuden prosesseissa on havaittu, että yhteistyön ohella siihen liittyi vastustausta, välttämistä, torjumista.

Osallisuudessa voidaan kohdistaa huomio osallistumisen tasoon, päätöksentekoon osallisuudessa, osallistuvien toimintojen luonteeseen ja lapsen ominaisuuksiin osallistujina (Sinclar, 2004). Lapsen ikä määrittää hänen osallisuuttaan toimintaan ja oppimiseensa. Myös se, työskenteleekö lapsi asian parissa pitkään vai onko kyse kertaluontoisesta toiminnasta, vaikuttaa lapsen osallisuuden muotoutumiseen. Myös sillä on merkitystä, pyritäänkö lasten osallisuudella yhteiseen päätöksentekoon vaikuttamaan häneen itseensä, ryhmään vai yhteisöön.

Osallistuminen edellyttää vastavuoroisuutta, jossa opettaja on tietoinen omasta ja lasten toiminnasta ja hänellä on tämän vastavuoroisuuden perusteella halua muuttaa toimintaansa (esim. Boyden \& Ennew, 1997). Lasten osallistuminen vahvistaa heidän itsetuntoaan, kehittää päätöksentekotaitoja, suojelee lapsia ja parantaa lasten oikeuksia (Mayall, 1999; Sinclair, 2004). Keskeistä lasten osallistumisen tukemisessa on tutkijoiden mukaan reflektiivinen työtapa.

Keskeinen merkitys osallisuudella on lapsen oppimisessa (esim. Berthelsen, 2009). Osallisuus tekee oppimisesta kaksisuuntaista. Vuorovaikutus, johon lapsi osallistuessaan saa aikaan merkityksiä, syventää oppimista ja vahvistaa lapsen osallisuutta. Samalla lapsi tulkitsee ja uusintaa oppimisen kohteita, ympäristöä, kulttuuria ja sosiaalisia suhteita muokaten myös muiden osallisuutta (Corsaro, 1997).

Kontrollin tiukkuus vaikuttaa monella tapaa lasten osallistumiseen (Emilson \& Folkesson, 2006). Se vähentää lasten toimimisen mahdollisuuksia ja toimintamateriaalien valintaa. Myöskään dialogi opettajan ja lapsen välillä ei kehity suotuisasti. Tiukka kontrollin taso rajoittaa opettajaa 
tarkastelemasta asiaa lasten näkökulmasta. Kun opettajan kontrollin aste vähenee lasten ja opettajan välinen dialogi on vapaampaa, opettaja tarjoaa enemmän tukea, kuuntelee lapsia ja reagoi jatkuvasti lapsen aloitteisiin. Alhaisen kontrollin myönteinen vaikutus auttaa opettajaa kunnioittamaan lasten kommunikaatiota ja maailmaa sellaisena kuin se voidaan nähdä ja kuulla.

Lasten kuunteleminen kuuluu osana lapsen osallisuuden tukemiseen (Sinclair, 2004). Se on kuitenkin melko passiivinen keino ja tarvitsee tuekseen aktiivisempia keinoja kuten lasten ottaminen mukaan päätöksentekoon sekä työ- ja toimintatapojen muuttamista lasten osallistumisen lisäämiseksi kunnioittaen lapsen ääniä ja näkemyksiä. Keskeistä muutoksessa on, että lapset näkevät ja kokevat ne mielekkäinä ja että niillä on vaikutusta. Lasten osallisuuden lisäämisessä on tärkeää antaa siitä informaatiota, lisätä tukea, parantaa aikuisten ja lasten välistä vuorovaikutusta, kehittää kasvatuskäytäntöä ja kommunikaation taitoja sekä lisätä luottamusta lapsiin.

Lapsen osallisuuden tukeminen edellyttää usein sitä, että aikuinen oppii uusia työskentelytapoja, joiden avulla lapsia voidaan tukea tuomaan esille omia näkemyksiään, kehittämään omia näkemyksiään, tekemään yhdessä päätöksiä ja toimimaan ryhmässä (esim. Kirby \& Gibbs, 2006). Tuessa voidaan käyttää sekä lapsilähtöisiä että aikuisjohtoisia toimintatapoja. Lapsilähtöisintä toimintatapaa edustaa ratkaisu, jossa aikuinen jättää lapsen toimimaan yksin olleen kuitenkin saatavilla tarvittaessa. Aikuisjohtoisin tapa on toimia niin, että lasten aloitteet ja näkemykset jätettään pääsääntöisesti ottamatta huomioon. Näiden kahden ääripään väliin sijoittuvat lapsilähtöisestä käsin tarkasteltuna havainnointi, tekeminen mahdolliseksi, toiminta, neuvonta ja informaation antaminen. Esiintyy kuitenkin näkemyksiä, joiden mukaan lapsikeskeisellä lähestymistavalla aikuinen herkistyy paremmin lasten osallisuuteen kuin aikuiskeskeisellä (Mayall, 2002; Sinclair, 2004).

Lapsia kunnioittava tukeva kasvatuskäytäntö perustuu lasten aktiiviseen kuunteluun, reflektointiin, keskusteluun, väittelyyn ja tulkintaan (Dahlberg \& Moss, 2005). Tässä prosessissa sekä aikuisten että lapsen näkemys on tärkeää. Vaikka reflektiivinen lähestymistapa on keskeistä lasta ja hänen osallistumistaan tukevassa pedagogiikassa, huomiota tulisi kiinnittää osallisuuden aktiiviseen kehittämiseen. Aktiiviset kasvattajat ovat myös kriittisiä reflektoinnissaan, joka mahdollistaa muutoksen. 
Lasten osallisuutta ei ole läsnä kasvatusinstituutiossa ilman aikuisten sitoutumista osallisuuden tukemiseen (Emilsson \& Johansson, 2009). Yhteiskunnan demokraattiset arvot korostavat osallisuutta. Ne muuttuvat todellisiksi vasta kun niitä tarjotaan lapselle. Lapsi ei voi valita osallisuutta, ellei aikuinen tarjoa hänelle siihen mahdollisuutta.

Osallistumisessa on keskeistä päätöksenteko, joka koskee sekä yksityistä lasta että lapsia yhteisössä (Thomas, 2007). On myös keskeistä tiedostaa, että on olemassa osallistumista ja aktiivista osallistumista (Sinclair et al., 2004). Edellistä pidetään yllä kuuntelemisella ja neuvojen antamisella. Aktiivisessa osallisuudessa lapset voivat ymmärtää, että heidän osallisuutensa otetaan vakavasti ja tällä on todellista merkitystä. Yhteisöllinen osallisuus kohdistuu lasten oikeuksien ylläpitämiseen, ammatillisen etiikan toteuttamiseen, kasvatuskäytännön kehittymiseen, päätöksentekokäytänteiden kehittämiseen, lasten taitojen kehittämiseen sekä lasten itsetunnon tukemiseen. Yksilöllisyys-yhteisöllisyys -ulottuvuuden lisäksi keskeistä on tarkastella osallisuutta myös ulottuvuudella, jossa osallisuutta tukevaa käytäntöä joko muutetaan tai sitä ei pyritä muuttamaan (esteet).

\section{Osallisuuden kehittyminen ja kehittäminen}

Osallisuuden kehittämisessä on ollut suurta merkitystä Shierin (2001) ideoimalla osallisuuden tasomallilla (Venninen et al., 2010). Malli tarkastelee osallisuutta aikuisen ja lapsen välisen vuorovaikutuksen kautta (Taulukko 3).

Kuulluksi tuleminen edustaa tässä mallissa ensimmäistä osallisuuden tasoa. Kysymyksessä on myös nähdyksi ja kohdatuksi tuleminen. Kasvattajan havainnointitaidot ja kyky lukea lapsen ilmaisua kokonaisvaltaisesti ovat tällä tasolla tärkeitä toiminnallisia valmiuksia. Toisen tason toiminnoissa lapsia osallistetaan tukemalla heitä ilmaisemaan mielipiteitään ja näkemyksiään. Kasvattaja pyrkii toimillaan mahdollistamaan lapsen luottamuksen syntymisen sekä luomaan vuorovaikutustilanteita, joissa lapsi kokee, että hänen asiaansa halutaan kuulla ja hänen ilmaisullaan on merkitystä. Tunnusomaista osallisuuden kolmannelle tasolle on lasten mielipiteiden huomioon ottaminen. Tätä tukevissa kasvatusmenettelyissä herkistytään lapsen ilmaisuihin ja näkemyksiin sekä lapsen toimintaan. Edellä mainittuja osallisuuden tasoja tulisi huomioida lapsiryhmän yhteistä toimintaa suunniteltaessa ja toteutettaessa, rakentamalla suunnitelmia lapsilta 
saatujen aloitteiden, tarpeiden ja kiinnostuksenkohteiden varaan sekä antamalla lapsille palautetta siitä, miten lasten ajatukset näkyvät toiminnassa. Perustelut myös sille, miksei kaikkia toiveita voida toteuttaa juuri sellaisina tai miksi ryhmässä tehdään kompromisseja lasten näkemysten välillä, auttavat lapsia ymmärtämään omia vaikutusmahdollisuuksiaan. Näillä kolmella osallisuuden tasolla aikuinen mahdollistaa lasten osallisuutta.

Taulukko 3. Lapsen osallisuuden tasot ja kasvattajan toimenpiteet (Shier, 2001; Venninen et al., 2010)

\begin{tabular}{|c|c|c|c|}
\hline $\begin{array}{l}\text { Lapsen osalli- } \\
\text { suuden tasot }\end{array}$ & $\begin{array}{l}\text { Aikuinen avautuu } \\
\text { ja hänellä on aito } \\
\text { halu toteuttaa } \\
\text { lapsen osallisuus }\end{array}$ & $\begin{array}{l}\text { Aikuinen tekee } \\
\text { mahdolliseksi } \\
\text { toteuttaa lapsen } \\
\text { osallisuuden }\end{array}$ & $\begin{array}{l}\text { Aikuisella on } \\
\text { valmiita toiminta- } \\
\text { tapoja toteuttaa } \\
\text { lapsen osallisuutta }\end{array}$ \\
\hline $\begin{array}{l}\text { 1. Lapset tulevat } \\
\text { kuulluksi }\end{array}$ & $\begin{array}{l}\text { Valmius kuuntele- } \\
\text { miseen }\end{array}$ & $\begin{array}{l}\text { Työskentelee lasta } \\
\text { kuullen }\end{array}$ & $\begin{array}{l}\text { Toiminnassa on } \\
\text { vakiintunut tapa } \\
\text { kuunnella lasta }\end{array}$ \\
\hline $\begin{array}{l}\text { 2. Lapsia } \\
\text { autetaan } \\
\text { ilmaisemaan } \\
\text { näkemyksiä }\end{array}$ & $\begin{array}{l}\text { Valmius tukea } \\
\text { lasta ilmaisemaan } \\
\text { näkemyksiään }\end{array}$ & $\begin{array}{l}\text { Työskentelee } \\
\text { tukien lasta } \\
\text { ilmaisemaan } \\
\text { näkemyksiään }\end{array}$ & $\begin{array}{l}\text { Toiminnassa on } \\
\text { vakiintunut tapa } \\
\text { tukea lapsia ilmai- } \\
\text { semaan näkemyk- } \\
\text { siään }\end{array}$ \\
\hline $\begin{array}{l}\text { 3. Lasten mieli- } \\
\text { piteet otetaan } \\
\text { huomioon }\end{array}$ & $\begin{array}{l}\text { Valmius ottaa } \\
\text { huomioon lasten } \\
\text { mielipiteet }\end{array}$ & $\begin{array}{l}\text { Päätöksentekopro- } \\
\text { sessissa otetaan } \\
\text { huomioon lasten } \\
\text { mielipiteet }\end{array}$ & $\begin{array}{l}\text { Lasten mielipiteille } \\
\text { annetaan niille } \\
\text { kuuluva arvo } \\
\text { päätöksenteko- } \\
\text { prosessissa }\end{array}$ \\
\hline $\begin{array}{l}\text { 4. Lapset ote- } \\
\text { taan mukaan } \\
\text { päätöksenteko- } \\
\text { prosessiin }\end{array}$ & $\begin{array}{l}\text { Valmius ottaa lapsi } \\
\text { mukaan päätök- } \\
\text { sentekoprosessiin }\end{array}$ & $\begin{array}{l}\text { Toimintatavat } \\
\text { sallivat lasten } \\
\text { ottamisen mukaan } \\
\text { päätöksentekoon }\end{array}$ & $\begin{array}{l}\text { Lapset otetaan } \\
\text { mukaan päätök- } \\
\text { sentekoon }\end{array}$ \\
\hline $\begin{array}{l}\text { 5. Lapset jakavat } \\
\text { vallan ja vastuun } \\
\text { päätöksenteko- } \\
\text { prosessissa }\end{array}$ & $\begin{array}{l}\text { Valmius jakaa } \\
\text { aikuisen valtaa } \\
\text { lasten kanssa } \\
\text { päätöksenteko- } \\
\text { prosessissa }\end{array}$ & $\begin{array}{l}\text { Toimintatavat } \\
\text { sallivat vallan ja } \\
\text { vastuun jakamisen } \\
\text { aikuisten ja lasten } \\
\text { keskinäisessä } \\
\text { päätöksenteko- } \\
\text { prosessissa }\end{array}$ & $\begin{array}{l}\text { Lapset ja aikuiset } \\
\text { jakavat vallan ja } \\
\text { vastuun päätök- } \\
\text { senteossa }\end{array}$ \\
\hline
\end{tabular}


Mallin neljännelle tasolle on tunnusomaista kasvatustoimenpiteet, joissa lapset osallistuvat aikuisen kanssa päätöksentekoon ja sitä edeltävään suunnitteluun. Mahdollistaessaan lasten osallistumisen suunnitteluun ja päättämiseen kasvattajat luopuvat vallastaan ohjata ylhäältäpäin lasten toimintaa. Tämä saattaa alussa johtaa jonkinasteiseen sekasortoon ja välttämättä yhdessä päätetyt toiminnot, säännöt ja asiat eivät heti onnistu. Lapsen osallistuminen päätöksen tekemiseen edellyttää mahdollisuuksia harjoitella ja kokeilla toiminnan edellytysten ja toiminnan riittävyyttä. Kasvattajalta edellytetään taitoa muuttaa suunnitelmia ja tämä tulisi selostaa myös lapsille perusteluineen. Viidennelle osallisuuden tasolle on tunnusomaista pyrkimys käytäntöön, jossa lapset jakavat valtaa ja vastuuta päätöksenteossa aikuisten kanssa ja saavat kokemuksia vastuuseen kasvamisesta ja onnistuneista yhteisistä ponnistuksista yhteisten tavoitteiden eteen.

Myös Reunamo (2007) on kehittänyt mallin lapsen osallisuuden tukemiselle. Idea perustuu lapsen osallistuvaan näkemykseen päiväkodin vuorovaikutustilanteissa. Tässä mallissa lapsen osallistuvia näkökulmia tarkastellaan kahden perusulottuuden avulla. Näistä toinen liittyy lapsen valmiuteen muokata omia näkökulmiaan ympäristön asettamien tilanteiden mukaisesti. Toisena ulottuvuutena on näkökulma, jossa lapsi pyrkii muuttamaan ympäristön asettamien tilanteiden ehtoja. Reunamon mukaan osallistuva näkemys toteutuu parhaiten silloin, kun lapsen näkemys liittyy tilanteisiin ja ympäristössä on tapahtunut muutosta. Tällöin lasten huomio voi kohdistua tavanomaista laajemmalle ja vuorovaikutustilanteisiin haetaan muutosta.

\section{Lapsen osallisuus ja sen esteitä päiväkodin käytänteissä}

Kattavan kuvan lapsen osallisuudesta voi saada VKK-Metron kehittämishankkeesta, jossa kerättiin aineistoa Helsingin, Vantaan, Espoon ja Kauniaisen päiväkodeista. Lapsen osallisuutta koskevaan selvitykseen vastasivat kasvatus- ja opetushenkilöstö tiimeissä, joita oli 1143 (Venninen et al., 2010). Tuloksissa ilmeni, että lapsilla oli suurin päätösvalta leikkeihin ja taidepainotteisten aktiviteettien materiaalien valintaan. Vähiten mahdollisuutta oli vaikuttaa perushoitoon sekä ympäristön ja sen ilmiöiden tutkimiseen. 
Tulosten mukaan päiväkodin säännöt sekä tukivat että rajoittivat lapsen osallisuutta. Valtaosa lasten leikkitoiminnan säännöistä arvioitiin lasten osallisuutta tukeviksi. Useimmiten mainittu sääntö olivat se, että kaikki otetaan mukaan leikkiin, mutta myös oikeus valita leikki ja leikkikaverit sekä mahdollisuus leikkiä yksin mainittiin. Rajoittavina sääntöinä tuli esiin lasten lukumäärän rajoittaminen leikkipisteisiin, leikin lopettaminen ja leikin häiritsijän pois sulkeminen. Vuorovaikutukseen ja ryhmän keskinäiseen kanssakäymiseen liittyviä sääntöjä tunnistettiin päiväkodeissa runsaasti. Painotus oli kaveruussäännöillä ja keskustelusäännöillä. Sosiaaliset säännöt nähtiin valta osin lasten osallisuutta edistäviksi. Estäviä sääntöjä tunnistettiin varsin vähän ja ne kohdistuivat lähinnä vuoron ja puheenvuoron odottamiseen sekä käytöstapoihin.

Myös aikuisten toimintaa koskevat säännöt nähtiin päiväkodeissa sekä lapsen osallisuutta rajoittavina että sitä tukevina (Venninen et al., 2010). Osallisuutta tukevina korostettiin lapsen kuulemista, lasten aloitteiden huomioon ottamista, aikuisen kysymistä lapsilta, ristiriitojen ratkaisemista yhdessä ja lapsen kunnioittamista. Aikuisjohtoiset säännöt olivat usein niitä, joita pidettiin lasten osallistumisen esteinä. Päiväkodeissa kiellettyjä toimintoja olivat useasti toisten huono kohtelu ja kiusaaminen sekä toisten vahingoittaminen. Monissa päiväkodeissa oli myös liikkumista rajoittavia sääntöjä sekä turvallisuutta ylläpitäviä sääntöjä.

Lasten osallisuuden esteet voitiin jakaa kolmeen ryhmään (Venninen et al., 2010). Osa oli sellaisia, joihin aikuiset eivät voineet vaikuttaa. Näitä olivat esimerkiksi henkilökunnan ja lasten määrä. Osa oli sellaisia, joihin aikuiset katsoivat voivansa vaikuttaa jossain määrin. Näitä olivat aikuisten väsymys ja vanhempien odotukset. Kolmanteen ryhmään kuuluivat esteet, joihin aikuiset katsoivat voivansa itsenäisesti vaikuttaa. Näitä olivat etenkin rutiinit, piintyneet toimintatavat, toimintojen ajoitus, keskittymättömyys, tarve aikuiskontakteihin sekä puutteet organisaatiossa.

\section{Lapsen osallisuuden kehittäminen päiväkodeissa ja esiopetuksessa}

VKK-Metro hankkeen tutkimuspäiväkodeissa seurattiin ja arvioitiin lapsen osallisuuden kehittymistä vuosina 2010-2011 (Venninen et al., 2011). Vuonna 2010 tutkimuspäiväkotien tiimeistä 94 vastasi kyselyyn ja vuonna 2011 tiimivastaukset saatiin 74 tiimiltä. Vertailu suoritettiin molempina 
vuosina vastanneiden tiimien osalta sekä avoimien vastausten että asteikollisten muuttujien osalta. Osallisuuden kehittymistä lähestyttiin Shierin (2001) tasomallin pohjalta, jota on edellä selostettu tarkemmin. Tulokset lapsen osallisuuden kehittymistä eri tasoilla on esitetty kuvassa 1.

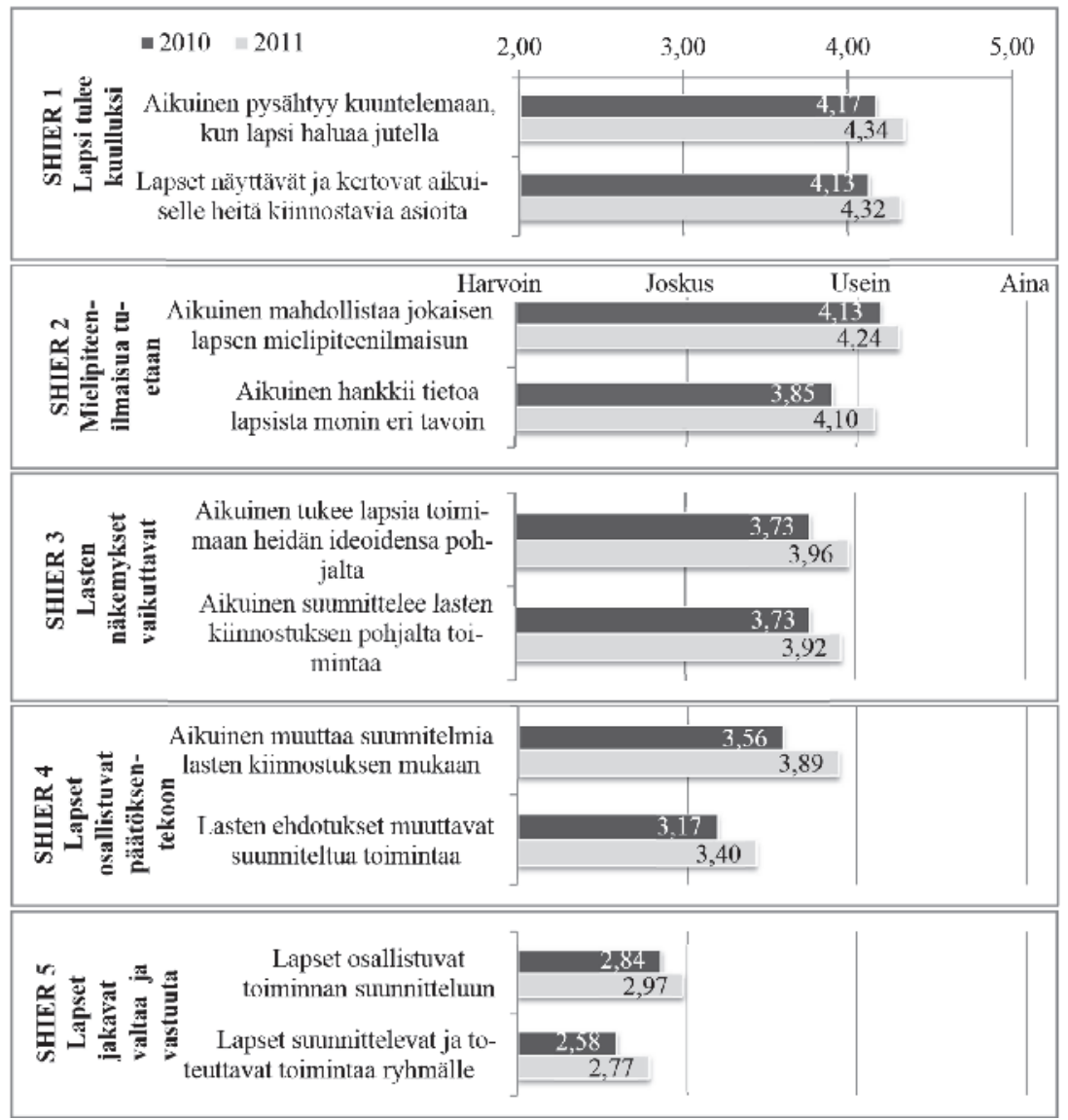

Kuva 1. Osallisuuden tasojen kehittyminen VKK Metro -tutkimuspäiväkodeissa vuosina 2010-2011 (Venninen et al., 2011). Arvot kuvaavat tiimivastausten keskiarvoja asteikolla $1-5$ ( $1=$ ei koskaan, $2=$ harvoin, $3=$ joskus, $4=$ usein, $5=$ =aina). 
Tulokset osoittavat, että päiväkodeissa tapahtunut herkistyminen lapsen osallisuuden tukemiseen on tuottanut tulosta. Seurannan perusteella lasten osallisuus oli kehittynyt positiiviseen suuntaan kaikilla osallisuuden tasoilla. Lasten osallisuus oli tiimien arvioinnin mukaan kehittynyt erityisesti osallisuuden tasolla, jonka keskiössä on lasten tukeminen omien näkemysten ilmaisussa. Myös tätä vaativimmissa osallisuuden tasoissa, joissa tavoitteena on ollut lasten ottaminen mukaan päätöksentekoon ja vallan ja vastuun jakaminen lasten ja aikuisten kesken päätöksenteossa, lapsen osallisuuden kehittäminen on edistynyt päiväkodeissa. Tulokset osoittavat, että osallisuuden tietoinen kehittäminen on herkistänyt varhaiskasvattajia tukemaan lasten osallisuutta kokonaisvaltaisesti, eikä siinä ole rajoituttu kehittämään vain osallisuuden joitain tasoja. Lasten osallisuus on tutkimuspäiväkodeissa otettu osaksi arjen toimintaa ja lasten osallisuutta on opittu mahdollistamaan monissa arjen toiminnoissa.

Lapsen osallisuuden kehittymistä tarkasteltiin tutkimuspäiväkodeissa myös suhteessa lasten toimintamahdollisuuksiin (Venninen et al., 2011). Seurannan tulokset osoittavat, että ne olivat edelleen kehittyneet toimintavuoden aikana. Esimerkiksi lasten mahdollisuudet vaikuttaa fyysiseen ympäristöönsä ja siinä toimimiseen olivat parantuneet. Vastaavasti arviot, joissa lapset eivät voineet koskaan vaikuttaa asiaan, olivat vähentyneet. Myös lasten mahdollisuudet vaikuttaa taiteelliseen toimintaan oli parantuneet ja arviot, joiden mukaan lapset eivät koskaan voineet vaikuttaa asiaan, olivat vähentyneet. Tuloksissa oli havaittavissa, että lasten toimintamahdollisuuksien paraneminen oli yhteydessä aikuisen sitoutumisen kasvuun. Useissa arvioissaan tiimit kuvasivat aikuisen roolin keskeisyyttä lasten toiminnan mahdollistajana.

\section{Kansainvälisiä periaatteita lasten osallisuudesta}

Kansainvälinen järjestö "Save the Children" on pyrkinyt kiteyttämään periaatteita, joilla tehdään tietoiseksi ja pyritään edistämään lapsen osallisuutta (Standards in children's participation, 2005). Päätavoitteina on edistää lapsen kunnioitusta ja arvostusta sekä herkistää kuuntelemaan lapsia ja oppia tästä. Toivomuksena on, että jokaiseen lapseen tulee suhtautua toiveikkaasti ja tarjota hänelle mahdollisuuksia osallisuuteen. Periaatteet on kiteytetty seitsemään ulottuvuuteen. 
Ensimmäisessä korostetaan eettistä suhtautumista ja asennoitumista aikuisen ja lapsen väliseen valtarakenteeseen. Eettinen sitoutuminen on tärkeää, jotta osallisuus perustuu lapsen parhaaksi eikä aikuisen ja lapsen väliseen valtarakenteeseen ja erilaiseen statukseen. Aikuisen suhtautuminen lapseen tulisi olla aitoa, läpinäkyvää, kunnioittavaa ja vastuullista. Lapsilla tulee olla oikeus ilmaista vapaasti mielipiteitään. Lapsen tulisi voida tietää mahdollisuutensa osallistua heitä koskevaan päätöksentekoon alusta alkaen.

Aikuisten ja lasten rooleista toiminnassa ja sen suunnittelussa on tarpeen sopia yhteisymmärryksessä. Aikuisen tulisi antaa riittävää ja jatkuvaa informaatiota lasten osallisuudesta ja toteutumisesta. Lapset tarvitsevat ammattikasvattajien ja vanhempien sekä tarpeen vaatiessa lähiyhteisön tukea osallisuuteen kasvamisessa. Tämä vahvistaa demokratiaa ja on omiaan vähentämään syrjäytymistä ja eriarvoisuutta. Osallisuuden toteutumisesta tulee keskustella lasten kanssa. Tässä yhteydessä tulee pohtia myös osallisuuden esteitä.

Toisessa periaatteessa korostetaan lasten osallisuuden vapaaehtoisuutta. Vapaaehtoisuus ymmärretään niin, että lapsi voi milloin tahansa niin halutessaan irtautua osallisuudesta. Osallisuudelle tulisi tarjota riittävästi aikaa ja resursseja. Osallistumisessa tulisi ottaa huomioon lasten muut sitoumukset ja toiminnat esimerkiksi päiväkodissa, esikoulussa, koulussa ja kotona. Näitä pitää kunnioittaa. Osallisuutta tulisi toteuttaa tavalla ja puitteissa, joka on sopusoinnussa lapsen kykyihin ja mielenkiinnon kohteisiin. Lapset olisi otettava mukaan osallisuuden suunnitteluun. Toimintaympäristössä olevat avaintoimijat tulisi ottaa mukaan lasten osallisuuden avustamiseen ottaen huomioon sekä työt että pojat.

Kolmas periaate kiinnittää huomiota lapsiystävälliseen ja sallivaan toimintaympäristöön, jossa lapsi voi kokea turvallisuutta, on tervetullut ja joka rohkaisee osallisuuteen. Osallisuuden laatuun ja sen tuloksellisuuteen myötävaikuttaa suuresti sitä tukeva myötämielinen toimintaympäristö. Osallisuuden tulee tukea lapsen itsearvostusta ja luottamusta tytöillä ja pojilla sekä eri-ikäisillä ja erilaisin kyvyin omaavilla lapsilla. Osallistuminen perustuu aikuisten ja lasten väliseen kumppanuuteen, johon tarvitaan yhteistä kasvua ja kehittymistä. Osallisuudelle tulisi tarjota riittävästi aikaa ja resursseja. Ammattikasvattajilta ja vanhemmilta edellytetään herkkyyttä ja positiivista asennoitumista lasten osallisuuden ymmärtämiseen. Osallistumista tuetaan järjestämällä lapsiystävällisiä ja ilmapiiriltään miellyttäviä 
kokoontumisia, joihin voivat osallistua myös erityisen tuen tarpeessa olevat lapset. Tieto ja kokemuksia jaetaan. Lapsilta tiedustellaan millaista informaatiota he tarvitsevat osallisuudesta. Informaatio tulisi tarjota sellaisessa muodossa ja kielellä, jonka lapsi ymmärtää myös silloin kun lapsella on esimerkiksi kielen, näön tai kuulon vajavuuksia. Erityistä huomiota tulee kiinnittää informaatiossa lapsiin, joiden äidinkieli poikkeaa valtakulttuurista. Liiaksi teknisen kielen käyttöä tulee välttää.

Neljännessä periaatteessa kiinnitetään lisää huomiota tasavertaiseen osallistumisen mahdollisuuteen. Lapsen osallisuutta tukeva toiminta on haasteellista eikä siinä ole tilaa lasten syrjinnälle ja poissulkemiselle. Juuri syrjäytymisuhan alla oleville lapsille osallisuus on erityisen tärkeää. Lapsilla tulee olla tasa-arvoinen mahdollisuus osallisuuteen iästä, rodusta, sukupuolesta, kielestä, kehittymisen viivästymisestä, sosio-ekonomisesta taustasta tai etnisestä taustasta riippumatta. Kaikkien eikä vain harvojen lasten tulee päästä osallisuuteen. Tämän vuoksi osallisuuden toteutuksen tulee olla joustavaa ja ottaa huomioon lasten erilaiset tarpeet. Lasten iän, sukupuolen ja kyvykkyyden vaihtelu tulee otattaa huomioon. Jos osallistuvien lasten määrää on syystä tai toisesta tarpeen rajoittaa on suositeltavaa, että lapset itse valitsevat demokraattisten periaatteiden mukaan keskuudestaan edustajansa osallistuvaan toimintaan. Perheen ja lähiyhteisön tuki osallisuudessa on tarpeellinen syrjäytymisuhan alla oleville lapsiryhmille.

Viides periaate kohdistaa huomion kasvatushenkilöstöön. Erityistä huomiota tulee kiinnittää henkilöstön tehokkuuteen ja luottamukseen osallistaa lasta. Henkilöstöltä edellytetään korkeaa koulutusta, ammattitaitoa ja ymmärrystä osallisuudesta. Herkkyys ja sitoutuminen osallisuuden toteuttamiseen ja edistämiseen on tärkeää. Ammatillisessa koulutuksessa tulee antaa tietoja, taitoja ja valmiuksia lapsen osallisuudesta ja sen toteuttamisesta, jotta kasvattajat ja opettajat kykenevät osallistuvaan työtapaan eriikäisten ja erilaisten lasten kanssa. Tässä tehtävässä kasvattajat ja opettajat tarvitsevat ammatillista tukea ja arviointitaitoja. Ammatillisessa kehittymisessä kohteina voivat olla esimerkiksi kommunikointitaidot, konfliktien ratkaisu, monikulttuuriset lapset ja vanhemmat. Tiimityöskentely lapsen osallisuudessa on tärkeää ja sen tulee perustua toinen toistensa kunnioittamiseen ja rehellisyyteen. On myös tärkeää, että kasvattajat ja opettajat voivat ilmaista aidosti ja rakentavalla tavalla näkemyksiään ja huoliaan lasten osallisuudesta niin että niistä ei muodostu ongelmia. 
Kuudennen periaatteen keskeisenä kohteena ovat lapset. Osallistumisen tulee tukea lapsen turvallisuutta ja suojella lasta. Kasvatuksesta ja opetuksesta vastaavien tahojen tulee minimoida riskit ja mahdolliset negatiiviset seuraukset toiminnasta, jossa osallistetaan lasta. Mahdollisia riskejä tulee arvioida ja tässä tulee kiinnittää huomiota myös lapsen suojelemiseen toisten lasten väärinkäytöksiltä ja epätarkoituksenmukaisesta käyttäytymisestä. Kasvatuksesta ja opetuksesta vastaavien tulee tiedostaa omat lailliset ja eettiset oikeutensa ja velvollisuutensa koskien omaa ja toisten käyttäytymistä. Tässä yhteydessä on syytä pohtia esimerkiksi sitä, miten menetellään, jos havaitsee toisten käyttäytymisessä osallistumista ehkäisevää käyttäytymistä. Näitä tilanteita on tarpeen dokumentoida ja pohtia yhdessä henkilöstön kesken. Erityistä huomiota tulee kiinnittää lapsiin, joiden perusturvallisuus on uhattuna ja jotka tarvitsevat ylimääräistä tukea ja apua sekä osallisuuden esteiden poistamista. Osallisuuden esteitä ja puutteita tulee seurata tarkoin ja arvioida. On myös oltava valmius ryhtyä tarvittaviin jatkotoimenpiteisiin ja pidempiaikaiseen seurantaan osallisuuden tukemiseksi. Osallisuutta koskevan tiedon tulee olla luottamuksellista. Epäkohdista tulee voida ilmaista ja niistä tulee voida keskustella luottamuksellisesti. Menettelytavat epäkohtien ilmaisuun ja käsittelyyn tulee suunnitella ja varmistaa, että ne ovat saatavilla muodossa ja kielellä, joka ei sulje pois ketään ryhmää (esim. monikulttuurisuus, vähemmistökielet jne.). Osallistuva toiminta tulee nähdä lapsen oikeutena.

Seitsemännessä lasten osallisuutta koskevassa periaatteessa kohdistetaan huomio jatkuvan seuraamisen ja arvioinnin merkitykseen. Kunnioitus lapsen osallisuuteen osoitetaan sitoutumalla jatkuvaan seurantaan ja arviointiin osallisuudesta kiinnittäen erityistä huomiota sen laatuun ja merkitykseen. Tässä yhteydessä on tärkeää, että lapsille muodostuu käsitys heidän osallisuutensa vaikutuksista ja merkityksestä. On myös eduksi, että lapset voivat tavalla tai toisella osallistua seurantaan ja arviointiin, jossa he ovat olleet kohteena ja joka koskee heitä. Lapset odottavat välitöntä ja selkeää palautetta osallisuudestaan. Palautteen tulee kohdistua kaikkiin lapsiin. Lasten tyytyväisyydestä osallisuuteen on tärkeää saada palautetta samoin kuin lasten näkemyksistä tavoista parantaa osallisuutta. Kasvattajilta ja opettajilta odotetaan jatkuvaa ja välitöntä kommentointia ja palautetta osallisuudesta, joka tulee antaa tavalla ja kielellä, jonka lapset kokevat ystävälliseksi ja jonka he ymmärtävät. Virheet ja puutteet tulee tunnistaa ja parantaa osallistuvaa toimintatapaa. Kasvattajat ja opettajat keskustelevat 
ja arvioivat lasten osallisuutta suhteessa omaksuttuun toimintatapaan sekä ideoivat ja ehdottavat tehokkaampia toimintatapoja. Tarpeelliseksi katsottuihin tukitoimenpiteisiin ryhdytään.

\section{Johtopäätöksiä}

Lapsen osallisuuden kehittämisen tekevät tärkeäksi ainakin seuraavat perustelut. Ensinnäkin osallisuus kuuluu lasten perusoikeuksiin. Toiseksi lapsilla ovat luontaiset edellytykset ja herkkyys kuvata asioita omasta perspektiivistään käsin. Kolmanneksi osallisuus lisää lasten itseluottamusta ja tietoisuutta omasta itsestä. Neljänneksi osallisuuden kautta lapset oppivat yhteistyötaitoja sekä aikuisiin että toisiin lapsiin. Viidenneksi kasvatuskäytännöissä, joissa korostetaan lapsen osallisuutta, herkistytään lapsen tarpeisiin. Kuudenneksi lasten osallisuus on omiaan lisäämään yleistä kiinnostusta lapsen kehitystarpeisiin ja heidän asemaansa yhteiskunnassa. Seitsemänneksi lapset osallistuvat erilaisella syvyydellä ja eri tavoin toimintaan riippuen heidän iästään ja toiminnan puitteista. 


\section{Leikin monet mahdollisuudet}

\section{Leikin olemus}

Leikki ja sen merkitys on kiinnostanut jo pitkään (esim. Goldstein, 2012). Pohdinnassa ovat olleet mukana monen tieteenalan edustajat ja ajattelijat. Varhaisimmat teoriat leikistä esitettiin 1800-luvun lopulla ja 1900 luvun alussa. Näissä miellettiin leikki välineenä lapsen ylimääräisen energian purkamiselle, jonka avulla lapsi vapauttaa sisäisistä energiaansa ja ympäristön aiheuttamia esteitä ja rajoituksia (Spencer). Hieman toisenlaisen tulkinnan mukaan (Lazarus, Patrick) leikki voi toimia keskeisenä levon ja rentoutumisen välineenä toiminnassa, joka on suhteellisen uutta lapsille. Näitä tilanteita lapsi kohtaa alinomaa erityisesti varhaislapsuudessa. Esitettiin myös näkemys, jonka mukaan leikin avulla lapsi harjoittelee taitoja, joita hän tarvitsee myöhemmin selvitäkseen elossa (Gross). Tässä yhteydessä viitattiin esimerkiksi eläinten tai lasten leikkimieliseen taisteluun. Rekapitulaatioteorian (Hall; Wund) mukaan lapsi käy leikin kehityksessä läpi kerraten vaiheita, joita ihmiskunta on käynyt lävitse kulttuurisen kehittymisen saatossa. Kysymyksessä ovat kulttuuriset rituaalit, joita ihmisillä on esiintynyt pitkän kehityskaarensa aikana villi-ihmisestä sivistyneeksi ihmiseksi. Leikki on mielletty myös välineeksi, jota lapsi tarvitsee aikuismaisen käyttäytymisen harjoittelussa (Appleton). Varhaisiin leikin teorioihin voidaan vielä liittää tulkinta, jossa leikki nähtiin lapsen minän kasvuun liittyväksi (Lange; Claparde). Tämän tulkinnan mukaan lapsi harjoittaa ja ilmaisee leikin avulla kasvavaa minäänsä ja kognitiivisia taitojaan.

Uudempien teorioiden kiinnekohtana ovat olleet usein kehityspsykologiset näkemykset, jota korostavat lapsen aktiivista roolia kehittymisessä ja oppimisessa. Leikin avulla lapsi voi saada aikaan merkityksellistä ja kokemusperäistä toimimista ja oppimista. Leikki mahdollistaa sekä fyysisen että mentaalisen aktiviteetin parhaiten silloin, kun lapsella on siinä aktiivinen rooli (esim. Piaget ja Vygotsky). Erityisesti Vygotskyn teoreettiset näkemykset ovat avanneet tietoisuuden sille, että leikki tapahtuu sosiaalisessa ja kulttuurisessa ympäristössä lapsen arkitoimintojen ja vuorovaikutuksen avulla. Kehittyäkseen lapsi tarvitsee aktiviteetteja, joiden avulla hän syventää nykykokemuksiaan ja tietoaan, mutta myös aktiviteetteja, joiden avulla hän orientoituu ja harjoittelee vaikeampia lähikehityksen taitoja, joita tarvitaan tulevassa kehittymisessä ja oppimisessa. Modernin käsityksen mukaan 
lapsen leikki ja sosiaalinen kanssakäyminen ovat keskeisiä välineitä lapsen ajattelun, älyllisen ja sosiaalisen päättelyn, kielen ja vuorovaikutuksen sekä luovuuden kehittymiselle.

Leikin oletetaan heijastavan parhaalla mahdollisella tavalla lapsen kehityksen tilaa ja kulkua. Leikki on dynaamista, alati muuntuvaa, monisensorista, vuorovaikutuksellista, luovaa ja mielikuvitusrikasta. Kun lapsi leikkii, hänen psyykkinen energiansa ja aivot ovat täysillä mukana. Varhaisvuosien leikin oletetaan olevan johtava toiminta kehittymiseen ja oppimiseen (Vygotsky, 1978). Leikki mahdollistaa lapselle sekä sen, mikä on mahdollista että myös sen, mitä tässä ja nyt tapahtuu (esim. Winnicott, 1982). Leikki on hämmästyttänyt ja kiehtonut monia suuria ajattelijoita. Esimerksi Robert Oppenheimer on todennut, että leikkivät lapset saattavat omata kyvyn ratkaista oman tieteenalani (fysiikka) keskeisiä ongelmia, koska heillä on taitoja tehdä havaintoja, jotka minä itse olen kadottanut jo aikoja sitten (McLuhan \& Fiore, 1967). Kuuluisa arkkitehti Frank Lloyd Wright on todennut, että hänen kykynsä taustalla ovat kokemukset puupalikoilla leikkimisestä Fröbelin lastentarhassa (Rubin, 1989). Penisilliinin keksijä Alexander Fleming puolestaan on todennut, että hän leikkii mikrobeilla ja tämä tarjoaa varsin miellyttävän tavan rikkoa sääntöjä (Cole, 1988).

\section{Leikin teorioita}

Erilaiset teoreettiset suuntaukset avaavat erilaisia selitysmalleja lapsen leikille. Psykoanalyyttisen (esim. Anna Freud, 1936; Bunker \& Sigmund Freud, 1936) lähestymistavan mukaan leikki antaa mahdollisuuden käsitellä erityyppistä ahdistusta. Nämä voivat kohdistua objekteihin, jotka liittyvät ulkoiseen maailmaan liittyviin pelkoihin. Oletuksena on, että erityisesti varhaisessa lapsuudessa lapsi on psyykkisesti liian heikko käsittääkseen ja ottaakseen vastaan ulkoisen maailman tapahtumia. Tällöin lapsella on pyrkimys suojella itseään fyysisen voiman avulla tai mukauttaa ympäristön tapahtumat oman mielen mukaiseksi. Tällaisessa tilanteessa lapsen minässä kehittyy erilaisia puolustusmekanismia niitä kohteita vastaan, jotka lapsi kokee epämieluisaksi ja vaaralliseksi. Puolustusmekanismeina lapsi käyttää fantasiaa tai toimintaa, joka sulkee tai kieltää ulkoisen maailman realiteetin. Esimerkkinä voi olla pieni käsilaukku tai sateenvarjo, jonka avulla lapsi kuvittelee olevansa varttunut. Leikkiaseilla lapsi voi kuvitella 
olevansa voimakas ja urhoollinen. Nuket voivat saada aikaan tunteen äitiydestä. Leikkijunat, autot tai rakennuspalikat voivat olla keinoja, joiden avulla lapsi saa mielihyvää ja tunnetta ulkoisen maailman kontrolloinnista. Lapsi voi ahdistua myös omien viettien ja vaistojen vuoksi, jotka voivat aiheuttaa pelkoja. Myös kehittyvä tietoisuus yliminästä voi aiheuttaa lapselle ahdistusta. Leikin avulla lapsella on monia mahdollisuuksia purkaa ja käsitellä ahdistustaan.

Kehittäessään kuuluisaksi tullut teoriaansa myös Piaget (1951) tutki ja analysoi lasten leikkiä. Hänen mukaansa leikki tarjoaa rentoutuneen olotilan, jossa oppiminen on usein helppoa. Piaget'lle leikki ja oppiminen eivät kuitenkaan ole sama asia. Hänen mukaansa lapsen kognitiivinen kehittyminen edellyttää sekä assimilaation että akkommodaation työstämistä, kun puolestaan leikki lähinnä assimilaatioprosesseja.

Piaget hahmotteli kehityspsykologiseen teoriaansa liittyvän leikin teorian. Teoriassa eritellään neljä keskeistä lapsen kehitykseen liittyvää leikin lajia. Näistä ensimmäinen on sensomotorisessa kehitysvaiheessa tapahtuva leikki. Tälle on tunnusomaista fyysinen aktiviteetti, jonka avulla lapsi toistaa sensomotorisia toimintoja esimeriksi heiluttamalla toistuvasi jalkaansa ja päätään, heittää palloa tai esineitä, koputtelee pintoja, heiluttaa narussa riippuvia esineitä jne. Tällaiset toiminnot tuottavat lapselle suurta tyydytystä. Toimintojen luonne on toistava. Niiden kehityspsykologinen merkitys on koordinoida havaintoja ja fyysistä toimintaa sekä muodostaa sisäisiä rakenteita, jotka toimivat perustana lapsen kasvulle ja kehittymiselle.

Esioperationaalisella kaudella noin 2-vuoden iässä leikin luonne muuttuu. Symbolien asteittainen hallinta näkyy symbolisten leikkien ilmaantumisessa ja kehittymisessä. Symbolisten leikkien avulla lapsi kykenee tuottamaan oman mielikuvansa luomia symboleita ilmaisemaan sitä, mitä hän ei vielä kykene ilmaisemaan kielen ja käsitteiden avulla. Symbolinen leikki on osin tietoista, mutta siihen liittyy runsaasti mielikuviin ja fantasiaan perustavaa ainesta. Näitä voivat olla kiinnostus sukupuolesta, ahdistukset, pelot, vihamieliset tunteet, ihastukset, toiveet, halut jne. Tunnusomaisia ovat kuvittelu- ja fantasialeikit, joita lapsi harjoittaa usein roolileikeissä olemalla vauva, äiti, isä, poliisi, palomies, opettaja jne. Symbolisen leikin avulla lapsi kykenee työstämään ahdistusta tuottavia tapahtumia ja saada ne näyttämään päinvastaiselta (esim. vihaisesta koirasta voi tulla leikissä kiltti). Vaikka symbolinen leikki on voittopuolisesti tunnevaltaista ja mielikuvukseen perustuvaa, lapsi kehittää niiden avulla myös loogista 
ajatteluaan. Hän näkee tapahtumissa kokonaisuuksia, mistä jokin alkoi, mitä sitten seurasi ja mihin tapahtumat päättyivät. Tätä hän voi kerrata mielessään leikkien avulla uudestaan ja uudestaan, jäsentää sitä ja koota tapahtumia uudella tavalla. Ennen kouluikää lapsen leikkiin ilmaantuvat erilaiset sääntöleikit, leikkien rakenne alkaa hahmottua ja leikkiä sävyttää lisääntyvä sosiaalinen vuorovaikutus. Leikeissä on runsaasti monenlaisia rakentelu- ja roolileikkejä.

Seitsemän ikävuoden tienoilla lapsi siirtyy Piaget'n mukaan uuteen kehitysvaiheeseen (konkreettiset operaatiot). Ajattelu ja loogisuus lisääntyvät. Leikit saavat tarkemman rakenteen, säännöt täsmentyvät ja leikkien sosiaalinen ulottuvuus tulee tietoisemmaksi. Leikeissä lapsi harjoittelee sitä, mikä on sallittua ja mikä on sääntöjen mukaista. Leikkitoverit tulevat yhä keskeisemmiksi ja kilpailemisesta tulee tärkeä. Rakenteluleikeistä tulee vaativia. Keskeiseksi muodostuu se, että rakennelmat tehdään oikein. Probleemat ja uudet haasteet kiinnostavat.

Millä tavoin toinen keskeinen Piaget'n aikakauden kehityspsykologi Vygotsky (1978) hahmotti leikin? Vygotskyn mukaan nimenomaan leikki aktivoi kehittymisen perusprosesseja tavalla, joka mahdollistaa lapsen kehittymisen ja oppimisen vaativalle uudelle lähikehityksen alueelle. Vygotskyn kiinnostus lapsen kielen ja ajattelun perusprosesseihin ohjasi häntä kiinnostumaan lapsen leikkiin. Vygotsky havaitsi, että lapsilla oli tapana keskustella erityisesti roolileikkien aikana. Lapset kehittävät tarinoita ja loihtivat tarinoita eri hahmoille. Toinen keskeinen havainto oli, lapset kuuntelevat ja jäljittelevät leikeissä toisten lasten tarinoita ja selityksiä. Tämä auttaa lapsia sanavaraston ja muiden kielellisten taitojen kehittämisessä. Lasten kerronnassa välittyy myös monipuolista tietoa ympärillä olevasta maailmasta. Nämä kaikki auttavat erityisesti lapsia, joiden kielen ja ajattelun taidot ovat alemmalla tasolla.

Vygotskyn (1978) kognitiivisen kehittymisen teorian keskiössä on oletus, jonka mukaan ulkopuolisesta maailmasta tuleva informaatio siirtyy ja sisäistyy kielen avulla. Koska kieli on sekä symboli että kulttuurin aikaansaama väline, leikki on keskeinen osa sekä kielen kehittymiselle että ulkoisen maailman ymmärtämiselle. Leikkiessään lapset pyrkivät ymmärtämään maailmaa sisäisen puheen avulla. Tämän tapahtuu usein niin, että lapset puhuvat ääneen leikkiessään ja toimiessaan. Kuuntelemalla lapsen puhetta leikkien aikana, aikuiset ja kasvattajat voivat päästä selville millä tavoin lapset hahmottavat maailmaa ja millaisen merkityksen he antavat 
ilmiöille ja tapahtumille. Lapsen tulkinnoissa ovat usein läsnä aikuiset, joita he imitoivat roolileikeissään (pestäänpä nyt kädet ja ryhdytään syömään jne.). Leikin yhteydessä käytetty kieli toimii myös lapsen kognitiivisten prosessien, kielen ja ajattelun kontrollin välineenä. Vygotskyn tulkinnan mukaan lapsi siirtyy ulkoisesta aikuisten ja toisen kontrolloimasta ajattelusta ja päättelystä asteittain omaan itsesäätelyyn.

Kielen ohella Vygotsky (1978) kiinnitti erityistä huomiota lapsen sosiaaliseen vuorovaikutukseen olettaen, että kehittymisen perusluonne on alussa sosiaalinen. Näin olleen leikkien tulisi painottua aluksi roolileikkeihin, joissa lapsi voi omaksua ja ottaa käyttöönsä erilaisia rooleja ja liittää niihin monenlaista kieltä. Tämä prosessi auttaa lasta siirtymään ulkoisesta kielen ja ajattelun kontrollista sisäiseen. Leikki toimii tärkeänä välineenä tässä prosessissa ja sen kautta lapsi voi tulla kyvykkäämmäksi kielen käytössä ja oman ajattelun päättelyn säätelyssä.

\section{Leikin vaikutukset lapsen kehittymiseen}

Leikki on ollut suosittu tutkimuskohde ja sen vaikutuksista lasten kasvuun, kehittymiseen ja oppimiseen on runsaasti tutkimustietoa. Tutkimusten perusteella voi päätellä, että leikillä voi olla myönteisiä ja monipuolisia vaikutuksia lapsen kokonaiskehittymiseen (esim. Goldstein, 2012). Itse asiassa on vaikeaa löytää tutkimuksia, jotka viestisivät muuta. Leikin tutkimusta suoritetaan nykyisin monella tieteenalalla kuten biologiassa, psykologiassa, sosiologiassa, kasvatustieteissä ja neurotieteissä. Näiden perusteella on yhä vakuuttavampaa, että leikillä ei ole myönteisiä vaikutuksia vain lapsen tiedollisen alueen toimintoihin vaan nämä ulottuvat myös muille aluille kuten emootioihin ja sosiaaliseen vuorovaikutukseen. Viime kädessä leikin on oletettu parantavan lapsen elämänlaatua ja terveyttä ja näin auttaa lasta saavuttamaan kehittymisensä potentiaalia. Yhteiskunnan kannalta leikin on oletettu heijastuvan koko yhteiskunnan kehittymiseen, koska leikki edistää kommunikaatiota, yhteistyötaitoja ja erilaisten roolien omaksumista.

Yleisvaikutuksen ohella leikillä on omia spesifejä vaikutuksia lapsen kehittymisen ja kasvun alueisiin (esim. Goldstein, 2012). Aivotutkimuksen mukaan (esim. Shutton-Smith, 1997) näyttää siltä, että leikki edistää aivojen kehittymistä ja kasvua, kasvattaa muistikapasiteettia, lisää neuraalisia yhteyksiä, saa aikaan uusia hermoratojen yhteyksiä ja näiden kautta tekee lapsesta kyvykkäämmän ajattelijan ja oppijan. Näiden lisäksi on havaittu, 
että leikki tehostaa toisten emotionaalisen tilan havaitsemista ja auttaa jäsentämään olosuhteissa tapahtuvia jatkuvia muutoksia. Lapsuudessa tapahtuva lapsen aivojen nopea kasvu saa aikaan ylikapasiteetin, jota lapsi ei kykene käyttämään, jos se tätä ei työllistetä. Leikin myötävaikutuksella lapsi voi työllistää kasvavaa aivokapasiteettiaan ja oppia oppimaan oppimisen taitoja muiden taitojen ohella. Leikin välityksellä lapsi ei niinkään opi spesifiä tietoa tai taitoa. Pikemminkin kyse on yleisten ajattelun ja päättelyn taitojen oppimisesta ja oppimaan oppimisen taidoista, joita tarvitaan esimerkiksi probleeman ratkaisussa ja tähän liittyvässä abstraktissa ajattelussa sekä joustavassa ajattelussa ja päättelyssä. Joustava ajattelu kykenee liittämään yhteen monenlaista informaatiota ja soveltamaan tätä uusiin tilanteisiin. Neurologisella tasolla leikin on todettu lisäävän proteiinin kasvua, joka edesauttaa ajattelun ja päättelyn jäsentämistä, ohjaamista ja tulevan toiminnan suunnittelussa. Yhtenä pitkän aikavälin tuotoksena leikin oletetaan antavan perustaa moraalin muodostumiselle ja tätä kautta emotionaaliselle älykkyydelle. Erityisesti sosiaalisen leikin on arveltu antavan perustaa oikeudentajun muodostumiselle (esim. Azar, 2002).

Leikin myönteinen vaikutus lapsen kognitiivisen alueen kehittymiselle on moninainen. Lapsen monet kognitiiviset perustaidot kuten luova probleemanratkaisu, yhteistyötaidot, looginen päättely, älyllinen suoriutumiskyky ja suosituksi tuleminen toisten lasten keskuudessa kehittyvät leikin myötävaikutuksella (Goldstein, 1992). Leikkitoiminnot kehittävät myös lapsen tarkkaavaisuutta, jota tarvitaan erityisesti kognitiivisissa toiminnoissa ja perustaidoissa. Kielelliset ja matemaattiset taidot ovat tärkeitä lapsen tiedolliselle kehittymiselle. Leikki tukee ja edistää kumpaakin näistä taidoista (esim. Schultz, 2008 ; Fisher, 2011). Leikki edistää luovaa ajattelua (Pellegrini, 2005) etenkin silloin, kun leikki on suhteellisen vapaata ja strukturoimatonta (Howart-Jones, 2002).

Emotionaalisella alueella (esim. Goldstein, 2012) leikillä on havaittu olevan monia myönteisiä vaikutuksia. Esimerkiksi vihantunteet, ahdistus, stressi ja ärtyneisyys voivat vähetä. Leikki vapauttaa ilon, mahdollistaa yksityisyyden kokemisen, lisää itsearvostusta ja myötävaikuttaa hallinnan kokemuksiin. Leikki voi saada aikaan emotionaalista joustavuutta ja avoimuutta. Onnistunut leikkikokemus voi lisätä tyyneyden tunnetta, anteeksiantoa, joustavuutta, kykyä kohdata yllätyksiä ja muutosta sekä voi lievittää emotionaalista tuskaa. Sosiaalisella alueella leikki voi edistää empatiaa, asioiden jakamista, vaihtoehtojen ja valintojen tuottamista, avoimia 
vuorovaikutussuhteita, non-verbaalisia taitoja, tarkkaavaisuutta sekä kiintymistä muihin.

Yhteenvetona voi todeta, että tutkimusten mukaan (esim. Fisher, 1992) leikki voi edistää lapsen kehittymisessä merkittävästi joustavuutta ja kieltä sekä voi vähentää sosiaalisia ja emotionaalisia ongelmia. Leikki auttaa lasta rakentamaan vahvan perustan oppimiselle. Spontaanisuus, ihmettely, luovuus, mielikuvituskyky, luottamus oppimiseen ja kehittymiseen, itsearvostus ja sosiaaliset suhteet prosessoituvat leikin avulla. Koska aikaisempi kehittyminen säätelee myöhempää, leikin rooli korostuu. Leikin kannustava vaikutus lapselle on monelta osin siitä, että leikki on lapselle usein omaehtoista ja pitää yllä itsesäätöistä oppimista.

\section{Leikki osana pedagogiikkaa}

Eräs keskeisimmistä lapsen leikin oivaltamisessa ja sen hyödyntämessä kasvatus- ja opetustapahtumassa on ollut lastentarha-aatteen isä Friedrich Fröbel. Monet hänen oivalluksensa leikin merkityksestä olivat aikaansa edellä (esim. Ojala, 1993). Näitä olivat valmistetut leikkivälineet, askartelut, tutustuttaminen elämänmuotoihin (esim. tornin rakentaminen), tunnistamismuotoihin (esim. neliö) ja kauneusmuotoihin (esim. perusmuodot ja niiden yhdistelmät), leikin ja askartelun merkitys kouluun valmentamisessa jne.

Tietämys leikin merkityksestä lapsen kehittymiselle, kasvulle ja oppimiselle on lisääntynyt valtavasti Fröbelin jälkeen. Leikin monipuolisuus tarjoaa monia pedagogisia mahdollisuuksia lasten kehittymisen ja oppimisen tukemiseen (esim. Goldstein, 2012). Leikki voi olla yksinleikkiä, leikkiä toverin kanssa, pienryhmäleikkiä tai leikkiä koko ryhmän kanssa. Syntymän jälkeen lasten leikki on sensomotorista, jolloin lapset leikkivät kehollaan tutkiskelleen miten sen osat toimivat, ääntelevät, heiluttavat käsiään ja jalkojaan, pitävät kiinni esineistä ja pudottavat niitä jne. Myöhemmin leikkiin kuuluu samanaikaisleikkiä, jolloin lapset hakeutuvat toisten lasten lähelle mutta eivät vielä leiki yhdessä. Näiden jälkeen lapset yleensä kiinnostuvat sosiaalisista leikeistä, jolloin he tutustuvat leikkitovereihin ja haluavat leikkiä yhdessä. Symboliset leikit, joista keskeisin on roolileikki, edustavat sosiaalisen leikin kehittyneintä muotoa. Tähän yhdistyy mielikuvitusta, tarinankerrontaa, luovuutta ja ympärillä olevan maailman hahmottamista. Leikkivälineet ovat keskeinen osa lasten leikkikulttuuria. Niiden 
luonne muuttuu ajan saatossa ja informaatioteknologia tarjoaa runsaasti uusia mahdollisuuksia virtuaaliseen leikkiin. Aikuiset ja kasvattajat voivat olla mukana aktiivisesti leikissä suorasti tai epäsuorasti (esim. Hakkarainen, 2002). Suoran ohjauksen eräs ongelma on aikuisen ja lapsen näkökulmien ero, muuta toisaalta sen avulla aikuinen voi palauttaa leikin aikaisempiin vaiheisiin tai alkuun ja tukea sen etenemistä. Epäsuora leikin ohjaus kohdistuu usein leikkitilojen varustamiseen, jäsentämiseen ja leikkitilanteiden luomiseen. Suhteellisen vapaalla leikillä on keskeinen merkitys ja sen otaksutaan motivoivan lasta ja kehittävän monipuolisti hänen oppimistaan (esim. American Academy of Pediatrics, 2011). Leikki on monipuolista myös siksi, koska se voi tapahtua sisällä tai ulkona, erilaisissa kasvatusympäristöissä kotona, päiväkodissa, esikoulussa ja koulussa, vapaa-aikana, lomakautena, matkoilla, vierailujen yhteydessä jne. Leikin toivotaan siirtyvän varhaiskasvatuksesta ja esikoulusta myös runsaammin kouluun.

Suomessa tutkitaan ja kehitetään aktiivisesti lasten leikkiä. Kalliala (1999) on perehtynyt lasten leikkikulttuuriin ja sen muutoksiin. Huolena on uhka leikin vähenemisestä. Siksi kasvattajien ja opettajien tulisi antaa viesti "luvassa leikkiä päivittäin" (Kalliala, 2008). Hännikäinen (1992) on perehtynyt leikin teorioihin ja pohtii esimerkiksi leikin motivaationaalista perustaa. Hakkarainen on perehtynyt erityisesti Vykogtsky'n teoreettisiin näkemyksiin leikistä ja käynnistänyt tämän ohjaama pedagogisia kokeiluja (Hakkarainen \& Veresov, 1998; Hakkarainen, 2010). Helenius on ollut aktiivinen leikin tutkija, kehittäjä ja puolestapuhuja (esim. Helenius \& Korhonen, 2008; Hintikka, Helenius \& Vähänen, 2004). Alanen ja Karila (2009) ovat viime aikoina analysoineet leikin merkitystä lapsuuden, lapsuuden instituutioiden ja lasten toiminnan kannalta.

\section{Johtopäätöksiä}

Monilla foorumeilla kasvattajia ja vanhempia on informoitu, valistettu ja ohjattu lapsen leikin merkitykseen ja sen käyttöön kasvatuksessa ja opetuksessa. Opettajien perus- ja täydennyskoulutuksessa ja pedagogiikan kehittämisaktiviteeteissa leikki on usein kohteena. Seuraavassa eräs koonti käytännön ohjeista leikin tukemiseksi (esim. Goldstein, 2012; Dietze \& Kashin, 2011; Fisher et al., 2010; Burton, 2011): 
- Kasvattajat ja opettajat voivat olla roolimalleina lapsille luoden positiivisia asenteita leikkiä kohtaan, rohkaisemalla lapsia leikkimään ja luomalla tasapainoa sisä- ja ulkoleikkien käytölle. Silloin kun aikuiset osallistuvat lapsen leikkiin, heidän tehtävänään on ohjata leikkiä, osallistua siihen ja laajentaa leikkiä. Tässä kaikessa pitää välttää sanelua ja dominoivaa osallistumista.

- Leikkiympäristöä rakennettaessa suunnitellaan mitä leikkivälineitä, materiaaleja ja varusteita lapsille tarjotaan. On tärkeää tarjota erilaisia materiaaleja ja leikkikokemuksia ottaen huomioon myös vaikeusaste. Materiaalien valinta on tärkeää, koska se herättää ja pitää yllä motivaatiota leikkiin. Leikkiympäristön suunnittelussa tulee ottaa huomioon sekä sisä- että ulkotilat, joita tulisi olla riittävästi. Leikkiympäristön tulisi mahdollistaa lapselle tehdä valintoja ja kokeiluja.

- Kasvattajan ja opettajan tehtävänä on tarkkailla huolella ja säännöllisesti lasten leikkitoimintoja ja leikkivälineiden käyttöä. Näin saadaan tärkeää tietoa lapsen mielenkiinnon kohteista, kyvyistä ja vahvuuksista sekä oppimisen ja kehittymisen mahdollisuuksista. Havainnointi auttaa aikuisia huomaamaan, missä lapset mahdollisesti tarvitsevat tukea ja apua.

- Leikin yhteydessä on tärkeää tarkkailla ja dokumentoida lasten puhetta ja kommunikointia. Tämä antaa tärkeää tietoa lasten kielen kehityksestä, mielenkiinnon kohteista, mielikuvituksesta, ajattelusta ja päättelystä sekä tavasta, jolla lapsi hahmottaa ilmiöitä ja maailmaa. Kasvattajat ja opettajat voivat osallistua keskusteluun aika ajoin ja esittää lapsille kysymyksiä.

- Aikuisten tehtävänä on auttaa lapsia tunnistamaan leikin yhteydessä esiintyviä käsitteitä ja auttaa lapsia tunnistamaan samanlaisuuksia ja erilaisuuksia sekä tekemään yleistyksiä ja johtopäätöksiä. Näin voidaan tukea lapsen probleemanratkaisutaitoja.

Vaikka leikillä on havaittu olevan monipuolisia myönteisiä vaikutuksia lasten kokonaiskehittymiselle, leikin ja oppimisen suhde ei ole yksiselitteinen. Tämä käy ilmi, jos esimerkiksi tarkastelemme Piaget'n ja Vygotskyn käsityksiä leikistä. Piaget hahmottaa leikin liittyvän pääsääntöisesti assosiatiiviseen oppimiseen. Hänen mukaansa lapsen syvemmät ajattelun ja päättelyn rakenteet eivät välttämättä kehity leikin kautta. Näin hahmotettuna leikki ei niinkään kehitä oppimista, vaan se pikemminkin rikastuttaa 
sitä. Toisaalta kasvattajat ja opettajat voivat nojautua Vykogtsky'n näkemykseen, jonka mukaan lapsen leikki on johtava toiminto korkeamman asteiseen oppimiseen, joka liittyy lapsen kielen, ajattelun ja päättelyn kehittymiseen. Sosiaalisessa vuorovaikutuksessa tapahtuva leikki toimii keskeisenä kehityksellisenä välineenä, jonka avulla lapsi voi orientoitua nykykehitystä vaativimpiin lähikehityksen haasteisiin. Joka tapauksessa kasvattajien ja pedagogien kannalta tilanne on suotuisa. Lapsen leikillä on merkitystä. Se tukee joka tapauksessa lapsen oppimiseen liittyviä prosesseja ja parhaassa tapauksessa keskeisiä kieleen, ajatteluun ja päättelyyn liittyviä kehittymisen, kasvun ja oppimisen ydinprosesseja. 


\section{Monikulttuurinen kasvatus ja opetus}

\section{Monikulttuurisuuskasvatuksen tunnusmerkkejä}

Monikulttuurisuudella on monia merkityksiä ja sitä on käsitteellistetty eri tavoin (esim. Banks, 2008; Gorski, 1999). Erään määritelmän mukaan monikulttuuriskasvatuksella pyritään luomaan yhdenvertaiset kasvatukselliset mahdollisuudet erilaisen rodullisen, kansallisen, väestöryhmän, sosiaalisen ja kulttuurisen taustan omaaville lapsille (Banks, 2008). Tavoitteena on antaa lapsille tietoja, asenteita ja taitoja, joita tarvitaan moniarvoisessa demokraattisessa yhteiskunnassa toimimiseen ja vuorovaikutukseen, neuvotteluun ja kommunikointiin eri ihmisryhmien kanssa. Tätä kautta halutaan saada aikaan kansalaisuutta ja oikeudenmukaisuutta tukevia yhteisöjä, joita pyrkivät yhteiseen hyvään.

Monikulttuurisuuteen liittyy kulttuurien kohtaaminen eli akkulturaatio (Barry, 2002). Tällöin vähemmistökulttuuri voi sulautua joko kulttuurienemmistöön tai monikulttuurisuuteen. Jos sulautumista ei pääse tapahtumaan, vähemmistökulttuuri segregoituu omaksi osakulttuurikseen eikä siinä tapahdu muutosta. Sulautumisessa vähemmistöryhmät voivat säilyttää oman kulttuuri-identiteettinsä sopeutuessaan valtaväestöön. Samalla myös enemmistökulttuuri voi muuttua ja sopeutua monikulttuurisuuteen. Keskeistä onnistuneen akkulturaation kannalta on pitääkö henkilö omaa etnistä tai kulttuuri-identiteettiään arvokkaana ja kykeneekö hän myönteiseen vuorovaikutukseen valtaväestön kanssa.

\section{Miksi on tärkeää kehittää monikulttuurista}

\section{kasvatusta?}

Koulutuksen merkityksen ja vaikutusten seurannassa on havaittu, että nyky-yhteiskunnassa, ja mitä enenevässä määrin tulevassa yhteiskunnassa, kasvatuksessa ja koulutuksessa menestyminen on olennaista sosiaalisen tasa-arvon aikaansaamisessa ja sosiaalisen poissulkemisen ennalta ehkäisyssä. Euroopassa on havaittu, että koulussa menestymisen indikaattoreina ovat koulutuksessa pysyminen, ylemmän keskiasteen läpikäyminen ja osallistuminen kolmannen asteen kasvatukseen (Preventing social exclusion, 2001). Koulussa epäonnistumisen keskeisinä indikaattoreina voidaan pitää erityisesti pysyvää alisuoriutumista, kykenemättömyyttä saavuttaa 
oppimisen minimistandardit, varhaista koulusta poisjäämistä, kykenemättömyyttä saavuttaa välttämättömiä työelämän valmiuksia ja taitoja sekä taitojen puuttumista osallistua ja integroitua työelämään ja yhteiskuntaan (OECD, 1998). Kasvatuksellinen poissulkeminen ja syrjäytyminen merkitsevät nyky-yhteiskunnassa kasvualustaa sosiaaliseen syrjäytymiseen, jonka seurauksena henkilön mahdollisuudet kapenevat täysipainoiseen toimimiseen yhteiskunnassa, koulutukseen osallistumiseen, verkostoitumiseen ja mahdollisuuksien kapenemiseen kansalaisena.

Sosiaalista ja koulutuksellista syrjäytymistä on ryhdytty tarkastelemaan suuntaamalla huomio vallitseviin kasvatussysteemeihin ja kasvatuskäytäntöihin (esim. Ojala, 2010; INCLUD-ED, 2011). Tässä yhteydessä on nostettu esiin inkluusio vastakohtana poissulkemiselle. Inklusiivinen kasvatus perustuu ajattelutapaan, jossa korostetaan kaikkien lasten ja oppilaiden oikeutta kuulua tavallisiin yhteisöihin sen sijaan, että heidät sijoitettaisiin omiin erillisiin ryhmiin tai kouluihin. Inkluusiota tukevien ja kehittävien käytänteiden avulla halutaan lujittaa lasten ja perheiden sosiaalista liittymistä sekä auttaa lasten oppimista. Inkluusiota poissulkevat kasvatus- ja opetuskäytänteet puolestaan luovat esteitä sosiaaliselle hyväksynnälle ja kanssakäymiselle sekä tehokkaalle oppimiselle. Monikulttuuriset, oppimisvaikeuksia omaat ja haavoittuvissa elinolosuhteissa kasvavat lapset ja oppilaat sekä heidän perheensä ovat vaarassa marginalisoitua ja syrjäytä, mikäli kasvatus- ja opetuskäytänteitä ei toteutua ja kehitetä inkluusion periaatteella.

Jotta kasvatussysteemit ja käytänteet voisivat muuttua, on tärkeää kehittää kaikille yhteinen kasvatussysteemin, joka ei segregoi. On myös tarpeen minimoida eriyttämiseen perustuvat kasvatuskäytännöt ja alentaa suoriutumisen standardeja lapsilla ja oppilailla, joilla on todennäköinen riski syrjäytyä. Tarvitaan sekä tasa-arvoisia mahdollisuuksia kaikille että erilaisuuden mahdollisuutta, jotta päästään hyviin tuloksiin. Lähiympäristön ja yhteiskunnan aktiivinen osallistuminen on välttämätöntä tuettaessa lapsia ja perheitä, jotka kuuluvat ryhmiin, joilla on todennäköinen riski syrjäytyä. Tätä toimintaa pitää koordinoida ja täsmentää toiminnan tavoitteita. Näin voidaan edistää oppimissuorituksia ja vähentää poissulkemista.

Monikulttuurisuuskasvatuksen keskeisiä tekijöitä ovat erilaisuuden ja yhteenkuuluvuuden hyväksyminen. Jotta tähän tavoitteeseen voitaisiin päästä, on varottava leimaamasta lapsia ja perheitä, joilla on vähemmistötausta kulttuurin, rodun, etnisyyden ym. seikan suhteen. Tutkimukset (esim. 
Vanderbroeck, 2007) osoittavat, että vähemmistötaustaiset lapset alisuoriutuvat esiopetuksessa ja koulussa. Syynä ovat yhteiskunnan ja koulutuksen rakenteelliset tekijät, jotka saavat aikaan materiaalista ja sosiaalista vajaatilaa eli deprivaatiota. Deprivaatiovaarassa ovat erityisesti perheet ja lapset, joihin kohdistuu sosiaalista poissulkemista ja syrjintää, joilla on alhaisempi koulutustaso ja joilla on alentuneet odotukset itsestä tai lasten koulutusmahdollisuudesta.

Lasten etnisellä ja alhaisella sosioekonomisella taustalla on yleensä kummallakin lasten oppimista haittaavia vaikutuksia. Kun nämä kaksi taustatekijää yhdistyvät, muodostuu vakavampia esteitä lasten kehittymiselle ja oppimiselle (Education, Audiovisual and Cultural Executive Agency P9 Eurydice, 2009). Tutkimukset kuitenkin osoittavat myös sen, että silloin kun alhaisen sosio-ekonominen tausta ja monikulttuurisuustaustan omaavilla lapsilla on pääsy laadukkaaseen kasvatukseen ja opetukseen lasten oppisaavutusten välillä on vain vähän eroja. Esimerkiksi Englannissa on havaittu, että intialaistaustaiset lapset voivat yltää valtakulttuurilapsia parempiin suorituksiin matematiikassa (Sylva et al., 2008). Tämän vuoksi yhteiskunnan on tuettava sosiaalista integraatiota, kasvatusta ja työelämään pääsyä erityisesti syrjäytymisuhan alla olevissa ryhmissä.

\section{Monikulttuurisuuskasvatuksen kehittäminen}

Monikulttuurisuuskasvatuksen kehittäminen tapahtuu vahvistamalla inklusiivistä kasvatusta ja opetusta. Monikulttuurisessa kasvatuksessa ja opetuksessa tarvitaan kasvatusinstituution ja oppimisen uudistamista, joka takaa erilaisille lapsille tasa-arvoisen oppimisen ja siirtymisen työelämään ja yhteiskuntaan (Banks, 2004). Uudistamisen prosessissa kasvatusinstituutiolla (esim. päiväkoti, esikoulu, koulu ja näiden normit, arvot ja tavoitteet), opetussuunnitelmalla ja ympäröivällä yhteisöllä on keskeinen merkitys. Monikulttuurinen kasvatus- ja opetus voidaan hahmottaa monitasoiseksi sosiaaliseksi kokonaisuudeksi, jossa kulttuurit voivat kohdata ja jossa vallitsee myönteinen asennoituminen kulttuurien moninaisuuteen. Kasvatusinstituution toimintakulttuurilla, ihmissuhteilla sekä opettajien, lasten ja oppilaiden tasa-arvoisilla vuorovaikutus- ja osallistumismahdollisuuksilla on tärkeä merkitys. Opetustapojen ja järjestelyjen tulisi perustua yhteistyöhön ja ryhmäytymiseen, jota voidaan vahvistaa harraste- ja kerhotoiminnalla. Monikulttuurisessa opetuksessa tulee kiinnittää riittävää 
huomiota opetusmateriaaleihin, opetussuunnitelmaan, arviointikriteereihin ja piilo-opetussuunnitelmaan.

Monikulttuurisen opetuksen kehittämisprosessi edellyttää jatkuvaa kehittämistä ja arviointia. Tässä prosessissa seuraavilla toimenpiteillä on keskeinen merkitys (esim. Sylva et al. 2008; Education, Audiovisual and Cultural Executive Agency P9 Eurydice, 2009; Ojala, 2010; INCLUD-ED, 2011):

- Vähemmistötaustaisten ja syrjäytymisuhan alla olevien vanhempien roolia tulee systemaattisesti tukea suhteessa lapsen oppimiseen (esim. lukea lapselle joka päivä).

- Päivähoidon, esikoulun ja koulun tulee systemaattisesti auttaa lapsia eri oppiaineissa, mutta erityisesti kielen ja ajattelun taidoissa.

- Kasvatusinstituution opetussuunnitelmaa tulee toteuttaa herkistymällä pedagogisiin painotuksiin ja toteutustapoihin, joissa kunnioitetaan vähemmistöryhmien ja syrjäytymisuhan alla olevia perheitä.

- Pitää asettaa kriittiseen tarkasteluun enemmistökulttuurin varaan rakennettu pedagogiikka. Tällöin oletetaan, että esimerkiksi esikoulun ja koulun opetussuunnitelmassa ei ole puutteita ja tavoitteeksi asetetaan kaikkien lasten ja perheiden sopeuttaminen vallitsevaan kasvatus- ja opetuskäytäntöön.

- Perheet tarvitsevat päivähoidossa, esikoulussa ja koulussa henkilöstön, jossa ei ole yksinomaan laatua vaan erilaisuutta (etnisyys, kansallisuus, monikulttuurisuus jne.).

- Vähemmistöryhmien ja syrjäytymisuhan alla olevien perheiden lasten opetukseen ja kasvatukseen tarvitaan enemmän rahaa lasta kohden, pidempiaikaista hoitoa, kasvatusta ja opetusta (esim. varhain aloitettu esiopetus/päivähoito) sekä intensiivisempää pedagogiikkaa, jossa kiinnitetään huomiota sekä akateemiseen että sosiaaliseen oppimiseen, lapsille ominaiseen oppimisstrategiaan, leikkiin, vuorovaikutukselliseen oppimiseen ja aktiiviseen oppimiseen.

- Etukäteen määritellyt tiukat oppimisen standardit ja niiden saavuttamiseen tähtäävät pedagogiset keinot voivat johtaa epätehokkaisiin ja haitallisiin kasvatuksellisiin ja opetuksellisiin menettelytapoihin vähemmistöryhmien ja syrjäytymisuhan alla olevien perheiden lasten opetuksessa ja kasvatuksessa. 
- Vähemmistötaustaiset ja syrjäytymisuhan alla olevat perheet ja lapset tarvitse monenlaisia formaaleja (asiantuntijat) ja informaaleja (esim. lähiö) tukiverkostoja: terveys- ja sosiaalipalvelut, kouluttautumista vanhemmuuteen, kouluttautumista työelämään ja ammattiin, vapaa-ajan aktiviteetit jne.

- Opettajat, jotka toimivat vähemmistöryhmien ja syrjäytymisuhan alla olevien perheiden lasten opetuksessa ja kasvatuksessa, tarvitsevat perus- ja täydennyskoulutuksen, joka orientoi ja valmentaa heitä toimimaan näiden perheiden ja lasten parissa.

Monikulttuurisen kasvatuksen ja opetuksen toteutuksessa on keskeistä, että kasvatuksen ja opetuksen sisällöt integroidaan tavalla, jossa otetaan huomioon kulttuurien kirjo ja etnisyys, vältetään tiettyjen ihmisryhmien leimaamista ja ennakkoluuloja poistetaan tiettyjä etnisiä ryhmiä kohtaan (Banks, 2004). Kaiken kaikkiaan on kysymys siitä, että pedagogiikkaa kehitetään kaikille tasa-arvoiseksi.

\section{Esimerkkejä inklusiivisen monikulttuurisuuskasva- tuksen kehittämisestä esiopetuksessa ja koulussa}

\section{Eurooppalainen INCLUD-ED -projekti}

Vuosina 2007-2011 pyrittiin EU:n rahoittaman viisivuotisen tutkimusohjelman (INCLUD-ED) avulla analysoimaan ja kehittämään Euroopassa monikulttuurista kasvatusta esikouluissa ja kouluissa (esim. Ojala, 2010). Hankkeeseen on osallistunut 14 yliopistoa Helsingin yliopisto mukaan lukien. Analyysin kohteina olivat sekä kasvatussysteemit että kasvatusinstituutioiden opetuskäytänteet. Tutkimusaineistona olivat asiakirjat, haastattelut (opettajille, vanhemmille, lapsille/oppilaille, asiantuntijoille ja paikallisyhteisön edustajille) sekä havainnointi. Seuraavassa esitetään tiivistetysti INCLUD-ED -projektin päätuloksia liittyen kasvatussysteemeihin ja inklusiiviseen kasvatus- ja opetuskäytänteisiin (esim. Actions for success in schools in Europe, 2009; Ojala, 2008; Ojala et al., 2010; Ojala, 2010; INCLUD-ED, 2011).

Eurooppalaisen kehittämisprojektin aineiston ja sen analyysin perusteella inklusiivistä kasvatusta ja opetusta tukevat erityisesti seuraavat kasvatussysteemiin liittyvät tekijät: 
- Vältetään sijoittamasta oppilaita kyvyn, sosiaalisen taustan tai etisyyden perusteella eri kouluihin tai koululuokkiin. Tällainen sijoittelu on erityisen haitallinen alhaisen sosio-ekonomisen tason ja etnisen taustan omaaville lapsille ja oppilaille. Erillissijoittelu vaikuttaa saavutuksiin ja myöhempään ammatillistumiseen lisäten eriarvoisuutta. Erillissijoittelu ei yleensä paranna oppimisvaikeuksia omaavien lasten suorituksia vaan voi jopa huonontaa niitä.

- Heterogeenisten ryhmien ja koululuokkien on todettu yleensä parantavan lasten ja oppilaiden oppimistuloksia sekä lapsilla, jotka oppivat hyvin että lapsilla, joiden oppimisessa on erityisiä vaikeuksia. Tämän lisäksi heterogeeniset ryhmät ja koululuokat tarjoavat mahdollisuuden vuorovaikutukseen, yhteistyöhön ja kommunikaatioon tavalla, joka edistää ryhmän sisäisiä suhteita, käyttäytymistä ja sosiaalisia taitoja.

- Alhaisen sosio-ekonomisen taustan ja etnisen taustan omaaville lapsille ja oppilaille on erityisen tärkeää päästä ja olla läsnä heterogeenisissä ryhmissä ja koululuokissa. Näin heillä on enemmän mahdollisuuksia oppimiseen ja myönteisiin sosiaalisiin suhteisiin.

- Lapsille ja oppilaille on tärkeää olla laaja-alaisessa vuorovaikutuksessa kaikkiin heidän kasvatukseensa vaikuttaviin sosiaalisiin toimijoihin (agentteihin). Tässä vuorovaikutuksessa perheellä ja lähiyhteisöllä on keskeinen asema. Erityisesti alhaisen sosio-ekonomisen taustan ja etnisen taustan omaavien lasten ja oppilaiden oppimistuloksiin vaikuttaa perheiden ja lähiyhteisön aktiivinen osallistuminen. Vasta kulttuurinen ja kasvatuksellinen vuorovaikutus yhdessä voivat tukea ja edistää lasten ja oppilaiden oppimistuloksia.

- Perheen ja lähiyhteisön osallisuus monipuolistaa ja uudistaa kasvatusinstituutiossa tapahtuvaa vuorovaikutusta, tarjoaa uusia rooleja ja roolimalleja sukupuoliroolit mukaan lukien. Tämä luo edellytyksiä tasa-arvoisempaan oppimiseen ja sukupuolten väliseen vuorovaikutukseen.

- Inklusiivinen kasvatusote on erityisen tärkeä alhaisen sosio-ekonomisen taustan ja etnisen taustan omaaville lapsille, oppilaille ja heidän perheilleen.

- Inkluusiota voidaan menestyksellisesti toteuttaa lapsiryhmässä ja koululuokassa lasten heterogeenisellä ryhmittelyllä suhteellisen pienin resurssilisäyksin, jakamalla ryhmä tai luokka inklusiviisiin 
osaryhmiin, antamalla lapsille ja oppilaille lisäaikaa oppimiseen kasvatusinstituutiossa ja sen ulkopuolella sekä yksilöllisillä inklusiivisilla oppimissuunnitelmilla ja valinnoilla.

- Keskeistä heterogeenisten ryhmien menestykselliselle oppimiselle on monipuolinen, jatkuva ja aito interaktio vertaisryhmän sisällä ja toimintaan osallistuviin ammattikasvattajiin, vanhempiin ja lähiyhteisön osallistujiin.

\section{Havaintoja monikulttuurisen pedagogiikan kehittämisestä esiopetuksessa ja koulun alussa (INCLUD-ED -projekti)}

INCLUD-ED -projektin yhtenä tavoitteena oli analysoida ja seurata inklusiivistä kasvatusta ja opetusta esiopetuksessa ja koulun alussa. Seurannassa olivat mukana yksiköt, joissa pyrittiin toteuttamaan inklusiivistä monikulttuurista pedagogiikka lapsiryhmissä, joissa oli huomattava määrä alhaisen sosio-ekonomisen taustan ja monikulttuurisen tausta omaavia lapsia. Pedagogiikan analyysissa huomion kohteena olivat sekä monikulttuurisuutta tukevat ja kehittävät inklusiiviset käytänteet että inkluusiota poissulkevat käytänteet. Inkluusiota tukevien ja kehittävien käytänteiden avulla haluttiin lujittaa lasten ja perheiden sosiaalista liittymistä sekä auttaa lasten oppimista. Inkluusiota poissulkevien kasvatus- ja opetuskäytänteiden puolestaan oletettiin luovan esteitä sosiaaliselle hyväksynnälle ja kanssakäymiselle sekä tehokkaalle oppimiselle. Oletuksena oli, että tämän tapainen monikulttuurisuuskasvatuksen toteuttaminen tukee pedagogista ja yhteiskunnallista segregaatiota ja johtaa ihmisten ja ihmisryhmien syrjäytymiseen.

Esiopetuksessa ja koulun alussa tapahtuvan monikulttuurisuuskasvatuksen toteutuksesta hankittiin seurantaan perustuvaa tutkimustietoa Suomesta, Espanjasta, Kyproksesta ja Latviasta. Tutkimusaineistosta tehtiin vertaileva analyysi, jonka päätulokset esitetään seuraavassa (Ojala, 2008). Analyysissä kohdistettiin huomio kahteen pääulottuvuuteen: (a) kasvatusja opetuskäytännöt sekä (b) vanhempien ja lähiyhteisön osallistuminen. Näitä kumpaakin tarkasteltiin sen suhteen, oliko käytäntö inkluusiota tukevaa vai sitä poissulkevaa.

\section{Kasvatus- ja opetuskäytännöt}

Neljästä maasta kerätyt tulokset osoittivat, että varhaiskasvatukseen ja koulun alkuun kohdistetussa pedagogiikassa, jossa on läsnä monikulttuurisia 
lapsia, oli sekä inkluusiota tukevia mutta myös sitä estäviä segregoivia käytänteitä kuitenkin niin, että inkluusiota tukevia pedagogisia käytänteitä esiintyi enemmän. Inkluusiota estäviä käytäntöjä havaittiin etenkin ryhmitettäessä lapsia homogeenisiin ryhmiin (sukupuoli, kyvykkyys, etnisyys), henkilöstön alhaisessa mitoituksessa, erityislapsien tuen ja tarpeen huomiotta jättämisessä ja alhaisissa kehitys- ja oppimisodotuksissa.

Käytännöt olivat inkluusiota edistäviä kun (a) lapset olivat heterogeenisessä ryhmissä suhteessa ikään, sukupuoleen, kykytasoihin ja etniseen taustaan, (b) lapset sijoitettiin homogeenisesti eri luokkiin, (c) oppimisympäristö oli monikulttuurisuutta tukeva, (d) opettajien tukena oli lisäresursseja erityisoppilaita ja etnisen taustan omaavia lapsia varten (esim. vähemmistökielten tukeminen), (e) ryhmissä ja luokissa vallitsi yhteenkuuluvuuden tunne, (f) lapset saivat riittävää yksilöllistä tukea ja ohjausta, (g) opetussuunnitelmaa muokattiin ja kehitettiin erityislasten ja maahanmuuttajataustaisten lasten tarpeita silmälläpitäen sekä (h) lapsiin kohdistettiin voimakkaan positiivisia odotuksia. Näin toteutettu monikulttuurisuuskasvatus edistää sosiaalista yhteenkuuluvuutta ja parantaa lasten oppimistuloksia tavalla, josta hyötyvät etenkin alhaisen sosio-ekonomisen ja etnisen tausta omaavat lapset ja heidän perheensä.

Inkluusiota tukevia pedagogisia käytänteitä havaittiin varhaiskasvatuksen, esiopetuksen ja koulun välisessä yhteistyössä, modernin informaatioteknologian sovelluksissa sekä tavassa, jossa etnisen taustan omaavilla lapsille luotiin mahdollisuuksia olla vuorovaikutuksessa kaikkiin lapsiin. Keskeistä inklusiivisten muuntuvien pedagogisten käytänteiden aikaansaamisessa olivat opettajan positiiviset asenteet, monikulttuurisen oppimisympäristön luominen, aktiivinen yhteistyö vanhempiin ja henkilöresurssien riittävyys ja niiden tarkoituksenmukaisen käyttö.

\section{Vanhempien ja lähiyhteisön osallistuminen lasten kasvatukseen ja oppimiseen}

Kasvatus- ja opetuskäytäntöihin kytkeytyvänä mutta myös omana tärkeänä inkluusioon liittyvänä tekijänä INCLUD-ED -projektissa on pidetty vanhempien ja lähiyhteisön osallistumista. Kasvatuksen ja oppimisen onnistumisen näkökulmasta vanhempien ja lähiyhteisön osallistumista voidaan myös analysoida kahdessa ulottuvuudessa. Toisessa on kysymys osallistumista tukevista inklusiivisistä, uudistuvista osallisuuden aktiviteeteista 
ja toisessa inkluusiota estävistä, segregoivista aktiviteeteista (esim. INCLUD-ED, 2011; Ojala, 2010).

Suomesta, Espanjasta, Kyprokselta, ja Latviasta kerätyn monikulttuurisen tutkimusaineiston perusteella keskeinen osallistumista tukeva ja myös sitä rajoittava tekijä oli vanhempien osallistuminen päätöksentekoon ja oppimisprosessiin koskien kasvatuksen ja oppimisen kohteena olevaa lasta (Ojala, 2008). Kaikissa neljässä maassa tehtiin havaintoja, joiden mukaan suurin osa osallistumista estävistä tekijöistä liittyi vanhempiin. Näiden havaintojen mukaan osa vanhemmista ei juuri osallistu lasten tai oppilasta koskevaan kasvatukselliseen ja opetukselliseen päätöksentekoon eikä myöskään oppimisprosessin tukemiseen päiväkodissa, esikoulussa tai koulussa. Vanhempien alhaiseen osallisuuteen liittyi usein myös passiivisuus aloitteiden teossa tai jos niitä tehtiin, ne kohdistuivat yleensä teknisiin ja pintapuolisiin seikkoihin. Esimerkiksi lapsen havainnointia sinänsä pidettiin riittävänä. Osallistumisen passiivisuuta vanhemmat perustelivat esimerkiksi toteamalla, että valtiovalta ja viranomaiset säätelevät lasten oppimisen. Etnisten vähemmistöjen vanhemmilla oli usein tunne siitä, että he eivät hallitse riittävästi enemmistökulttuurin kieltä, jolloin heillä ei ole juurikaan halua keskustella ammattikasvattajien, opettajien ja asiantuntijoiden kanssa. Vanhemmat saattoivat ajatella myös niin, opettajilla on muutenkin työnsä vaativuuden, työkiireen ja aikapulan vuoksi niin paljon velvollisuuksia ja toimintaa, joten heitä ei ehkä pidä rasittaa vanhempien osallisuuteen. Opettajat olivat kuitenkin havainneet, että vanhempien korkea koulutustaso myötävaikutti vanhempien aktiiviseen osallistumiseen.

Vanhempien ja lähiyhteisön osallisuus kasvatusinstituutioissa, joissa on monikulttuurisia lapsia ja oppilaita, voi kuitenkin olla aktiivista ja inkluusiota tukevaa (esim. Ojala, 2008). Neljän edellä mainitun maan vanhemmissa oli suhteellisen runsaasti myös niitä, jotka osallistuivat aktiivisesti lastensa kasvatusta ja opetusta koskevaan päätöksentekoon päivähoidossa, esikoulussa ja koulussa sekä olivat aktiivisesti läsnä tukemassa lapsen oppimisprosessia. Tässä toiminnassa käytettiin seuraavia inklusiivistä muutosta tukevia menettelytapoja:

- Opettajat motivoivat vanhempia osallistumaan lasten oppimisaktiviteetteihin ja rohkaisevat vanhempia yhteistyön aktiviteeteissa.

- Vanhempainilloissa ja kokouksissa opettajat informoivat lasten vanhempia lasten oppimisesta ja käyttäytymisestä. 
- Opettajat antoivat vanhemmille yksilöllistä tukea.

- Päiväkodeissa, esikouluissa ja kouluissa järjestettiin vanhemmille suunnattuja teemailtoja, joiden yhteydessä heillä oli mahdollisuus olla lasten kanssa, oppia heidän kanssaan ja tutustua toisiin lapsiin, vanhempiin ja opettajiin.

- Opettajat selostivat vanhemmille lasten työskentelyä oppimisen eri alueilla.

- Opetussuunnitelmaa suunniteltiin ja sitä kehitettiin demokraattisemmaksi.

Vanhempien ja lähiyhteisön osallistumisen aktivoinnissa ja tukemisessa koskien päätöksentekoon osallistumista ja lapsen oppimisprosessin tukemista erityisesti monikulttuurisen taustan vanhempien tarpeiden tunnistaminen osoittautui neljän edellä mainitun maan kokemuksissa tärkeäksi (esim. Ojala, 2008). Nämä tarpeet tulisi tunnistaa ja vanhempien tekemiä aloitteita tukea. Monikulttuurisen taustan omaavien vanhempien mahdollisuudet osallistua lastensa kasvatusta ja oppimista koskevaan päätöksentekoon tulisivat olla samat kuin valtaväestön. Päiväkodin, esikoulun ja koulun organisaatiossa tulisi olla tilaa ja erilaisia tapoja tukea perheitä ja lähiyhteisön toimijoita osallistumaan päätöksentekoon ja toimintaan.

\section{Keinoja tukea perheiden ja muun lähiyhteisön osallisuutta}

INCLUD-ED -projektissa arvioitiin erilaisia keinoja tukea perheiden ja muun lähiyhteisön osallisuutta erityisesti syrjäytymisuhassa olevien lasten ja perheiden elämäntilanteessa (esim. Gatt et al. 2011; Duque \& Ojala, 2011; Sodré \& Ojala, 2010). Seuranta-aineistoa hankittiin varhaiskasvatuksesta, esikoulusta ja koulusta. Kuudesta maasta, Suomi mukaan lukien, hankitun aineiston perustella voitiin tunnistaa erilaisia osallisuutta tukevia keinoja, joita käytettiin kasvatusinstituutioissa. Näitä olivat informaation antaminen lapsen toiminnasta ja oppimisesta, vanhempien neuvonta, ratkaisuja pohtiva yhteinen ideointi, lapsen toiminnan ja oppimisen yhteinen arviointi sekä vanhempain kasvatus. Näitä keinoja arvioitiin sen suhteen, missä määrin niillä voitiin havaita vaikutuksia lapsen oppimiseen ja edistymiseen erityisesti kielellisissä ja matemaattisissa aineissa.

Tuloksena oli havainto, jonka mukaan kahdella ensimmäisellä edellä mainitulla keinolla ei voitu juurikaan edesauttaa lapsen oppimista kasvatusinstituutiossa. Sen sijaan ratkaisuja pohtiva yhteinen ideointi, lapsen 
toiminnan ja oppimisen yhteinen arviointi sekä vanhempain kasvatusohjelmat olivat sellaisia, että niillä voitiin todeta olevan positiivisia vaikutuksia lapsen ja oppilaiden oppimiseen.

Ratkaisuja pohtivaan yhteiseen ideointiin liittyy perheiden ja muun yhteisön osallistuminen yhteiseen päätöksentekoon. Ideoinnissa vanhemmilla ja muilla lähiyhteisön jäsenillä tulisi olla tasa-arvoinen asema keskustella ja pohtia opettajan kanssa lapsen ja oppilaan oppimisesta huolimatta siitä, että vanhemmilla ja lähiyhteisön jäsenillä yleensä on alempi akateemisen tietämyksen taso verrattuna opettajaan. Demokraattista osallistumista voidaan toteuttaa esimerkiksi moniäänisillä keskusteluryhmillä, joihin osallistuvat opettajat, perheet ja lähiyhteisön muut jäsenet (esim. opiskelijat jne.). Keskusteluryhmiin osallistumisen tulee olla vapaaehtoista ja perustua aitoon mielenkiintoon ja haluun auttaa yhdessä lasta oppimisessa. Keskusteluissa voidaan käsitellä opetussuunnitelmaan ja oppimiseen liittyviä asioita, pohtia lasten ja oppilaiden poissaoloja ja niiden syitä jne. Demokraattiset keskusteluryhmät ovat omiaan poistamaan ennakkoluuloja, lisäämään keskinäistä kanssakäymistä ja rohkaisemaan perheitä tuomaan esille omia näkemyksiään ja ehdotuksiaan. Niiden avulla myös opettajien ja lasten vuorovaikutus voi lujittua ja lapsen motivaatio oppimiseen voi lisääntyä.

Oppimisen tasa-arvoisen ja yhteisen arvioinnin on todettu lisäävän vanhempien ja muiden lähiyhteisön jäsenten osallisuutta ja tehostavan oppilaan ja lasten oppimista (Duque \& Ojala, 2011). Opettajien, perheiden ja muiden lähiyhteisön jäsenten osallistuminen tasa-arvoisina kasvatusinstituution ja lapsen arviointiin poikkeaa yleensä siitä, mitä opettajat tekevät yksin. Yhteisarviointi perustuu tasa-arvoiseen osallisuuteen, jossa perheen jäsenet, vapaaehtoiset osallistujat, lähiyhteisön edustajat, kasvatuksesta ja opetuksesta vastaavat viranomaiset ja opettajat yhdessä keskustelevat, pohtivat ja tekevät johtopäätöksiä kasvatusinstituutiossa tapahtuvasta opetuksesta ja oppimisesta. Kokemusten mukaan tämän tapainen dialoginen ja tasa-arvoinen lähestymistapa arviointiin voi tuottaa uutta näkemystä ja tietoa, joka voi heijastua myönteisellä tavalla lapsen ja oppilaan oppimisprosessiin ja kasvatusinstituution tapaan suunnitella ja toteuttaa opetus ja oppiminen. Suomessa omaksuttu tapa laatia yhdessä vanhempien kanssa lapselle ja oppilaille yksilöllinen kasvatus- ja oppimissuunnitelma on eräs tapa, jonka avulla voidaan toteuttaa ainakin osin dialogista ja demokraattista arviointia. 
Erityisesti syrjäytymisuhan alla oleville lapsille, oppilaille ja vanhemmille voidaan suunnitella kasvatusinstituution, muiden lähiyhteisön edustajien ja kasvatuksen ja opetuksen asiantuntijoiden avulla perhekasvatusohjelmia tukemaan kasvatusinstituutiossa tapahtuvaa opettamista ja oppimista. Näillä on voitu ratkaisevasti tukea ja parantaa lapsen kielellisiä ja matemaattisia taitoja, joissa huono edistyminen myötävaikuttaa lapsen syrjäytymiseen koulussa ja yhteiskunnassa (Duque \& Ojala, 2011).

\section{Inklusiivisen kasvatuksen ja opetuksen yhteydet lapsen oppimiseen ja kehittymiseen}

Vaikka perheiden ja muun lähiyhteisön aktiivinen osallistuminen päätöksentekoon ja lapsen oppimisprosessiin sinänsä ovat keskeistä menestykselliselle inklusiiviselle kasvatukselle ja opetukselle, on tärkeää tarkastella yksityiskohtaisemmin näiden toimenpiteiden heijastumista lapsen ja oppilaiden oppimisprosessiin ja tuloksiin (Ojala, 2008). Esiopetusta ja koulun alkua koskevaa seuranta-aineistoa analysoitaessa pelkistyi kaksi inkluusiota ehkäisevää tekijää. Näistä toinen liittyi vanhempien alhaiseen motivaatioon ja arvostuksen kasvatusinstituuttia kohtaan. Toinen liittyi opettajien ennakkokäsityksiin siitä, että vanhempien osallistumisella ei ole juurikaan merkitystä lasten ja oppilaiden menestymiseen kasvatusinstituutissa.

Inkluusiota tukevia havaintoja koskien perheen ja muun lähiyhteisön osallistumisen vaikutuksia oli edellä mainitussa tutkimusaineistossa suhteellisen runsaasti. Useimmat näistä liittyivät vanhempien osoittamaan mielenkiintoon osallistua lasten kasvatukselliseen ja oppimiseen liittyvään päätöksentekoon kasvatusinstituutiossa. Tämän seurauksena yleensä tapahtui uutta oppimista, joka näkyi myönteisenä oppimissaavutuksena sekä paransi lasten oppimismotivaatiota ja kanssakäymistä muihin lapsiin. Myös yhteenkuuluvuuden tunne päiväkodissa, esikoulussa ja koulussa sekä lapsi- ja oppilasryhmässä tuki inklusiiviseen muutokseen perustuvan kasvatuksen ja opetuksen toteuttamista. Opetussuunnitelman demokratisointi ja vanhempien osallistuminen lastaan koskevaan kasvatukselliseen ja opetukselliseen päätöksentekoon paransivat kasvatuksen ja opetuksen laatua. Osallistumalla päätöksentekoon sekä lapsen ja oppilaan oppimisprosessiin vanhemmat olivat oppineet ymmärtämään sen, kuinka tärkeää on olla kiinnostunut lapsen oppimisesta ja edistymisestä. Kasvatukselliseen ja opetukselliseen päätöksentekoon osallistuminen tarjosi vanhemmille konkreettisia keinoja ja mahdollisuuksia jakaa kasvatusvastuutaan. Vanhemmat myös 
kokivat, että tiivistynyt kanssakäyminen opettajien kanssa auttoi heitä käsittelemään ja olemaan kanssakäymisessä lapseen uudella tavalla.

\section{Perhekasvatus ja lähiyhteisön mukaantulo}

Osana inklusiivistä muutokseen tähtäävää monikulttuurisuuskasvatusta tukevaa toimintaa ovat perhekasvatus ja lähiyhteisökasvatus (esim. Duque \& Ojala, 2011).

Perhekasvatustoiminta pyritään järjestämään perheiden ja lähiyhteisön tarpeiden pohjalta niin, että nämä tahot ottavat osaa ohjelman suunnitteluun ja toteutukseen. Tavoitteena on antaa ja tukea taitoja, joita lapsi ja oppilas tarvitsevat nyky-yhteiskunnassa ja tulevassa syrjäytymisen ennaltaehkäisemiseksi. Esimerkkeinä voidaan mainita kirjallisuuskerhot, tietokonekerhot jne. Toiminta on erityisen tärkeää perheille, joiden arjesta puutuvat tämän kaltaiset virikkeet ja aktiviteetit (esim. lapselle ei koskaan tai yleensä lueta jne.).

INCLUD-ED -projektin (Duque \& Ojala, 2011) kokemusten perusteella perhekasvatus voi toimia tehokkaana interventiona niin, että vanhemmat kiinnittivät lisääntyvää huomiota lasten kotitehtäviin ja niiden tukemiseen. Lapsen ja oppilaan perspektiivistä perhekasvatuksen ohjelmat auttoivat selkeyttämään ja ymmärtämään kodin ulkopuolisen kasvatuksen ja opetuksen tavoitteita. Erityisen hyödyn perhekasvatuksen ohjelmista saavat syrjäytyneet lapset ja heidän perheensä.

Kouluoppimisen ja sitä edeltävän oppimisen kannalta keskeisessä asemassa ovat erityisesti lapsen ja oppilaan kielelliset ja matemaattiset taidot. Tämän vuoksi lasten ja oppilaiden taidot näissä aineissa joko poissulkevat tai edistävät erityisesti koulutuksellista ja yhteiskunnallista syrjäytymistä. Neljän edellä mainitun maan seuranta-aineistossa havaittiin, että opettajat toteuttivat inkluusiota poissulkevaa käytäntöä erityisesti silloin, kun he eivät ottaneet huomioon näiden aineiden opettamisessa ja oppimisessa lasten ja vanhempien monikulttuurisuutta eivätkä myöskään osallistaneet vanhempia lastensa kasvatus- ja oppimisprosessiin (Ojala, 2008). Kasvatus- ja opetus toteutui inkluusiota tukevaksi silloin, kun opettajat kehittivät opetussuunnitelmaa ja oppimista vanhempien myötävaikutuksella monikulttuurisuutta tukevaksi. Tällaisella käytännöllä oli varsin positiivinen vaikutus lapsen ja oppilaiden oppimissaavutuksiin erityisesti kielessä ja matematiikassa. 
Perheiden ja muun lähiyhteisön osallisuuden eräänä esteenä olivat monissa maissa sukupuoleen kohdistuvat stereotypiat. Tämä oli selkeimmin erottuva inkluusiota estävä tekijä edellä mainitun neljän maan esiopetuksessa ja koulun alussa (Ojala, 2008). Stereotypiaan liittyy myös opettajien sukupuoli, jolle on tunnusomaista naisopettajien valtaenemmistö. Yhteistyölle kasvatusinstituution ja kodin välillä on tyypillistä se, että yhteistyökumppaneina ovat yleensä äidit isien jäädessä taka-alalle. Tällainen stereotypia on läsnä erityisesti monikulttuurisen taustan perheissä. On olemassa myös käytänteitä, joissa lapset ja oppilaat voidaan ryhmittää kasvatusinstituutiossa sukupuolen mukaan. Inklusiivisen muutoshakuisen monikulttuurisuuspedagogiikan toteutukselle on keskeistä, että erityisesti alhaisen sosioekonomisen taustan ja monikulttuurisuustaustan omaavat vanhemmat voisivat irtautua sukupuoleen liittyvistä stereotypioista. Yhtä tärkeää on myös muuttaa kasvatusinstituutiossa mahdollisesti omaksuttuja sukupuoleen kohdistuneita stereotypioita. Kaiken kaikkiaan keskeistä on, että monikulttuurisuuskasvatuksesta kehittyy kaikille kulttuuriryhmille kuuluvaa yhteistä toimintaa.

\section{Yhteenvetoa monikulttuurisuuskasvatuksen toteutumisessa (INCLUD-ED -projekti)}

Eurooppalaisen INCLUD-ED -projektin tuloksissa voitiin tunnistaa monia inkluusiota tukevia pedagogia käytänteitä (esim. Ojala, 2010). Lasten pitäisi voida toimia heterogeenisissa ryhmissä. Erityisesti monikulttuurisen tausta omaavat lapset tarvitsevat yksilöllistä huomiota. Esiopetuksen ja koulun tulisi tiivistää yhteistyötä erityisesti monikulttuurisessa kasvatuksessa. Lapsen ja oppilaan hyvät informaatioteknologiset valmiudet ja taidot ehkäisevät ennalta myöhempää koulutuksesta syrjäytymistä. Ennakko-odotusten ja opettajien asenteet monikulttuurisia lapsia kohtaan tulisi olla korostuneen positiivisia. Oppimisympäristö tulisi rakentaa ja muokata monikulttuuriseksi. Monikulttuurisen taustan omaamilla perheillä tulee olla todellisia mahdollisuuksia yhteistyöhön ammattikasvattajien kanssa, jossa sekä esikoulun että koulun tulisi olla aloitteellinen. Monikulttuurisuuskasvatus vaatii ylimääräisiä resursseja. Tukiverkostojen ja lähiympäristön tulisi olla aktiivinen monikulttuurisuuskasvatuksen tukemisessa. Opetussuunnitelmaa tulisi muokata ja rakentaa monikulttuuriseksi, jossa monikulttuurisen taustan omaamilla vanhemmilla on keskeinen asiantuntemus, jota pitäisi hyödyntää. Huomion kiinnittäminen perusoppiainekseen, 
kuten esimerkiksi kieli, matematiikka ja informaatioteknologia, ehkäisee tehokkaasti syrjäytymisen. Sukupuolten välinen epätasa-arvo ja sen mahdollinen vahvistuminen on ilmeinen vaara monikulttuurisuuskasvatuksessa. Siksi sitä pitää välttää tietoisesti ja aktivoida myös isiä osallistumaan monikulttuuriseen kasvatukseen niin kotikasvatuksessa kuin kodin ulkopuolisessakin.

\section{Esimerkkejä monikulttuurisuuden kehittämisestä suomalaisessa päivähoidossa ja esiopetuksessa}

\section{MONIKU-hanke}

Vuosina 2005-2007 toteutetun MONIKU-hankkeen tavoitteena oli tuottaa pääkaupunkiseudun kunnille (Espoo, Helsinki, Kauniainen ja Vantaa) yhteinen toimintamalli sekä käsitteet monikulttuurisen varhaiskasvatuksen toteuttamiseen. Toimintamalliin liitettiin (1) kuntien monikulttuuristen varhaiskasvatuspalvelujen järjestämisen ja toteuttamisen suuntaviivat, (2) kasvatuskumppanuus ja lapsen oman äidinkielen tukeminen, (3) lapsen kokonaisvaltaisen hyvinvoinnin ja sosiaalisen vahvistamisen edistäminen erityisesti suomi toisena kielenä opettamista systematisoimalla sekä (4) varhaiskasvatushenkilöstön monikulttuurisen tietämyksen, osaamisen ja ammattitaidon vahvistaminen. Toimintamallin lähtökohtana oli kuntien olemassa olevien monikulttuurisen varhaiskasvatuksen työkäytäntöjen ja menetelmien kokoaminen ja arvioiminen sekä uusien työmenetelmien kehittäminen ja levittäminen.

Esimerkkinä kehittämishankeen tuotoksista voidaan mainita kehittävät vertaiskäynnit, joiden avulla pyrittiin tukemaan ja kehittämään varhaiskasvatushenkilöstön tietämystä, osaamista ja ammattitaitoa monikulttuurisessa päivähoidossa. Tässä menetelmässä tehdään perinteisestä opintokäynnistä poikkeava vierailu vertaisryhmään tai -yksikköön, jonka aikana tutustutaan ja arvioidaan kohteena olevan yksikön henkilöstön valitsemaa kehittämisaluetta ja annetaan palaute jatkokehittämiseksi.

MONIKU-hankkeen kokemukset kehittävästä vertaiskäynnistä olivat positiivisia. Menetelmä toimi oppimisen viitekehyksenä ja sen avulla toiminnan arviointi yksiköissä lisääntyi. Henkilöstön arvioinneissa kehittävä vertaiskäynti osoitti, missä monikulttuurisen varhaiskasvatuksen osa-alueissa yksiköt ovat hyviä ja missä on parantamisen varaa. Käynnin avulla 
vertaiskumppanilta opittiin uusia käytäntöjä, joiden avulla voitiin reflektoida omaa toimintaa.

MONIKU-hankkeen jalkautumista ja kehittymistä pääkaupunkiseudulla on myös arvioitu ja seurattu (Venninen, 2009). Päähavaintona oli, että monikulttuurisuuskasvatuksen toteutumisessa on jokseenkin suurta vaihtelua. Jatkokehittelyssä pidettiin tärkeänä nostaa esiin seuraavia näkökulmia:

- Monikulttuurisuuskasvatus on kaikille kuuluvaa toimintaa, jonka avulla voidaan kasvattaa avarakatseisia ja suvaitsevia kansalaisia.

- Monikulttuurisuuskasvatus vaatii aikaa ja energiaa. Siinä vaaditaan jaksamista, jota pitää tukea.

- Henkilöstön osaamiseen ja kehittämiseen tulee kiinnittää huomiota. Oman osaamisen heikkouksia tai aukkoja pitää voida tunnustaa ja ilmaista.

- Kasvatuskumppanuus on erityisen tärkeää vieraan kieli- ja kulttuuritaustan omaavien perheiden kohdalla.

- Heikosti suomen kieltä taitaville tulee järjestää kielikoulutusta. Tämän lisäksi tulee huolehtia henkilökunnan riittävästä englannin kielen taidosta.

- Erityisesti alle 3-vuotiaiden lasten ryhmien henkilökunnan monikulttuurisuuteen liittyvää osaamista on lisättävä. Kehittävät vertaiskäynnit voivat tässäkin kohderyhmässä olla hyvänä tukena.

\section{MUCCA-hanke}

Helsingin päiväkodeissa toteutettiin vuosina 2008-2009 monikulttuuriskasvatusta tukeva ja kehittävä MUCCA-hanke (Kuusisto, 2010). Kehittämiskohteina olivat oppimisympäristö, lapsen kasvun ja kehityksen tukeminen sekä kasvatuskumppanuus.

Oppimisympäristöä kehitettiin monikulttuurisuutta viestiväksi ja tukevaksi kuvaston ja esineistön, lastenkirjojen, lelujen, musiikin, soittimien, draamaesitysten sekä aikuisten esittämien satujen ja tarinoiden suhteen. Lasten kasvua ja kehitystä tuettiin pienryhmätoimintaa lisäämällä, kotikielellä esitetyillä laululla, eri kulttuureihin liittyvillä juhlapäivillä, kokoamalla tietoa eri kulttuureista henkilökunnan käyttöön, saduilla sekä valitsemalla vuoron perään viikon henkilö esittelyn kohteeksi. Kasvatuskumppanuutta pyrittiin edistämään yhteisöllisyyden ja luottamuksen lisäämiseksi 
esim. keräämällä satuja näyttelyksi eri perheistä, päiväkodissa tapahtuvilla vanhempien vesivärimaalauksilla (esimerkiksi mummon talo Marokossa), kulttuuritapahtumilla (musiikki, tanssi, nukketeatteri, ruoka), järjestämällä lasten, perheiden ja henkilökunnan esityksiä kykyjen illoissa, järjestämällä vapaamuotoisia vanhempain kahviloita, järjestämällä taide-esityksiä (nukketeatteri, näytelmät ja musiikkiesitykset) sekä kiinnittämällä lisää huomiota päivähoidon aloittamisen teemojen valintaan (esim. islamilaisten yhteistyö imaamin kanssa). 


\section{Tasa-arvo pedagogisena haasteena}

\section{Tasa-arvon perusteita suomalaisessa koulutuspolitiikassa}

Demokraattisen yhteiskunnan olemassaolo ja kehittyminen perustuu pyrkimykseen kohdella kansalaisia tasa-arvoisina. Tämä koskee niin aikuisia kuin lapsiakin, eri väestöryhmiä ja alueellista tasa-arvoa. Tasa-arvoa pidetään yllä ja ohjataan lainsäädännön avulla. Valtiovalta ja viranomaiset myös seuraavat ja arvioivat miten tasa-arvo yhteiskunnan eri alueilla kulloinkin toteutuu.

Demokratian ylläpidossa ja etenkin sen kehittämisessä suomalaisella koulutuspolitiikalla on keskeinen asema. Koulutuspolitiikan tavoitteena on taata kaikille, syntyperän, taustan ja varallisuuden rajoittamatta yhtäläiset mahdollisuudet ja oikeudet sivistykseen, laadukkaaseen maksuttomaan koulutukseen sekä täysivaltaisen kansalaisuuden edellytykset. (Koulutus ja tutkimus vuosina 2011-2016; Kehittämissuunnitelma, 2012).

Syrjäytymisen ennaltaehkäisyn lisäksi, jota tässä julkaisussa on tarkasteltu omassa luvussaan, kasvatusta erityisesti sukupuolten väliseen tasa-arvoon on ryhdytty korostamaan lisääntyvässä määrin. Hallituksen hyväksymässä koulutuksen ja kehittämisen kehittämissuunnitelmassa (2012) todetaan, että tavoitteena on kaventaa sukupuolten välisiä eroja koulutuksessa, koulutukseen osallistumisessa sekä koulutuksen suorittamisessa sekä vähentää koulutuksen periytyvyyttä. Esiopetuksen opetussuunnitelman perusteissa (2010) painotetaan sitä, että esiopetuksessa on huomioitava myös sukupuolen erityistarpeet. Tämä takaa omalta osaltaan lapsille tasa-arvoiset mahdollisuudet oppimiseen ja koulun aloittamiseen. Vastaavasti perusopetuksen opetussuunnitelman perusteissa todetaan, että keskeinen päämäärä on edistää sukupuolten välistä tasa-arvoa. Tavoitteena on antaa tytöille ja pojille valmiuksia toimia yhteiskunnassa sekä työ- ja perhe-elämässä yhtäläisin oikeuksin ja velvollisuuksin. Edellä mainitut koulutukselliset tavoitteet asettavat varhaiskasvatukselle, esiopetukselle ja perusopetukselle haasteen sukupuolten välisen tasa-arvon toteuttamiselle. 


\section{Tytöt ja pojat oppijoina}

Oppimisen seuranta ja arviointi suhteessa sukupuoleen on keskeistä, jotta voisimme arvioida, miten sukupuolten välinen tasa-arvo toteutuu koulutuksessa ja kasvatuksessa. Koska mahdollisuudet vaikuttaa tasa-arvon toteutumiseen ovat lapsen varhaisvuosina paremmat kuin myöhemmin, erityisen tärkeää on seurata lapsen oppimista ja kehittymistä jo ennen kouluikää, esiopetuksessa ja koulun alussa.

\section{Kehittymisen eriaikaisuus}

Seurattaessa lasten kehittymistä tyttöjen ja poikien kehitysrytmi on havaittu erilaiseksi. Erot näkyvät jo varhain. Esimerkiksi Arden ja Plomin (2006) seuratessaan lasten älyllistä kehittymistä ikävuosina 2-10 havaitsivat, että tyttöjen kehityssaavutukset kasautuivat yläpäähän ja vastaavasti poikien alapäähän. Eräässä pitkittäisseurannassa kohteena oli muistitehtävistä suoriutuminen ikävuosina 5-19 (Lowe et al., 2003). Tulokset osoittivat, että tytöt olivat parempia verbaalisissa tehtävissä, kun sitä vastoin pojat olivat edistyneempiä spatiaalisuutta (tilan havaitseminen ja 3-ulotteisuus) mittavissa tehtävissä. Poikien osalta löydös tukee myös Hautamäen tutkimusryhmän havaintoja lapsista koulun alkaessa (Hautamäki et al., 2001). Yhtenä tuloksena oli, että pojat suoriutuvat tyttöjä paremmin visuaalisen muistin osalta. Päätulos tässä aineistossa oli kuitenkin, että tyttöjen ja poikien välillä ei esiintynyt merkittäviä eroja oppimisvalmiudessa eikä päättelyä edellyttävässä ajattelussa. Kuitenkin tehtävissä, jossa vaaditaan yksityiskohtien huomioon ottamista, tarkkuutta ja keskittyneisyyttä (esim. piirrokset, muotojen kopiointia, taittoja) tytöt olivat poikia merkittävästi parempia.

Sukupuolierot heijastuvat myös sosio-emotionaaliseen alueeseen. Esimerkiksi Keenan ja Shaw (2003) havaitsivat, että tytöt osoittivat poika paremmin kykenevänsä kontrollimaan käyttäytymistä jo alle kolmivuotiaina ja ero poikiin kasvoi esikouluiässä. Yhtenä mahdollisena selittävänä tekijänä tutkijat esittävät olettamusta, jonka mukaan ympäristö sosiaalistaa tyttöjä kontrolloimaan käyttäytymistään voimakkaammin kuin mitä tapahtuu poikien suhteen. Seurannassa tytöt ovat myös osoittautuneet paremmiksi käsittelemään emootioitaan ja heillä näyttää esiintyvän vähemmän ongelmia sosiaalisessa vuorovaikutuksessa ja käyttäytymisessä (esim. Mercurio, 2003). 
Myös vanhempien sosio-ekonominen ja koulutuksellinen tausta näyttävät heijastuvan hieman eri tavoin tyttöihin ja poikiin. Eräässä seurannassa kattaen ikävuodet 3-5 havaittiin, että vanhempien sosio-ekonominen tausta oli yhteydessä poikien ongelmakäyttäytymiseen mutta ei tyttöjen (Childs \& McKay, 2001; Hill et al., 2006). Erityisen selvää tämä yhteys oli pojilla, jotka kasvoivat alemman sosioekonomisen taustan perheissä. Ilmiöön liittyi vielä se, että opettajille voi muodostua pysyvä negatiivinen mielikuva pojista, jotka koetaan oppitunneilla häiritseviksi, huonosti kykeneviksi olemaan mukana päivittäisissä rutiineissa ja hyperaktiivisiksi (Childs \& Mckay, 2001).

Myös Suomessa tehdyt havainnot tyttöjen ja poikien erilaisesta asennoitumisesta ja käyttäytymisestä opetustilanteissa tukevat edellä kuvattuja havaintoja. Hautamäen ja kumppaneiden (2001) tutkimusaineiston mukaan tytöt työskentelivät ahkerammin ja pitivät oppimiskokemuksia merkityksellisempinä poikiin verrattuina koulunkäynnin alussa. Myös asenteet opettajiin ja luokkatovereihin olivat tytöillä positiivisemmat kuin pojilla. Kuitenkin oli näyttöä siitä, että pojat arvioivat itseensä positiivisemmin kuin tytöt. Pojat arvioivat koulun ulkopuolisten tekijöiden merkityksen koulusuorituksiin merkityksellisemmiksi kuin tytöt. Myös arviot kyvyistä matematiikassa ja matematiikan oppimisesta olivat pojilla korkeammat verrattuna tyttöihin.

\section{Tyttöjen ja poikien saavutukset oppimisessa}

Esimerkiksi vuoden 2009 PISA-tutkimuksissa on analysoitu myös sukupuolten välisiä eroja koulun oppimistuloksissa (Sulkunen et al., 2009). Kohteena ovat olleet äidinkielen, matematiikan ja luonnontieteiden oppimistulokset 15-vuoden iässä. Kaikissa tutkimukseen osallistuvissa maissa sukupuolierot lukutaidossa olivat tyttöjen hyväksi. Arvion mukaan tyttöjen keskimääräinen ero poikiin voisi vastata noin yhden kouluvuoden edistystä. Huomattavaa tuloksissa oli, että ero tyttöjen eduksi oli Suomessa OECD-maiden suurin. Tarkasteltaessa heikoimpia lukijoita sukupuolierot vielä kärjistyvät. Suomessa heikoimpien lukijoiden ryhmään sijoittui tytöistä $3 \%$ ja pojista $13 \%$. Tämäkin ero oli OECD-maiden suurin. Tytöt olivat poikia parempia kaikilla lukutaidon osa-alueilla, joita olivat lukutaito, tiedonhaku, ymmärtäminen ja tulkinta sekä pohdinta ja arviointi. 
Poikien potentiaalinen vahvuus tyttöihin nähden kouluoppimisessa on ollut havaittavissa matematiikassa. Vuoden 2009 PISA-tutkimuksessa kaikki maat mukaan ottaen pojat olivat menestyneet yleensä tyttöjä paremmin, joskaan erot eivät olleet kovin suuria. Suomessakin tulos oli samansuuntainen kuitenkin niin, että tyttöjen ja poikien matematiikan osaamisessa erot olivat varsin pienet kuitenkin poikien hyväksi. Ero kasvoi jossain määrin, kun tarkastelun kohteeksi otettiin korkeimmat suoritustasot. Tähän ryhmään kuului $23 \%$ pojista ja $20 \%$ tytöistä. Luonnontieteiden osaamisessa vuoden 2009 PISA-aineisto osoitti, että useissa maissa (21 maata), mutta ei kaikissa (11 maata), tytöt menestyivät poikien paremmin. Näin tapahtui myös Suomessa, jossa tytöt menestyivät poikia paremmin. Saavutettujen pistemäärien ero ei kuitenkaan ollut erityisen huomattava.

Myös opetushallituksen tutkimuksissa eri oppiaineiden osaamisesta koulussa on kiinnitetty huomiota sukupuolen välisiin eroihin. Vuonna 2006 arvioitiin äidinkielen (suomi tai ruotsi) ja matematiikan osaamista perusopetuksen kolmannella luokalla (Huisman, 2006). Tulokset osoittivat, että tyttöjen osaamisen taso äidinkielessä oli poikia korkeampi. Myös tyttöjen asenne äidinkieltä kohtaan oli positiivinen, kun sitä vastoin poikien asenne yleensä oli negatiivinen. Matematiikassa ei havaittu selkeitä sukupuolen välisiä eroja lukuun ottamatta algebraa, jossa poikien oppimisen taso oli korkeampi kuin tyttöjen. Asenteissa matematiikkaan pojat olivat myönteisempiä kuin tytöt. Tuloksista voitiin havaita, että pojilla $25 \%$ ja tytöillä 16 $\%$ oppimaan oppimisen taidot olivat alhaiset. Tulos kohdentui erityisesti äidinkielen ja matematiikan oppimiseen.

Luonnontieteiden osaamisessa tehdyt eräät aikaisemmat arviot ovat osoittaneet Suomessa, että tämän vuosituhannen alussa yleisesti ottaen pojat olivat tyttöjä parempia (Rajakorpi, 1999; Rajakorpi, 2000; Halkka, 2003). Kuitenkin sekä tytöillä että pojilla oli oppimisessaan omat vahvuutensa. Tyttöjen vahvuus oli biologia ja poikien fysiikka ja kemia. Vieraissa kielissä (englanti ja ruotsi) tyttöjen osaamisen taso on ollut poika korkeampi (Jakku-Sihvonen et al., 1996; Tuokko, 2000, 2002, 2003). Taideaineissa sekä uskonnossa ja etiikassa tyttöjen taidot on todettu olevan poikia edistyneemmät mukaan lukien asenteiden myönteisyys (Korkeakoski, 1998; Rusama, 2002). 


\section{Havaintoja tyttöjen ja poikien oppimisesta esiopetuksessa ja koulun alussa}

Helsingin yliopiston ja Helsingin kaupungin käynnistämässä tutkimushankkeessa on analysoitu tyttöjen ja poikien oppimista esiopetusvuoden päättyessä ja sen jatkumaa koulun 1. ja 2. luokilla (Ojala \& Talts, 2007; Ojala, 2007). Arvioinnin tulokset esiopetuksessa ja koulun alussa on esitetty liitekuvissa 3-5.

Liitekuvissa 3-5 esitetyt tulokset tyttöjen ja poikien oppimistuloksista esiopetuksen päättövaiheessa ja koulunkäynnin alussa vuosiluokilla 1-2 tukevat kehityspsykologisia havaintoja. Näyttää siltä, että erot eivät perustu ainoastaan tyttöjen ja poikien erilaiseen kypsymiseen ja kehityksen erilaiseen etenemiseen vaan niihin yhdistyy tavoitteellinen oppiminen ja opettaminen kasvatusinstituutioissa. Saatujen tulosten mukaan tyttöjen ja poikien oppiminen eriytyy jo esiopetusvaiheessa ja koulu eriyttää niitä edelleen.

Tulosten mukaan esiopetuksessa tyttöjen oppiminen näyttää olevan yleisti ottaen korkeammalla tasolla kaikissa muissa oppiaineissa matematiikkaa lukuun ottamatta, jossa pojat ovat hieman tyttöjä parempina oppijoina. Kouluun siirryttäessä, jossa tavoitteellisen oppimisen merkitys entisestään lisääntyy, tyttöjen ja poikien erot poikiin nähden lisääntyvät edelleen kaikissa tutkituissa oppiaineksissa matematiikkaa lukuun ottamatta. Koulunkäynnin edetessä erot pyrkivät edelleen lisääntymään. Merkittävimmät erot olivat esiopetuksen päättövaiheessa suoritettujen merkitsevyystestausten (varianssianalyysi) perusteella tulosten mukaan tyttöjen eduksi oppimaan oppimisen taidoissa, sosiaalisissa taidoissa, uskonnossa ja etiikassa, terveyskasvatuksessa, fyysisessä ja motorisissa taidoissa sekä taideaineissa. Erot fyysisen ja motorisen sekä taiteen alueilla olivat erityisen suuret. Toisen kouluvuoden keväällä tyttöjen oppimisen taso oli poikia merkitsevästi korkeampi oppimaan oppimisen taidoissa, sosiaalisissa taidoissa, äidinkielessä, uskonnossa ja etiikassa, liikunnassa ja terveystiedossa sekä kaikissa perusopetuksen taideaineissa. Erityisen suuria erot olivat tyttöjen eduksi äidinkielessä ja taideaineissa. 


\section{Alueellinen tasa-arvo esiopetuksessa ja koulussa}

\section{Havaintoja esiopetuksesta}

Laajoja maata koskevia selvityksiä varhaiskasvatuksen ja esikoulun oppimistuloksista alueellisen tasa-arvon kannalta ei ole toistaiseksi käytettävissä. Suppeampia arviointeja sen sijaan on tehty esiopetuksesta. Ojalan (2007) keräämästä aineistosta koskien Helsingin kaupungin esiopetusta kävi ilmi lasten oppimistulosten epätasainen alueellinen jakautuminen (Liitekuva 8).

Liitekuva 8 osoittaa, että suuressa kaupungissa kuten Helsingissä lasten esiopetusta koskevat oppimistulokset voivat vaihdella esiopetuksen alueellisen sijainnin mukaan. Tuloksissa erottuu etenkin alue (Liitekuvassa 8 alue X1), jossa lasten oppimistulokset olivat muita alueita korkeammat ja vastaavasti alue, jossa oppimistulokset olivat kaikkien matalimmat (Liitekuvassa 8 alue X 7). Kysymys saattaa olla samantapaisista sosioekonomista taustatekijöistä kuin Kuuselan (2006) raportissa esitettiin. Pääkaupunkiseudulla alueelliseen erilaistumiseen ja tätä kautta lasten oppimistuloksiin vaikuttaa todennäköisesti myös maahanmuuttajaperheiden sijoittelu tiettyihin kaupungin osiin (Esiopetusaineistossa tällaista aluetta edustaa X7 liitekuvassa 8).

Toinen näyte esiopetuksen alueellisesta tasa-arvosta perustuu Helsingin yliopiston koulutuksen arviointikeskuksen arvioon lapsen oppimaan oppimisen taidoista, joita arvioitiin Vantaan peruskouluissa ensiluokkalaisilla lapsilla (Vainikainen ym., 2011). Aineisto kattoi yli 2000 oppilasta. Oppimaan oppimisen taitoja arvioitiin osaamistehtävillä, jotka kohdistuivat analogiseen päättelytaitoon, maailman hahmottamiseen, muistiin, tarkkuuteen ja nopeuteen sekä ohjeiden noudattamiseen (osaamisalueet). Koulutuksellista tasa-arvoa analysoitiin luokkien, koulujen ja alueiden, kotitaustan sekä sukupuolten välisinä eroina.

Tulosten mukaan lapsen oppimaan oppimisen taidoissa voitiin havaita, että koulujen väliset erot olivat varsin pieniä. Tutkijat arvioivat, että koulukohtainen vaihtelu selitti vain $0-4 \%$ oppimaan oppimisen seitsemästä osaamisalueesta. Eniten (4\%) koulukohtaisia eroja oli ohjeen noudattamisessa. Kolmella osaamisalueella koulukohtainen vaihtelu ei vaikuttanut lainkaan lasten oppimaan oppimisen taitoihin. Jossain määrin enemmän voitiin havaita luokkakohtaista vaihtelua, mutta senkin suurus jäi kokonaisuudessaan pieneksi. Arvioidusta osaamisalueesta riippuen luokkakohtainen vaihtelu 
selitti 5-18\% oppimaan oppimisen taitojen kokonaisvaihtelusta. Suurin osa kokonaisvaihtelusta voitiin selittää oppilaiden välisillä eroilla, jotka osaamisalueesta riippuen selittivät 82-95\% kokonaisvaihtelusta.

Arvioinnissa hyödynnettiin myös opetta-arvioita, jotka kohdistuivat työskentelytaitoihin, oivaltavuuteen, lukemiseen, kirjoittamiseen ja laskemiseen. Tulokset näilläkin osa-alueilla olivat hyvin samankaltaiset kuin osaamistehtävillä saadut. Koulukohtainen vaihtelu ei selittänyt lainkaan kokonaisvaihtelua. Luokkakohtainen vaihtelu selitti osa-alueesta riippuen 4-18\% opettajien arvioista oppilaan osaamisesta. Opettajien arvoissa lukemisen luokkakohtainen vaihtelu oli vähäisintä (4 \%) ja matematiikan korkein (20\%). Yksilökohtainen vaihtelu selitti osa-alueesta riippuen 84-95 $\%$ opettajien arvioiden kokonaisvaihtelusta.

Vantaan esiopetuksesta kerättyä aineistoa tarkasteltiin myös oppilaiden kotitaustan mukaan, joka luokiteltiin perustuen äidin koulutukseen. Tuloksista kävi ilmi, että useimmissa osaamistehtävissä kotitaustan koulutukselliset erot olivat varsin pieniä eikä äidin koulutustaso juurikaan selittänyt oppimaan oppimisen osaamisen tasoa (selitysosuus vain 1-3\%). Parhaiten kotitausta selitti osaamista maailmanhahmotustehtävässä, säännön noudattamisesta ja ohjeen ymmärtämisessä. Myöskään opettaja-arviot eivät yhdistyneet äidin koulutustason vaihteluun (selitysosuus vain 1-4 \%). Opettaja-arvoissa oli kuitenkin havaittavissa yhteys äidin koulutustasoon. Mitä korkeampi äidin koulutus oli, sitä taitavammiksi ja oivaltavammiksi opettajat arvioivat lapsen. Opettajat arvioivat korkeasti koulutettujen äitien lapset muita lapsia osaavammaksi lukemisessa, kirjoittamisessa ja laskemisessa. Korkeasti koulutettujen äitien lapsilla todettiin olevan myös harvemmin vaikeuksia edellä mainituissa oppiaineissa.

\section{Havaintoja perusopetuksesta}

Opetushallitus seuraa maassamme koulujen antamaa opetusta ja lasten oppimista myös alueellisen tasa-arvon lähtökohdista käsin. Käyttäen vuosina 1998-2004 suoritettuja oppimisen arviointeja matematiikassa, äidinkielessä, luonnontieteissä, englannin A-kielessä ja ruotsin B-kielessä kuudesluokkalaisilla oppilailla (oppilaita yhteensä yli 90 000) opetushallitus on koonnut Kuuselan (2006) toimesta tulokset läänikohtaisesti (Liitekuva 6).

Kuuselan (2006) tuottama raportti antaa varsin myönteisen kuvan alueellisen tasa-arvon toteutumisesta Suomen perusopetuksessa vuosina 
1998-2004. Oppimistuloksissa ei ole alueellisesti suuriakaan eroja. Läänikohtaiset oppimistulokset ovat lähellä toisiaan. Kuitenkin oppisaavutukset Pohjois-Suomessa ovat olleet hieman muuta maata alhaisemmat. Tämä on ilmennyt erityisesti Lapin läänissä, jossa tietynlaisen marginaaliryhmän ovat muodostaneet maaseutukoulujen pojat. Tasa-arvoa tukeva havainto tutkimusaineistossa oli kuitenkin se, kaupunki- ja maaseutukoulujen oppilaiden keskimääräisissä oppimistuloksissa ei ole juurikaan eroja. Kun oppimistulosten analyysia jatkettiin ottamalla huomioon oppilaiden sosioekonomisen taustan (vanhempien koulutustaso ja työllisyys) vaikutukset oppimistuloksiin, erot tasoittuivat vieläkin enemmän. Tämä osoittaa, että läänien välisille eroille on mahdollista löytää pikemminkin sosiologisia kuin perusopetuksen toteutuksesta johtuvia eroja.

Verratessa oppilaiden oppimissaavutuksia koulukohtaisesti havaittiin, että suurin osa kunnista ja kouluista oli lähellä maan yhteistä keskiarvoa (Liitekuva 7). Eroja löytyi kuitenkin ääripäissä. Suhteellisen pienessä osassa kouluja ja kuntia oppimissaavutukset voivat olla keskiarvoa huomattavasti alempia ja vastaavasti toisessa ääripäässä huomattavasti korkeampia. Kävi myös ilmi, että maaseudulla oppimistulosten vaihtelu oli lähinnä koulujen sisäistä, mutta suurissa kaupungeissa etupäässä koulujen välistä. Suurissa kaupungeissa koulujen välisiin eroihin vaikuttaa myös valikoituminen haluttuihin kouluihin. Kaupunkikoulut olivat myös keskimäärin suurempia kuin maaseutukoulut.

\section{Kohti sukupuolisensitiivistä varhaisvuosien kasvatusta ja opetusta}

Sukupuoleen liittyvää kasvatusta ja opetusta on ryhdytty tarkastelemaan lisääntyvässä määrin sukupuolisensitiivisestä painotuksesta käsin. Yleisesti ottaen sukupuolisensitiivisessä kasvatuksessa pyritään tiedostamaan sukupuoliin liittyvät käsitykset ja stereotypiat sekä edistää sukupuolten välistä tasa-arvoa (esim. Ylitapio-Mäntylä, 2012).

Tematiikkaan liittyvä tutkimus on kansainvälisesti ollut runsasta ja kotimainen tutkimus heijastelee tätä trendiä. Tutkimustoiminta ja niiden tuomat tarkastelukulmat ovat monitieteisiä. Keskeisiä teemoja ovat olleet mm. lapsen sukupuoli-identiteetti ja sen kehittyminen, isän ja äidin rooli, kodin ulkopuolisten kasvatusinstituutioiden kuten esim. päiväkodin ja koulun toimintaperiaatteet, tyttöjen ja poikien suoritteet oppimisessa, 
kasvatuksen ja opetuksen tasa-arvokysymykset liittyen sukupuolten tasaarvoon jne. (esim. Wingrave, 2018).

Kognitiivisesti painottuneessa kehityspsykologisessa tutkimuksessa esimerkiksi lasten sukupuoli-identiteetti on usein kuvattu iän mukaan porrastuvana prosessina (esim. Kohlberg, 1996). Ensimmäisessä vaiheessa noin 2,5 -vuoden iässä lapsi alkaa olla tietoinen omasta ja toisten sukupuolesta. Tällöin lapsi alkaa ymmärtämään sukupuoleen liittyviä ilmaisuja kuten tyttö tai poika sekä sitä, mitä tämä tarkoittaa jokapäiväisessä toiminnassa. Sukupuoli-identiteetti ei kuitenkaan tässä iässä ole kiinteä vaan lapsi saattaa ajatella, että sukupuoli voi muuttua eikä ole pysyvä. Lapsi voi ymmärtää, että tytöillä ja pojilla on erilainen ruumiinrakenne. Muiden sukupuoleen liittyvien ominaisuuksien ymmärtämisessä saattaa kuitenkin olla vaikeuksia. Kehityksen jatkuessa noin 5-vuoden iässä tietoisuus sukupuolesta alkaa juurtua. Tällöin lapsi alkaa ymmärtämään esimerkiksi sen, että sukupuoli ei muuttuu esimerkiksi iän karttuessa. Identiteetti on kuitenkin vasta muotoutumassa. Lapsi saattaa esimerkiksi ajatella, että sukupuoleen liittyvien fyysisten ominaisuuksien muuttaminen voi saada muutosta sukupuoleen. Kolmannessa vaiheessa noin 7-vuoden iässä lapsen sukupuoliidentiteetin sisäistymisprosessi alkaa kiinteytyä osaksi ajattelun ja päättelyn rakenteita. Tällöin sisäistynyt identiteetti saattaa säilyä aikuisikään.

Sukupuolisensitiivistä kasvatusta ja oppimista voidaan tarkastella myös sosiaalisen oppimisen teorian kautta (esim. Bandura, 1986; Bandura \& Walters, 1963). Tässä teoriassa korostetaan oppimismekanismeja ja prosesseja, joihin lapsi osallistuu vuorovaikutuksessa kasvu- ja kehitysympäristössään. Eräs keskeinen käsite sosiaalisen oppimisen teoriassa on havainnoiva oppiminen, jota usein nimitetään myös mallioppimiseksi. Havainnoituaan lasten käyttäytymistä Bandura kumppaneineen päätyi oletukseen, jonka mukaan ihmiset oppivat toimimaan ja käyttäytymään havainnoimalla toisten käyttäytymistä. Näistä muodostuu malleja, jotka voivat usein vahvistua toistuessaan. Mallit voivat olla aitoja havaintoja toisten käyttäytymisestä. Ne voivat myös olla verbaalisia ohjeita tai vihjeitä, joilla kuvataan ja selitetään toisten käyttäytymistä. Kolmas malli on symbolinen, jotka välittyvät esim. kirjojen, elokuvien, TV-ohjelmien, sosiaalisen median ym. välityksellä. Teoriassa on yhtymäkohtia klassiseen behavioristiseen oppimisen teoriaan (esim. toistuminen, vahvistuminen, sammuminen jne.). Uutta aineista teoriaan on omaksuttu kognitiivisesta psykologiasta kiinnittämällä huomiota oppimisen sisäisiin välittäviin prosesseihin kuten 
tarkkaavaisuuteen, muistiin ja motivaatioon. Tätä viitekehystä käyttäen ainakin osaa tyttöjen ja poikien havaitusta käyttäytymisestä voidaan tulkita käyttäytymismallien kautta muotoutuvana.

Sukupuolisensitiivisyyttä on lähestytty myös sosiaalisen konstruktion näkökulmasta. Lähestymistapa ankkuroituu sosiologiseen tulkintaan sukupuolesta (esim. Ryle, 2012). Tällöin sukupuoli nähdään opittuna käyttäytymisenä, joka muotoutuu kulttuurisesti sosiaalisessa vuorovaikutuksessa. Sukupuoleen liittyvä sosialisaatioprosessi alkaa periaatteessa jo ennen lapsen syntymää esimerkiksi annettaessa lapsi nimi, lapsen huoneen varustamisessa, leikkikalujen hankkimisessa jne. Oletuksena on, että varhaislapsuudesta alkaen lapsen perhe, kasvattajat ja opettajat, toveri- ja harrastusryhmät, lähiyhteisöt jne. säätelevät ja vaikuttavat lapsen sukupuoli-identiteetin muotoutumiseen. Näiden muotoutumista ohjaavat usein kulttuuriset odotukset ja sukupuoleen liittyvät stereotypiat. Sosialisaatioprosessissa lapsi rakentaa omaa identiteettiään osana sosiaalisesti muotoutuneita rakenteita kuten sosiaalinen kerrostuma (luokka), sosiaalinen vuorovaikutus toimintaympäristöissä, sosiaalisen toiminnan valtarakenteet, kulttuuri, käsitykset sukupuolisuudesta jne. Sukupuolen sosiologisessa teoreettisessa tarkastelussa on nähtävissä myös vaikutteita symbolisesta interaktionismista, jonka keskiössä on mikrotasolla tapahtuva päivittäinen vuorovaikutus, jonka tuottaa ja haastaa käsityksiä sukupuolesta (esim. West \& Zimmerman, 1987). Näkemyksen mukaan sukupuoli tuotetaan tulkinnan kautta lapsen sosiaalisessa kentässä. Tähän liittyen oletetaan, että käsitys sukupuolesta on joustava ja periaatteessa altis muutoksille.

Biologiset selitykset lapsen sukupuolieroille ovat olleet pitkään esillä (esim. Moi, 1999). Wingraven (2016) suhteellisen uusi tutkimus osoittaa, että biologiset selitykset tyttöjen ja poikien toistaan poikkeavaan käyttäytymiseen ja oppimiseen voivat olla myös nykypäivää. Tämä tutkimus tehtiin Englannissa tapaustutkimuksena, jossa analysoitiin ryhmäkeskustelujen avulla varhaiskasvatuksen ammattilaisten odotuksia ja ymmärrystä lasten käyttäytymisestä ja oppimisesta. Wingraven (2016) tutkimuksen yleisenä havaintona oli, että pienten lasten parissa työskentelevien opettajien näkemykset näyttivät perustuvan itseään toteuttavaan, lähes muuttomattomana säilyneeseen, näennäistieteelliseen ja tietynlaiseen sokeuteen jäsentää ja tulkita lapsia oppijoina. Tässä tulkinnassa työt ja pojat nähtiin erilaisina, jonka vuoksi heille tulisi tarjota erilaisia oppimiskokemuksia. Tämän tapaiset havainnot ovat lisänneet kiinnostusta myös aivojen kehitystä ja 
toimintaa koskevaan tietoon kysymällä, voidaanko esimerkiksi tyttöjen ja poikien aivotoiminnoissa löytää eroja (esim. Schmitz, 2010). Tukijoita on kiinnostanut saada vastauksia, ovatko esimerkiksi aivojen toiminnalliset erot perustaltaan lähinnä biologisia vai liittyvätkö ne lasten erilisiin kasvukokemuksiin. Kasvukokemusten puolesta näyttää viestivän esimerkiksi aivojen suuri plastisuus, joka on erityisen voimasta lapsen varhaisvuosina. Plastisuus on aivojen muutoskykyä, jonka saavat aikaan kokemukset. Jos tyttöjen ja poikien oppimiskokemukset ovat erilaisia, voi olettaa, että aivojenkin toimissa havaitaan eroja. Biologisten erojen selitysvoimaa kaventaa myös havainto, jonka mukaan tyttöjen ja poikien väliset erot näyttävät olevan suuremmat kuin tyttöjen ja poikien sisäiset (esim. Kimmel, 2005; Wingrave, 2016).

Suomessa tehdyt tutkimukset viestivät, että sukupuolisensitiivistä kasvatusta ja opetusta rajoittavia stereotypioita esiintyy varhaislapsuuden kasvatustoiminnassa (esim. Alasaari \& Katainen, 2016; Alasaari, 2013, Alasuutari, 2016; Ylitapio-Mäntylä, 2005). Ennakko-odotukset tyttöjen ja poikien eroista ovat kohdistuneet esimerkiksi kärsimättömyyteen ja äänekkyyteen (esim. pojat rajuja ja kärsimättömiä - tytöt rauhallisia ja hiljaisia), leikkiaktiviteetteihin (esim. rakenteluleikit pojille - kotileikit tytöille), kiusaamiseen (esim. kiusaajat yleensä poikia) jne. Alasuutarin (2016) tapaustutkimuksessa, jossa dokumentoitiin päivähoidon työntekijän ja vanhemman välistä kasvatuskeskustelua, havaittiin kolme sukupuoleen liittyvää keskustelutapaa. Yksiä näistä viittasi sukupuolineutraaliin. Tässä puhetavassa sukupuoli ei saa erityistä merkitystä. Tätä tapahtui usein, kun kuvattiin lapsen toimintaa päiväkodin rutiineissa ja käytännöissä (esim. ruokailu, päiväunet, esikoulutehtävät, ohjatut toiminnat jne.). Toisessa Alasuutarin (2016) havaitsemassa puhetavassa lapsen sukupuoli mainittiin ilman, että sille annetiin eritystä merkitystä ("tytöttely" ja "pojittelu"). Tällöin lapsi todetaan tytöksi tai pojaksi tilanteessa, jossa sukupuoleen liittyvän sanan olisi voinut jättää pois. Kolmas Alasuutarin havaitsema puhetapa oli sellainen, että sukupuoli sai erityisen merkityksen. Tämän tapaista sukupuolittunutta puhetapaa havaittiin toistuvasti erityisesti silloin, kun puhuttiin lapsen leikkikavereista ja leikistä. Lapsen sukupuolta pidettiin tärkeänä myös silloin kun puhuttiin hankalasta käyttäytymisestä.

Myös ulkomaisissa tutkimuksissa on havaittu sukupuolirooleihin liittyviä stereotypioita kasvatus- ja opetuskäytännöissä. Niitä on havaittu esimerkiksi pedagogisessa toiminnassa (esim. Warin \& Adriany, 2017), 
oppimisodotuksissa (esim. Wingrave 2016), leikkitoiminnoissa (esim. Cherney \& Dampsey, 2014; Chapman 2015; Huggins, 2014), lasten kirjallisuudessa (esim. Floyd, 2013) jne. Syventävänä esimerkkinä voidaan tarkastella Floyden (2013) tutkimusta, jossa analysoitiin lastenkirjallisuudessa esiintyviä sukupuoleen liittyneitä roolimalleja USA:ssa ja Norjassa. Havainnot USA:sta ovat toistuvasti osoittaneet esimerkiksi sen, että miehet yleensä kuvataan johtajina ja ajattelijoina, kun sitä vastoin naiset sijoitetaan usein kirjoissa kotiympäristöön, jossa heillä on traditionaalisia rooleja. Kun vertailukohdaksi otettiin norjalainen lastenkirjallisuus oletettiin, että tässä yhteiskunnassa miesten ja naisten roolit voisivat viestiä tasa-arvoa, jota Norjassa tunnetusti korostetaan. Tämä oletus toteutui, mutta vain osaksi. USA:ssa lastenkirjallisuus esitti Norjaa useammin naiset traditionaalisissa rooleissa. Norjassa oli yleistä, että lastenkirjojen sukupuoliroolit olivat neutraaleja. Tästä huolimatta Norjassakin havaittiin tarvetta edistää sukupuolten välistä tasa-arvoa lastenkirjallisuudessa.

Toinen syventävä esimerkki sukupuoleen liittyvistä stereotypioista perustuu Kankan ja kumppaneiden (2019) tutkimukseen, jossa analysoitiin lasten elokuvien ja televisio-ohjelmien välittämää ammatillista kuvaa ja roolia. Näissä havaittiin tyypillisiä sukupuoleen liittyviä stereotypioita. Tutkijoita kiinnosti erityisesti stereotypioiden pysyvyys siirryttäessä varhaislapsuudesta murrosikään. Tulokset osoittivat sen, että sukupuoleen liittyvät stereotypiat lisääntyivät iän myötä kuitenkin niin, että muutos oli pojilla voimakkaampaa kuin tytöillä. Kun työt ja pojat olivat 12 -vuotiaita, stereotypioiden havaittiin vähenevän. Tulosten todettiin tukevan Kohlbergin teoriaan mukaista kehitystä, jonka mukaan lasten sukupuoleen liittyvät stereotypiat voimistuvat noin 6-vuoden ikään asti väheten asteittain tämän jälkeen.

Yhteenvetona sukupuolisensitiivisen kasvatuksen ja opetuksen kehittämisestä on tärkeää tiedostaa, että lasten sukupuoli-identiteetti on intensiivisessä kehitysvaiheessa erityisesti lapsen varhaisvuosina. Toiseksi muutoksen keskiössä on lapsen kasvatus- ja oppimisympäristö, joka välittää lapselle sukupuoleen liittyviä malleja ja odotuksia. Lapsen kasvun ja oppimisen kehittymisen myötä nämä mallit ja vaikutteet sisäistyvät kiinteiksi ajattelu ja päättelyn rakenteiksi, joita esimerkiksi Wingraven (2016) tapaan voidaan nimittää tiedoksi sukupuolesta. On oletettu, että lapsen kognitiivisiin rakenteisiin voi kehittyä sukupuoleen liittyvä pysyvämpi rakenne (skeema), joka alkaa muotoutua jo noin 1-vuoden iässä (esim. Starr et al., 
2017; Wingrave, 2016). Kasvatuksen ja opetuksen kannalta on tärkeää tiedostaa, missä määrin tämä tieto on sukupuolisesti sensitiivistä. Jos sukupuoleen liittyviä stereotypioita esiintyy, niitä voidaan esimerkiksi edellä mainitun Norjan esimerkin keinoin muuttaa vahvistamalla sukupuolten tasa-arvoon perustuvia yhteiskunnallisia ja koulutuksellisia toimenpiteitä kasvatuksen ja opetuksen keinoin. 


\section{Päiväkodin ja koulun kehittäminen}

\section{Päiväkoti toiminta- ja kehittämisympäristönä}

Erityisesti Suomessa päiväkodin toiminnalle on tunnusomaista moniammatillisuus (esim. Karila \& Nummenmaa, 2001; Venninen, 2007; Kupila, 2007). Moniammatillisuus liittyy sekä päiväkodin sisäiseen toimintaan että sen yhteistyötahoihin. Riippuen siitä miten moniammatillisuus toimii päiväkotitasolla sillä voi olla omat vahvuutensa ja heikkoutensa (esim. Kupila, 2007). Vahvuutena voi esimerkiksi olla erilaisen osaamisen tarjoaminen ja hyödyntäminen. Moniammatillisuus voi myös tarjota suotuisan kasvualustan päivittäiselle vuorovaikutukselle ja kohtaamiselle, jossa erilaisuus ja samanlaisuus kohtaavat. Heikkoutena puolestaan voi olla esimerkiksi epäselvyys toimenkuvissa, ammattiryhmien väliset eturistiriidat jne. Kysymys liittyy pohjimmaltaan siihen, toteutetaanko vastuuta ja missä määrin yhteisenä vai jaettuna.

Toinen keskeinen tunnusmerkki päiväkotiemme toiminnassa on tiimityöskentely (esim. Venninen, 2007; Kupila, 2007). Tiimit pyrkivät vastaaman lapsiryhmän ohjauksesta. Myös päiväkodin kehittämisessä tiimeillä on keskeinen merkitys (esim. Venninen et al., 2014). Tiimityöskentely on haasteellista. Se voi muodostua monen taustatekijän ja vuorovaikutusdynamiikan suhteen hyvin erilaiseksi. Odotukset tiimityöskentelyn onnistumiselle ovat korkeat niin työn tuloksellisuuden kuin yhteisen vastuun suhteen. Myös aikaresurssit ja materiaaliset resurssit voidaan kokea riittämättömiksi. Tiimeissä kuitenkin toimitaan ja opitaan. Tämä voi muodostaa sillan yksilöllisen ja yhteisöllisen oppimisen välille. Työskentelyä voidaan lujittaa esimerkiksi tiimisopimusten avulla, joissa tarkennetaan tiimin jäsenten osaamista ja vastuuta (Hujala \& Forsen, 2010).

Päiväkodin henkilöstön pedagogista osaamista päivitetään ja kehitetään. Merkittävän vastuun tästä ottaa johtaja, jolla on vastuu kehittämisestä. Päiväkodin johtajan rooli ja tehtävät ovat olleet muutoksessa, jonka kuluessa on siirrytty jaettuun johtajuuteen (esim. Venninen et al., 2014; Spillane et al., 2004; Heikka et al., 2013). Lähtökohtana on ajatus, jonka mukaan jokaisella työyhteisössä työskentelevällä on enemmän osaamista kuin toisilla jossain osaamisen alueella, mutta kukaan ei omaa kaikkea osaamista. Jaettua johtajuutta toteutetaan vähentämällä toimijoiden ulkoista kontrollia ja lisäämällä autonomiaa (Venninen et al., 2014; Cecchin 
\& Wennerberg Johansen, 2009). Toiminnassa korostuu vuorovaikutus ja avoin kommunikaatio.

Jaetun johtajuuden toimintaperiaatteita voidaan soveltaa myös aluekohtaisessa päiväkodin pedagogisessa kehittämisessä. Kehittämisen kohteeksi voidaan ottaa esimerkiksi hallintokäytänteet ja niiden muuttaminen. Tällaista toimintaa on dokumentoitu esimerkiksi Helsingin pääkaupunkialueella (Venninen et al., 2014). Kohteena oli ammatillinen kehittyminen sekä päiväkodin että hallinnon henkilöstöllä VKK -metron kehittämisprojektin yhteydessä vuosina 2007-2009. Tulosten perusteella voitiin havaita, että jaetun johtajuuden periaatteet tukevat sekä päiväkodin henkilöstön että hallinnossa työskentelevien ammatillista kehittymistä kohti avoimuutta, luottamusta ja jaettua vastuuta. Kehittämisprosessi myötävaikutti siihen, että pedagogisen uudistamisen vastuu ei ollut yksipuolisesti päiväkotien tiimeillä tai hallinnolla. Kehittämisprosessissa oli keskeistä jaettu vastuu ja avoin vuorovaikutus pedagogisten toimijoiden ja hallinnon välillä.

\section{Koulun uudistaminen}

Koulun kehittämisessä voidaan käyttää useita lähestymistapoja. Kehittäminen voi ohjautua ylhäältä alaspäin, alhaalta ylöspäin, kaksisuuntaisesti tai verkostojen välityksellä (Rajakaltio, 2014). Ylhäältä alaspäin etenevässä kehittämisessä vastuu on viranomaisilla ja johtajilla, joiden pyrkimyksenä on kohdistaa kouluun hallinnollisella tasolla kehiteltyjä uudistuksia. Tässä prosessissa korostuu johtaminen ja tehokkaan muutoksen aikaansaaminen. Toteutus tapahtuu usein julkisin varoin toimivina kehittämisprojekteina, joiden painopiste vaihtuu. Lähestymistavan heikkoutena ovat usein pinnallisuus ja muutosten lyhytkestoisuus. Kehitys voi ilmetä puheena ja retoriikkana ilman kosketusta opetuksen rakenteisiin ja käytänteisiin. Ylhäältä alaspäin johdetuissa kehittämisprojekteissa opettajat myös väsyvät helposti, joka omalta osaltaan voi johtaa muutosvastarintaan.

Alhaalta ylöspäin etenevä kehittäminen käynnistyy työyhteisössä. Kantavana voimana on päivittäinen työyhteisössä tapahtuva vuorovaikutus, keskustelu, ideointi ja aloitteet kehittää koulua. Prosessi on reflektiivistä ja dialogista, jossa koulun kasvatuskäytänteitä ja opetusta pohditaan, analysoidaan ja arvioidaan yhdessä kehittämisen näkökulmasta. Alhaalta ylöspäin etevää kehittämistä on tarpeen johtaa. Sen kantavana voimana on keskinäinen luottamus. Asiantuntijoita hyödynnetään ja yhteistyötä 
voidaan laajentaa muihin kouluihin. Kaksisuuntainen kehittäminen etenee kiinteässä vuorovaikutuksessa alhaalta ylös ja ylhäältä alaspäin. Näin voidaan yhdistää työyhteisölähtöinen ja hallintolähtöinen kehittäminen. Koulun uudistuksia voidaan toteuttaa myös verkottumalla (esim. Akvaarioprojektit; Ojala \& Siekkinen, 1998; Forss-Pennanen, 2006). Kysymyksessä on yhteisöllinen kehittäminen. Verokostuminen tarjoaa avoimen keskustelufoorumin, joka voi vahvistaa ja monipuolistaa kehittämistä. Se voi lisätä myös kehittämisen jatkuvuutta. Verikostuvassa kehittämisessä sen hallinta ja johtajuus voi olla vaikeaa ja kehittämisen ydinajatus saattaa hämärtyä.

Rajakaltion (2014) arvion mukaan on mielekästä yhdistää erilaisia lähestymistapoja koulun kehittämiseen. Yhteisöllistä lähestymistapaa voi kuitenkin pitää keskeisenä. Rajakaltio on raportoinut projektia (Yhteisöllinen koulu), jossa haluttiin tukea kouluja opiskelun kolmiportaisen tuen kehittämisessä koulutuksen ja konsultoinnin avulla. Tavoitteena oli vahvistaa kollegiaalista ja moniammatillista toimintakulttuuria, koulujen pedagogista ja oppimiseen liittyvää tukea, yhteisöllisyyttä ja hyvinvointia sekä opettajien täydennyskoulutusta. Projektia toteutettiin koulujen, kuntien opetustoimen ja yliopiston yhteistyönä. Kokeilun kuluessa kunnat ideoivat omia kehittämisalueitaan. Tulosten tärkeänä antina voi pitää kehittämisprosessin esteiden ja edistävien tekijöiden koontia. Esteinä olivat jääminen retoriikan ja byrokratian tasolle, pedagogisen johtajuuden puuttuminen, muutospaineet ja sisäiset jännitteet, irrallisuus arjen toiminnasta, yhteisöllisten rakenteiden puuttuminen, oppilaan unohtuminen, opetustyön jäykät rakenteet sekä resurssien niukkuus. Myös useita kehittämistyötä edistäviä tekijöitä identifioitiin. Näitä olivat pedagogisen johtajan rooli, kehittämisen kiinnittyminen kunnan opetustoimeen, yhteisölliset rakenteet, osallisuus, vuorovaikutus ja keskusteleva kehittämiskulttuuri, pysyvät kehittämisrakenteet, täydennyskoulutus, moniammatillisuus, oppilaskeskeisyys, verkottuminen sekä kehittämisen pitkäjännitteisyys. 


\section{Refleksiivinen lähestymistapa kasvatustoiminnan kehittämisessä}

\section{Refleksiivisen toiminnan tunnusmerkkejä}

Refleksiivinen toiminta on avoin muutoksille. Tunnusomaista muutoshakuiselle käytännön kehittämiselle on, että se etenee prosessinomaisesti askel askeleelta. Eteneminen sisältää useita osavaiheita. Näitä ovat tietoisuus muutoksen tarpeellisuudesta, sitoutuminen muutokseen, visio muutoksesta, vision sisäistäminen ja lopuksi muutoksen siirtäminen todellisuuteen.

Refleksiivistä lähestymistapaa on sovellettu toiminnan kehittämiseen eri alueilla kasvatus ja opetus mukaan lukien (esim. Ojala \& Venninen, 2010). Reflektiivistä kehittämistä on pyritty hahmottamaan esimerkiksi kuvaamalla sitä suhteessa tarkoitukseen, sisältöön ja prosessiin (Osterman \& Kottkamp, 1993).

Tarkoituksena on saada aikaan toiminnan muutosta niin, että on itse tietoinen muutoksesta. Muutos ilmenee ajattelussa, tunteissa, sosiaalisessa vuorovaikutuksessa ja toimintakulttuurissa. Muutoksen sisältö muodostuu monitasoisesta tiedosta, joka voi olla yleistä, persoonallista, annettua, probleemaorientoitunutta, tiettyihin sisältöihin kytkeytyvää tai/ja prosessiorientoitunutta. Tieto ankkuroituu myös teoreettisiin lähestymistapoihin kuitenkin niin, että teoria ja käytännön toiminta ovat jatkuvassa vuorovaikutuksessa. Näin muotoutuu toimintaa jäsentävä käyttöteoria.

Keskinen tunnusmerkki reflektiolle on prosessikeskeisyys, jolle on tunnusomaista ajatuksen vaihto, kokeilu, yhteistoiminnallisuus, kokonaisvaltaisuus ja persoonalliset näkemykset. Prosessiin osallistuvien asiantuntijoiden roolina ei ole opettaa vaan tukea muutosta. Käytännön toimijat ovat oppijoita eivätkä opetettavia. Tehtävänä on kehittää ja tutkia toimintaympäristöä toimintatutkijoiden tapaan.

Merkittävä pedagoginen uudistaja Dewey (1993) lähestyi reflektiota erottamalla toisistaan rutiininomaisen reflektion ja reflektiivisen toiminnan. Rutiininomainen reflektio kohdistaa huomion kasvatustapahtuman ulkoisiin puitteisiin, vakiintuneisiin toimintatapoihin, traditioihin ja auktoriteettinäkemyksiin. Refleksiivisessä toiminnassa henkilö tarkastelee työtään hellittämättä ja huolella tarkoituksena kehittää työtään. Tällöin kasvatus voi uudistua tavalla, jossa tavoitteet ovat dynaamisia eivätkä tarkkaan etukäteen suunniteltuja ja johda kasvatuskäytäntöä staattisuuteen. Tiukka 
etukäteismäärittely johtaa siihen, että tavoitteet eivät kiinnity oppimisprosessiin ja sen kontekstiin. Näin lapsella ei ole mahdollisuutta oppia prosessien ja kontekstin kautta. Jos sen sijaan oppiminen etenee dynaamisten tavoitteiden avulla, toiminnan tavoitteet jäsentyvät toiminnasta sinänsä, jolloin näin saavutettu dynaaminen tavoite saa aikaan toiminnan, joka johtaa johonkin uuteen dynaamiseen tavoitteeseen. Tärkeä ehto tällaiselle dynaamisesti ohjautuvalle oppimiselle on taata sille riittävästi aikaa. Toiminnan kautta huomio kiinnittyy käytäntöön, jota tarkastellaan monipuolisesti, avoimesti ja vastuuta tuntien.

Reflektiiviseen toimintaan liittyy tietoista ajattelua, jolle on tyypillistä probleemanratkaisutyyppinen lähestymistapa, jossa pohditaan ja testaan erilaisia vaihtoehtoja käytännön kehittämiselle ja muutetaan toimintaa ajattelun ja kokemusten perusteella. Tälle vastakkaista on toiminta, jota ei reflektoida tai sitä reflektoidaan vain vähän. Tällöin käytännön toiminnasta tulee rutiininomaista tai heittelehtivää. Siinä noudatetaan traditioita ja aikaisempia käytäntöjä. Tällöin myös teoreettinen tieto sovelletaan mekaanisesti ilman pohdintoja ja tietoisuutta sen liittymisestä käytännön tilanteisiin.

Reflektiivisessä toiminnan analyysissa probleeman ratkaisulla on keskeinen merkitys ja siksi se on eräs reflektion yleisistä tunnusmerkeistä (esim. Hutton \& Smith, 1994). Siihen sisältyy toiminnan ajattelua ja erittelyä tavoitteena löytää uusia ratkaisuja. Probleemanratkaisutyyppisellä toiminnan kehittämisellä pedagogit voivat saada syvenevää ymmärrystä toiminnasta siinä kontekstissa missä se tapahtuu kiinnittämällä huomiota toiminnan tavoitteiden ja toteutuksen välisiin ongelmiin.

Kriittisyyttä pidetään yhtenä keskeisenä reflektiivisen kehittämisen tunnusmerkkinä (esim. Hutton \& Smith, 1994; Brookfield, 1995). Toiminnan reflektioon liittyvä kriittisyys kehittyy usein pitkäaikaisena itsekriittisenä ajatteluna siitä, miten toimintaa pitäisi muuttaa ja kehittää. Kriittisyydellä voi olla myös edellistä laajempi tietoisuuden taso, jolloin toimija alkaa pohtia syvällisemmin käytäntöä ohjaavaa kasvatusideologiaa ja sitä sääteleviä arvoja. Tällöin reflektio ei enää kiinnity suoraan toimintaan vaan toimintaa ohjaaviin ja jäsentäviin uskomuksiin ja arvoihin. Tällaista tietoisuuden tasoa liittyy esimerkiksi Dahlbergin ym. (1999) tapaan hahmottaa pedagoginen dokumentointi. Pedagogista dokumentointia tarkastellaan yksityiskohtaisemmin tässä luvussa myöhemmin. 
Toiminnan kriittisessä reflektiossa yhteinen ajattelu ja pohdinta kollegojen kanssa on keskeistä. Tällöin kollegat ovat kriittisiä ystäviä. Ajatusten vaihto toisten kanssa kehittää reflektion syvyyttä, antaa siihen uutta perspektiiviä ja rohkaisee testaamaan omia ajatuksia. Sosiaalinen reflektio saa aikaan muutosta jokaisen toimijan ajattelussa, jolloin he voivat jakaa kokemuksia, synnyttää uusia tulkintoja ja nostaa esiin uusia kysymyksiä (Mezirow, 2000). Kun toimijat voivat yhdessä toimia kriittisinä ystävinä palaute toiminnasta sekä sen probleemoista ja kehittämisen suunnista voidaan tehdä monipuolisen ja yhdessä avatun palautteen avulla (Venninen, 2007).

Reflektiivisessä toiminnan kehittämisessä on kiinnitetty huomiota myös siihen, miten syvälle reflektiivinen ajattelu prosessoituu. Näin tarkastellen reflektio voi saada eri tasoja (esim. Van Manen, 1977; Ojala \& Venninen, 2011). Usein refleksiivinen toiminta alkaa sillä, että henkilö ryhtyy keräämään toiminnasta faktoja. Se voi tapahtua esimerkiksi dokumentoinnin avulla. Tällainen reflektointi on pääosin kasvatuskäytännön teknistä kuvaamista. Siina kirjataan ekologisesti orientointuneen tutkimusaineiston keräämisessäkin omaksutun tavan mukaan tarkkaan ylös tapahtumat ja niiden konteksti ilman, että samalla ryhdytään tulkitsemaan niitä. Tulkinta tehdään myöhemmin. Reflektioprosessin edetessä pohdinnan syvyys lisääntyy. Kasvatuskäytäntöä tarkastellaan kiinnittämällä huomiota esimerkiksi sen tavoitteisiin, prosesseihin ja toivottuun tulokseen. Yhteinen ja avoin pohdinta on keskeistä. Reflektio voi edeltä vielä seuraavan vaiheeseen, jolle on tunnusomaista kriittisyyden lisääntyminen. Kriittiseen reflektioon liittyy periaatteellista pohdintaa kasvatuskäytännön päämääristä ja sen toteutuksesta, moraalista ja eettistä pohdiskelua, avointa arviointia sekä avoimuutta kuunnella ja toimia muiden kanssa. Kriittisessä reflektiossa käytäntöä voidaan pohtia esimerkiksi suhteessa kasvatuksen ja opetuksen yhteiskunnalliseen, sosiaaliseen, poliittiseen, kulttuuriseen ja pedagogiseen perustehtävään.

\section{Reflektion mallintaminen}

Korthagen (2001) on pyrkinyt mallintamaan teorian ja kasvatuskäytännön kohtaamista kehittämänsä ALACT-mallin avulla ( $\mathrm{A}=$ Action, $\mathrm{L}=$ Looking back on the action, $\mathrm{A}=$ Awareness of essential aspects, $\mathrm{C}=$ Creating alternative methodes of action, $\mathrm{T}=$ Trial). Mallin mukaan teorian ja käytännön 
kohtaaminen voi edetä viiden toisiinsa liittyvien osaprosessien kautta: (a) toiminta, (b) toiminnan reflektointi, (c) tietoisuus olennaisista tekijöistä, (d) vaihtoehtoisten toimintatapojen kehittäminen, ja (e) uusi toiminta.

Kun ollaan toiminnan vaiheessa, tärkeää on kiinnittyä koettuihin konkreettisiin probleemoihin sellaisina kuin ne esiintyvät ja niissä puitteissa missä ne esiintyvät. Refleksiivisessä käytännön kehittämisessä on tärkeää pitää yllä halukkuutta muuttumiseen ja kehittymiseen siten, että yllykkeet tähän eivät tule ulkoa käsin ja ne vastaavat toimijoiden tarpeita. Keskeistä on riittävä motivaatio muutokselle. Tätä seuraavassa osavaiheessa toimijoiden tulisi reflektoida syvällisemmin toimintaa. Tähän prosessiin liittyy esimerkiksi tarkempi pohdinta kasvatuskäytännön puitteista, omista pyrkimyksistä sekä omakohtaisista ajatuksista ja keinoista, joilla voi syventää reflektiota. Reflektiossa on tärkeää säilyttää avoimuus lapsista ja aikuisista tehdyille havainnoille, ajatuksille, tunteille, tarpeiden pohdinnalle, toiminnan erityispiirteille ja eri osapuolten näkemyksiin. Esimerkiksi aktiivisilta toimijoilta saaduilla roolimalleilla voi olla tärkeä merkitys käytännön kehittämisessä. Syvenevän reflektion avulla tietoisuus kasvatus- ja opetuskäytännön olennaista tekijöistä voi syventyä ja reflektio voi sisäistyä uudelle tasolle. Tässä vaiheessa voidaan saada aikaan kosketuspinta myös teoreettisempiin kiinnekohtiin. Keskeistä on säilyttää yhteys tiedon ja teorian omakohtaiseen tarkasteluun siten, että kiinnittyminen käytännön toimintaan ei katoa. Lisääntyä sisäinen ja teoreettinen pohdiskelu myötävaikuttaa siihen, että toimijat ryhtyvät pohtimaan ja työstämään vaihtoehtoisia tapoja jäsentää ja toteuttaa kasvatuskäytäntöä. Näiden muotouduttua henkilöt ovat valmiita kokeilemaan ja työstämään käytäntöä uudella tavalla ja edellä kuvattu reflektiivinen prosessi voi tavallaan alkaa alusta.

Toisena refleksiivisen toiminnan mallina tarkastellaan Östermanin ja Kotkampin (1993) kehittämää kokeellisen oppimisen mallia. Tämä malli on edellistä yleisemmällä tasolla, mutta siinä on myös samantapaisia osatekijöitä. Kokeellisen oppimisen mallin keskeiset osatekijät ovat (a) konkreettiset kokemukset, (b) havainnointi ja analyysi, (c) uudelleen jäsentyvä käsitteellistäminen, ja (d) aktiivinen kokeilu.

Tässä mallissa lähtökohtana reflektiolle ovat konkreettiset kokemukset kasvatuskäytännöstä. Huomio voi kiinnittyä johonkin mieltä askarruttavaan seikkaan, joita on vaikea ratkaista vallitsevalla kasvatuskäytännöllä. Ensimmäisen vaiheen jälkeen voidaan siirtyä kasvatuskäytännön tarkempaan havainnointiin ja analyysiin. Toimija voi pohtia, havainnoida ja 
analysoida toimintaansa kiinnittämällä huomiota esimerkiksi siihen, mitä hän todella teki ja mitä ehkä jäi tekemättä. Havainnoinnin ja analyysiin avulla toiminnan todellisuutta ja ideaalia voi haarukoida ja selkeyttää näiden välistä mahdollista kuilua. Näin toimijalla on mahdollisuus ammentaa uutta ainesta, uusia keinoja ja uusia välineitä saadakseen aikaan paremmin toimiva kasvatuskäytäntö. Tämän tueksi hän usein tarvitsee uudelleen jäsentyvää teoria-ainesta ja toimintaa ohjaavia periaatteita. Edellisten osaprosessien ohjaamana toimijat ryhtyvät vallitsevan kasvatuskäytännön vaihtoehtoisiin aktiivisiin kokeiluihin. Edellytyksenä on, että tähän liittyy riittävää motiivia ratkaista aikaisemmin esiintyviä probleemoita tai aukkoja. Edellä esitellyn mallin perusidea voidaan pelkistää periaatteessa yksikertaiseksi: Reflektoiva kasvatus- ja opetuskäytännön uudistaminen saa alkunsa kysymyksistä ja päättyy syvenevän reflektion kautta toiminnan muuttamiseen.

Erään uusimmista reflektion malleista ovat kehittäneet Black ja Plowright (2010). Malli kuvaa reflektiivistä oppimista ja käytäntöä moniulotteisena. Ulottuvuudet koostuvat reflektion (a) lähteistä, (b) tavoitteista ja (c) tarkoituksesta. Reflektion lähde kohdistuu oppimiskokemukseen ja käytäntöön. Reflektion tavoitteena on oppiminen. Reflektion tarkoituksena on kehittää oppimista ja käytäntöä. Mallin tarkoituksena on selittää oppimista ammatillisessa kehittymisessä, johon kokemukset, reflektio, uudistuminen ja kehitys liittyvät osaprosesseina. Uudistumisprosessia tukee dokumenttipohjainen dialogi toiminnasta, dialogi oman itsensä kanssa ja voimaatuminen toiminnassa.

\section{Havaintoja varhaiskasvatuksen ja esiopetuksen kehittämisestä reflektion avulla}

Pääkaupunkiseudulla toimi vuosina 2008-2009 yhteensä 21 tutkimuspäiväkotia Helsingissä, Vantaalla, Espoossa ja Kauniaisissa (Mäkitalo ym., 2009). Yhteisenä tavoitteena oli kehittää päiväkodin pedagogiikka reflektiivisen työskentelymallin tukemana. Refleksiivistä kehittämisprosessia seurattiin tiimien tasolla (tiimejä noin 300, joissa noin 1500 lasta) toistuvilla elektronisilla kyselyillä ja ryhmähaastatteluilla (Ojala \& Venninen, 2011). Tiimit kuvasivat ja arvioivat tiiminsä vuorovaikutusta, esille nostettuja ideoita ja niihin suhtautumista. Myös tiimin kehittämistehtävän toteuttamiseen liittyviä ongelmia ja niihin löytyneitä ratkaisuja kuvattiin. 
Kerätyn aineiston analyysissä kohdistettiin erityistä huomiota siihen, millaisella syvyydellä tiimit toimivat refleksiivisessä kehittämisessä. Analyysin perusteella tiimien refleksiivisessä prosessissa esiintyi neljä reflektion syvyyttä kuvaavaa tasoa (Ojala \& Venninen, 2011):

(1) Rutiininomainen toiminta (5\% tuotetuista luonnehdinnoista, esimerkki: Meillä yksi henkilö teki aina kaikki tietokonehommat ). Se ei sisällä reflektiota tai sisältää sitä vain hyvin vähän. Tasolle on tyypillistä asioiden ja toiminnan rutiininomainen läpikäyminen ja huomion kiinnittäminen toiminnan tyypillisiin ja vakiintuneisiin puitteisiin.

(2) Toiminnan kuvaaminen (61\% tuotetuista luonnehdinnoista, esimerkki: Meil oli tässä ryhmässä kanssa kamerakännykkä käytössä. Ja niinkun täs on tullu, niin ihan samalla tavalla hyvin positiivinen oli palaute ja kaikki vanhemmat tykkäs ja kaikki vanhemmat kävivät lastensa kanssa niitä kattomassa; toinen esimerkki: Ja me tehtiin siihen kaavakkeeseen muutoksia. Me ei tehty konkreettisesti sinne kaavakkeeseen, vaan me keskenämme puhuttiin ja sovittiin.. ). Tässä reflektion tasossa toiminnasta tehdään havaintoja, mutta pohditaan niitä pintapuolisesti. Tarkastelu kohdistuu siihen, mitä kukakin teki tai mitä tapahtui. Oliko lopputulos onnistunut vai menikö joku pieleen? Ei pysähdytä pohtimaan, miten asiat vaikuttavat toisiinsa tai mitä erilaisia vaihtoehtoja olisi ollut.

(3) Toiminnan analyysi (24\% tuotetuista luonnehdinnoista, esimerkki: Mä sanoisin, että mun tapa havainnoida oli hyvin pintapuolista sillälailla, että mä lähinnä katoin, että se on niinkun siinä ikätasolla, et se käyttäytyy normaalisti. Et mä en koskaan ajatellu, et sitä voi sillai hyödyntää..., toinen esimerkki: Ja sithän tosiasia vaan on, että jos me täällä keskustellaan, niin jokainen kuulee vähän eri tavalla riippuen siitä omasta näkökulmasta mitä ottaa niinkun vastaan siitä keskustelusta...). Tässä reflektiotasossa toiminnasta tehdään havaintoja (reflection in action) ja pohditaan esimerkiksi sitä, miten voisi kehittää toimintaa. Pohditaan myös tapahtumaketjuja, mahdollisia syy- ja seuraussuhteita sekä sitä, mitkä toimintavaihtoehdot parhaiten vievät kohti asetettuja tavoitteita. 
(4) Lähtökohtien pohdinta (10\% tuotetuista luonnehdinnoista, esimerkki: Alettiin pohtimaan sitä, että miksi päivähoidon julkisuuskuva on negatiivinen. ...Ja vanhusten hoidolla on vielä huonompi ... miksi kaikki lööpit vedetään aina niistä epäonnistumisista..; toinen esimerkki: Täällä tehdään hienoja asioita ja merkittäviä asioita. Ja jotenkin se, että osattaisi itsekin olla ylpeitä siitä. Kyllä minun mielestä myös sitä kautta on kasvattanut sitä tietoisuutta siitä - ja oman työn arvostamista. Tämä on hirveän laaja-alaista omankin työn dokumentointia samalla.. ; kolmas esimerkki: Tämä on integroitu ryhmä, missä me ollaan. Kun oli havainnoinut lapsia ja huomannut niiden erilaiset oppimistyylit, niin antoi tosiaan luvan lapsille. Yksi sai minuutin välein pompahtaa ylös, ja teki kuitenkin ne tehtävät melkein paremmin kuin ne, jotka istuivat koko ajan. Niillä oli ajatukset jossain muualla, ja ne piirtelivät jotain. Mutta tämä, joka pomppi koko ajan ylös, niin se oli kuullut kaikista parhaiten oleellisen sieltä. Tosiaan siinä samassa ryhmässäkin oli niin erilaisia oppijoita).

Keskeistä neljännen ja syvimmän tason reflektiossa on tarkastella toimintaa sen pohjalta, miksi toimimme tietyllä tavalla. Toimintaa ohjaavien perusteiden merkitystä pyritään hahmottamaan. Pohditaan tarkemmin yhteyttä omaan käyttöteoriaan. Toimintaa voidaan tarkastella teoreettisessa viitekehyksessä, jolloin vanhoja toimintatapoja arvioidaan uuden tutkimusja teoriatiedon pohjalta. Myös uusille ajatuksille haetaan tukea tutkimusja teoriatiedosta. Toimintaa voidaan tarkastella myös yhteiskunnallisessa (makrotaso) viitekehyksessä: Miten lapsuus on muuttunut ja mitä haasteita se asettaa pedagogiselle toiminnalle? Mitkä omat tai yhteiskunnan arvot johtavat toimimaan tietyllä tavalla? Miten erilaiset toimijoihin kohdistuvat vaatimukset vaikuttavat toteuttamaamme pedagogiseen toimintaan? Millaisia vaatimuksia yhteiskunta asettaa lasten vanhemmille ja miten voimme kasvatuksessa ja opetuksessa vastata niihin? Edellisen lisäksi lähtökohtien pohdinnassa toimintaa voidaan tarkastella yksilön ja työyhteisön tasolla (mikrotaso): Mitkä omat kokemukseni ovat johtaneet minut ajattelemaan kyseisestä asiasta tietyllä tavalla? Miksi tietty tilanne aina herättää minussa positiivisia / negatiivisia tunteita? Mihin perustan oman ammattitaitoni? Mitkä asiat työyhteisömme toimintakulttuurissa vaikuttavat siihen, että lukuisista työtehtävistämme huolimatta nautimme työstämme / koemme jatkuvasti toimivamme kiireessä? Miksi meidän työyhteisömme on se, joka 
jatkuvasti keksii uusia työtapoja eikä halua ottaa käyttöönsä uutta toimintatapaa, jota muut ovat kehittäneet? Mihin kieltämisemme perustuu? jne.

VKK-METRO -hankkeen kokemusten perusteella on mahdollista pelkistää monia reflektiivisen kehittämisen periaatteita, jotka ovat osoittautuneet toimiviksi silloin, tavoitteena on yhdessä toimien ja reflektoiden kehittää pedagogisen toiminnan arkea (Ojala, 2009; Venninen, 2009). Seuraavassa esitetään näistä eräitä keskeisimpiä:

- Reflektiossa tarvitaan kykyä irtautua aikaisemmasta käytännöstä, tarkastella omia uskomuksia ja omaa käytäntöä. Se on reflektiota toiminnasta (katsoa taakse mitä on tapahtunut) ja toiminnan reflektiota (ymmärtää että tietty tapa ei toimi ja muuttaa tapaa).

- Reflektion tulee olla jatkuvaa ja muutokseen tähtäävää. Muutos edellyttää positiivista asennoitumista, valmiutta ottaa riskejä ja tehdä erehdyksiä ja myös epäonnistua. Keskeistä on dokumentoida omat ja muiden kokemukset. Muutos edellyttää tyytymättömyyttä asiantilaan ja tietoisuutta muutoksen tarpeellisuudesta. Sitoutuminen muutokseen on tärkeää. Muutokseen tarvitaan visiota, jota asteittain sisäistetään. Muutos siirretään kasvatuskäytännön todellisuuteen, jossa se etenee vaiheittain.

- Reflektiossa ongelmat ovat ystäviä. Muutos on oppimista, joka on varustettu epävarmuudella. Tietty ahdistus ja vaikeudet ovat taustavoimia onnistuneeseen muutokseen. Edistymiseen liittyy runsaasti ongelman ratkaisuprosesseja.

- Muutos on matka, ei suunnitelma: tee, suunnittele, tee, suunnittele lisää, tee tämä jne. Kasvatus- ja opetuskäytännön muutos edellyttää usein myös ympäristön muutosta.

- Henkilökohtaisen ja työyhteisön autonomian säilyttäminen muutoksessa on keskeistä. Muutoksen kuluessa voidaan esittää kysymyksiä itselle: Mitä teen (kuvaus), mitä tämä merkitsee (informaatio), miten olen päätynyt olemaan tällainen (kohtaaminen), miten teen asiat eri tavoin (rekonstruktio).

- Refleksiivisen käytännön muuttamisen tavoite tulee olla dynaaminen eikä sitä voida asettaa selkeästi etukäteen. Täsmälliset etukäteistavoitteet johtavat staattisuuteen ja erottavat tavoitteen toiminnasta. Kysymyksessä on sarja dynaamisia muutoksia, toiminnan tavoitteet syntyvät toiminnasta sinänsä. 
- Muutoksen yhteydessä on tärkeää vapautua perfektionismista. Käytännön muuttuessa kehitytään taidoissa tutkia, kommunikoida ja olla luova. Oppiminen on neuvottelevaa. Muutoksessa liikutaan toiminnan lähialueella eikä pyritä paikallaan pysyvään tilaan ja tavoitteeseen. Refleksiivinen käytäntö lisää vastuuntuntoa ja halua jakaa työtä toisten kanssa.

- Muutokset vaativat resursseja, joista keskeisiä ovat muutokselle varattu aika ja usko muutokseen. Muutos vaatii voimaa, jolla se hallitaan. Tämä saadaan avoimuudesta ja jatkuvasta vuorovaikutuksesta. Muutos on kokonaisvaltaista, jossa lapsien, opettajien, vanhempien, lähiyhteisön ja laajemman yhteiskunnan olisi oltava mukana.

\section{Reflektiivinen kehittäminen pedagogisen dokumentoinnin avulla}

Dahlbergin ym. (1999) käsitys reflektion merkityksestä pedagogiseen toimintaan korostaa pedagogisen dokumentoinnin tärkeyttä. Heidän mukaansa pedagogiselle dokumentoinnille ovat tunnusomaisia seuraavanlaiset oletukset:

- Toimii välineenä reflektoida pedagogista toimintaa ja keinona saada aikaan eettinen suhde omaan itseensä, toisiin ja maailmaan.

- Toimii keinona, jolla pedagogi voi toimina myös tutkijana.

- Kysymyksessä ei ole tavanomainen observointi ja dokumentointi, jossa tarkoituksena on havainnoida ja dokumentoida objektiivista sosiaalista todellisuutta.

- On prosessi, jolla rakennetaan sosiaalista todellisuutta ja konkreettista pedagogista toimintaa.

- Pedagoginen dokumentointi toimii keinona teorian ja käytännön yhdistämiselle, jolloin siirrytään teoretisoinnista pedagogiseen käytäntöön ja opettamiseen.

- Pedagogisen dokumentoinnin avulla pintatasolle jääneet havainnot syvenevät pedagogien antamiin aitoihin merkityksiin.

- Tarjoaa mahdollisuuden päästä käsiksi ja ymmärtää tiedon ja oppiaineksen sosiaalisen ja yhteiskunnallisen merkityksen. 
Dahlberg ym. (1999) mukaan pedagogisen dokumentoinnin avulla voidaan auttaa pedagogeja siirtymään sosiaalisesti ulkopuolisesta (socially outsider) aktiviteettien havainnoista niiden sosiaalisten ja yhteiskunnallisten merkityssisältöjen rakentamiseen (socially insider). Dokumentointi voi toimia välineenä, jonka avulla saadaan aikaan refleksiivinen ja demokraattinen pedagoginen käytäntö. Dokumentoinnin avulla pedagogiseen käytäntöön voi etsiä syvempää merkitystä, lisätä omaa vastuuntuntoa ja tehdä sitoutuneita päätöksiä. Dokumentointi tarjoaa konkreettisen näkyvän keinon pedagogeille ja muille keskustella ja neuvotella avoimesti ja demokraattisesti pedagogiikasta.

Pedagogisessa dokumentoinnissa tarkastellaan ja pyritään ymmärtämään pedagogista käytäntöä ja sitä, mihin lapsi kykenee ilman etukäteen määriteltyjä tai ajateltuja oppimisen ja kehittymisen normeja tai odotuksia. Siinä ei oleteta, että se mitä dokumentoidaan edustaa suoraan sitä, mitä lapsi sanoo ja tekee tai mitä pedagogiikassa on todella tapahtunut. Pedagoginen dokumentointi on Dahlbergin ym. (1999) mukaan näkemisen prosessointia. Tähän liittyy ajatus siitä, että se mitä dokumentoidaan, ei kuvaa todellisuutta. Dokumentointi nähdään sosiaalisena konstruktiona, jossa pedagogi valitessaan sen mitä dokumentoi, osallistuu todellisuuden konstruointiin ja rekonstruointiin. Pedagogisen toiminnan merkitys ei synny näkemisestä ja havainnoista sinänsä. Merkitys rakennetaan tulkinnan avulla. Dokumentoinnin avulla rakennetaan suhde itseen pedagogina ja suhde lapseen/lapsiin, joiden ajattelua, sanomista ja toimintaa dokumentoidaan. Näin hahmotettuna pedagoginen dokumentointi ei ensisijaisesti ole objektiivista ja neutraalia arviointia vaan prosessi, jossa sitoudutaan ja osallistutaan pedagogiseen toimintaan. Se mitä dokumentoidaan, perustuu valintaan, johon pedagogi osallistuu. Myös se mitä ei valita on valinta.

Dahlbergin ym. (1999) mukaan pedagoginen dokumentointi on ennen kaikkea prosessi, jossa keskeinen sisältö on pedagogisessa toiminnassa. Sisällön dokumentoinnissa käytäntöä kirjataan ja tallennetaan mahdollisimman usein ja yksityiskohtaiseksi. Kohteena on se, mitä lapset sanovat ja tekevät, mitä tuotoksia lapset tuottavat, ja kuinka pedagogi on vuorovaikutuksessa lapsiin ja heidän tapaansa työskennellä. Keinoja pedagogiseen dokumentointiin voivat olla tapahtumien ja erityisesti lasten puheen kirjaaminen, nauhoittaminen ja videointi, valokuvaaminen, tietokonetallenteet sekä lasten töiden ja tuotosten arkistointi. Keskeistä on, että dokumentoinnin avulla pedagogiikka tehdään konkreettiseksi ja näkyväksi. 
Kerätyn dokumentointiaineiston prosessoinnissa koottua sisältöä/materiaalia käytetään pedagogisen työn reflektointiin tietoisella ja demokraattisella tavalla. Reflektointi etenee eri tasoilla ja syvyydellä:

(a) pedagogin itsereflektio

(b) pedagogien keskinäinen reflektio

(c) reflektointi suhteessa toisiin reflektioihin

(d) reflektointi suhteessa lapsen reflektioihin

(e) reflektointi suhteessa lasten keskinäisiin reflektioihin

(f) reflektointi suhteessa lasten vanhempiin

(g) reflektointi suhteessa päättäjiin

Dokumenttiaineiston ja reflektion avulla pedagogin on mahdollista päästä toiminnan syvempään pohdiskeluun kiinnittämällä huomiota mitä tehtiin ja sanottiin suhteessa lapseen (lapsen taso) ja suhteessa pedagogiseen toimintaan (sosiaalinen konstruktio). Pohdiskelussa on kysymys siitä, miten pedagogi on konstruoinut/jäsentänyt lapset, oman itsensä ja pedagogisen toiminnan. Tämän lisäksi pohditaan kuinka oppiva lapsi ja oppiva pedagogi ovat rakentaneet pedagogisen toiminnan, kuinka tieto on rakennettu tai millaisia välineitä ympäristö tarjoaa konstruointiin (kokeilut, symbolit). Huomiota kiinnitetään mihin lapset sitoutuvat, millaisia teorioita/ajatuksia/ideoita lapsilla on omasta toiminnastaan, miten pedagogi voi tukea ja rohkaista lapsia omaan teoretisointiin ja ideointiin tai miten pedagogi salli ja tukee lapsen työskentelyä ja oppimista ajallisesti pitkäjännitteisenä ja syventävänä oppimisena.

Pedagogisessa dokumentoinnissa suositaan projektityöskentelyä. Sen yhteydessä dokumentoidaan mitä nähdään, tehdään ja tuotetaan. Herätetään itsereflektio, yhteinen reflektio ja keskustelu. Laajennetaan keskustelua verkkoon (esim. 2 päivän intensiivinen verkkokeskustelu kerran kuussa jne.). Pohditaan historiallista, teoreettista ja filosofista ulottuvuutta suhteessa opetukseen, oppimiseen, opetussuunnitelmaan ja yhteiskuntaan ja niiden muutoksiin. Havainnoidaan ja dokumentoidaan kuinka lapset keksivät ja dokumentoivat maailmaa ja miten heidän oppimisprosessinsa etenevät.

Pedagoginen dokumentointi voi olla väline kriittiseen pedagogisen toiminnan reflektointiin, jolloin pedagogit alkavat kriittisemmin tutkia ja kehittää omaa pedagogiikkaansa. Käyttämällä välineenä pedagogista dokumentointia refleksiivinen pedagogi pitää yllä elävää ja kriittistä keskustelua 
pedagogisesta käytännöstä ja olosuhteista. Dokumentoinnin avulla voi ymmärtää lapsen asemaa ja merkitystä pedagogisessa ympäristössä: kuinka näemme lapsen ja mitä meille sana/käsite lapsi merkitsee.

Erityisesti varhaiskasvatuksen ja esiopetuksen pedagogisessa kehittämisessä on saatu myönteisiä kokemuksia pedagogisen dokumentoinnin käytänteistä myös suomalaisissa päiväkodeissa. Näitä on raportoitu VKKMetron kehittämistoiminnan yhteydessä. Perustuen päiväkotien pedagogiseen kehittämiseen Keskinen ja Lounassalo (2011) ovat luonnehtineet pedagogista dokumentointia kasvatuksen kaikupohjaksi, tieksi lasten osallisuuteen, lasten vertaiskulttuuria arvostavaksi, käden ojennukseksi vanhemmille, avuksi aikapulaan, mahdollisuudeksi vähentää pakkotahtisuutta sekä sillaksi kokemuksen ja tutkimustiedon välille. Pedagoginen dokumentointi avaa Keskisen ja Lounassalon mukaan mahdollisuuden kuvata erilaisin tavoin toimintaa ja elämää päiväkodin toimintaympäristössä. Se on ikään kuin tiedusteluretki mahdollisuuteen. Pedagogisessa dokumentoinnissa vahvistetaan lasten kokemuksia, niitä tallennetaan ja niitä tulkitaan. Varhaiskasvatustoiminnan sisällöt tulevat näkyviksi tavalla, jossa lapset ja aikuiset vanhemmat mukaan lukien pääsevät niihin osalliseksi. Toiminnan arviointi ja seuranta on osallistuvaa.

\section{Ammatilliset kompetenssit ja osaamisalueet Varhaiskasvattajan ja esiopettajan kompetenssit}

Kompetenssilla tarkoitetaan yksilön pätevyyttä ja hänen saamansa koulutuksen pätevyyttä kulloisenkin tehtävään (esim. Hätönen, 2003). Tämän ohella kompetenssit voivat tarkoittaa myös yksilön kykyä suoriutua työtehtävissä. Kompetenssin oletetaan koostuvan työtehtävän edellyttämistä tiedoista, taidoista, kyvyistä ja asenteista. Nämä muodostuvat koulutuksen antamista tiedoista, kokemuksesta, arvoista ja toimimisesta sosiaalisissa verkostoissa. Kompetenssin rinnalla on ryhdytty käyttämään myös osaamiskäsitettä (esim. Poikela, 2002). Kompetenssin ja osaamisen yhteydessä viitataan usein myös kvalifikaation, jolloin mukaan otetaan ammattihenkilön pätevyyden lisäksi myös työn vaatimukset (esim. Uusitalo, 2005).

Ajallemme on tunnusomaista vaatimus laadukkaasta kasvatuksesta ja opetuksesta. Vaikka laatu muodostuu useista osatekijöistä, näistä eräs keskeisimmistä kohdistuu kasvattajan ja opettajan kyvykkyyteen, jota on ryhdytty tarkastelemaan kompetenssin ja osaamisen näkökulmasta. Perusta 
laadukkaalle ammattikäytännölle muotoutuu peruskoulutuksessa. Tämän jälkeen ammatillisen kehittymisen laatua pidetään yllä ja kehitetään työpaikkojen ja viranomaisten yhteistyönä. Kehittäminen edellyttää ammattikäytäntöjen jatkuvaa seurantaa ja arviointia.

Euroopan Komission toimeksiannosta on tehty analyysi ja ehdotus varhaiskasvattajan/esiopettajan kompetensseista (Corel, 2011). Ehdotus perustuu tutkimukseen, jossa varhaiskasvattajan/esiopettajan kompetensseja kartoitettiin kyselyllä 14 EU-maassa. Pohjoismaita edustivat Tanska ja Ruotsi. Näin hankittua tietoa syvennettiin seitsemällä maakohtaisella tapaustutkimuksella. Pohjoismaita tässä edusti Tanska.

Hankittua kompetenssitietoa jäsennettiin kahdessa ulottuvuudessa. Näistä toinen on yksilöllinen, pedagogin omaan taitavuuteen liittyvä. Henkilökohtaisen kompetenssin muodostumiseen ja kehittymiseen vaikuttaa ratkaisevasti ammatillinen koulutus. Henkilökohtaisen kompetenssin muodostuminen on miltei poikkeuksetta pitkäaikainen prosessi. Olla kompetentti ja tulla kompetentiksi on jatkuva prosessi, jolla pedagogi muodostaa ammatillisia kykyjä ja taitoja, toteuttaa ja kehittää kasvatuskäytäntöä sekä omaksuu ammatilliset arvot ja siihen liittyvän ammattietiikan. Kompetenssin toinen ulottuvuus on edellistä laajempi ja se liittyy kasvatuksen ja opetuksen toimintakenttään, joka voidaan hahmottaa systeeminä. Voidaan ajatella, että laadukas kasvatus ja opetus ei synny yksinomaan kasvattajan/ opettajan omaamasta kompetenssista ilman kompetenssia systeemiä. Tämä muodostuu yksilön, ammatillisen tiimin, instituution ja laajemman yhteiskunnan vuorovaikutuksen kentässä.

Eurooppalaisessa tuotoksessa kompetenssit on jäsennetty toinen toisiinsa liittyvin tasoihin niin, että ne yhdessä muodostavat kompetenssisysteemin (Corel, 2011). Spesifit kompetenssit on jaettu neljään tasoon liittyen yksilöön, toimintayksikössä toimiviin tiimeihin, toimintayksiköiden väliseen vuorovaikutukseen sekä ohjantaan ja hallinnointiin. Kuhunkin tasoon on kohdistettu kompetensseja, joka liittyvät tietoon, kasvatuskäytäntöön ja arvoihin.

\section{Yksilötason kompetenssit}

Yksilötason kompetenssit luovat perustan ammatillisen kompetenssin muotoutumiselle. Näitä ei hahmoteta niinkään valmiina taitoina (teenkö asioita oikein?) vaan ne muotoutuvat yksilön reflektiona kasvatuskäytännöstä 
ja kasvatuksen arvoista (teenkö oikeita asioita?). Reflektio tapahtuu kyselevänä ja kriittisenä tavalla, jossa yksilö prosessoi ja pyrkii liittämään toinen toisiinsa tietoa, kasvatuskäytäntöä ja kasvatuksen arvoja. Tämän tapainen prosessointi on keskeistä kasvattajan/opettajat vaativassa ja jatkuvasti muotoutuvassa toiminnassa, jota ei voi edeltä käsin ennustaa kovinkaan tarkasti. Keskeiseksi muodostuu käytännön päivittäinen uudelleen rakentaminen, konstruointi ja rekonstruointi.

Liitetaulukkoon 1 on tiivistetty Euroopan komission asiantuntijoiden tuottamat yksilötason kompetenssit, jotka on jaoteltu tietoon, kasvatuskäytäntöön ja arvoihin. Tieto kohdistuu lapsen kokonaiskehittymiseen, oppimisen strategioihin, kommunikointiin lasten kanssa, vanhempien kanssa tehtävään yhteistyöhön, tiimityöskentelyyn, monikulttuuriseen toimintaan, osallistumiseen laajempaan keskusteluun ja päätöksentekoon sekä lapsen hoitoon, terveyteen ja hyvinvointiin. Esimerkiksi tietoon lasten erilaisista oppimisstrategioista on yhdistetty kasvatus- ja opetuskäytäntöjä, joissa korostetaan oppimisympäristön luomista, pienryhmissä tapahtuvaa projektioppimista, symbolileikkien käyttöä, opetussuunnitelman laadintaa tarkoituksella tukea orastavaa lukutaitoa, matematiikkaa ja luonnontiedettä, äidinkielen tukemista monikielisyys huomioon ottaen sekä erityisen tuen antamista lapsille. Edellä kuvattuihin käytäntöihin liitetään kompetenssikuvauksessa arvoja, joissa korostetaan lapsikeskeisen lähestymistavan omaksumista, oppimisen ymmärtämistä sosiaalisena konstruktiona ja monitieteisenä sekä monikielisyyden tukemisen tärkeyttä.

\section{Yksikkötason kompetenssit}

Kasvattaja/opettaja ei toimi yksin vaan hän osa ammatillista tiimiä, joka muotoutuu toimintayksikössä yksilön ja tiimin välisessä jatkuvassa vuorovaikutuksessa. Tähän prosessiin vaikuttaa olennaisella tavalla teorian ja käytännön välinen vuorovaikutus, jonka kautta yksikköön muotoutuu pedagoginen toimintakulttuuri. Tätä kulttuuria uudistetaan yhteisöllisen kriittisen reflektion, ammatillisen täydennyskoulutuksen ja kokeilu- ja tutkimustoiminnan avulla.

Liitetaulukkoon 2 on tiivistetty yksikkötason ammatillisia kompetensseja suhteessa tietoon, ammattikäytäntöihin ja arvoihin. Tieto kohdistuu pedagogiseen tietoon varhaiskasvatuksesta/esiopetuksesta ja sen erityisluonteesta, kontekstuaaliseen oppimiseen, oppivaan organisaatioon, 
johtamiseen ja johtajuuteen, tietoon koulutuksesta (koulutuksen antama pedagoginen tieto varhaiskasvatuksesta ja sen erilaisuudesta), aikuisoppimiseen sekä tietoon lähiyhteisön käytännöistä. Kuhunkin tiedon alueeseen on liitetty lyhyt kuvaus ammattikäytänteistä. Esimerkiksi pedagogiseen tietoon varhaiskasvatuksesta ja sen eritysluonteesta kohdistetaan ammattikäytänteitä, jotka liittyvät yhteiseen pedagogiseen sitoutumiseen, riittävän ajan varaamiseen suunnitteluun sekä dokumentointiin ja pedagogiseen arviointiin. Edellä kuvattuihin ammattikäytäntöihin liitetään kompetenssikuvauksessa arvoja, joissa korostetaan demokraattisuutta ja erilaisuuden hyväksymistä, ammatillisen kehittymisen ymmärtämistä jatkuvana henkilökohtaisena oppimisprosessina ja ammatillisena kasvuna sekä ammatillisen kasvun ymmärtämistä vuorovaikutuksena käytännön ja teorian välillä tavalla, joka edellyttää tukea.

\section{Toimintayksiköiden väliset kompetenssit}

Yksilön ja toimintayksikön ammatillinen kyvykkyys on yhteydessä ulkopuolelta tuleviin odotuksiin ja vaatimuksiin. Tällöin yksiköt ovat vuorovaikutuksessa toisiinsa ja muihin toimijoihin. Tämän tason ammatillinen toiminta edellyttää tietoa ulkoisista toimijoista ja siitä, miten niiden kanssa tehdään yhteistyötä. Myös tieto lähiyhteisön tukevasta toiminnasta on tärkeää. Tiedon hankinnassa korostetaan monitieteisyyttä (hoitotieteet, pedagogiikka ja sosiologia). Hankittua tietoa toteutetaan käytäntönä, jossa verkotutaan, toimitaan yhteistyössä muihin toimijoihin ja perheisiin, tehdään yhteistyötä perusopetuksen ja koulutusta antavien tahojen kanssa sekä tehdään kansainvälistä yhteistyötä. Toimintayksiköiden välistä toimintaa tuetaan arvoilla, joissa korostetaan demokratiaa ja erilaisuuden hyväksymistä, tasa-arvoa, lasten näkökulmaa ja monitieteistä lähestymistapaa.

\section{Ohjantaa ja hallinnointia koskevat kompetenssit}

Kasvatuksessa/opetuksessa edellytettäviin kompetensseihin vaikuttaa myös yhteiskunta, joka pitää yllä ja kehittää ammatillisen toiminnan perusteita. Tähän vaaditaan laajaa tietoa varhaiskasvatuksen/esiopetuksen toteutuksesta paikallisella, alueellisella, kansallisella ja kansainvälisellä tasolla. Tieto kohdistuu myös lasten ja perheiden oikeuksiin, monikulttuurisuuteen ja sosiaalisen eriarvoisuuden vähentämiseen. Ohjannan ja hallinnoinnin 
käytännöt liittyvät riittävien resurssien hankkimiseen sekä paikallisen, aluekohtaisen ja valtakunnallisen tason koordinointiin.

Näiden lisäksi käytännön toiminta kohdistuu kasvatus- ja opetussuunnitelmien laadintaa, seurantaan ja arviointiin, monisektoriseen yhteistyöhön (kasvatus, kulttuuri, sosiaalipalvelut, työvoima, terveys, lainsäädäntö) sekä ammatillisen kasvun tukemiseen. Ohjaustoimintaan ja hallinnointiin liittyvät arvot, joissa korostuvat lasten oikeudet suhteessa yhteiskuntaan, kehittymisen ja oppimisen potentiaalisuuteen, erilaisuuden ja samanlaisuuden (inkluusio) hyväksyminen, kasvaminen demokratiaan sekä kansantalouden ja hyvinvoinnin ylläpitäminen ja kehittäminen.

Yhteenvetona voidaan todeta, että EU:n pyrkimystä hahmottaa varhaiskasvatuksen ja esiopettajan ammatillisia kompetensseja kokonaisvaltaisesti voi pitää kannatettavana huolimatta siitä, että kansalliset opetussuunnitelmat, opettajankoulutus ja toimintakulttuurit poikkeavat aina jossain suhteessa toinen toisistaan Euroopan sisällä. Kompetenssien kuvaus yksilötasolla, toimintayksikön tasolla, yksiköiden välisenä vuorovaikutuksena sekä hallinnon ja ohjannan tasoilla antaa mahdollisuuden tarkastella monesta ulottuvuudesta ja ammatillisista intresseistä käsin kasvatus- ja opetustoimintaa tiedon, ammatillisten käytänteiden ja arvojen näkökulmasta. Voi toivoa, että EU:n esimerkki rohkaisee kehittämään tarkennettuja makohtaisia varhaiskasvatuksen ja esiopetuksen ammatillisten kompetenssien kuvauksia. Näistä voi olettaa olevan hyötyä monenlaiseen käyttötarkoitukseen (esim. koulutuksen järjestäjät, yksikkökohtainen toiminta, vuorovaikutus muihin yksikköihin, ammatillinen koulutus, paikallinen ja valtakunnallinen ohjanta ja kehittäminen jne.)

\section{Osaamisalueet suomalaisessa varhaiskasvatustyössä}

Työntekijän kompetenssin ohella voidaan kiinnittää huomiota myös työelämän vaatimuksiin (kvalifikaatiovaatimukset). Tällöin huomio voidaan kohdistaa osaamisalueisiin, joita suomalaisessa varhaiskasvatustyössä on ryhdytty tarkastelemaan moniammatillisesti (Karila \& Nummenmaa, 2001). Päiväkodeissa tapahtuvan työn keskeisiä osaamisalueita Karila ja Nummenmaa ovat eritelleet liittämällä niihin ydinosaamista. Ehdotuksessa pelkistetään neljä keskeistä osaamisaluetta ja niihin liittyvää ydinosaamista seuraavasti: 


\begin{tabular}{|l|l|}
\hline $\begin{array}{l}\text { 1. Toimintaympäristön ja } \\
\text { perustehtävien tulkinta }\end{array}$ & Kontekstiosaaminen \\
\hline 2. Varhaiskasvatus & $\begin{array}{l}\text { Kasvatus-, hoito- ja pedagoginen } \\
\text { osaaminen }\end{array}$ \\
\hline 3. Yhteistyö ja vuorovaikutus & $\begin{array}{l}\text { Vuorovaikutusosaaminen ja } \\
\text { yhteistyöosaaminen }\end{array}$ \\
\hline 4. Jatkuva kehittäminen & $\begin{array}{l}\text { Reflektio-osaaminen ja tiedonhal- } \\
\text { lintaosaaminen }\end{array}$ \\
\hline
\end{tabular}

Toimintaympäristön ja perustehtävien tulkintaan liittyvä kontekstiosaaminen liittyy kasvatuksen yhteiskunnallisen ja kulttuurisen lähtökohtien ymmärtämiseen, päiväkodin toiminnan tuntemukseen sekä varhaiskasvatusta ja esiopetusta koskevan lainsäädännön ja ohjauksen yleiseen tietämykseen. Varhaiskasvatusosaaminen liittyy kasvatuskäsityksiin, työntekijöiden ja lasten väliseen vuorovaikutukseen, pedagogiikkaan ja hoitoon. Yhteistyö- ja vuorovaikutusosaaminen koostuu työntekijöiden keskinäisistä ja yhteistyökumppaneiden välisestä ydinosaamisesta. Jatkuvan kehittämisen osaaminen liittyy työssä oppimiseen. Tässä tarvitaan ydinosaamista oman työn arvioinnista ja kehittämisestä (reflektio-osaaminen) sekä tiedonhallintaosaamista. Karilan ja Nummenmaan osaamisalue-ehdotus perustuu lähestymistapaan, jossa korostuu päiväkotityön yhteisöllisyys ja moniammatillisuus.

Karilan ja Nummenmaan ajatusten pohjalta on pyritty identifioimaan päiväkodissa työskentelevien peruskoulutukseltaan erilaisten työntekijöiden ammatillista erityisosaamista. Ammattiryhmäkohtaisessa tarkastelussa lastentarhanopettajan (nykyisin varhaiskasvatuksen opettaja) osaamisalueissa painottuvat kasvatuksen, pedagogiikan ja opetuksen osaaminen, lapsen kehityksen tukemisen osaaminen sekä asiantuntijuuden ja työn kehittämiseen liittyvä osaaminen (Sosiaali- ja terveysministeriö, 2007). Ydinosaamisessa korostuu suunnittelu ja arviointi (Karila \& Nummenmaa, 2001). 


\section{Johtopäätöksiä}

Peruskoulutusta ja sen jälkeistä ammatillista kasvua ja kehittymistä on tarkoituksenmukaista hahmottaa jatkumona (esim. Taguma et al., 2102). Hyvin koulutetut kasvattajat ja opettajat eivät omaa ainoastaan laadukkaan peruskoulutuksen vaan he pitävät huolta siitä, että peruskoulutuksessa omaksutut taidot eivät katoa. Kasvattajan ammatilliset kompetenssit kehittyvät työyhteisössä toimimalla, jossa täydennetään pedagogisia tietoja tai taitoja, jäsennetään uudelleen ja luodaan uusia toimintatapoja. Tässä prosessissa erityisesti pedagogisten ja ammatillisten taitojen reflektiivisellä kehittämisellä on keskeinen merkitys.

On olemassa vankkaa näyttöä siitä, että hyvin koulutetut kasvattajat ja opettajat voivat saada aikaan lasten ja oppilaiden edistymisen tiedollisissa ja sosiaalisissa taidoissa (esim. Sylva et al., 2010; Taguma et al., 2102). Mutta laadullinen koulutus yksin ei ole riittävä takaamaan laadullisen varhaiskasvatuksen. Keskeistä on taitavuus, jolla hyvin koulutetut kasvattajat ja opettajat luovat laadullisesti korkeatasoisen pedagogisen ympäristön toiminnalleen. Tähän pedagogiseen taitavuuteen liittyy monia ulottuvuuksia, joihin liittyvät myös taidot johtajuudessa, probleemanratkaisutaidot, toimintasuunnitelmien kehittäminen ja hyvät verbaaliset taidot. On myös havaittu, että hyvin koulutetut kasvattajat ja opettajat voivat luoda työyhteissään toimintamalleja, jotka rohkaiset ja kannustavat muita työyhteisön jäseniä. Näin kiinnittyminen työyhteisöön lujittuu ja rohkaisee työskentelemään alalla pitkään. Pitkäaikainen työskentely onkin yksi kasvatuksen ja opetuksen laadun ylläpitämisen ja kehittämisen osatekijä (Sylva et al., 2010).

Kasvatuksen laadullisen kehittämisen yhteydessä johtajuus ja siihen liittyvät taidot ovat saaneet lisääntyvää huomiota (esim. Sylva et al., 2010). Henkilöstön laatua pidetään yllä johtajuudella, joka motivoi ja rohkaisee tiimityöskentelyyn, jakaa avoimesti tieto ja panostaa henkilöstön kehittämiseen (OECD, 2006). Tämä on myös yhteydessä johtajan omaan koulutuksen tasoon ja ammatilliseen kehittymiseen. Laadullisesti hyvällä johtajuudella voidaan vaikuttaa myönteisesti sekä lapsen lyhyen että pitkän aikavälin kehittymiseen sekä tiedollisen että sosiaalisen kehittymisen alueella (Sylva et al., 2010).

OECD:n varhaiskasvatuksen ja esiopetuksen laatua analysoivan verkoston raportissa on tuotu esiin se, että Suomessa on oivallettu johtajuuden 
tärkeä merkitys varhaiskasvatustoiminnalle (Taguma et al., 2012). Raportissa Suomea rohkaistaan kehittämään henkilöstön taitoja ja kompetensseja johtajuudessa. Raportissa Suomi saa tunnustusta henkilöstön ammatillista pätevyyttä ylläpitävästä täydennyskoulutuksen järjestämisestä ja sen kustannusten jakamisesta. Täydennyskoulutukseen on Suomessa velvoite, jollaista vielä ei ole kaikissa OECD-maissa. Ammatillisen täydennyskoulutuksen kehittämiseksi henkilöstö tarvitsee uusia taitoja informaatioteknologian käytössä ja monikulttuurisuuskasvatuksen kehittämisessä. Myös henkilöstön kelpoisuusvaatimuksiin tulisi kiinnittää huomiota. Suomessa kerran hankittu kelpoisuus kattaa koko työuran ajan. Eräissä OECD-maissa kelpoisuus on voimassa 3-vuotta, jonka jälkeen se pitää päivittää uusien vaatimusten ja haasteiden mukaisesti. Tällainen menettely on omiaan parantamaan henkilöstön ammatillista pätevyyttä ja sen laatua. Edellisen lisäksi Suomea kehotetaan kiinnittämään huomiota varhaiskasvatushenkilöstön uusintamiseen tarjoamalla nuorille uudentyyppisiä mahdollisuuksia tutustua varhaiskasvatukseen ja kouluttautua tämän jälkeen tähän ammattiin. Suomessa varhaiskasvatuksen henkilöstö on lähes kokonaan naisvaltaista ja keski-ikä on hieman yli 40-vuotta.

Niin päiväkodin kuin koulun kehittäminen on keskeistä ja ajankohtaista. Tieto ja kokemus uudistamisen strategioista, toteutuksista ja esteistä lisääntyvät. Vaikka koulun ja päiväkodin kehittämisrakenteet eivät toistaiseksi ole kaikilta osin yhteismitallisia, esimerkiksi Rajakaltion (2014) raportoimat havainnot opetustoimen -joka nykyisin kattaa varhaiskasvatuksen- kehittämisstrategiasta, koulujen (päiväkotien) uudistuvasta toimintakulttuurista ja yliopiston asiantuntemuksen hyödyntämisestä ovat keskeistä. Tietämys kehittämisen ennakoivista esteistä ja myönteisiin tuloksiin vaikuttavista tekijöistä on hyödyllistä tietoa, joka auttaa kehittämisessä niin kouluissa kuin päiväkodeissa. Kouluhallinnon uusimpana tulokkaana erityisesti varhaiskasvatus ja esiopetus tarvitsevat pitkäjännitteisen kehittämisohjelman, jossa hyödynnetään koulutoimen kehittämisessä saatuja kokemuksia, mutta samalla herkistytään varhaiskasvatuksen omaleimaisuuteen.

Reflektion käytöstä ammatillisten käytänteiden kehittämissä on olemassa runsaasti tutkittua tietoa ja käytännön kokemuksia. Tulokset pääkaupunkiseudun päiväkotien ja esiopetuksen refleksiivisistä prosesseista antavat aiheen olettaa, että kasvatustoimintaa prosessoidaan ja uudistetaan eri syvyydellä. Tyypillisintä näyttää olevan se, että toiminnasta tehdään 
havaintoja, mutta pohditaan niitä pintapuolisesti. Toiseksi yleisintä on reflektoida toimintaa analyyttisemmin pohtimalla esim. eri vaihtoehtoja tai syy- ja seuraussuhteita. Tällaiseen reflektioon liittyy usein myös pohdintaa toiminnan kehittämisestä. Syvällisintä ja monipuolisinta reflektion tasoa esiintyi kuitenkin suhteellisen vähän. Tällöin huomio suunnataan toiminnan perusteisiin. Pohdiskeluun voidaan liittää tutkimus- ja teoriatietoa, innovatiivisia uusia ajatuksia, lapsuuden merkityksen pohtimista, toiminnan arvopohjaa, työyhteisön toimintakulttuuria jne. Kasvatus- ja opetuskäytänteiden uudistamisen kannalta on rohkaisevaa, että rutiininomaista ja teknistä reflektiota näyttää esiintyvän vain vähän. Refleksiivistä ammattikäytäntöä kehitettäessä tavoitteeksi on perusteltua asettaa varhaiskasvatuksen ja esiopetuksen pohdinnan lisääminen suhteessa omiin ja työyhteisön käytänteisiin ja arvopäämääriin. Pohdinnan tulee ulottua myös lapseen ja lapsuuteen sekä näitä tukeviin arvopäämääriin.

Reflektio rohkaisee tarkastelemaan avoimesti, kyselevästi ja tarpeen vaatiessa kriittisesti kasvattajan ja opettajan omia kasvatuskäsityksiä ja käytänteitä. Refleksiiviseen prosessiin liittyy myös ajatusten jakaminen ja pohdinta työyhteisössä. Yhteisenä tavoitteena on uudistaa kasvatusajattelua ja vakiintuneita käytänteitä. Refleksiivisessä prosessissa pedagoginen dokumentointi voi tarjota mielekkään välineen. Dokumentoinnin avulla kasvattajat ja opettajat voivat saada konkreettisen ja aidon käsityksen siitä, miten lapsi mieltää pedagogisen toiminnan. Tämä puolestaan avaa mahdollisuuden jäsentää pedagogista toimintaa suhteessa lapsen, kasvattajan ja työyhteisön pyrkimyksiin ja kokemuksiin. Pedagogisen dokumentoinnin keskeinen pyrkimys on kehittää pedagogiikka.

Myös pyrkimys kehittää kasvattajan tai opettajan kompetensseja on ajankohtainen. Vaikka varhaiskasvattajan tai esiopettajan kompetensseista vallitsisi ainakin pääpiirteittäinen yksimielisyys, niiden kehittäminen herättää myös ristiriitaisia ajatuksia (Vandenbroeck et al., 2012). Kompetenssien ja osin myös osaamisen voidaan ajatella tavalla tai toisella liittyvän pyrkimykseen lisätä tehokkuutta. Eräs keino lieventää tehokkuusajattelua voi olla menettelytapa, jossa kompetensseja synnytetään yhdessä kentän työntekijöiden kanssa huomioimalla heidän henkilökohtaiset kokemuksensa ja toimintakulttuuri.

Kasvatukseen ja lapsen kehittymiseen liittyvät myös sellaiset kysymykset kuten miten pedagogi toimii suhteessa erilaisiin lapsiin, miten kompetenssit sopivat erilaisille opettajatyypeille, voidaanko saada aikaan laaja 
yhteisymmärrys ja sitoumus kasvattajien kesken kompetenssiperustaisesta toiminnasta, soveltuvatko kompetenssit erilaisiin kasvatusympäristöihin jne.

Kompetenssikuvauksia voi tarkastella myös vallankäytön perspektiivistä. Tieto ja kenellä sen tuottamisessa ja hallinnoinnissa on valta-asema linkittyvät. Valta-asema vaikuttaa jo siihen millaista tietoa kerätään, miten sitä analysoidaan ja miten sitä levitetään. Näin ollen on varottava, että emme välitä tai rajoita yksinomaan valta-asemastamme käsin kasvatus- ja opetushenkilöstölle heidän toimintaansa ohjaavia ajatusmalleja ja rakenteita.

Varhaiskasvatukseen ja esiopetukseen liittyvät kompetenssikuvaukset ovat yhteydessä myös professioon, joka on suomalaisessa varhaiskasvatuksessa moniammatillinen. Joitain toimintoja tehdään yhdessä, joitain perustuen yksikkökohtaiseen työnjakoon ja joitain ehkä perustuen ammatillisen koulutuksen tuottamaan pätevyyteen. Tämä asettaa suuria haasteita kompetenssikuvauksille.

Kompetenssikuvausten eräänä rajoituksena voi olla se, että niistä tulee malli, jota jokaisen tai suuren enemmistön ajatellaan noudattavan. Tällöin voi jäädä taka-alalle erilaisuuden oikeutus. Kaikille yhtenäiset koulutukselliset ja kasvatuskäytännön standardit eivät ehkä olekaan ytimiä, kun etsitään ja kuvaillaan kasvattajien kompetensseja ja laatua. On myös mahdollista, että laatu löytyykin erilaisuudesta, jossa on jotain yhteistä mutta myös omaperäisyyttä, luovuutta ja uudistumista. Meidän olisi siis hyväksyttävä ehkä nykyistä tietoisemmin myös erilaisuus kasvattajissa, kasvatusfilosofiassa, kasvatusympäristössä, lapsissa ja perheissä. Tämän tapaisista erilaisuuksista me tarvitsemme esimerkkejä, emme ehkä niinkään siitä, missä kasvattajat ovat yhteisellä tasolla. Kompetenssikuvaukset eivät saisi häivyttää herkkyyttä tunnistaa ja hyväksyä erilaisuutta kasvattajissa ja opettajissa. 


\section{Pedagogisen kehittämisen haasteita}

\section{Toimenpiteitä lasten oikeuksien edistämiseen}

YK:n lasten oikeuksien julistuksen tarkoituksena ei ole jäädä vain julistukseksi, vaan sen on tarkoitus johtaa konkreettisiin toimenpiteisiin yhteiskunnan eri alueilla kasvatus ja opetus mukaan lukien. Suomen UNICEF onkin laatinut lapsen oikeuksien käsikirjan, jonka tarkoituksena on kiinnittää erityistä huomiota konkreettisiin toimenpiteisiin lapsen oikeuksien vahvistamisessa (Hetemäki, 2011). Taustana on Euroopan komission hyväksymä lapsen oikeuksia koskeva toimintasuunnitelma (Lapsen oikeuksia koskeva EU:n toimintasuunnitelma, 2011). Suunnitelmassa korostetaan, että lasten oikeuksien näkökulma on otettava huomioon kaikissa lapsia koskevissa toimenpiteissä. Näihin liittyvät esimerkiksi lapsen oikeus erityiseen suojeluun ja huolenpitoon, oikeus ilmaista näkemyksiään häntä koskevissa asioissa ikänsä ja kehitystasonsa mukaisesti ja saada ne otetuksi huomioon, halventavan kohtelun, seksuaalisen väärinkäytön ja väkivallan kieltäminen, edun ensisijaisuus, oikeus kehitykseen ja syrjimättömyyteen, osallisuuden hyväksyminen ja tukeminen sekä oikeudet lepoon, leikkiin ja vapaa-aikaan. Tärkeänä toimenpiteenä lapsen edun ensisijaisuuden toteuttamisessa pidetään lapsivaikutusten arviointia (esim. Hakalehto-Wainio, 2010).

Lapsen kehityksen oikeuteen kuuluvat tasapainoinen kehitys ja hyvinvointi, läheiset ja jatkuvat ihmissuhteet, mahdollisuus saada ymmärrystä ja hellyyttä, iän ja kehitystason mukainen valvonta ja huolenpito, turvallinen kasvuympäristö, ruumiillinen koskemattomuus sekä oikeus itsenäistymiseen ja vastuuseen kasvamiseen. Lasten oikeutta osallisuuteen ja vaikuttamiseen voidaan tukea herkistymällä lasten näkemyksiin ja ottamalla ne aidosti huomioon. Kohteena on niin yksityinen lapsi kuin lapsiryhmä. Lapsen oikeus ilmaista näkemyksiään häntä koskevissa asioissa kuuluu kaikille lapsille ja vahvistaa mielipiteen ja sananvapauden kehittymistä. Osallisuuteen ja vaikuttamiseen liittyy myös oikeus informaatioon ja yksityisyyteen. Pidetään tärkeänä, että lapsen oikeus ilmaista näkemyksiään ei jää vain lapsen vastuulle. Aikuisten velvollisuutena on tarjota lapselle riittävästi tietoa näkemysten perustaksi, luoda myönteinen ilmapiiri ja keskustelukulttuuri, kannustaa lasta näkemystensä ilmaisuun sekä osoittaa aidosti arvostus lapsia kohtaan. 
Jo sinänsä moniin varhaista kasvatusta koskeviin laatu-ulottuvuuksiin ei toistaiseksi ole kovinkaan näkyvästi liitetty lapsen oikeuksia. Kasvatus voidaan kuitenkin nähdä myös lapsen oikeutena (esim. Hakalehto-Wainio, 2010; Kalland ym., 2013). Tämä yksin ei ole riittävää. Tavoitteena on taata lapselle oikeus laadullisesti hyvään kasvatukseen. Tällöin laatukysymystä lähestytään myös lapsen oikeuksien kannalta.

Varhaiskasvatuksen, esiopetuksen ja koulun laatuvaatimuksiin lapsen oikeuksien kannalta voidaan liittää useita keskeisiä tavoitteita (esim. Hammarberg, 1997), joita voidaan kehittää edelleen. Näitä ovat lasten tasaarvoinen kohtelu tarjoamalla heille yhdenvertaiset mahdollisuudet kehittää persoonallisuuttaan ja lahjakkuuttaan sekä älyllisiä ja fyysisiä kykyjään täyteen potentiaaliin. Kasvatuksen tehtävänä on kehittää lapsen kunnioitusta humaanisiin oikeuksiin ja vapauteen sekä valmistaa lasta vastuulliseen elämään demokraattisessa yhteiskunnassa. Kasvatuksessa ja sen arjessa syrjinnän poistaminen on keskeistä. Yksikään lapsi ei saisi joutua syrjinnän kohteeksi vaan jokaisen lapsen tulisi voida elää onnellista lapsuutta ja nauttia oikeuksistaan. Lapsen edun esisijaisuutta voi toteuttaa kasvatuksessa suhteessa opetussuunnitelmaan ja sen toteuttamiseen. Keskeisiä kysymyksiä tällöin esimerkiksi ovat toteutuvatko lapsen toivomukset ja mielenkiinnon kohteet, antaako kasvatus taitoja todelliseen elämään globaalisessa ja paikallisessa merkityksessä, kehittyykö lapsen kunnioitus luontoa ja ympäristöä kohtaan tai ovatko opetuksen metodit lapsiystävällisiä.

Herkistyminen lapsen näkemyksiin ja ääniin on keskeistä lapsen oikeuksien toteutuksessa. Kasvatuksen ja opetuksen laatukysymyksenä tätä voi pohtia kysymällä kuunnellaanko lasta kasvatuksen arjessa, voivatko lapset vaikuttaa opetuksen, kasvatuksen ja toiminnan rakenteisiin ja niitä jäsentäviin suunnitelmiin, voivatko lapset tuoda esiin omia poikkeavia näkemyksiään opettajan laatimiin suunnitelmiin, rohkaiseeko opettaja/ kasvattaja lapsia demokraattiseen ja kriittiseen ajatteluun tai saako lapsi lisääntyvää ymmärrystä ihmisoikeuksista.

Lapsen oikeuksien tarkasteleminen kasvatuksen laatukysymyksenä antaa mahdollisuuden tarkastella myös kasvatuksen ja oppimisen menetelmiä (esim. Hammarberg, 1997). Yleisellä tasolla lapsen oppimista tulisi tukea lapsiystävällisillä tavoilla, jossa lapsilla on oikeus ja mahdollisuus olla utelias, tehdä kysymyksiä, saada vastauksia kysymyksiinsä, perustella toteamuksiaan, olla eri mieltä sekä testata ja koetella ehdotuksiaan ja ratkaisujaan. Lapsella on oikeus sekä tietää että olla tietämättä, luoda uuttaa, 
olla spontaani ja saada tunnustusta ja arvonantoa. Lapsiystävällisessä opettamisessa ja oppimisessa suositaan pienryhmätoimintaa ja -keskustelua, opitaan toimien ja leikkien sekä arvostetaan luontoa, ympäristöä ja taidetta. Kriittisen ajattelun ja oppimisen antaman ilon tulisi kohdata. Oppimaan oppimisen taidot ovat keskiössä luoden perustaa elinikäiselle oppimiselle. Keskeistä kasvattajille ja opettajille on herkistyä toteuttamaan opetusta, kasvatusta ja oppimista tavalla, joka ei hyväksy syrjintää, perustuu parhaalla tavalla lasten intresseihin, tukee lapsen kaikinpuolista kehittymistä kohti jokaisen lapsen kasvu- ja kehityspotentiaalia sekä kunnioittaa ja pyrkii toteuttamaan lasten ääniä, toivomuksia ja perusteluita. Kasvatuksen laatuarviointi monipuolistuu ottamalla käytäntöön menetelmiä, joissa pedagogista toimintaa seurataan, arvioidaan ja kehitetään kiinnittämällä huomiota suunnitelmien, menetelmien ja toteutuksen lapsivaikutuksiin.

\section{Lapsiorientoitunut pedagogiikka}

Uudentyyppistä pedagogista jäsennystä lapsiulottuvuuteen ovat tuottaneet Sommer kumppaneineen (2013). Tekijät pelkistävät lapsiulottuvuuden kahteen toisiinsa liittyvään perspektiiviin. Näistä toista nimitetään lapsiperspektiiviksi ja toista lasten perspektiiviksi. Silloin kun pedagogiikassa herkistytään näihin kumpaankin, pedagogiikkaa voi nimittää lapsiorientoituneeksi. Seuraavassa eritellään yksityiskohtaisemmin tällaista pedagogiikka.

Lapsiperspektiivissä on kysymys aikuisen pedagogisesta tietoisuudesta ja herkkyydestä ymmärtää lasten näkemyksiä, kokemuksia, ilmaisuja ja toimintaa. Kysymyksessä eivät ole lapsen kokemukset. Vaikka aikuisella olisi halukkuutta ja taitoa päästä mahdollisimman lähelle lasten kokemusmaailmaa, lapsiperspektiivi muodostuu aikuisten jäsentämänä. Lapsiperspektiivi muotoutuu vuorovaikutuksessa ja keskustelussa lasten kanssa aikuisten pyrkiessä ymmärtämään lasten kokemuksia, näkemyksiä ja ympäristön tapahtumia. Tekijät pelkistävät seuraavat viisi tekijää, jotka ovat keskeisiä lapsiperspektiivin juurruttamisessa pedagogiseen käytäntöön:

- Lapsen näkeminen persoonana.

- Empaattinen osallistuminen ja kanssakäyminen lasten kanssa.

- Taito tulkita kunnioittavasti ja ymmärtävästi lasten ilmaisuja ja lasten esille tuomia merkityksiä. 
- Lapsen ohjaaminen herkällä tavalla häntä tukien ja laajentamalla hänen aloitteisuuttaan.

- Varhainen kasvatus, hoito ja opetus tapahtuvat dialogisessa prosessissa lapsen ja kasvattajan välillä tavalla, jossa kumpikin osapuoli jäsentää oppimista. Joskus kasvattajat ovat määräävässä asemassa joskus taasen lapset.

Lasten perspektiivissä on Sommerin ja kumppaneiden (2013) hahmottamana kysymys lasten omista kokemuksista, näkemyksistä ja ymmärryksestä. Kysymys on siitä, miten lapsi itse hahmottaa toimimisensa ja oppimisensa sekä millaisia merkityksiä ja tulkintoja lapsi antaa niille. Aikuiset, kasvattajat ja opettajat pyrkivät pääsemään käsiksi ja sisälle tähän maailmaan, mutta vain lapset itse voivat kokea ja ilmaista omat perspektiivinsä ja tulkintansa.

Laadullisessa varhaisvuosien pedagogiikassa sekä lapsen että lasten perspektiivi ovat keskeisessä asemassa. Laadun kannalta on kuitenkin tärkeää, että kumpikin perspektiivi voisi kohdata ja täydentää toisiaan. Näin ei kuitenkaan aina tapahdu. Pramling (1983) esittää tästä havainnollisen esimerkin. Opettaja halusi lasten oppivan aikakäsityksen. Opettaja jäsensi oppimista niin, että lapset tekivät askartelemalla kellon. Kun opettaja halusi päästä selville lasten oppimisesta ja aikakäsityksen muodostumisesta, hän haastatteli lapsia. Lasten vastaukset viestivät seuraavaa: me oppimme tekemään kellon. Voimme tulkita, että lapsen oppiminen jäi pelkästään tekemisen kuvaukseksi suureksi osaksi siksi, että pedagogin ja lasten mieltämismaailma ja ymmärrys eivät kohdanneet. Oppimisen tulos olisi todennäköisesti ollut erilainen, mikäli opettaja olisi tutkinut, kokeillut, keskustellut ja etsinyt jaetun ymmärtämisen keinoin erilaisia tapoja aikakäsityksen oppimiseen ja ymmärtämiseen yhdessä lasten kanssa.

\section{Uudistuvat arviointikäytänteet}

\section{Varhaiskasvatuksen nykytilan arviointi}

Kansallinen arviointikeskus on vuonna 2017 julkaissut varhaiskasvatuksen arvioinnin nykytilaa koskevan raportin (Mikkola ym., 2017). Raportin alussa hahmotellaan varhaiskasvatuksen arvioinnin tehtävää toteamalla, että tavoitteena on turvata varhaiskasvatuslain tarkoitus ja tukea 
varhaiskasvatuksen kehittämistä. Arviointia luonnehditaan omaleimaiseksi ja perusopetuksen arvioinnista poikkeavaksi. Perusopetuksen arvioinnista todetaan, että sen yksi keskeinen painopiste on oppimisen tulokset. Raportin mukaan varhaiskasvatuksen arvioinnilla on lähinnä ohjaava merkitys ja siksi sitä suunnataan toimintaympäristöön ja lapsen oppimisen, kehityksen ja hyvinvoinnin edellytyksiin.

Selvitys tehtiin sähköisellä kyselyllä ja siihen vastasi 316 varhaiskasvatuksen järjestäjää. Nykytilan arvioinnissa kohdennettiin huomio etenkin itsearviointiin, jonka tarkoituksena on syventää varhaiskasvatuksen järjestäjien ymmärrystä varhaiskasvatuksen tavoitteista ja toiminnan paikallisen tason kehittämisestä. Tulokset viestivät, että itsearvinnon käytänteissä oli suurta kirjoa, joka tulkittiin perustuvan laadunhallintaan ja itsearviointiin liittyvästä käsitteellisestä hajanaisuudesta, toimintaympäristöjen eroista ja järjestäjien erilaisista tarpeista. Valtaosa järjestäjistä (67\%) ilmoitti tekevänsä systemaattista toiminnan itsearviointia. Varhaiskasvatussuunnitelman perusteiden osa-alueista järjestäjät ilmoittivat kehittävänsä erityisesti pedagogisen toiminnan arviointia. Toimenpiteenä ehdotetaan, että arviointikeskus aloittaa laadunarvioinnin mallin kehittämisen, johon se ryhtyikin vuonna 2019.

Varhaiskasvatuksen nykytilaa hahmottava raportti (2017) kokoaa yleisellä tasolla nykykäytänteitä eikä tarjoa juurikaan uutta. Kyseisessä raportissa varhaiskasvatuksen arviointiin tuodaan aineista varhaiskasvatuksen laadunhallinnasta, joka vaikeuttaa raportin pääsanoman seuraamista ja ymmärtämistä. Pelkästään käsitteellisesti selkeämpää olisi analysoida kasvatuksen ja opetuksen arviointikäytänteitä omana osa-alueenaan ja laadun hallintaa omanaan. Kansallisen koulutuksen arviointikeskuksen raportissa (Atjonen ym., 2019) perusopetuksen oppimisen ja osaamisen arviointi analysoidaan kytkemättä tätä laadunhallinnan arviointiin.

Varhaiskasvatuksen nykytilaa arvioivassa raportissa esitetty vastakkainasettelu perusopetuksen arviointiin on kategorinen ja antaa perusopetuksen arvioinnista varsin yksipuolisen kuvan kanavoimalla sen perustarkoituksen lähinnä lasten oppimistulosten arviointiin. Tutustuminen kansallisen koulutuskeskuksen oppimisen ja osaamisen arviointiin perusopetuksessa (Atjonen ym., 2019) tarjoaa perusopetuksen arvioinnista huomattavasti monipuolisemman ja oikeamman kuvan. Toinen kärjistetty vuoden 2017 -raportissa oleva viesti koskee rinnastusta Pohjoismaihin ja Keski-Eurooppaan. Esimerkiksi Bennettin (2006) analyysit OECD-maiden 
varhaiskasvatuksen perusolemuksesta arviointikäytänteet mukaan luettuna viestivät, että Pohjoismailla on paljon yhteistä mutta myös eroavaisuuksia. Bennettin analyysin mukaan Keski-Europan maat myös eroavat monessa suhteessa toisistaan. Erot eri maiden kesken vielä lisääntyvät, kun tarkasteluun otetaan muita OECD -maita. Näin hahmottaen esimerkiksi Pohjoismainen varhaiskasvatuksen ideologia arviointikäytänteineen on mieluiten poikkeus eikä se voi sen vuoksi olla yksiselitteisesti tavoiteltava malli. Pitäytyminen vallitsevaan arviointikulttuuriin ei ole kantava voimavara uudistamisessa, jota varhaiskasvatus tarvitsee myös arvioinnin osalta.

Vastakkainasettelun sijasta varhaiskasvatuksen ja perusopetuksen arvioinnista olisi voinut etsiä yhteisiä periaatteita ja käytänteitä suhteessa lasten oppimiseen ja osaamiseen, jota joka tapauksessa tapahtuu myös varhaiskasvatuksessa. Näin olisi tullut kyseenalaiseksi esimerkiksi se, että modernin arvioinnin tulisi suuntautua ensisijaisesti vain toimintaympäristöön ja sen luomiin edellytyksiin. Poissulkemisen sijasta varhaiskasvatuksen ja perusopetuksen arvioinnin kehittämisessä kannattaisi hyödyntää kummankin osapuolen tietämystä ja voimavaroja etsimällä polkuja yhteisen arviointikulttuurin kehittämiseen.

Arvioinnin keskeinen tavoite ei ole antaa palautetta ainoastaan kasvatuksen toimintaympäristön (rakenne ja prosessit) toimivuudesta. Ydinprosesseja ovat oppiminen, kehittyminen ja opettaminen, jotka ovat tavoitteellisia. Laadukas toimintaympäristö tietenkin tukee näitä, mutta tämä yksin ei saa aikaan toivottua tulosta. Tähän tarvitaan oppimista ja tätä stimuloivaa opettamista. Näiden perusluonne on tahdonalaista, päämääriin ja tavoitteisiin pyrkivää henkistä aktiviteettia, joka pelkistyy tai sisäistyy oppimiseen ja kehittymiseen riippumatta ratkaisevasti lapsen tai oppilaan toimintaympäristöstä. Esimerkiksi paljon huomiota saanet kansainväliset PISA-tulokset viestivät, että korkeisiin tai alhaisiin pistemäärin voidaan päätyä hyvinkin erilaissa toimintaympäristössä.

Jo yksiomaan se, että lapsen oppimista ja kehittymistä ryhdytään arvioimaan, viestii kiinnostuksesta ja arvostuksesta lapsia ja oppilaita kohtaan, kuten esimerkiksi Atjonen (2019) toteaa. Pramlingin pitkäaikainen ja perusteellinen tutkimustoiminta sekä alle kouluikäisten että kouluikäisten lasten käsityksestä siitä, mitä oppiminen on ja miten se tapahtuu, osoittaa ainakin kaksi seikkaa (esim. Pramling, 1986; Dovenborg \& Pramling, 1992). Ensinnäkin lapset ovat tietoisia oppimisesta. Toiseksi lapset miltei 
poikkeuksetta iloitsevat ja arvostavat sitä, että opettajia kiinnostaa, mitä lapsi on oppinut ja miten oppiminen on tapahtunut.

Yhteenvetona voi todeta, että myös varhaiskasvatuksen arvioinnin olemusta pitää jäsentää ennakkoluulottomasti ja analyyttisesti lasten oppimiseen ja kehittymiseen liittyvien käsitteiden, teorioiden ja tutkimusten kehikossa siihen tapaan kuin perusopetuksen osalta on jo tehty (Atjonen 2019). Varhaiskasvatus ansaitsee tämän!

\section{Varhaiskasvatuksen laatuindikaattorit}

Varhaiskasvatuksen arvioinnin kansallisesta ohjauksesta vastaavat opetusja kulttuuriministeriö, Opetushallitus ja kansallinen arviointikeskus. Kansallisen koulutuksen arviointikeskus on julkaissut vuonna 2019 varhaiskasvatuksen laatuindikaattorit (Vlasov ym., 2018; Kansallisen koulutuksen arviointikeskus 2019). Julkistetussa laadun arvioinnissa kohdistetaan huo-mio kahteen laadun tekijään: prosessi- ja rakennetekijöihin. Näiden avulla on tarkoitus arvioida ja ohjata varhaiskasvatuksen kansallista ja paikallista pedagogisen toiminnan tasoa. Kutakin tasoa varten on laadittu niitä koske-vat laatua kuvaavat indikaattorit.

Rakenteelliset laadun indikaattorit kohdistuvat (a) ohjaavaan lainsäädäntöön, (b) varhaiskasvatuksen riittävyyteen, saatavuuteen ja inklusiivisyyteen, (c) varhaiskasvatusta ohjaavaan opetussuunnitelmaan, (d) henkilöstön perus- ja täydennyskoulutukseen sekä osaamisen kehittämiseen, ( e ) huoltajille suunnattuun varhaiskasvatusta koskevaan ohjaukseen ja neuvontaan, (f) varhaiskasvatuspalvelujen ohjaukseen, neuvontaan ja valvontaan, (g) yhtenäiseen koulutus- ja kasvatusjärjestelmään ja siirtymiin, (h) varhaiskasvatuksen arvioinnin ja kehittämisen rakenteisiin sekä (i) varhaiskasvatuksen oppimisympäristöihin. Laatua kuvaavat prosessi-indikaattorit kohdistuvat (a) henkilöstön ja lapsen väliseen vuorovaikutukseen, (b) pedagogiseen suunnitteluun, dokumentointiin, arviointiin ja kehittämiseen, (c) pedagogiseen toimintaan ja oppimisympäristöön, (d) johtamisen pedagogisen toiminnan tasoon, (e) vuorovaikutukseen ja ryhmän ilmapiiriin, (f) henkilöstön keskinäiseen vuorovaikutukseen ja monialaiseen yhteistyöhön sekä (g) henkilöstön ja huoltajien väliseen vuorovaikutukseen.

Rakenteita koskevia indikaattoreita on 34 ja prosesseja 26 eli yhteensä

60. Indikaattoreiden tulisi arviointikeskuksen määritelmän mukaan olla konkreettisia ja todennettavissa. Avoimeksi jää ainakin toistaiseksi, kuinka 
tämä tavoite toteutuu ja kuinka se käytännössä tehdään. Voi kysyä, onko näin runsaan indikaattorimäärän avulla mahdollisesti suoritettu laadun analyysi ylipäätään hallittavissa. Ehkä vieläkin keskeisempi kysymys on, miten 60 indikaattorin avulla mahdollisesti kerätty arviointitieto välittyy kasvatuksesta ja opetuksesta vastaaville käytännön toimijoille niin, että toimijat motivoituvat ja ryhtyvät laadun kohentamiseen.

Voi myös todeta, että pelkkien verbaalisten laatulausumien avulla varhaiskasvatuksen laadun tilaa ja etenkin sen tasoa on vaikea todeta ilman kriteereitä, joiden avulla ilmaistaan laatuarvioinneissa asian tilaa tai tasoa. Askarruttavana seikkana on laatuindikaattoreiden kohdistaminen vain rakenne- ja prosessitekijöihin. On tärkeä huomata, että varhaiskasvatussuunnitelman perusteissa (2016) tavoitteena on myös velvoite oppimiseen. Kansainvälisten esimerkkien mukaan varhaiskasvatuksen laadun arvioinnin tulisi ulottua myös lapsen/oppilaiden oppimisen ja kehittymisen enenemiseen ja sen tasoon. Esimerkiksi perusteellisen EPPE-projektin projektin tulokset Englannissa ovat voineet tarjota riittävän konkreettista palautetta varhaiskasvatuksen laadusta, joka kiinnittyy pedagogiseen toimintaan ja lasten oppimiseen opetussuunnitelman sisältöalueilla (esim. Sylva et al., 2010). Toistaiseksi kansallisen arviointikeskuksen varhaiskasvatusta koskevat viimeaikaiset julkaisut ovat kohdentuneet laadun arviointikriteereihin ja varhaiskasvatussuunnitelman perusteiden toimeenpanoon. Tällaista arviointia ovat esimerkiksi Wood ja Hedges (2016) luonnehtineet lähinnä kontrolliin ja vallan ylläpitämiseen tähtääväksi byrokraattiseksi laadun arvioinniksi, joka irtautuu kasvatuksen ja opetuksen todellisuudesta ja sen keskeisistä toimijoista opettajista/kasvattajista ja etenkin lapsista/oppilaista.

On tarpeen kiinnittää huomiota vielä indikaattorikokoelman laadinnan taustana olevaan teoriaan. Raportissa ilmenee, että kansallisen koulutuksen arvioitikeskuksen julkistaman varhaiskasvatusta koskevan indikaattorikokoelman perusta kiinnittyy Bronfenbrennerin kehitysekologiseen teoriaan (Bronfenbrenner, 1979). Tämän teorian teoreettisen konstruktion ytimessä on kasvun ja kehittymisen ekologinen ympäristö. Ympäristöä kuvataan asteittain laajenevina kehinä (mikrotaso, mesotaso, eksotaso ja makrotaso). Tämän teorian käyttämisessä on tärkeää huomata Bronfenbrennerin itsensäkin havaitsemat rajoitukset. Tämän vuoksi Bronfenbrenner sisällytti malliinsa uusia elementtejä. Uudistettu malli nimettiin PPCT- malliksi (Bronfenbrenner, 1994; Tudge etc., 2009). Lyhenteet tulevat sen pääelementtien englanninkielisistä käsitteistä Process- Person- Context- Time 
(Prosessi-Henkilö-Konteksti-Aika). Merkittävät käsiteelliset lisäykset kohdistuvat kehittyvän henkilön/persoonan aktiiviseen rooliin ja lähellä oleviin lähiprosesseihin (proximal processes), joihin vaikuttavat yksilön ja ympäristön ominaispiirteet mutta myös kehittymisen tulos.

Kansainvälisissä arvioissa on pohdittu Bronfenbrennerin teorian etuja ja rajoituksia (esim. Tudge et al., 2009; Watts et al., 2009; Darling, 2007; Shaffer, 2009). Näissä arvioissa Bronfenbrennerin teoreettinen anti erityisesti kehityspsykologiseen teoriaan saa kiitosta korostamalla ympäristön ja kehittyvän henkilön välistä aktiivista vuorovaikutusta. Arvioinneissa nostetaan myös esille teorian rajoituksia. Näistä yksi kohdistuu kritiikkiin kehitykseen vaikuttavista ympäristötekijöistä. Näitä on periaatteessa rajaton määrä, joka tekee niiden haltuunoton käytännössä mahdottomaksi eikä niiden kokoaminen kehitettyyn ekologiseen systeemiin muuta miksikään tätä ongelmaa. Vaikka pyrkimyksenä olisi saada ymmärrystä vain yhteen kehitykseen vaikuttavaan tekijään, teorian mukaan tulkintaan tulee ottaa kaikki mallissa hahmotetut ekologisen systeemin tasot ja niiden tekijät. Shafferin (2009) mukaan huomattavana puutteena on etenkin se, että Bronfenbrennerin teoria ei vastaa keskeiseen kysymykseen: Kuinka lapset varttuessaan prosessoivat ympäristöstä välittyvää informaatiota ja oppimista!

\section{Varhaiskasvatuksen laatu arjessa}

Kansallinen koulutuksen arviointikeskus on tehnyt vuonna 2019 arvion varhaiskasvatuksen laadusta arjessa (Repo ym., 2019). Tavoitteena oli selvittää, miten varhaiskasvatussuunnitelman uusien perusteiden (2016 ja 2018) asettamat tavoitteet toteutuvat. Arvioinnin kohteena oli päiväkotien ja perhepäiväkotien henkilöstön pedagoginen toiminta. Henkilöstöä pyydettiin arvioimaan pedagogista toimintaansa suhteessa varhaiskasvatussuunnitelmassa esitettyihin tavoitteisiin ja sisältöihin sekä suunnitelmien toteuttamisen rakenteellisiin tekijöihin. Tulosten mukaan sisällölliset tavoitteet toteutuivat useimmissa päiväkodeissa ja perhepäiväkodeissa hyvin, mutta osassa heikosti. Myös turvallisuus, myönteinen ilmapiiri ryhmissä, lasten oikeus leikkiin ja leikkipedagogiikka toteutuivat arvioinnin mukaan varhaiskasvatuksen perusteiden mukaisesti. Sen sijaan taidekasvatuksen, ilmaisun, musiikin, liikunnan ja lukutaidon valmiuksia kehittävien toimintojen toteutuksessa nähtiin puutteita. Hyvällä pedagogisella johtamisella ja konkreettisella paikallisella varhaiskasvatussuunnitelmalla sekä henkilöstön 
täydennyskoulutuksella nähtiin olevan tärkeä merkitys varhaiskasvatussuunnitelman toteutuksessa. Toteutuksen esteitä olivat henkilöstön vaihtuvuus, johtamisjärjestelmä ja henkilöstön pedagoginen osaaminen.

Kokonaisuudessaan selvitys jää alustavaksi ja osin pintapuoliseksi. Kvantitatiivisen aineiston oheen liitetyn laadullisen aineiston mukaanotto ja aidot aineistoesimerkit tuovat selvitykselle konkretiaa. Tulosten painoarvoa on omiaan alentamaan etenkin alhainen vastusprosentti (henkilöstö $54 \%$, päiväkodin johtajat $60 \%$ ja perhepäivähoitajat $54 \%$ ). Tämän vuoksi selvityksen tulokset voitaneen yleistää vain noin puoleen päiväkodeista ja perhepäiväkodeista. Päiväkotien johtajien kohdalla yleistettävyys on hieman parempi, mutta vastaamattomien osuus tässäkin kohdejoukossa oli suuri (40\%). Selvityksessä jää kaipaamaan lasten ja vanhempien ääniä. Varhaiskasvatussuunnitelman perusteissa korostetaan myös kytkeymää kansainväliseen vertailuun, jota olisi toivonut mukaan.

\section{Perusopetuksen laatukriteerit}

Suomalaisen perusopetuksen laadun ylläpitämiseksi ja arvioimiseksi on vuonna 2012 tuotettu laatukriteerit (Perusopetuksen, perusopetuksen aamu- ja iltapäivätoiminnan sekä koulun kerhotoiminnan laatukriteerit, 2012). Niillä pyritään tukemaan opetuksen korkea laatu ja monipuolinen tarjonta sekä turvaamaan opetukselliset ja sivistykselliset perusoikeudet lapsille ja nuorille asuinpaikasta, kielestä ja taloudellisesta asemasta riippumatta. Laatukriteeristö toimii johtamisen välineenä, jonka kautta arvioidaan toiminnan nykytilaa ja kehitetään sitä. Paikallisen tason arviointi- ja muutosprosesseissa perusopetuksen laatukriteereiden toivotaan tarjoavan opetus- ja kasvatusalan ammattilaisille tutkimus- ja arviointitietoon sekä voimassa oleviin säädöksiin perustuvan työvälineen, joka auttaa kouluja arvioimaan ja kehittämään joustavasti paikallista toimintaa. Laatukriteerit antavat myös mahdollisuuden painottaa paikallisia laatukriteereitä, jotka on koettu tärkeiksi perusopetuksen toteutuksessa.

Laatukriteerit tarjoavat mahdollisuuden arvioida lyhyen ja pidemmän aikavälin vaikutuksia koulujen toiminnassa. Laatukriteereihin kiinnittyvän arviointitiedon avulla voidaan tunnistaa koulutuksen epäkohtia ja korjata niitä vuosittain kuntien toiminnan ja taloudellisten resurssien puitteissa. Laatukriteerit voivat jäsentää myös alueellista yhteistyötä. Perusopetuksen 
laatukriteeristön erityisenä tarkoituksena on tarjota työväline, jolla koulut ja ylläpitäjät voivat yhdessä arvioida toimintaansa.

Perusopetuksen laatukriteerit kohdistuvat kahteen keskeiseen elementtiin, joina ovat rakenteiden laatu ja toiminnan laatu. Rakenteiden laatuun liittyvät johtaminen, henkilöstö, taloudelliset resurssit ja arviointi.

Toiminnan laadussa kohdistetaan huomio seuraaviin yhdeksään alueeseen:

- opetussuunnitelman toteuttaminen

- opetus ja opetusjärjestelyt

- oppimisen, kasvun ja hyvinvoinnin tuki

- osallisuus ja vaikuttaminen

- kodin ja koulun yhteistyö

- fyysinen oppimisympäristö

- oppimisympäristön turvallisuus

- perusopetuksen aamu- ja iltapäivätoiminta

- koulun kerhotoiminta

Laatukriteerit on jäsennetty laatukortteihin (yhteensä 13), jotka sisältävät kuvausosan, laadun kriteerit ja toimintaa tukevia kysymyksiä. Laatukortit sisältävät kriteereitä sekä opetuksen järjestäjälle että kouluille. Uutena perusopetuksen laatukriteereihin on lisätty perusopetuksen aamu- ja iltapäivätoiminnan sekä koulun kerhotoiminnan laatukortit.

Tiivistäen, perusopetuksen laatukriteerit ohjaavat opetuksen järjestäjiä ja kouluja arviointikäytänteiden ylläpidossa ja kehittämisessä seuraavasti:

- Arviointi- ja kehittämistoimintaa toteutetaan systemaattisesti ja suunnitelmallisesti.

- Opetuksen järjestäjällä ja koululla on toimintansa tarpeisiin soveltuva arviointijärjestelmä.

- Arviointijärjestelmän tuottamaa tietoa käytetään opetuksen kehittämisessä sekä toiminnan ja talouden suunnittelussa.

- Opetuksen järjestäjän ja koulujen arviointiosaamista kehitetään suunnitelmallisesti.

- Opetuksen järjestäjällä ja koululla on yhteisesti sovitut arvioinnin periaatteet. 
- Arviointi ja kehittämistoimintaan osallistuvat myös oppilaat, vanhemmat ja oppilashuoltohenkilöstö sekä tarpeiden mukaan myös muu henkilöstö.

\section{Oppimisen ja osaamisen arviointi perusopetuksessa}

Kansallisen koulutuksen arviointiryhmä on vuonna 2019 tuottanut perusteellisen julkaisun oppimisen ja osaamisen arvioinnista perusopetuksessa ja lukiokoulutuksessa (Atjonen ym., 2019). Sen tarkoituksena oli selvittää, millaisia kokemuksia ja käsityksiä rehtoreilla, opettajilla, oppilailla ja huoltajilla oli arviointimenetelmistä, -käytänteistä ja -kulttuurista. Kohteena olivat paikalliset opetussuunnitelmat, joiden arviointikäytänteitä selvitettiin sähköisin kyselyin sekä otantayksiköissä järjestetyillä pienryhmäkeskusteluilla. Vastaajia oli yli 8000.

Arviointiryhmä (Atjonen ym., 2019, 31-35; 240-244) kohdistaa arvioinnin päättöarviointiin (summatiivinen) ja opintojen aikaiseen (formatiiviseen), jotka ovat sekä opettajan että oppilaan apuvälineitä. Päättöarvioinnissa on kysymys osaamisen ja opintojen aikaisen oppimisen arvioinnista. Laajan aineiston perusteella arviointiryhmä on tehnyt kehittämissuosituksia. Suositusten perustana on toteamus, jonka mukaan arviointi ja pedagogiikka liittyvät erottamattomasti toisiinsa ja vielä niin, että arviointi on käytännössä yksi vaikuttavimmista keinoista ohjata opetus-, opiskelu- ja oppimisprosesseja. Esimerkiksi opettajien arviointikäytänteitä koskevissa suosituksissa korostetaan (a) arviointimenetelmien monipuolistamista niin, että oppimisprosessien läpinäkyvyys ja osaamisen osoittaminen eri tavoin lisääntyvät (nämä kannustavat opiskelua) ja niin, että (b) oppimisen tavoitteisiin ja kriteereihin perustuvaa arviointia vakiinnutetaan ja niiden tietämystä lisätään myös oppijoiden ja huoltajien keskuudessa. Arviointiosaamista koskevissa suosituksissa suositellaan opettajien pitkäjännitteisen arviointiosaamisen vahvistamista ja monipuolistamista sekä oppijan arviointiosaamisen kehittämistä ohjaamalla ja osallisuuden vahvistamisella erityisesti itse- ja vertaisarviointitaidoissa. Edellisten lisäksi korostetaan hyvän pedagogisen johtajuuden keinoin rakentuvaa arviointikuluttuuria, joka rohkaisee kokeilemaan erilaisia arviointikäytänteitä.

Johtopäätöksenä voi todeta, että kansallisen arviointikeskuksen raportti sisältää monipuolista analyysia oppimisen ja osaamisen arvioinnista ja sen kehittämisestä. Erityisesti suositukset jatkuvan (formatiivisen) 
arvioinnin merkityksestä voi ymmärtää sellaiseksi, että nämä voisivat soveltua myös varhaiskasvatuksen ja esiopetuksen arkeen varsinkin tilanteessa, jossa varhaiskasvatus ja perusopetus kuuluvat samaan hallinnonalaan. Arviointiperiaatteiden yhteneväisyyden lisääminen ja kehittämien varhaiskasvatuksen, esiopetuksen ja koulun välillä on omiaan vahvistamaan oppimisen ja opettamisen jatkumoa, jotta "tietää missä on menossa". Kahden toisistaan poikkeavan erillisen arviointikulttuurin ylläpitäminen ei ole hallinnollisesti perustelua ja siitä koituvia etuja on vaikea hahmottaa.

Opetushallituksen toimesta perusopetuksen arviointia on vuonna 2019 ryhdytty uudistamaan (Opetushallitus, 2019). Kohteena on kehittää uusia kriteereitä ja täsmennyksiä arviointiin tavoitteena lisätä arvioinnin yhdenvertaisuutta ja arvosanojen vertailukelpoisuutta. Uudistustyön alkuvaiheessa pyritään laatimaan arvioinnin kriteereitä arvosanoille 5, 7 ja 9 määrittelemällä, mitä oppilaan on osattava saadakseen kyseisen arvosanan. Tavoitteena on saada koko maahan yhtenäisemmät arvioinnin periaatteet tueksi kouluille ja opettajille. Uudistus kohdistuu kaikkiin vuosiluokkiin ja sen yhteydessä täsmennetään missä vaiheessa aloitetaan numeroarviointi. Uudistyö pyritään saamaan päätökseen keväällä 2012.

\section{Esimerkkejä lasten/oppilaiden oppimisen ja osaamisen arvioinnista}

Englannin kansalliseen opetussuunnitelmaan on ikävuodesta 5 lähtien liittyy arviointijärjestelmä, jossa lasten/oppilaiden oppimista seurataan systemaattisesti koko oppivelvollisuuden ajan. Arviointi kiinnittyy kansallisen opetussuunnitelman pääalueisiin, joissa tapahtuvaa oppimista opettajat seuraavat dokumentoiden lasten/oppilaiden oppimista ja sen etenemistä havainnoinnin, valokuvien, portfolionäytteiden ym. avulla.

Ennen oppivelvollisuutta lapset voivat osallistua esiopetukseen, joka on usein koulujen yhteydessä ns. vastaanottoluokissa. Kansallista arviointia varten on kehitetty arviointijärjestelmä, jolla pyritään arvioimaan lasten oppimista ja kehittymistä perusopetuksen siirtymisvaiheessa, jolloin lapset Englannissa ovat 4-5 -vuotiaita (esim. Bradbury, 2011; Bradbury, 2014; Early years foundation stage, 2018). Arviointia varten on kehitetty indikaattorit, jotka on jaettu seitsemään pääalueeseen: (a) kommunikaatio ja kieli, (b) fyysinen kehittyminen, (c) sosiaalinen ja emotionaalinen kehittyminen, (d) äidinkieli ja kirjallisuus, (e) matematiikka, (f) tieto ja 
ymmärtäminen maailmasta sekä (g) esittävä taide ja suunnittelu. Lasten olleessa keskimäärin 5-vuotiaita opettajat kokoavat hankkimansa dokumenttiaineiston päättöarviointina kansalliseen kriteeristöön, jonka avulla he arvioivat lasten/oppilaiden oppimisen ja kehittymisen tason käyttäen 3-portaista kriteeristöä: (3) ylittää odotetun kehittymisen, (2) vastaa odotettua kehittymistä tai (1) ei yllä odotettuun kehittymiseen (Early years foundation stage profile, 2018).

Englannissa omaksuttu tapa arvioida lasten/oppilaiden oppimista on herättänyt myös kysymyksiä sen soveltuvuudesta pienten lasten oppimiseen. Esimerkiksi Bradbury $(2011,2014)$ on tehnyt etnografisia tapaustutkimuksia Lontoon kouluissa, joissa huomattava määrä 4-5 -vuotiaita edusti vähemmistöryhmiä. Keskeisen puheenvuoron tuloksissa saavat opettajat, joiden arviointiprosessista kerättiin yksityiskohtaista tietoa. Seurannan kohteena olevat opettajat tekivät jatkuvia havaintojaan lasten oppimisesta ja edistymisestä olemalla aktiivisessa vuorovaikutuksessa heidän kanssaan. Bradbury (2014) nimesi tämän neutraaliksi prosessiksi hankkia lapsista objektiivista opettajien tietotaitoa arvostavaa arviointitietoa. Tutkimuksen kohteena olevat opettajat korostivat sitä, että lapset pitää löytää taitavan opettajan tapaan uudestaan ja uudestaan. Merkittävää oli, että vasta kun opettajat ottivat käyttöön opettajan omaan aktiiviseen prosessointiin perustuvan arviointitiedon, he olivat kykeneviä tekemään mielestään luotettavan päättöarvioinnin ja pisteyttämisen kansallisen arvioinnin kuvaamiin oppimisen tasoihin. Näin tehdessään kohderyhmän opettajat tekivät kriittisiä havaintoja kansallisen standardoidun päättöarvioinnin käytänteistä ja painotuksista. Haastatellut opettajat arvostivat havaintoihin perustuvan objektiivisen tiedon keräämistä. Vaikeutena oli kuitenkin monissa tapauksissa pisteyttää omat havainnot päättöarvioinnin kansallisiin oppimisen tasoihin.

\section{Johtopäätöksiä}

Arviointimenettelyt kytkeytyvät omaksuttuun opetussuunnitelmaideologiaan. Esimerkiksi Wood ja Hedges (2016) ovat analysoineet kriittisesti varhaisvuosien opetussuunnitelmien taustalla olevia perusolettamuksia. Analyysissa kiinnitettiin huomiota kansallisten opetussuunnitelmien sisältöön, loogisuuteen ja sisäiseen selkeyteen sekä kontrolliin. Tutkijat tunnistivat varhaiskasvatuksen kentässä käytetyissä opetussuunnitelmissa kaksi 
valtavirtaa. Ensimmäinen näistä hyödyntää kehityspsykologista ja kasvatuspsykologista teoriaa ja tutkimusta. Kehitys- ja kasvatuspsykologisessa orientaatiossa korostetaan lapsikeskeisyyttä, leikkiä, toimintaa, lapsen/oppilaiden tarpeita jne. Taka-alalle jää aikuisen rooli oppimisen ohjaamisessa ja opetuksen suunnittelussa.

Toinen vallitseva varhaisvuosien opetussuunnitelman perusta Woodin ja Hedgesin (2016) mukaan painottaa strategista suunnittelua ja ohjausjärjestelmää. Opetussuunnitelma rakennetaan viranomaisten ohjaamana ja kontrolloimana. Siinä tähdätään opetussuunnitelman mukaisiin lyhyen, keskipitkän ja pitkän aikavälin tavoitteisiin. Opetussuunnitelman toimivuutta kontrolloidaan kyselyin ja arviointiraporttien avulla, joiden pohjalta pyritään tekemään suosituksia opetussuunnitelman ja oppimisen tehostamiseksi. Viranomaisten käynnistämissä selvityksissä ja arvioinneissa jää varsin usein taka-alalle alueen tutkimuksellinen anti, koska päätavoite on ulkoisessa kontrollissa.

Wood ja Hedges (2016) nostavat harkittavaksi myös kolmannen vaihtoehdon, jonka keskiössä on dynaaminen pedagoginen toiminta ("working theory"). Tässä vaihtoehdossa opetussuunnitelman rakentamisen aineksia on ideoitu tutustumalla Uuden-Seelannin kansalliseen suunnitelmaan ja liittämällä siihen kriittisen teorian korostamia ajatuksia kehityspsykologisen teorian ja vallankäytön/kontrollin rajoituksista. Ajatuksena on ideoida dynaaminen opetussuunnitelma, joka korostaa oppimiskokemuksia, toimintaa ja uudelleen hahmottamista. Keskiössä tällöin ovat (a) lapset - jotka voivat päättää tekemisestään ja keskusteluistaan toinen toistensa kanssa ja (b) heidän parissaan työskentelevät ammattilaiset - jotka tukevat monipuolisesti oppimista ja kehittymistä (esim. leikki, vuorovaikutussuhteet, päämäärä-hakuinen ja reflektoiva opettaminen). Vaihtoehdon esittäjät otaksuvat, että ideoidulla mallilla voitaisiin poistaa aukkoja tai puutteita, joita heidän mukaansa liittyy kahteen vallitsevaan opetussuunnitelmamalliin kohdistuen sisältöön, loogisuuteen sekä sisäiseen selkeyteen ja kontrolliin

Suomalaisen varhaiskasvatuksen ja esiopetuksen kansallisen opetussuunnitelman perustat kytkeytyvät Woodin ja Hedgesin (2016) esittämistä vaihtoehdoista kansainvälisesti laajasti levinneeseen valtavirtaan, joka korostaa yhtäältä kehityspsykologisen ja kasvatuspsykologisen teorian ja tutkimuksen tärkeyttä ja toisaalta valtiovallan ohjantaa ja kontrollia. Lasten oppimista ja opetussuunnitelman toteutusta seurataan ja dokumentoidaan lapsikohtaisesti, yksikkökohtaisesti ja aika ajoin valtakunnallisesti. Näin 
muodostunutta arviointikokonaisuutta ei kuitenkaan esimerkiksi Englannin tapaan koota maassamme systemaattisesti esimerkiksi vuosittain toistuvana kokoavana arviointina, joka ilmaisisi oppimisen ja osaamisen suunnan ja tason opetussuunnitelman pääalueilla jatkumona varhaiskasvatus-esiopetus-koulun alku. Tällainen arviointi tarjoaisi arvokasta palautetta vanhemmille, opetushenkilöstölle, kunnallisille päättäjille, tutkijoille ja kansallisen opetussuunnitelman laatijoille. Lasten oppimisen systemaattinen seuranta ja arviointi tarjoaa pedagogisesti tärkeää palautetta korjaavien ja tukevien pedagogisten toimenpiteiden käynnistämiselle ajoissa ja ennalta ehkäisee näin oppimisen ja kehittymisen erojen kasvua. Myös mahdollisuudet kasvatussuunnitelman/opetussuunnitelmien tavoite ja sisältöalueiden keskinäiseen vertailuun ja oppimisen ja osaamisen seurantaan paranisivat.

Myöskään maamme varhaiskasvatuksen laatuindikaattorit eivät sisällä lapsen oppimisen ja kehittymisen tasolle ulottuvia indikaattoria ja näitä tarkentavia kriteereitä (Varhaiskasvatuksen laatuindikaattorit, 2019). Laadun arviointi keskittyy vain rakenteisiin ja presseihin, joihin on liitetty indikaattoreita. Näidenkin kuvaus jää yleiselle tasolle, joilla yleisten laatulausumien avulla luonnehditaan varhaiskasvatuksen tavoiteltavaa tilaa. Edellä esitelty Bradburyn $(2011,2104)$ lähestymistapa Englannissa omaksuttuun kansalliseen 4-5-vuotiaiden lasten kokoavaan arviointiin tarjoaa konkreettisia keinoja saada aikaan kriteeripohjainen oppimisen ja osaamisen tasoa kuvaava arviointisysteemi (Early years foundation stage profile, 2018), jossa hyödynnetään opettajien tietämystä ja dokumentoituja havaintoja lapsen oppimisprosessista esimerkiksi vuosittain suoritettavassa kokoavassa arvioinnissa. Tämän tapainen kriteeripohjainen arviointi kiinnittyy opetussuunnitelman/kasvatussuunnitelman keskeisinä pidettyihin tavoitteisisin, joihin voidaan liittää viitteelliset oppimisen ja osaamisen väljät tasot (esim. tasot $A-C$, jossa $A=$ oppiminen ja osaaminen ylittää oletetun keskimääräiseen tasoon, $\mathrm{B}=$ oppiminen ja osaaminen vastaa oletettua keskimääräistä tasoa ja $\mathrm{C}=$ oppiminen ja osaaminen alittaa oletetun keskimääräisen tason; suositellaan tukevia toimenpiteitä). Näin mahdollisesti muodostuvan tasokuvauksen etua voi tulkita Vygotsky'n (esim., 1978) teorian avulla niin, että oppijalle ja arviointia suorittavalla opettajalle hahmottuu sekä nykyoppisen että potentiaalisen lähioppimisen taso. 


\section{Näkökulmia varhaisvuosien opettamisen ja oppimisen jatkuvuuteen}

OECD -analyyseissa suomalainen varhaiskasvatus yhdessä pohjoismaiden kanssa sijoittuu yhtenäisen järjestelmän maihin (Bennett, 2006). Tälle on ominaista varhain aloitettu lasten kasvatus ja opetus, joka kattaa ikävuodet 1-6. Monissa Euroopan maissa varhaiskasvatus on eriytynyttä, joka ilmenee siten, että pienempien yleensä alle 3-vuotiaiden kasvatus ja hoito ei sisälly opetusviranomaisten vastuulle.

Eriytyneen ja yhtenäisen varhaiskasvatusjärjestelmän ja koulun aloituksen vertailu Suomen kannalta on mielenkiintoista. Varhaiskasvatusideologiassa Suomi voi toteuttaa monia muita maita paremmin kasvatuksen, hoidon ja oppimisen integraatiota. Kun otetaan tarkasteluun varhaiskasvatuksen, esiopetuksen ja perusopetuksen vuosiluokkien 1-2 opetussuunnitelmat, opetuksen ja oppimisen jatkuvuus integroidusti ei olekaan enää itsestään selvyys. Opettamisesta ja oppimisesta tuleekin eriytynyt ja katkelmallinen.

Varhaiskasvatuksen, esiopetuksen ja koulun alun (perusopetuksen vuosiluokat 1-2) kokonaisvaltainen tarkastelu on tärkeää. Tällä vaiheella on lapselle itseisarvo sinänsä olla lapsi ja luoda lapsuutta. Ajanjakso luo myös perustan lapsen elinikäiselle oppimiselle ja kehittymiselle, joka on tulevaisuutta. Suomalaisessa kasvatus- ja koulutusjärjestelmässä ratkaisevassa asemassa oleva päivähoito, esiopetus ja perusopetuksen alku ratkaisevat varsin pitkälle, millaista lapsuutta lapsemme elävät ja millaiseksi heidän tuleva oppimisensa ja kehittymisensä muodostuu. Sellaiset tärkeät elämässä ja oppimisessa tarvittavat perustaidot, kuten yhteistyötaidot, identiteetti ja autonomisuus, osallisuuteen kehittyminen, merkityksen luominen, luovuus, probleeman ratkaisutaidot, oppimaan oppimisen taidot sekä oppimisen pitkäjännitteisyys saavat perustansa varhaisten elinvuosien oppimiskokemuksissa.

Opetussuunnitelmallisesti päivähoidon varhaiskasvatus, esiopetus ja perusopetuksen vuosiluokkien 1-2 tarjoamat oppimisen polut ovat maassamme katkelmallisia. Kuten myös Karila kumppaneineen (2013) ovat havainneet, siirtymät varhaiskasvatuksesta esi- ja alkuopetukseen jäsentyvät erilaisista toimintakulttuureista. Vaikka opetussuunnitelmilla on yhteistä arvopohjaa ja koulutuspoliittisia tavoitteita, niiden pohjalta muotoutuva oppiminen ja opettaminen ei kohtaa toisiaan. Asiaa ei kykene korjaamaan 
sinänsä mielekäs toivomus kasvattajien ja opettajien välisestä yhteistyöstä. Opetussuunnitelmia on sitä paitsi ryhdytty uudistamaan erillisinä, vaikka niiden yhteydessä esitetäänkin toivomus jatkuvuudesta siirryttäessä uuteen opetussuunnitelmakontekstiin. Vastuu jatkuvuudesta langetetaan päiväkodin, esiopetuksen ja alkuopetuksen opettajille miettimättä tarkemmin, mitä todellisia mahdollisuuksia opettajilla on jatkuvuuden toteuttamiseen.

Lapsemme kokevat intensiivisimmän kehittymisensä ja oppimisensa vaiheessa poikkeuksellisen monta kasvatuksellista ja opetuksellista siirtymää oppimisympäristöihin, jotka ovat tavoitteiltaan, sisällöstään ja toimintakulttuureiltaan erilaisia. Erilliset opetussuunnitelmat vaikeuttavat erityisesti lapsen oppimisen jäntevää pitkäaikaista seurantaa ja arviointia sekä myöhästyttävät tätä kautta korjaavien toimenpiteiden tehokasta käynnistämistä ja jatkuvuutta. Eheytystä ei myöskään tue se, että varhaiskasvatuksessa, esiopetuksessa ja perusopetuksessa toimivat kasvattajat ja opettajat ovat saaneet toisistaan poikkeavan peruskoulutuksen. Myös ammattia ylläpitävä ja täydentävä koulutuskin on usein erillistä.

Miksi siis pitää yllä opetussuunnitelmien erillisyyttä, kun voimme kehittää varhaisvuosiin liittyvää oppimisen ja opettamisen jatkumoa? Jos lähtökohdaksi otetaan oppimisen ja opettamisen jatkumo, varhaisia elinvuosia koskevaa kasvatus- ja koulutusideologiaa tulisi muuttaa. Periaatteessa ratkaisuja on vain kahdenlaisia. Perusopetusta voidaan aikaistaa tai esiopetusta pidentää alkavaksi yleiseurooppalaisen käytännön mukaisesti ehkä jo kolmen vuoden iässä. Tätä tukemaan pitäisi luoda nykyistä yhtenäisempi opettajien peruskoulutus, joka olisi maisteritasoinen.

Tutkimuksellisen tiedon nopea lisääntyminen lapsen varhaisesta oppimisesta, kehittymisestä ja opettamisesta, oppiaineksien vaativuus ja moninaisuus, uudistuvat opetuskäytännöt, lisääntyvä tietoisuus lasten ja nuorten hyvinvoinnin ylläpitämisen tärkeydestä, lasten sosiaalisten taitojen kehittämisen tärkeys, luovuuden keskeinen merkitys, oppimaan oppimisen taitojen merkitys oppimiselle sekä probleemanratkaisutaitojen kehittämisen tärkeys ovat esimerkkejä ja perusteluja sille, että opettajien peruskoulutus tulisi mitoittaa yhtä vaativaksi kaikille opettajille. Keskeistä on, että lasten varhaisopetus jatkumona perustuu tutkimuspohjaiseen ja tieteelliseen lähestymistapaan luoden perustan uusiutuvalle kasvatus- ja opetusajattelulle ja tiedolle. 
Perusta pitkän aikavälin koulutushalukkuudelle, oppimismotivaatiolle ja oppimiselle ratkaistaan koulutusuran alussa eikä sen loppupäässä. Yhteiskunnan on siksi mielekästä panostaa varhaiskasvatuksen, esiopetuksen ja perusopetuksen alkuvaiheen koulutusjärjestelmän kehittämiseen. Tehokkaat koulutukselliset ja pedagogiset toimenpiteet perusopetuksen loppupäässä tapahtuvat liian myöhään ja ne tulevat järjestäville tahoille kalliiksi.

Opetuksen ja oppimisen jatkuvuuden lisäämiseksi tavoitteellisen oppimisen ja opettamisen jatkuvuutta olisi lisättävä esiopetuksessa ja päivähoidon toteuttamassa varhaiskasvatuksessa. Näin siirtymä kouluun helpottuu. Tavoitteellinen jatkuvuuteen pyrkivä opetussuunnitelma tarjoaa oppimisen ja opettamisen seurannalle ja arvioinnille käyttökelpoisemman ja tehokkaamman kehyksen kuin katkelmalliset ja spesifit varhaiskasvatukseen, esiopetukseen ja perusopetuksen vuosiluokkiin 1-2 räätälöidyt opetussuunnitelmat.

Opetuksen ja oppimisen jatkuvuuden katkelmallisuudesta on haittaa myös kasvatuksen ja opetuksen laadun seurannassa, arvioinnissa ja kehittämisessä. Erilliset varhaiskasvatuksen, esiopetuksen ja perusopetuksen laadun arvioinnit eivät kykene antamaan riittävän kokonaisvaltaista lapsen oppimiseen ja kehittymiseen liittyvää pidempiaikaista palautetta. Näin laadun kehittämisestä tulee katkelmallinen ja sattumanvarainen. Henkisiä ja taloudellisia voimavaroja ja tehokkuutta menetetään. Keskeistä varhaiskasvatuksen, esiopetuksen ja perusopetuksen laadun arvioinnissa on seuranta, jossa opetusta ja oppimista arvioidaan pidemmällä tähtäimellä seuraamalla lasten siirtymistä varhaiskasvatuksesta esiopetukseen ja tätä kautta perusopetukseen. Englannissa suoritettu EPPE-seuranta (esim. Sylva et.al., 2010) tarjoaa hyvän esimerkin tällaisesta laadun arvioinnista, jonka avulla voidaan kehittää myös opetuksen ja oppimisen laatua.

Yhteistyö ja sen edelleen kehittyminen kodin, kasvatusta ja opetusta toteuttavien tahojen sekä hallintokuntien välillä on tärkeää. Aktiivisella ja toimivalla yhteistyöllä tuetaan lapsen oppimisen ja kehittymisen jatkumoa, korjataan lapsen oppimisen ja kehittymisen esteitä ja mahdollisia viivästymiä sekä varmistetaan lapsen hyvinvointia. Oman erityisen haasteensa muodostaa kasvatuksellinen ja opetuksellinen inkluusio ja monikulttuurisuus, jonka menestyksellinen toteuttaminen edellyttää katkeamatonta pedagogista jatkuvuutta.

Toimivaa kasvatusta pidetään yllä ja sitä uudistetaan seurannalla ja arvioinnilla. Keskeistä varhaiskasvatuksen, esiopetuksen ja perusopetuksen 
opetussuunnitelmien arvioinnissa ja seurannassa on kiinnittää lisääntyvää huomiota lapsen oppimisen ja kehittymisen monipuoliseen ja useasti toistuvaan dokumentointiin ja arviointiin, jota kootaan yhtenäisellä viitekehyksellä. Yhteinen arviointikehys mahdollistaa pidemmän tähtäimen arvioinnin ja seurannan. Uutena omana arvioinnin ja seurannan kohteena voisi olla huomion kiinnittäminen kasvatuksen ja opetuksen lapsivaikutuksiin, lasten voimavaroihin ja hyvinvointiin. 


\section{Lähteet}

A guide to measuring children's well-being (2009). The new economics foundation. A guide to measuring children's well-being. Backing the Future: Practical guide 2. London: The new economics foundation.

Actions for success in school in Europe (2009). European Commission. Contributors: University of Barcelona (Spain), Donau-Universitaet Krems-Univeritaet Fuer Weiterbildung (Austria, Krems), Centre for European policy studies (Belgium, Brussels), Univeristy of Cyprus (Cyprus, Nicosia), University of Helsinki (Finland, Contributors Tiina Kalliokoski, Anna-Leena Lastikka, Mikko Ojala \& Jyrki Reunamo), Elte Barczi Gustav Eötvös Lorand University (Hungary, Budabest), Universita degli studi de Firenze (Italy, Florence), Dublin City university (Ireland, Dublin), Vytato Didzojo Universitetas (Lithuania, Kaunas), University Ta Malta (Malta, Msida), Baltic Institute of Social Sciences (Latvia, Riga), Universitatea De Vest Din Timisoara (Romania, Timissoara), Andragoski Center Republike Slovenije ( Slovenia, Ljubljana), University of Nottingham (United Kingdom, Nottingham) \& Autonomous University of Barcelona (Spain, Barcelona).

Adolph, K. E., \& Berger, S. E. (2006). Motor development. In W. Damon, R. Lerner, D. Kuhn \& R.S. Siegler (Eds.), Handbook of child psychology. Vol. 2: Cognition, perception, and language. New York: Wiley.

Aho, S. (1996). Lapsen minäkäsitys ja itsetunto. Helsinki: Oy Edita Ab.

Ahonen, T., Taipale-Oiva, S., Kokko, J., Kuittinen, T., \& Cantell, M. (2001). Motoriikka. Teoksessa T. Ahonen, T. Siiskonen \& T. Aro (toim.), Sanat sekaisin. Kielelliset oppimisvaikeudet ja opetus kouluiässä. Jyväkylä: PS-kustannus.

Ahonen, T., Viholainen, H., Cantell, M., \& Rintala, P. (2005). Motoriikka ja oppimisvaikeudet. Teoksessa P. Rintala, T. Ahonen, M. Cantell \& A. Nissinen (toim.), Liiku ja opi. Liikunnasta apua oppimisvaikeuksiin. Jyväskylä: PS -kustannus.

Ahtola, A., \& Kontturi, M. (2011). Kysely koulupsykologin työstä. Toteutettu psykologiliiton kautta internetpohjaisena kyselynä toukokuussa 2011 yhteistyössä koulupsykologitoimikunnan kanssa.

Alanen, L., \& Karila, K. (toim.) (2009). Lapsuus, lapsuuden instituutiot ja lasten toiminta. Tampere: Vastapaino.

Alanen, L., \& Mayall, B. (Eds.) (2001). Conceptualizing child-adult relations. London: Routledge-Falmer

Alasaari, N. \& Katainen, R. (2016). Selvitys sukupuolten tasa-arvon edistämisestä varhaiskasvatuksessa. Sosiaali- ja terveysministeriön raportteja ja muistioita 2016:36.

Alasalmi, E. (2008). Lasten lukujonotaitojen kehitys sekä yhteydet lukemisen ja matematiikan valmiuksiin. Opettajankoulutuslaitos. Jyväskylän yliopisto. Pro gradu -tutkielma.

Alasuutari,M. (2016). Tytön ja pojan varhaiskasvatus. Teoksessa Sukupuolikysymys (toim.) M. Husso \& R. Heiskala, suvut 122-141.

Alcock, S. (2007). Playing with rules and routines: Children making mealtimes meaningful and enjouable. Early Years, 27(3), 281-293.

Allard, E. (1993). Having, loving, being: An alternative to the Swedish model of welfare research. In M. Nussabaum \& A. Sen (Eds.), The quality of Life. Oxford: Clarendon Press.

American Academy of Pediatricians (AAP). (2011). The policy statement "Media use by children younger than two years". AAP National Conference \& Exhibition in Boston, October 18, 2011. 
Andersson, B.-E. (1992), Effects of Day-Care on Cognitive and Socioemotional Competence of Thirteen-Year-Old Swedish Schoolchildren. Child Development, 63, 20-36.

Andersson, B-E. (1986). Home care or external care? A study of the effects of public child care on children's development when 8 years old. Reports on Education and Psychology, 2. Department of educational research. Stockholms insitute of education. Andersson, B-E., \& Stander, K. (2004). Perceptions of school and future adjustment to life: A longitudinal study between the ages of 18 and 25. Scandinavian Journal of Educational Research, 48(5), 459-476.

Anisfield, M. (1984). Language development from birth to three. Hillsdale, NJ.: Erlbaum.

Arden, R., \& Plomin, R. (2006) Sex differences in variance of intelligence across childhood. Personality \& Individual Differences, 41(1), 39-48.

Aries, P. (1973). Centuries of childhood. Harmonsworth: Penquin.

Aro, M., \& Laakso, L. (toim.) (2011). Taaperosta taitavaksi toimijaksi: itsesäätelytaitojen kehitys ja tukeminen. Jyväskylä: Niilo Mäki Instituutti.

Atjonen, P., Laivamaa, H., Levonen, A., Orell, S., Saari, M. Sulonen, K., Tamm, M., Kamppi, P., Rumpu, N., Hietala, R. \& Immonen, R. (2019). "Että tietää, missä on menossa". Oppimisen ja osaamisen arviointi perusopetuksessa ja lukiokoulutuksessa. Kansallinen koulutuksen arvioitikeskus. Julkaisut 7:2019.

Aunio, P. (2008). Matemaattiset taidot ennen koulun alkua. NMI-Bulletin, 18(4), 63-74.

Aunola, K., Leskinen, E., Lerkkanen, M.-K., \& Nurmi, J.-E. (2004). Developmental dynamics of math performance from preschool to grade 2. Journal of Educational Psychology, 96(4), 699- 713.

Ayres, A. J. (2008). Aistimusten viidakossa. Sensorisen integraation häiriö ja terapia. Jyväskylä: PS- kustannus.

Azar, B. (2002). It's more than fun and games. Monitor on Psychology, 33(3), 50-51.

Banks, J. (2008). An Introduction to multicultural education. Boston: Allyn \& Bacon.

Bandura, A. \& Walters, R. (1963). Social Learning and Personality Development. New York: Holt, Rinehart \& Winston.

Bandura, A. (1986). Social Foundations of Thought and Action. Englewood Cliffs, NJ: Prentice-Hall.

Barnett, W. S. (1996). Lives in the balance: Age-27 benefit-cost analysis of the HighScope Perry Preschool Program. Monographs of the HighScope Educational Research Foundation, 11. Ypsilanti, MI: HighScope Press.

Barry, B. (2002). Culture and equality: An egalitarian critique of multiculturalism. Boston: Harvard University Press.

Beck, U. (1992). Risk society. New York: Sage.

Belsky, J., Vandell, D., Burchinal, M., Clarke-Stewart, K. A., McCartney, K., Owen, M., \& the NICHD Early Child Care Research Network (2007). Are there long-term effects of early child care? Child Development, 78(2), 681-701.

Bennet, J. (2006). Mikä Suomessa on niin kohdallaan? Huomioita Suomen, Ranskan ja Irlannin varhaiskasvatusjärjestelmästä. Esitelmä Sosiaali- ja terveysministeriön järjestämässä kutsuseminaarissa, huhtikuu 2006. Helsinki, Säätytalo.

Bennet, J. (2006). What's so grate about Finland? Presentation at Helsinki April 2006 organized by the Finnish Ministry of Social Affairs.

Berthelsen, D. (2009). Participatory learning. In D. Berthelsen, J. Brownlee \& and E. Johansson (Eds.), Participatory learning in the early years: research and pedagogy. London: Routledge.

Bigge, M. L., \& Shermis, S.S. (1992). Learning theories for teachers. New York: Harper Collins. 
Black, P. E., \& Plowright, D. (2010). A multi-dimensional model of reflective learning for professional development. Reflective Practice 11(2), 245-258.

Bowlby, J. (1969). Attachment. Attachment and Loss. Vol. I. London: Hogarth.

Bowlby, J. (1973). Separation: Anger and Anxiety. Attachment and loss. Vol. 2. London: Hogarth.

Boyden, J., \& Ennew, J. (1997) (Eds.). Children in focus: A manual for participatory Research with Children. Stockholm: Rädda Barnen.

Bradbury, A. (2011). Rethinking assessment and inequality: the production of disparities in attainment in early years education. Journal od Education Policy, Vol. 26, No. 5, September 2011, 653-676.

Bradbury, A. (2014a). Learning, assessment and equality in Early Childhood Education (ECE) in England. European Early Childhood Education Journa, 22 (3), 347-354.

Bradbury, A. (2014b). Early childhood assessment: observation, teacher "knowledge" and production of attainment data in early years settings. Comparative Education 03 July 2014, Vol.50(3), pp.322-339

Bronfenbrenner, U. (1979). The ecology of human development. Cambride, Mass: Havard University Press.

Bronfenbrenner, U. (1994). Ecological models of human development. In International encyclopedia of education, Vol. 3, 2.

Brookfield, S. (1995). Becoming a critically reflective teacher. San Francisco: Jossey Bass.

Brotherus, A. (2004). Esiopetuksen toimintakulttuuri lapsen näkökulmasta. Helsingin yliopiston soveltavan kasvatustieteen laitos. Tutkimuksia 251.

Bunker, A. A., \& Freud, S. (1936). The problem of anxiety. Psychoanalytical Quarterly Press: New York.

Burlingham, D. (1973). The Preoedipal Infant-Father Relationship. Psychoanal. St. Child, $28,23-47$.

Burton, R. (2011). It's time to stop defending play. Exchange, 199, 68-71.

Cacciatore, R. (2008). Aggression portaat: Opetusmateriaali kouluille. Helsinki: Opetushallitus.

Cacciatore, R. (2008). Kiukkukirja: Aggression käsikirja - vauvasta kouluikään, toim. V. Hurme. Väestöliitto: VL-markkinointi.

Carroll, A., McCarty, M., Houghton, S., Sanders O'Connor, E. \& Zadow, C (2018). Reactive and proactive aggression as meangful distinctions at the variable and person level in primary school-aged children. Aggressive Behavior, Sep 2018, Vol. 44, Issue 5, pages 431-441.

Cecchin, D., \& Wennerberg Johansen, M. (2009). Integrationg leadership and pedagogy in early childhood institutions. Professional pedagogical leadership, BUPL, The Danish federation of early childhood teacher and youth educators. Poster presented at the EECERA Conference, Strasbourg, August 2009.

Chapman, R. (2016). A case study of genderded play in preschools: How childhood educator's perception of gender influence children's play. Early Child Development and Care, Volume 186, Issue 8, pp.1271-1284.

Cherney, I. D. \& Dempsey, J. (2010). Young children's classification, stereotyping and play behaviour for gender neutral and ambiguous toys. Educational Psychology, Vol. 30, No. 6, October 2010, 651-669.

Chi, F-m. (2010). Reflection as teacher inquiry: examples from Taiwanese in-service teachers. Reflective Practice, 11(2), 171-183.

Childs, G., \& McKay, M. (2001). Boys starting school disadvantaged: Implications from teachers' ratings of behaviour and achievement in the first two years. British Journal of Educational Psychology, 71(2), 303-314. 
Chomsky, M. (1957). Syntactic Structures. The Hague, London: Mouton.

Chomsky, M. (1964). Current Issues in Linguistic Theory. The Hague, London: Mouton.

Chomsky, M. (1966). Topics in the Theory of Generative Grammar. The Hague: Mouton.

Cole, K. C. (1988, November 30). Play, by definition, suspends the rules. The New York Times, p. C16.

Core (2011). Compentence requirements in early childhood education and care. A study for the European Commission Directorate-General for Education and Culture. University of East London. Final report. University of East London \& Universiteit Gent.

Corsaro, W. A. (1997). The Sociology of Childhood. Thousand Oaks, CA,: Pine Forge Press.

Cunha et al., (2005). Interpreting the evidence of life-cycle skill formation. IZA Discussion Paper Series, No. 1575, Institute for the Study of Labour, Bonn, Germany, July.

Dahlberg, G., \& Moss, P. (2005). Ethics and politics in early childhood education. London and New York: Routledge/Falmer.

Dahlberg, G., Moss, P., \& Pence, A. (1999). Beyond quality in early childhood education and care. Postmodern perspectives. London: Falmer Press.

Darling, N. (2007). Ecological systems theory: The person in the center of the circles. Research in Human Development, 4 (3-4), 203-2017.

Developmentally appropriate practice in early childhood programs serving children from birth through age 8. (2009). National Association for the Education of Young Children (NAEYC).

Dewey, J. (1933). How we Think. A Re-statement of the Relation of Reflective Thinking in the Educative Process. Chicago: Henry Regnery.

Dex, S., \& Hollingworth, K. (2012). Children's and young people's voices on their wellbeing. The Childhood Wellbeing Research Center. University of London: Institute of Education.

Dietze, B., \& Kashin, D. (2011). Playing and learning in early childhood education. Amazon.

Dockett, S., \& Perry, P. (2002). Who is ready for what? Young children starting school. Contemporary Issues in Early Childhood, 3(1), 67-89.

Dodge, K. (1991). The structure and function of reactive and proactive aggression. In D. Pepler \& K. Rubin (Eds.), The development and treatment of childhood aggression. Hillsdale, NJ.: Lawrence Erlbaum, 201-218.

Doing Better for Children (2009). OECD Publishing Paris.

Donaldson, M. (1982). Miten lapsi ajattelee? Espoo: Weilin \& Göös.

Dovenborg, E. \& Pramling, I. (1992). Att förstå barns tankar: metodik för barnintervjuer. Stockholm: Almqvist \& Wiksell.

Duque, E., \& Ojala, M. (2011). Participation that Makes a Difference: Decisive, Evaluative and Educative Family and Community Involvement in Successful Schools in Europe. Paper presented European Conference on Educational Research (ECER). September 2011. Berlin.

Early years foundation stage profile (November 2018). 2019 handbook. Standarsd \& Testing Agency. London: COV. UK.

Early years foundation stage statutory framework (2017). London: Gov. Uk. Department of Education.

Ebrahin, H. (2011). Children as agents in early childhood. Education as Change, 15(1), $121-131$.

Education at a glance (2015). OECD indicators. Paris: OECD

Education at a glance (2018). OECD indicators. Paris: OECD

Education at a glance (2019). OECD indicators. Paris:OECD. 
Education, Audiovisual and Cultural Executive Agency P9 Eurydice (2009). Tackling social and cultural inequalities through early childhood education and care in Europe. Brussels.

Emilson, A., \& Johansson, E. (2009). The desirable toddler in preschool: Values communicated in teacher and child interactions. In D. Berthelsen, J. Brownlee \& E. Johansson (Eds.), Participatory learning in the early years: research and pedagogy. London: Routledge. Emilsson, A., \& Folkesson, A-M. (2006). Children's participation and teacher control. Early Child Development and Care, $176(3$ \& 4), 219-238.

Esi- ja perusopetuksen opetussuunnitelmajärjestelmän toimivuus (2010). Helsinki: OKM. Esiopetuksen opetussuunnitelman perusteet (2010). Helsinki: Opetushallitus.

Esiopetuksen opetussuunnitelman perusteet (2014). Opetushallitus. Määräykset ja ohjeet 2014:96

Fisher, E. P. (1992). The impact of play on development: A meta-analysis. Play and Culture, $5,159-181$.

Fisher, K., Hirsh-Pasek, K., Golinkoff, R.M., Berk, L., \& Singer, D. (2010). Playing around in school: Implications for learning and educational policy. In A. Pellegrini (Ed.), Handbook of the Development of Play (pp. 341-362). New York, NY: Oxford Press.

Floyd, C. (2013). Gender depiction in preschool books: A comparison between early care and education classrooms in the United States and Norway. Dissertation Abstracts International, A: The Humanities and Social Sciences, Volume 74, Issue 2.

Forss-Pennanen, P. (2006). Uuden oppimista, kokeilua ja pohtimista. Yhteisöllisiä ja yksilöllisiä polkuja esi-ja alkuopetuksen yhteistyössä. Cydenius-instituutin tutkimuksia 3/2006. Jyväskylän yliopisto.

Foundation stage profile (2003). London: Department for education and skills.

Freire, P. (1998). Pedagogy of freedom. Ethics, democracy and civic courage. Lanham, MD: Rowman \& Littlefield.

Freud, A. (1936). The Ego and the Mechanisms of Defence. London: Karnac Books.

Gatt, S., Ojala, M., \& Soler, M. (2011). Promoting Social Inclusion Counting with Everyone: Learning Communities and INCLUD-ED. International Studies in Sociology of Education, 21(1), 36-47.

Gesell, A. (1930). The mental growth of pre-school child. New York: Macmillan.

Gesell, A., \& Ilg, F.L. (1949). Child development: An introduction to the study of human growth. New York: Harper \& Row.

Ginsburg, H. \& Ertle, B. (2008). Knowing the mathematics in early childhood mathematics. In B. Spodek \& O.N. Saracho (editors) Contemporary perspectives on mathematics in early chilldhood edcation. Charlotte, NC: IAP/Information Age Pub.

Goldstein, J. (2012). Play in children's development, health and well-being. Toy industrie of Europe (TOE). Brussels.

Gorski, C. (1999). A brief history of multicultural education. Educational Exchange, November 1999.

Gulbrandsen, L. M. (2012). Being a child, coming of age. Exploring processes of growing up. In M. Hedegaard, M., Aronsson, K., Hojholt, C. \& Ulvik, O. S. (Eds.), Children, childhood, and everday life. Children's perspectives. Charlotte, NC: Information age.

Hakala, L. (1999). Liikunta ja oppiminen. Mitä merkitystä on kuperkeikalla? Jyväskylä: Gummerus.

Hakalehto-Wainio, S. (2010). Lapsen osallisuus lastensuojelussa. Onni löytyy arjesta. Mannerheimin Lastensuojeluliitto.

Hakkarainen, P. (2010). Lähikehityksen vyöhyke - pedagoginen kulmakivi? Suomen kasvatustieteellinen aikakausikirja. Saarijärvi: Saarijärven Offset $\mathrm{Oy}$. 
Hakkarainen, P., \& Veresov, N. (1998). Leikki, mielekkyys ja lapsen kehitys. Suomen kasvatustieteellinen aikakausikirja. Saarijärvi: Saarijärven Offset Oy.

Halkka, K. (2003). Lukion fysiikan ja kemian oppimistulosten arviointi 2001. Oppimistulosten arviointi 2/2003. Opetushallitus. Helsinki: Yliopistopaino.

Hammarberg, T. (1997). A school for children with rights. Innocenti lectures. International Child Development Centre. Florence, Italy: Unicef.

Hannula, M. S., Räsänen P., \& Lehtinen, E. (2007). Development of counting skills. Role of spontaneous focusing on numerosity and subitizing-based enumeration. Mathematical Thinking and Learning, 8(1), 51-57.

Harms, T., \& Clifford, R. M. (1980). Early childhood environmental rating scale (ECERS). New York: Teachers College Press.

Harting, M. (2003). Esi- ja alkuopettajien pedagogisen ajattelun kohtaaminen. Joensuun yliopiston kasvatustieteellisiä julkaisuja N:o 93.

Hartup, W. W. (1992). Having friends, making friends, and keeping friends: Relationships as educational contexts. ERIC Digest. Champaign, IL: ERIC Clearinghouse on Elementary and Early Childhood Education.

Hautamäki, J. (1995). Älyllinen kehitys ja koulutus. Teoksessa P. Lyytinen, M. Korkiakangas \& H. Lyytinen (toim.), Näkökulmia kehityspsykologiaan. Kehitys kontekstissaan. Helsinki: WSOY, 219-247.

Hautamäki, J., Arinen P., Hautamäki, A., Lehto, J., Lindblom, B., Kupiainen, S., Outinen, K., Pekuri, M., Reuhkala, M. \& Scheinin, P. (2001). Luokanopettajille tarkoitetun seulan toimivuus Helsinki-aineiston perusteella. Helsingin kaupunki. Opetusvirasto A 17:2001.

Hedegaard, M., Aronsson, K., Hojholt, C., \& Ulvik, O. S. (Eds.) (2012). Children, childhood, and everyday life. Children's perspectives (pp. 3-21). Charlotte, NC: Information age.

Heikka, J., Waniganayake, M., \& Hujala, E. (2013). Contextualizing Distributed Leadership Within Early Childhood Education: Current Understandings, Research Evidence and future Challenges. Educational Management Administration \& Leadership, 41(30), 30-44).

Helenius, A., \& Korhonen, R. (2008). Pedagogiikan palikat. Johdatus varhaiskasvatukseen ja-kehittymiseen. Helsinki: WSOY.

Hetemäki, I. (toim.) (2011). Lapsen oikeuksien sopimuksen käsikirja. (UNICEF). Edita.

High/Scope Program Quality Assessment_Preschool version (1998). Ypsilanti, MI: High/ Scope Press.

Hill, A. L., Degnan, K. A., Calkins, S. D., \& Keane, S. (2006). Profiles of externalized behavioural problems for boys and girls across preschool. The roles of emotion regulation and inattention. Developmental Psychology, 42(5), 913-928.

Hoffrén, J., Lemmetyinen, I., \& Pitkä, L. (2010). Esiselvitys hyvinvointi-indikaattoreista: mittareiden vertailu ja kehittämiskohteet. Helsinki: Sitra.

Holopainen, L., Ahonen, T., Tolvanen, A., \& Lyytinen, H. (2000). Two alternative ways to model the relation between reading accuracy and phonological awareness at preschool age. Scientific Studies of Reading, 4(2), 77-100.

Huggins, V. (2014). Children at play: Learning gender in the early years. Education 3-13. Volume 42, Issue 3.

Huisman, T. (2006). Luen, kirjoitan ja ratkaisen. Peruskoulun kolmasluokkalaisten oppimistulokset äidinkielessä ja kirjallisuudessa sekä matematiikassa. Oppimistulosten arviointi 7/2006. Helsinki: Opetushallitus. 
Hujala, E., Backlund-Smulter, T., Koivisto, P., Parkkinen, H., Sarakorpi, H., Suortti, O., Niemelä, T., Kuronen, I., Knubb-Manninen, G., Smeds-Nylund, A-S., Hietala, R., \& Korkeakoski, E. (2012). Esiopetuksen laatu. Koulutuksen arviointineuvoston julkaisuja 61. Jyväskylä.

Hujala, E., Fonsén E., \& Elo, J. (2012). Evaluating the quality of the child care in Finland. Early Child Development and Care, 182(3-4), 299-314.

Hujala, E., Junkkari, P., \& Mattila, S. (2006). Päivähoidon toimivuuden arviointia. Suomen Varhaiskasvatusyhdistys ry-verkkolehti Varhaiskasvatus tänään.

Hujala, E., Puroila, A.-M., Parrila-Haapakoski, S., \& Nivala, V. (1998). Päivähoidosta varhaiskasvatukseen. Jyväskylä: Gummerus.

Huolila, R., Kinos, S., Kärki, M-L., Lehtinen, L., Saralehto, L., \& Saranpää, P. (1999). Kouluvalmiuden arviointi Turussa. Päivähoidon, vanhempien ja kasvatus- ja perheneuvolan yhteistyötä. Turun kaupungin sosiaalikeskuksen julkaisu nro 1A/1999.

Hutton, N., \& Smith, D. (1994). Reflection in Teacher Education: Towards definition and implementation. Teaching and Teacher Education, 11(1), 33-49.

Hytönen, J. (2004). Esiopetuksen tavoitteiden saavuttaminen ja esiopetuksen jatkumo perusopetukseen. Esiopetuksen toimivuus ja vaikuttavuus Helsingin kaupungissa vuosina 2001-2003. Studia Paedogogica 31. Soveltavan kasvatustieteen laitos. Vantaan täydennyskoulutuslaitos. Helsingin yliopisto.

Hytönen, J., \& Krokfors, L. (2002). Esiopetuksen toimintaympäristö, esiopetusta antava opettaja ja esiopetuksen tavoitteiden painottuminen toimintakaudella 2001-2002. Esiopetuksen toimivuus ja vaikuttavuus Helsingin kaupungissa vuosina 2001-2002. Tutkimusraportti 1. Helsingin kaupungin sosiaaliviraston tutkimuksia 2002:1.

Hännikäinen, M. (1992). Roolileikkiin siirtyminen leikin kehitysvaiheena. Piagetilainen näkökulma. Jyväskylän yliopiston kasvatustieteen laitoksen julkaisuja 2.

Härkönen, U. (2003). Mitä termit varhaiskasvatus ja esiopetus tarkoittavat? Kasvatustieteiden tiedekunnan tutkimuksia 86. Savonlinnan opettajankoulutuslaitos. Joensuun yliopisto.

Hätönen, H. (2003). Osaamiskartoituksesta kehittämiseen. Helsinki: Educa.

Högström, B., \& Saloranta,O. toim. (2001). Esiopetus tavoitteellisen oppimispolun alkuna. Helsinki: OPH.

Ilg, F. L., \& Ames, L. B. (1964). School readiness. New York: Harper \& Row.

Ilg, F. L., Ames, L., Haines, J., \& Gillespie, C. (1978). School readiness: Behavior tests used at Gesell Institute. New York: Harper \& Row.

Iloa, leikkiä ja yhdessä tekemistä. Varhaisvuosien fyysisen aktiivisuuden suositukset (2016). Opetus- ja kulttuuriministeriön julkaisuja 2016:21.

INCLUD-ED (2011). Strategies for inclusion and social cohesion in Europe from education. Annex 1-Description of work. Sixth Framework Programme. Priority 7. Citizens and governancy in knowledge-based society. European Union.

Jakku-Sihvonen, R., \& Kuusela, J. (2002). Mahdollisuuksien koulutuspolitiikan tasa-arvo. (2. korjattu painos). Arviointi 7/2002. Opetushallitus. Helsinki: Yliopistopaino.

Jakku-Sihvonen, R., Lindström, A., \& Lipsanen, S. (toim.) (1996). Toteuttaako peruskoulu tasa-arvoa? Arviointi 1/1996. Opetushallitus. Helsinki: Yliopistopaino.

James, A., Jenks, C., \& Prout, A. (1998). Theorising childhood. Oxford: Policy Press.

Janus, M., \& Offord, D. (2000). Readiness to learn at school. Canadian Journal of Policy Research, 1(2), 71-75.

Jauhiainen, A. (1993). Koulu, oppilaiden huolto ja hyvinvointivaltio. Suomen oppivelvollisuuskoulun oppilashuollon ja sen asiantuntijajärjestelmien muotoutuminen 1800-luvun lopulta 1900-luvulle. Turun yliopiston julkaisuja, sarja C:98. 
Jenks, C. (Ed.) (1982). The sociology of childhood: Essential readings. London: Batsford. Järviluoto, M., \& Väänänen, P. (2008). Virikkeitä motoriikan kehittämiseen ja arviointiin varhaiskasvattajille Lahden seudulla. Lahden ammattikorkeakoulu. Liikunnan ja vapaa-ajan koulutusohjelma. Opinnäytetyö.

Kalland, M., Satuli-Kukkonen, R., \& Hakalehto-Wainio, S. (2013). MLL:n lausunto varhaiskasvatusta koskevien säädösten uudistamisesta opetus- ja kulttuuriministeriölle.

Kalliala, M. (1999). Enkeliprinsessa ja itsari liukumäessä. Leikkikulttuuri ja yhteiskunnan muutos. Tampere: Tammer-Paino Oy.

Kalliala, M. (2008). Kato mua! Kohtaako aikuinen lapsen päiväkodissa? Helsinki: Gaudeamus.

Kanka, M. H., Wagner, P., Buchmann, M. \& Spiel, C. (2019). Gender-sterotyped preferences in childhood and early adodescence: A comparison of cross-sectional and longitudinal data. European Journal of Develpmental Psychology, Volume 16, 2019, Issue 2.

Kansallisen koulutuksen arvioitikeskuksesta säädetty laki (2013). Finlex 1295/2013.

Karikoski, H. (2008). Lapsen koulunaloittaminen ekologisena siirtymänä. Vanhemmat informantteina lapsen siirtymisessä esiopetuksen kasvuympäristöstä perusopetuksen kasvuympäristöön. Oulu: Oulu University Press.

Karila, K., Kinos, J., \& Virtanen, J. (2001). Varhaiskasvatuksen teoriasuuntauksia. Juva: PS-Kustannus

Karila, K., Lipponen, L., \& Pyhältö, K. (2013). Siirtymät varhaiskasvatuksen, esi- ja alkuopetuksen rajapinnoilla. Raportit ja selvitykset 2003:17. Opetushallitus

Karvonen, P. (2000). Hyppää pois - lapsen motoriikan arviointi ja kehittäminen. Helsinki: Tammi.

Kaskela, M., \& Kekkonen, M. (2006). Kasvatuskumppanuus kannattelee lasta. Opas varhaiskasvatuksen kehittämiseen. Oppaita 63. Helsinki: Stakes.

Katz, L. (1993). Multiple perspectives on the quality of early childhood programmes. European Early Childhood Research Journal, 1(2), 5-9.

Kaukiainen, A., Junttila, N., Kinnunen, R., \& Vauras, M. (2005). MASK-monitahoarviointi oppilaan sosiaalisesta kompetenssista. Oppimistutkimuskeskus. Turun yliopisto.

Keenan, K., \& Shaw, D. S. (2003) Exploring the etiology of antisocial behaviour in the first years of life. In B.B. Lahey, T. E. Moffitt \& A. Caspi (Eds.), Causes of conduct disorder and juvenile delinquency. New York: Guilford Press, 153-181.

Kekäle, J. \& Eerola, P. (2014). Isyyden tarinamarkkinoilla. Teoksessa P. Eerola ja J. Mykkänen Isyyden tarinamarkkinoilla, 19-29.

Keltikangas-Järvinen, L. (1994). Hyvä itsetunto. Porvoo Helsinki Juva: WSOY.

Keskinen, R., \& Lounassalo, J. (2011). Pedagoginen dokumentointi. Leppoistava osallisuuden mahdollistaja. Teoksessa A-R. Mäkitalo, S. Nevanen, M. Ojala, S. Tast, T. Venninen \& B. Vilpas (toim.), Löytöretkellä osallisuuteen (ss. 199-216). Kehittämistä ja tutkimista päiväkodin arjessa II. Pääkaupunkiseudun sosiaalialan osaamiskeskus SOCCAn ja Heikki Waris -instituutin julkaisusarja nro 25.

Ketonen, R., Palmroth, A., Röman, M., Salmi, P. \& Poikkeus, A-M. (2003). Kieli ja kommunikaatio. Teoksessa T. Siiskonen, T. Aro, T. Ahonen \& R. Ketonen (toim.), Joko se puhuu? Kielenkehityksen vaikeudet varhaislapsuudessa. Jyväskylä: PS-kustannus, $176-198$.

Kimmel, M. S. (2005). The gender of desires: Essays on male sexuality. Albany: State University of New York Press.

Kincheloe, J., \& Steinberg, S. (1997). Changing Multiculturalism. Buckingham, UK: Open University Press. 
Kirby, P., \& Gibbs, S. (2006). Facilitating Participation: Adults' Caring Support Roles within Child-to-Child Projects in Schools and After-School Settings. Children \& Society, 20(3), 209-222.

Kirves, L., \& Stoor-Grenner, M. (2010). Kiusaavatko pienetkin lapset? Helsinki: MLL \& Folkhälsan.

Kiuru, N., Lerkkanen, M.-K., Niemi, P., Poskiparta, E., Ahonen, T., Poikkeus, A.-M., \& Nurmi, J.-E. (2013). The role of reading disability risk and environmental protective factors in students' reading fluency in Grade 4. Reading Research Quarterly, 48(4), 349-368.

Kiviluoto, H. (1963). Koulupsykologin työ Suomessa. Kansalaiskasvatuksen keskuksen julkaisuja 1. Helsinki: Otava.

Kohlberg, L. (1984). The psychology of moral development. The nature and validity of moral stages. San Francisco, CA: Harper \& Pow.

Kohlberg, L. 1996. A cognitive-developmental analysis of children's sex-role concepts and attitudes. In E. E., Maccoby, editor, The develpment of sex differences. Stanford Univ. Press, CA, pp.82-173.

Kontuuri, M. (2011). Psykologi kouluvalmiuden arvioijana. Neljä tapausta kouluvalmiustutkimuksen merkityksestä. Pro-gradu -tutkielma. Itä-Suomen yliopisto. Psykologian oppiaine.

Korkeakoski, E. (1998). Lasten ja nuorten taidekasvatus peruskoulussa ja lukiossa. Lasten ja nuorten taidekasvatuksen tuloksellisuus peruskoulussa ja lukiossa III osa. Arviointi 9/1998. Opetushallitus. Helsinki: Yliopistopaino.

Korkeakoski, E., \& Siekkinen, T. (toim.) (2010). Esi- ja perusopetuksen opetussuunnitelmajärjestelmän toimivuus. Puheenvuoroja sekä arviointi-ja tutkimustuloksia. Koulutuksen arviointineuvoston julkaisuja 52 ja 53.

Korkeamäki, R-L. (2011). Kieli ja vuorovaikutus oppimisympäristöissä. Teoksessa M. Nurmilaakso \& A-L. Välimäki (toim.), Lapsi ja kieli - kielellinen kehittyminen varhaiskasvatuksessa. Helsinki: Unigrafia Oy.

Korkiakangas, M. (1995). Sosiaalisen kognition kehitys. Teoksessa P. Lyytinen, M. Korkiakangas \& H. Lyytinen, Näkökulmia kehityspsykologiaan. Kehitys kontekstissaan (ss. 188-201). Helsinki:

Korthagen, F. A. J. (2001). Linking Theory and Practice: The pedagogy of realistic teacher Education. Paper presented at the Annual Meeting of the American Educational Research Association. Seattle, April 2001.

Koski, T. (2012). Kasvatuskumppanuus - myytti vai todellinen yhteistyömalli. Kasvatustieteen pro gradu -tutkielma. Oulun yliopisto. Kasvatustieteiden tiedekunta.

Kronqvist, E-L., \& Pulkkinen, M-L. (2007). Kehityspsykologia. Matkalla muutokseen. Helsinki: WSOY.

Kujala, T., Krause, C. M., Sajaniemi, N., Silvén, M., Jaakkola, T., \& Nyyssölä, K. (toim.) (2012). Neuro- ja kognitiotieteellinen näkökulma. Tilannekatsaus tammikuu 2012. Opetushallitus: Muistiot 2012:1.

Kumpulainen, K., Krokfors, L., Lipponen, L., Tissari, V., Hilppö, J., \& Rajala, A. (2010). Oppimisen sillat. Kohti osallistavia oppimisympäristöjä. Helsinki: Helsingin yliopisto.

Kupila, P. (2007). "Minäkö asiantuntija?" Varhaiskasvatuksen asiantuntijan merkitysperspektiivin ja identiteetin rakentuminen. Jyväskylä studies in education, psychology and social research 302 .

Kurikka, L., Yläneva, L., Anttila, A., Soimetsä, M., Evijärvi, M., \& Karjalainen, K. (2004). Liikkeiden säätely. VSSHP/TYKS/2004. Fysiatrian yksikkö, Kuntoutusklinikka \& Lastenklinikka. 
Kurtz, L. A. (2007). Understanding motor skills in children with dyspraxia, ADHD, Autism, and other learning disabilities: A guide to improving coordination. London: Jessica Kingsley.

Kuusela, J. (2006). Temaattisia näkökulmia perusopetuksen tasa-arvoon. Oppimistulosten arviointi 6/2006. Opetushallitus.

Kuusisto, A. (2010). Kulttuurinen, kielellinen ja katsomuksellinen monimuotoisuus päiväkodissa: haasteita ja mahdollisuuksia. Helsingin kaupungin sosiaalivirasto. Tutkimuksia 2010:3.

Kärnä, A., Voeten, M., Little, T., Alanen, E., Poskiparta, E., \& Salmivalli, C. (2013). Effectiveness of the KiVa antibullying program: Grades 1-3 and 7-9. Journal of Educational Psychology, 105, 535-551.

Laaksonen, M. (2011). Lapsen hyvinvointia kartoittavat lomakkeet pääkaupunkiseudun varhaiskasvatuksessa syksyllä 2011. Mona Laaksonen, maisteriharjoittelija (varhaiskasvatus) 9.12.2011. Katse lapseen -hanke, Helsinki: VKK-Metro.

Laine, K., \& Neitola, M. (toim.) (2002). Lasten syrjäytyminen päiväkodin vertaisryhmästä. Suomen Kasvatustieteellinen Seura. Turku: Pallosalama.

Laki lasten päivähoidosta (1973). Finlex 36/1973.

Laki peruskoululain muuttamisesta 1/2011. Laki 682/1993.

Laki perusopetuslain muuttamisesta esiopetuksen osalta (2014). Finlex 1040/2014.

Lappalainen, K., \& Sointu, E. (2013). Vahvuuksia tunnistamalla käyttäytymisen ja tunteiden hallintaa koulussa. Itä-Suomen kehittämisverkosto (ISKE-hanke). Itä-Suomen yliopisto. Erityispedagogiikka.

Lappalainen, K., Hotulainen, R. Kuorrelahti, M., \& Thuneberg, H. (2008). Vahvuuksien tunnistaminen ja tukeminen sosio-emotionaalista kompetenssia rakentamassa. Teoksessa K. Lappalainen, M. Kuittinen \& M. Meriläinen (toim.), Pedagoginen hyvinvointi. Turku: Suomen kasvatustieteellinen seura.

Lappalainen, K., Savolainen, H., Kuorelahti, M., \& Epstein, M. H. (2009). An international assessment of the emotional and behavioral strengths of youth. Journal of Child and Family Studies, 18(6), 746-753.

Lapsen oikeuksia koskeva EU:n toimintasuunnitelma (2011). Bryssel: Euroopan Unioni.

Lasten hyvinvoinnin kansalliset indikaattorit (2011). Tavoitteena tietoon perustuvan lapsipolitiikan johtaminen. Opetus- ja kulttuuriministeriön työryhmämuistioita ja selvityksiä 2011:3.

Laurent, G., Hecht, H. K., Ensink, K. \& Borelli, J. L. (2018). Emotional Understanding, Aggression, and Social Functioning Among Preschoolers. American Journal of Orthopsychiatry.

Lehtovaara, A. (1950). Stanfort-Binet -tyyppinen testistö kouluikäisten ja aikuisten älykkyyden arviointia varten. Lastensuojelun keskusliiton julkaisuja n:o 7.

Leinonen, J., \& Ojala, M. (2010). "Parasta on kun jaettu kokemus siirtyy jaetuksi iloksi" Lapsen osallisuus pääkaupunkiseudun päiväkodeissa. Helsinki: Soccan työpapereita 3:2010.

Leinonen, J., Venninen, T., \& Ojala, M. (2011). Päivähoitohenkilöstön näkemyksiä lasten osallisuuden tukemisessa. Teoksessa A-R. Mäkitalo, S. Nevanen, M. Ojala, S. Tast, T. Venninen \& B. Vilpas (toim.), Löytöretkellä osallisuuteen. Kehittämistä ja tutkimista päiväkodin arjessa II (ss. 83-97). Pääkaupunkiseudun sosiaalialan osaamiskeskus SOCCAn ja Heikki Waris -instituutin julkaisusarja nro 25.

Lepistö, M. (2009). Kodin ja koulun yhteistyö lapsen kasvun ja kehityksen tukena alakoulussa. Pro gradu -tutkielma. Opettajankoulutuslaitos, Jyväskylän yliopisto. 
Leppänen, U., Niemi, P., Aunola, K., \& Nurmi, J-E. (2006). Development of reading and spelling finish from preschool to grade 1 and grade 2. Scientific Studies of Reading, 10(1), 3-30.

Lerkkanen, M-K., \& Poikkeus, A-M. (2006). Lukemisvaikeuksien ja matemaattisten taitojen kehityksen riskitekijät esiopetusvuonna. Alkuportaat-tutkimuksen pilottivaiheen tuloksia. NMI Bulletin, 16(3), 4-12.

Levine, E. \& Tamburrino, M. (2013). Bullying among young children. Strategies for prevention. Early Childhood Education Journal, 2014, 42: 271-278.

Lewitt, E. M., \& Baker, L. S. (1995). School readiness. Critical Issues for Children and Youths, 5, 128-139.

Linnilä, M-L. (2006). Kouluvalmiudesta koulun valmiuteen. Poikkeuksellinen koulunaloitus koulumenestyksen, viranomaistaelausuntojen ja perheiden kokemusten valossa. Jyväskylä Studies in Education, Psychology and Social Research, 294.

Lipponen, L. (2011). Kohti osallistavaa oppimista ja pedagogiikkaa. Varhaiskasvatusmessut 07.10. 2011.

LIS-YC, The Leuven Involvement Scale for Young Children (1994). Manual. Ferre Laevers (Ed.), Experiencial Education Series 1. Leuven: Centre for Experiencial Education.

Lowe, P. A., Mayfield, J. W., \& Reynolds, C. R. (2003) Archives of Clinical Neuropsychology, $18(8), 865$.

LukiMat - Perustietoa matematiikan oppimisesta ja oppimisvaikeuksista. http://www. lukimat.fi/

Lumiaro, E. (2007). Esiopetusmuoto ja koulunaloituksen onnistuminen. Pro gradu -työ. Kasvatustiede. Luokanopettajankoulutus. Soveltavan kasvatustieteen laitos. Helsingin yliopisto.

Lyons-Ruth, K. (1991). Rapprochement or approchement: Mahler's theory reconsidered from the vantage point of recent research on early attachment relationships. Psychoanalytic Psychology 8, 1-23.

Lyytinen, P. (1988). Suomen kielen taivutusmuotojen hallinta 2-9 -vuotiailla. Katsaus psykologiseen tutkimukseen. Jyväskylän yliopiston psykologian laitokset julkaisuja 297.

Lyytinen, P. (1995). Lapsen kielen ja kommunikaatiotaitojen kehitys. Teoksessa P. Lyytinen, M. Korkiakangas \& H. Lyytinen (toim.), Näkökulmia kehityspsykologiaan. Kehitys kontekstissaan. Helsinki: WSOY.

Lyytinen, P. (2003). Kielenkehityksen varhaisvaiheet. Teoksessa T. Siiskonen, T. Aro, T. Ahonen \& R. Ketonen (toim.), Joko se puhuu? Kielenkehityksen vaikeudet varhaislapsuudessa (ss. 48-68). Juva: PS-kustannus.

Lyytinen, P., Korkiakangas, M. ja Lyytinen, H. (toim.) (1995). Näkökulmia kehityspsykologiaan. Kehitys kontekstissaan. Porvoo: WSOY.

Mahler, M. S., Pine, F., \& Bergman, A. (1975). The psychological birth of the human infant. Symbosis and individuation. London: Hutchinson \& Co.

Marien, P., \& Abutalebi, J. (Eds.) (2008). Neuropsychological Research. A Review. New York: Psychology Press.

Markström, A. M., \& Hallden, G. (2009). Children's strategies for agency in preschool. Children and Society, 23, 112-122.

Maslow, A. (1954). Motivation and Personality. New York: Harper.

Matsumoto, D. (1999). Culture and self: An empirical assessment of Markus' and Kitayama's theory of independent and interdependent self-construction. Asian Journal of Social Psychology, 2, 289- 310. 
Mattila, K. (2009). Motoriikka paremmaksi (MOPA). Motoristen taitojen harjaannuttaminen oppimisen tukena. Kehittämishankeraportti. Jyväskylän ammattikorkeakoulu.

Mattinen, A. (2006). Huomio lukumääriin. Tutkimus 3-vuotiaiden lasten matemaattisten taitojen tukemisesta päiväkodissa. Turun yliopiston julkaisuja, sarja C, 247.

Mattinen, A., Räsänen, P., Hannula, M. M., \& Lehtinen, E. (2010). Nallematikka - Varhaisten matemaattisten oppimisvalmiuksien kehittämisohjelma. Jyväskylä: Niilo Mäki Instituutti.

Mayall, B. (2002). Towards a sociology for childhood. Thinking from children's lives. Buckingham: Open University Press.

McClellan, D. E., \& Katz, L.G. (2001). Assessing young children's social competence. ERIC-US.

McLuhan, M., \& Fiore, Q. (1967). The medium is the massage. New York: Bantam.

Meisels, S. J. (1999). Assessing readiness. In R. R. Pianta \& M. M. Cox (Eds.), The transition to kindergarten. Baltimore, MD: Paul Brookers, 39-66.

Mercurio. C. M. (2003) Guiding boys in the early years to lead healthy emotional lives. Early Childhood Educational Journal, 30(4), 255-258.

Mezirow, J. (2000). Learning to think like an adult. Core concepts of transformation theory. In J. Mezirow et al. (Eds.), Learning as transformation. Critical perspectives on a theory in progress. San Francisco, CA: Jossey-Bass, 3-33.

Mikkola, A., Repo, L., Vlasov, J., Paananen, M. \& Mattila, V. (2017) Varhaiskasvatuksen arvioinnin nykytila. Kansallisen koulutuksen arviointikeskus. Julkaisut 22:2017.

Miller, P. H. (2011). Theories of developmental psychology. New York, NY; Worth.

MLL:n lausunto varhaiskasvatusta koskevien säädösten uudistamisesta (2013). Varhaiskasvatus on lapsen oikeus - MLL:n lausunto 19.2.2013 varhaiskasvatuslaista. Kannanotot ja lausunnot. Mannerheimin Lastensuojeluliitto.

Moi, T. (1999). What is a woman? And other essays. Oxfoed: Oxford University Press.

Moniku-hanke (2005-2007). Sosiaalisen vahvistaminen pääkaupunkiseudun varhaiskasvatuksessa. Socca - Pääkaupunkiseudun sosiaalialan osaamiskeskus.

Montie, J. E., Xiang, Z., \& Schweinhart, L. J. (Eds.) (2007). The role of preschool experience in children's development. Longitudinal findings from 10 countries. Ypsilanti, MI: High/Scope Press.

Moss, P. (1994). Defining quality: Values, stakeholders and processes. In P. Moss \& A. Pence (Eds.), Valuating quality in early childhood services. New approaches to defining quality (pp. 1-9). London: Paul Chapman.

Myöhänen, M. (2011). Esiopetuskirjojen harjoitukset kielellisen tietoisuuden kehittäjinä. Annales Univeristatis Turkuensis, Sarja C Osa -Tom.313. Scripta Lingua Fennica Edita. Turun Yliopisto.

Mäkinen, O., \& Pitkäaho, M. (2008). Lasten matematiikan taidot peruskoulun ensimmäisellä luokalla, vanhempien lastensa oppimista koskevat uskomukset ja oppimisvaikeuden riski. Psykologian laitos. Jyväskylän yliopisto. Pro gradu -tutkielma.

Mäkitalo, A-R M., Ojala, M., Venninen, T., \& Vilpas, B. (toim.) (2009). Löytöretkellä omaan työhön. Kehittämistä ja tutkimista päiväkodin arjessa. Pääkaupunkiseudun sosiaalialan osaamiskeskus SOCCAn ja Heikki Waris -instituutin julkaisusarja nro 22, 2009. Helsinki: Yliopistopaino.

NAEYC. (2009). Developmentally appropriate practice in early childhood programs serving children from birth through age 8. The National Association for the Education of Young Children.

National curriculum in England: framework for key stages 1 to 4 (2014). London: Gov. Uk. Department of Education 
Neitola, M. (2011). Lapsen sosiaalisen kompetenssin tukeminen - vanhempien epäsuorat ja suorat vaikutustavat. Turun yliopiston julkaisuja. Annales universitatis Turkuensis. Sarja - Ser. C osa - Tom. 324. Scripta Lingua Fennica Edita.

Nevalainen, V. (2007). Hyvä koulupsykologinen tutkimus. Teoksessa S. Raninen \& T. Takalo (toim.), Psykologina koulussa (ss. 63-70). Helsinki: Edita.

NICHD Early Child Care Research Network (2002). Early child care and children's development prior to school entry: Results from the NICD study of early child care. American Educational Research Journal, 39, 133-164.

NICHD Early Child Care Research Network (2005). Child care and child development in the primary grades: Results from the NICD study of early child care. American Educational Research Journal, 43, 537-570.

Nieminen, P. (1991). Äidin ja lapsen kommunikaatio ja lapsen kielen omaksuminen. Acta Universitatis Temperensis, ser. A, vol. 323.

Nieto, S., \& Bode, P. (2008). Affirming diversity: The sociopolitical context of multicultural education. Boston, MA : Allyn \& Bacon.

Numminen, P. (1995). Alle kouluikäisten lasten havaintomotorisia ja motorisia taitoja mittaavan APM-testistön käsikirja. Liikunnan ja kansanterveyden julkaisuja 98.

Nurkkala, V-M. (2007). Luistaako lukeminen liikunnan avulla? Motoristen ja kognitiivisten taitojen välinen yhteys. Biomekaniikan pro -gradu tutkielma. Liikuntabiologian laitos. Jyväskylän yliopisto.

Nurmi, J-E., Kiuru, K., Lerkkanen, M.-K., Niemi, P, Poikkeus, A.-M., Ahonen, T., Leskinen, E., \& Lyyra, A.-L. (2013). Teachers adapt their instruction in reading according to individual children's literacy skills. Learning and Individual Differences, 23, 7279.

Nurmilaakso, M. (2011). Pienen lapsen kielellinen tietoisuus osana kielen kehitystä. Teoksessa M. Nurmilaakso \& A-L. Välimäki (toim.), Lapsi ja kieli - kielellinen kehittyminen varhaiskasvatuksessa. Helsinki: Unigrafia Oy.

Näveri, L. (2018). Matikkaa lapsen kanssa. Helsinki: ELLI Early Learning Oy.

O'Brien, C., \& Hayes, A. (1995). Normal and impaired motor development. London: Chapman \& Hall. OECD (1998). Overcoming failure at school. OECD Publishing Paris.

Oinonen, P. (1969). Kouluvalmiuden ongelma - milloin lapsi on kypsä kouluun. Porvoo: WSOY.

Ojala, M. \& Venninen, T. (2011). Developing reflective practice for day care centres in the Helsinki Metropolitan. Reflective Practice, Issue 12.3

Ojala, M. (1993). Varhaiskasvatuksen perusteita ja haasteita. Helsinki: Kirjayhtymä.

Ojala, M. (1999).Teacher's and parents' predictions about each other's priorities for young children (Chapter VIII). In D. P. Weikart (Ed.), What should young children learn? Teacher and parent views in 15 countries (pp.157-175). Ypsilanti, MI: High/Scope Press.

Ojala, M. (2000). Parent and teacher expectations for developing young children: A cross-cultural comparison between Ireland and Finland. European Early Childhood Education Research Journal, (8)2, 39-61.

Ojala, M. (2004). Helsinki Study: Learning in the modern preschool settings for six-year-old children. Journal of Teacher Education and Training, 4, 45-56.

Ojala, M. (2004). Looking for quality in early childhood education. In M. Lundkvist \& C. Öhberg (red.), Det synliga barnet. Praktiska och teoretiska perspektiv på pedagogiken (pp.131-140). Rapport från Pedagogiska fakulteten vid Åbo Akademi, Nr. 9. 
Ojala, M. (2005). How Finland is researching early childhood education. In B. Spodek \& O. $\mathrm{N}$. Saracho (Eds.), International perspectives on research in early childhood education ( pp. 79-118). Information Age Publishing: Greenwich, Connecticut.

Ojala, M. (2007). Learning by gender during transition from preschool to school in new Finnish curriculum context. In J. Hytönen (Ed.), Education for democracy as a part of education for sustainable development. $4^{\text {th }}$ International Journal of Teacher Education and Training conference: Post-Conference-Book. Research report 287. Department of Teacher Education, University of Helsinki.

Ojala, M. (2008). Cross-case comparative analysis for Pre-Primary Schools. INCLUD-ED. Project 2: European effective educational practices: How is education contributing to overcome or reproduce social exclusion? Department of Behavioural Sciences. University of Helsinki.

Ojala, M. (2009). Varhaiskasvatuksen käytännön kehittäminen reflektion avulla. Teoksessa A-R. Mäkitalo, M. Ojala, T. Venninen \& B. Vilpas (toim.) (2009). Löytöretkellä omaan työhön. Kehittämistä ja tutkimista päiväkodin arjessa. Pääkaupunkiseudun sosiaalialan osaamiskeskus SOCCAn ja Heikki Waris -instituutin julkaisusarja nro 22, 2009, 27-36.

Ojala, M. (2010). Developing multicultural early childhood education in a Finnish context. International Journal of Child Care and Education Policy, 2010, 4(1), 13-22.

Ojala, M., \& Opper, S. (1994). Study findings: use of organized facilities. In P. P. Olmsted \& D. P. Weikart (Eds.), Families speak: Early childhood care and education in 11 countries (pp. 141-184). Ypsilanti, MI: High/Scope Press.

Ojala, M., \& Siekkinen, M. (1988). Esi- ja alkuopetuksen kehittäminen. Valtakunnallisen akvaarioprojektin esi- ja alkuopetuksen aiheverkon arviointia. Joensuun yliopiston kasvatustieteiden tiedekunnan selosteita nro 67.

Ojala, M., \& Talts, L. (2007). Preschool achievement in Finland and Estonia: cross-cultural comparison between the cities of Helsinki and Tallinn. Scandinavian Journal of Educational Research, 51(2), 205-221.

Ojala, M., Niemelä, R., \& Lastikka, A-L. (2010). Case study of the Finnish local project working towards social cohesion in 2010. INCLUD-ED. Project $6.4{ }^{\text {rd }}$ round (WP 22). Department of Teacher Education. University of Helsinki.

OKM - Pisa 2012 (2013). Suomalaisnuorten osaaminen laskussa. OKM. Tiedotteet 2013/12. Opetus- ja kulttuuriministeriö (2016). Tiedote 6.12.2016.

Opetus- ja kulttuuriministeriön koulutuksen ja tutkimuksen kehittämissuunnitelma vuosille 2011-2016. Helsinki: Valtioneuvosto.

Osterman, K., \& Kottkamp, R.B. (1993). Reflective practice for educators. Improving schooling through professional development. Newbury Park, California: Corwin Press.

Peda.net -verkosto. https//www. peda.net/

Pehkonen, M. (1999). Liikuntataitojen oppiminen ja opettaminen: Telinevoimistelutaidot ja peruskoulun liikuntaopetus (väitöskirja). Liikuntakasvatuksen julkaisuja 2. Liikuntakasvatuksen laitos \& Liikuntakasvatuksen tutkimus- ja kehittämiskeskus. Jyväskylän yliopisto.

Penn, H. (1994). Working in conflict: Developing a dynamic model of quality. In P. Moss \& A. Pence (Eds.), Valuating quality in early childhood services. New approaches to defining quality (pp. 10-27). London: Paul Chapman.

Peruskoululaisten matematiikan taidoissa huolestuttavia puutteita, OPH, 19.3.2013.

Perusopetuksen opetussuunnitelman perusteet (2014). Opetushallitus. Määräykset ja ohjeet 2014:96. 
Perusopetuksen, perusopetuksen aamu- ja iltapäivätoiminnan sekä koulun kerhotoiminnan laatukriteerit (2012). Opetus- ja kulttuuriministeriön julkaisuja 2012:29.

Perusopetuslaki 1998. Finlex 21.8.1998/628.

Phillips, D. C., \& Soltis, J. F. (2004). Perspectives on learning. New York \& London: Teachers College. Columbia University.

Piaget, J. (1951). Play, dreams and imitation in childhood. New York: Norton.

Piaget, J. (1967). Six psychological studies. London: London University Press.

Piaget, J. (1969). Psychology of intelligence. Paterson, N.J.: Littlefield, Adams.

Piaget, J. (1971). Structuralism. London: Routledge and Kegan Paul.

Piaget, J. (1975). The moral judgment of the child. London: Routledge \& Kegan.

Plessis, J. Du . (2003). Getting ready: National school readiness indicators. Brainline.

Poijärvi, P-L., \& Teikari, V. (1968). Koulukypsyyden määrittely Lehtovaaran kypsyyskokeen, verbaalista järkeilyä mittaavan kouluvalmiustestin sekä äitien arvioinnin perusteella. Reports from the department of psychology 73. Jyväskylän yliopisto.

Poikela, E. (2002). Osaamisen arviointi. Teoksessa R. Honkonen (toim.), Koulutuksen lumo - retoriikka, politiikka ja arviointi. Tampere: Tampere University Press, 229-245.

Poikkeus, A-M. (1995). Lasten toverisuhteet ja sosiaaliset taidot. Teoksessa P. Lyytinen, M. Korkiakangas \& H. Lyytinen (toim.), Näkökulmia kehityspsykologiaan. Kehitys kontekstissaan. Porvoo: WSOY.

Pramling, I. (1983). The child's conception of learning. Göteborg: Acta Universitatis Gotheburgensis.

Pramling, I., Klerfelt, A., \& Graneld-Williams, P. (1995). 'Först var det roligt, sen' blev det tråkigt och sen' vande man sig.. ". Barns möte med skolans värld. Göteborgs Universitet. Rapporter från Institutionen för metodik is lärarutbildning 9.

Preventing social exclusion (2001). Report by the Social Exclusion Unit. London: Cabinet Office.

Prout, A., \& James, A. (1997). A new paradigm for the sociology of childhood? Provenance, promise and problems. In A. James \& A. Prout (Eds.), Construction and reconstruction childhood: Contemporay issues in the sociological study of childhood (pp. 7-33). London: Falmer Press.

Puolakanaho, A. (2007). Early prediction of reading. Phonological awareness and related language and cognitive skills in children with familial risk for dyslexia. Jyväskylä studies in education, psychology and social research 317. Jyväskylän yliopisto.

Puolakanaho, A., Ahonen, T., Aro, M., Eklund, K., Leppänen, P., Poikkeus, A-M., Tolvanen, A., Torppa, M., \& Lyytinen, H. (2008). Developmental links of very early phnolological and language skills to second grade reading outcomes. Strong to accuracy but only minor influency. Journal of Learning Disabilities, 41(4), 353-370.

Puroila, A-M., Estola, L., \& Syrjälä, L. (2012). Does Santa exist? Children's everyday narratives as dynamic meeting places in a day care centre context. Early Child Development and Care, 182(2),

Rajakaltio, H. (2014). Yhteisvoimin kohti uudistuvaa koulua. Koulun kehittämisen toimintamalli - täydennyskoulutuksen ja kehittämisprosessin yhteen nivominen. Raportit ja selvitykset 2014:9. Opetushallitus.

Rajakorpi, A. (1999) Peruskoulun 9.-luokkalaisten luonnontieteiden oppimistulosten arviointi. Keväällä 1998 pidetyn kokeen tulokset. Oppimistulosten arviointi 2/1999. OPH. Helsinki: Yliopistopaino.

Rajakorpi, A. (2000) Matematiikan ja luonnontieteiden kehittämishankkeen toinen lähtötasoarviointi. Peruskoulussa ja lukiossa syksyllä 1999 pidetyn kokeen tulokset. Arviointi 10/2000. OPH. Helsinki: Yliopistopaino. 
Rajala L. 2008 Matemaattisten valmiuksien ohjaamiseen liittyvät opetuskäytännöt esiopetuksessa. Pro gradu -tutkielma. Opettajankoulutuslaitos. Jyväskylän yliopisto.

Rausku-Puttonen, H., \& Lerkkanen, M-K. (2010). Vuorovaikutuksen laadun yhteys lasten oppimiseen ja motivaatioon: Alkuportaat-tutkimuksen tuloksia. Jyväskylän yliopisto, Opettajankoulutuslaitos \& Oppimisen ja motivaation huippuyksikkö. Varhaiskasvatuksen kansallinen kutsuseminaari 15.11.2010. Helsinki.

Rautopuro. J. (toim.) (2013). Hyödyllinen pakkolasku. Matematiikan oppimistulokset peruskoulun päättövaiheessa 2012. OPH: Koulutuksen seurantaraportit 2013:3.

Repo, L. (2015). Pienet lapset ja kiusaamisen ennaltaehkäisy. Jyväskylä: PS-kustannus.

Repo, L., Paananen, M., Eskelinen, M., Mattila, V., Lerkkanen, M-K., Gammelgård, L., Ulvinen, J., Marjanen, J., Kivistö, A. \& Hjelt, H. (2019). Varhaiskasvatuksen laatu arjessa. Varhaiskasvatussuunnitelmien toteutuminen päiväkodeisssa ja perhepäivähoidossa. Kansallinen koulutuksen arviointikeskus. Julkaisut 15:2019.

Reuhkala, M., \& Scheinein, P. (2001). Ensiaskeleet-oppimisen edellytykset. Luokanopettajille tarkoitetun seulan toimivuus Helsinki-aineiston perusteella. Helsingin kaupunki, Opetusvirasto, A 17:2001.

Reunamo, J. (2007). Tasapainoinen varhaiskasvatus. Erilaisia tapoja suhtautua muutokseen. Helsinki: WSOY.

Rimpelä, M. (2007). Hyvinvointineuvola lapsiperheiden tukena: Ideasta toteutukseen. Stakes/KHS/ Terveyden edistämisen vertaistietohanke. 24.5.2007.

Rogoff, B. (2003). The nature of human development. New York: Oxford University press.

Ronkanen, N. (2009). Lasten motorisen kehityksen arviointikoulutus Ruununmyllyn päiväkodin henkilökunnalle. Satakunnan ammattikorkeakoulu. Fysioterapian koulutusohjelma.

Rubin, J. S. (1989). The Froebel-Wright kindergarten connection: A new perspective. Journal of the Society of Architectural Historians, 48(1), 24-37.

Ruokolainen, R., \& Alila, K., (toim.) (2004). Varhaiskasvatuksen laatu on osaamista ja vuorovaikutusta. Varhaiskasvatuksen laadunhallinnan ja ohjauksen kehittämishankkeen julkaisu. Helsinki: Sosiaali- ja terveysministeriö.

Rusama, J. (2002) Uskonto, elämänkatsomustieto ja tapakasvatus. Oppimistulosten arviointi perusopetuksen päättövaiheessa 2001. Oppimistulosten arviointi 5/2002. Helsinki: Yliopistopaino.

Rutanen, N. (2007). Two-year-old children as co-constructors of culture. European Early Childhood Education Research Journal, 15(1), 59-69.

Ryle, R. (2012). Questioning gender: A sociological exploration. London: Sage Publication.

Rönkä, M., Lerkkanen, M.-K., Poikkeus, A.-M., Nurmi, J.-E., \& Kiuru, N. (2011). Lukuja laskutaidon sekä oppiainekohtaisten minäkäsitysten yhteydet lapsen sosiaaliseen asemaan vertaisryhmässä. Psykologia, 46(5), 312-327.

Salmi, S., \& Lipponen, L. (2013). Lapsen voimavarat hyvinvoinnin edistäjinä. Alle kouluikäisten lasten hyvinvoinnin tukeminen vanhempien, päivähoidon ja neuvolan yhteistyössä. Socca. Pääkaupunkiseudun sosiaalialan osaamiskeskus. Työpapareita 2013:1.

Salmivalli, C. (2003). Kiusaamiseen puuttuminen: Kohti tehokkaita toimintamalleja. Jyväskylä: PS- kustannus.

Salmivalli, C. (2005). Kaverien kanssa. Vertaissuhteet ja sosiaalinen kehitys. Jyväskylä: PS-kustannus.

Salmivalli, C. (2010). Koulukiusaamiseen puuttuminen. Kohti tehokkaita toimintamalleja. Jyväskylä: PS-kustannus.

Scarr, S., Eisenberg, M., \& Deater-Deckard, K. (1994). Measurement of quality in child care centres. Early Childhood Research Quarterly, 9(2), 131-151. 
Schmitz, S. (2010). Sex, gender and the brain: Biological determinism versus social cultural constructivism. In sex and gender in biomedicine: Theories, methodologies, results, edited by I. Klinge and C. Weisemann, 57-79. Guttenberg: University of Guttenberg.

Schulz, L. E., Standing, H. R., \& Bonawitz, E. B. (2008). Word, thought, and deed: The role of object categories in children's inductive inferences and exploratory play. Developmental Psychology, 44, 1266-1276.

Schweinhart, L. J., \& Weikart, D. P. (1981, December). Effects of the Perry Preschool Program on youths through age 15. Journal of the Division for Early Childhood. Reston, VA: Council for Exceptional Children.

Schweinhart, L. J., \& Weikart, D. P. (1988). The High/Scope Perry Preschool Program. In R. H. Price, E. L. Cowen, R. P. Lorion, \& J. Ramos-McKay (Eds.), Fourteen ounces of prevention: A casebook for practitioners. Washington, DC: American Psychological Association.

Schweinhart, L. J., Barnes, H. V., \& Weikart, D. P. (1993). Significant benefits: The High/Scope Perry Preschool study through age 27.Monographs of the HighScope Educational Research Foundation, 10. Ypsilanti: HighScope Press.

Schweinhart, L. J., Berrueta-Clement, J. R., Barnett, W. S., Epstein, A. S., \& Weikart, D. P. (1985, Summer). Effects of the Perry Preschool Program on youths through age 19 A summary. Topics in Early Childhood Special Education, 5, 26-35.

Schweinhart, L. J., Heckman, J. J., Malofeeva, L., Pinto, R. Moon, S., \& Yavitz, A. (2010). The cost- benefit analysis of the Preschool Curriculum Comparison Study. Final Report to the John D. and Catherine T. MacArthur Foundation. Ypsilanti, MI: HighScope.

Schweinhart, L. J., Montie, J., Xiang, Z., Barnett, W. S., Belfield, C. R., \& Nores, M. (2005). Lifetime effects: The HighScope Perry Preschool study through age 40. Monographs of the HighScope Educational Research Foundation, 14. Ypsilanti, MI: HighScope Press.

Schön, D. (1987). Educating the reflective practitioner: Toward a new design for teaching and learning in the professions. San Francisco: Jossey-Bass.

Seefeldt, V., \& Haubenstricker, J. (1982). Patterns, phases, or stages: An analytical model for the study of developmental movement. In J. A. S. Kelso \& J. E. Clark (Eds.), The development of movement control and coordination (pp. 309-318). New York: Wiley.

Shaffer, D. R. (2009). Social and personality development, 6th ed. California: Wadsworth.

Shier, H. (2001). Pathways to Participation. Children and Society, 15, 107-117.

Shutton-Smith, B. (1997). The ambiguity of play. Cambridge, Mass: Harvard University Press.

Sinclair, R. (2004). Participation in practice: making it meaningful, effective and sustainable. Children \& Society, 18(2), 106-118.

Siren-Tiusanen, H. (1995) Motorisen kehityksen kontekstisidonnaisuus. Teoksessa P. Lyytinen, M. Korkiakangas \& H. Lyytinen (toim.), Näkökulmia kehityspsykologiaan. Kehitys kontekstissaan. Helsinki: WSOY.

Skinner, B. F. (1953). Science and human behavior. New York: MacMillan.

Sodré, T., \& Ojala, M. (2010) Dialogic communicative acts communicative acts of power in research. Revista signos, 43, Número Especial Monográfico No. 2, 377-391.

Sommer, D., Pramling Samuelsson, I., \& Hundeide, K. (2013). Early childhood care and education: a child perspective paradigm. European Early Childhood Education Research Journal, 21(4),

Spillane, J. P., Halverson, R., \& Diamond, J. P. (2004). Towards a theory of leadership practice: a distributed perspective. Journal of Curriculum Studies, 36(1), 3-34.

Spodek, B., \& Saracho, O. (Eds.) (2005). International perspectives on research in early childhood education. Greewich, Connecticut: Sage. 
Standards in children's participation (2005). London: The International Save the Children Alliance. Starting Strong II. Early Childhood Education and Care (2006). Paris: OECD.

Stern, D. N. (1985). The Interpersonal World of the Infant: A View from Psychoanalysis and Development. New York: Basic Books.

Stobart, G. (2008). Testing times. The uses and abuses of assessment. London: Routledge.

Sulkunen, S., Välijärvi, J., Arffman, I., Harju-Luukkainen, H., Kupari, P., Nissionen, K., Puhakka, E., \& Reinikainen, P. (2009). PISA 2009. Ensituloksia. Opetus- ja kulttuuriministeriö \& Jyväskylän yliopisto, Koulutuksen tutkimuslaitos.

Sylva, K., Melhuish, E., Sammons, P., Siraj-Blatchford, I., \& Taggart, B. (2004). The Effective Provision of Preschool Education (EPPE) Project: Final Report. Report No. SSU/FR/2004/01, Department for Education and Skills, Nottingham.

Sylva, K., Melhuish, E., Sammons, P., Siraj-Blatchford, I., Taggart, B., Hunt, S., Jelicic, H., Barreau, S., Grabbe, Y., Smees, R., \& Welcomme, W. (2008). Effective pre-school and primary education 3-11 project (EPPE 3-11). Final report from the primary Phase: Preschool, school and family influences on children's development during key stage 2 (ages 7-11). Research report DCSF-RRO61. Department for children, school and families. The UK government.

Sylva, K., Melhuish, E., Sammons, P., Siraj-Blatchford, I., \& Taggart, B. (2010). Early childhood matters: Evidence from the effective pre-school and primary education project. London: Routledge.

Sääkslahti, A. (2018). Liikuntaa varhaiskasvatuksessa. Jyväskylä: PS-kustannus.

Taajamo, M. \& Puhakka, E. (2019). Opetuksen ja oppimisen kansainvälinen tutkimus TALIS 2018. Perusopetuksen vuosiluokkien 7-9 ensitulokset, Osa 1. Opetushallitus. Raportit ja selvitykset 2019:8.

Taguma, M., Litjens, I., \& Makowiecki, K. (2012). Quality matters in early childhood education and care. Finland. Paris: OECD.

Tarkka, K., Komi, A., Nevanen, S., \& Tuominiemi-Lilja, T. (toim.) ( 2013). Hyve hallussa. Opas vanhempien, päivähoidon ja neuvolan yhteistyön vahvistamiseen lapsen laajan 4- vuotistarkastuksen yhteydessä. Socca - pääkaupunkiseudun sosiaalialan osaamiskeskus. Helsinki: Star-Offset Oy.

Tauriainen, L. (2000). Kohti yhteistä laatua. Henkilökunnan, vanhempien ja lasten laatukäsitykset päiväkodin integroidussa erityisryhmässä. Jyväskylä Studies in Education, Psychology and Social Research, No. 165.

The Good Childhood Report (2012). London: The Children's Society.

The state of the world's children (2007). Women and Children. The Double Dividend of Gender Equality in 2006. The United Nations Children's Fund (UNICEF). December 2006.

Thelen, E. (1995). Motor development. A new synthesis. American Psychologist, 50, 79-95.

Thelen, E. (2000). Motor development as foundation and future of developmental psychology. International Journal of Behavioral Development, 24, 385-397.

Thomas, N. (2007). Towards a theory of children's participation. International Journal of Children's Rights, 15, 199-218.

Thornberg, R. (2010). Schoolchildren's social represenations on bullying causes. Psychology in the Schools, 47(4), 311-327.

Tieteelliset perusteet varhaisvuosien fyysisen aktiivisuuden suosituksille (2016). Opetus- ja kulttuuriministeriön julkaisuja 2016:22.

Tudge, J. R., Mokrova, I., Hatfield, B. E. \& Karnik, R. B. (2009). Uses and missuses of Bronfenbrenner's bioecological theory of human development. Journal of Family Theory \& Riview 1, December 2009: 198-210. 
Tulevaisuuden perusopetus - valtakunnalliset tavoitteet ja tuntijako (2012). Opetus- ja kulttuuriministeriön työryhmämuistioita ja selvityksiä 2012:6.

Tuokko, E. (2000) Peruskoulun 9. vuosiluokan englannin (A1-kieli) oppimistulosten kansallinen arviointi 1999. Oppimistulosten arviointi 3/2000. Helsinki: Yliopistopaino.

Tuokko, E. (2002) Perusopetuksen päättövaiheen ruotsin kielen oppimistulosten kansallinen arviointi 2001. Oppimistulosten arviointi 3/2002. Helsinki: Yliopistopaino.

Tuokko, E. (2003) Perusopetuksen päättövaiheen englannin kielen oppimistulosten kansainvälinen arviointi 2002. Suomen tulokset. Oppimistulosten arviointi 3/2003. Helsinki: Yliopistopaino.

Tuomi, J. (2010). Oppaan kehittämisestä perheliikuntaan. Liikuntapedagogiikan pro gradu -tutkielma. Liikuntatieteiden laitos. Jyväskylän yliopisto.

UNESCO (2010). Early Childhood Care and Education (ECCE ) Unit. Paris.

Uusitalo, I. (2005). Työ tekijäänsä opettaa - sosionomi (AMK) asiantuntijavalmiuksia oppimassa. Turun ammattikorkeakoulun tutkimuksia 17. Turku: Turun kaupungin palvelukeskus

Vagle, M. D. (2010). Re-framing Schon's call for a phenomenology of practice: a postintentional approach. Reflective Practice, 11(3), 393-407.

Vainikainen M.-P., Marjanen J., Kupiainen S., Gustavson, N., \& Hautamäki J. (2011). Oppimaan oppiminen Vantaan peruskouluissa. Ensiluokkalaisten oppimisvalmiudet syksyllä 2010. Vantaan kaupungin sivistysvirasto ja Koulutuksen arviointikeskus.

Vainikainen, M-P., Marjanen, J., Kupiainen, S., Gustavson, N., \& Hautamäki. J. (2010). Oppimaan oppiminen Vantaan perusopetuksessa. Vantaan kaupungin sivistysvirasto \& Helsingin yliopiston koulutuksen arviointikeskus.

Waksler, F. C. (1991). Studying the Social Worlds of Children: Sociological Readings. London: Falmer Press.

Valsiner, J. (2007). Culture in minds and societies. Foundations of cultural psychology. Los Angeles: Sage.

Valtonen, R., Ahonen, T., Lyytinen, P., \& Lyytinen, H. (2004). Co-occurrence of developmental delays in a screening study of 4-year-old Finnish children. Developmental Medicine and Child Neurology, 46, 436-443.

Valtonen, R., Ahonen, T., Lyytinen, P., \& Tolvanen, A. (2007). Screening for developmental risks at 4 years of age: Predicting development two years later. Nordic Psychology, 59(2), 95-108.

Valtonen, R., Ahonen, T., Tolvanen, A., \& Lyytinen, P (2009). How does early developmental assessment predict academic and attentional-behavioural skills at group and individual levels? Developmental Medicine \& Child Neurology, 51(10), 792-799.

Van Manen, M. (1977). Linking ways of knowing with ways of being practice. Curriculum Inquiry, 6,

Vandell, D. L., Belsky, J., Burchinal, M., Steinberg, L., \& Vandergrift, N. (2010). Do effects of early child care extend to the age of 15 years. Results from the NICHD Study of early child care and youth development. Child Development, 81(3), 737-756.

Vandenbroeck, M. (2007). Beyond anti-bias education: Changing conceptions of diversity and equity in European early childhood education. European Early Childhood Education Research Journal, 15(1), 21-35.

Vandenbroeck, M. (2012). Evidence-based practice, Professionalism and respect for diversity: A tense relation. Asiapacific Journal of Research. The Pacific in Early Childhood Education. Early Childhood Education Research Association, 6(1), 1-20.

Vandenbroeck, M., Roets, G., \& Roose, R. (2012). Why the evidence-based paradigm in early childhood education and care is anything but evident. European Early Childhood Education Research Journal, 20(4), 537-552. 
$\begin{array}{llll}\text { Varhaiskasvatuslaki } & \text { (2015). } & \text { Finlex } & \text { 580/2015. } \\ \text { Varhaiskasvatuslaki } & \text { (2018). } & \text { Finlex } & \text { 540/2018. }\end{array}$

Varhaiskasvatussuunnitelman perusteet (2004). Helsinki: Stakes.

Varhaiskasvatussuunnitelman perusteet (2016). Opetushallitus. Määräys 39/011/2016.

Warin, J. \& Adrinany, V. (2017). Gender flexible pedagogy in early childhood education. Journal of Gender Studies, Volume 26, Issue 4.

Watts, J., Cockcroft, K. \& Duncan, N. (2009). Developmental Psychology, 2nd edition. Cape Twon: UCT Press.

Weikart, D. P. (1966). Preschool programs: Preliminary findings. Journal of Special Education, 1(2), 163-181.

Venninen, T. (2007). "Olen enemmän alkanut pohtimaan ja sanomaan ääneen mitä ajattelen" - ammatillinen kehittyminen ja yhteisöllinen palaute päiväkodin työtiimeissä. Tutkimuksia 282. Helsingin yliopiston soveltavan kasvatustieteen laitos.

Venninen, T. (2009). Monikulttuurisuus pääkaupunkiseudun päiväkodeissa - kyselyn tulokset. Soveltavan kasvatustieteen laitos / VKK-Metro .

Venninen, T., Leinonen, J., \& Ojala., M. (2014). Distributed leadership as administrative practice in Finnish Early Childhood Education and Care. Educational Management Administration \& Leadership. Resubmitted with reviews 8.1.2014.

Venninen, T., Leinonen, J., Ojala, M., \& Lipponen, L. (2012). Creating conditions for reflective practice in early childhood education. International Journal of Child Care and Education Policy, 6(1),

West, C. \& Zimmerman, D.H. 1987. Doing gender. Gender \& Society, Volume 1, Issue 2. June 1987.

WHO Multicentre Growth Reference Study Group. (2006). WHO motor development study. Geneva.

Viholainen, H. (2006). Motorisen kehityksen yhteys kielellisiin taitoihin. NMI-bulletin 16. Jyväskylä: Niilo Mäki Instituutti.

Wingrave, M. (2018). Perceptions of gender in early years. Gender and Education, Volume 30, 2018, Issue 5.

Winnicott, D. (1971). Playing and reality. Kent: Chatman.

Winnicott, D. W. (1982). Playing and reality. London: Routledge.

Wise, S. P. and Shadmehr, R. (2002 ). Motor control. In V.S. Ramachandran (Ed), Encyclopedia of the Human Brain, vol. 3, (pp. 137-157). San Diego, CA.: Academic Press.

von Wendt, L., \& Voutilainen, A. (2008). Lasten hyvinvoinnin ja oppimisvalmiuksien

arviointi 3-7 vuoden iässä. Diagnostiikka ja seulonta lastenneurologian kannalta. Helsingin yliopisto: HYKS/HY.

Vlasov, J., Salminen, J., Repo, L., Karila, K., Kinnunen, S., Mattila, V., Nukarinen, T., Parrila, S. \& Sulonen, H. (2018). Varhaiskasvatuksen laadun arvioinnin perusteet ja suositukset. KARVI, Kansallisen koulutuksen arviointikeskus. Julkaisut 24:2018.

Wood, E. \& Hedges, H. (2016). Curriculum in early childhood education: critical questions about content, coherence, and control. The Curriculum Journal, 27 (3), pp. 387-405.

Woodhead, M. (1996). In search of the rainbow. Pathways to quality in large-scale programmes for young disadvanted children. Early Childhood Development: Practice and Reflection. No.10. The Hague: Bernand van Leer Foundation.

Vuorio, J-M. (2005). Esiopetusikäisen lapsen lukukäsitteen kehittyminen esiopetusvuoden aikana. Teoksessa J. Hytönen (toim), Esiopetuksen prosessi ja vaikutukset. Esiopetuksen toimivuus ja vaikuttavuus Helsingin kaupungissa 2001-2003. Tutkimusraportti 3. Tutkimuksia 259. Helsingin yliopiston soveltavan kasvatustieteen laitos, 39-56.

Vygotksy, L. S. (1978). Mind in society. The development of higher psychological processes. Cambridge, Mass.: Harvard University Press.

Wäre, M., Lerkkanen, M-K., \& Hannula, M. M. (2009). Pikkumetsän esiopetus. Helsinki: WSOY.

YK:n lapsen oikeuksien yleissopimus (1989). Suomen YK-liitto. 
Ylitapio-Mäntylä, O. (2012) Leikillä ja toiminnalla ei ole sukupuolta. Teoksessa Outi Ylitapio-Mäntylä (toim.) Villit ja kiltit. PS-kustannus. 2012.

Young Minds (2012). A guide to measuring children's well-being. Backing the Future: Practical guide

Yudina, E., (Ed.) (2007). Rediscovering Vygotsky. The enduring impact of a Russian psychologist. International perspectives / Early years / Schools Magazine. A Children in Europe magazine special edition. Children in Scotland, Edinbourg. 


\section{Liitteet}

Liitetaulukko 1. Yksilötason kompetenssit eurooppalaiselle varhaiskasvatukselle ja esiopetukselle (CoRe, 2011)

\begin{tabular}{|c|c|c|}
\hline Tiedot & Kasvatuskäytäntö & Arvot \\
\hline \multirow[t]{4}{*}{$\begin{array}{l}\text { Tieto lapsen } \\
\text { kokonaiskehit- } \\
\text { tymisestä eri } \\
\text { alueilla }\end{array}$} & $\begin{array}{l}\text { Sitoutunut ja } \\
\text { vastuuntuntoinen } \\
\text { vuorovaikutussuhde lapseen }\end{array}$ & $\begin{array}{l}\text { Lasten tarpeiden huomioon } \\
\text { ottaminen tavalla, joka tukee } \\
\text { heidän kehityspotentiaali- } \\
\text { aan ja osallisuutta kasvatus- } \\
\text { instituutiossa }\end{array}$ \\
\hline & $\begin{array}{l}\text { Lasten havainnointi } \\
\text { kohdistuen kehitystarpeisiin }\end{array}$ & $\begin{array}{l}\text { Kokonaisvaltainen näkemys } \\
\text { kasvatuksesta suhteessa } \\
\text { oppimiseen, hoitoon ja } \\
\text { kasvatustoimenpiteisiin }\end{array}$ \\
\hline & $\begin{array}{l}\text { Kasvatustoiminnan laaja- } \\
\text { alainen suunnittelu ja toteutus } \\
\text { tukien lapsen tarpeita ja } \\
\text { kokonaiskehittymistä }\end{array}$ & $\begin{array}{l}\text { Sitoutuminen inklusiiviseen } \\
\text { lähestymistapaan } \\
\text { kasvatuksessa }\end{array}$ \\
\hline & $\begin{array}{l}\text { Lapsen kehityksen } \\
\text { systemaattinen dokumentointi } \\
\text { kasvatustapahtumassa }\end{array}$ & \\
\hline \multirow[t]{6}{*}{$\begin{array}{l}\text { Tieto lasten } \\
\text { erilaisista } \\
\text { oppimisen } \\
\text { strategioista }\end{array}$} & $\begin{array}{l}\text { Oppimisympäristön luominen } \\
\text { ja organisointi }\end{array}$ & $\begin{array}{l}\text { Lapsikeskeinen } \\
\text { lähestymistavan omaksuminen, } \\
\text { jossa lapsi nähdään } \\
\text { kykenevänä, aktiivisena ja } \\
\text { oman oppimisensa ohjaajana }\end{array}$ \\
\hline & $\begin{array}{l}\text { Pienryhmässä tapahtuvan } \\
\text { projektioppimisen käyttö } \\
\text { tavalla, joka perustuu lasten } \\
\text { mielenkiinnon kohteisiin }\end{array}$ & $\begin{array}{l}\text { Oppiminen ymmärretään } \\
\text { sosiaalisena konstruktiona } \\
\text { ja avoimena prosessina } \\
\text { tavalla, joka tukee sosiaalista } \\
\text { kanssakäymistä ja rohkaisee } \\
\text { uuteen oppimiseen }\end{array}$ \\
\hline & $\begin{array}{l}\text { Symbolileikkien käyttö ja } \\
\text { niihin soveltuvien materiaalien } \\
\text { tarjonta }\end{array}$ & $\begin{array}{l}\text { Oppiminen hahmotetaan } \\
\text { monitieteisesti }\end{array}$ \\
\hline & $\begin{array}{l}\text { Opetussuunnitelman laadinta } \\
\text { tavalla, joka tukee orastavaa } \\
\text { lukutaitoa, matematiikkaa ja } \\
\text { luonnontiedettä }\end{array}$ & Monikielisyyden tukeminen \\
\hline & $\begin{array}{l}\text { Äidinkielen tukeminen } \\
\text { ottaen huomioon myös } \\
\text { monikielisyyden }\end{array}$ & \\
\hline & $\begin{array}{l}\text { Erityisen tuen antaminen } \\
\text { lapsille persoonallisessa ja } \\
\text { yksilöllisellä tavalla }\end{array}$ & \\
\hline $\begin{array}{l}\text { Tieto kommuni- } \\
\text { koinnista lasten } \\
\text { kanssa ja osalli- } \\
\text { suudesta }\end{array}$ & $\begin{array}{l}\text { Arvostaa ja rohkaista lapsia } \\
\text { ilmaisun erimuodoissa }\end{array}$ & $\begin{array}{l}\text { Lasten tukeminen kansalaisuu- } \\
\text { teen ja yhteiskunnan sosiaali- } \\
\text { seen ja kulttuuriseen elämään }\end{array}$ \\
\hline
\end{tabular}




\begin{tabular}{|c|c|c|}
\hline & $\begin{array}{l}\text { Mahdollistaa lapsille kokemuk- } \\
\text { set paikallisessa ja ihmiskun- } \\
\text { nan kulttuuriperinteessä } \\
\text { (taide, draama, musiikki, } \\
\text { tanssi, urheilu jne.) }\end{array}$ & $\begin{array}{l}\text { Demokraattisuuden, } \\
\text { solidaarisuuden, aktiivisen } \\
\text { kansalaisuuden, luovuuden } \\
\text { ja itsensä toteuttamisen } \\
\text { vaaliminen }\end{array}$ \\
\hline & $\begin{array}{l}\text { Rohkaisee lapsia kulttuurien } \\
\text { tuottamiseen heidän } \\
\text { ilmaisemallaan tavalla }\end{array}$ & \\
\hline & $\begin{array}{l}\text { Osallistutaan paikallisiin juhliin } \\
\text { ja kulttuuritapahtumiin ja } \\
\text { näyttelyihin }\end{array}$ & \\
\hline & $\begin{array}{l}\text { Rakennetaan yhdessä lasten } \\
\text { kanssa pedagogista tietoa }\end{array}$ & \\
\hline \multirow[t]{9}{*}{$\begin{array}{l}\text { Tieto } \\
\text { työskentelystä } \\
\text { vanhempien ja } \\
\text { paikallisyhteisön } \\
\text { kanssa }\end{array}$} & $\begin{array}{l}\text { Paikallisyhteisön tarpeiden } \\
\text { analysointi tarkoituksena } \\
\text { työskennellä tehokkaasti } \\
\text { vanhempien ja erityisryhmien } \\
\text { kanssa }\end{array}$ & $\begin{array}{l}\text { Demokraattisen ja } \\
\text { inklusiivisen työskentelytavan } \\
\text { omaksuminen lasten } \\
\text { kasvatuksessa ja yhteistyössä } \\
\text { vanhempiin sosiaalisen } \\
\text { koheesion takaamiseksi }\end{array}$ \\
\hline & $\begin{array}{l}\text { Pitää yllä yhteistyötä vanhem- } \\
\text { piin perustuen molemminpuo- } \\
\text { liseen ymmärrykseen, luotta- } \\
\text { mukseen ja yhteistyöhön }\end{array}$ & $\begin{array}{l}\text { Hyväksytään vanhempien } \\
\text { kasvatusvastuu lastensa } \\
\text { pääkasvattajana }\end{array}$ \\
\hline & $\begin{array}{l}\text { Pitää yllä avointa kommuni- } \\
\text { kointia ja vastavuoroista } \\
\text { kommunikointia vanhempiin }\end{array}$ & \\
\hline & $\begin{array}{l}\text { Pitää yllä jatkuvaa dialogia } \\
\text { ja tiedonkulkua (esim. } \\
\text { dokumentit, käytäntö jne.) }\end{array}$ & \\
\hline & $\begin{array}{l}\text { Otetaan mukaan vanhemmat } \\
\text { päätöksentekoon heidän } \\
\text { näkemystään kunnioittaen }\end{array}$ & \\
\hline & $\begin{array}{l}\text { Konstruoidaan pedagogista } \\
\text { tietoa yhdessä vanhempien } \\
\text { kanssa heitä kunnioittaen }\end{array}$ & \\
\hline & $\begin{array}{l}\text { Työstetään vanhempien ja } \\
\text { paikallisyhteisön aloitteita } \\
\text { eteenpäin }\end{array}$ & \\
\hline & $\begin{array}{l}\text { Kehitetään varhaiskasvatusta } \\
\text { yhdessä paikallisyhteisön } \\
\text { kanssa }\end{array}$ & \\
\hline & $\begin{array}{l}\text { Pidetään yllä yhteistyötä toisiin } \\
\text { tahoihin }\end{array}$ & \\
\hline \multirow[t]{3}{*}{$\begin{array}{l}\text { Tieto } \\
\text { tiimityöskentelystä }\end{array}$} & $\begin{array}{l}\text { Käydään läpi jatkavasti } \\
\text { kasvatuskäytäntöä yksilöllisesti } \\
\text { ja yhdessä }\end{array}$ & $\begin{array}{l}\text { Otetaan käyttöön } \\
\text { demokraattinen ja kriittinen } \\
\text { reflektiivinen työskentelytapa }\end{array}$ \\
\hline & $\begin{array}{l}\text { Jaetaan asiantuntijuutta } \\
\text { kollegoiden kanssa } \\
\text { tiimipalaveroissa }\end{array}$ & \\
\hline & $\begin{array}{l}\text { Keskustellaan ja opitaan } \\
\text { asioista, joista ollaan eri mieltä }\end{array}$ & \\
\hline
\end{tabular}




\begin{tabular}{|c|c|c|}
\hline & $\begin{array}{l}\text { Kehitetään yhdessä kollegojen } \\
\text { kanssa käytäntöä }\end{array}$ & \\
\hline & $\begin{array}{l}\text { Konstruoidaan yhteistyössä } \\
\text { pedagogista tietoa doku- } \\
\text { mentoimalla ja kollektiivisella } \\
\text { arvioinnilla }\end{array}$ & \\
\hline \multirow[t]{3}{*}{$\begin{array}{l}\text { Tieto erilaisista } \\
\text { työskentelyn } \\
\text { puitteista } \\
\text { (esim. inter- } \\
\text { kultturaalinen jne.) }\end{array}$} & $\begin{array}{l}\text { Kehitetään inklusiivistä } \\
\text { käytäntöä tarkoituksena } \\
\text { edistää lasten ja perheiden } \\
\text { sosialisaatiota moniarvoisuutta } \\
\text { kunnioittaan }\end{array}$ & $\begin{array}{l}\text { Otetaan käyttöön demokraat- } \\
\text { tinen ja inklusiivinen lähesty- } \\
\text { mistapa perustuen moniarvoi- } \\
\text { suuteen }\end{array}$ \\
\hline & $\begin{array}{l}\text { Tulla toimeen } \\
\text { ennustamattoman ja } \\
\text { epävarman kanssa }\end{array}$ & \\
\hline & $\begin{array}{l}\text { Kehittää inklusiivistä } \\
\text { pedagogista käytäntöä }\end{array}$ & \\
\hline \multirow[t]{2}{*}{$\begin{array}{l}\text { Tieto varhaiskas- } \\
\text { vatuksesta laajem- } \\
\text { massa paikallisessa, } \\
\text { kansallisessa ja } \\
\text { kansainvälisessä } \\
\text { kontekstissa }\end{array}$} & $\begin{array}{l}\text { Aktiivinen osallistuminen } \\
\text { paikalliseen lasten ja } \\
\text { perheiden oikeuksia ja } \\
\text { osallisuutta edistävään } \\
\text { toimintaan }\end{array}$ & $\begin{array}{l}\text { Lasten ja perheiden oikeuden } \\
\text { edistäminen koskien aktiivista } \\
\text { kansalaisuutta, solidaarisuutta } \\
\text { ja elinikäistä oppimista }\end{array}$ \\
\hline & $\begin{array}{l}\text { Ammatillinen verkostuminen } \\
\text { (esim. ammattiyhdistys) ja } \\
\text { paikalliseen poliittiseen pää- } \\
\text { töksentekoon osallistuminen } \\
\text { pedagogisena asiantuntijana }\end{array}$ & \\
\hline $\begin{array}{l}\text { Tieto lasten } \\
\text { terveydestä, } \\
\text { hoidosta ja } \\
\text { suojelusta }\end{array}$ & $\begin{array}{l}\text { Lasten turvallisuuteen, hygi- } \\
\text { eniaan ja ruokatottumuksiin } \\
\text { liittyvät käytännöt }\end{array}$ & $\begin{array}{l}\text { Lasten hyvinvointiin } \\
\text { sitoutuminen }\end{array}$ \\
\hline
\end{tabular}


Liitetaulukko 2. Yksikkötason ammatilliset kompetenssit (CoRe, 2011)

\begin{tabular}{|c|c|c|}
\hline Tieto & Käytäntö & Arvot \\
\hline \multirow[t]{3}{*}{$\begin{array}{l}\text { Pedagoginen tieto } \\
\text { varhaiskasvatuksesta ja } \\
\text { sen erityisluonteesta }\end{array}$} & $\begin{array}{l}\text { Yhteinen sitoutuminen } \\
\text { pedagogiseen työhön (esim. } \\
\text { toimintayksikön profiili) }\end{array}$ & $\begin{array}{l}\text { Demokraattisuus ja erilaisuuden } \\
\text { hyväksyminen }\end{array}$ \\
\hline & $\begin{array}{l}\text { Henkilöstöllä on riittävästi } \\
\text { yhteistä aikaa suunnitelmien, } \\
\text { dokumentoinnin ja työn } \\
\text { läpikäymiseen }\end{array}$ & $\begin{array}{l}\text { Ymmärretään ammatillinen } \\
\text { kehittyminen jatkuva } \\
\text { oppimisprosessina } \\
\text { henkilökohtaisena ja } \\
\text { ammatillisena kasvuna }\end{array}$ \\
\hline & $\begin{array}{l}\text { Otetaan käyttöön systemaattinen } \\
\text { tapa käytännön dokumentointiin } \\
\text { ja pedagogiseen arviointiin }\end{array}$ & $\begin{array}{l}\text { Ymmärretään ammatillinen } \\
\text { kasvu vuorovaikutuksena } \\
\text { käytännön ja teorian välillä } \\
\text { tavalla, joka edellyttää tukea }\end{array}$ \\
\hline $\begin{array}{l}\text { Tieto kontekstuaalisesta } \\
\text { oppimisesta ja } \\
\text { lähiyhteisön } \\
\text { käytännöistä }\end{array}$ & $\begin{array}{l}\text { Varataan mahdollisuuksia } \\
\text { yhteiseen oppimiseen } \\
\text { (toimijoiden välinen ja ulkoinen } \\
\text { ohjaus) } \\
\text { Henkilöstölle annetaan jatkuvaa } \\
\text { ohjantaa }\end{array}$ & $\begin{array}{l}\text { Varhaiskasvatusinstituutiot } \\
\text { toimivat kriittisen reflektion } \\
\text { yhteisöinä vuorovaikutuksessa } \\
\text { lasten, vanhempien laajemman } \\
\text { yhteyskunnan muuttuviin } \\
\text { tarpeisiin }\end{array}$ \\
\hline & $\begin{array}{l}\text { Työstetään lähestymistapoja } \\
\text { jatkuvaan ammatilliseen } \\
\text { kehittymiseen työyhteisössä eri } \\
\text { toimijoiden kesken }\end{array}$ & \\
\hline $\begin{array}{l}\text { Tieto oppivista } \\
\text { organisaatioista } \\
\text { ja reflektiivisestä } \\
\text { oppimisesta }\end{array}$ & $\begin{array}{l}\text { Tarjotaan ohjelmia jatkuvaan } \\
\text { ammatilliseen kehittymiseen } \\
\text { perustuen käytäntöön ja } \\
\text { työntekijöiden tarpeisiin }\end{array}$ & $\begin{array}{l}\text { Hahmotetaan } \\
\text { varhaiskasvatusinstituutiot } \\
\text { sosiaalisen koheesion lujittamisen } \\
\text { foorumeina }\end{array}$ \\
\hline $\begin{array}{l}\text { Tieto johtamisesta ja } \\
\text { johtajuudesta }\end{array}$ & $\begin{array}{l}\text { Tarjotaan erilaisia mahdolli- } \\
\text { suuksia jatkuvaan ammatilliseen } \\
\text { kehittymiseen (esim. yksiön } \\
\text { sisäiset, toimintatutkimukset, } \\
\text { verkostot jne.) } \\
\text { Kannustetaan ja palkitaan } \\
\text { osallistumisesta ammatilliseen } \\
\text { kehittymiseen } \\
\text { Mahdollisuuksia osallistua } \\
\text { ammatilliseen lisä- ja } \\
\text { täydennyskoulutukseen } \\
\text { Mahdollisuuksia urakiertoon, } \\
\text { säännölliset tapaamiset } \\
\text { kollegoiden, vanhempien ja } \\
\text { paikallisyhteisön kanssa } \\
\text { Tarjotaan pedagogista tukea } \\
\text { henkilöille, jotka työskentelevät } \\
\text { riskiympäristöissä }\end{array}$ & \\
\hline
\end{tabular}




\begin{tabular}{|c|c|c|}
\hline $\begin{array}{l}\text { Tieto koskien } \\
\text { koulutusta: } \\
\text { Pedagoginen tieto }\end{array}$ & $\begin{array}{l}\text { Rekrytoidaan erityistyöntekijöitä } \\
\text { yhteisön tarpeen mukaan } \\
\text { Otetaan käyttöön ohjelmia, } \\
\text { joissa teoria ja käytäntö ovat } \\
\text { tasapainossa }\end{array}$ & $\begin{array}{l}\text { Hahmotetaan ammatillistumien } \\
\text { sosiaalisena ja kulttuurillisena } \\
\text { prosessina }\end{array}$ \\
\hline \multirow{3}{*}{$\begin{array}{l}\text { Tieto koskien } \\
\text { koulutusta: Tieto } \\
\text { aikuisoppimisesta ja } \\
\text { siihen kytkeytyvästä } \\
\text { refleksiivisyydestä }\end{array}$} & $\begin{array}{l}\text { Otetaan käyttöön ohjelmia, } \\
\text { jotka kehittävät kulttuurista } \\
\text { tietoisuutta ja ilmaisua }\end{array}$ & \\
\hline & $\begin{array}{l}\text { Koulutusta ja oppimista tarjotaan } \\
\text { erilaisin menetelmien (esim. } \\
\text { luennot, pienryhmätyöskentely, } \\
\text { projektit, työskentely } \\
\text { käytännössä jne.) }\end{array}$ & $\begin{array}{l}\text { Hahmotetaan ammatillistuminen } \\
\text { jatkuvana oppimisprosessina, } \\
\text { johon liittyy sekä } \\
\text { henkilökohtaista että } \\
\text { ammatillista kasvua }\end{array}$ \\
\hline & $\begin{array}{l}\text { Tarjotaan yksilöllistä } \\
\text { tukea ja tutorointia sekä } \\
\text { koulutusyksikössä että työssä }\end{array}$ & $\begin{array}{l}\text { Ymmärretään ammatillinen } \\
\text { kasvu vuorovaikutukseen } \\
\text { perustuvana oppimisprosessina }\end{array}$ \\
\hline \multirow{2}{*}{$\begin{array}{l}\text { Tieto koskien } \\
\text { koulutusta: Tieto } \\
\text { kontekstuaalisesta } \\
\text { oppimisesta ja } \\
\text { lähiyhteisön } \\
\text { käytännöistä }\end{array}$} & $\begin{array}{l}\text { Luodaan mahdollisuuksia } \\
\text { käytännön yhteiseen } \\
\text { reflektointiin vertaisryhmässä }\end{array}$ & \\
\hline & $\begin{array}{l}\text { Tarjotaan ammatillistumiselle } \\
\text { inkluusiivistä ja joustavaa } \\
\text { lähestymistapaa, joka laajentaa } \\
\text { näkemyksiä traditionaalisista } \\
\text { oppijoista ja erityisryhmistä } \\
\text { Kehitetään lähestymistapoja, } \\
\text { jossa voidaan soveltaa ei-formaa- } \\
\text { lista ja informaalista oppimista } \\
\text { Rohkaistaan ammatilliseen } \\
\text { liikkuvuuteen } \\
\text { Tarjotaan mahdollisuuksia pereh- } \\
\text { tyä interkultturaaliseen kasvatuk- } \\
\text { seen (esim. luennot, pienryhmä- } \\
\text { työskentely, kenttätyö jne.) }\end{array}$ & $\begin{array}{l}\text { Ymmärretään ammatillinen } \\
\text { kasvu vuorovaikutuksena } \\
\text { käytännön ja teorian välillä } \\
\text { tavalla, joka edellyttää tukea }\end{array}$ \\
\hline
\end{tabular}


Liitetaulukko 3. Karkeamotoristen taitojen kehitysodotuksia ikävuosina 3-7

1. $3 \mathrm{v}$

2. Seisoo yhdellä jalalla hetken

3. Hyppää tasajalkaa

4. Ajaa kolmirataspyörää

5. $4 \mathrm{v}$

6. Hyppää yhdellä jalalla paikallaan 4-5 kertaa

7. Haara-perushyppy

8. Seisoo yhdellä jalalla 5-6 sek.

9. Kävelee viivaa pitkin

10. $5 \mathrm{v}$

11. Vaihtohyppy

12. Kantapää - varvaskävely

13. Seisoo yhdellä jalalla 10 sek.

14. $6 \mathrm{v}$

15. Osaa juosta ulkona lujaa

16. Ottaa pallon kiinni ja heittää

17. $7 \mathrm{v}$

18. Seisoo yhdellä jalalla 20 sek.

19. Hyppää yhdellä jalalla paikallaan yli 20 kertaa 
Liitetaulukko 4. Hienomotoriikan kehitysodotuksia ikävuosina 3-6

1. $3 \mathrm{v}$

2. Käsien bilateraalinen toiminta ja sorminäppäryys kehittyvät

3. Kätisyyden vakiintuminen

4. Kiertää pullon korkin auki ja kiinni

5. Repii paperin käsien vastakkaisliikkeillä

6. Kynäote sormenpääote tai aikuismainen kolmisormiote

7. $5 \mathrm{v}$

8. Kätisyys vakiintunut

9. Kynäote aikuismainen kolmisormiote

10. Rakentelee taitavasti palikoilla ja legoilla

11. Leikkaa saksilla ympyrän

12. Sorminaputus/peukalo-sormikoe onnistuu

13. $6 \mathrm{v}$

14. Oikea kynäote

15. Jäljentää kolmion

16. Sitoo kengännauhat 
Liitetaulukko 5. Esimerkki keskustelurungosta, joka koskee 4-vuotiaan lapsen hyvinvointia kielellisen kehittymisen alueella:

- Ymmärtää tavallista puhetta

- Kiinnostuu sanaleikeistä ja riimittelystä (kielellinen tietoisuus).

- Käyttää kieliopillisesti oikeita lauseita sisältäen myös sivulauseet.

- Kertoo tarinoita, satuilee ja kertoo asioista ja tapahtumista (kertova puhe).

- Käyttää puheessaan adjektiiveja ja osaa kuvailla esineitä ja asioita.

- Puhuu selkeästi, vaikka joitain äänteitä voi puuttua.

- Osaa keskustella ja kuunnella muita sekä esittää kysymyksiä kuulemastaan.

- Kyselee paljon miksi ja mitä varten kysymyksiä ja kaipaa niihin selvitystä.

Mahdollisia kielelliseen kehittymiseen liittyvissä huolenaiheissa voidaan kiinnittää huomiota seuraaviin seikkoihin:

- Lapsen sanavarasto on suppea.

- Lapsi ei ymmärrä annettuja ohjeita.

- Lapsen puheessa esiintyy runsaasti äännevirheitä.

- Lapsen puheesta on vaikea saada selvää.

- Lapsen puheessa on huomattavia kieliopillisia virheitä.

- Lapsen puheessa esiintyy niukasti kertovaa ja kuvailevaa puhetta.

- lapsella on esiintynyt änkytysoireita vähintään kolme kuukautta. 


\section{Liitekuvat}

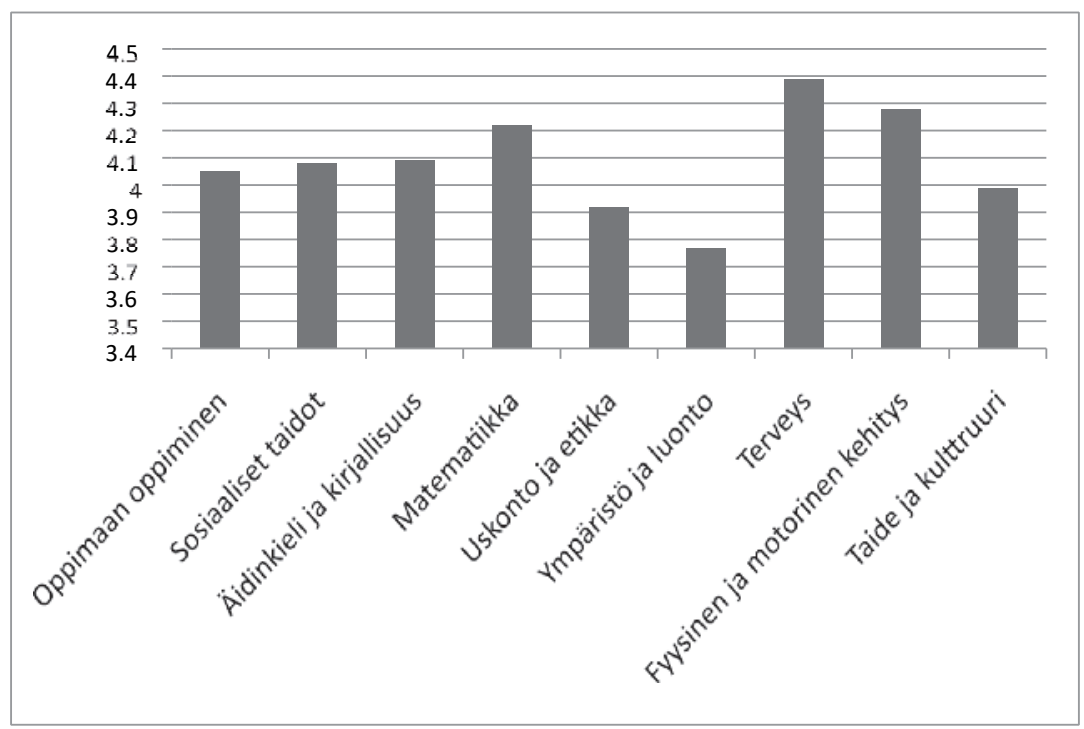

Liitekuva 1. Lasten ( $n=226)$ oppimistavoitteiden saavuttaminen esiopetuksen päättövaiheessa (Ojala \& Talts, 2007)

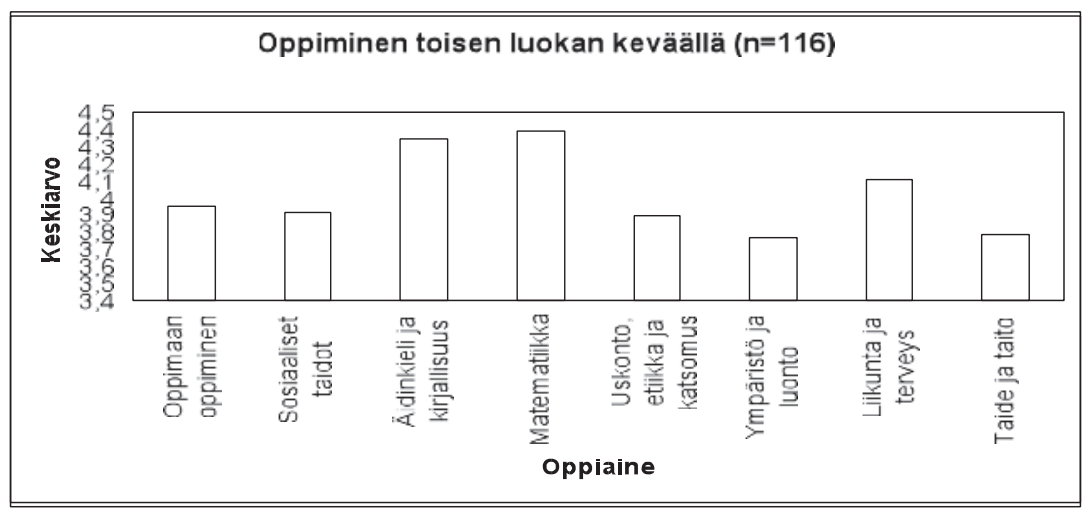

Liitekuva 2. Opettajien arviot oppilaiden oppimisesta perusopetuksen vuosiluokkien 1-2 päättövaiheessa Helsingin kaupungissa (Ojala, 2007). Seurannan kohteena ovat olleet esiopetuksessa olleet helsinkiläislapset, joiden oppimista esiopettajat arvioivat esiopetuksen päättövaiheessa (vertaa liitekuva 1). 


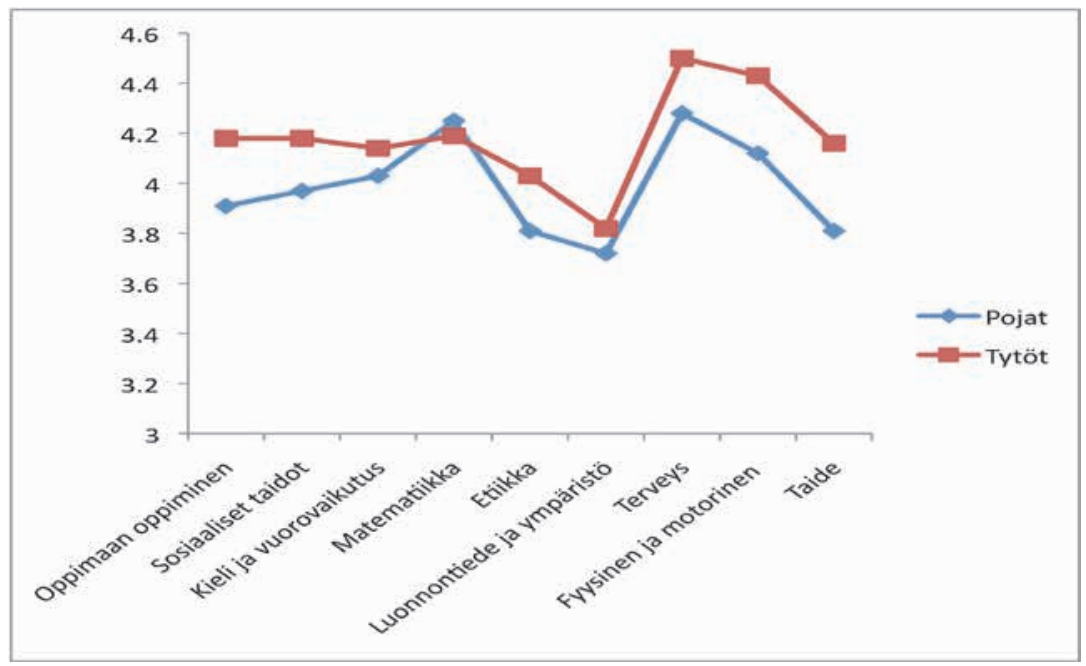

Liitekuva 3. Oppiminen sukupuolen mukaan keskiarvoina esiopetuksessa (Pojat $n=104$, Tytöt $n=112$ )

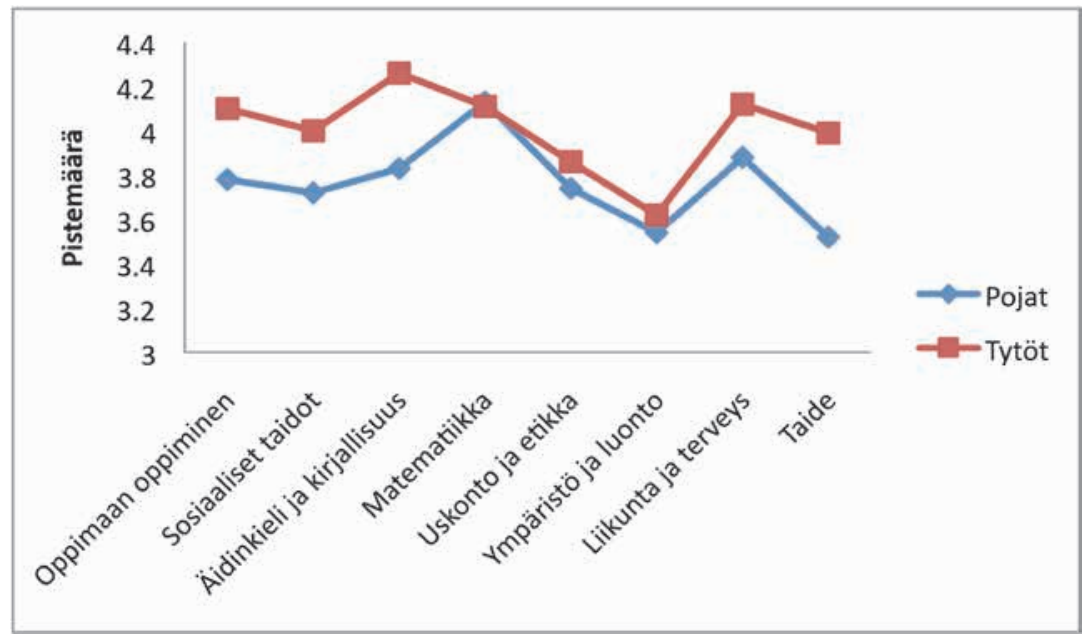

Liitekuva 4. Tyttöjen ja poikien oppiminen ensimmäisen kouluvuoden keväällä 


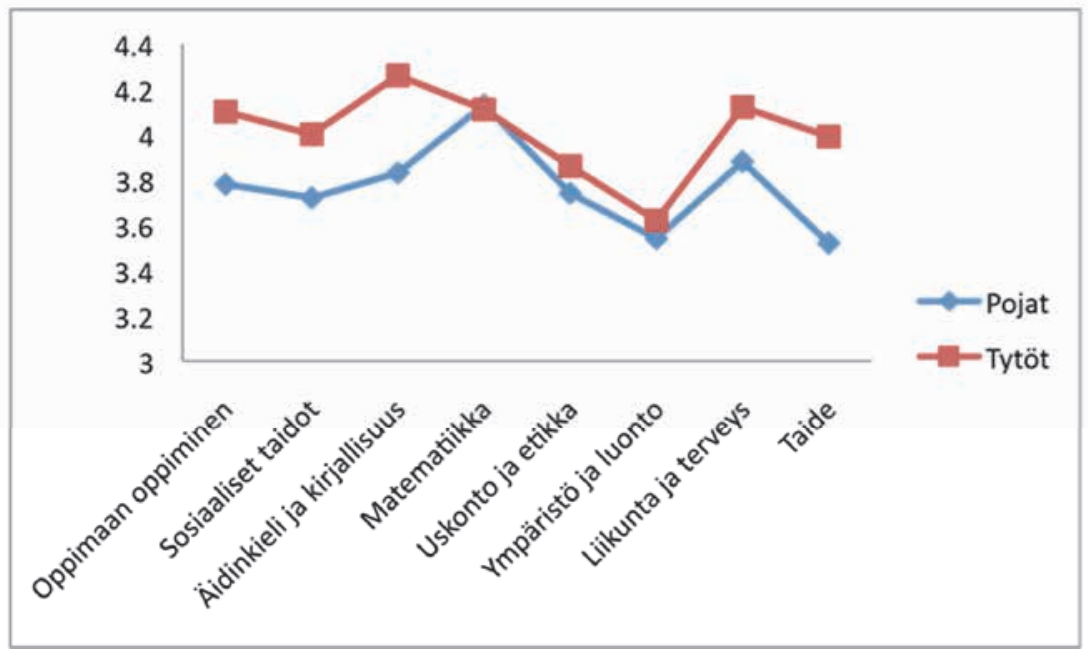

Liitekuva 5. Oppiminen sukupuolen mukaan koulussa toisen kouluvuoden keväällä

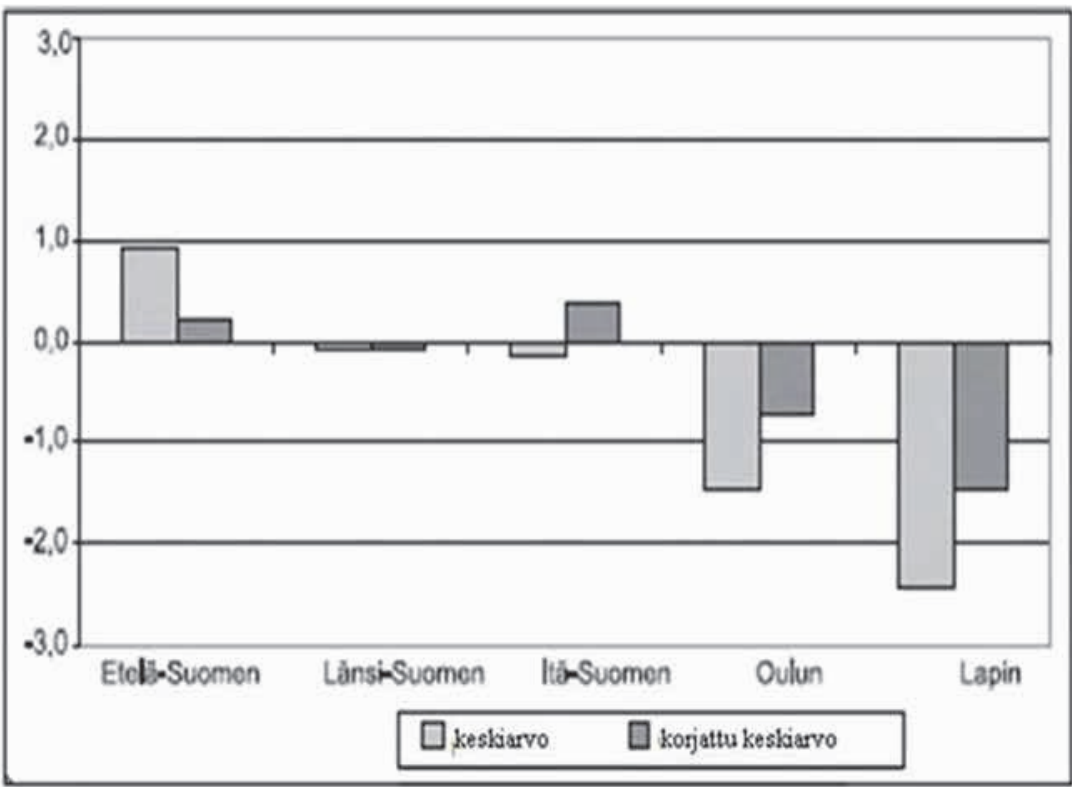

Liitekuva 6. Oppilaiden läänikohtaiset oppimistulokset perusopetuksen 6. luokalla (Kuusela, 2006). Tuloksissa yhdistetty äidinkieli, matematiikka, luonnontieteet sekä englannin ja ruotsin kielet. 


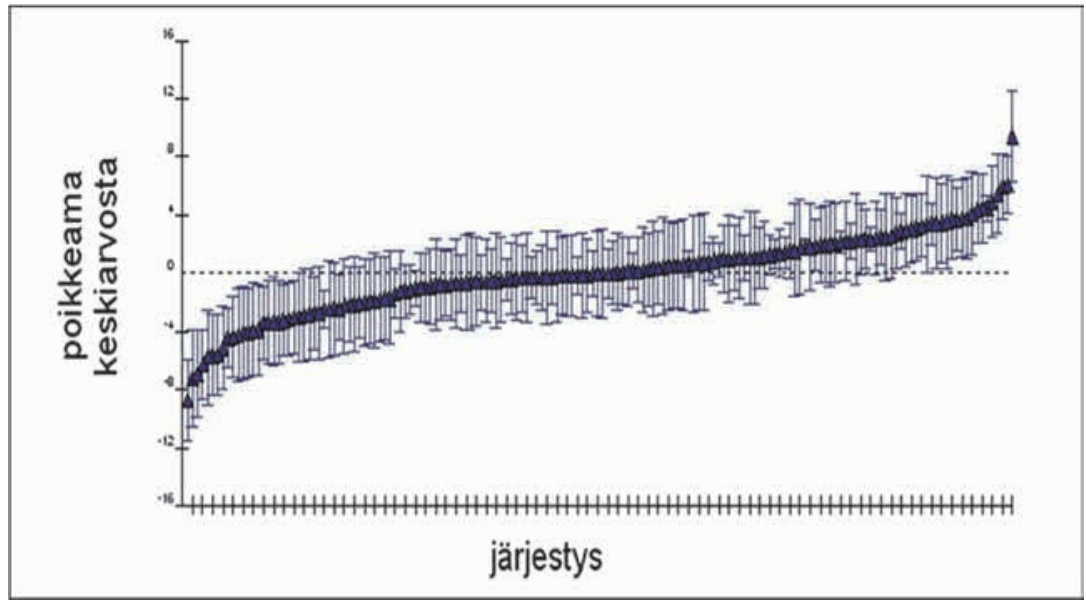

Liitekuva 7. Koulujen erot oppimistuloksissa perusopetuksen kuudennella luokalla (Kuusela, 2006). Tuloksissa yhdistetty äidinkieli, matematiikka, luonnontieteet sekä englannin ja ruotsin kielet.

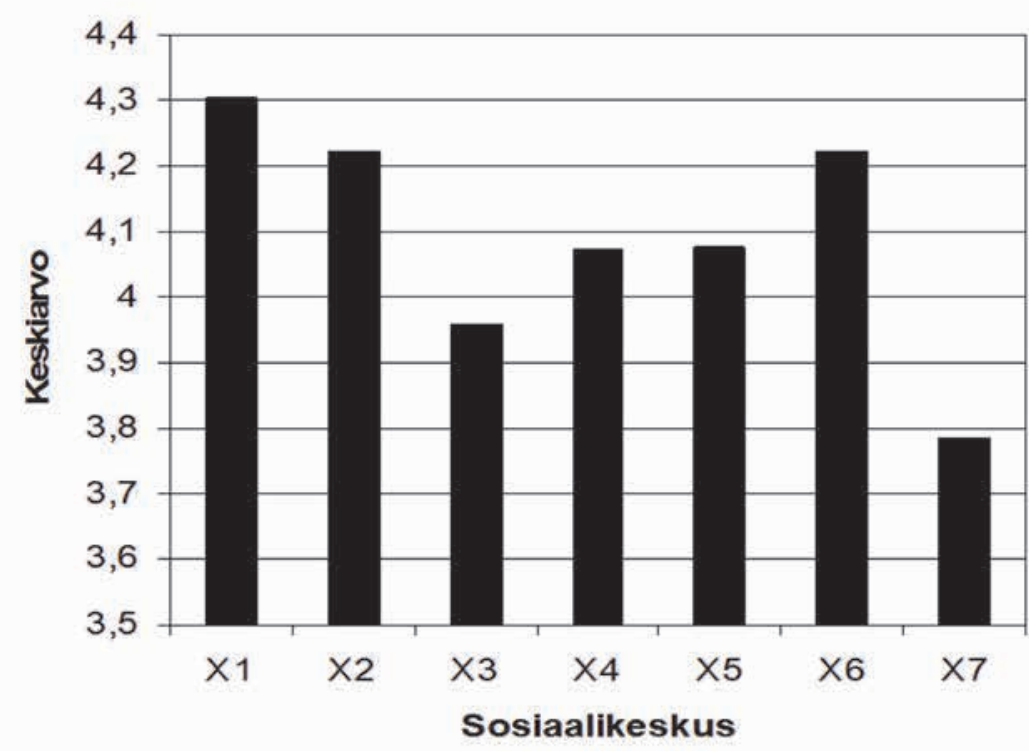

Liitekuva 8. Esiopetuksen oppimistulosten alueellinen jakautuminen Helsingin kaupungissa (Ojala, 2007) 